\title{
ARCHAEOLOGICAL DATA RECOVERY AT DRILL PAD U19au, NYE COUNTY, NEVADA
}

\author{
by \\ Gregory H. Henton \\ and \\ Lonnie C. Pippin \\ with Contributions by \\ Martha L. Hemphill \\ Cari L. Lockett \\ Cheryl N. Nowak \\ Laurie A. Walsh
}

OCT 311999

Technical Report No. 55

ISSN 1043-335X

ISBN $0-945920-55-5$

Prepared for

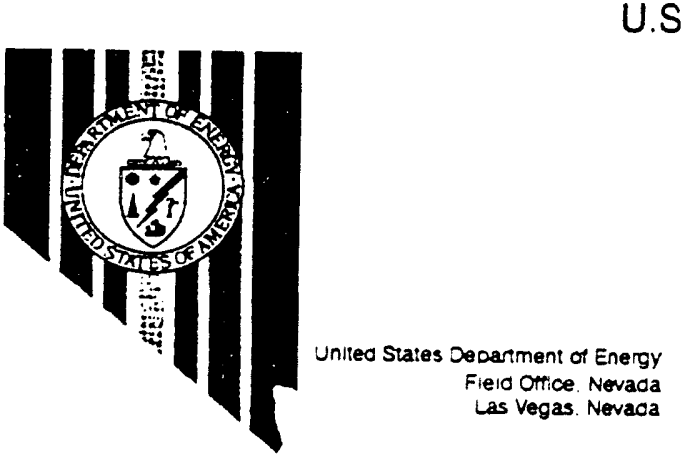
U.S. Department of Energy
Field Office, Nevada
Las Vegas, Nevada

The work upon which this report is based was supported by the U.S. Department of Energy under Contract \#DE-ACO8-9ONV 10845 
This report was prepared as an account of work sponsored by the United States Government. Neither the United States nor the United States Department of Energy, nor any of their employees, makes any warranty, express or implied, or assumes any legal liability or responsibility for the accuracy, completeness or usefulness of any information, apparatus, product or process disclosed, or represents that its use would not infringe privately owned rights. Reference herein to any specific commercial project, process, or service by trade name, mark, manufacturer, or otherwise, does not necessarily constitute or imply its endorsement, recommendation, or favoring by the United States Government or any agency thereof. The views and opinions of authors expressed herein do not necessarily state or reflect those of the United States Government or any agency thereof.

This report has been reproduced directly from the best available copy.

Available to DOE and DOE contractors from the Office of Scientific and Technical Information, PO Box 32, Oak Ridge, TN 37831; prices available from (615) 576-8401, FTS 626-8401.

Available to the public from the National Technical Information Service, U.S. Department of Commerce, 5285 Port Royal Road, Springfield, VA 22161. 


\section{CONTENTS}

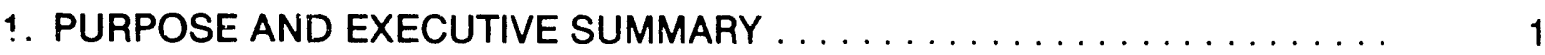

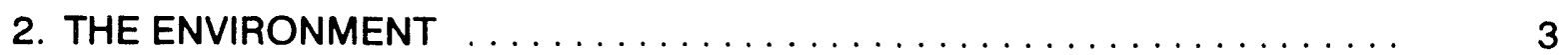

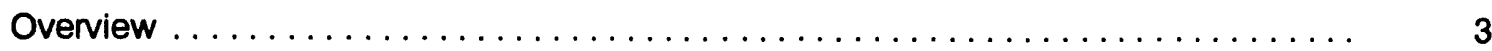

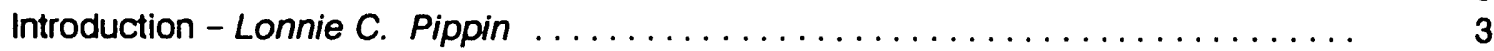

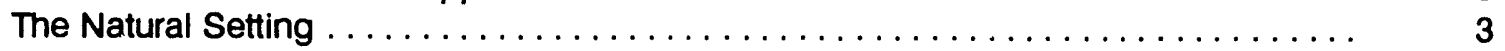

Physiography and Geology $\ldots \ldots \ldots \ldots \ldots \ldots \ldots \ldots \ldots \ldots \ldots \ldots \ldots \ldots, \ldots \ldots$

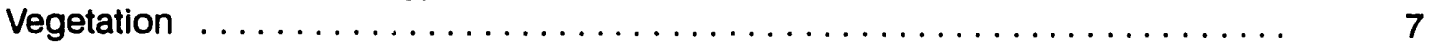

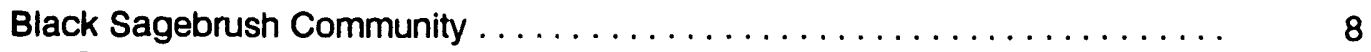

Big Sagebrush Community .............................. 8

Juniper and Pinyon-Juniper Woodlands . . . . . . . . . .

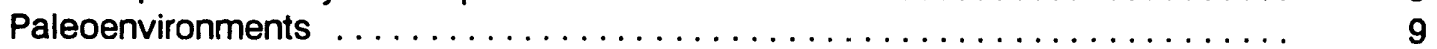

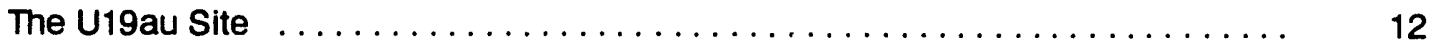

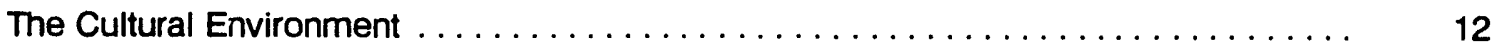

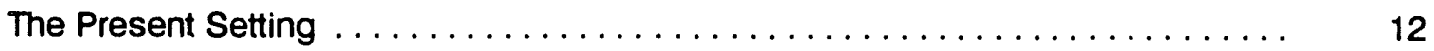

Historic Setting ...................................... 13

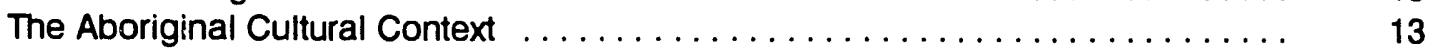

The Numa ........................................ 13

Aboriginal Patterns of Resource Procurement $\ldots \ldots \ldots \ldots \ldots \ldots \ldots . \ldots 14$

The Prehistoric Cultural Context .......................... 18

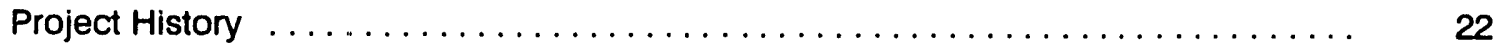

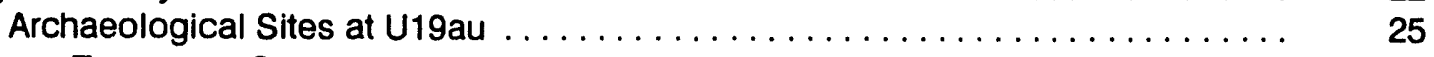

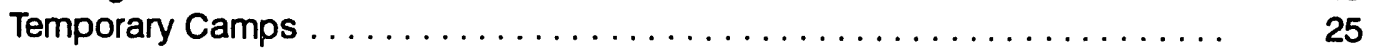

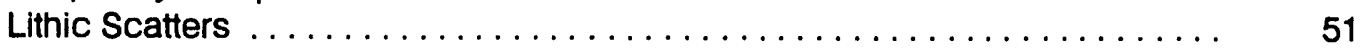

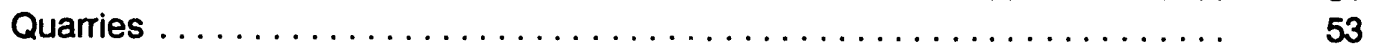

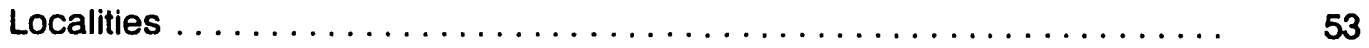

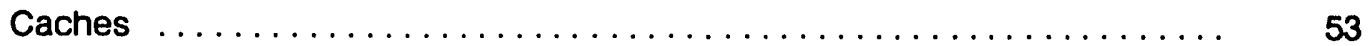

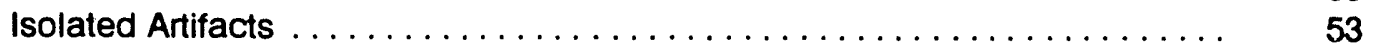

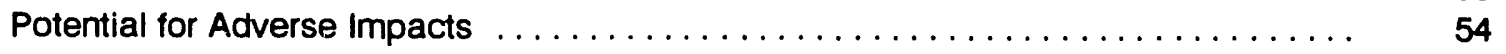

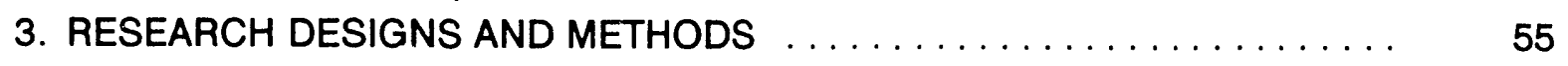

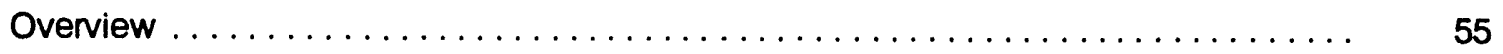

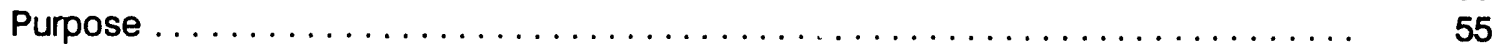

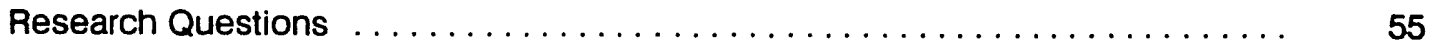

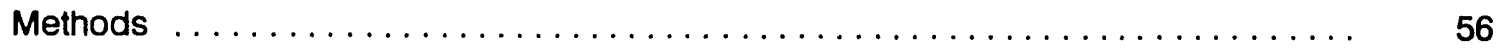

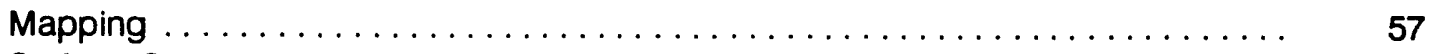

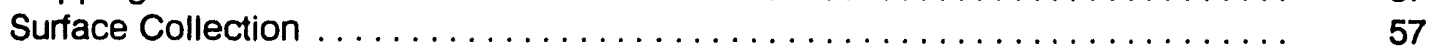

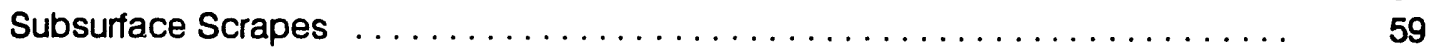

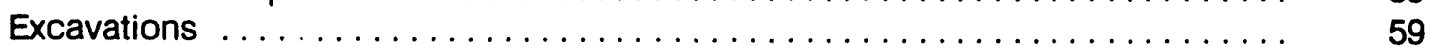

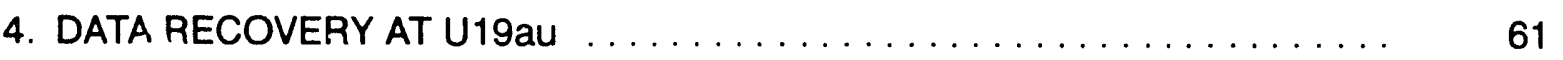

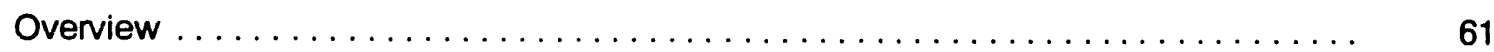

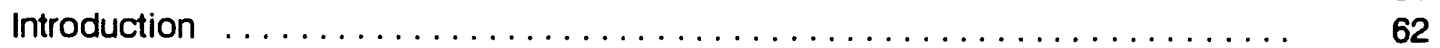

Archaeological Investigation Along the Access Road $\ldots \ldots \ldots \ldots \ldots \ldots \ldots \ldots .62$

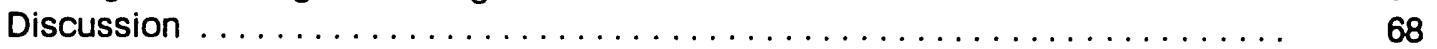

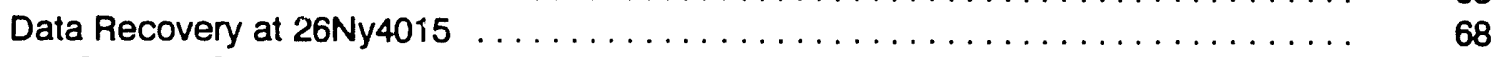

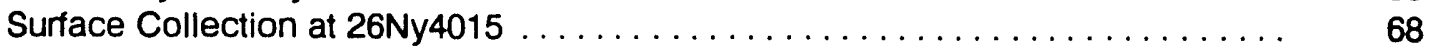

Bifaces ........................................... 76

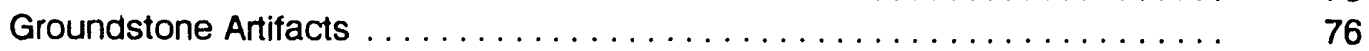

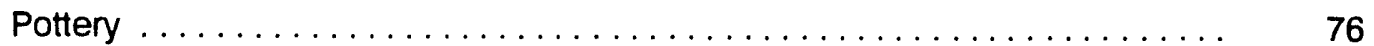

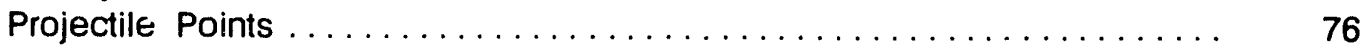

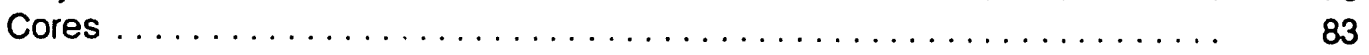


Modified Flakes $\ldots \ldots \ldots \ldots \ldots \ldots \ldots \ldots \ldots \ldots \ldots \ldots \ldots \ldots \ldots \ldots$

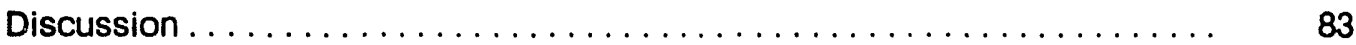

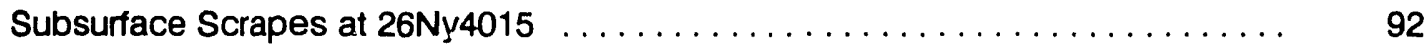

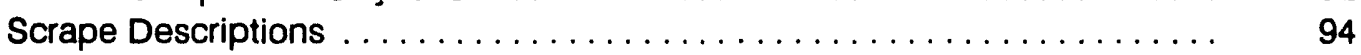

Chi-square Tests $\ldots \ldots \ldots \ldots \ldots \ldots \ldots \ldots \ldots \ldots \ldots \ldots \ldots \ldots \ldots \ldots \ldots$

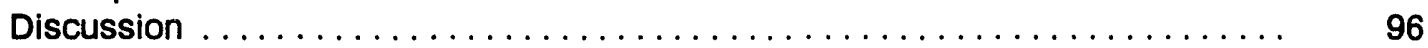

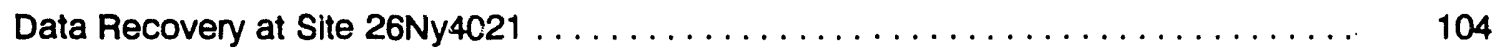

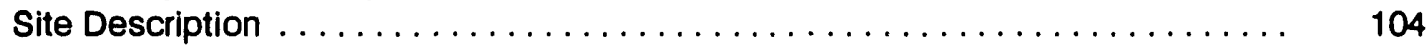

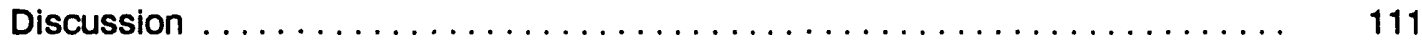

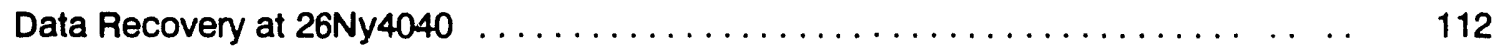

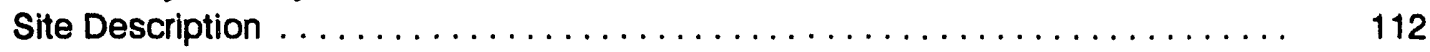

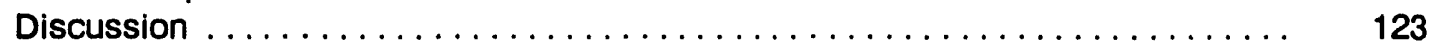

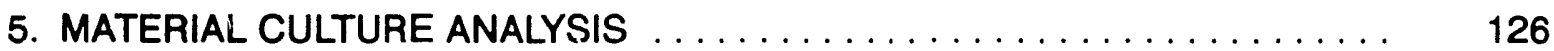

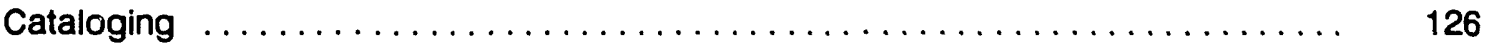

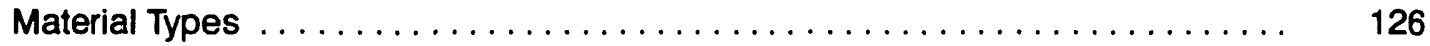

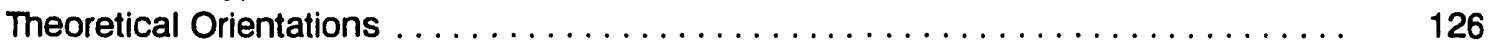

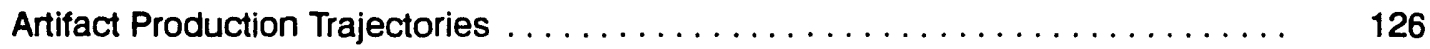

Functional Analyses $\ldots \ldots \ldots \ldots \ldots \ldots \ldots \ldots \ldots \ldots \ldots \ldots \ldots \ldots \ldots$

Debitage $\ldots \ldots \ldots \ldots \ldots \ldots \ldots \ldots \ldots \ldots \ldots \ldots \ldots \ldots \ldots \ldots \ldots \ldots$

Cores ........................................ 129

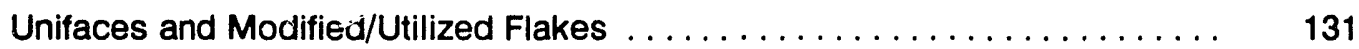

Bifacial Stage Form Trajectories $\ldots \ldots \ldots \ldots \ldots \ldots \ldots \ldots \ldots \ldots \ldots$

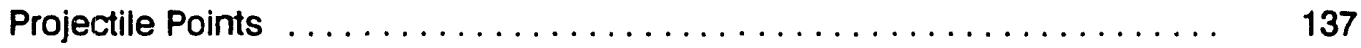

Groundstone Artifacts . . . . . . . . . . . . . . . . . . . . . . . 147

Hammerstones ............................... 147

Miscellaneous Artifacts $\ldots \ldots \ldots \ldots \ldots \ldots \ldots \ldots \ldots \ldots \ldots \ldots \ldots \ldots$

Historis Artifacts $\ldots \ldots \ldots \ldots \ldots \ldots \ldots \ldots \ldots \ldots \ldots \ldots \ldots \ldots$

Analysis Of Pottery From U19au - Cari L. Lockett . . . . . . . . . . . . . . . . . . . 152

Spatial Distribution $\ldots \ldots \ldots \ldots \ldots \ldots \ldots \ldots \ldots \ldots \ldots \ldots \ldots \ldots$

Sherd and Vessel Descriptions per Concentration $\ldots \ldots \ldots \ldots \ldots \ldots \ldots \ldots$

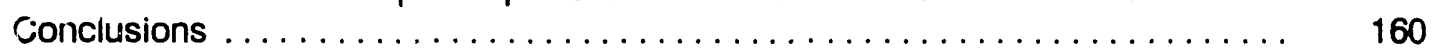

Pottery and Feature Associations . . . . . . . . . . . . . . . . . . . . . . . . . . . . . 167

Analysis $\boldsymbol{\Omega}_{i}$ Pollen and Macrofossil Samples

Martha $L$. Hemphill and Cheryl $L$. Nowak . . . . . . . . . . . . . . . . . . . 168

Introduction $\ldots \ldots \ldots \ldots \ldots \ldots \ldots \ldots \ldots \ldots \ldots \ldots \ldots \ldots \ldots \ldots \ldots \ldots \ldots$

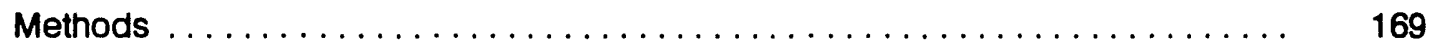

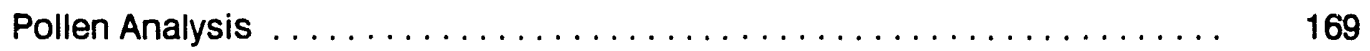

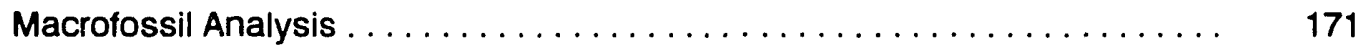

Results and Discussion $\ldots \ldots \ldots \ldots \ldots \ldots \ldots \ldots \ldots \ldots \ldots \ldots \ldots \ldots$

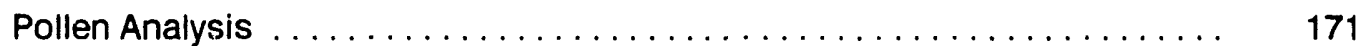

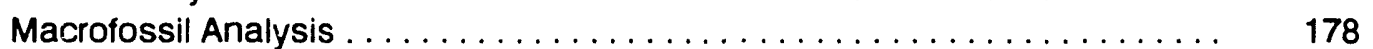

Conclusions $\ldots \ldots \ldots \ldots \ldots \ldots \ldots \ldots \ldots \ldots \ldots \ldots \ldots \ldots \ldots$

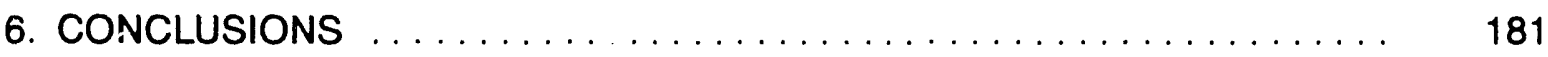

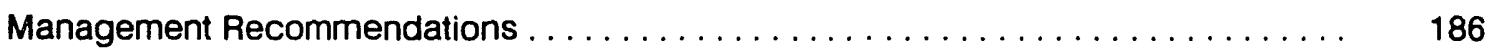

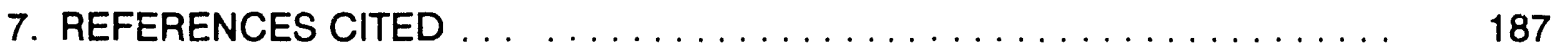

APPENDIX A - Descriptions And References For Artifacts $\ldots \ldots \ldots \ldots \ldots$ A-i

APPENDIX B - Uniface Analysis Attribute Codes $\ldots \ldots \ldots \ldots \ldots \ldots \ldots$ B-i

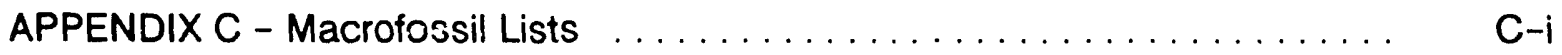




\section{TABLES}

Table 2-1. Percentage of Ground Covered by Trees, Shrubs, Herbaceous

Perennials, and Winter Annuals on Pahute and Rainier Mesas,

Southem Nye County, Nevada. . . . . . . . . . . . . . . . . . . . . . .

Table 4-1. Excavation Units and Subsurface Scrapes Conducted during

Archaeological Investigations at U19au, Nevada Test Site, Nevada. ...... 61

Table 4-2. Debitage Counts for Concentrations. ...................... 72

Table 4-3. Counts for Major Types of Debitage Standardized to 1,000 Items. . . . . . . . 72

Table 4-4. Nondebitage Surface Artifacts from Defined Concentrations at

U19au, Pahute Mesa, Nevada. ............................. 81

Table 4-5. Point Types with the Twelve Defined Concentrations. .............. 81

Table 4-6. Debitage from the Surface of Scrape 1, 26Ny4015, Pahute Mesa. . . . . . . . . 98

Table 4-7. Debitage from the Subsurface of Scrape 1, 26Ny4015, Pahute Mesa. . . . . . . 98

Table 4-8. Debitage from the Subsurface of Scrape 2, 26Ny4015, Pahute Mesa. . . . . . . 98

Table 4-9. Debitage from the Surface of Scrape 3, 26Ny4015, Pahute Mesa. . . . . . . . . 98

Table 4-10. Debitage from the Subsurface of Scrape 3, 26Ny4015, Pahute Mesa. ...... 98

Table 4-11. Debitage from the Surface of Scrape 4, 26Ny4015, Pahute Mesa. . . . . . . . . 99

Table 4-12. Debitage from the Subsurface of Scrape 4, 26Ny4015, Pahute Mesa. . . . . . . 99

Table 4-13. Debitage from the Surface of Scrape 5, 26Ny4015, Pahute Mesa. . . . . . . . 99

Table 4-14. Debitage from the Subsurface of Scrape 5, 26Ny4015, Pahute Mesa. . . . . . . 99

Table 4-15. Debitage from the Surface of Scrape 6, 26Ny4015, Pahute Mesa. . . . . . . . . 99

Table 4-16. Debitage from the Subsurface of Scrape 6, 26Ny4015, Pahute Mesa. . . . . . . 100

Table 4-17. Debitage from the Surface of Scrape 7, 26Ny4015, Pahute Mesa. ........ 100

Table 4-18. Debitage from the Subsurface of Scrape 7, 26Ny4015, Pahute Mesa. ...... 100

Table 4-19. Debitage from the Surface of Scrape 8, 26Ny4015, Pahute Mesa. . . . . . . . 100

Table 4-20. Debitage from the Subsurface of Scrape 8, 26Ny4015, Pahute Mesa. . . . . . 101

Table 4-21. Debitage from the Surface of Scrape 13, 26Ny4015, Pahute Mesa. . . . . . . . 101

Table 4-22. Debitage from the Subsurface of Scrape 13, 26Ny4015. Pahute Mesa. ..... . 101

Table 4-23. Debitage from the Surface of Scrape 14, 26Ny4015, Pahute Mesa. ........ 101

Table 4-24. Debitage from the Surface of Scrape 15, 26Ny4015, Pahute Mesa. . . . . . . . 102

Table 4-25. Debitage from the Subsurface of Scrape 15, 26Ny4015, Pahute Mesa. ..... 102

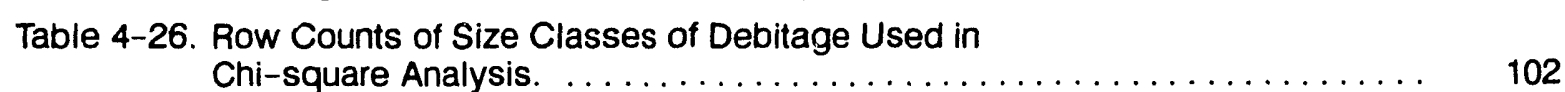

Table 4-27. Results of Chi-square Tests for all Size Classes . . . . . . . . . . . . . . . 102

Table 4-28. Results of Chi-square Tests for all Size Classes Greater
than $1 / 4$-inch. $\ldots \ldots \ldots \ldots \ldots \ldots \ldots \ldots \ldots \ldots \ldots \ldots \ldots \ldots \ldots \ldots \ldots \ldots \ldots \ldots$

Table 4-29. Results of Chi-square Tests for Debitage Type. . . . . . . . . . . . . 103

Table 4-30. Comparison of Surface and Subsurface Debitage, Counts for
Scrapes with more than 20 Artifacts on the Surface. . . . . . . . . . . . 103

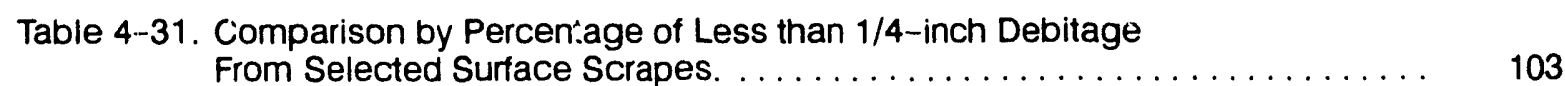

Table 4-32. Percentages of Debitage Types for Selected Concentrations at 26Ny4021, U19au, Pahute Mesa, Nevada. ................... 112 
Table 4-33. Percentages of Material Types for Selected Debitage Concentrations at 26Ny4021, U19au, Pahute Mesa, Nevada.

Table 5-1. Definitions of Flake Type Categories Used in the Analysis of Debitage from the U19au Drill Pad Area.

Table 5-2. Definitions of Core Types Used in the Analysis of Cores from the U19au Project Area.

Table 5-3. Cores from Archaeological Investigations at U19au, Pahute Mesa, Nevada. . 130

Table 5-4. Modified/Utilized Flake Analysis for U19au, Pahute Mesa, Nevada. . . . . . . . . 134

Table 5-5. Production Sequence for Bifacially Flaked Stone Tools. $\ldots \ldots \ldots \ldots \ldots \ldots .137$

Table 5-6. Analysis of Projectile Points from the U19au Drill Pad archaeological Investigations, Pahute Mesa, Nye County, Nevada.

Table 5-7. Analysis of Drills from Archaeological Investigations at U19au,

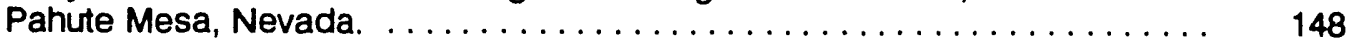

Table 5-8. Pottery Vessels Identified in the U19au Project Area. . . . . . . . . . . . . . . . $\quad 154$

Table 5-9. Pottery Vessel Distribution and Ethnohistoric Feature Association for Selected Areas on Pahute Mesa. . . . . . . . . . . . . . . . . . . . . 168

Table 5-10. U19au Pollen Samples from Pottery Sherds. . . . . . . . . . . . . . . . . . 170

Table 5-11. U19au Pollen Samples from Sediments. . . . . . . . . . . . . . . . . . . . . . . . . $\quad 170$

Table 5-12. Analysis of Pollen Samples (1-15) at U19au, Painute Mesa, Nevada. . . . . . 172

Table 5-13. Pollen Samples from Artifacts at U19au, Pahute Mesa, Nevada. . . . . . . . . . . 174

Table 5-14. Pearson's Correlation for Pollen Samples 1-30 for U19au. . . . . . . . . . . . . . . . 175

Table 5-15. Pearson's r Correlation for Pollen Samples from Artifacts at U19au. . . . . . . 178

Table 5-16. Significance of Plant Taxa Present in Charcoal Stains at 26Ny4040. . . . . . 178

Table 5-17. Significance of Plant Taxa Present in the Brush Structure at 26Ny4040. . . . . . 179

Table 5-18. Significance of Plant Taxa Present in the Humic Mat at 26Ny4040. . . . . . . 179

Table 6-1. Number of Recognizable Structures Present at Archaeological Site at U19au. $\quad 183$ 


\section{FIGURES}

Figure 2-1. Map of the Nevada Test Site and surrounding environs,

Nye County, Nevada. ............................. 4

Figure 2-2. Map showing Pahute Mesa, its major geographic features, and the

U19au project area. ................................

Figure 2-3. Various cultural chronologies proposed for the prehistory of Southern

Nevada and adjacent California. ......................... 20

Figure 2-4. Archaeological sites recorded during the original survey for drill pad

area U19au, Pahute Mesa, Nevada. ...................... 23

Figure 2-5. Archaeological sites recorded during the original survey for the access road to U19au, Pahute Mesa, Nevada. ...................... 24

Figure 2-6. Archaeological site map of the northern portions of site 26Ny4015,

Pahute Mesa, Nevada. .............................. 26

Figure 2-7. Archaeological site map of Locus 1, site 26Ny4015, Pahute Mesa,

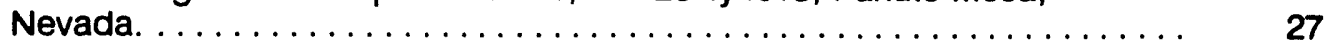

Figure 2-8. Archaeological site map for site 26 Ny 4021 as originally recorcled,

Pahute Mesa, Nevada. ............................. 29

Figure 2-9. The three rock ring structure features as originally recorded, from site 26Ny4021, Pahute Mesa, Nevada. ........................ 30

Figure 2-10. Photograph of Feature 1 of site 26 Ny4021 as originally discovered. ..... 31

Figure 2-11. Photograph of Feature 2 of site 26 Ny4021 as originally discovered. . . . . 31

Figure 2-12. Photograph of Feature 2 of site 26 Ny 4021 as originally discovered. . . . . 32

Figure 2-13. Photograph of Feature 3 of site 26 Ny 4021 when originally discovered. ... . 32

Figure 2-14. Archaeological site map for site 26Ny4022, Pahute Mesa, Nevada. . . . . . 33

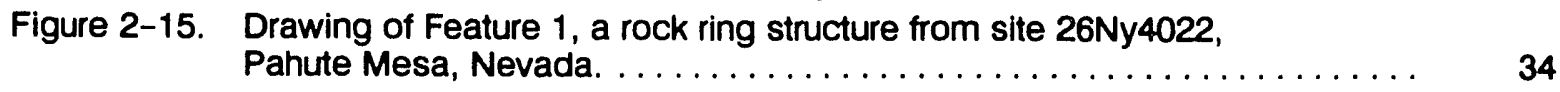

Figure 2-16. Drawing of Feature 2 from site 26Ny4022, Pahute Mesa, Nevada. . . . . . 35

Figure 2-17. Archaeological site map for site 26Ny4023, Pahute Mesa, Nevada. ..... 36

Figure 2-18. Drawing of Feature 1, a possible pinyon nut cache from site 26Ny4023. . . 37

Figure 2-19. Drawing of Feature 2, a brush structure from site 26 Ny4023. . . . . . . 38

Figure 2-20. Drawing of Feature 3, a brush structure from site 26 Ny4023. . . . . . . 39

Figure 2-21. Drawing of Feature 4, a brush structure from site 26Ny4023. . . . . . . 40

Figure 2-22. Drawing of Feature 5, a brush structure from site 26 Ny4023 ......... 41

Figure 2-23. Photograph of Feature 1, a possible pinyon nut cache from site 26Ny4023. 42

Figure 2-24. Photograph of Feature 2, a brush structure from site 26 Ny $4023 \ldots \ldots \ldots . \quad 43$

Figure 2-25. Photograph of Feature 3, a possible pinyon nut cache from site 26Ny4023. 43

Figure 2-26. Photograph of Feature 4, a brush structure from site 26 Ny4023 . . . . . . . 44

Figure 2-27. Photograph of Feature 5, a brush structure from site 26Ny4023 . . . . . . 44

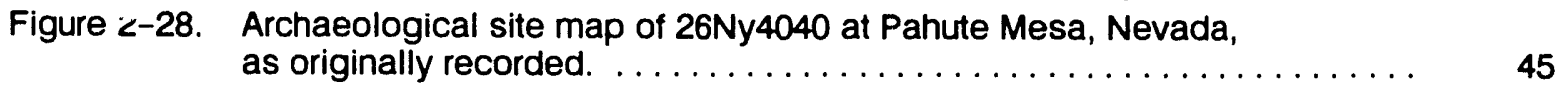

Figure 2-29. Drawing of Feature 1, a brush structure from site 26 Ny $4040 . \ldots \ldots \ldots \ldots . . \ldots 46$

Figure 2-30. Drawing of Feature 2, a brush str scture from site 26 Ny4040. . . . . . . . 47

Figure 2-31. Drawing of Feature 3, a brush structure from site 26 Ny $4040 . \ldots \ldots \ldots \ldots .48$

Figure 2-32. Photograph of Feature 1, a brush structure for site 26 Ny4040 . . . . . . 49

Figure 2-33. Photograph of Feature 2, a brush structure from site $26 \mathrm{Ny} 4040 \ldots \ldots \ldots .49$

Figure 2-34. Photograph of Feature 3, a brush structure from site 26 Ny4040....... 50

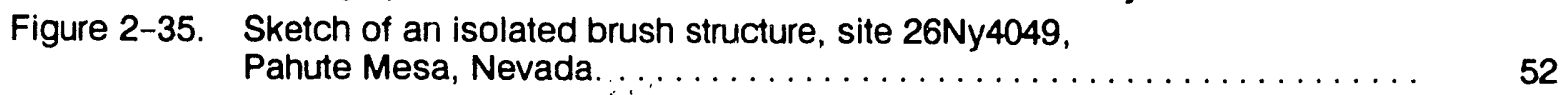

Figure $3-1$. Collection Grid Baseline and Meridians $\ldots \ldots \ldots \ldots \ldots \ldots \ldots \ldots \ldots$ 


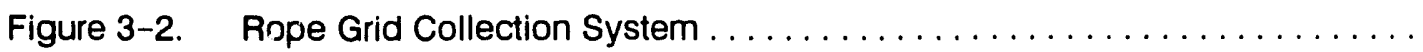

Figure 4-1. Surface collection area, and the locations of excavation units and subsurface scrapes for the drill pad area of the U19au archaeological investigations, Pahute Mesa, Nevada. .....................

Figure 4-2. Surface collection area, and the locations of excavation units and subsurface scrapes for the access road area of the U19au

archaeological investigations, Pahute Mesa, Nevada. ..............

Figure 4-3. West and north sidewall profiles for Test Excavation Unit 1, U19au archaeological investigations, Pahute Mesa, Nevada. ............ 66

Figure 4-4. West and north sidewall profiles for Test Excavation Unit 2, U19au archaeological investigations, Pahute Mesa, Nevada. ..............

Figure 4-5. West and north sidewall profiles for Test Excavation Unit 3, U19au archaeological investigations, Pahute Mesa, Nevada.

Figure 4-6. Debitage density, log scale, for the U19au drill pad area (site 26Ny4015), Pahute Mesa, Nevada. .................... 70

Figure 4-7. Defined debitage concentrations for the U19au drill pad area,

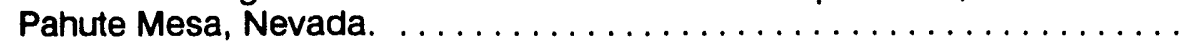

Figure 4-8. Tree diagram of the distances between the defined debitage concentrations based on proportions of debitage types for the U19au

drill pad area, Pahute Mesa, Nevada. .......................

Figure 4-9. Histograms of the proportions of debitage types for the defined concentrations of debirage at the drill pad area of U19au,

Pahute Mesa, Nevada.

Figure 4-10. Distribution map of Stage I bifaces in the U19au drill pad area,

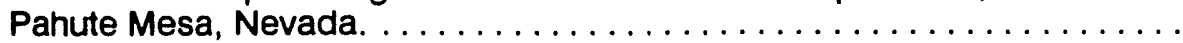

Figure 4-11. Distribution map of Stage II bifaces in the U19au drill pad area,

Pahute Mesa,

Nevada.

Figure 4-12. Distribution map of Stage III bifaces in the U19au drill pad area,

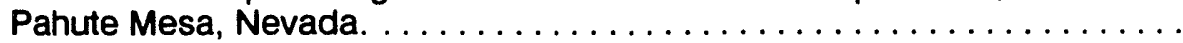

Figure 4-13. Distribution map of drills and Stage IV and V bifaces in the U19au

drill pad area, Pahute Mesa, Nevada. ......................

Figure 4-14. Distribution map of manos and millingstones in the U19au drill pad area,

Pahute Mesa, Nevada. ................................. 82

Figure 4-15. Distribution map of Gatecliff and Gypsum projectile points in the U19au drill pad area, Pahute Mesa, Nevada. ...................... 84

Figure 4-16. Distribution map of miscellaneous projectile points in the U19au drill pad area, Pahute Mesa, Nevada. ..................... 85

Figure 4-17. Distribution map of Elko projectile points in the U19au drill pad area, Pahute Mesa, Nevada. .............................. 86

Figure 4-18. Distribution map of Fosegate projectile points in the U19au drill pad area, Pahute Mesa, Nevada. ..............................

Figure 4-19. Distribution map of Cottoriwood projectile points in the U19au drill pad area, Pahute Mesa, Nevada. ...........................

Figure 4-20. Distribution map of Desert Side-Notched projectile points in the U19au drill pad area, Pahute Mesa, Nevada. 70 1 73 4 77 
Figure 4-25. Drawing of Feature 1, as excavated, from site 26Ny4021 . . . . . . . . . . 106

Figure 4-26. Photograph of Feature 1, as excavated, from site 26Ny4021 . . . . . . . . . . 107

Figure 4-27. Photograph of Feature 2, as excavated, from site 26Ny4021 . . . . . . . . . 108

Figure 4-28. Drawing of Feature 2, as excavated, from site 26Ny4021 . . . . . . . . . . . 109

Figure 4-29. Drawing of Feature 3, as excavated, from site 26Ny4021 . . . . . . . . . . 110

Figure 4-30. Photograph of Feature 3, as excavated, from site 26Ny4021 . . . . . . . . . 111

Figure 4-31. Archaeological site map after excavations at 26Ny4040,

Pahute Mesa, Nevada. . . . . . . . . . . . . . . . . . . . . . . . . . . . . . . 113

Figure 4-32. Drawing of Feature 1, as excavated, from site 26Ny4040. . . . . . . . . . 114

Figure 4-33. Photograph of Feature 1, as excavated, from site 26Ny4040. . . . . . . . 115

Figure 4-34. Photograph of Feature 2, as excavated, from site 26Ny4040 . . . . . . . 116

Figure 4-35. Photograph of artifacts from Feature 1, site 26Ny4040 . . . . . . . . . 116

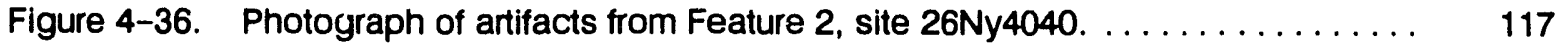

Figure 4-37. Drawing of Feature 2, as excavated, from site 26Ny4040 . . . . . . . . . 118

Figure 4-38. Drawing of Feature 3, as excavated, from site 26Ny4040 . . . . . . . . 119

Figure 4-39. Photograph of Feature 3, as excavated, from site 26 Ny4040 . . . . . . . 120

Figure 4-40. Photograph of artifacts from Feature 3, site 26Ny4040 . . . . . . . . 120

Figure 4-41. Photograph of artifacts from Feature 3, site 26 Ny4040 . . . . . . . . $\quad$ i21

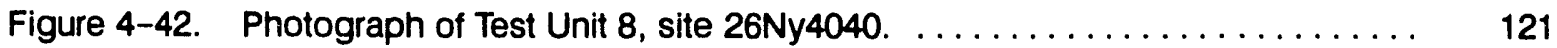

Figure 4-43. East and south sidewall profiles for Test Excavation Unit 8, at 26Ny4040. . . 122

Figure 4-44. Debitage density map for site 26Ny4040, Pahute Mesa, Nevada. . . . . . . . 124

Figure 4-45. Photograph of miscellaneous artifacts from 26Ny4040,

Pahute Mesa, Nevada ............................ 125

Figure 5-1. Generalized flow diagram for chipped stone tool manufacture and use . . . 127

Figure 5-2. Photograph of cores from the U19au archaeological investigations,

Pahute Mesa, Nevada ................................ 131

Figure 5-3. Photograph of modified flakes from the U19au archaeological

investigations, Pahute Mesa, Nevada ..................... 132

Figure 5-4. Photograph of modified flakes from the U19au archaeological

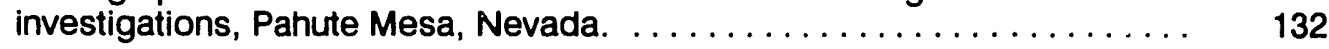

Figure 5-5. Photograph of utilized flakes from the U19au archaeological

investigations, Pahute Mesa, Nevada. .................... 133

Figure 5-6. Photograph of bifaces from the U19au archaeological investigations,

Pahute Mesa, Nevada. ............................. 138

Figure 5-7. Location of metric attributes of projectile points summarized in projectile point analysis table.

Figure 5-8. Photograph of Pinto, Humboldt and Large Side-Notched projectile points from the U19au archaeological investigations, Pahute Mesa, Nevada. . ...

Figure 5-9. Photograph of Gatecliff and Gypsum projectile points from the U19au archaeological investigations, Pahute Mesa, Nevada. ...............

Figure 5-10. Photograph of Elko projectile points from the U19au archaeological investigations, Pahute Mesa, Nevada. ......................

Figure 5-11. Photograph of Rosegate projectile points from the U19au archaeological investigations, Pahute Mesa, Nevada. ..................... 146

Figure 5-12. Photograph of Cotton'wood and Desert Side-Notched projectile points from the U19au archaeological investigations, Pahute Mesa, Nevada. . . . 149

Figure 5-13. Photograph of drills from the U19au archaeological investigations, Pahute Mesa, Nevada.

Figure 5-14. Photograph of a hammerstone and manos from the U19au archaeological investigations, Pahute Mesa, Nevada. . . . . . . . . . . . 150

Figure 5-15. Photograph of millingstones from the U19au archaeological investigations, Pahute Mesa, Nevada. 
Figure 5-16. Photograph of miscellaneous prehistoric artifacts from the U19au archaeological investigations, Pahute Mesa, Nevada).

Figure 5-17. Photograph of miscellaneous historic artifacts from the U19au archaeological investigations, Pahute Mesa, Nevada . ............ 151

Figure 5-18. Photograph of buttons and beads from the U19au archaeological investigations, Pahute Mesa, Nevada. ..................... 153

Figure 5-19. Photograph of historic artifacts from the U19au archaeological investigations, Pahute Mesa, Nevada. ...................... 153

Figure 5-20. Locations of pottery concentrations at the U19au drill pad area, Pahute Mesa, Nevada. ............................ 161

Figure 5-21. Generalized shapes of pots found in the Nevada Test Site area. . . . . . 162

Figure 5-22. Partial reconstructions of pots from sites found in the vicinity of U19au, Pahute Mesa, Nevada. .............................. 163

Figure 5-23. Partial reconstructions of pots from sites found in the vicinity of U19au, Pahute Mesa, Nevada.

Figure 5-24. Photograph of partially reconstructed pot from pottery Concentration 2, Pahute Mesa, Nevada. ................................ 165

Figure 5-25. Photograph of a partially reconstructed pot and additional sherds from pottery Concentration 4 from the U19au archaeological investigations, Pahute Mesa, Nevada.

Figure 5-26. Photograph of pottery cups from U19au archaeological investigations, Pahute Mesa, Nevada. ............................... 166

Figure 5-27. Photograph of decorated potsherds from the U19au archaeological investigations, Pahute Mesa, Nevada.

Figure 5-28. Photograph of reconstructed vessel 1 from pottery Concentration 15 (26Ny4021) from the U19au archaeological investigations, Pahute Mesa, Nevada. . . . . . . . . . . . . . . . . . . . . . . . . . . . . . . . . 167

Figure 5-29. Relative trequency diagram for pollen from pottery. . . . . . . . . . . . . 176

Figure 5-30. Relative Frequency Diagram for pollen from sediment samples. . . . . . . 177 


\section{ACKNOWLEDGMENTS}

Many individuals have contributed to this project and to each we owe a special debt of gratitude. Frank Bingham of the Department of Energy's Health-Physics Division was instrumental in the project's development and funding, and without his help, the project would not have been possible. Bob Bivona, of the Nevada Test Site Office in Mercury, helped coordinate the various aspects of the archaeological investigations with development and construction activities at the Test Site. Logistical support at the Test Site was provided by Auda Morrow and Shirley Richardson of the Civil Effects Testing Organization (CETO), which was replaced after the conclusion of the investigation by the Basic Environmental Compliance and Monitoring Program (BECAMP).

The archaejlogical investigations at UI9au have been one of the largest field proiects conducted by DRI for the Department of Energy at the Nevada Test Site. Most of the people associated with DRI's soutriern Nevada archaeological program helped in one form or another to the completion of this project. The original survey was conducted by Gregory Henton, J. Brantley Jackson, Steven James and Vera Morgan. Data recovery was directed by Ronald L. Reno, assisted by Cari Lockett and Alvin McLane. Field crew included Charles Amsden, Nicholas Chapin, John Garrett, Calvin Nichols, Cheryl Nowak, and Christopher Pierce. Initial cataloging was conducted by Cari Lockett, as was the analysis of the pottery. Calvin Nichols assisted in the reconstruction of the pottery used in Ms. Lockett's analysis. Flotation samples were processed and described by Cheryl Nowack, pollen samples were processed by Carol Bailey. The pollen samples were counted and analyzed by Peter Wigand and Martha Hemphill. Sue Ann Monteleone described the modified flakes and must of the historic artifacts, Laurie Walsh described the projectile points and cores. Linda Adkins and Jan Walker produced most the line drawings for the report, Stephan Durand and Jason Grimes produced the Computer assisted graphics. Carol Bailey photographed the artifacts and printed the photographs. The text was typed by Shirley Garcia and edited by Lois Snedden. Finally, the document was assembled by Ramona Reno and Susan Sawatzky. 


\section{PURPOSE AND EXECUTIVE SUMMARY}

Since the early 1960s, Pahute and Rainier mesas, situated in the northwestern portion of the Nevada Test Site, southern Nye County, Nevada, have been used by the U.S. Department of Energy (DOE) and the U.S. Department of Defense (DOD/DNA) for nuclear weapons testing. In accordance with the Limited Test Ban Treaty signed in August 1963, this testing has been restricted to underground localities. Nevertheless, construction activities accompanying underground nuclear tests result in the disturbance of the surface terrain around each test. In compliance with Federal legislation (National Historic Preservation Act of 1966 [PL 89-665] and National Environmental Policy Act of 1969 [PL 91-190]), the U.S. Department of Energy (DOE), Field Office, Nevada, has long required that cultural resources studies must precec'e all land-disturbing activities on the Nevada Test Site (U.S. Department of Energy 1983). In accordance with 36 CFR Part 800 , these studies consist of archaeological surveys conducted prior to the land-disturbing activities. The intent of these surveys is to identify and evaluate all cultural resources that might be adversely affected by the proposed construction activity. If cultural resources do not occur in the proposed project area or consist only of small sites and isolates that can be collected during the surveys, then the DOE documents that a cultural resources reconnaissance was conducted and allows the project to proceed. If, on the other hand, cultural resources occur in the zone of direct impact of a scheduled activity, then DOE follows one of two options to mitigate any potential adverse impacts. Initially, DOE makes every effort to design or modify project activities to physically avoid direct or indirect impacts to cultural resources. However, if this option is not possible, then DOE mitigates any potential adverse impacts through data recovery studies.

U19au, a one-square-kilometer drill pad and access, was scheduled for ground-disturbing activities. An archaeological survey of the affected areas was conducted in 1983, and numerous significant archaeological resources were recovered. Project modification was not $\exists$ feasible option, and a data recovery plan was prepared to mitigate adverse impacts to the archaeological sites. After consultation with the Nevada Division of Historic Freservation and Archaeology, the DOE authorized the Social Sciences Center (now Quaternary Science Center) of the Desert Research Institute to conduct the data recovery. Field work was initiated in 1986 and completed in 1987. DOE subsequently developed the site and conducted the test.

This report presents the final analysis of the data recovered from archaeological investigations conducted at the U19au drili site and access road. This report includes descriptions of the archaeological sites as recorded during the original survey, the research design used to guide the investigations, the method and techniques used to collect and analyze the data, and the results and interpretations of the analysis.

In summary, the valley in which the U19au project area resides has seen considerable aboriginal utilization for at least the last 3,500 years continuing into the late nineteenth century. It is likely that at least in the later stages of this occupation, pine nut harvesting as described ethnographically was an important activity, but evidence suggests that hunting, gathering of economic plants other than pine nuts, and procuring toolstone were also important activities. 
Since data recovery in the proposed affected areas has been completed and DOE's activities at U19au conducted, no further management recommendations are made concerning the area mitigated. This does not, however, include all of the area originally inspected for the drill pad. Significant archaeological sites still exist around the perim- eter of the area subjected to data recovery, and they have been and continue to be vulnerable to adverse impacts from scheduled and unscheduled activities of the DOE. This is particularly critical as some of these sites contain structures and other uncommon aboriginal features that present more opportunities to investigate aboriginal lifestyles. 


\section{THE ENVIRONMENT}

\section{Overview}

Pahute Mesa is a broaa open volcanic plateau which includes the northwest portions of the Nevada Test Site. This area ranges in elevation from 1750 to $2241 \mathrm{~m}$ and the predominate vegetation is pinyon-juniper woodland and open sagebrush. Until the advent of the Neilis Gunnery Ranges and subsequent underground atomic tesiing, this area was little used by Euroamericans, but the pine nuts and other food resources were important resources for aboriginal populations. Ethnographically, Pahute Mesa was an important pine nut gathering area for the western Shoshone and southern Paiute. This ethnographic use of the area represents the culmination of the development of prehistoric societies interaction with the arid southern $\mathrm{Ne}$ vada environment which has occurred over the last 10,000 or so years.

Archaeological interest in the U19au drill site occurred after it was selected for the site of an underground nuclear test in 1983. An archaeological reconnaissance of the pad area recorded 40 archaeological sites; an additional four were recorded during the survey of the access road. Many of these sites are unique because they contain features rarely available for study and were determined to be potentialIy eligible for inclusion in the National Register of Historic Places. In 1986, DOE decided that development of this event site should proceed, and many of the archaeological sites discovered could not be avoided. They requested DRI to develop and implement data recovery at these sites.

\section{Introduction}

Lonnie C. Pippin

To fully understand the nature of cultural resources on Pahute Mesa, we must first understand the environmental context of those cultural resources. This is important because variability in that environmental context influenced the behavior that produced those re- sources. The environmental context includes all the characteristics and processes of the lithosphere, biosphere, and atmosphere and should be viewed from both a site-specific and a regional perspective. The natural environment, therefore, consisted if the plants and animals used for food; the physiographic features that provided shelter, water, mineral and toolstone resources; and the landforms on which people lived. Like culture, the natural environment is dynamic. Not only did it change through time, but also it changed the way it influenced the nature of cultural resources. Just as the natural environment influenced the nature of culturci development, that cultural development equally influenced the nature of its natural environment. Consequently, the consideration of the relationship between the natural environment and cultural resources should be an integral part of research designs. Just as cultures may influence their natural environment, they may also influence cultural development in adjacent areas by such processes as cultural exchange, technological development, demography, and epidemiology. Hence, the consideration of a cultural resource's environmental context should also include its cultural setting.

\section{The Natural Setting}

\section{Physiography and Geology}

Pahute Mesa is a large east-west-trending, step-faulted, volcanic plateau that traverses the extreme northwestern portion of the Nevada Test Site and portions of the Nellis Air Force base Bombing and Gunnery Range (Figure 2-1). It rises in elevation from about $1750 \mathrm{~m} \mathrm{(5740} \mathrm{ft)} \mathrm{around} \mathrm{the} \mathrm{bases} \mathrm{of} \mathrm{Black}$ Mountain, Quartz Mountain and Tolicha Peak toward the west to $2296 \mathrm{~m}$ (7530 ft) at Echo Peak on Split Ridge in the east. Slightly farther east of Split Ridge, Pahute Mesa joins Rainier Mesa which rises to a maximum elevation of $2341 \mathrm{~m}$ (7679 ft) and marks the southern extent of the north-south-trending Belted 


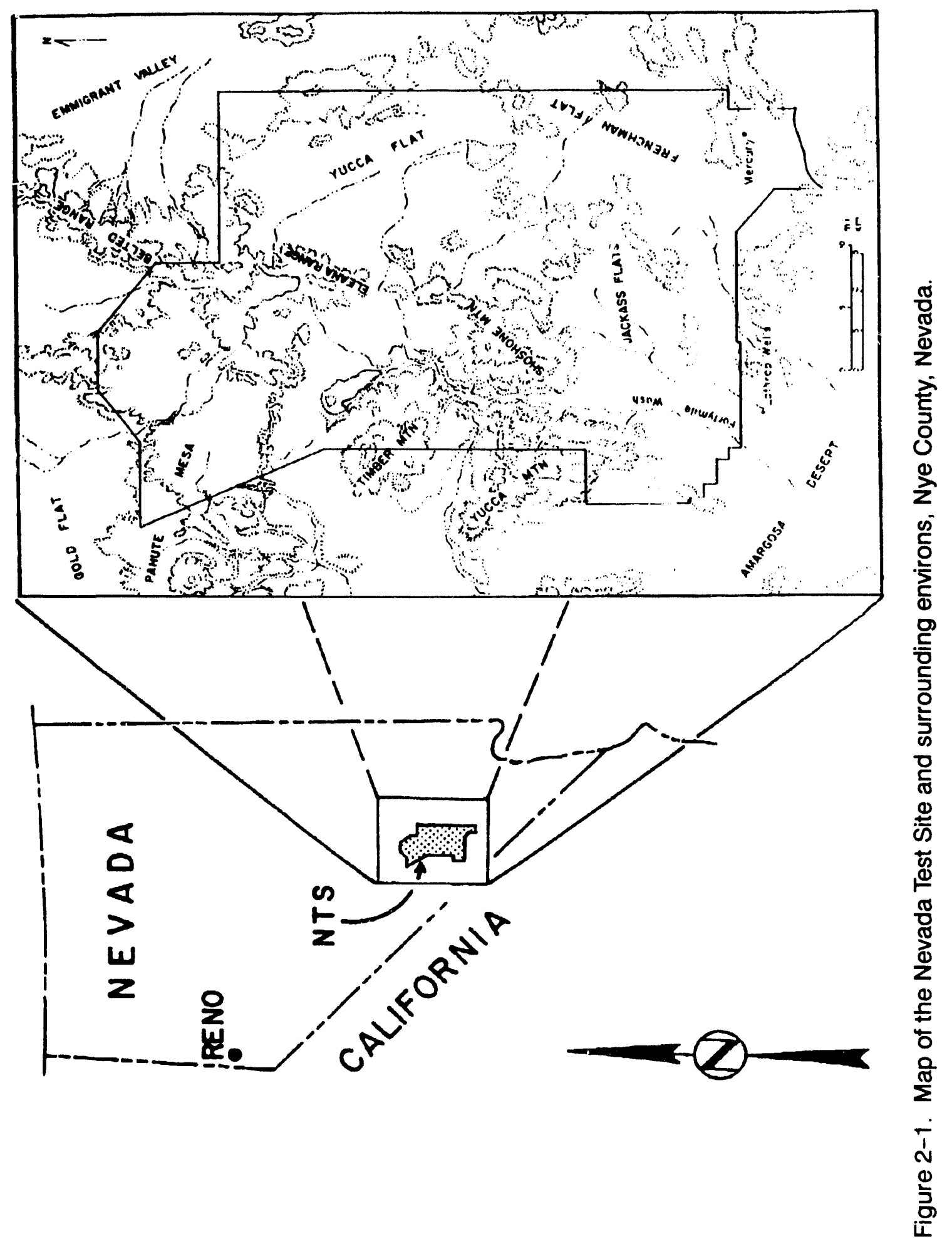


Range (Figure 2-2). The plateau's southern margin is clearly marked by the steep slopes of the Timber Mouritain caldera (Byers et al. 1976; Byers and Barnes 1976). Its northwestern boundary is more difficult to define as the cuesta gently slopes into the southwestern portion of Gold Flat. Toward the north and northeast, Pahute Mesa is marked by more precipitous slopes into Gold Flat and Kawich Valley; its northern boundary is less clear, however, where it joins Saucer Mesa of the southern Kawich Range and Rainier Mesa of the southern Belted Range.

Thirsty Canyon, which eventually flows into the Amargosa River and Death Valley, drains the southwestern portion of Pahute Mesa and provides a natural route of travel to the Oasis Valley-Beatty area $25 \mathrm{~km}$ (16 miles) to the southeast of the study area. Fortymile Wash, another major tributary of the Amargosa River, is a natural route of travel to the Ash Meadows area in the Amargosa Desert. It drains surface runoff along the southern margin of Pahute Mesa via several steep-walled but relatively short canyons entrenched into the mesa's edge. Most surface runoff from Pahute Mesa, however, drains toward the north. Silent Canyon, leading to Gold Flat, is the largest and longest of these northern drainages, but others include Grass Spring Canyon, another drainage leading to Gold Flat, and Lambs Canyon, Gritty Gulch, and Kawich Canyon, all leading to the southern portion of Kawich Valley. These drainages, along with limited faulting, have produced a landform that, although macrotopographically resembling a cuesta, is actually characterized by a series of small to rather prominent, north-south-trending, flat-topped ridges separated by shallow alluvial valleys, fault scarps, or, occasionally, steep canyons.

Pahute Mesa is composed of volcanic rocks from at least four separate volcanic centers. The earliest rocks, represented by the Tub Springs and Grouse Canyon members of the Belted Range Tuff, were apparently ex- truded as ash flows and pumice-rich, air-fall tuffs from the Silent Canyon Volcanic Center during late Miocene time some 13 to $15 \mathrm{mil}-$ lion years ago (Noble et al. 1968; Byers et al. 1976; Orkild, Sargent, and Snyder 1969). These rocks are most exposed in the Big Burn Valley area directly below and southeast of Pahute Mesa, but also occur along the western edge of Dead Horse Flat, where the mesa joins the Kawich Range, and in the Gold Meadows area north of Rainier Mesa (Sargent and Orkild 1973; Orkild, Sargent, and Snyder 1969). Unlike the cther volcanic centers in the region, where the caldera areas are relatively well defined, the Silent Canyon caldera is largely obscured by younger, unrelated volcanic rocks. Late Miocene rocks belonging to the Tiva Canyon and other members of the Paintbrush Tuff, extruded from the Claim Canyon volcanic center around 12 million years ago, are exposed along the southern edge of Pahute Mesa in the vicinity of Picture Rock and Blacktop Buttes.

On the eastern half of Pahute Mesa most of these later volcanic rocks, including the widespread Ammonia Tanks and Rainier Mesa members of the Timber Mountain Tuff, were extruded from the Timber Mountain volcanic center during early Pliocene time (11 million years ago). However, on the western half of Pahute Mesa and in certain areas west of Dead Horse Flat and in the upper Silent Canyon area, these Timber Mountair tuffs are overlain by late Pliocene rocks of the Black Mountain volcanic center. Finally, early Quaternary basalts occur as lava flows and dikes in the Basalt Ridge area of northwestern Pahute Mesa.

Basal vitrophyres containing nodules of densely welded, glassy tuff (obsidian) locally occur within several members of the Thirsty Canyon Tuff as well as in the Ammonia Tanks and Rainier Mesa members of the Timber Mountain Tuff. These nodules, although generally relatively small, provided a valuable and highly sought-after source of stone for an- 


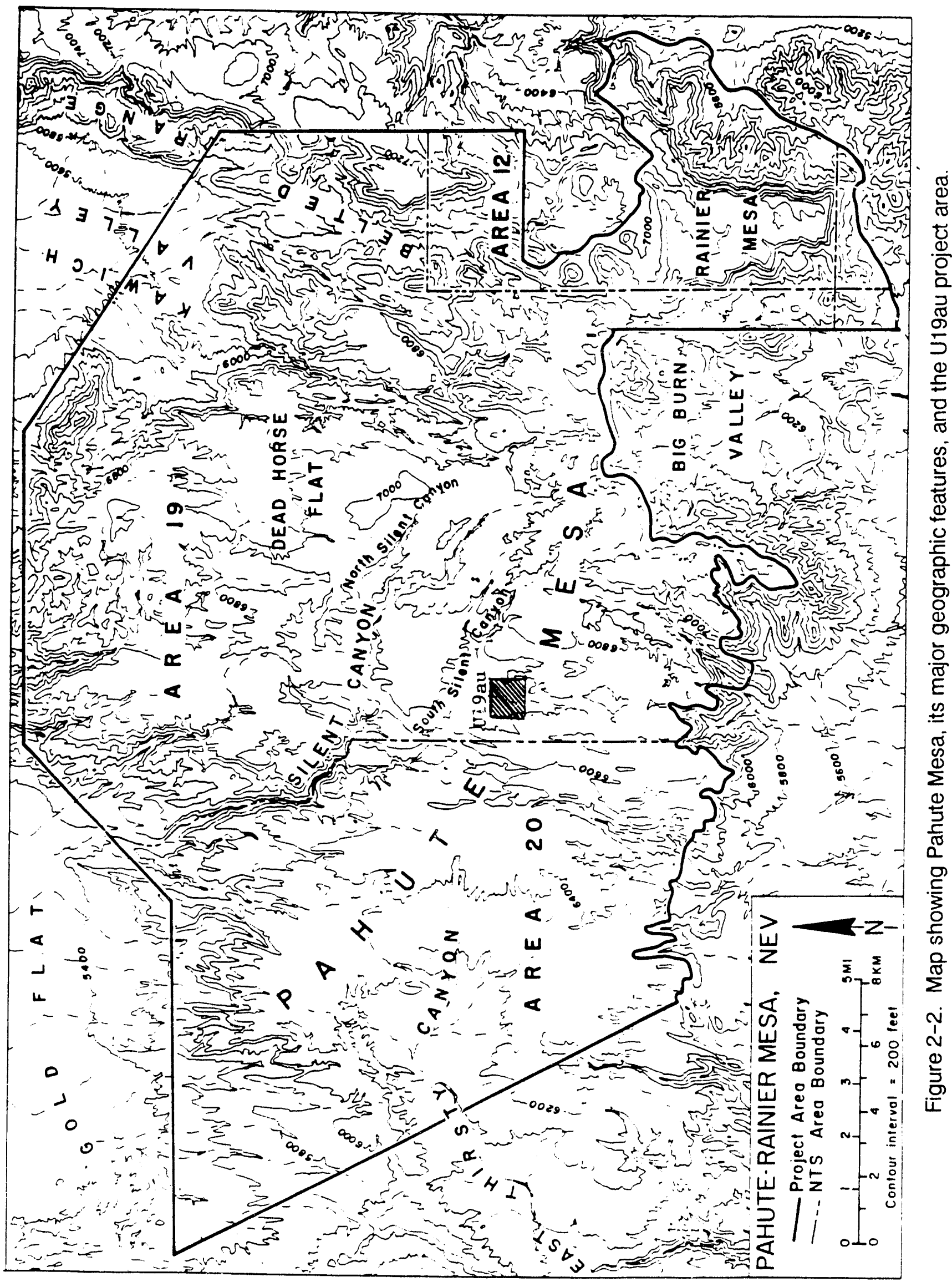


cient tool knappers. The specific distribution and rare earth geochemistry of these obsidian deposits is not well known, but examples collected from the Split Ridge and Falcon Canyon areas display a geochemistry distinct from other obsidian source: on the Nevada Test Site (Richard Hughes, personal communication 1985). Glassy deposits within the older volcanic rocks of Pahute Mesa are generally devitrified and probably were not used for toolstone. Nevertheless, opalized silica and silicified tuffs occurring within these volcanic rocks provide another source of knappable toolstone. Again the distribution of these siliceous cryptocrystalline rocks is not well known. Large tabular to blocky tuff suitable as toolstone for millingstones and manos, as well as for building material for caches, hunting blinds, and house structures, occurs throughout the volcanic deposits in the study area.

Most Quaternary (less than two million years old) deposition on Pahute Mesa is represented by unconsolidated alluvial, colluvial, residual, and aeolian sediments. The deeper, more conspicuous, occurrences of colluvium and alluvium were mapped by Oikild, Sargent, and Snyder (1969) and Sargent and Orkild (1973), but in general these deposits have been comparatively little studied. While Hoover, Swadley, and Gordon (1981) have mapped major divisions within the surficial deposits on the Nevada Test Site, their studies did not include Pahute Mesa. This is unfortunate because cultural resources may be buried in these surficial sediments. Substantial deposits of alluvium occur along Silent Canyon and most of its tributaries, as well as within several other unnamed and relatively broad mesa-top valleys. In most other areas, these Quaternary sediments occur as relatively thin deposits of sheet wash, aeolian loess, and residuum from weathering bedrock. Turbation and frost heaving are relatively high in these thin deposits and may hide a variety of cultural rema:ns, including the most recent (e.g., buried 50 caliber shell casings).

Although essentially no stratigraphic work has been done on the Quaternary sediments of Pahute Mesa, limited exposures in borrow pits, gullies, and archaeological test excavations have been examined. These limited observations indicate that little, if any, late Pleistocene sediment may be present on the mesa, a situation consistent with the results of J. O. Davis (1978, 1983a, 1983b, 1985) in central and northern Nevada. Apparently, runoff during the late Pleistocene carried sediments off the mesa. However, as effective precipitation decreased after about 18,000 years ago, sediment began to accumulate. The bulk of the sediment on Pahute Mesa seems to be less that 5,000 years old or so as it lacks the mid-Holocene soil (Toyeh Soil of Morrison 1964; soil S5 of Haynes 1967). The apparent absence of older Holocene sediments may indicate that episodes of stripping and eroding of soil from the mesa occurred at intervals during the Holocene. In a few places, older redder sediments are buried beneath these younger Holocene deposits. These redder sediments are undated, but they may have been deposited during the last interpluvial interval, about 75,000 to 125,000 years ago.

\section{Vegetation}

Plants provided a substantial part of the diet of both the prehistoric and historic aborigines who inhabited southern Nevada, and the distribution of vegetative resources greatly influenced their settlement patterns (Steward 1938). Beatley (1976:58-68, fig. 3) describes the distribution and composition of three major vegetation communities on and around Pahute Mesa: the black sagebrush community, the big sagebrush community, and the pinyon-juniper woodlands. Table 2-1 lists the maximum ground coverage in each of these communities. Although it is convenient to categorize the terrestrial vegetation in the 
study area according to these three zonal associations, plant species are distributed according to their individual ecological requirements, and boundaries between these zones are often vague (Daubenmire 1966; Mclntosh 1967; Whittaker 1967). Similarly, the aborigi- nal populations that occupied this region undoubtedly relied on selected plants for their sustenance. Consequently, the distribution of hoth individual species and overall plant communities is important to understanding ancient cultural systems.

Table 2-1. Percentage of Ground Covered by Trees, Shrubs, Herbaceous Perennials, and Winter Annuals on Pahute and Rainier Mesas, Southern Nye County, Nevada.*

\begin{tabular}{lrrr}
\hline Vegetation & \multicolumn{3}{c}{ Ve g e t a ti o n C o m m un it y } \\
\hline Type & Black Sagebrush & Big Sagebrush & Pinyon-Juniper \\
Trees/Shrubs & $37.3 \%$ & $32.6 \%$ & $34.8-43.9 \%$ \\
Perennial Herbs & $3.8 \%$ & $6.6 \%$ & $7.0-31.1 \%$ \\
Winter Annuals & $5.3 \%$ & $7.7 \%$ & $0.0-15.7 \%$ \\
Total Coverage & $46.4 \%$ & $46.9 \%$ & $41.8-90.7 \%$ \\
\hline
\end{tabular}

* Data from Beatley (1976:58-64)

\section{Black Sagebrush Community}

Black sagebrush (Artemisia nova) forms a low, closely spaced, shrub cover on shallow, residual soils between about 1525 and 1830 $\mathrm{m}$ (5000 and $6000 \mathrm{ft}$ ) in elevation. This community is especially well developed in the northwestern portion of Pahute Mesa, but occurs throughout the project area in a mosaic with the big sagebrush community. Stickyleaved rabbitbrush (Chrysothamnus viscidiflorus ssp. puberulus) is the most commonly associated shrub, but Nevada ephedra (Ephedra nevadensis) and banana yucca (Yucca baccata) are also consistently, if only sparsely, present.

Hedgehog cactus (Echinocereus ongelmannii var. chrysocentrus and $E$. triglochidiatus) and the rarer dagger cholla (Coryphantha vivipara var. rosea) are the most commonly encountered cacti. Squirreltail (Sitanion hystrix), needlethread grass (Stipa speciosa), and Indian rice grass (Oryzopsis hymenoides) are the predominant native grasses. The introduced cheat grass (Bromus tectorum) now dominates in disturbed areas and on active colluvial slopes. Several herbaceous annuals and perennials, which may have been important food or medicinal resources for aboriginal hunters and gatherers, also occur in this community. Among these are wild parsley (Lomatium nevadense), balsam root (Balsamorhiza hookeri), stinkweed (Cleomella hillmanii), globe mallow (Sphaeralcea ambiqua spp. monticola), and wild onion (Allium nevadense).

\section{Bio Sagebrush Community}

Big sagebrush (Artemisia tridentata) becomes the dominant ground cover on the deeper, better drained soils at elevations between 1525 and $1830 \mathrm{~m}$ (5000 and $6000 \mathrm{ft}$ ). Big sagebrush occurs in narrow ecotones with blackbrush (Coleogyne ramosissima) and/or spiny hop-sage (Grayia spinosa) or with four-wing saltbush (Atriplex canescens) and/or winterfat (Ceratoides lanata) in areas below Pahute and Rainier mesas. Like most areas on the mesa, big sagebrush communities in the project area occur in a mosaic with black sagebrush or as parklands in an open pinyon-juniper woodland.

Other shrubs associated with big sagebrush on the mesa top include winterfat, sticky-leaved rabbitbrush, Mormon tea 
(Ephedra viridis), horsebrush (Tetradymia glabrata), wild buckwheat (Eriogonum microthecum), and cliffrose (Cowania mexicana), but these taxa usually comprise less than five percent of the total shrub coverage. Flabbitbrush (Chrysothamnus nauseosus) may codominate or even dominate along washes through valley bottoms on the mesas. Cliffrose, service berry (Amelanchier utahensis), bitterbrush (Purshia glandulosa), snowberry (Symphoricarpos longiflorus), and wormwood (Artemisia ludoviciana) grow along the more rocky washes and around bedrock outcrops. Common native grasses found in the big sagebrush community include speargrass (Stipa comata) and squirreltail.

Juniper and Pinvon-Juniper Woodlands

Above about $1830 \mathrm{~m}(6000 \mathrm{ft})$ in elevation, juniper (Juniperus osteosperma) and pinyon (Pinus monophylla) enter the sagebrush communities. In most areas on Pahute and Rainier mesas above $1830 \mathrm{~m}$, pinyon and juniper form a more or less open woodland with parklike areas of big or black sagebrush. Many of the shrubs found in the sagebrush communities (e.g., ephedra, sticky-leaved rabbitbrush, horsebrush, snowberry, service berry, bitterbrush, and cliffrose) form the understory in the pinyon-juniper woodlands. Additional shrubs that are more or less restricted to this woodland, particularly along bedrock exposures and canyon edges, include squaw or lemonade berry (Rhus trilobata), squaw currant (Ribes cereum), gooseberry (Ribes velu. tenum), mountain mahogany (Cercocarpus ledifolius), cream-bush (Holodiscus microphyllus), linanthus (Linanthus nuttallii), prickly phlox (Leptodactylon pungens var. pulchriflorum), and Gambel oak (Quercus gambellii).

Beatley (1976:65-67) lists over 160 different taxa of perennial and annual herbs that grow in the pinyon-juniper woodlands of Pahute Mesa. Known food resources among these taxa include the roots or bulbs of the wild onion (Allium atrorubens), wild parsley (Lomatium foeniculaceum spp. fimbriatum), mariposa lily (Calochortus bruneaunis), buttercup (Fritillaria atropurpurea), stickweed (Lappula occidentalis), and broomrape (Orobanche corymbosa); the seeds of stickweed, gromwell (Lithospermum ruderale), goosefoot (Chenopodium atrovirens, C. berlandieri var. zschaskei, C. fremontii, C. incanum, C. gigantospermum, C. leptophyllum), stickleaf (Mentzelia albicaulis, M. montana); and various grasses (Agropyron spicatum, Stipa pinetorum, Elymus cinereus).

\section{Pale jenvironments}

Using evidence from packrat middens found at various localities on and around the Nevada Test Site, Spaulding (1983a) has postulated that major changes have occurred in the area's climate during the last 45,000 years. He hypothesizes that 45,000 years ago average annual temperatures were at least $2^{\circ}$ $\mathrm{C}$ lower than today and winter precipitation exceeded current values by as much as 20 percent. By about 18,000 years ago, during maximum glacial conditions, average summer temperatures are reconstructed at $6^{\circ}$ to $8^{\circ} \mathrm{C}$ less than those of today with average annual precipitation exceeding present quantities by about 30 to 40 percent. According to Spaulding (1983a), postglacial warming probably regan shortly thereafter, and, by about $9,00 J$ to 10,000 years ago, average annual temperatures and precipitation approached present values. Spaulding's (1983a) reconstructions for full-glacial climate fall between previous scenarios that envision a slightly more moist and less cold pluvial climate (Antevs 1952; Broecker and Orr 1958; Mifflin and Wheat 1979; Snyder and Langbein 1962; Van Devender 1973) and those that postulate a drier and colder late glacial maximum (Brakenridge 1978; Dohrenwend 1984).

LaMiarche's $(1973,1974)$ studies of treeline changes in the White Mountains of eastern California and southwestern Nevada have provided a good record of fluctuations in temperatures of southern Nevada during the last 
6,000 years - a time period poorly represented in Spaulding's (1983a) packrat midden record. Although adequate precipitation is probably the most important aspect in the elevation of lower tree line, the position of upper tree line in this and other high mountain ranges appears to be more closely related to warm-season temperatures (LaMarche 1973:647-652). Tree-ring-dated remains of bristlecone pines (Pinus longaeva) now grovsing above present tree line in the White Mountains indicate that between 6,000 and 4,000 years ago summer temperatures may have been as much as $2^{\circ} \mathrm{C}$ higher than today's. Summer cooling, resulting in a lowering of tree line, apparently began about 3,500 years ago and lasted until about 2,500 years ago. This was followed by a period of continued cool temperatures but apparently drier conditions, as evidenced from fluctuations in lower tree line. Another major drop in tree line, probably reflecting the onset of cold and dry conditions during the neoglacial, occurred between about 800 to 400 years ago. Finally, the welldocumented mid-nineteenth century warming trend (Brinkmann 1976; Mitchell 1961:247-149, figs. 1, 2, 4; Reitan 1974) was reflected by high reproduction rates of bristlecone pines and the establishment of scattered seedlings at higher elevations during the past 100 years (LaMarche 1973:653-658; LaMarche 1974, fig. 5).

Although incomplete, our knowledge of vegetation change on the Nevada Test Site during the terminal Pleistocene and Holocene epochs has increased dramatically with the development of packrat midden studies in the surrounding region (Baker 1983:121-123; Martin and Mehringer 1965; Mehringer 1977; Spaulding, Leopold, and Van Devender 1983; Van Devender and Spaulding 1979). Early records of fossil pollen from Searles Lake, California (Leopold 1967, 1970; Roosma 1958), and Tule Springs, Nevada (Mehringer 1967), reflect a considerable expansion of woodlands across the Mojave Desert to the south of Pahute Mesa during the Wisconsin glacial maximum about 18,000 years ago. Mehringer (1967:189-192, fig. 38) postulated that a marked change from juniper-sagebrush to sagebrush-shadscale vegetation occurred about 12,000 years ago in the Las Vegas Valley.

This reconsstruction of terminal Pleistocene vegetation in the vicinity of the Nevada Test Site is confirmed by dated packrat middens from Owl Canyon near Ash Meadows (Mehringer and Warren 1976:125) and from the mountains around Frenchman Flat (Wells and Jorgensen 1964:Table 1). These middens, now situated in areas inhabited by Mojave Desert shrubs (Larrea tridentata and Ambrosia dumosa), contained abundant remains of juniper (Juniperus osteosperma). In fact, until recently, most glacial-age macrofossil records from the Mojave Desert contained evidence of woodlands at lower elevations (Spaulding, Leopold, and Van Devender 1983; Van Devencler and Spaulding 1979). Nevertheless, the rniddens also indicate that these woodlands differed considerably from present woodland plant associations (Spaulding, Leopold, and Van Devender 1983:273-276, fig. 14.7, Table 14.3). Hence, while some species (e.g., juniper) occurred more than $1000 \mathrm{~m}$ below their current limits, others were displaced less that $400 \mathrm{~m}$ or so, and some (e.g., shadscale [Atriplex confertifolia]) actually occurred much higher in elevation than they do today. Furthermore, Spaulding (1983a) has reported the existence of several Late Wisconsin packrat middens from the Specter Range, situated about $20 \mathrm{~km}$ southeast of Yucca Mountain, that completely lack woodland conifers. Rather they contain abundant macrofossils of desert sinrubs and succulents such as woolly scale-broom (Lepidospartum latisquamum), prickly pear (Opuntia sp.), matchweed (Gutierrezia microcephalla), desert almond (Prunus fasciculata), barrel cactus (Echinocactus polycephalus), horsebrush (Tetradymia cf. glabrata), twinfruit 
(Menodora spinescens), and Joshua tree (Yucca brevifolia), as well as shadscale. However, there is no evidence of frost-sensitive desert plants such as creosote bush, desert spruce (Peucephyllum schottii), or bursage (Ambrosia dumosa), and Spaulding (1983a) infers that a regional vegetation mosaic of cold desert shrub and woodland inhabited elevations beiow $1000 \mathrm{~m}$ (3300 $\mathrm{ft}$ ) in the Mojave Desert during the last part of the Late Wisconsin.

This generalization provides a picture of potential vegetative resources at the lower elevations on the Nevada Test Site at the time of human arrival in this region 11,000 to 12,000 years ago or so, but it does not provide a picture of the vegetation on Pahute Mesa nor vegetative changes during the later Holocene. Late Pleistocene packrat middens situated at $1810 \mathrm{~m}(5900 \mathrm{ft})$ in the volcanic. Eleana Range, $4 \mathrm{~km}$ south of Rainier Mesa, contain abundant quantities of pinyon and juniper along with mountain mahogany (Cercocarpus ledifolius), snowberry (Symphoricarpos sp.), sagebrush (Artemisia sec. Tridentata), bitterbrush (Purshia tridentata), desert sage (Salvia dorrii), prickly phlox (Leptodactylon pungens), and other woodland associates (Spaulding 1983b:90-91, Table 23). Limber pine (Pinus flexilis), present in middens dating 15,900 years ago, is absent in younger middens, and Spaulding (1983b:109) believes that the Eleana Range locality was near the upper limit of late-Wisconsin pygmy conifer woodlands. The lower elevations of Pahute Mesa probably also supported a pygmy conifer woodland at the time of the first human arrival in this area. Evidence from the Horse Thief Hills and Eureka View packrat middens in Eurska Valley (Spaulding 1980:35-38, Tables 5 and 6) indicates that the lower limits of this woodland might have been $1615 \mathrm{~m}$ $(5000 \mathrm{ft})$ or lower, but this border probably varied with exposure, substrate, and topographic position.
A subalpine forest might have covered the upper elevations of Pahute Mesa during the terminal Pleistocene. Limber pine was the dominant macrofossil in all of Spaulding's (1981:Table 38) Ice Age middens between 1860 and $2040 \mathrm{~m}(6100$ and $6690 \mathrm{ft})$ in the Sheep Range, and bristlecone pine (Pinus longaeva) occurred with limber pine between 2040 and $2400 \mathrm{~m}$ (6690 to $7870 \mathrm{ft}$ ) in elevation. Consequently, during glacial maximum conditions, these trees might have also occupied portions of Pahute Mesa. By 11,000 years ago or so, however, limber pine had retreated to above $2380 \mathrm{~m}(7800 \mathrm{ft})$ in the Sheep Range and, if it had ever been present, was probably absent on Pahute Mesa (Spaulding 1981:192). Spaulding (1981:192) notes that the absence of a Wisconsin-age fir-pine forest or: the Sheep Range is perplexing. Mehringer and Ferguson (1969:284-287) recorded the presence of white fir (Abies concolor) in a 12,000-year-old packrat midden at an elevation of $1910 \mathrm{~m}(6265 \mathrm{ft})$ in the Clark Mountains south of the Nevada Test Site, and today white fir grows with both pinyon (lower elevational limit) and limber pine (upper elevational limit) between 2620 and 2770 m (8600 and $9100 \mathrm{ft}$ ) on the Groom Range northeast of the Nevada Test Site. Consequently, glacialage vegetation on Pahute Mesa might also have included white fir.

Evidence for the establishment of and fluctuations in Holocene vegetation on Pahute Mesa is also extremely limited. Packrat middens, dating between 8300 and 7900 years ago, are reported from the Sheep Range over $100 \mathrm{~km}$ east of the study area, from the Marble Mountains over $200 \mathrm{~km}$ south of Pahute Mesa, and from northern Eureka Valley $130 \mathrm{~km}$ northwest of Pahute Mesa. The Penthouse 1 midden in the Sheep Range, dated at 8100 years B.P., was dominated by plants currently inhabiting this site and, except for a few surviving junipers, lacked the woodland mesophytes that characterized 
that area during the Late Wisconsin (Spaulding 1981:98-103, 192, Table 14). Similarly, packrat middens in the Marble Mountains and in northern Eureka Valley, dated at 7,930 years B.P. and 8,330 years B.P. respectively, also were characterized by flora currently growing at those sites (Spaulding 1980:34, Tables $4 a$ and 9). Consequently, except for a few extralocals, vegetation was probably reaching its present composition and zonation by about 8000 years ago. In the Mojave Desert, although creosote bush was probably near its current distribution by this time, bursage, the other major component of that area, probably did not reach its current distribution until about 6,000 or 7,000 years ago (Spaulding 1980:43-47). Evidence also points to minor fluctuations in vegetative composition during the middle Holocene. Two packrat middens, situated in current desert vegetation about $150 \mathrm{~m}$ below the present woodland boundary in the Sheep Range, contained the remains of pinyon and juniper and were dated at 5210 years B.P. (the Desert View Site) and 3520 years B.P. (the Basin Wash Site). Using this evidence, Spaulding (1981:209; Spaulding 1983b:120) postulates increased effective moisture during the middle Holocene.

\section{The U19au Site}

The event site for U19au is located in a shallow north-trending valley about four $\mathrm{km}$ north of the south rim of Pahute Mesa at an elevation of about $1980 \mathrm{~m}(6500 \mathrm{ft})$. This valley is drained by a series of unnamed, ephemeral tributaries of South Silent Canyon, one of the two major south flowing drainage systems for the mesa. The major stream flows through a small, steep--walled channel formed by a fault in the welded tuff bedrock approximately two $m$ below the floor of the valley. The west side of the valley is formed by a relatively uniform, gentle slope terminated by cliffs beyond the boundaries of the project area. The maximum elevation here is about $2020 \mathrm{~m}(6620 \mathrm{ft})$. The eastern side of the valley is formed by convoluted and stepped welded tuff cliffs creating numerous small valleys and level benches and ultimately a leveltopped ridge at about $2010 \mathrm{~m}$ (6600 ft) in elevation.

All of the major vegetation communities fourid on Pahute Mesa are found at U19au big sagebrush on the deeper alluvial soils of the valleys; black sagebrush on the shallow soils at the edges of the valleys and on the benches; and pinyon-juniper on the ridges, benches, and slopes.

\section{The Cultural Environment}

\section{The Present Setting}

In 1941, the U.S. Army established its Las Vegas Army Air Field School in Las Vegas and acquired over three million acres of land in Nye, Lincoln, and Clark counties for use as a gunnery and bombing range. As World War II drew to an end, the Army's school was deactivated. In May 1949, control of this area, now known as the Nellis Air Force Báse Bombing and Gunnery Range, was transferred to the U.S. Air Force (Bergin and Roske 1978).

The construction of the Nevada Test Site facilities began in January of 1951. However. the Atomic Energy Commission, in control at the time, did not officially withdraw the original 1,760-square-km (680-square-mile) test range (limited to Yucca and Frenchman flats and areas to the west) until February of 1952. The first nuclear test, code-named ABLE of Operation RANGER, was a one-kiloton device airdropped over Frenchman Flat on January 27, 1951 (Liverman 1977:12-13). Between that time and 1963, when the Limited Test Ban Treaty was ratiilied, there were numerous above-ground nuclear weapons tests conducted in Yucca and Frenchman flats. Many of the roads, steel towers, bunkers, and houses built to support these tests remain today.

During the early 1960s, the test site was expanded to include the eastern portion of Pahute Mesa. Also during this time, a series of nuclear cratering tests was condusted on the Nevada Test Site under the Plowshare pro- 
gram. The first and lai yest of these events, code-named SEDAN, was situated in the northeastern corner of Yucca Flat. That event excavated an impressive crater of approximately $340 \mathrm{~m}(1115 \mathrm{ft})$ in diameter and $98 \mathrm{~m}$ (320 ft) in depth. Other, smaller, cratering tests were situated on Buckboard Mesa directly south of Pahute Mesa and at the Spooner Event northwest of Trail Ridge on Pahute Mesa.

Since the ratification of the Limited Test Ban Treaty, all nuclear tests on Pahute Mesa have been conducted underground in vertical holes drilled into the bedrock. These tests have resulted in additional road networks across Pahute Mesa, and numerous drill pads, skid trails, subsidence craters, storage yards, and other installations.

The early federal withdrawal of the project area from public access has had several beneficial effects on the cultural resources located there. First of all, although unauthorized collection of antiquities has undoubtedly occurred since withdrawal, it is probably much less than in areas still open to public access. In addition, the Nevada Test Site, unlike other areas in the western United States, has not been subjectec' to extensive grazing and the other impacts (e.g., farming, mining, resiJential development) of modern society, and the vegetation there still largely reflects pristine conditions. Hence, not only is the natural context exceptionally well preserved, but so are the cultural resources. In addition, because of the requirements of designing nuclear tests and determining their effects, the Nevada Test Site is perhaps one of the best studied areas in the western United States. Extensive studies on the environmental setting and the changes to that setting have been conducted since federal land withdrawal (O'Farrell and Emery 1976).

\section{Historic Setting}

The Euroamerican historic period of the Nevada Test Site begins in 1849 when a party of emigrants wandered through the area on their way to California (Koenig 1967; Long 1950; Lingenfelter 1986). Although Worman (1969:5-6) and Long (1950:104) refer to a possibly earlier expedition by the Mormon Battalion, evidence for that expedition is restricted to a date (1847) and name (R. J. Byor) carved on a rock used in constructing a stone cabin at Cane Spring, and information on its original context is not available. Apparently, Pahute Mesa was never heavily used by Euroamericans. Nevertheless, since early emigrant routes passed near and mining and ranching occurred adjacent to Pahute Mesa, there was probably casual historic use of the area.

\section{The Aboriginal Cultural Context}

\section{The Numa}

When the first Euroamerican explorers and immigrants entered what is now southern Nevada, they encountered widely scattered groups of primitive hunters and gatherers who spoke different dialects of closely related Utoaztecan languages. These peoples usually called themselves the Numas, Numos, Numes, Nunas, but are now commonly referred to as Southern Paiute and Shoshone (Fowler and Fowler 1971:37). Although, early explorers often described these Native Americans as "miserable diggers" who represented "the lowest state of human existence, living not even in communities, but in the elementary state of families ..." (Fremont 1845:12), the Numa had a highly tuned and successful adaptation to a hard environment. A well-defined but flexible seasonal round permitted the Numa to coordinate the seasonal availability of plants and arimals into an overall subsistence-settlement strategy. Their demographic pattern usually centered around a semipermanent base camp where food, fuel, and water could be stored for consumption during the winter. Between early spring and fall, subsistence groups, often nuclear families, left their residential base in search of seasonally available resources. 
Steward (1938:93-99, 182-185) reports that between 1875 and 1880 at least nine Shoshone families or family groups maintained winter camps in the present bounds of the Nevada Test Site. These residential bases included: 1) Ungiakuda, situated two to three miles east of Ammonia Tanks; 2) Mutsi, 10cated on or adjacent to Pahute Mesa northwest of Ammonia Tanks; 3) Sivahwa, situated a few miles north of Mutsi; 4) Tuna'va, located at Whiterock Spring; 5) Wi:va_at Oak Spring; 6) Kuikun at Captain Jack Spring; 7) Tupipa at Tippipah Spring; 8) Hugwap at Car ə Spring; and 9) Pokopa at Topopah Spring just south of Shoshone Mountain in the northern end of Topopah Valley. Three of these population centers occur within or just adjacent to Pahute Mesa. The Native Americans occupying these residential bases, although classified as Belted Range Shoshone, were linked through intermarriage and cooperation with the Shoshone living near Beatty in Oasis Valley. In fact, Beatty Shoshone seasonally entered what is now the Nevada Test Site to gather Indian rice grass seeds along the northern bajada of Jackass Flats south of the project area, chia on Yucca Mountain in the far southwestern corner of the Nevada Test Site, wild rye seeds in the vicinity of Ammonia Tanks, and pinyon nuts on Pahute Mesa itself (Steward 1938:96). The fall rabbit drive, the only true communal economic activity of these people, was usually held in Yucca Flat south of Whiterock Spring and was attended by the Belted Range Shoshone, the Beatty Shoshone, and the Kawich Shoshone, and occasionally by the Southern Paiute from the vicinity of Ash Meadows. A fall festival or fandango held either at Wungiakuda or at Beatty, when rabbit populations were low in Yucca Flat usually preceded this rabbit drive (Steward 1938:98).

The Shoshone occupying the Nevada Test Site also had ties to the Southern Paiute of Pahrump Valley and Ash Meadows. Steward (1938:95) notes that the winter camp at
Cane Spring, called Pagambuhan by the Southern Paiute, had a mixed population and "was probably affiliated with the Ash Meadow Southern Paiute as much as with the Shoshone." Similarly, the Southern Paiute of Ash Meadows gathered pine nuts or hunted deer on Shoshone Mountain whenever the harvest in the Spring Mountains was poor and, conversely, invited the Shoshone to hunt deer or gather pine nuts in the Spring Mountains when the crop failed on Shoshone Mountain (Steward 1938:183-184). Both groups collected Indian rice grass seeds near Calico Hills in the southwestern portion of the Nevada Test Site, or near Big Dune in the Armagosa Desert when the Calico Hills crop failed.

Just as other groups utilized the Nevada Test Site environs, the Belted Range Shoshone who regularly lived there often traveled outside the area during their seasonal subsistence cycle. Furthermore, despite the lack of a rule for local exogamy or postmarital residence, the Shoshone residential bases usually consisted of blood-related. nonmarriageable persons, making Shoshone group composition highly fluid.

\section{Aboriginal Patterns of Resource} Procurement

Pine Nut Procurement - Several pine nut procurement strategies are represented in the ethnographic record. These range from the simple pattern of small social groups making short-term pine nut collecting excursions from a residential base located outside the pinyon-juniper woodland to the more complex strategy of concentrating residential bases in the pinyon-juniper woodland and using the pine nut harvest to support relatively large social groupings throughout the winter.

Steward (1933:241-242; Steward 1938: 52-53) has noted that, when pinyon nut crops were poor, the Owens Valley Paiute traveled to sinall, family plots, gathered whatever nuts were available, and then transported this harvest to their winter villages in the valley. Wheat 
(1967:14-15) describes a similar pattern for the Northern Paiute who occupied the Carson Sink. Because the mature nuts were gathered using wooden "pinyon hooks," conical carrying baskets, and various perishable sacks and mats, the archaeological remains produced by these activities are minimal (McGuire and Garfinkel 1976:83). Nevertheless, there are various modifications in the above pattern that would leave nonperishable archaeological remains in the resource zone.

While pine nuts are relatively easy to remove from dry mature cones, the immature cones are rather difficult to open unless subjected to a drying treatment. This could be accomplished by piling the cones on sunny slopes, heating them over or in camp fires, or roasting them in stone and/or grass-lined earth ovens (Dutcher 1893:381-382; Steward 1933:242; Stewart 1941:374; Wheat 1967:14). A hammerstone and anvil might also be used to open stubborn cones (Dutcher 1893:382). After unusually abundant harvest, the Owens Valley and other Northern Paiute groups cached excess nuts in grass, juniper-bark, pinyon-branch and/or rocklined and covered pits (Davis 1965, fig. 4a; Steward 1933:242; Stewart 1941:374; Wheat 1967:14). These features and artifacts might be preserved in the archaeological record.

Finally, temporary camps might be established in the pinyon woodlands during the nutting season, but abandoned as soon as the harvest was complete. An ethnographic example of this sort of campsite was observed by Dutcher (1893:379-380) when he accompanied the Panamint Shoshone in 1891. The campsite consisted of five or six circular structures or "corrals," with 60 to $90 \mathrm{~cm}$ (2 to $3 \mathrm{ft}$ ) high, vertical walls constructed of brush and pinyon branches. These corrals, each 2.5 to 3 $\mathrm{m}$ (8 to $10 \mathrm{ft})$ in diameter, were used as windbreaks during the night; occasionally, small hearths were maintained in the center of the structure. The archaeological remains of such a temporary camp would probably be quite similar to those discovered by Fenenga and Busby near Minden and Gardnerville, e.g., areas cleared of stones, firepits, rock circles, and scattered concentrations of discarded and lost artifacts (Fenenga 1975:figs. 1-7; Busby 1974).

When pinyon crops were abundant and winters were relativeiy mild, the Numa might establish more permanent winter settlements in the pinyon-juniper woodlands (Davis 1965:34-35; Steward 1933:239; Stewart 1941:371). These settlements differed from temporary campsites not only in the length of their occupation, but also in the activities and features associated with that occupation. The houses used at the residential bases were often more substantial and permanent than the temporary camp's windbreak or "corral." Steward (1933:242-263) describes the Owens Valley Paiute winter house as a "tentshaped" structure constructed by spanning a ridge pole, about $4.5 \mathrm{~m}$ (15 ft) long, between two uprights, about $2.5 \mathrm{~m}$ ( 6 to $7 \mathrm{ft}$ ) high. Using this ridge pole for support, a series of leaning posts were interlaced with pine boughs. The Mono Lake and Pakwidokado Northern Paiute, on the other hand, consiructed a conical-shaped house made of pinyon and juniper poles and boughs (Steward 1933:264; Stewart 1941:378).

The occupation of a residential base throughout the winter required stores of food either within the encampment or at various caches throughout the surrounding resource zone. Likewise, because the maintenance of a population over an extended period of time required foodstuffs other than pinyon nuts, we would expect the pine nut procurement strategy to be combined with the exploitation of other available resources. For example, the Owens Valley Paiute held communal rabbit, deer, and other large game drives during the fall after the pinyon harvest Steward (1933:254; Steward 1938:54). This practice was also followed by the Belted Range Shoshone and other Numic peoples around 
the project area, as well as by various Northern Paiute and Washo groups of western Nevada (Davis 1965:34-35; Downs 1966:27-32; Wheat 1967:14-15). Whether located in the pinyon-juniper woodland or in other resource zones, these semipermanent winter camps were the hub of many different subsistence activities.

Finally, the Northern Paiute of the western Great Basin, as well as other Great Basin groups, usually assembled for an annual social dance or fandango (Davis 1965:34; Harris 1940:53; Hopkins 1883:46-48; Steward 1933:320-321; Steward 1938:54, 60-61). Although these gatherings varied somewhat between groups, they usually included gambling, dancing, trading, philandering, courting, and praying for abundance of critical resources. Likewise, while some groups held their fandangos during the spring antelope hunt (Hopkins 1883:46-48), other groups gathered after the fall pine nut harvest (Steward 1933:320-321). Regardless of the season or their exact nature, these fandangos were commonly held at the larger semipermanent villages and attracted up to 300 people in some areas (Harris 1940:53; Steward 1938:237). Thus, they were effective mechanisms of social integration during which kinship ties and group solidarity were strengthened (Harris 1940:68-69; Steward 1938:90). Thomas (1972:146-148) has postulated that in addition fandangos operated as clearing houses for the dissemination of environmentally relevant information, and the location and abundance of critical resources, e.g. , water, small game, and pinyon nuts. Likewise, goods were probably redistributed at these gatherings.

One final aspect of pinyon nut procurement should be considered. Several scholars have emphasized the periodic unreliability of pinyon trees to produce nuts (Bettinger 1975:117-118; Stewaid 1938:27-28; Thomas 1973:160-161). This should not be interpreted to mean that pinyon nut yields were un. predictable. The life cycle of the pinyon tre? allows astute observers to predict the likely production of any specific crop as much as a year and a half in advance (Little 1938; Lanner 1981:76-81). By observing the new female cones, aborigines could tell where specific crops would be poor and where and when pinyon crops would provide a good harvest. The practice of sending scouts into the mountains to find the most promising pine nut area has been recorded for the Northern Paiute in the Carson Sink region, but undoubtedly applies to other Great Basin groups as well (Wheat 1967:12-13). Thus, by annual adjustments, the Great Basin Native Americans could buffer the impact of periodically poor crops.

Hunting Strategies - Steward (1938:33) felt that game procurement was only of secondary importance in Great Ejasin aboriginal subsistence activities, and this view has been widely echoed in the archaeological literature (Heizer and Baumhoff 1962:210-218; Thomas 1969:398-399). Nonethejess, as emphasized by Thomas (1983:41-57), the Numa exploited a large number and range of fauna, and the tactics used in this procurement undoubtedly hat a major influence on their adaptive strategies. Binford (1978) has distinguished between two major strategies of hunting game: the encounter and the intercept. Briefly, the encounter strategy, typically used to exploit low-density game, includes both the intentional and opportunistic search for game by traversing a region inhabited by that game. The intercept strategy, on the other hand, involves monitoring game movements, usually as herds, and ambushing this game at predetermined hunting locations.

Driving large game into enclosures where they could be conveniently shot with arrows is probably the most elaborate form of intercept hunting followed by Great Basin aborigines. Although usually mentioned in connection with antelope, Stewart (1941:366) notes that the Pakwidokado also hunted deer by this 
method, and Curtis (1926:71) records the $\mathrm{Pa}$ viotso as driving both deer and bighorn sheep "between very long wings paralleling a game trail, and so into a corral." Steward (1941:219) describes the features of central Nevada as consisting of a pole and brush corral with long wings converging to its opening, after noting earlier that the corrals built by the Owens Valley Paiute lacked the converging wings (Steward 1933:252). In some areas, women were stationed along the wings of a corral, or the sagebrush wings themselves might be set on fire, as game were driven into the enclosure (Lowie 1924:304-305).

The Southern Paiute of the Kaibab Plateau used a slightly different form of game drive. There, a long, $150 \mathrm{~m}$ (500 ft) barrier was constructed with an opening toward its middle, and antelope, driven toward the fence, were shot as they passed through this opening (Kelly 1964:50). Thomas and McKee (1974) discovered a prehistoric rock alignment in the Toiyabe Range of central Nevada that probably functioned in a similar fashion, and Pendleton and Thomas (1983) report a similar feature in Washoe County, Nevada. The Shoshone around Fort Ducherne dug a deep pit into which game were driven between the converging arms of a similar sagebrush drive (Lowie 1924:199). Another variation of this strategy is recorded for the Toedokado of the Carson Sink area. They braided a sagebrush rope "about the size of a man's wrist... and sometimes a mile lor ig" and stretched it over the tops of sagebrusi, thereby forming a corral (Stewart 1941:222). Finally, in Owens Valley, "men stationed 100 yards apart, hunted a large region, advancing with sage bark torches, firing brush and closing in to drive deer into a great circle, then shooting them down" (Steward 1933:253).

Despite this variability, all game drives were a communal effort (Steward 1938:34). Although some groups used dogs and/or fire, most systems relied on humans to drive and channel the game toward the enclosures
(Stewart 1941:366-367). Some drives covered as much as $32 \mathrm{~km}$ (20 miles) of terrain (Egan 1917:238-241). Shamanism was an important element of most game drives, and such activities as ceremonial dancing and smoking usually preceded the communal hunt (Hopkins 1883:55-57; Lowie 1924:303-305; Steward 1938:34). Consequently, the drives were usually held in the spring or fall when population massed at residential bases.

Driving game past concealed hunters was also a common intercept strategy of Great $\mathrm{Ba}$ sin aborigines (Stewart 1941:366-367). Muir (1894:320-322) recorded many stone enclosures on Great Basin summits that were probably used in hunting bighorn sheep (Pippin 1979). Ambushes of this nature are commonly recorded in the Great Basin archaeological record (Casjens 1974:11-12; Cressman 1942:66, 69; Fowler and Sharrock 1973:101; Heizer and Baumhoff 1962:20, 38-45, 52-56). Stewart (1941:366-367) notes that the Northern Paiute of western Nevada dug pits beside trails and springs where hunters lay waiting for game. Although this strategy might involve a large group effort, hunting parties probably consisted of only a few individuals.

The individual encounter strategy was probably the most common, but least efficient, hunting strategy of Great Basin aborigines. Steward (1938:36) associated this method particularly with the hunting of deer, although it was probably used for procuring all large game. Several groups used animalskin disguises while stalking game (Lowie 1909:185; Lowie 1924:195-197; Steward 1941:219), while others hid behind tufts of rabbitbrush (Kelly 1964:50) or simply tracked the game to opportunistic killing zones (Fowler and Fowler 1971:47). Because it lacked the need for facilities such as ambushes and game drives, this strategy of hunting resulted in rather low archaeological visibility (Thomas 1983:52-53) 
Small game were trapped and snared using a variety of techniques-spring-pole traps, nooses set on game trails and at rodent burrows, basket traps, deadfalls, and pitfalls (Steward 1933:254-255; Stewart 1941:368). Although burrowing animals could be dug, flooded, or smoked out of their homes while they were hiberr,ating or resting, most small mammals were probably procured throughout the year, largely by individual hunters using an encounter strategy.

But during the fall, usually in connection with other communal activities, large rabbit drives were held throughout the Great Basin (Chamberlin 1911:28; Lowie 1924:196-198; Lowie 1939:327; Kelly 1932:88; Kelly 1964:50-51; Steward 1933:253-254; Steward 1938:82-83, 97-98, 122, 163, 179). Most groups used a series of 2 to 10 large nets, 30 to $100 \mathrm{~cm}$ high and 15 to $30 \mathrm{~m}$ long, stretched across the valley floor and propped up with sticks (Wheat 1967:58-59, fig. 12). Part of the hunting party beat the brush, thereby chasing the rabbits toward the nets; the rest of the party stood behind the nets with clubs or bow and arrows. In the Salt Lake area, instead of using nets, the Shoshone surrounded and killed the rabbits with clubs or drove the rabbits into a series of loop snares (Steward 1938:179). Lowie (1924:197) noted that up to 40 rabbits per person could be obtained in one day. In some areas, as at Yucca Flat (Steward 1938:122), these drives lasted up to a month, but most groups gathered for only a week or so (Stewart 1941:368).

\section{The Prehistoric Cultural Context}

As pointed out in Nevada's Archaeological Element (Lyneis 1982a:2), "Nevada contains the record of one of the longest sequences of occupation by hunting and gathering peoples, and its prehistoric record provides a natural laburatory well-suited to the study of the population-resources balances which enabled hunter-gatherers to live in harmony with their environment for thousands of years." Anthropologists have long strived to understand the relationships between cultural behavior and its environmental context (Forde 1934; Harris 1977; Huntington 1914; Jochim 1981; Kroeber 1939; Steward 1938, 1955; Vayda and Rappaport i 968 ; Wissler 1926). The study of hunter and gatherer adaptations has the potential not only to identify the nature of these relationchips at a fundamental stage in human existence, but also to examine the processes through which these relationships may have shaped cultural development through time. The few hunters and gatherers remaining in the world today have been affected by the spread of modern technology. Furthermore, studies of existing societies reflect only a synchronic view of the processes behind hunter and gatherer adaptations. Although essential, these studies alone are not sufficient. Only the archaeological record provides the time depth necessary to address questions regarding diachronic and directional changes in these adaptations, and it is from this perspective that anthropologists may best understand the relationships between cultural behavior and its environment.

There are several existing summaries concerning prehistoric culture definition and chronology in southern Nevada. Several brief synopses for the IJevada Test Site and adjacent areas have been presented (Pippin and Zerga 1981:34-47; Reno and Pippin 1985:36-41; Pippin 1986:39-54). Warren, Knack, and Warren (1980) have written a cultural resource overview for the U.S. Bureau of Land Management's Amargosa-Mojave Basin Planning Units southwest of the Nevada Test Site, and Norwood, Bull, and Quinn (1980) have provided an overview of the adjacent Eureka, Saline. Panamint and Darwin regions of east central California. Similarly, Hauck et al. (1979) and Rafferty (1984) have prepared cultural resource overviews for the Las Vegas Valley area to the southeast of the 
Nevada Test Site. Finally, Lyneis (1982b) has recently reviewed the prehistory of the southern Great Basin.

The written prehistory of southern Nevada and adjacent California (Figure 2-3) is marked by a profusion of named and renamed "cultures", "industries," "phases," "traditions," and "periods" (Lyneis 1982b; Pippin and Zerga 1981; Warren 1967:169-172; Warren and Crabtree 1986). This chaotic state of culture definition and sequence construction is probably due to a scarcity of absolute dating, an emphasis on establishing localized chronologies, and the indiscriminate use of projectile point forms and other "diagnostic traits" as signifiers of ancient cultures. Thus, separate and often contrasting chronologies have been suggested for southeastern Nevada (Hauck et al. 1979:40; Rafferty 1984; Shutler 1967), Death Valley (Hunt 1960; Wallace 1977; Wallace and Wallace 1978), the Panamint Basin (Davis 1970), the Providence Mountains (Davis 1962; Donnan 1964), and the southern Mojave and Colorado deserts (Haury 1950:Table 12; Kowta 1969; Rogers 1939, 1958, 1966; Wallace 1962). Several of these chronologies are presented in Figure 2-3. For his work on the Nevada Test Site, Worman (1969:44-50) followed the terminology and dating presented by Rogers (1966:140).

The oldest cultural remains thus far discovered on the Nevada Test Site include two Clovis-style projectile points: one recovered by an amateur collector at the McKinnis Site (26Ny218) situated at the eastern edge of Timber Mountain (Worman 1969:32, 44-46, Plate 58 ) and the other found at $26 \mathrm{Ny} 3193$ along the terrace of Fortymile Wash near Yucca Mountain (Reno et al. 1989). These spear points are morphologically and technologically similar to projectile points usually found in association with Pleistocene megafauna and radiocarbon dated between 13,000 and 11,000 years ago (Davis and Shutler 1969; Tuohy 1968, 1969, 1974).
Worman (1969:46-47) postulates that the "San Dieguito Peoples" were the next to occupy the Nevada Test Site. This interpretation is based on cultural remains marked by large stemmed projectile points (Great Basin Stemmed Series) belonging to the Lake Mojave, Silver Lake, Haskett, and Parman styles. Because the artifact assemblages bearing these stemmed points often occur along the same pluvial lake shore localities as many of the so-called Clovis or Great Basin Concave Base projectile points, Warren (1980:19-20, 27-35) has lumped both under the rubric of the Lake Mojave Period and considers them to be contemporaneous. The assemblages marked by Great Basin Stemmed projectile points, however, are poorly dated. Warren (1980:19-20) uses radiocarbon dates from the C.W. Harris Site (Warren 1967:179-180, fig. 1) and Lake Mojave outlet (Ore and War. ren 1971:2561) to argue that these remains might be as much as 11,000 years old, but these dates are few and are not in direct association with the cultural remains. Recent radiocarbon dates from the Fort Inwin area (Dave Ferraro, personal communications 1986) and from Smith Creek Cave (Bryan 1979:186-191, 198-205) appear to support Warren's argument.

Although most researchers agree that the Lake Mojave/San Dieguito cultural materials are relatively early in age, they adamantly disagree on the placement and definition of the later, so-called Pinto or Little Lake remains. The Pinto Basin Complex was originally defined by Campbell and Campbell (1935) from cultural remains scattered along the ancient terraces of the Pinto River, about 200 miles south of the Nevada Test Site. However, stemmed, indented-base projectile points similar to those from the Pinto Basin have been found well outside the Mojave Desert (Lister 1953), and the terms Pinto and Little Lake Series have become loosely applied to a wide variety of projectile points from the Great Basin (Hester 1973:26-28). Thomas (1981) 


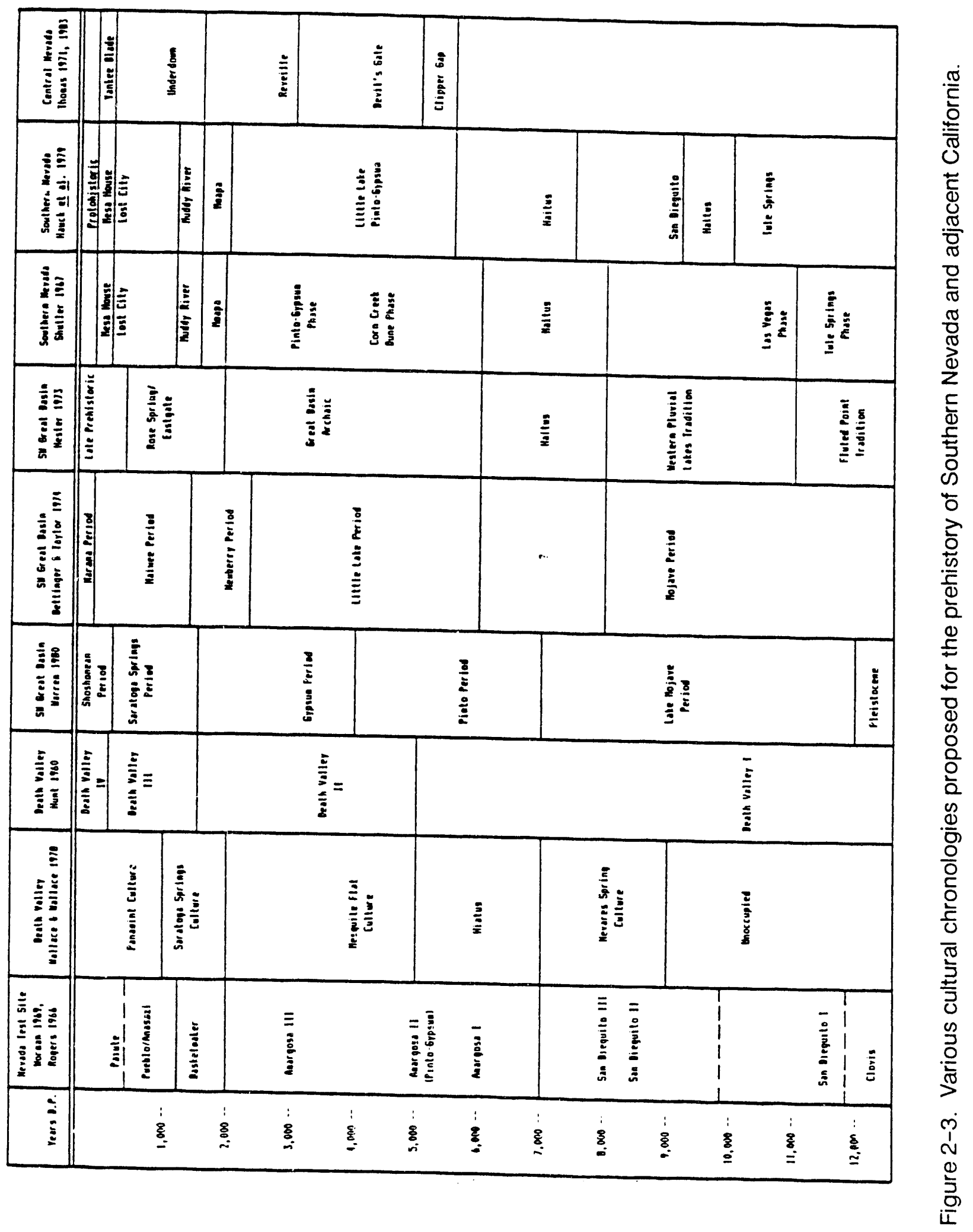


has suggested that the term Gatecliff Split Stem be used for the stemmed, indentedbase projectile points from the Central Great Basin; the more northern varieties have been called Bare Creek Series (O'Connell and Ambro 1968:1076) and Silent Snake Bifurcate Stem projectile points (Layton 1970:240-243).

These typological problems have had a noticeable effect on the dating and interpretation of the Pinto cultural assemblages. Absolute chronometric dates are not available for most Pinto sites in the Mojave Desert, but because these remains are commonly found with the Great Basin Stemmed assemblages on the shores of ancient pluvial lakes and rivers, some scholars (Antevs 1952; Campbell and Campbell 1935; Susia 1964; Warren 1980 ) have postulated that they must be quite early in age and reflect a continuum from the Lake Mojave or San Dieguito era. Other researchers (Wallace and Wallace 1978; Hester 1973; Bettinger and Taylor 1974), however, point to the better dated, but technologically different, stemmed and indented-base projectile points from archaeological sites in the central and northern Great Basin (Hester 1973:26-28). They argue that Pinto Series projectile points date much later and that there might have been an occupational hiatus between the San Dieguito and Pinto periods (Figure 2-3).

Worman (1969:47-48), following Rogers (1966), refers to the makers of the Pinto-, Elko-, and Gypsum-style projectile points as the Amargosans. In Death Valley, however, these projectile points are interpreted to reflect the Mesquite Flat Culture (Wallace and Wallace 1978:4-12). Warren (1980:35-49) and Bettinger and Taylor (1974) would place these points into two separate periods: the Pinto or Little Lake Period and the Gypsum or Newberry Period. Other prehistorians have lumped these atlatl dart points into the Great Basin Archaic (Hester 1973:fig. 25).

Few archaeological sites in the Mojave Desert contain either Gypsum- or Elko-style projectile points. Once thought to represent a weapon tip used to hunt Pleistocene megafauna (Harrington 1933:113-120), the Gypsum style of dart point is known from a stratigraphic context at only three sires in southern Nevada: Gypsum Cave (Harrington 1933), Etna Cave (Wheeler 1973), and O'Malley Shelter (Fowler, Madsen, and Hattori 1973). Radiocarbon dates from these sites date the Gypsum style of dart point between 4,000 and 2,900 years ago (Heizer and Berger 1970:14; Fowler, Madsen, and Hattori 1973:Tables 1, 4). This time range, of course, overlaps that for the Gatecliff style of dart point (Thomas 1981), and comparison of specimens from O'Malley Shelter reveal that these two point styles may also overlap typologically (Fowler, Madsen, and Hattori 1973:figs. 9a-j, 12a-g).

The Elko Series of dart points includes four varieties: the Elko Eared, Elko Contracting Stem (typologically identical to the Gypsum style), Elko Side-notched and Elko Corner-notched (Hester 1973:29-31). All four have been found on the Nevada Test Site. Elsewhere in southern Nevada and adjacent California, Elko Series dart points have been found stratigraphically mixed with Gypsum points (Lanning 1963:268, Table 3; Clewlow, Heizer, and Berger 1970:Table 2); stratigraphically above deposits dated at 3,870 years B.P. (Shutler, Shutler, and Griffith 1960:Plates 3, 7); and scattered throughout the deposits of O'Malley Shelter, the Scott Site, Newberry Cave, and Civa II Rockshelter (Busby 1979:Table 3c; Fowler, Madsen, and Hattori 1973: Tables 1, 4, 27; Smith et al. 1957). Hester (1973:31) has concluded that the Elko Series of projectile points reflect a time span between 4,000 and 1,500 years ago.

Worman (1969:48-49) uses the introduction of the bow and arrow, inferred from small projectile point sizes, to mark the transition between the Amargosa Complex and Basketmaker Culture on the Nevada Test Site. This same change in projectile point sizes charac- 
terizes what other researchers in the area have termed the Saratoga Springs Period (Wallace and Wallace 1978:12-21; Warren 1980:48-52), Haiwee Period (Bettinger and Taylor 1974:19), Death Valley III Period (Hunt 1960:136-140), or Rose Spring and Eastgate Period (Hester 1973:fig. 25). As Hester's terminology reflects, these small cornernotched and contracting-stem points have been called the Rose Spring arid Eastgate stvles, or simply the Rosegate Series. Rose Spring Corner-notched points occur in strata dated about 900 years ago at O'Malley Shelter (Fowler, Madsen, and Hattori 1973:Tables 1, 4) and are found stratigraphically above Elko Series projectile points at the Rose Springs Site (Lanning 1963:Table 3). Elsewhere in the Great Basin, the Rosegate styles have been dated between about 1,500 and 600 radiocarbon years ago (Hester 1973:31-34).

Anasazi sttery found on the Nevada Test Site indicates that these pueblo peoples also may have entered Pahute Mesa, raising intriguing questions about the interaction between the pueblo peoples and locally developing Archaic populations. From the associations of Intermountain Brownwares with Anasazi pottery at several archaeological sites, we suspect that the Numa and Anasazi knew one another and probably interacted (Shutler 1961a:11, Table 7; Worman 1969:43). Their contemporaneity is also indicated by Burial No. 3 at Lost City where a Southern Paiute Brownware jar and an Anasazi Washington black-on-gray bowl were both grave goods for the same individual (Shutler 1961a:29; Shutler 1961b).

\section{Project History}

Archaeological sites were first recorded in and around the U19au drill site area during an archaeological reconnaissance conducted for the access road to drill site U19ao in June of 1983. During this reconnaissance, 12 archaeological sites were recorded along the access road and another 4 in the U19ao drill pad area itself (Reno 1983), and DRI made recommendations concerning these archaeological sites. However, since the DOE did not proceed with the development of this drill site, the recommendations were not implemented.

In October of 1983, DOE requested DRI to conduct archaeological reconnaissances of several proposed drill sites on Pahute Mesa, including U19au (known at the time as U19as). Field work was conducted in the latter half of October and resulted in the discovery of a large complex of prehistoric and historic aboriginal sites. Notable among these sites were identifiable windbreaks and other habitation features seldom found in the archaeological record. The cultural material observed at the U19as [au] drill site was recorded as 40 archaeological sites -26 Ny 4015 through 26Ny4054 - (Figure 2-4 and 2-5) and included two of the sites along the access road to U19ao (Henton 1986:9). The division of the cultural material into these 40 sites was somewhat arbitrary as boundaries between the sites were often difficult to determine. Because of a change in DOE priorities, no further action was taken at U19as [au], and the reports of the surveys were left unfinished.

In spring of 1986, the Department of Energy renewed its interest in the U19as drill site, now officially known as U19au, determining that it was not in their best interest to avoid the archaeological resources in the valley near the drill site. Subsequently, DOE requested that DRI prepare and submit a data recovery plan to mitigate impacts from drilling a hole and detonating a nuclear device at the site. The first step was to complete the written report on the 1983 reconnaissance; this was submitted to DOE in the late spring of 1986 (Henton 1986). A data recovery plan was prepared and submitted to DOE in June of 1986. The details of the recommendations of this plan are described in detail later in this report. In summary, the data recovery plan identified 21 archaeological sites in danger of being im- 


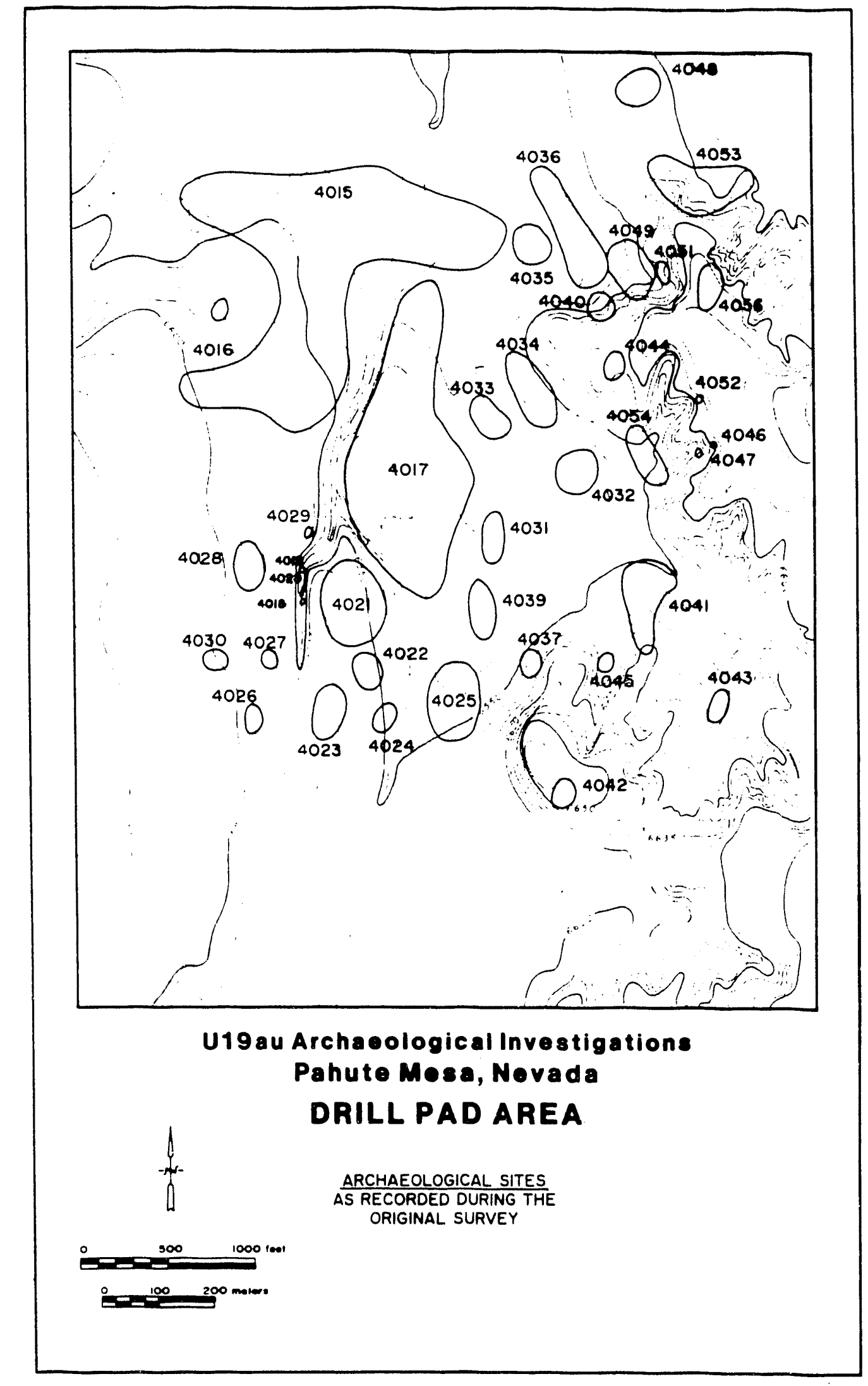

Figure 2-4. Archaeological sites recorded during the original survey for drill pad area U19au, Pahute Mesa, Nevada. 


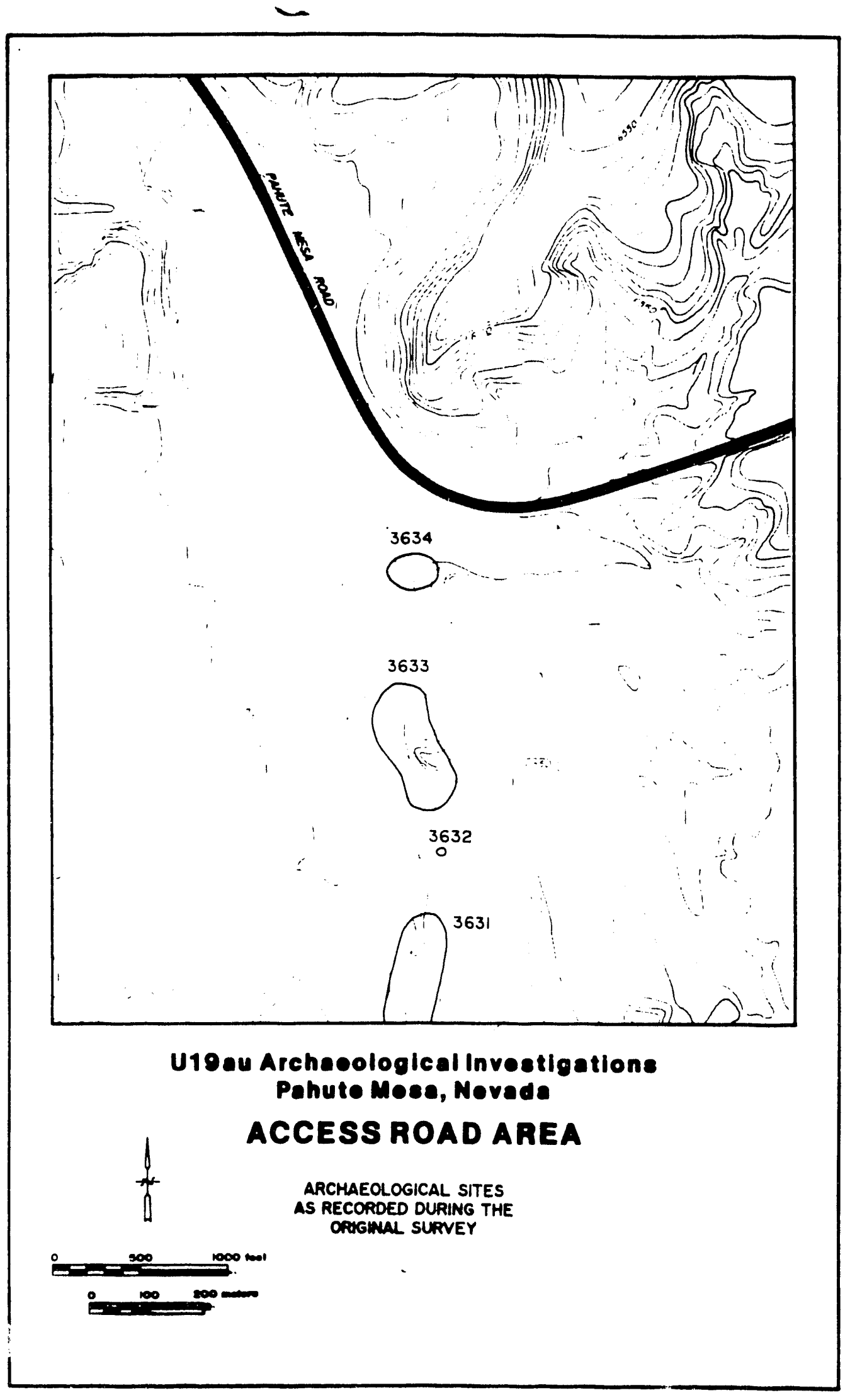

Figure 2-5. Archaeological sites recorded during the original survey for the access road to U19au, Pahute Mesa, Nevada. 
pacted by the development of the drill site and recommended various mitigation measures ranying from controlled surface collection to areal excavations (Pippin and Henton 1986). Field work was conducted during the summer of 1986 and until poor weather ended the field season in the fall. Field work was completed in the early spring of 1987. Cataloging of artifacts recovered at U19au commenced at DRI in Reno during the winter of 1986 and was completed by late spring in 1987 . Minor additional surface collection was conducted during the fall of 1987. The analysis of the artifacts was conducted during the spring of 1988.

\section{Archaeological Sites at U19au}

At the time of the reconnaissance, DRI used a field site-classification system which assigned sites into basic types using features and artifacts observed on the ground surface. The major site types found at U19au were temporary camps, lithic scatters, localities, and isolated artifacts. Under this system, temporary camps are sites which appear to serve as aboriginal campsites and are determined by the features present, e.g., structures or hearths, and by artifact diversity. Artifacts should be diverse, reflect different activities, and include milling implements, pottery, and/or a high percentage of flaked tools, as well as debitage. Lithic scatters are considered areas of stone tool manufacture or maintenance. They contain a preponderance of debitage and stage forms and lack the artifact diversity typical of temporary canıps. If evidence indicates the material being flaked is obtained at the site, the site is considered a quarry. Localities are small sites with a variety of inferred functions. They can range from small knapping stations to caches and are generally thought to represent a single event. Finally, isolated artifacts are those not found in proximity to other artifacts. In theory they represent a lost or discarded item.

Forty-six archaeological sites were recorded in the U19au drill site area (Figure2-4) or along the access road to the pad (Figure 2-5) from the Pahute Mesa Road (Table 2-2). Although they range from large temporary campsites to isolated artifacts, the division of the cultural resources into these sites is somewhat arbitrary.

\section{Temporary Camps}

Thirteen archaeological sites (26Ny4015, 4017, 4021-4023, 4040-4042, 4048-4050, 4053, and 4054) were recorded as temporary campsites. Site $26 \mathrm{Ny} 4015$ is a large and relatively diffuse temporary campsite with numerous observable surface features, including nine structure flats or rock rings, hearths, and other rock features. Artifacts observed included millingstones, pottery, and projectile points of the Desert Side-notched, Elko, Gatecliff, Pinto, and Great Basin Stemmed types.

Site 26 Ny 4015 is a diffuse temporary camp composed of several loci of activity. The site covers a large portion $(565,500 \mathrm{~m} 2)$ of a gently sloping easterly exposed ridge to the west and north of the drill site (Figure 2-4). Most of the southern portion of the site is composed of a diffuse scatter of tools and debitage; several surface features are observable to the north and west (Figure 2-6). These features are nine cleared areas, possibly for camping, and three rock cairns of unknown function (Figure 2-7). The first major locus is composed of features 1-6 - two cairns (Feature 1 and 2) and four clearings. A single millingstone and several potsherds were found at Feature 3-a 2.5-by-3 m clearing; several millingstones, brownware pot sherds, and fire-cracked rock at Feature 4-a $3 \mathrm{~m}$ clearing; millingstones and sherds at Feature 5 -another $3 \mathrm{~m}$ clearing; and fire-cracked rock, brownware sherds, and a Cottonwood projectile point at Feature $6-$ a 3 m clearing. In the diffuse scatter, temporally diagnostic artifacts include pottery, as well as Cottonwood, Elko, Gatecliff, and Pinto projectile points. Two additional clearings, Features 7 and 8 , are located about $30 \mathrm{~m}$ south of Feature 6 . 


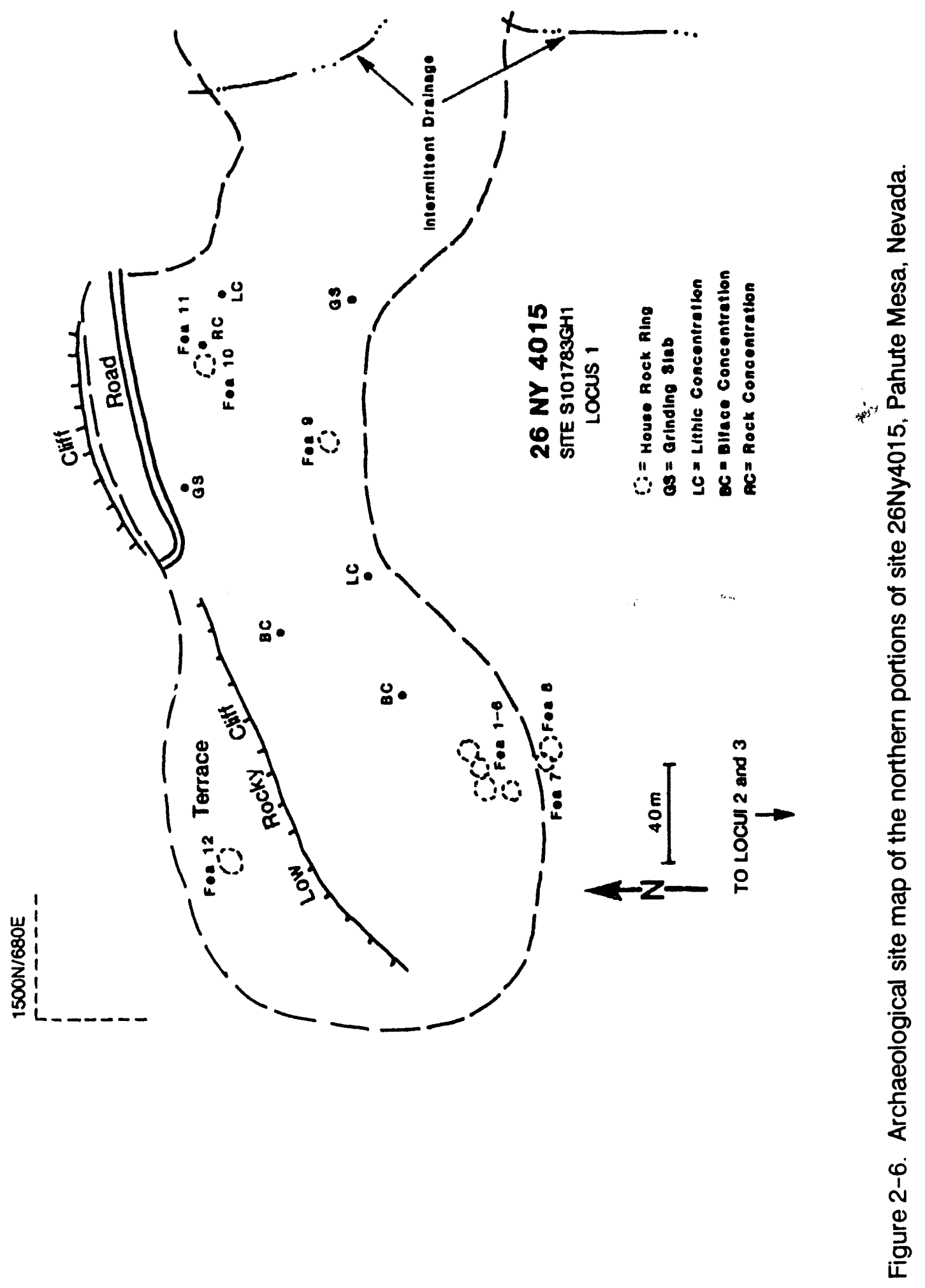




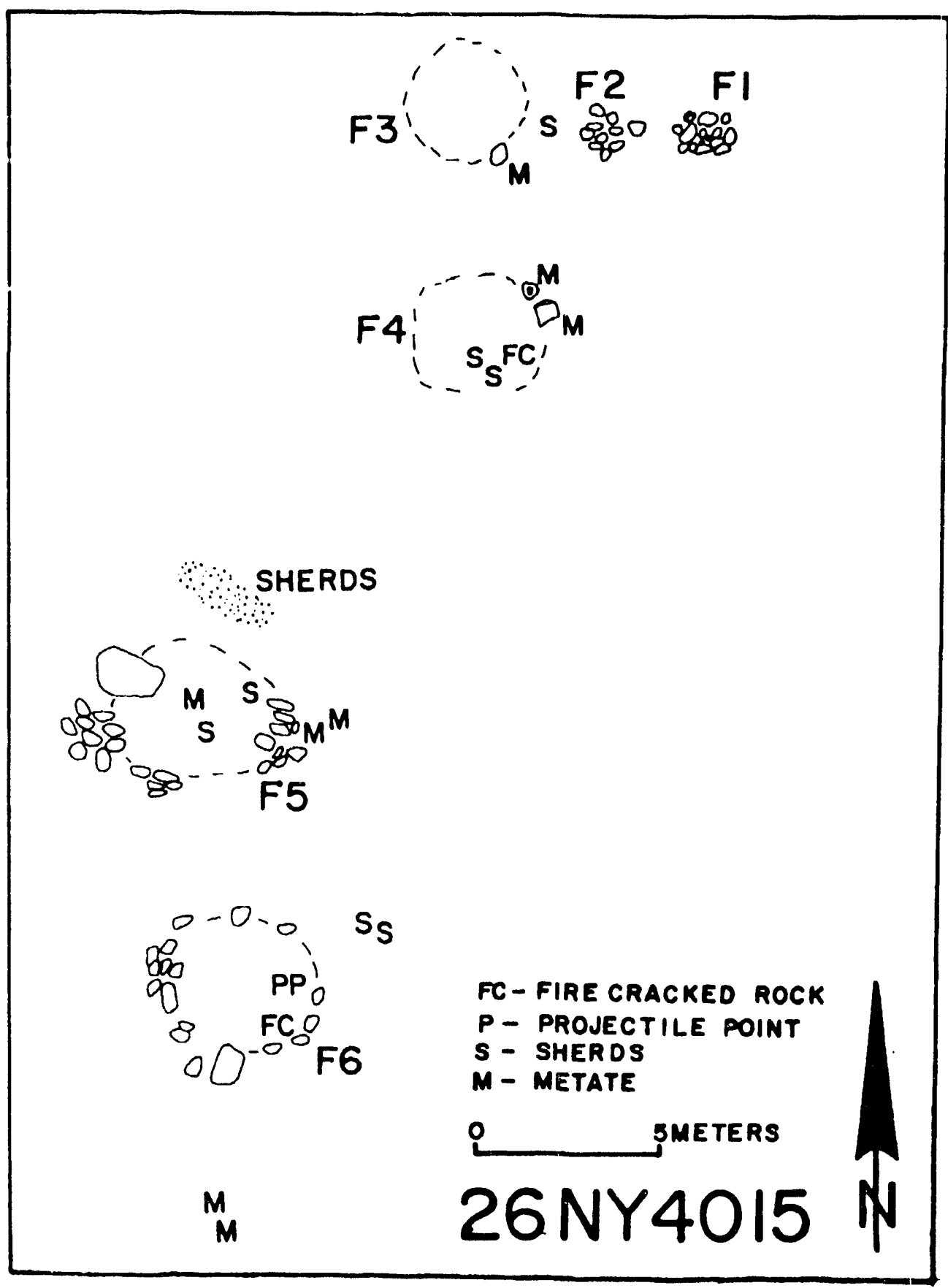

Figure 2-7. Archaeological site map of Locus 1, site 26Ny4015, Pahute Mesa, Nevada. 
One millingstone was found with these features. Feature 9, another clearing, is about 2 $\mathrm{m}$ in diameter and located $120 \mathrm{~m}$ northeast of the first cluster of shelters. It contained a scatter of brownware pottery and white welded debitage. Features 10 , a clearing, and 11, a rock pile, are located another $40 \mathrm{~m}$ to the northeast. Artifacts here include pottery and broken flaked stone tools. Finally, a small clearing, Feature 12, is located north of most of the site down a small slope. Six millingstone fragments, and Elko and Cottonwood projectile points were collected here.

Site $26 \mathrm{Ny} 4017$ is a moderately large (approximately $47,000 \mathrm{~m}^{2}$ ), but generally diffuse, temporary camp located around the drill center for the event site. This site, is one of several concentrations of artifacts found in the central portion of the project area. It is located in an alluvial valley dominated by big sagebrush (Artemisia tridentata). Artifacts observed at the time this site was recorded were Rosegate and Elko projectile points, as well as lithic debitage.

Site $26 \mathrm{Ny} 4021$ is a temporary camp composed of a diffuse scatter of artifacts and three clearings (Figure 2-8, 2-9). The first clearing is about $4.5 \mathrm{~m}$ in diameter with rocks piled along the west slope (Figure 2-10). About 20 plain brownware potsherds were found in and around the clearing. Feature 2 is another 4.5 $m$ clearing with rocks piled along the west and south edges (Figure 2-11, 2-12). There is a broken, moderately worn millingstone in the center of the clearing and small amounts of welded white tuff and obsidian debitage.

The final clearing is about $3 \mathrm{~m}$ in diameter with a small chamber, about $2 \mathrm{~m}$ in diameter, immediately adjacent and to the north edge (Figure 2-13). Plain brownware potsherds and small amounts of welded white tuff and obsidian debitage occur in and around the clearing. A fragment of an obsidian Elko projectile point was collected from the larger of the two clearings comprising this feature. Since 26 Ny 4021 was in an area of potential impacts, additional data recovery was conducted at this site and the resulis are described later in this report.

Site 26Ny4022 is another temporary camp composed of a large and diffuse lithic scatter and a cluster of habitation clearings at the south end of the site (Figure 2-14). The principle components of this cluster are a $5 \mathrm{~m}$ clearing. Feature 1 (Figure 2-15); a 2 m clearing. Feature 2 (Figure 2-16), adjacent to Feature 1; and small clearings which may or may not be aboriginal, Features 3 and 4 . Artifacts found at this site include two Gatecliff Split Stem projectile points, brownware pottery, and several millingstones.

Site 26 Ny4023 (Figure 2-17) is a temporary camp composed of at least four partially standing brush structures and one partially standing rock and brush feature. Feature 1 at this site is the brush and rock feature. It is constructed of about 100 naturally recurring stones and numerous juniper branches (Figure 2-18, 2-23). It might have been a cache for storing pine nuts. Feature 2 , formed by a living juniper tree, is a brush structure enhanced by the addition of a screen of juniper branches and anchored at the base by stones. Although partially collapsed, the branches of the screen appeared to extend from the stone piled on the ground to live branches in the juniper tree. Artifacts found within this shelter include a fragment of a metal bracket or can, a small brownware pottery saucer, a flatware table knife, and a clean Metapodial (deer bone) (Figures 2-19 and 2-24).

Feature 3 is another brush structure, similar to Feature 2, but having two "walls" forming a broad "V". The easterly wall appears to have been originally constructed by anchoring a forked branch vertically in a rock pile and laying a branch from the living juniper horizontally across the notch. Then additional branches were added to this framework (Figures 2-20 and 2-25). A single artifact, an eroded mano, was observed in this shelter. 


\section{ORIGINAL SITE MAP}

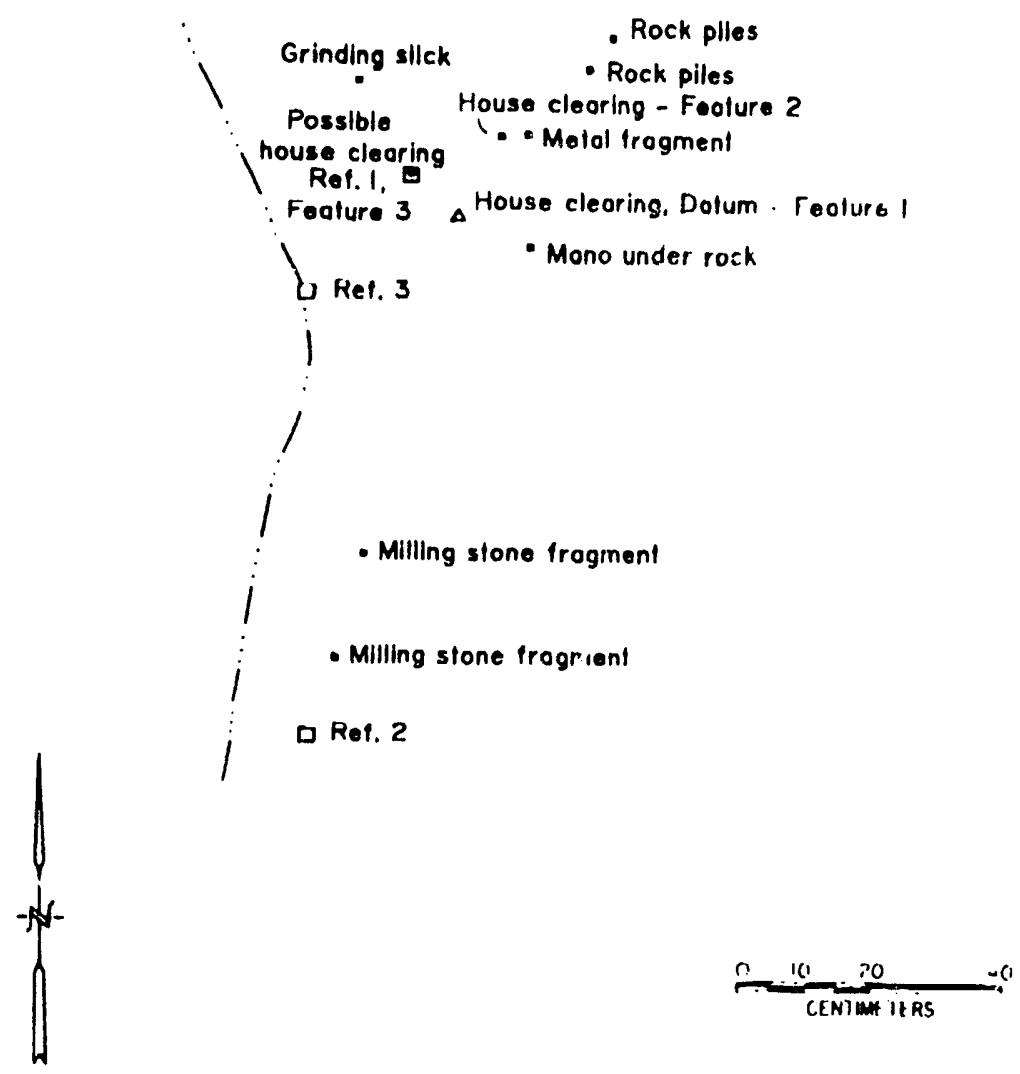

26NY4021

Figure 2-8. Archaeological site map for site 26 Ny4021 as originally recorded, Pahute Mesa, Nevada. 


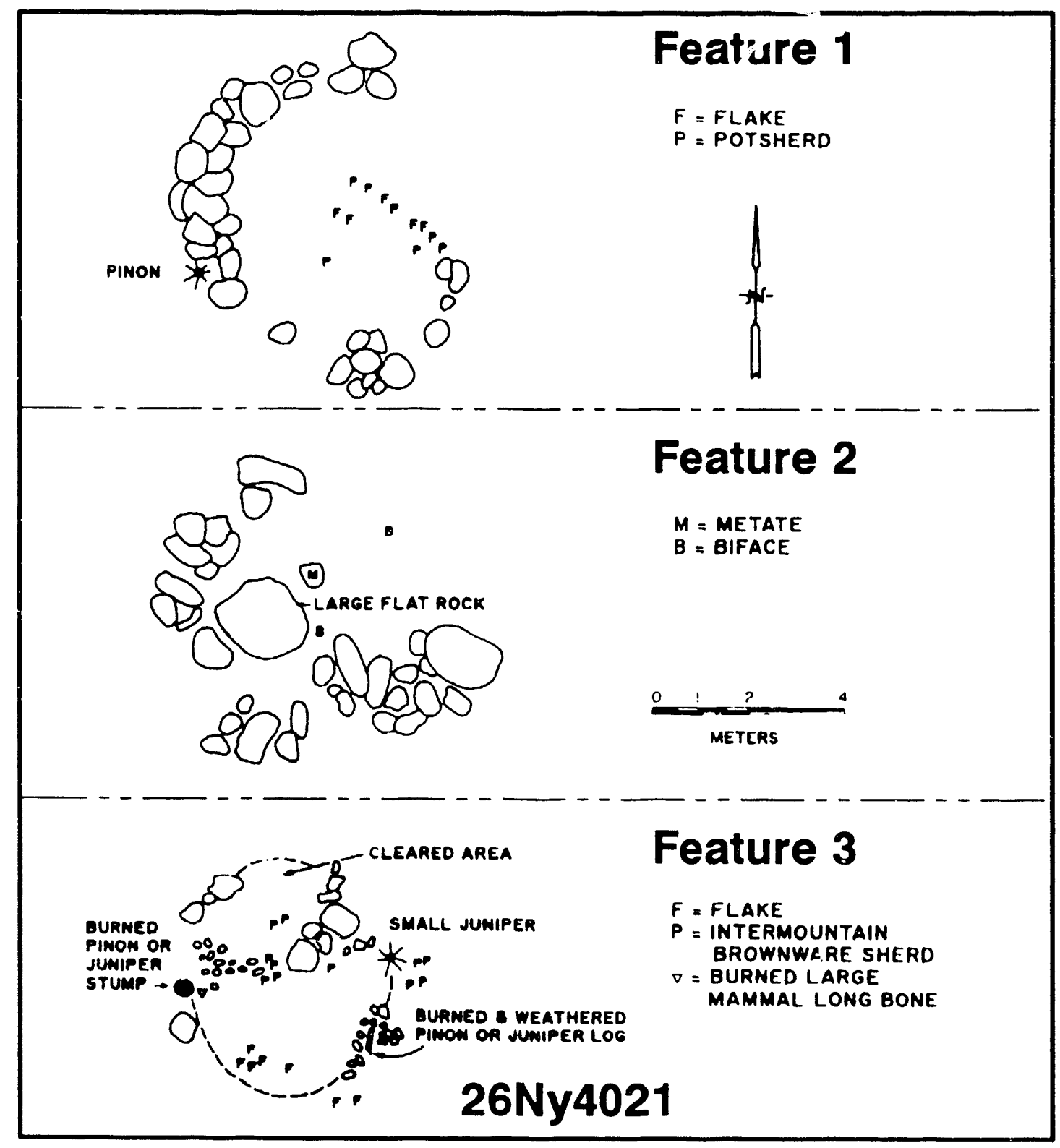

Figure 2-9. The three rock ring structure features as originally recorded, from site 26 Ny4021, Pahute Mesa, Nevada. 


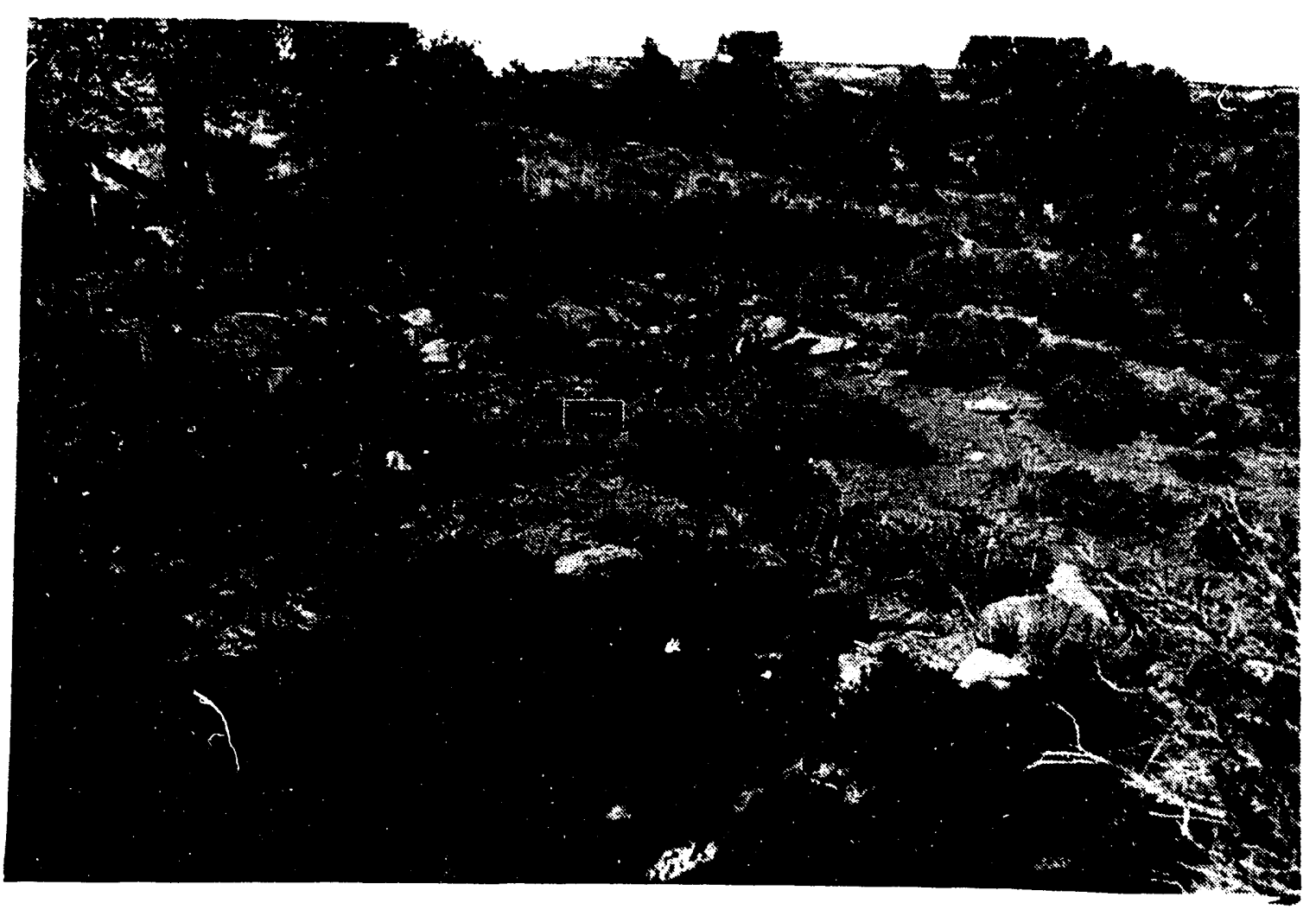

Figure 2-10. Photograph of Feature 1 of site 26 Ny4021 as originally discovered.

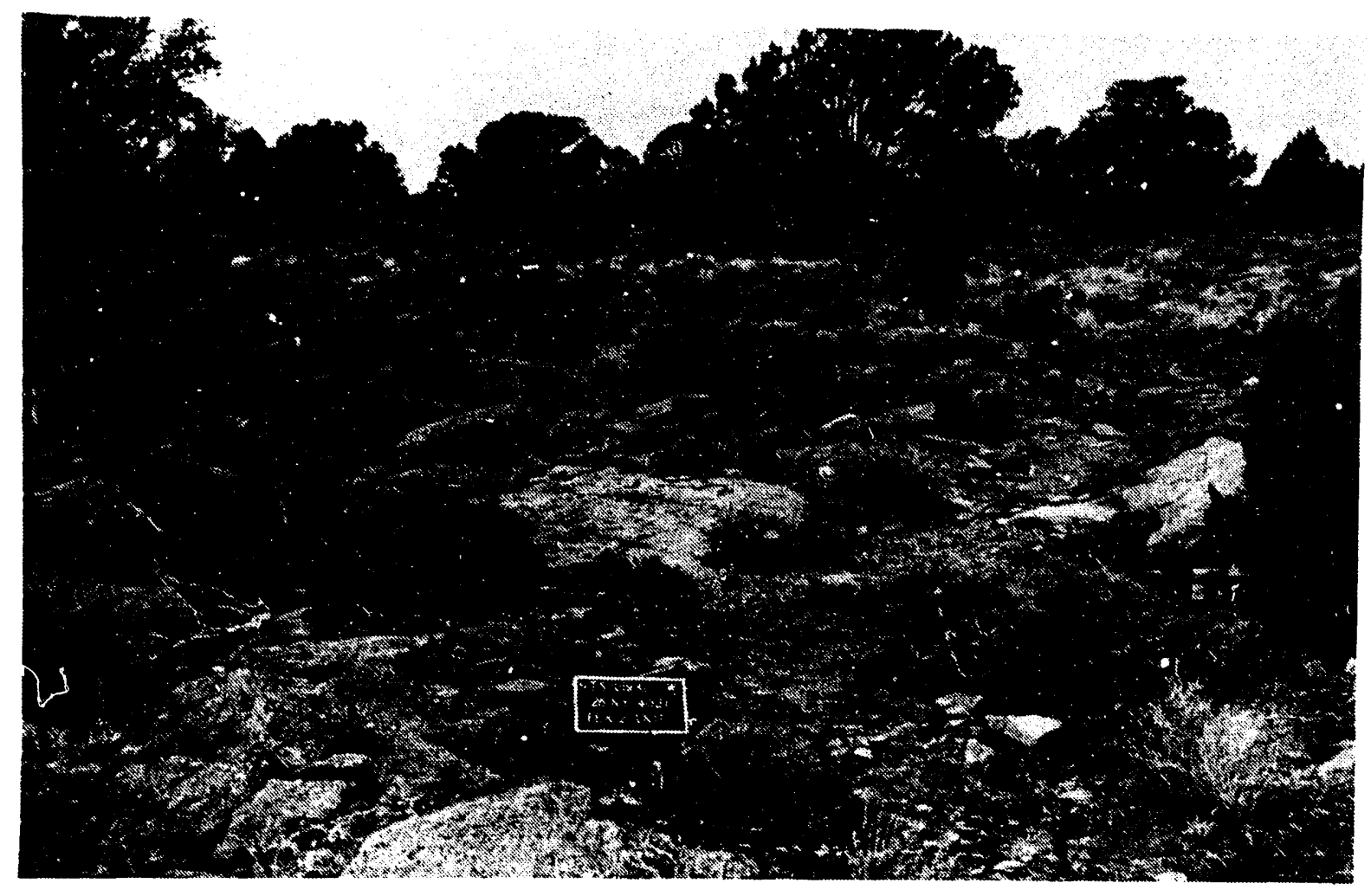

Figure 2-11. Photograph of Feature 2 of site 26 Ny4021 as originally discovered. 


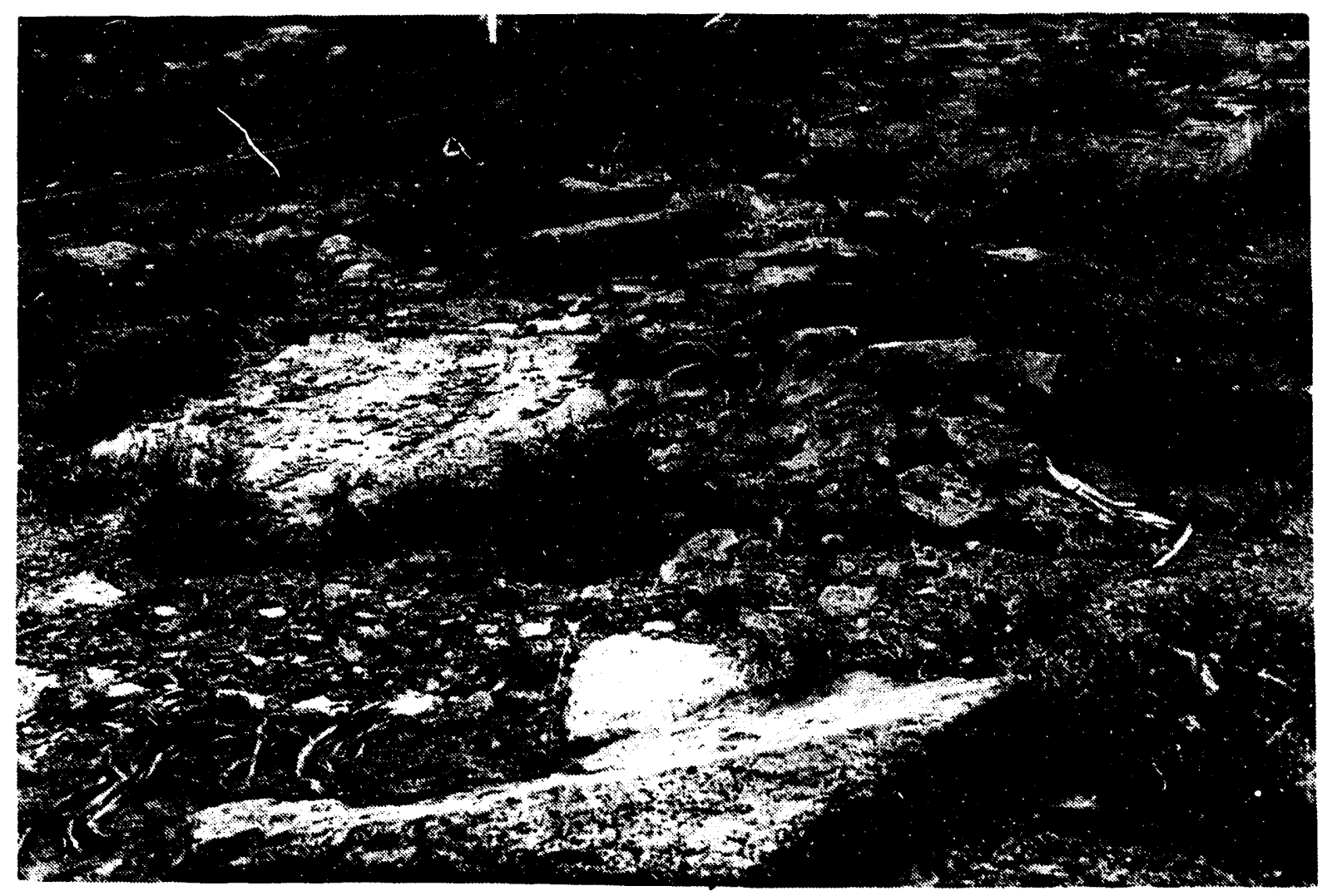

Figure 2-12. Photograph of Feature 2 of site 26 Ny4021 as originally discovered.

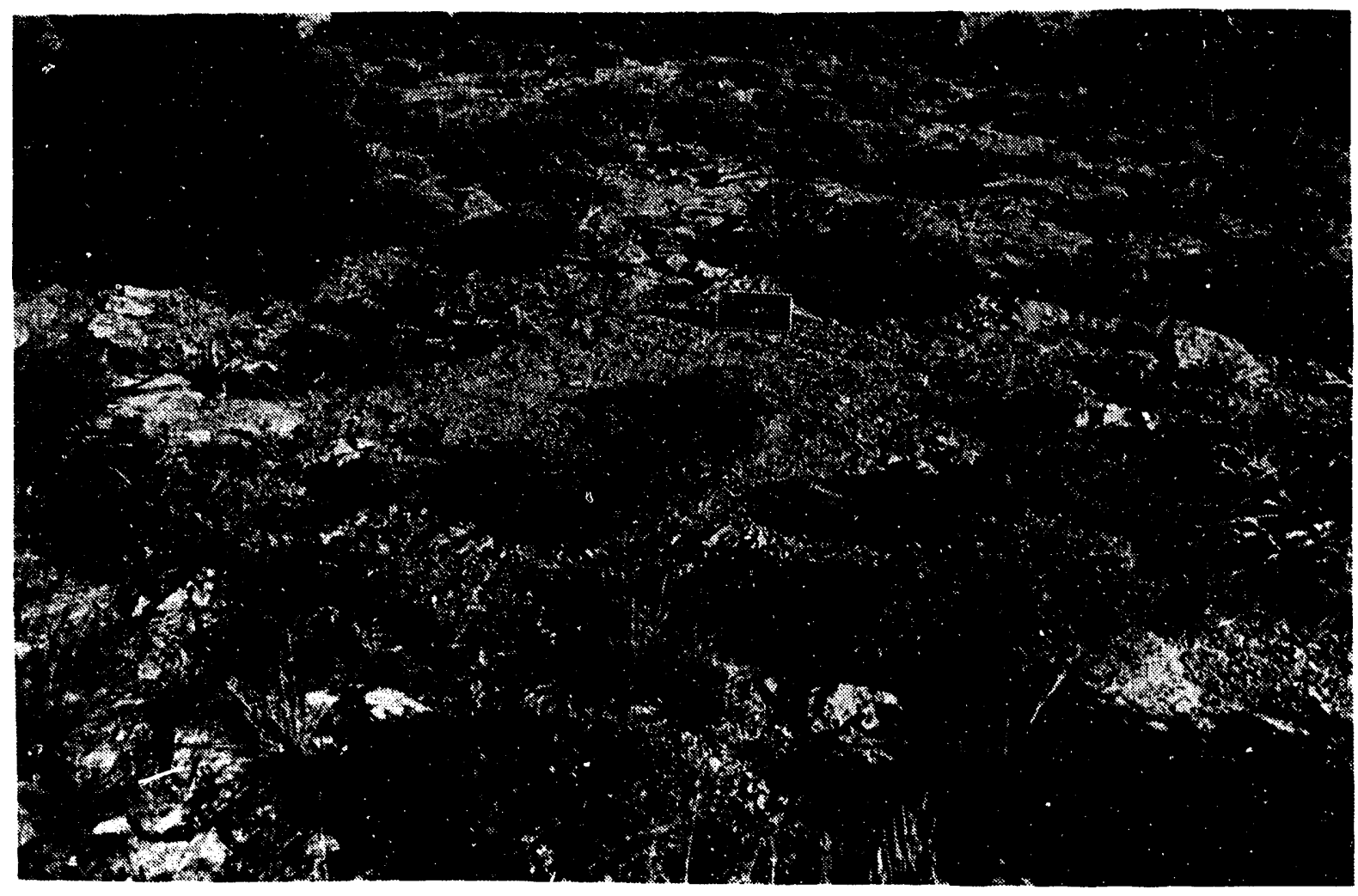

Figure 2-13. Photograph of Feature 3 of site 26 Ny 4021 when originally discovered. 


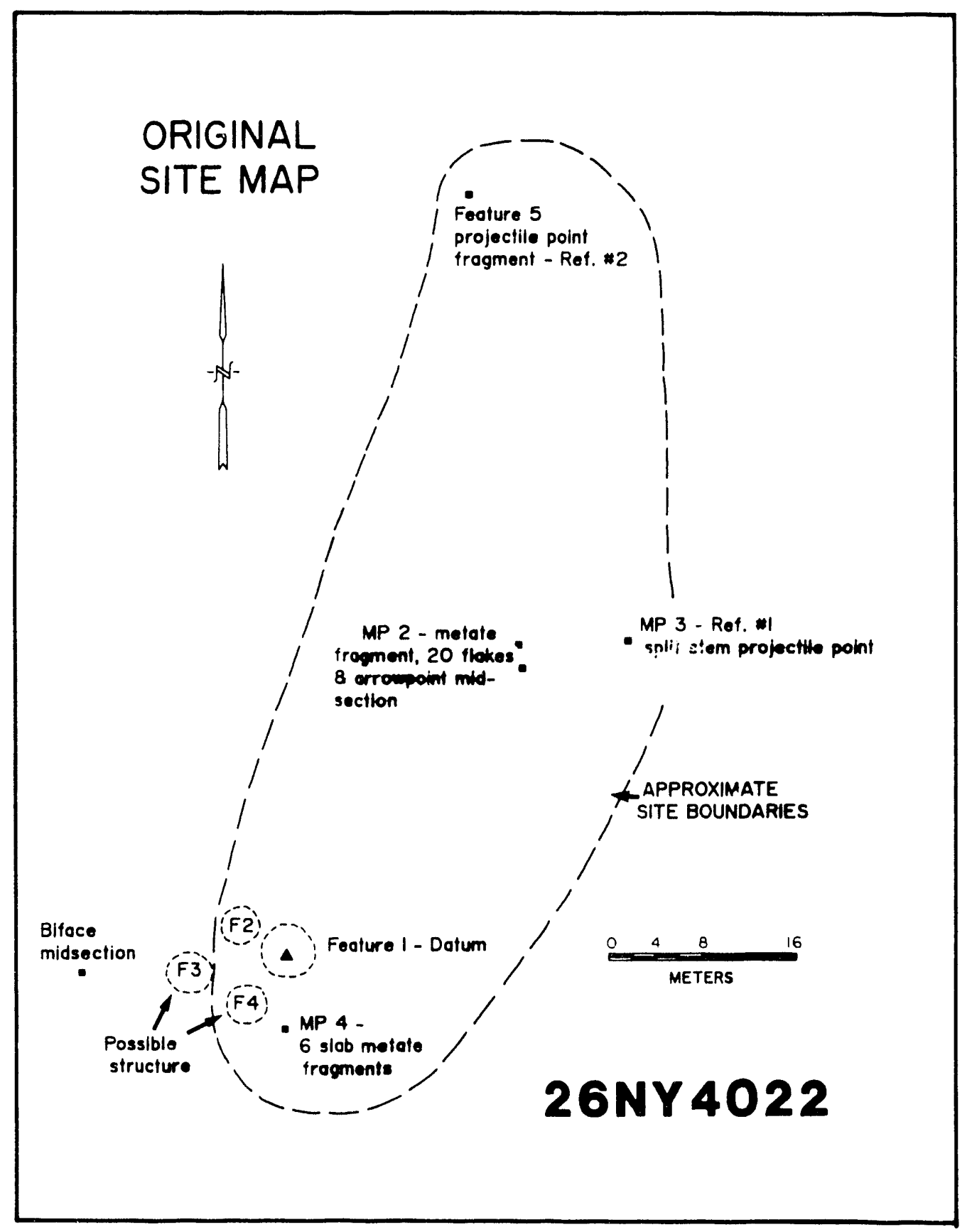

Figure 2-14. Archaeological site map for site 26Ny4022, Pahute Mesa, Nevada. 


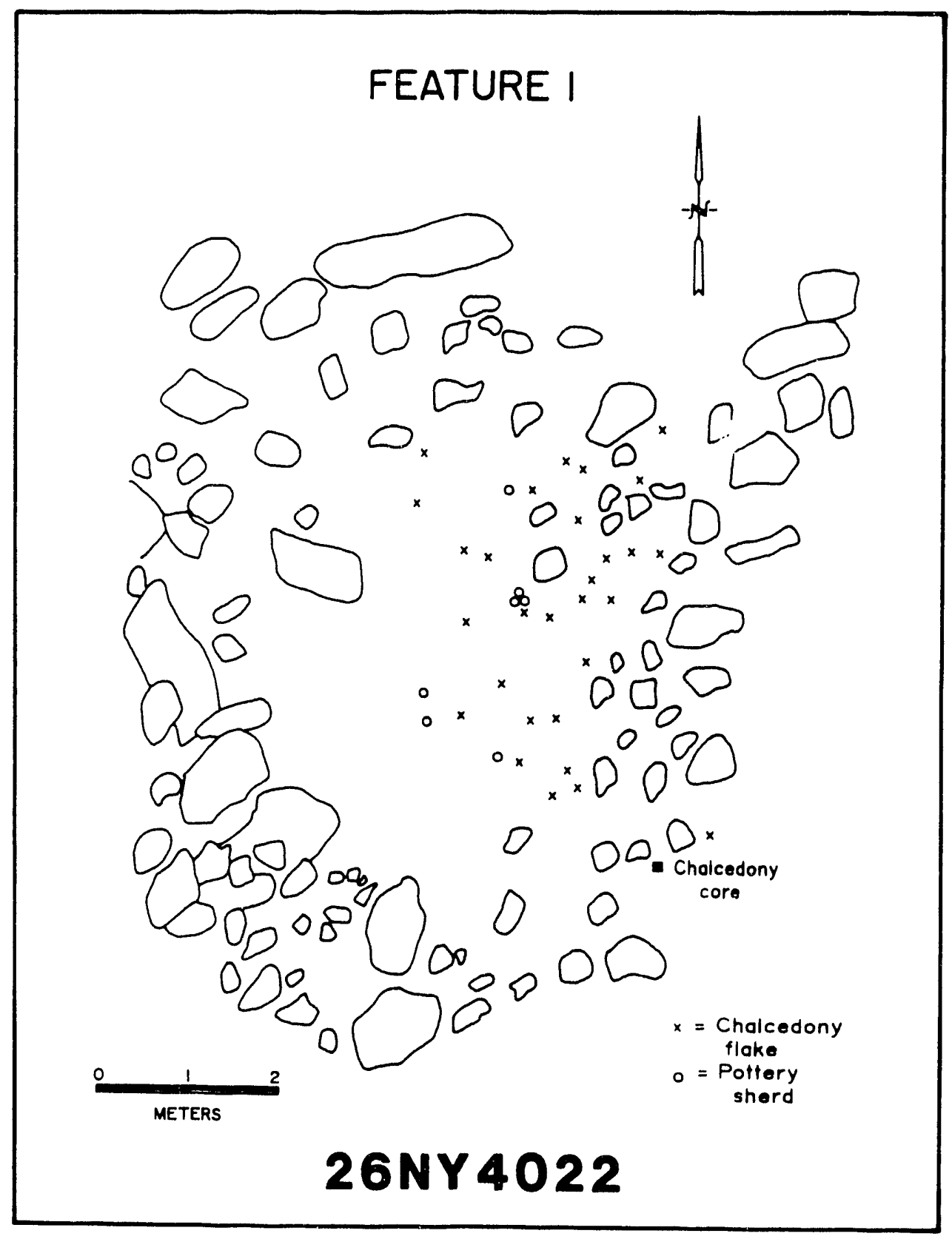

Figure 2-15. Drawing of Feature 1, a rock ring structure from site 26Ny4022, Pahute Mesa, Nevada 


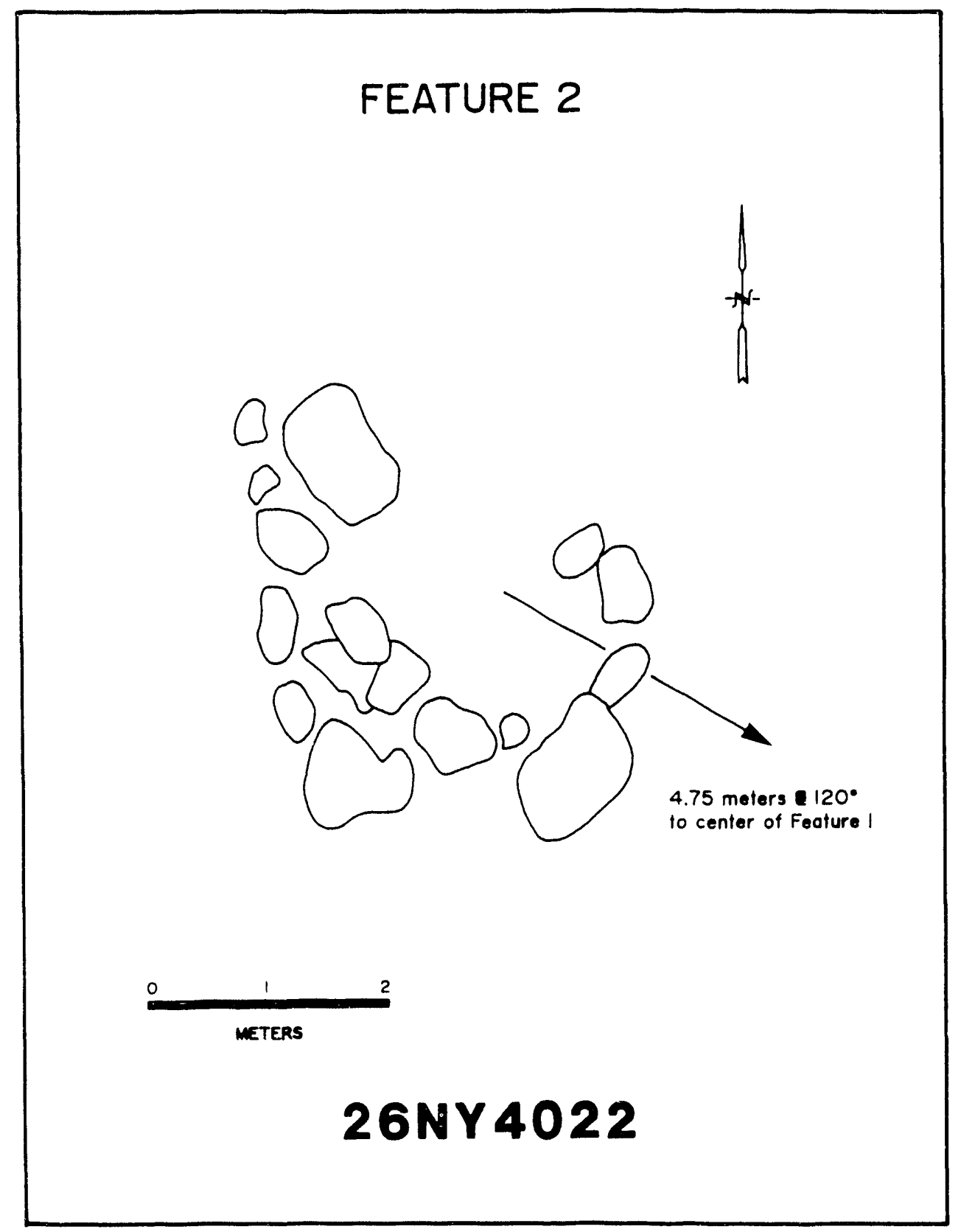

Figure 2-16. Drawing of Feature 2 from site 26Ny4022, Pahute Mesa, Nevada. 


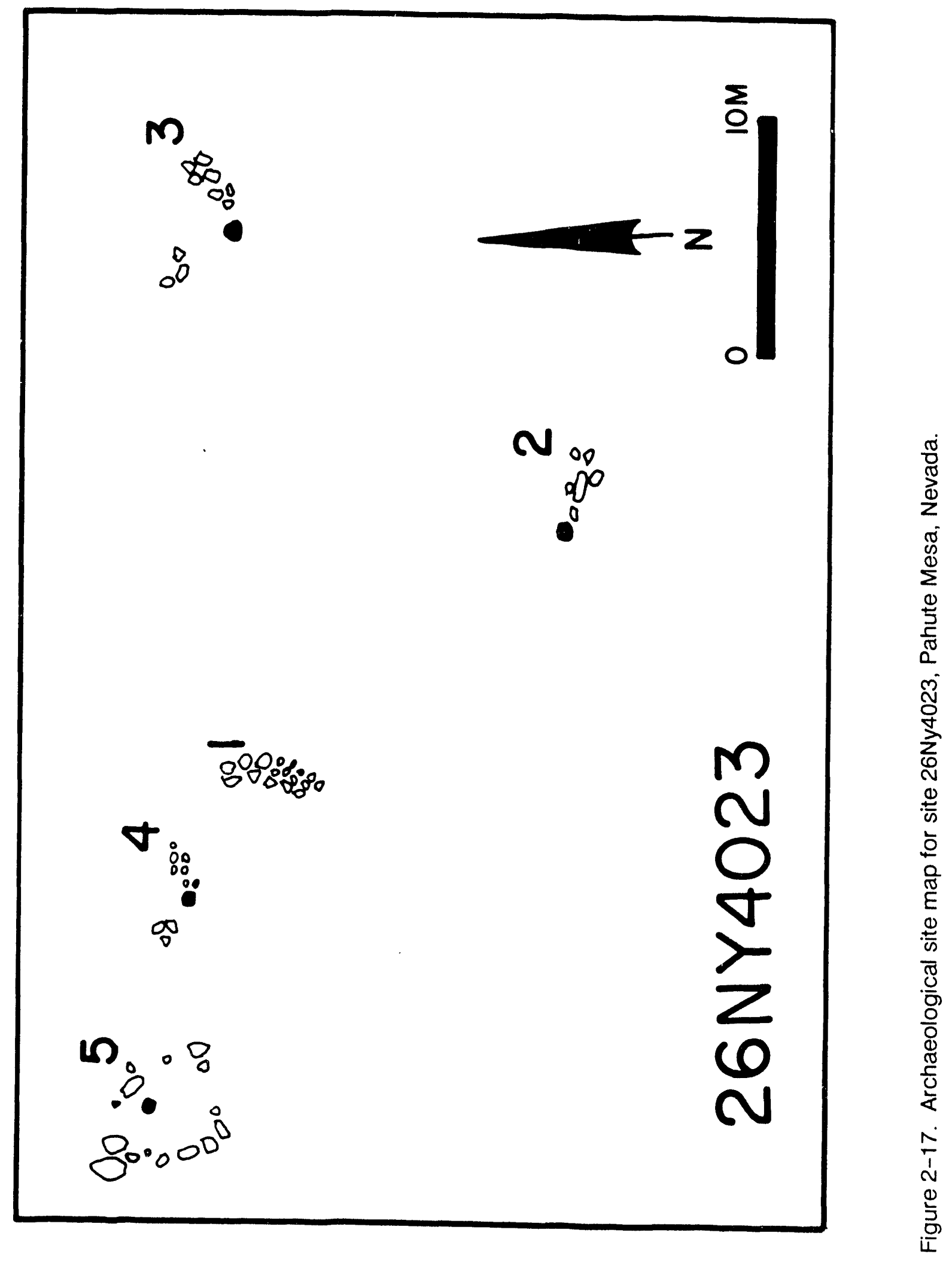




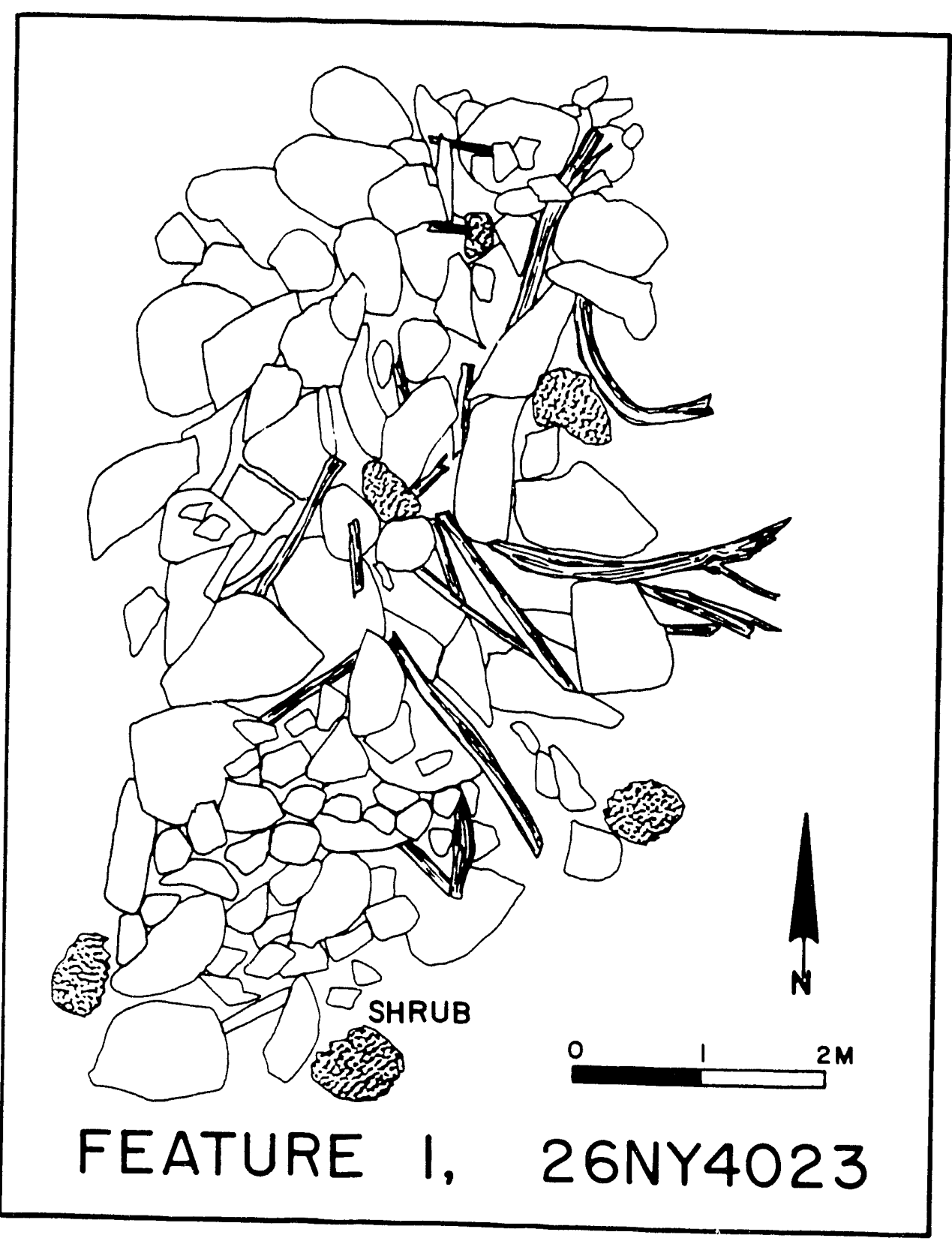

Figure 2-18. Drawing of Feature 1, a possible pinyon nut cache from site $26 \mathrm{Ny} 4023$. 


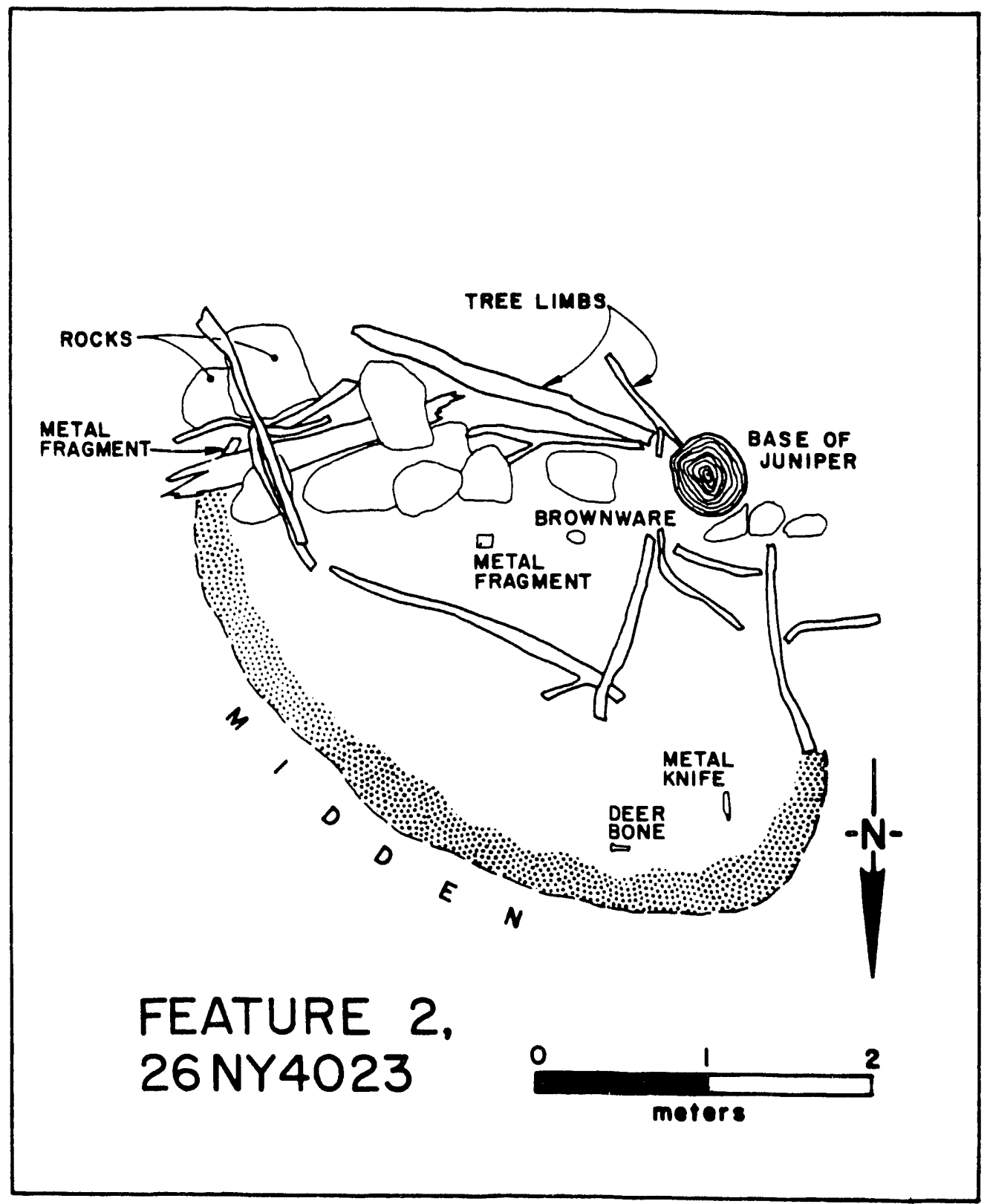

Figure 2-19. Drawing of Feature 2, a brush structure from site 26 Ny4023. 


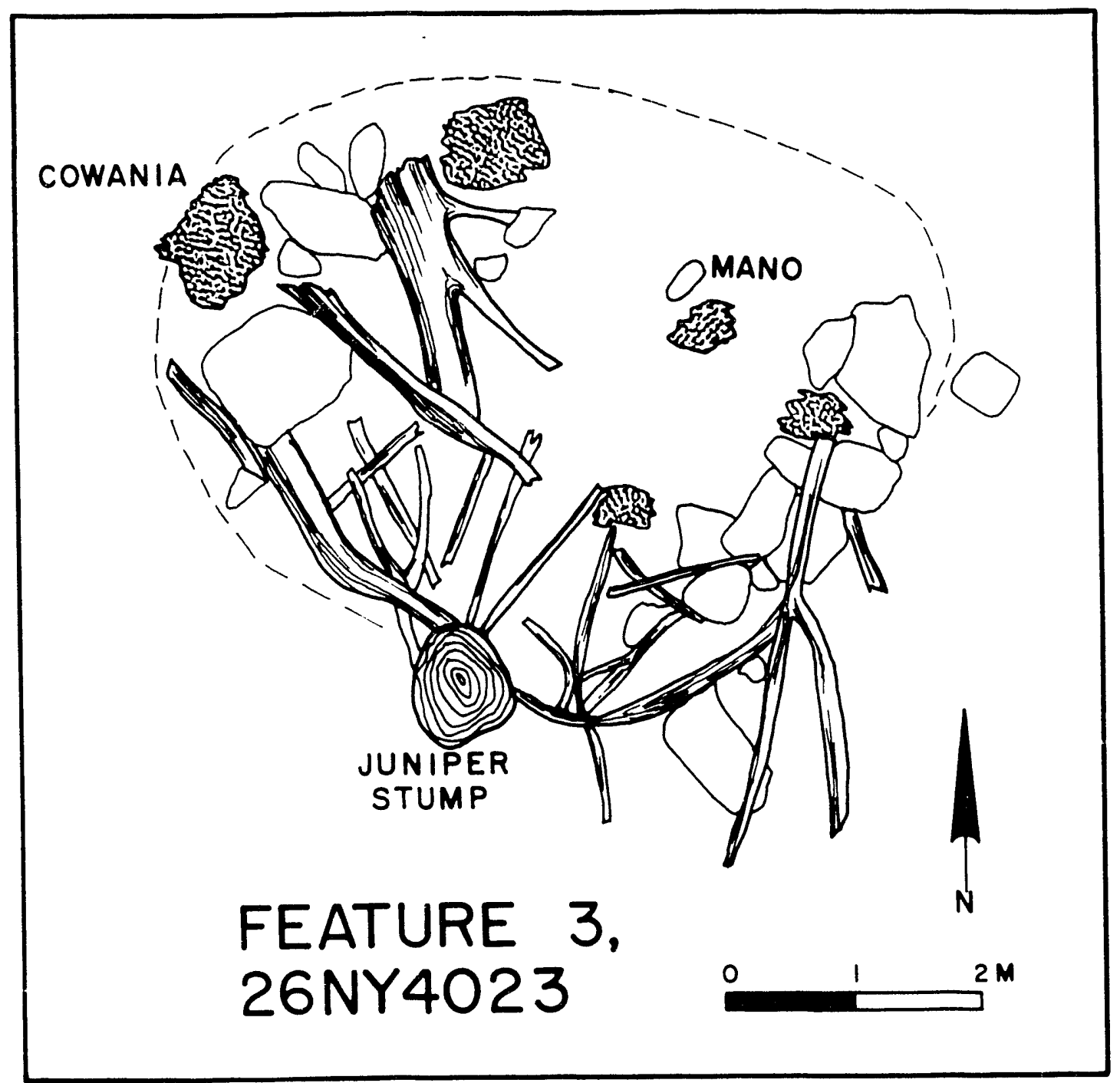

Figure 2-20. Drawing of Feature 3, a brush structure from site 26Ny4023. 


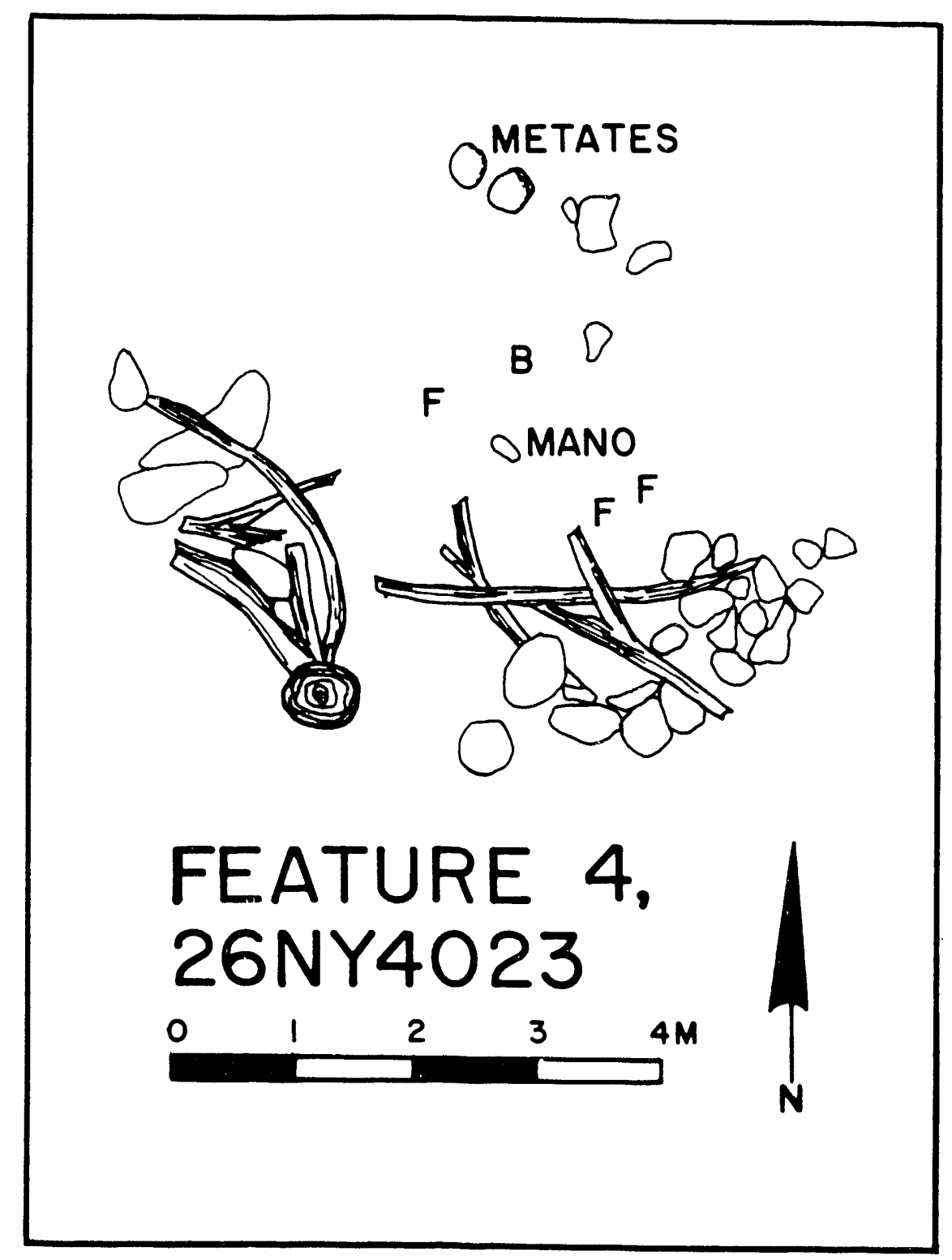

Figure 2-21. Drawing of Feature 4, a brush structure from site 26 Ny4023. 


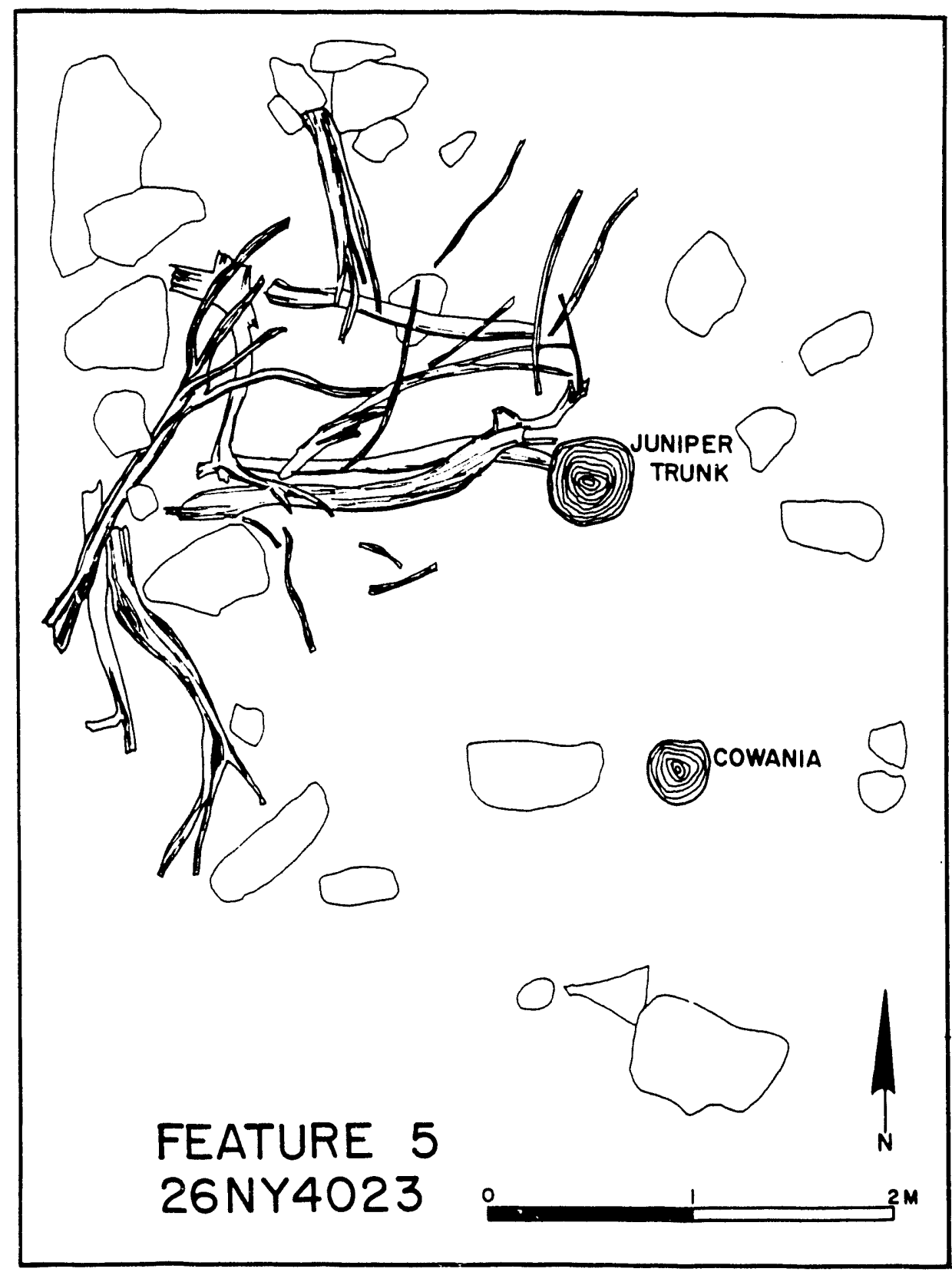

Figure 2-22. Drawing of Feature 5, a brush structure from site $26 \mathrm{Ny} 4023$ 


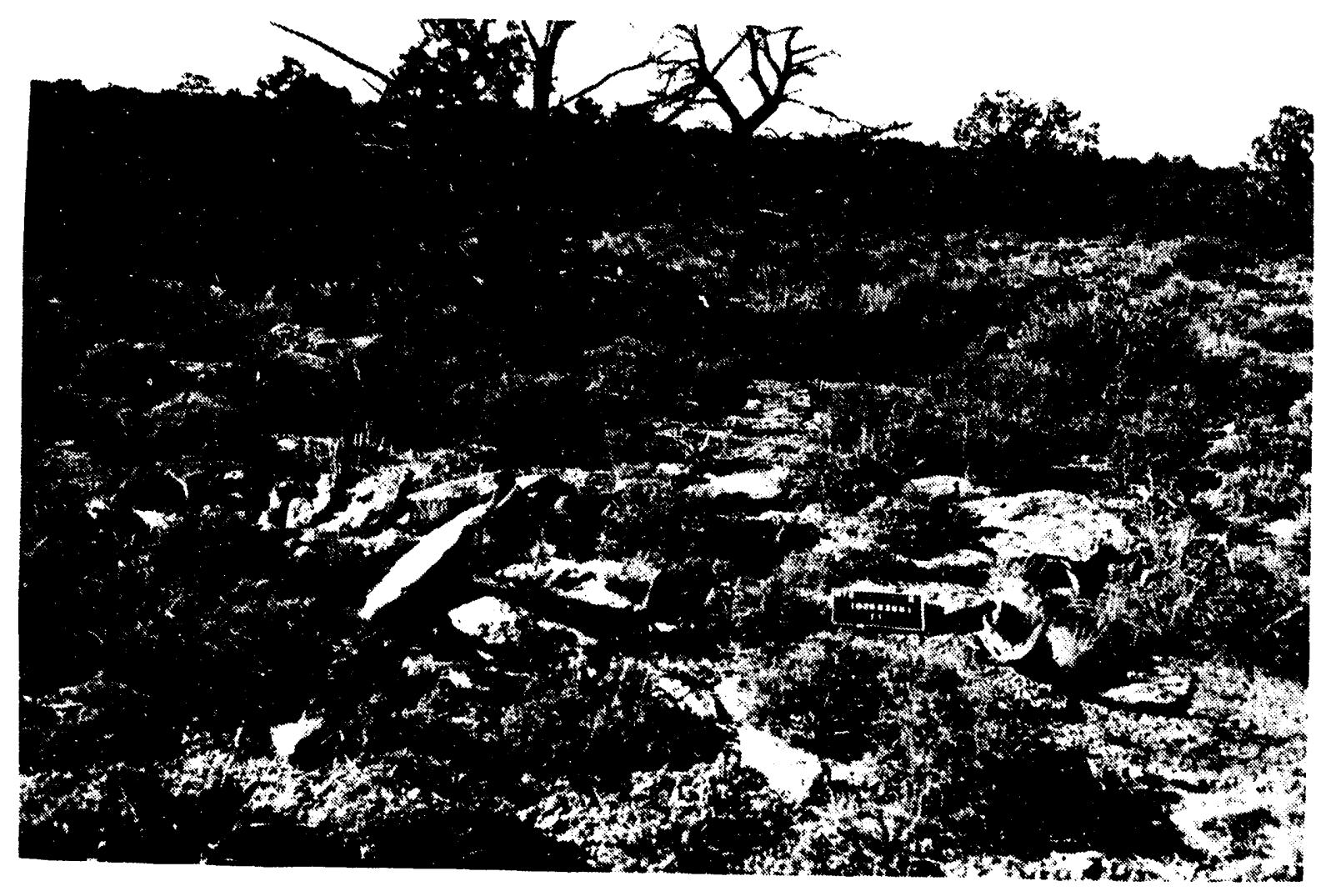

Figure 2-23. Photograph of Feature 1, a possible pinyon nut cache from site 26 Ny4023.

Feature 4 is also a structure created from a living juniper and two walls forming a broad "V". Like Feature 3, one wall appears to be built on a framework with a vertical forked stick anchored in a pile of rocks and a horizontal branch supported by the fork and the tree (Figure 2-21, 2-26). Artifacts found at this shelter include a mano, two millingstones, a broken biface, and a small amount of debitage.

The final observed feature at this site appears to be another, but less well-defined, brush structure. Numerous branches and rocks are found under a juniper tree, but no walls can be readily discerned. No artifacts were found here (Figure 2-22 and 2-27).

These structures appear to function as wind breaks or temporary shelters. The few artifacts indicate limited use. The historic artifacts indicate postcontact use.
Site 26 Ny4040 (Figure 2-28) is a collection of brush structures on the opposite side of the valley and north of $26 \mathrm{Ny} 4023$. The three brush structures at this site were similar to, though somewhat less distinct or elaborate than, those at 26Ny4023. Observed at Feature 1 were the remains of a single brush wall formed by a vertical forked stick in a rock, jile (now collapsed) and a horizontal branch from the notch to the living juniper (Figure 2-29, 2-32). While there is a considerable scatter of debitage at $26 \mathrm{Ny} 4040$, the only artifact observed in association with this feature was a single millingstone.

Feature 2, another single-walled shelter using the vertical forked-stick construction (Figure 2-30, 2-33), contained only a limited amount of debitage. A different construction was used for Feature 3 (Figure 2-31, 2-34). The final brush structure at site $26 \mathrm{Ny} 4040$, is 


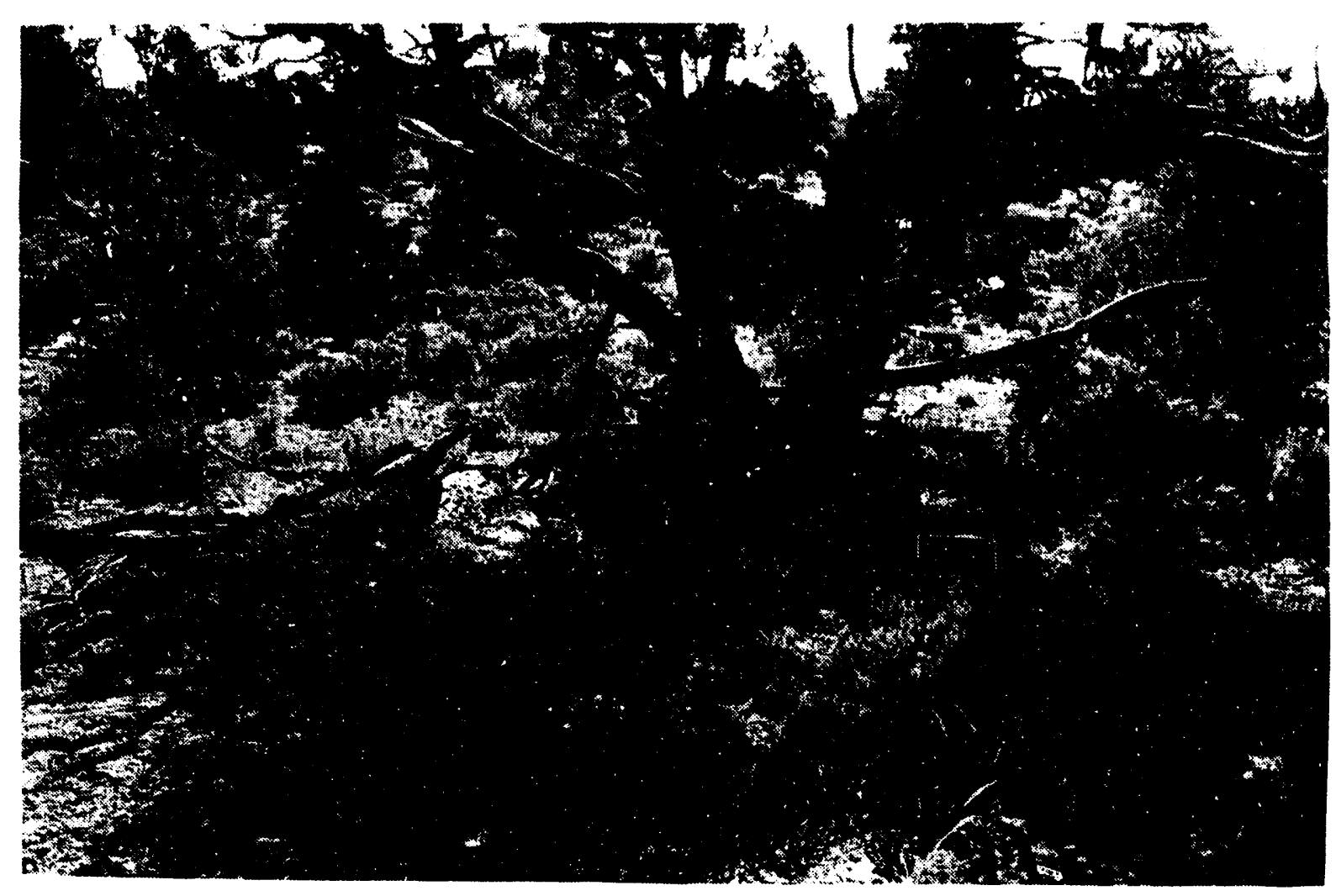

Figure 2-24. Photograph of Feature 2, a brush structure from site 26 Ny4023.

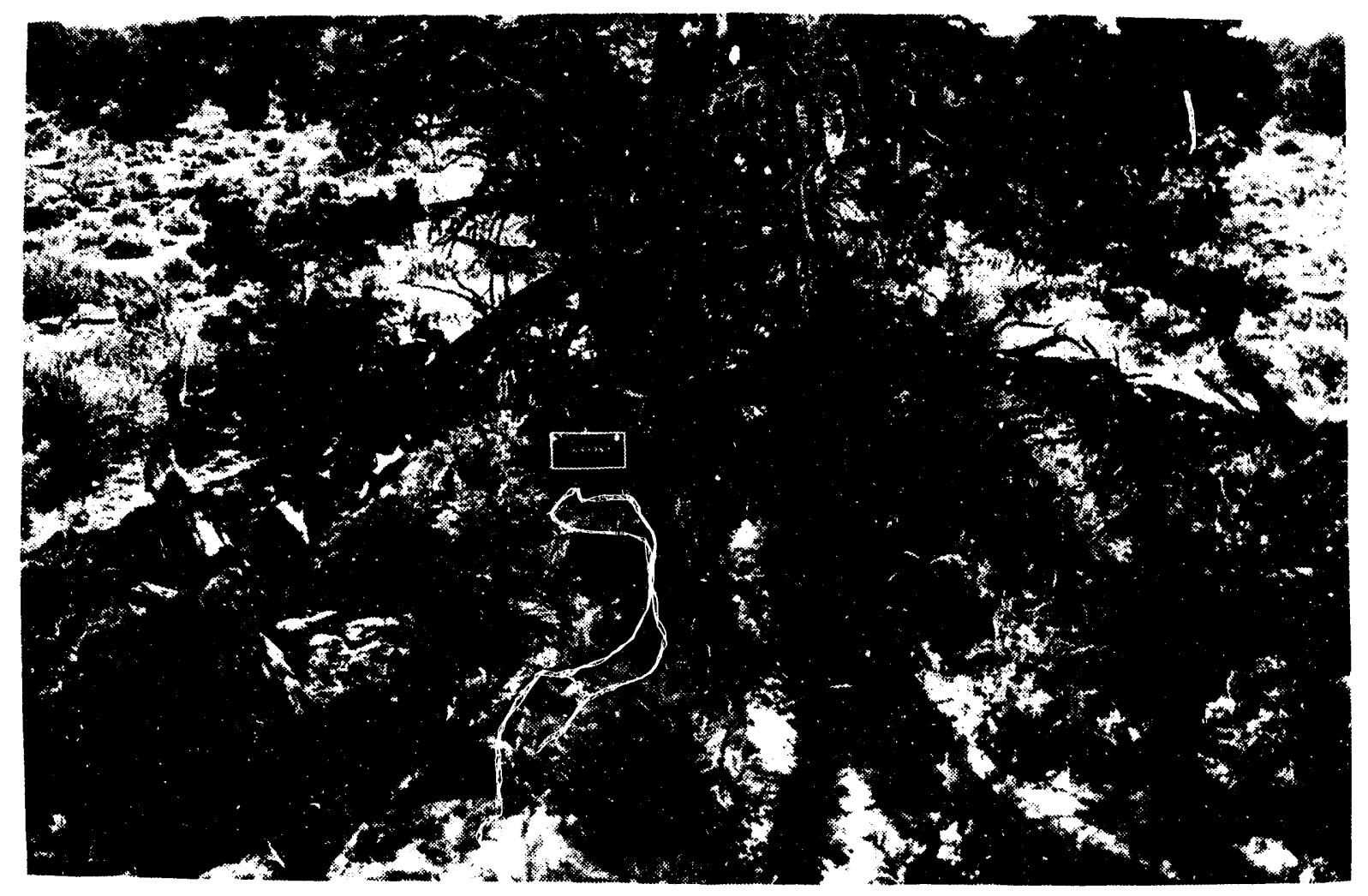

Figure 2-25. Photograph of Feature 3, a possible pinyon nut cache from site 26 Ny4023. 


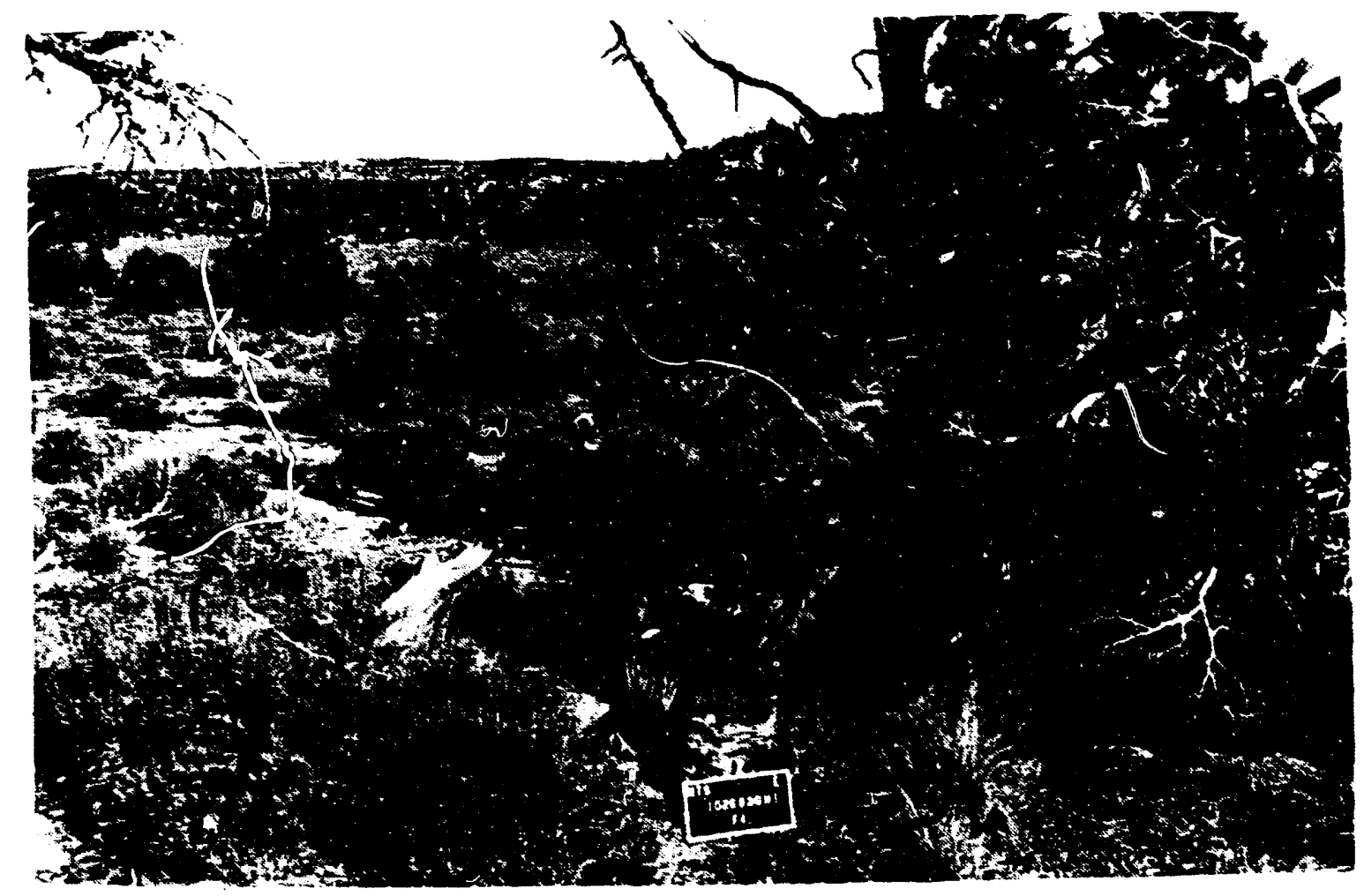

Figure 2-26. Photograph of Feature 4, a brush structure from site 26 Ny4023.

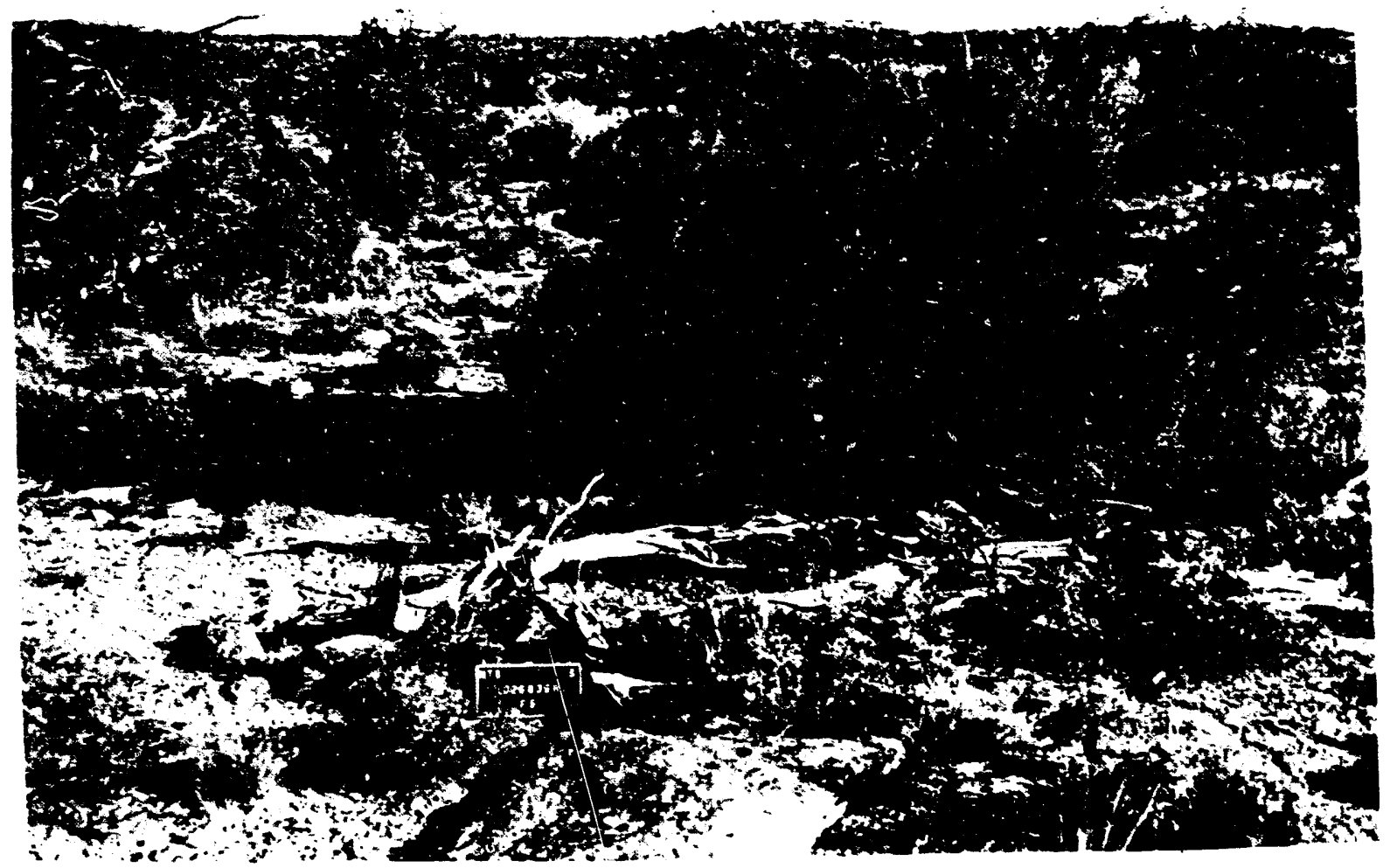

Figure 2-27. Photograph of Feature 5, a brush structure from site 26 Ny 4023. 


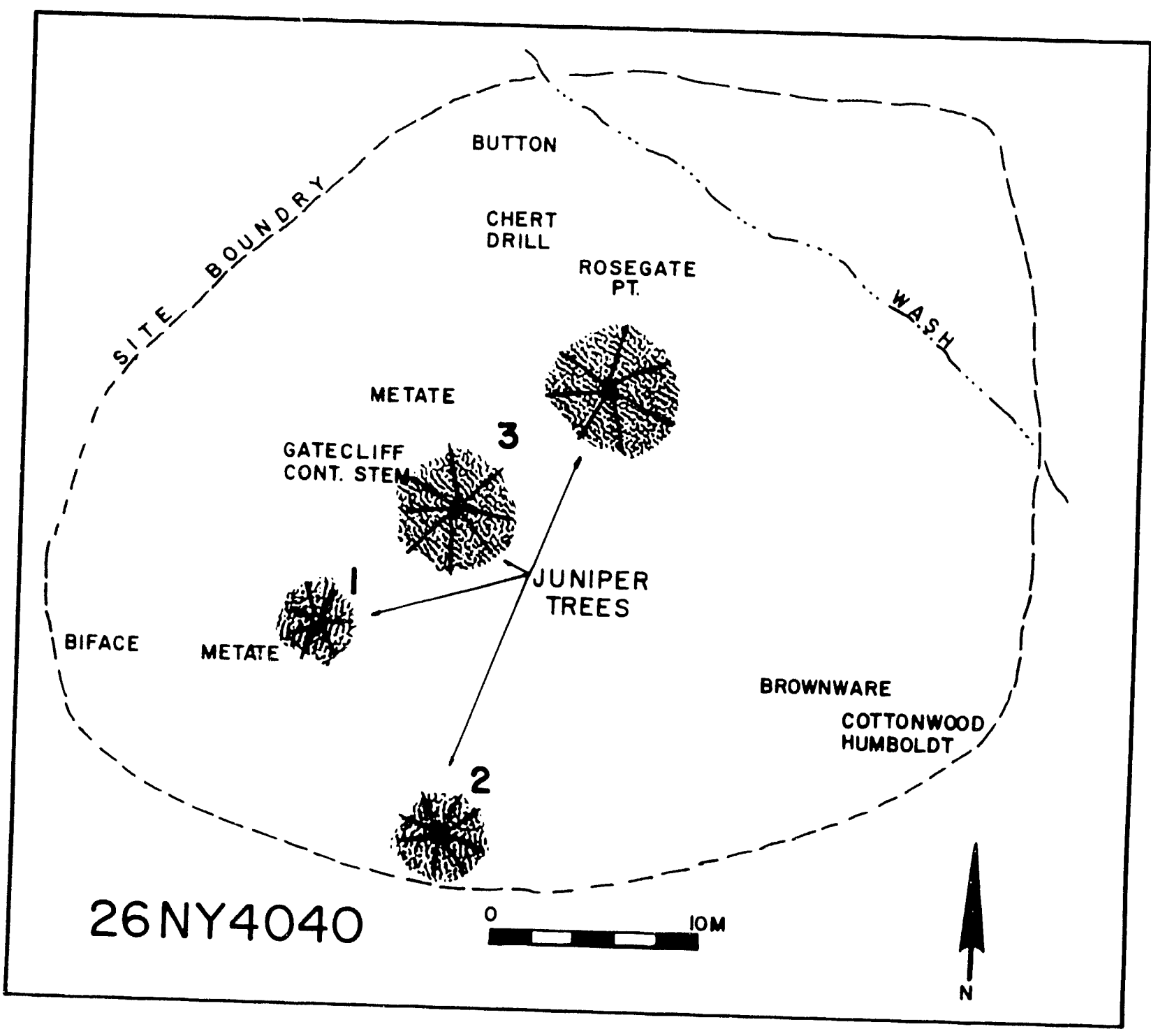

Figure 2-28. Archaeological site map of $26 \mathrm{Ny} 4040$ at Pahute Mesa, Nevada, as originally recorded. 


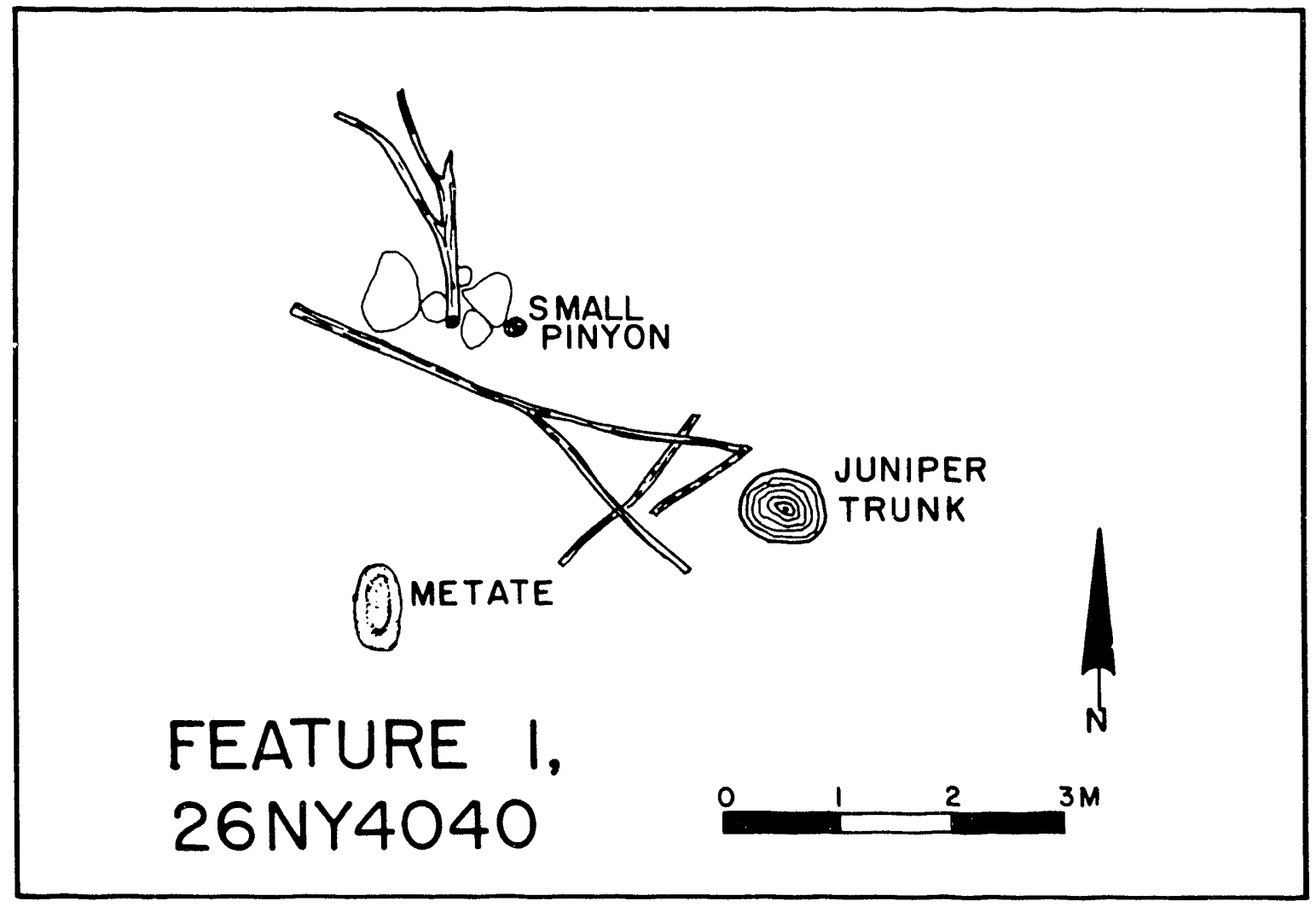

Figure 2-29. Drawing of Feature 1, a brush structure from site $26 \mathrm{Ny} 4040$. 


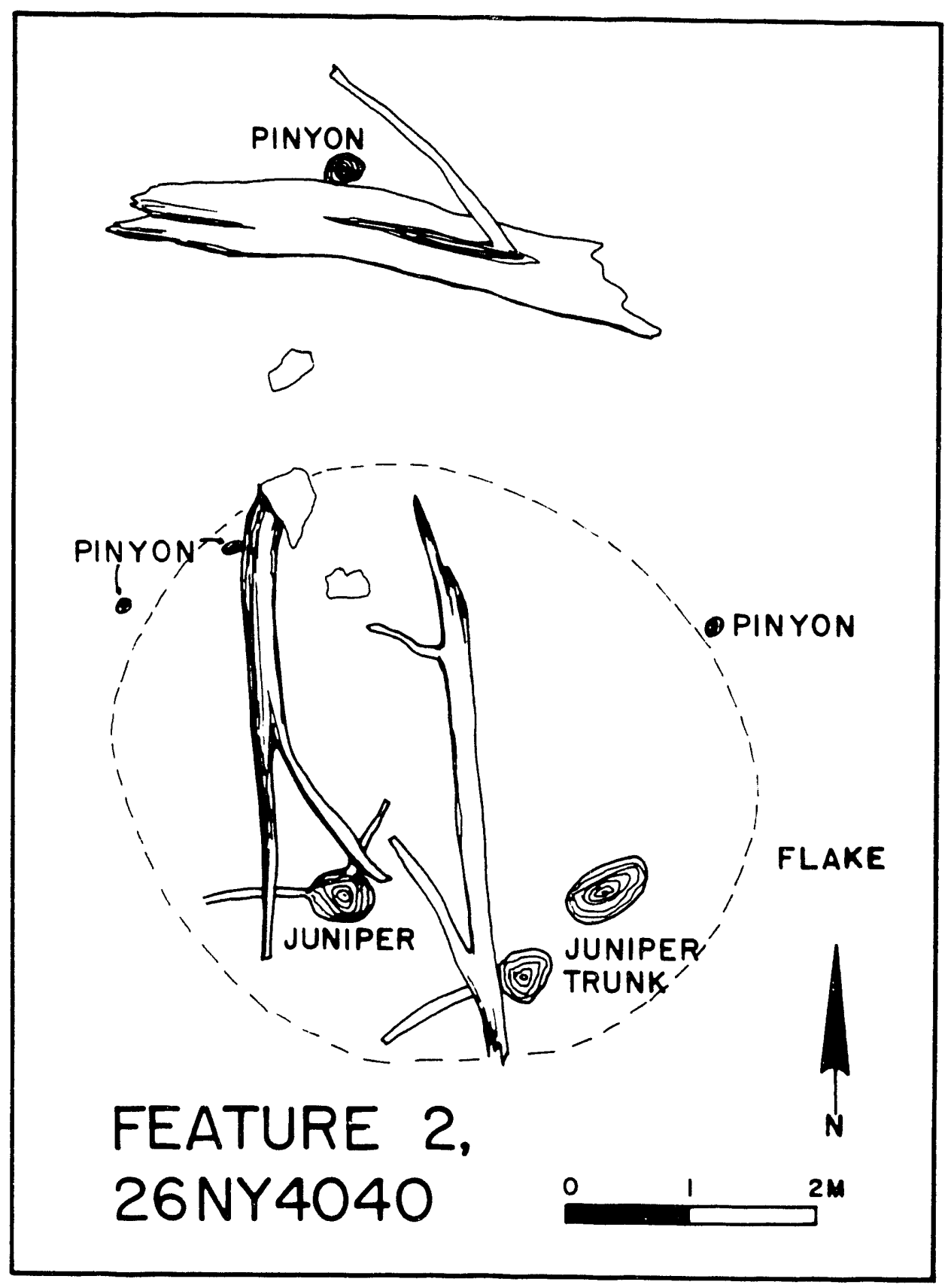

Figure 2-30. Drawing of Feature 2, a brush structure from site 26Ny4040. 


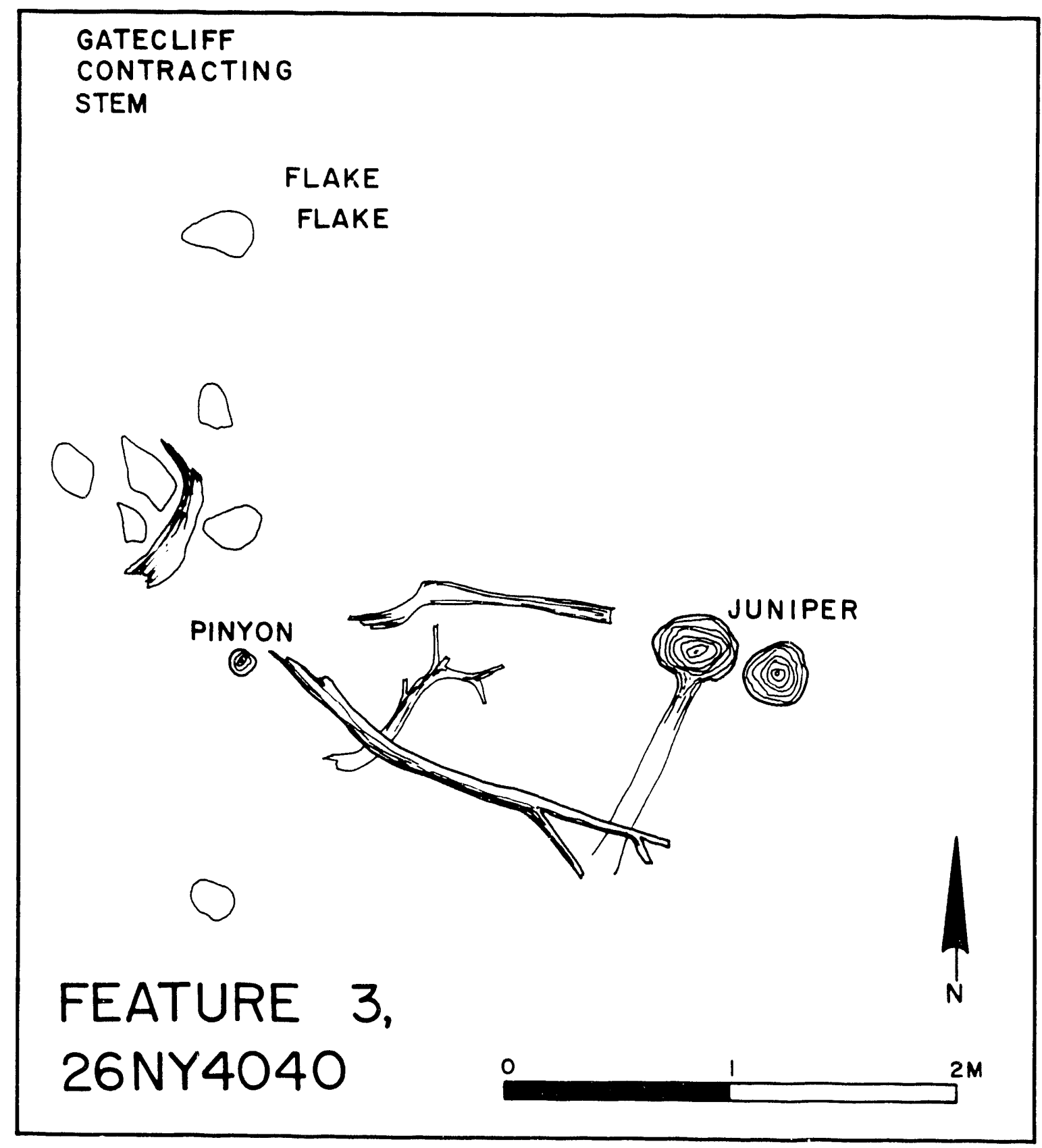

Figure 2-31. Drawing of Feature 3, a brush structure from site 26Ny4040. 


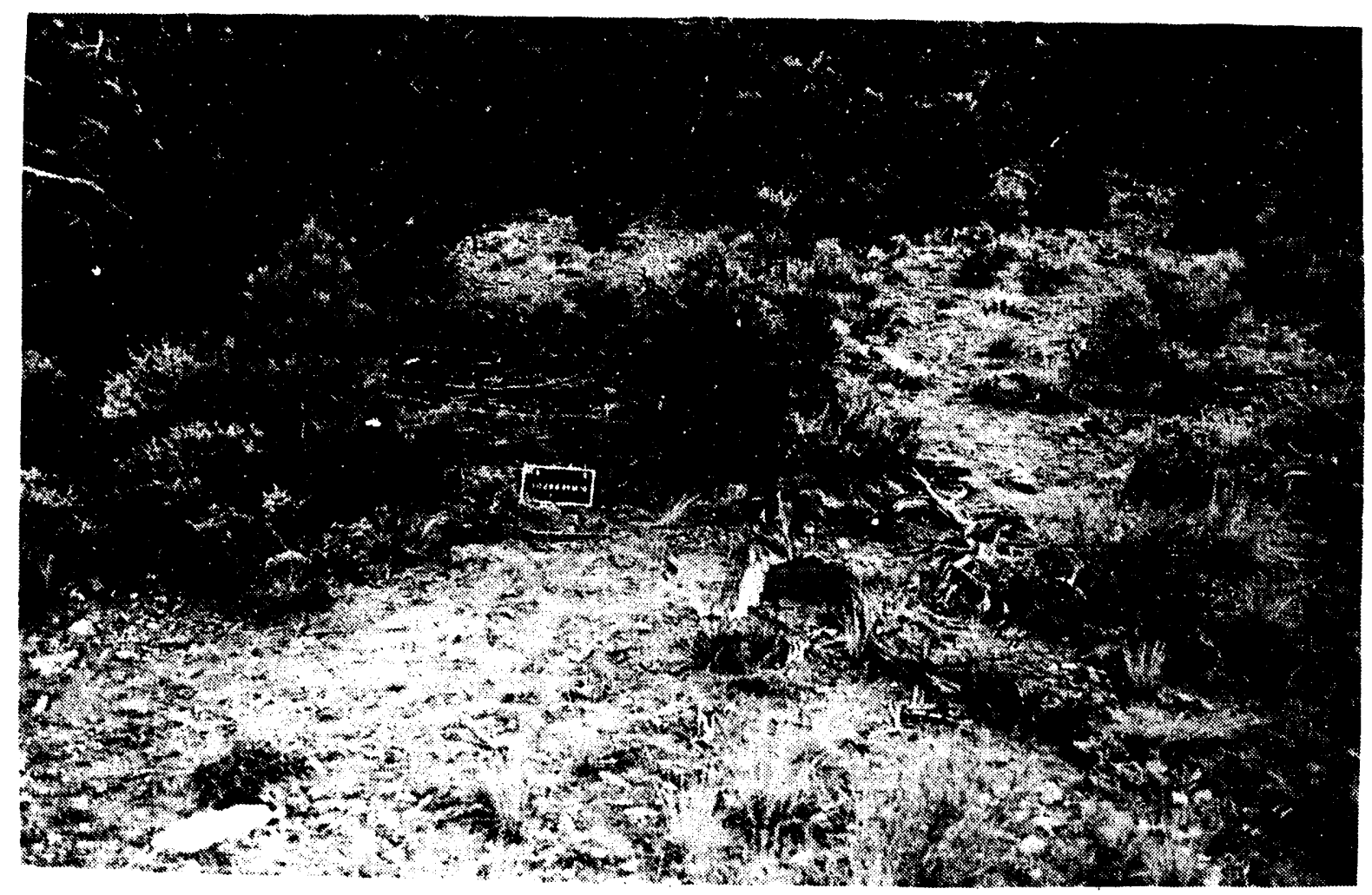

Figure 2-32. Photograph of Feature 1, a brush structure from site 26 Ny 4040.

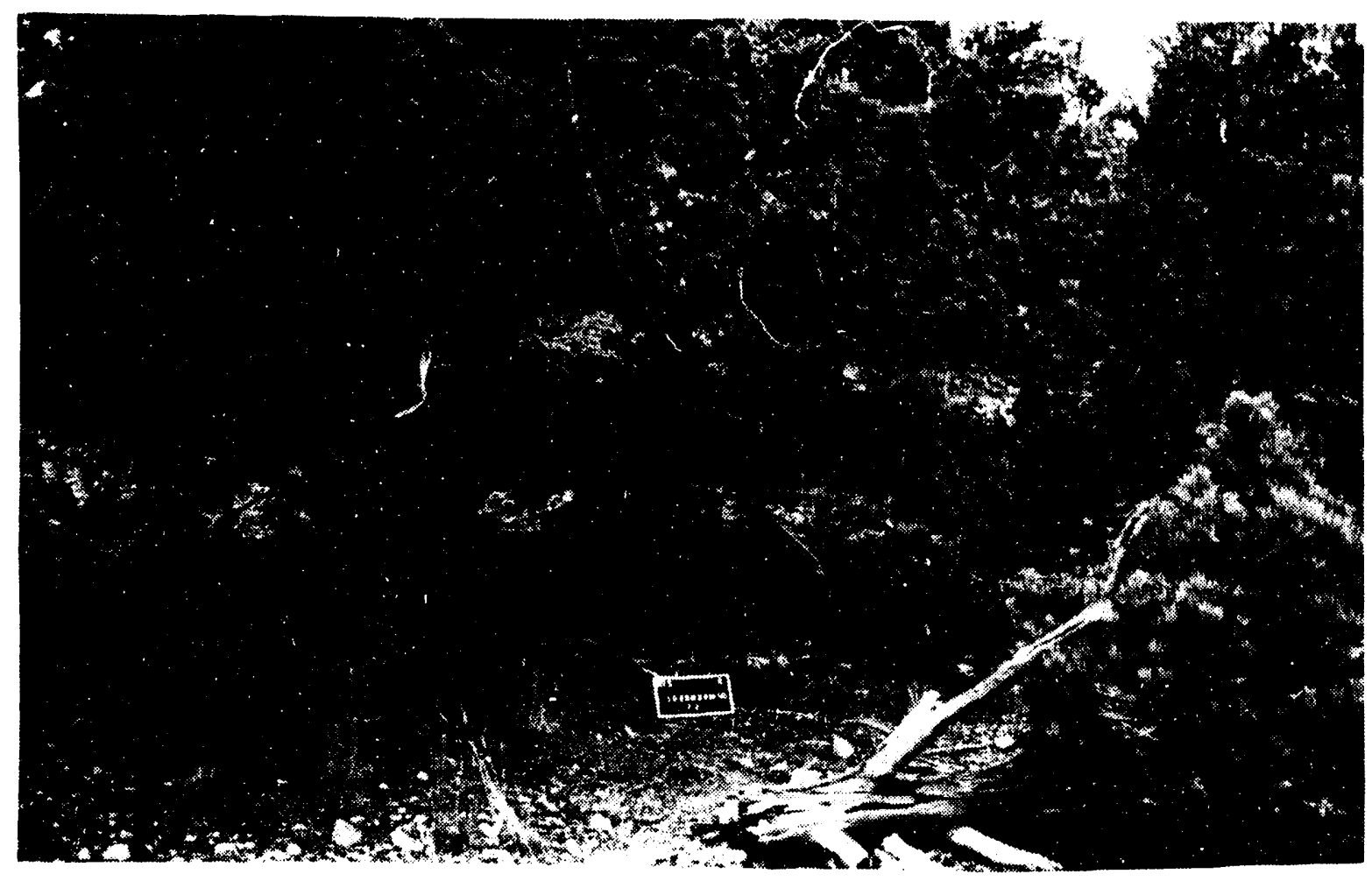

Figure 2-33. Photograph of Feature 2, a brush structure from site 26 Ny4040. 


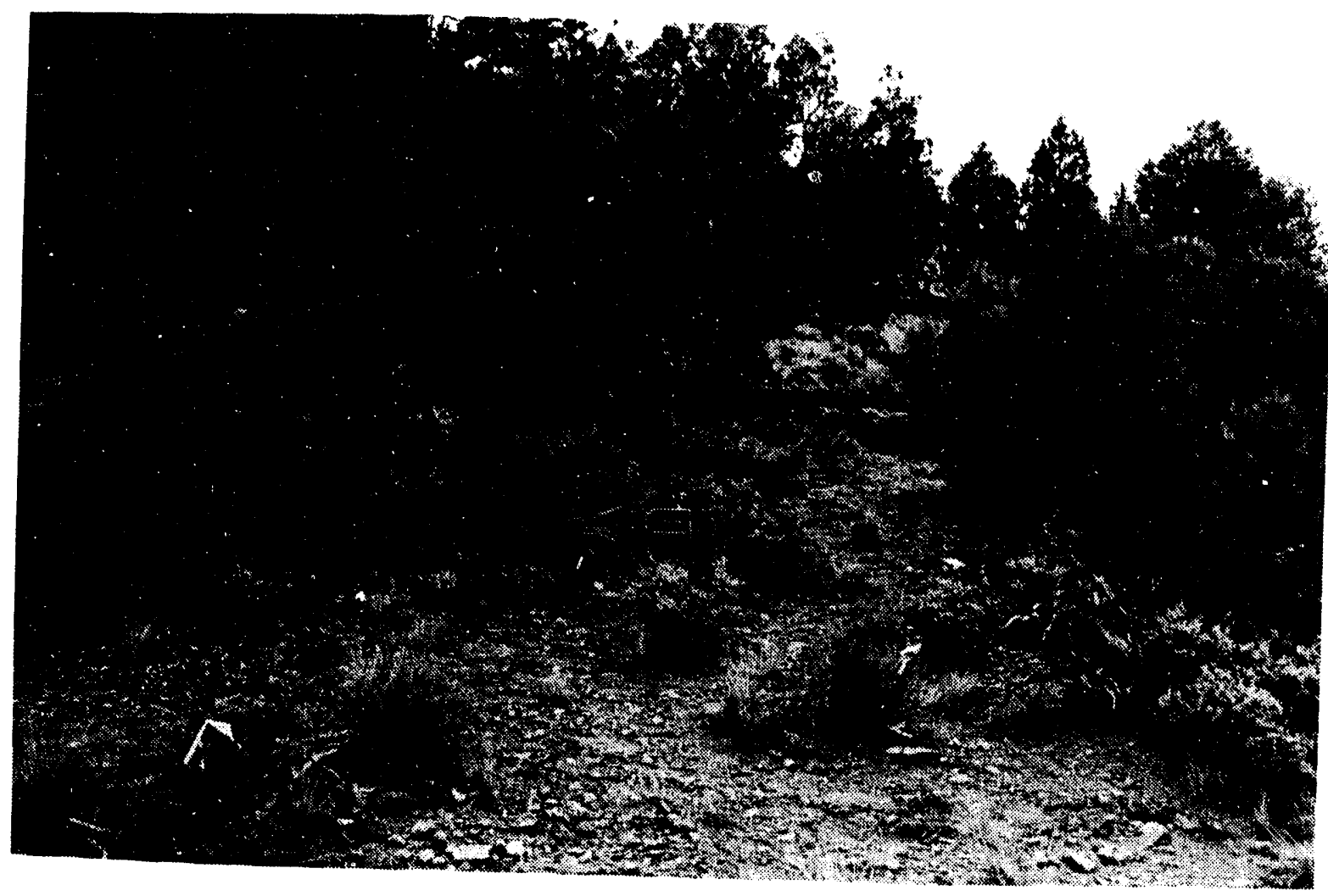

Figure 2-34. Photograph of Feature 3, a brush structure from site 26 Ny4040.

formed by two juniper trees and a brush wall with the branches leaned directly into the living junipers. Artifacts with this feature include two core reduction flakes. An obsidian Gypsum-type projectile point and a millingstone ware found nearby.

At 26 Ny4040, unlike $26 \mathrm{Ny} 4023$, there is considerable artifact scatter. Ample amounts of debitage, biface fragments, brownware potsherds, and projectile points were found at this site. Located in areas which could be directly impacted by the development of the event site, intensive data recovery was conducted here and is described later in this report.
No structures were observed at site 26Ny4041, another temporary camp located in an environment similar to $26 \mathrm{Ny} 4040$ in the southeast corner of the project. Artifacts included Rosegate and Elko projectile points and plain and decorated brownware pottery.

Site 26 Ny 4042 covers approximately 400 $\mathrm{m}^{2}$ and is composed primarily of white welded tuff debitage and a basin millingstone. This small camp is located on a ridge south of the project area. Site $26 \mathrm{Ny} 4048$, another relatively small temporary camp $\left(800 \mathrm{~m}^{2}\right)$ is located to the north of the project area in a shallow drainage just off a welded tuff ridge. Numerous millingstones: projectile points, including 
Desert Side-notched, Gatecliff, Pinto, and Humboldt types; and pottery, both plain brownware and plain Anasazi grayware, were observed when this site was recorded.

Temporary camp 26Ny4049 (Figure 2-35) is a large lithic and artifact scatter $\left(23,500 \mathrm{~m}^{2}\right)$ north of $26 \mathrm{Ny} 4040$. One brush structure was found at the east end of this site up a small drainage. This shelter is made with two living juniper trees and appears to have two walls, both constructed using vertical notched sticks. Only a small amount of debitage was observed at this shelter, but there was heavy tuff cover which may obscure more artifacts. The majority of the site, however, is composed of a low-density artifact scatter which included several loci of brownware potsherds, two Cottonwood triangular projectile pointi, and a mano. Site $26 \mathrm{Ny} 4050$ is a moderately sized $\left(4700 \mathrm{~m}^{2}\right)$ temporary camp composed of a dense scatter of white welded tuff debitage, several bifaces, two millingstones, and fire-cracked rock.

Archaeological site $26 \mathrm{Ny} 4053$ is a large $\left(31,400 \mathrm{~m}^{2}\right)$ temporary camp located on a broad slope with a northern exposure just below a welded tuff rim in the northeast corner of the project area. This site is diffuse, and there is no evidence of structures. Artifacts observed here include debitage, one mano, at least four millingstones, brownware pottery, one each Rosegate and Elko projectile points, and a tin can, which was probably used by aboriginals as a vessel.

The final temporary camp found during the original surveys is $26 \mathrm{Ny} 4045$, a relatively small site $\left(1700 \mathrm{~m}^{2}\right)$ located at the head of numerous small drainages due east of the drill site location. Two millingstones, brownware pottery, a mano fragment, and debitage were observed.

\section{Lithic Scatters}

Nine archaeological sites (26Ny3633, 26Ny3634, 26Ny4024, 26Ny4026, 26Ny4034-26NY4036, 26Ny4044, and
26Ny4046) were considered to be lithic scatters. Archaeological site $26 \mathrm{Ny} 3633$ was originally recorded as a very small $\left(50 \mathrm{~m}^{2}\right)$ lithic scatter located along the access road to the drill site. It contained 12 flakes of white chert and obsidian. Site 26 Ny 3634 is a smallish lithic scatter $\left(470 \mathrm{~m}^{2}\right)$ with approximately 50 biface thinning and core reduction flakes and a millingstone. Site 26 Ny4024 is a moderatesized $\left(2700 \mathrm{~m}^{2}\right)$ lithic scatter located to the southeast of temporary camps $26 \mathrm{Ny} 4021$, 26Ny4022, and 26Ny4023. Observed here were several concentrations of debitage and three projectile point fragments of the Rosegate and Elko types. Site 26 Ny4026 is another lithic scatter, approximately $1200 \mathrm{~m} 2$ in size, located to the southwest of the same temporary camps. Approximately 50 flakes, mostly associated with biface thinning, were observed along with an obsidian projectile point fragment, probably a Desert Sidenotched type.

Sites 26Ny4034, 26Ny4035, and $26 \mathrm{Ny} 4036$ are lithic scatters recorded in the central valley running north-south through the project area. All in the northeast portion of the project area, they are located in close proximity to temporary camps $26 \mathrm{Ny} 4015$, $26 \mathrm{Ny} 4040$, and $26 \mathrm{Ny} 4049$. Site 26Ny4034 located on a southeastern slope above the floor of the valley in the transition zone between sagebrush and pinyon-juniper, contained a dense lithic scatter. These were mostly obsidian and welded white tuff materials and core reduction and biface thinning debitage. Twenty-four potsherds, from at least two separate vessels, were also recorded. Site $26 \mathrm{Ny} 4035$ is composed of three loci of welded white tuff debitage, mostly core reduction and decortication debitage. Site $26 \mathrm{Ny} 4036$ is a relatively large $(2200 \mathrm{~m} 2)$ but diffuse scatter of debitage composed of some 40 flakes.

Lithic scatter 26 Ny 4044 is a moderately sized $\left(1650 \mathrm{~m}^{2}\right)$ site with two loci of welded white tuff debitage. It is located on a bench above and to the east of the valley floor and 


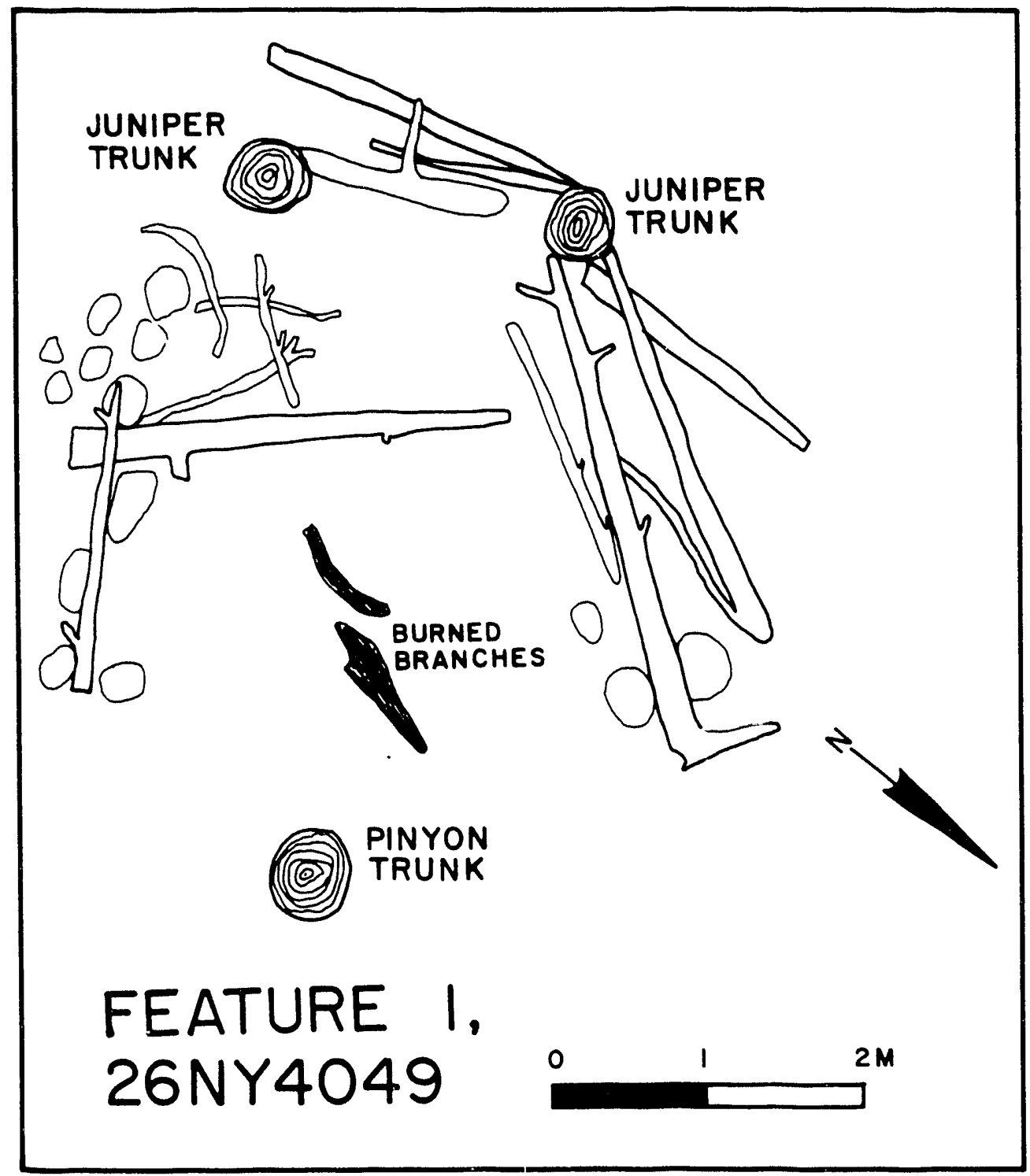

Figure 2-35. Sketch of an isolated brush structure, site 26Nv4049, Pahute Mesa, Nevada. 
below the top of the ridge. Debitage types included biface thinning, core reduction, and pressure flakes. Finally, 26Ny4046, a small lithic scatter of $80 \mathrm{~m}^{2}$, is located at the head of a drainage along the ridge east of the valley. It is approximately due east of the drill site center and consists of a single locus of approximately 20 flakes of chert core reduction and biface thinning debitage.

\section{Quarries}

One archaeological site, 26Ny4025, was labeled a quarry. This relatively large site of $5500 \mathrm{~m}^{2}$ consists of a low-density scatter of welded white tuff debitage and cores located in the valley bottom south of the temporary camps 26Ny4021, 26Ny4022, and 26Ny4023. Welded white tuff nodules were noted in the alluvium at the site.

\section{Localities}

Sixteen archaeological sites (26Ny3630, 26Ny3632, 26Ny4016, 26Ny4020, 26Ny4027, 26Ny4028, 26Ny4030-26Ny4033, 26Ny4038, 26Ny4039, 26Ny4043, 26Ny4045, 26Ny4051, and $26 \mathrm{Ny} 4052$ ) were recorded as localities. Site $26 \mathrm{Ny} 3630$ consists of four indeterminate flakes - three of welded white tuff and one of obsidian - scattered over a $100 \mathrm{~m}^{2}$ area. Site $26 \mathrm{Ny} 3632$ is another small locality (39 $\mathrm{m}^{2}$ ) also containing four flakes, all of white welded tuff. Both sites were found along the access road into the project area.

Locality $26 \mathrm{Ny} 4016$ is a small locality composed of four flakes and a Gatecliff-type projectile-point base. Site $26 \mathrm{Ny} 4020$, another small locality $\left(78 \mathrm{~m}^{2}\right)$ in the bottom of the drainage west of temporary camp 26Ny4021, consists of a rock overhang and three white welded tuff flakes. Sites $26 \mathrm{Ny} 4027,4028$, and 4030 are localities on a gently sloping hillside to the west of temporary camps 26Ny4021, 4022 , and 4023 . Site 26 Ny 4027 is a diffuse locus of 10 white welded tuff flakes scattered over $700 \mathrm{~m}^{2}$; the smaller $80-\mathrm{m}^{2} 26 \mathrm{Ny} 4028$ is composed of 10 welded tuff flakes: Site
$26 \mathrm{Ny} 4030$ is about $100 \mathrm{~m}^{2}$ in size and has four white welded tuff flakes.

Localities 26Ny4031, 26Ny4032, and $26 \mathrm{Ny} 4033$ are located in the central valley east of the drill hole center. Site $26 \mathrm{Ny} 4031$ is compused of two white welded tuff flakes. Site $26 \mathrm{Ny} 4032$ consists of about 10 flakes of a variety of materials, including obsidian, white welded tuff, and red chert. Site 26Ny4033 also contains approximately 10 flakes, mostly white welded tuff. Located in the same valley, but near the southern boundary of the project area, were two additional localities (26Ny4038 and $26 \mathrm{Ny} 4039$ ). Site $26 \mathrm{Ny} 4038$ was composed of two artifacts - a Pinto projectile point of obsidian ar. 1 a red chert flake. Site 26 Ny4039 consists of three artifacts - an obsidian projectile point midsection, an obsidian biface thinning flake, and a white welded tuff core reduction flake.

Site $26 \mathrm{Ny} 4043$ is a large $\left(1900 \mathrm{~m}^{2}\right.$ but diffuse locality composed of four flakes and a biface fragment located in a small drainage bottom. Locality $26 \mathrm{Ny} 4045$, located in a small valley in the southeast of the project area, contains a scatter of seven brownware potsherds and a white welded tuff flake. Site $26 \mathrm{Ny} 4051$ is a scatter of 70 brownware pottery fragments associated with a Rosegate type projectile point. This site is located up a small valley behind temporary camps $26 \mathrm{Ny} 4040$ and 26 Ny4049. The final locality, 26Ny4052, is a small knapping station composed of 30 white welded tuff core reduction and biface thinning flakes. This site is located on the ridge along the east side of the project.

Caches

One site, 26Ny4047, was classified as a cache. It consisted of an iron sickle blade stored in a wind-eroded hole in a low, welded tuff, cliff face.

Isolated Artifacts

Four archaeological sites were isolated artifacts (26Ny4018, 26Ny4019, 26Ny4029, and 26Ny4037). Sites 26 Ny 4018 and 
26 Ny4019 were projectile point fragments found in the wash next to locality $26 \mathrm{Ny} 4020$. The first fragment was unidentifiable, the second a Rosegate type of pink welded tuff. Site 26 Ny4029 consisted of a biface fragment of chert. It was located on a small bench to the west of the drainage which contained $26 \mathrm{Ny} 4018$ and $26 \mathrm{Ny} 4019$. Finally, $26 \mathrm{Ny} 4037$ was a single white welded tuff core reduction flake found in the central valley towards the southern end of the project area.

\section{Potential for Adverse Impacts}

In the development of an event site, such as U19au, the DOE and DRI have identified three stages of development where significant cultural resources may be adversely impacted. The first stage entails the construction of a 500 to $700-\mathrm{ft}$-square drill pad and access routes to the pad for personnel, equipment, and power. The second stage of potential adverse impacts to cultural resources involves two elements. The first element of this phase is the construction of a cableway and parking zone for the diagnostic trailers that monitor the nuclear test. The construction for this pad and cableway usually involves surface disturbance along a 600-ft-wide by 1500-ft-long corridor in one direction from the drill hole center. In the second element, remote sensing devices may be buried at a fixed radius of about $1200 \mathrm{ft}$ around the event site. The third stage of potential adverse impact involves the zone of disturbance caused by the detonation of the nuclear device. A roughly circular region with a radius somewhat less that $1200 \mathrm{ft}$ is undermined by the detonation and may form a subsidence crater. The detonation also sends shock waves through the bedrock and may cause the welded tuff cliff faces to collapse even at a relatively long distance from the event site. Finally, as part of the third stage, a pad is constructed for a small drill rig to drill into the cavity formed by the detonation and sample the gasses present. Usually, this pad is constructed outside the potential crater area, but within the $1200 \mathrm{ft}$ radius.

The net effect of the development at an event site is that all of the archaeological sites that occur in the 1200- $\mathrm{ft}$ radius, in the area of the trailer pad, or along the access route are destroyed by the development. At U19au, DRI identified 21 archaeological sites (26Ny3632-3634, 26Ny4015, 26Ny4017, 26Ny4020-26Ny4023, 26Ny4025, 26Ny4028, 26Ny4031-26Ny4036, 26Ny4039-26Ny4040, $26 \mathrm{Ny} 4044$, and $26 \mathrm{Ny} 4049$ ) recorded during the inspection of the access road to U19ao and the initial reconnaissance of U19as [au] that would be affected (Pippin and Henton 1986).

Contrary to DRI's recommendations, the DOE determined that two of these sites, 26 Ny4022 and 26Ny4023, were far enough away that they would not be impacted by the site's development and excluded them from data recovery, preferring avoidance to mitigation. Data recovery, described in detail later, consisted of a large areal surface collection supplemented with test excavations, surface feature exposures, and subsurface scrapes at the affected sites. 


\section{RESEARCH DESIGNS AND METHODS}

\section{Overview}

In 1988, Pippin and Henton formally proposed eleven broad and general research questions which were designed to guide archaeological investigations on Pahute Mesa so as to provide data pertinent to addressing information concerns of the Nevada Division of Historic Preservation and Archaeology and the scientific community (Pippin and Henton 1988). To realize the goals of the proposed investigations, methods were required which would provide the necessary information, and were based on the nature of the resources present. Since most of the cultural resources appeared to be surface scatters of artifacts and features, the primary method of data recovery was controlled surface collection. This surface collection data was supplemented by areal exposures at selected features. Test excavation were conducted in artifact concentrations which appeared to be in geologically depositional environments, and subsurface scrapes were conducted to help verify the recovery from the surface collections.

\section{Purpose}

Various environmental legislation, particularly the National Historic Preservation Act (NHPA) and the National Environmental Policy Act (NEPA) charge the DOE with the responsibility of identifying and preserving significant cultural resources on properties which they administer. Significance for most archaeological sites is defined in 36 CFR 60.4 as having "integrity of location, design, setting, materials, workmanship, feeling and association and. . that have yielded, or may be likely to yield, information important in prehistory or history." To help identify whether an archaeological site is significant in terms of this definition, the Nevada Division of Historic Preservation and Archaeology (NDHPA) has identified seven research domains which it considers important to the study of Nevada prehistory. These seven domains are studies of settlement patterns, subsistence systems, past environments and geochronology, trade and exchange, ideology and belief systems, directional change through the Archaic, and lithic analysis (Lyneis 1982a).

\section{Research Questions}

The types of information obtained from archaeological sites depends primarily on the data at the archaeological site and the questions asked during the investigations of the site. While one cannot be certain what information a given archaeological site may conceal, a strategy for investigations can be established beforehand based on previous knowledge of the area's archaeology and maximizing the potential to recover data of interest. Pippin (1986:39-54) and Pippin and Henton (1988:9-10) have reviewed the seven research domains presented in the state historic plan (Lyneis 1982a) regarding the archaeological record on Pahute Mesa and have developed eleven research questions which may be addressed by this record. The eleven questions, discussed in detail elsewhere (Pippin and Henton 1988:10-22), are listed below:

1) What are the relationships between Anasazi cultural remains on Pahute and Rainier mesas and those of the non-horticultural hunters and gatherers who traditionally utilized this environment?

2) What is the relationship between past fluctuations in the environment of Pahute and Rainier mesas and prehistoric patterns of settlement and subsistence?

3) What are the history and processes of past residential mobility and demography on Pahute and Rainier mesas?

4) What are the sources of raw materials used in artifacts and features found at cultural resources on Pahute and Rainier mesas? 
5) What strategies of subsistence resource utilization are represented in the archaeological record of Pahute and Rainier $\mathrm{Me}$ sas, how has this resource utilization affected settlement patterns, and how have these subsistence and settlement strategies or their relationship changed through time?

6) What is the history and magnitude of fluctuations in the environment of Pahute and Rainier mesas during the last 18,000 years?

7) What behavioral information (e.g., methods of tool manufacture, changes in lithic technology, economy of resource use, and nature of associated activities) is represented by lithic debitage at lithic scatters on Pahute and Rainier mesas?

8) What are the processes and chronology of sediment deposition on Pahute and Rainier mesas, and how may natural geologic and biotic processes have affected the nature of the archaeological record there?

9) How are ethnohistoric sites on Pahute and Rainier mesas represented in the archaeological record, and how may this information be used in modeling more ancient settlements and activities?

10) What are the spatial relationships of cultural remains on Pahute and Rainier mesas to each other and to available natural resources?

11) How old are the cultural remains in question?

Using these questions as guidelines for evaluating the archaeological sites found at U19au, these sites were found to be significant and potentially eligible to the National Register (Henton 1986:15). The NDHPA concurred with these findings, and the DOE was then responsible for preserving the scientific information potential of the sites. In situ preservation is preferred since curient archaeo- logical philosophy stresses preservation. This is also often the cheapest alternative for the land-managing agency. However, in situ preservation is not necessary when the scientific information at an archaeological site can be recovered and preserved through archaeological investigations. The DOE chose to meet its obligation of preservation by investigating the majority of the archaeological sites in preferen ze to in situ preservation.

\section{Methods}

To understand both the inter- and intrasite variability necessary to answer the questions posed above required a broad range of investigations at U19au. Appropriate methods for data recovery are dictated by two factors: the research questions being asked and the cultural material present at the site. Data recovery techniques were required for identifying the internal variability and associations necessary for intrasite analysis and for characterizing the site and its cultural components for intersite and environmental comparisons. It is not possible to know a priori what the actual archaeology of a given site based solely on surface reconnaissance. Still, reasonable estimates of the expected cultural material can be based on information from excavations of previously investigated sites in similar geological contexts. Most of the sites recorded at U19au, while rich in surface features, are located on shallow soils or bedrock. Others in areas of greater fill lack artifact density and features which previously indicated substantial subsurface material.

Therefore, the data recovery plan proposed for U19au involved a large-scale surface collection of the majority of the areas to be directly impacted. This was supplemented by substantial subsurface scrapes and shallow test excavations at habitation structures identified during the original survey. Four specific techniques were employed during the investigations: mapping, controlled surface collection, subsurface scrapes, and excavations. 


\section{Mapping}

Because many of the research questions depend on knowledge of cultural resources relationships or environmental features, detailed mapping was an important element in the data recovery. This is one of the primary methods of preserving these relationships. All sites investigated were mapped planimetrically, with important topographical and cultural features mapped to scale. These maps included the grid system used for provenience and for any excavation or surface scrape unit. Elevational information was not routinely included unless necessary for understanding particular features. These maps were compiled concurrently with the surface collections at U19au. The base maps of the site with the collection grid delineated were prepared prior to collection. ine collection grid was staked in the field (Figure 3-1), and detail added to the map as the collection proceeded. While most of tine area was mapped in this fashion, on occasion, to include relevant features located beyond the grid system, radial measurements were used and converted to grid coordinates. These measurements were made with a Brunton compass on a tripod and a 30-m Fiberglas tape. More detailed maps, at a larger scale, were created for investigations at sites with structures.

\section{Surface Collection}

Controlled surface collection was one of the principle data recovery techniques used at U19au. Its purpose was to recover a substantial percentage of the cultural material on the ground's surface while maintaining meaningful units of horizontal provenience. Surface collection was implemented by imposing a metric grid over the area of impacts and collecting the cultural material observed in each grid square. The units were usually $10-b y-10$ $m$ in size for general collection, but specific features were collected in 1-by-1 m units. Each unit was designated by the grid coordinate of its northeast corner.
The grid itself, oriented north-south and centered on the drill hole site for U19au, was given the arbitrary designation $1000 \mathrm{~N}, 1000 \mathrm{E}$ to allow for extension of the grid beyond the anticipated limits of impacts. The grid was established by locating a Brunton compass on the drill pad center point and setting reference points along the four major axes - north, east, south, and west. These lines were extended to encompass the area of expected impacts, originally about $750 \mathrm{~m}$ north-south by $600 \mathrm{~m}$ east-west. A flagged lath was placed at 150-m intervals along these baselines. Brush and limbs were cleared in areas of dense pinyon-juniper for open lines of sight to insure accuracy of the grid. Secondary east-west axes were established at intervals of $150-\mathrm{m}$ along the main north-south axis. Like the baselines, these secondary axes were flagged at $150-\mathrm{m}$ intervals and laths placed at $30-\mathrm{m}$ intervals between the flags. The final step before surface collection was to place pin flags at 10-m intervals between the flags and laths as temporary guides for gridding the site.

Once the baselines and secondary axes had been established, the majority of the area of impacts (a 1200-by-1200 m area) was collected using a mobile rope grid capable of delineating nine 10-by-10 m collection units (a $30-$ by $-30 \mathrm{~m}$ area). The flags on the baselines and secondary axes divided the site into approximately 17 collection areas 150 -by-150 $m$ in size. Each of these areas was collected in a systematic fashion. The habitation areas, surface scrapes, and other excavations were excluded from the general surface collection and were collected using a smaller unit size (1 square meter). The general collection of one of the 150-by-150 m collection areas usually involved the following steps:

1) Four ropes, calibrated to $30 \mathrm{~m}$ in length and marked every $10 \mathrm{~m}$, were laid out on the ground perpendicular to one of the axes and in one corner of the collection area. This created nine $10-b y-10$ m coi- 


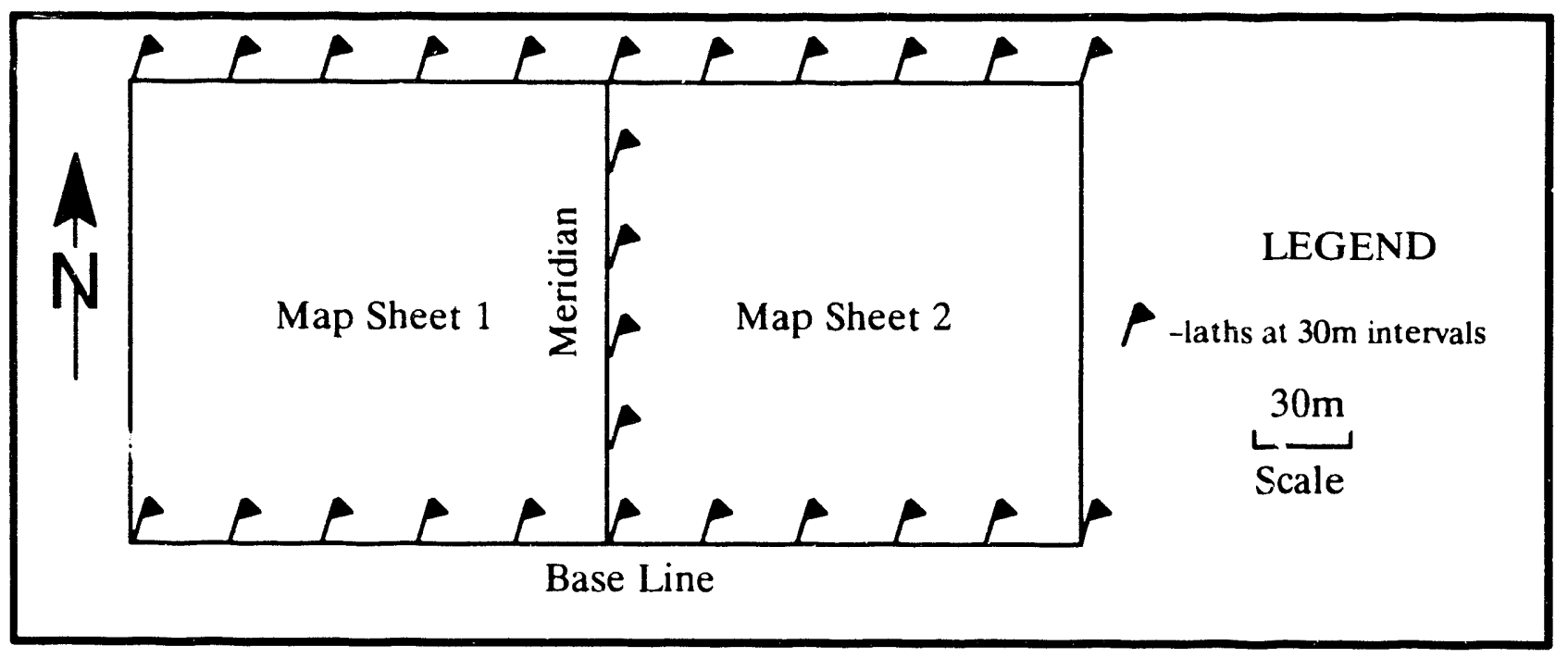

Figure 3-1. Collection Grid Baseline and Meridians

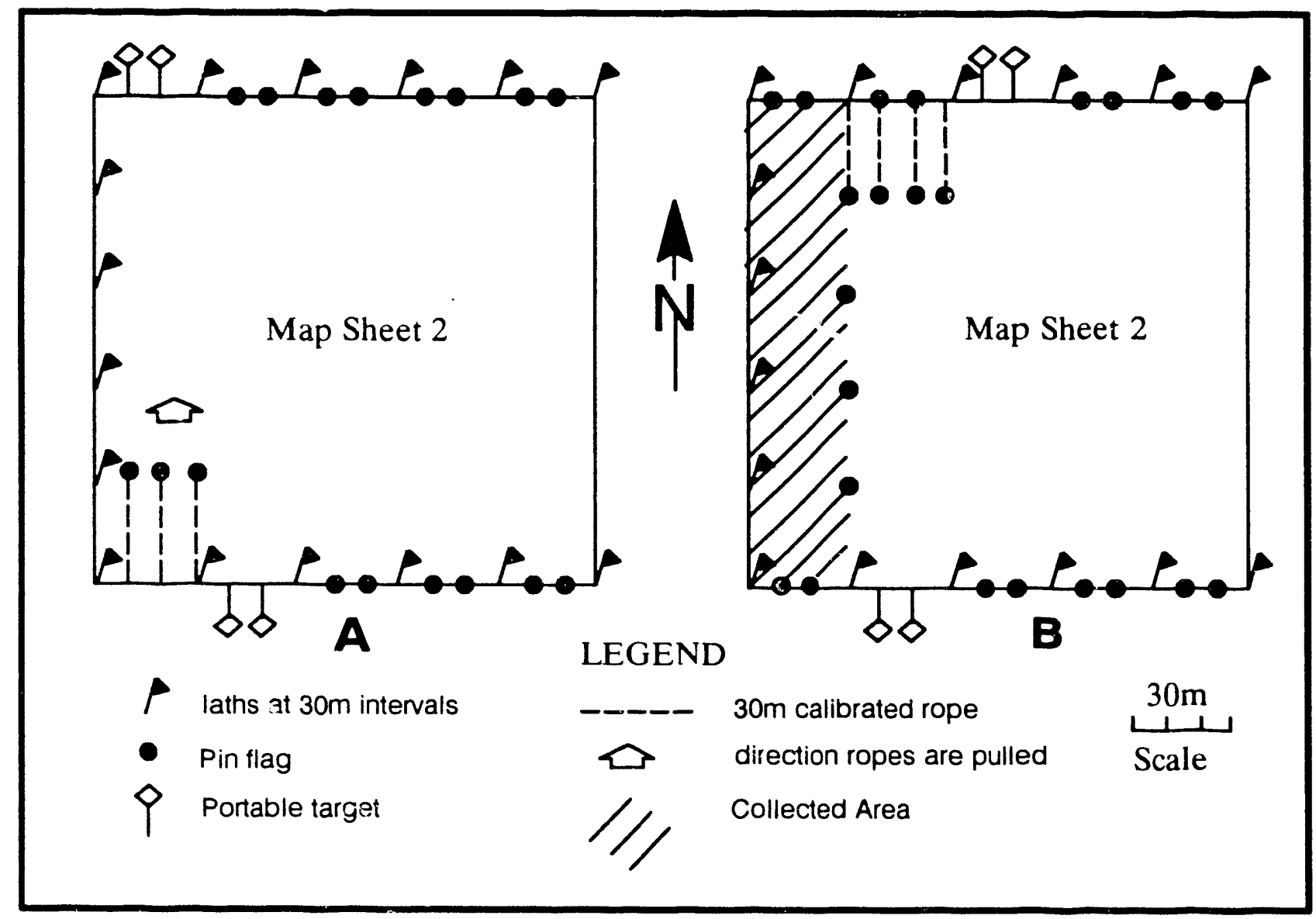

A - layout of ropes at start of the first column;

$B$ - layout of ropes at s'art of secund column.

Figure 3-2. Rope Grid Collection System 
lection units in a 3-by-3 $\mathrm{m}$ arrangement (Figure 3-2a).

2) These units were collected by archaeologists walking at closely spaced intervals inspecting the ground surface (see below).

3) After completing the collection of the existing nine units, the ropes were pulled and a new set of units created. The direction of the units was maintained by sighting with a Brunton compass. These new units were collected as described above.

4) After five pulls of the ropes, $150 \mathrm{~m}$, the far boundary of the collection area was reached. After the final units in this row were collected, the ropes were coiled, and the crew moved to the next row (Figure $3-2 b)$. The ropes were laid out and this row collected as before, but in the opposite direction.

5) The 150-by-150 m collection area was finished when five rows had been collected.

6) Each collection area which included areas of impact was collected in this manner.

Archaeologists inspected each collection unit by walking back and forth over the unit, spacing their transects no wider than two $\mathrm{m}$ apart. All nondiagnostic artifacts were collected as the walk-through proceeded and were placed in plastic bags. If a collection unit contained artifacts, it was assigned a reference number. This number was recorded on a tag which was placed in the bag, in a log identifying the provenience of the collection unit and the reference number, and on the site map. Diagnostic artifacts, e.g., projectile points or groundstone, received a "point" provenience, that is a location to the nearest meter. These artifacts received a separate reference number, $-a$ provenience calculated from the 10-by-10 $\mathrm{m}$ collection unit datum (northeast corner) - and were bagged separately.

\section{Subsurface Scrapes}

Subsurface scrapes provided a more detailed assessment of how well the visual collection represented the cultural material actually present or helped document the effects of turbation. Subsurface scrapes were performed in areas which appeared to have the potential for limited buried deposits or at locations of substantial accumulations of debitage. The methods for conducting these scrapes were as follows: 1) a rectilinear area was delimited (usually a 2-by-2 or 3-by-3 m area), 2) the unit was visually collected and the artifacts bagged and recorded, 3) the top 3 to $5 \mathrm{~cm}$ of soil was removed using a square shovel and screened through 1/4-inch mesh screen, and 4) the artifacts from the screen were bagged and assigned a reference number.

\section{Excavations}

Two types of excavation were conducted--test pits and area exposures. Test pits are one or more 1-by-1 m units located adjacent to each other and usually oriented north-south. Test pits are usually numbered consecutively by project, and if more than a single 1-by-1 unit is dug, each 1-by-1 receives a letter designation.

These units are dug in natural stratigraphic levels, if possible, or in arbitrary levels, if natural strata are too thick or are undetectable. Natural strata are generally divided into $10-\mathrm{cm}$ arbitrary levels unless reason exists to use a different width, e.g., sterile fill over irregular bedrock surfaces is often removed in wider than $10-\mathrm{cm}$ levels. Levels are the basic unit of observation and are numbered consecutively from the top level to the bottom. Cultural material on the surface is recorded as level 0 ; level 1 is the first level excavated. After each level is screened, a record is completed which contains site reference number, level reference numbers, location of the unit, depth of the level, cultural material recovered, soil matrix removed, and natural stratum being excavated. Strata recurds tire 
natural, observable soil stratigraphy. The surface of the unit is defined as stratum $A$, the first excavated stratum is stratum $B$. Stratums and levels may coincide, but often differences exist because breaks in strata may be hard to detect during excavation or a stratum may be thick enough to be divided into several levels. All levels of each unit receive a unique reference number, even if culturally sterile; and usually all artifacts from the level are logged with this number.

Soil is removed from the unit by shoveling it directly into a screen. If the distance to the screen is too far or the unit too deep, it may be moved to the screen in buckets. The soil is sifted through 1/4-inch mesh screen and then inspected for artifacts. Generally, all artifacts recovered from a level of a unit are logged together, but carbon, delicate artifacts, or samples may be stored separately. These are given a reference number different from that of the level itself. During the excavation, larger objects, rocks, features, or artifacts are left in situ, at least until the completion of the level. Depending on their nature or the nature of the excavation, they may be removed or left while excavations continue. Such items will be sketched in the level record, and photographed, if warranted. Excavations generally continue until the soil become culturally sterile, bedrock is encountered, or evidence indicates secondary deposition of cultural material by natural agents.

Records kept for each unit include the level record, discussed above, and a synopsis of the completed unit. If any special samples were taken, a special record is completed for each sample, and any reference numbers issued are recorded in a reference log. Two adjacent sidewalls are sketched, and the unit is photographed.

Area exposures are excavated much like test pits except that the unit size may be greater than 1-by-1 m, and they are not necessarily excavated to bedrock or sterile soil. Naturally observable features, e.g., a house pit or rock ring, or areas of arbitrary size, determined unit size and numbering. In such cases, reference numbers and provenience are based on suitable units depending on the nature of the exposure. 


\section{DATA RECOVERY AT U19au}

\section{Overview}

Data recovery is discussed in four parts. The first concerns the collections and excavations along the access road. Most of the depositional environments occurred at artifact concentrations along this road, and three of the concentrations were tested (Table 4-1). No substantial or significant cultural materials were identified in the subsurface deposits.

The majority of work effort went into the second phase of the investigations - a large scale surface collection of the main drill pad area $600-$ by $750-\mathrm{m}$ in size. The spatial distri- bution of debitage and other artifacts recovered from this surface collection was analyzed, and eleven distinct artifact concentrations, along with associated temporally diagnostic artifacts, were compared. The types and clusters of debitage allowed us to infer the functions of the concentrations.

Thirteen subsurface scrapes were conducted during the surface collection at the drill pad (Table 4-1). The collections from these were compared to the subsurface collections for four of the scrapes using chi-square tests. In three of the four cases, these tests indi-

Table 4-1. Excavation Units and Subsurface Scrapes Conducted during Archaeological Investi. gations at U19au, Nevada Test Site, Nevada.

\begin{tabular}{llllll}
\hline $\begin{array}{l}\text { Unit } \\
\text { Name }\end{array}$ & $\begin{array}{l}\text { Unit } \\
\text { Type }\end{array}$ & $\begin{array}{l}\text { Grid } \\
\text { North }\end{array}$ & $\begin{array}{l}\text { Location } \\
\text { East }\end{array}$ & $\begin{array}{l}\text { Area } \\
\mathrm{m}^{2}\end{array}$ & Comments \\
\hline Unit 1 & Test & 2231 & 969 & 1 & Test for buried component \\
Unit 2 & Test & 1965 & 942 & 2 & Test for buried component \\
Unit 3 & Test & 2096 & 932 & 1 & Test for buried component \\
Unit 4 & Exposure & 1315 & 1226 & 30 & Expose brush structure \\
Unit 5 & Exposure & 1305 & 1231 & 30 & Expose brush structure \\
Unit 6 & Exposure & 1323 & 1231 & 48 & Expose brush structure \\
Unit 7 & Scrape & 1175 & 1117 & 6 & Included with scrape 2 \\
Unit 8 & Test & 1294 & 1239 & 1 & Test charcoal feature \\
Unit 9 & Not used & & & & \\
Unit 10 & Exposure & 705 & 925 & 600 & Expose rock ring features \\
Scrape 1 & Scrape & 920 & 953 & 9 & Sample lithic scatter \\
Scrape 2 & Scrape & 1179 & 1116 & 24 & Sample lithic and pottery scatter \\
Scrape 3 & Scrape & 1375 & 1130 & 4 & Sample quarry \\
Scrape 4 & Scrape & 1453 & 920 & 9 & Sample lithic scatter \\
Scrape 5 & Scrape & 867 & 950 & 6 & Sample lithic and groundstone scatter \\
Scrape 6 & Scrape & 935 & 900 & 25 & Sample lithic scatter \\
Scrape 7 & Scrape & 1385 & 890 & 25 & Sample lithic and pottery scatter \\
Scrape 8 & Scrape & 718 & 960 & 12 & Sample lithic and groundstone scatter \\
Scrape 9 & Scrape & 864 & 726 & 6 & Sample artifact scatter \\
Scrape 10 & Not used & & & & \\
Scrape 11 & Not used & & & & \\
Scrape 12 & Scrape & 1110 & 754 & 16 & Sample lithic and pottery scatter \\
Scrape 13 & Scrape & 1122 & 762 & 16 & Sample lithic scatter \\
Scrape 14 & Scrape & 1133 & 793 & 15 & Sample artifact scatter \\
Scrape 15 & Scrape & 1270 & 702 & 12 & Sample artifact scatter \\
\hline
\end{tabular}


cated that the populations of artifacts could not be differentiated. However, a substantial proportion of the material, ranging from 50 to 200 percent of the surface material, is found subsurface.

Areal exposures of habitation features at two sites, $26 \mathrm{Ny} 4021$ and $26 \mathrm{Ny} 4040$, composed the final two parts of the data recovery efforts (Table 4-1). Investigations at the rock ring structures $26 \mathrm{Ny} 4021$ revealed a fire hearth which contained a white glass bead in the soil matrix and which was dated to $470 \pm 50$ years B.P., and numerous millingstone and pottery fragments. Investigations at the brush structure, $26 \mathrm{Ny} 4040$, revealed numerous artifacts and features, including a substantial number of historic artifacts. These artifacts were mostly associated with clothing or adornments and included buttons, beads, rivets, and brads.

\section{Introduction}

Data recovery at U19au involved four distinct activities, each associated with a major archaeological site found in the area of impacts. The first element of the data recovery was surface collection and test excavations along the access road to the drill site. The principle archaeological site investigated during this phase was $26 \mathrm{Ny} 3633$, a quarry, temporary camp and lithic scatter located to the north of the drill pad along the access road. A relatively low density, but continuous lithic scatter was found between $26 \mathrm{Ny} 3633$ and the pad site, and a corridor was collected through this scatter during the archaeological investigations. The surface collections around the drill pad center comprise the largest areal extent of archaeological investigations, and $26 \mathrm{Ny} 4015$ is the largest of many sites that were collected during this second phase of the project. Two important sites, $26 \mathrm{Ny} 4021$. located south and adjoining the 26Ny 4015 collection area, and $26 \mathrm{Ny} 4040$, located to the northeast of the drill hole center and within the 26 Nyy 4015 colliection area, were investigaied individually. Site 26 Ny4021 is a temporary campsite composed of at least three rock rings and associated features, and $26 \mathrm{Ny} 4040$ is a temporary camp composed of three brush structures. Area exposures, test excavations, and surface collections were conducted at $26 \mathrm{Ny} 4040$, area exposures and surface collections at 26 Ny4021.

\section{Archaeological Investigation Along the Access Road}

Four archaeological sites-26Ny3631, 26Ny3632, 26Ny3633, and 26Ny3634 - were recorded during the original survey of the access road for drill pad U19ao. Prior to data recovery, it was observed that these sites were actually concentrations of artifacts in a very diffuse scatter of cultural material in that end of the valley. Because of difficulties in defining archaeological site boundaries in this environment, collecting artifacts in and around the zones of proposed disturbance appeared to be the most practical way to investigate the cultural material along the access road. The collection grid was extended from the U19au drill hole center north and parallel to the access road until the Pahute Mesa road was reached (Figures 4-1 and 4-2). A corridor was collected along the proposed access road 30 to $40 \mathrm{~m}$ wide, depending on where the center line of the road fell in relation to the collection grid.

Concentrations of artifacts were collected at the previously recorded sites along the access road. The overall density of artifacts found was iow, usually between two and nine artifacts per 10-by-10 m collection unit. Most collection units between sites contained either a single artifact or none at all. Three concentrations of debitage were collected. These corresponded with archaeological sites $26 \mathrm{Ny} 3634$ - the northernmost site recorded during the U19ao access road survey; 26 Ny 3633 and 26 Ny3632-south of 26 Ny3634 and the largest of the access road sites; and 26 Niy $363 i$-south of 26 Ny $3633 / 26$ Ny 3632 


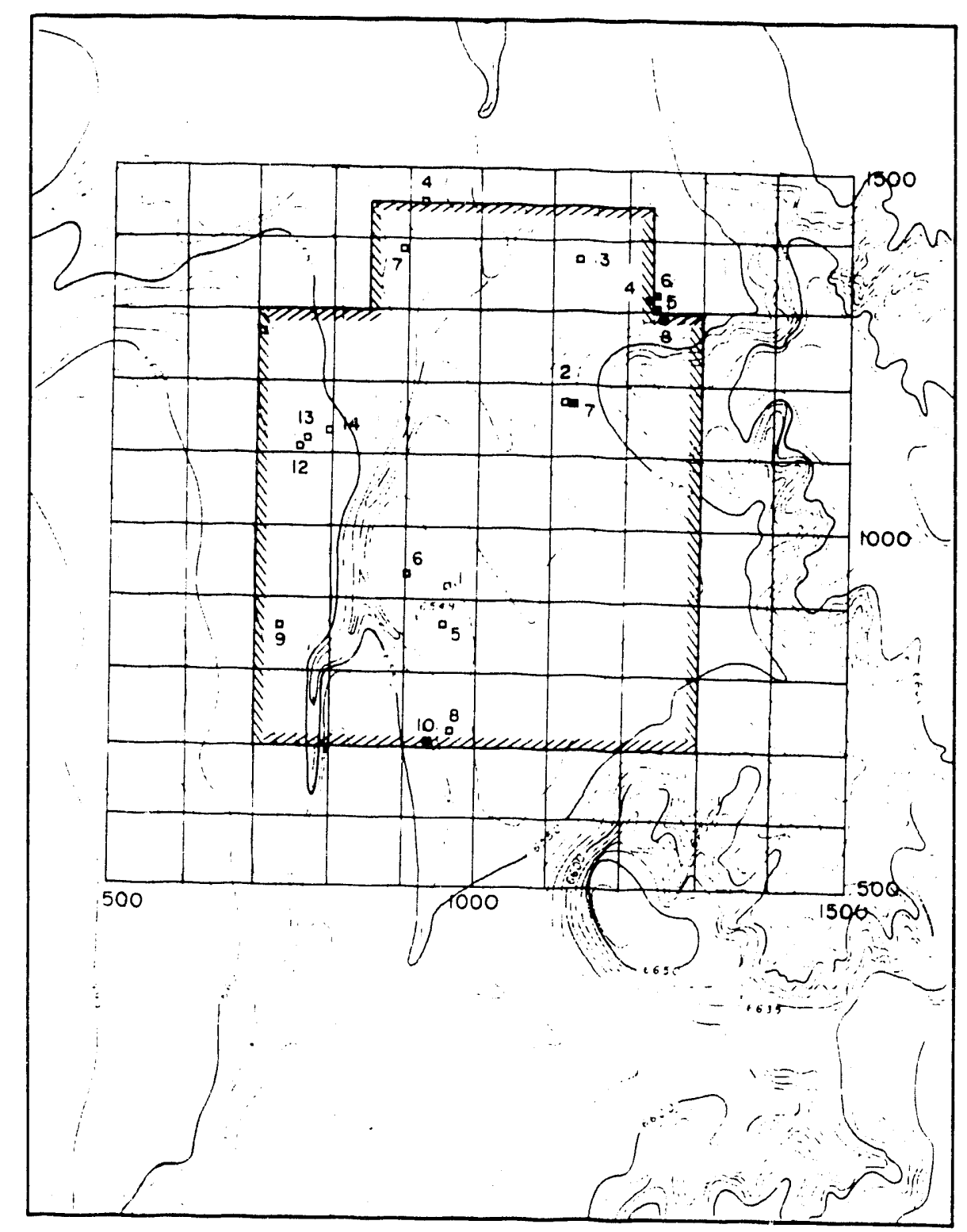

U19au Archaeological Investigations

Pahute Mesa, Nevada

DRILL PAD AREA

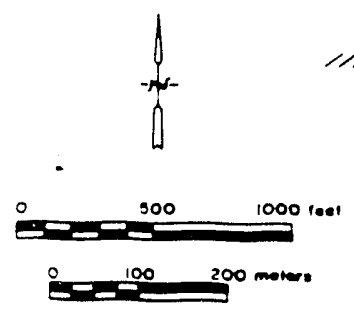

Figure 4-1. Surface collection area, and the locations of excavation units and subsurface scrapes for the drill pad area of the U19au archaeological investigations, Pahute ivesá, ìevauda. 


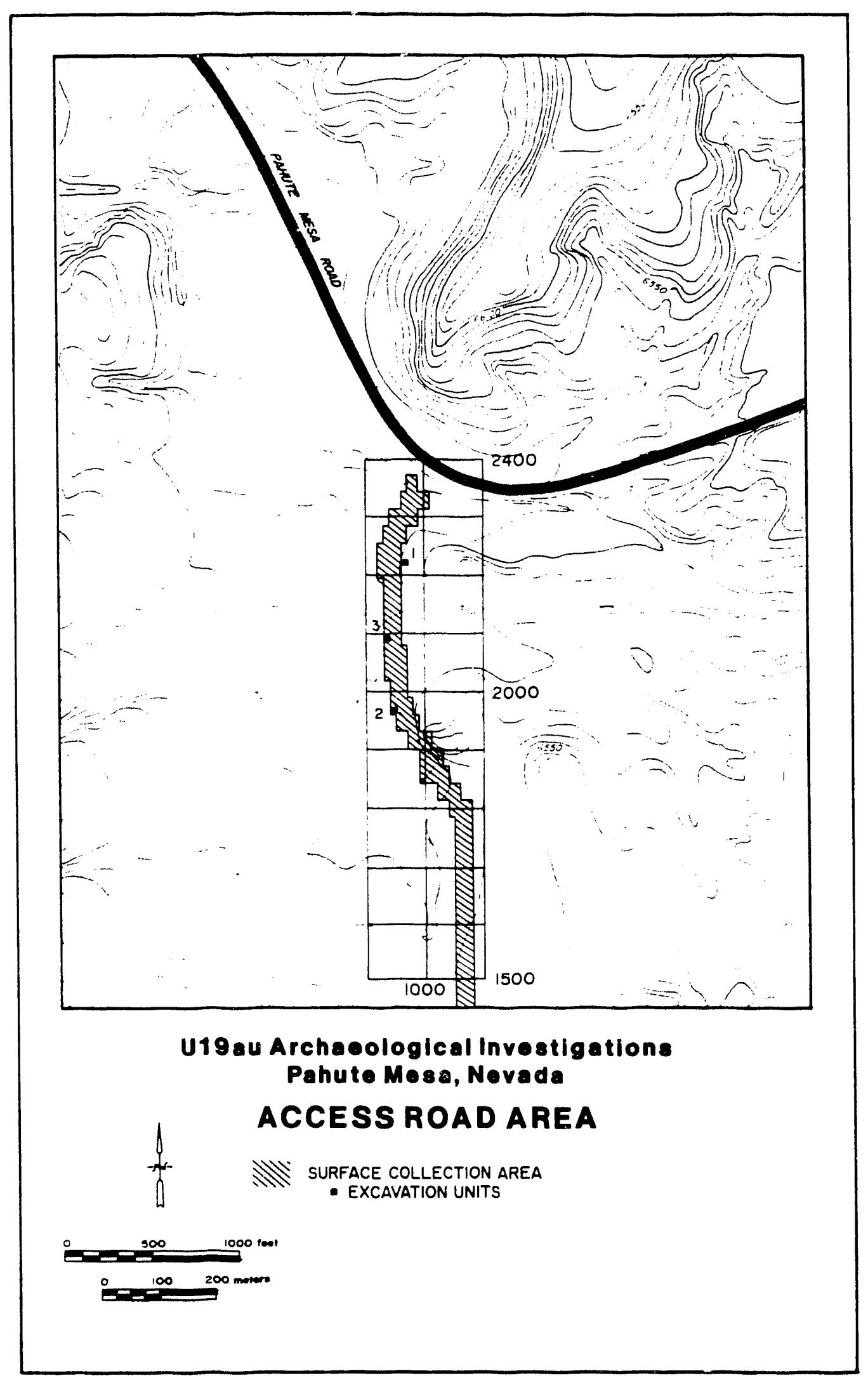

Figure 4-2. Surface collection area, and the locations of excavation units and subsurface scrapes for the access road area of the U19au archaeological investigations, Páhute Niesa, Nevada. 
and the last distinct concentration observed along the access road.

The 26 Ny 3634 concentration is a diffuse scatter about $150 \mathrm{~m}$ long running northsouth. The 61 artifacts collected from this site included one each; a white welded tuff, multidirectional core, an obsidian Stage I/II biface, a white welded tuff Stage I and Stage II bifaces, and a white welded tuff Rosegate projectile point. Of the 56 pieces of debitage recovered, 4 are decortication (7\%), 7 are core reduction $(13 \%), 12$ are pieces of shatter $(21 \%)$, and 33 are indeterminate $(59 \%)$. By material type, 9 percent are obsidian, 18 percent are fine-grained tuffs and cherts, and 73 percent are welded white tuff.

The 26Ny3632/3633 concentration occupies the area where these two sites were originally recorded. The core area of this concentration is approximately $150 \mathrm{~m}$ long, but a more diffuse segment extends about $100 \mathrm{~m}$ north and about $50 \mathrm{~m}$ south. Collected here were 125 artifacts, 117 were debitage. The remaining artifacts included two millingstones and an 'Drader, a plain brownware potsherd, and tiree bifaces. The abrader was a flat piece of naturally occurring welded tuff with striations due to grinding. The bifaces included 2 chert Stage III bifaces and an obsidian Stage II/III biface. Debitage in this concentration included 13 decortication flakes (11\%), 29 core reduction flakes (25\%), 9 biface thinning flakes $(8 \%), 22$ pieces of shatter $(19 \%)$, and 44 indeterminate flakes (38\%). Most of the debitage was white welded tuff or chalcedony ( $56 \%$ ), followed by cherts and fine-grained tuffs at 43 percent, and obsidian at 5 percent.

The southernmost concentration was 220 m long and contained 58 artifacts. Only one of these artifacts was not debitage - a white welded tuff Stage II biface. The remaining 57 artifacts were debitage and were distributed as follows: 3 decortication flakes (5\%), 11 core reduction flakes (19\%), 2 biface thinning fiakes ( $4 \%), 21$ pieces of shatter $(37 \%), 19 \mathrm{in}$ - determinate flakes $(33 \%)$, and 1 heat spall (2\%). Debitage fell into $84 \%$ white welded tuff or chalcedony, 12 percent fine-grained tuffs or chert, and 5 percent obsidian.

Excavations along the access route were conducted at three locations in depositional environments having the potential for buried cultural material. Unit 1 is the northernmost of the excavation units. It was a 1-by-1 m excavation unit placed to sample the subsurface of a lithic scatter on a colluvial slope coming off a ridge to the east of the road alignment. This unit, located at grid coordinates $2231 \mathrm{~m}$ north and $969 \mathrm{~m}$ east, was dug to a depth of about $53 \mathrm{~cm}$, where the surface of a layer of decomposing bedrock was encountered. Four strata observed during the excavations were identified in the field as stratum $A$, the surface material; stratum B, a loose sandy "A" soil horizon; stratum $C$, a stratum similar to $B$ but more compacted; and stratum D, similar to $B$ and $C$ but containing more gravels (Figure 4-3). Only one artifact - a white welded tuff indeterminate flake - was found in the unit in a burrow at about $40 \mathrm{~cm}$ in depth.

Excavation Unit 2 is the southernmost of the three excavation units placed along the access road. This unit consisted of two 1-by-1 $\mathrm{m}$ pits dug adjacent to and north and south of each other. The datum corner of the unit, its northeast corner, was located at grid coordinates $1965 \mathrm{~m}$ north, and $942 \mathrm{~m}$ east, and the unit was located to the west of both the existing and proposed access road. This unit, placed to sample the subsurface of a lithic scatter on a low interfluve near the end of a prominent ridge, was dug to a depth of about $47 \mathrm{~cm}$. Its stratigraphy was notably different from Unit 1. Five strata were observed: stratum $A$, the surface of the unit; stratum B, a gravel layer found on the surface; stratum $C, a$ silty gray-brown vesicular "A" horizon soil; stratum $D$, a more compact soil, also probably an " $A$ " horizon; and stratum E, a reddish clayey "B" horizon (Figure 4-4). Only two artifacts--a white welded tuff biface thinning 

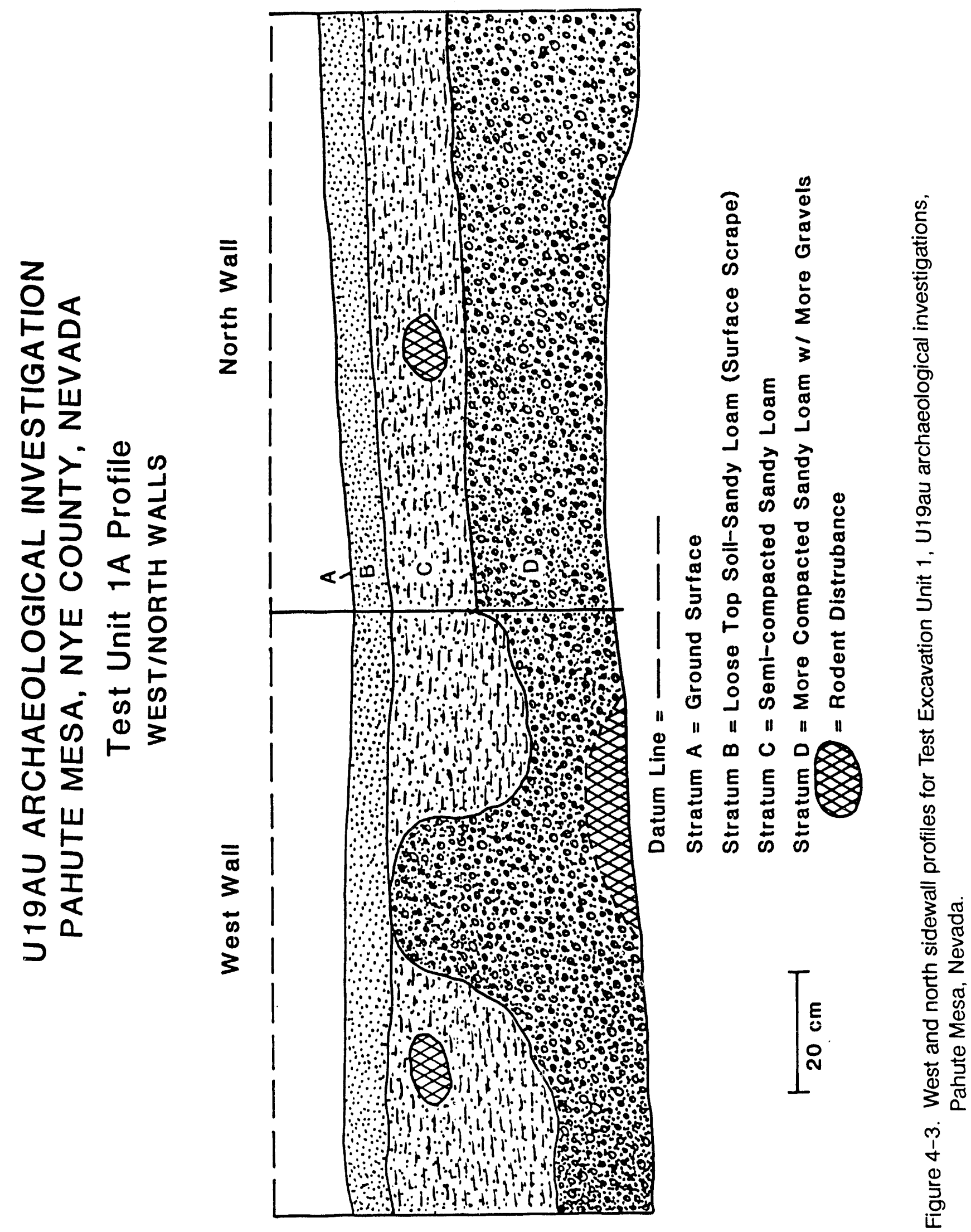

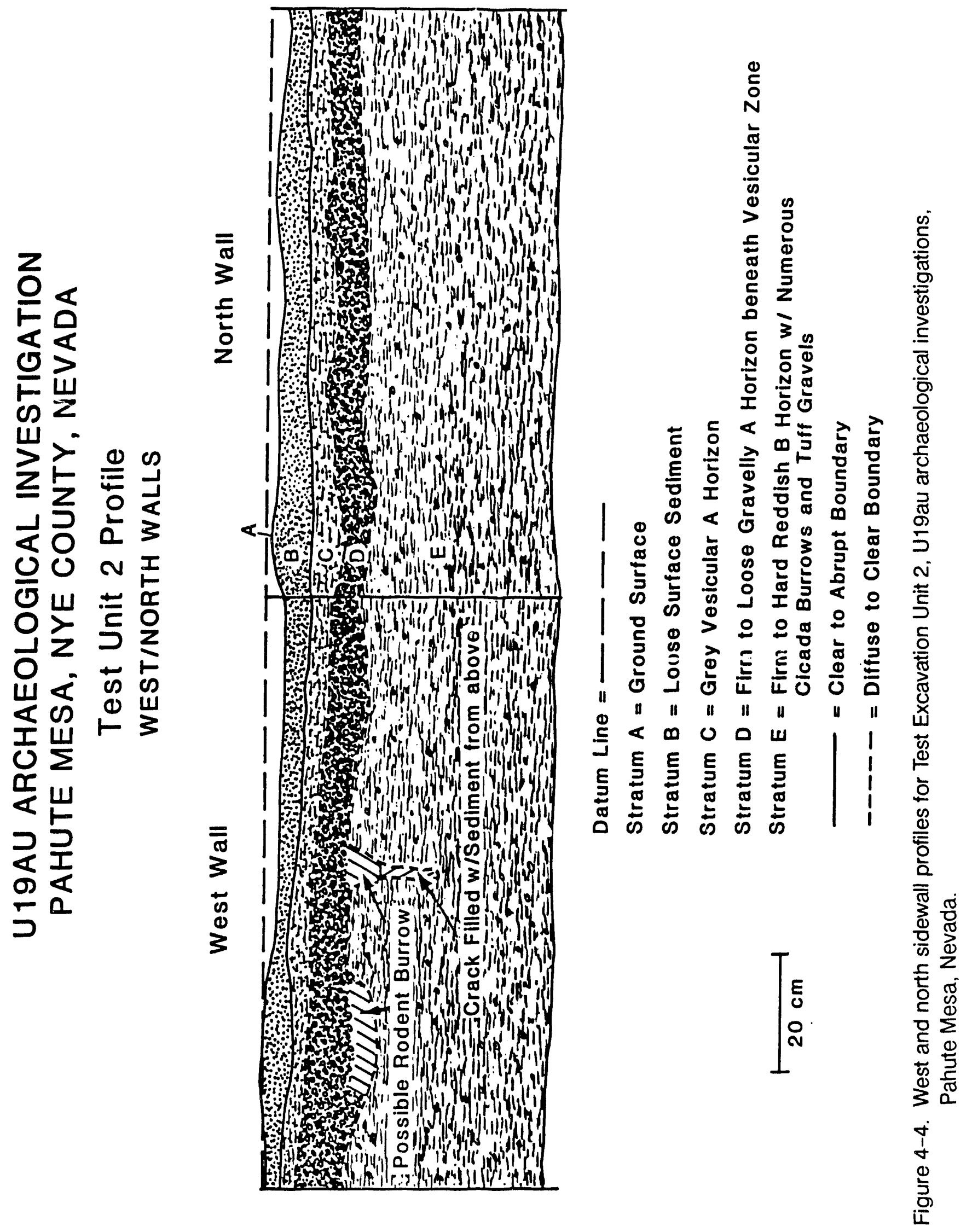
flake and a piece of shatter located in stratum $B$ (approximately $1-2 \mathrm{~cm}$ below the ground surface)-were found in this unit.

The final excavation, Unit 3, was located between Units 1 and 2 at grid coordinates $2096 \mathrm{~m}$ north and $932 \mathrm{~m}$ east. This unit was a 1-by-1 m unit dug to a depth of about $35 \mathrm{~cm}$. It was situated to test a lithic scatter in an area of rapid apparent deposition. The stratigraphy in this unit was similar to that of Unit 2 , and cultural material found here was limited to two flakes found on the surface (Figure 4-5).

\section{Discussion}

The road alignment follows the valley floor along the east side. While sites with diverse artifact assemblages indicative of aboriginal temporary camps were recorded nearby (Reno 1983), the materials recovered along the road right-of-way were primarily debitage. One millingstone fragment and three bifaces near each other at $26 \mathrm{Ny} 3632 / 3633$ and a single brownware potsherd further north were recovered. While this concentration may represent a small temporary camp, the diffusely scattered debitage is more likely the remains of peripheral activities conducted elsewhere in the valley. Since most of the debitage, and the bifaces as well, appear typical of the early stages of lithic reduction, they are probably associated with the procurement and initial reduction of locally available toolstone. Quarrying probably occurred in conjunction with other resource exploitation.

\section{Data Recovery at 26Ny4015}

\section{Surface Collection at 26Ny4015}

The archaeological surface materials in the valley around the drill hole center, with the exception of $26 \mathrm{Ny} 4021$ and $26 \mathrm{Ny} 4040$, formed a single archaeological site (26Ny4015). Except for special data recovery at sites $26 \mathrm{Ny} 4021$ and $26 \mathrm{Ny} 4040$ and collections along the road, the majority of data re- covery at U19au occurred as a extensive areal surface collection. This collection area of 600-by-750 $\mathrm{m}$ involved a total collection area of $418,500 \mathrm{~m}^{2}$. Aside from a concentrated quarry area in the northeast corner of the collection grid, this site was completely collected in 10-by- $10 \mathrm{~m}$ units. The grid units comprising the quarry area ranged from a 4 to a 64 percent sample. Artifacts recovered at 26Ny4015 totaled 12,704 items; 11,859 were debitage. For analytic purposes, the artifact counts for these sampled units were projected to the total number expected. Using projected figures, debitage counts rose to 22,358 items.

Eleven distinct concentrations (Figure 4-6 and $4-7$ ) of debitage, including $26 \mathrm{Ny} 4021$ and 26 Ny4040 (the southernmost and easternmost concentrations), can be observed in the valley area. These concentrations were labeled $A$ through $\mathrm{K}$, with $\mathrm{J}=26 \mathrm{Ny} 4021$ and $K=26$ Ny4040. The residual debitage not included in these concentrations was designated concentration $R$. The debitage counts for these concentrations are presented in Table 4-2.

To help determine the relationship of these concentrations to each other, a cluster analysis was performed on the types of debitage to see if they fell into natural groupings. The distance measure used for this analysis is Euclidean distance and is based on standardized counts of five major types of debitage-decortication, core reduction, biface thinning, shatter, and indeterminate (Table 4-3). Total counts for each concentration were standardized to 1,000 items. An average linking method was used on the Euclidean distances obtained from the comparisons of these standardized counts. Figure 4-8 shows the dendrogram from the cluster analysis. Figure 4-9 shows the histograms of relative frequencies of the debitage types for each of the concentrations.

The tree diagram reveals four basic groups: 1) D which contains high concentra- 

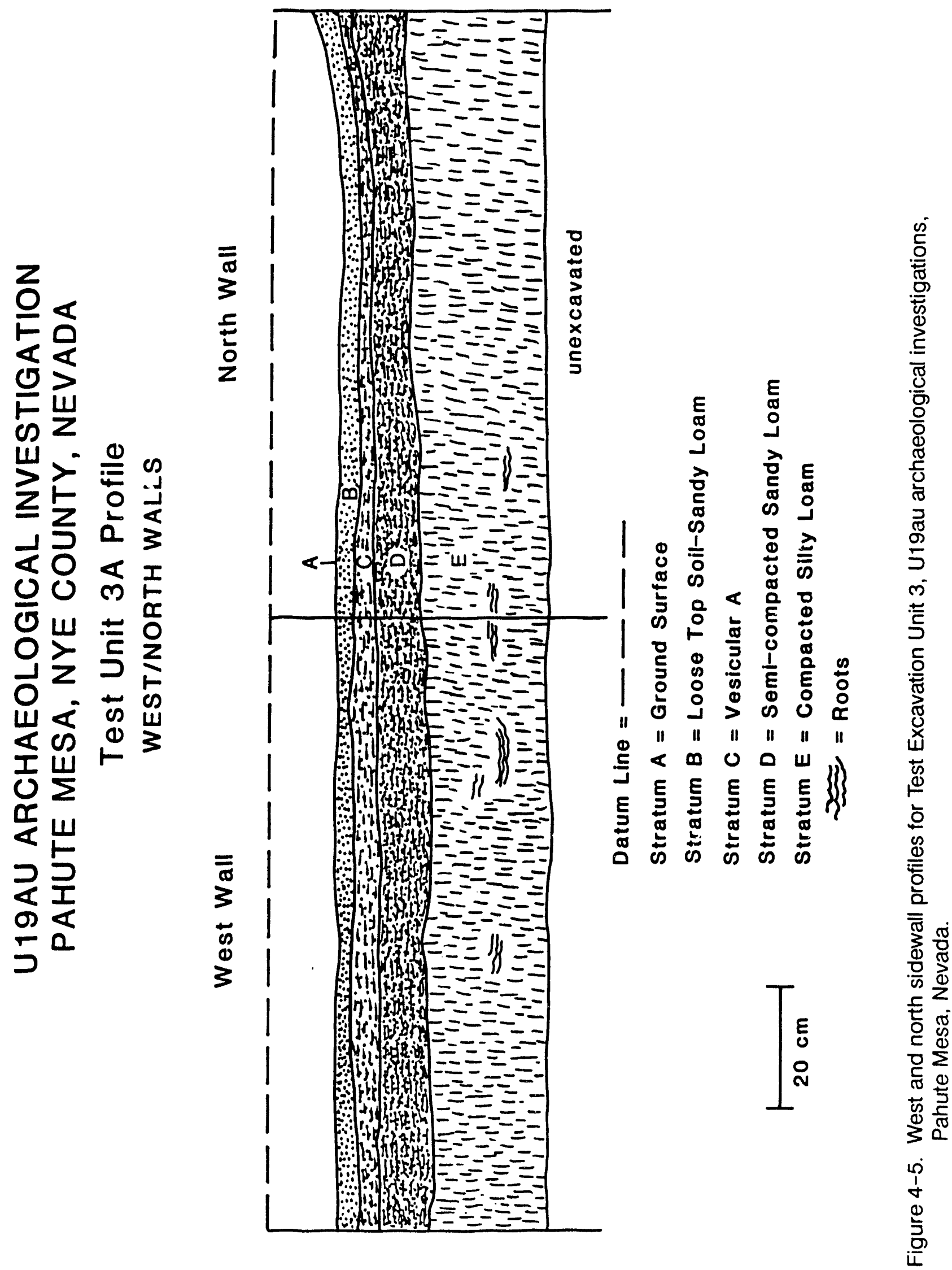


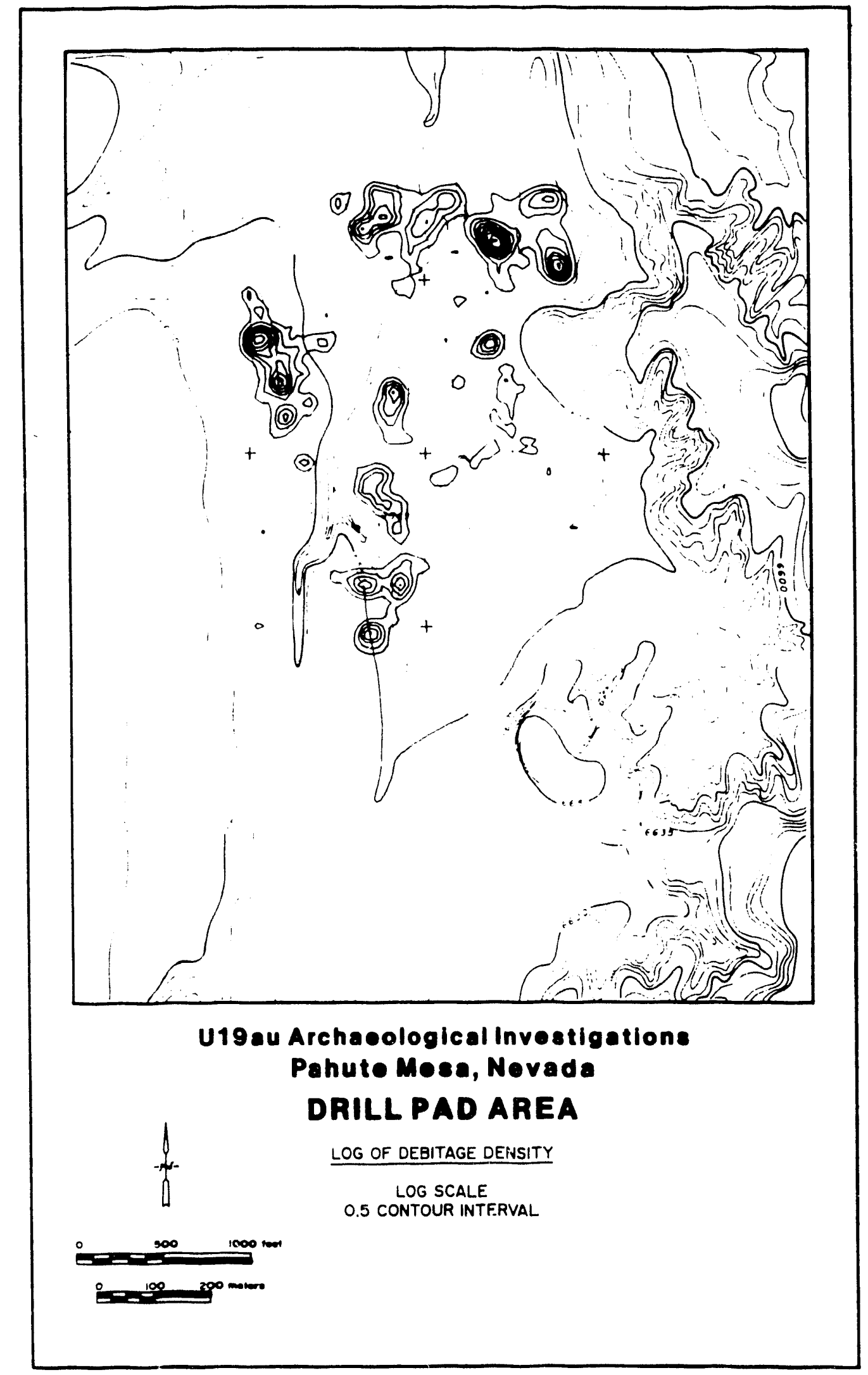

Figure 4-6. Debitage density, log scale, for the U19au drill pad area (site 26Ny4015), Pahute Mesa, Nevada. 


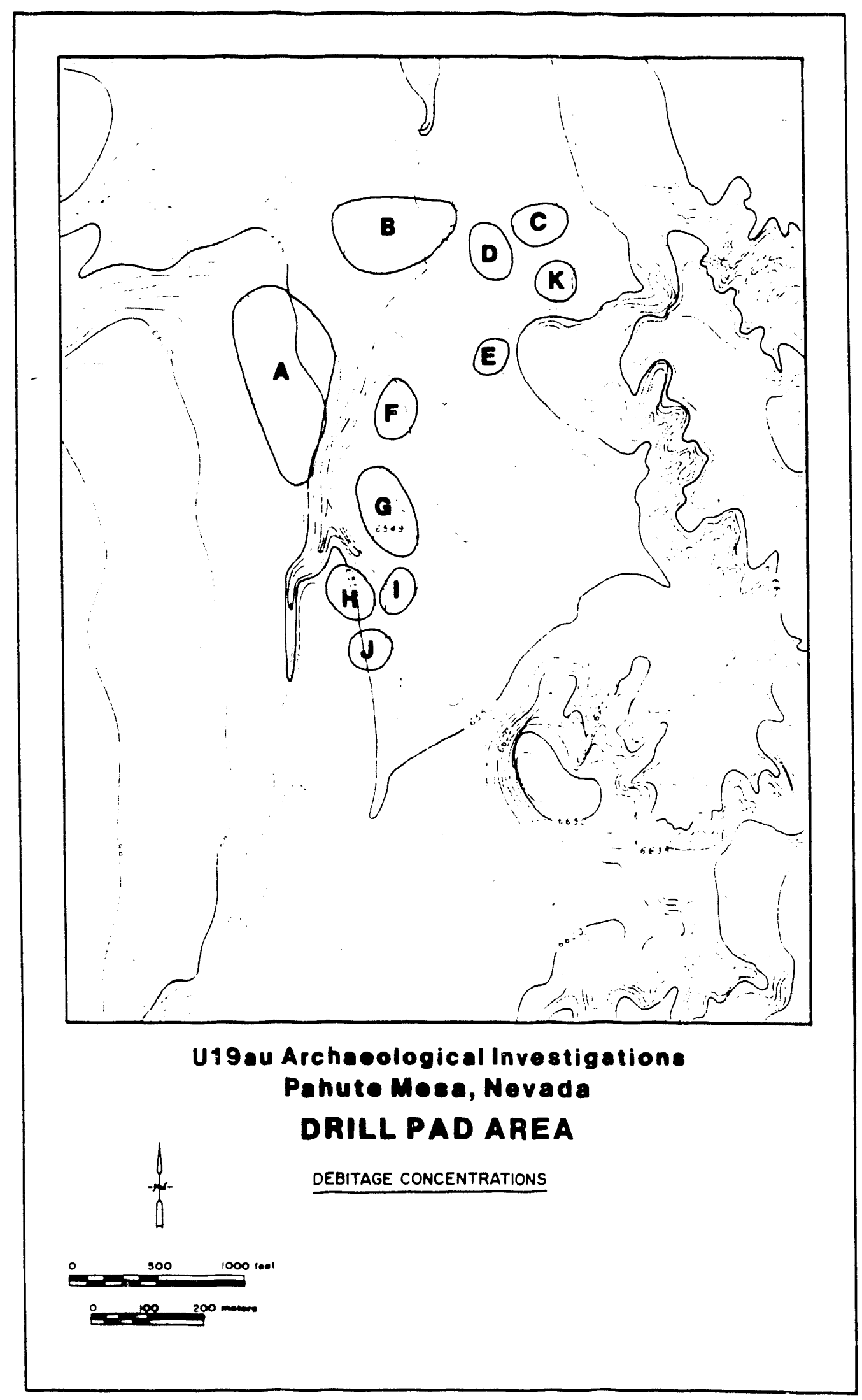

Figure 4-7. Defined debitage concentrations for the U19au drill pad area, Pahute Mesa, M! vada. 
Table 4-2. Debitage Counts for Concentrations.

\begin{tabular}{lrrrrrrrrr}
\hline & dec & cr & bft & pis & sha & ind & spl & total \\
\hline Conc A & 182 & 378 & 712 & 32 & 97 & 1850 & 16 & 3219 \\
Conc B & 161 & 243 & 168 & 1 & 220 & 602 & 2 & 1394 \\
Conc C & 23 & 52 & 19 & 0 & 13 & 81 & 0 & 188 \\
Cunc D & 1526 & 375 & 10 & 0 & 4988 & 6094 & 0 & 12993 \\
Conc E & 21 & 31 & 141 & 2 & 7 & 263 & 0 & 463 \\
Conc F & 21 & 133 & 96 & 0 & 28 & 270 & 0 & 548 \\
Conc G & 87 & 152 & 69 & 0 & 80 & 261 & 1 & 649 \\
Conc H & 14 & 45 & 26 & 0 & 17 & 144 & 6 & 246 \\
Conc 1 & 27 & 93 & 47 & 2 & 40 & 186 & 0 & 393 \\
Conc J & 25 & 20 & 39 & 6 & 41 & 123 & 5 & 248 \\
Conc K & 25 & 37 & 152 & 0 & 245 & 582 & 5 & 1091 \\
Conc R & 295 & 391 & 278 & 6 & 370 & 902 & 12 & 2236 \\
\hline
\end{tabular}

Key: dec $=$ decortication, $\mathrm{cr}=$ core reduction, $\mathrm{bft}=$ biface thinning, prs $=$ pressure, sha $=$ shatter, ind = indeterminate, $\mathrm{spl}=$ spall; Conc $\mathrm{R}=$ residual

Table 4-3. Counts for Major Types of Debitage Standardized to 1,000 Items.

\begin{tabular}{|c|c|c|c|c|c|c|c|}
\hline & dec & $\mathrm{cr}$ & $\mathrm{btt}$ & sha & ind & total & \\
\hline Conc $\mathrm{A}$ & 57 & 117 & 221 & 30 & 575 & 1000 & \\
\hline Conc B & 115 & 174 & 121 & 158 & 432 & 1000 & \\
\hline Conc $\mathrm{C}$ & 122 & 277 & 101 & 69 & 431 & 1000 & \\
\hline Conc D & 117 & 29 & 1 & 384 & 469 & 1000 & \\
\hline Conc E & 45 & 67 & 305 & 15 & 568 & 1000 & \\
\hline Conc $\mathrm{F}$ & 38 & 243 & 175 & 51 & 493 & 1000 & \\
\hline Conc $\mathrm{G}$ & 134 & 234 & 106 & 123 & 402 & 1000 & \\
\hline Conc $\mathrm{H}$ & 57 & 183 & 106 & 69 & 585 & 1000 & \\
\hline Conc 1 & 69 & 237 & 120 & 102 & 473 & 1000 & \\
\hline Conc J & 101 & 81 & 157 &, 65 & 496 & 1000 & \\
\hline Conc $\mathrm{K}$ & 23 & 80 & 139 & 225 & 533 & 1000 & \\
\hline Resid & & 132 & 175 & 124 & 165 & 403 & 1000 \\
\hline
\end{tabular}

Key: dec = decortication, $\mathrm{cr}=$ core reduction, $\mathrm{bft}=$ biface thinning, $\mathrm{prs}=$ pressure, sha $=$ shatter ind $=$ indeterminate, $\mathrm{spl}=$ spall; Conc $\mathrm{R}=$ residual

tions of shatter and indeterminate debitage; 2) $H, B, F, I, C, G$, and the residual debitage, characterized by relatively high core reduction debitage and moderate amounts of biface thinning debitage; 3 ) $\mathrm{J}$ and $\mathrm{K}$, characterized by an odd combination of shatter, biface thinning debitage, and, to a lesser extent, core reduction debitage, and 4) $A$ and $E$, two clusters where biface thinnir: $g$ and indeterminate debitage dominate.

Geographically, the group 2 concentrations appear in the central or open side val- leys. Group 1, composed only of the quarry, is quite distinctive in it debitage ratios. Group 3 contains both sios (26Ny4021 and 26 Ny4040) with habitation structures. Group 4 is composed of the large concentration. A, located on the centie western slope of the valley and a small concentration, $E$, on the gently sloping toe of the small ridge.

The debitage from concentration D clearly is the result of quarrying activity. The valley groups have debitage assemblages consistent with primary biface or tool reduction, but 


\section{TREE DIAGRAM}

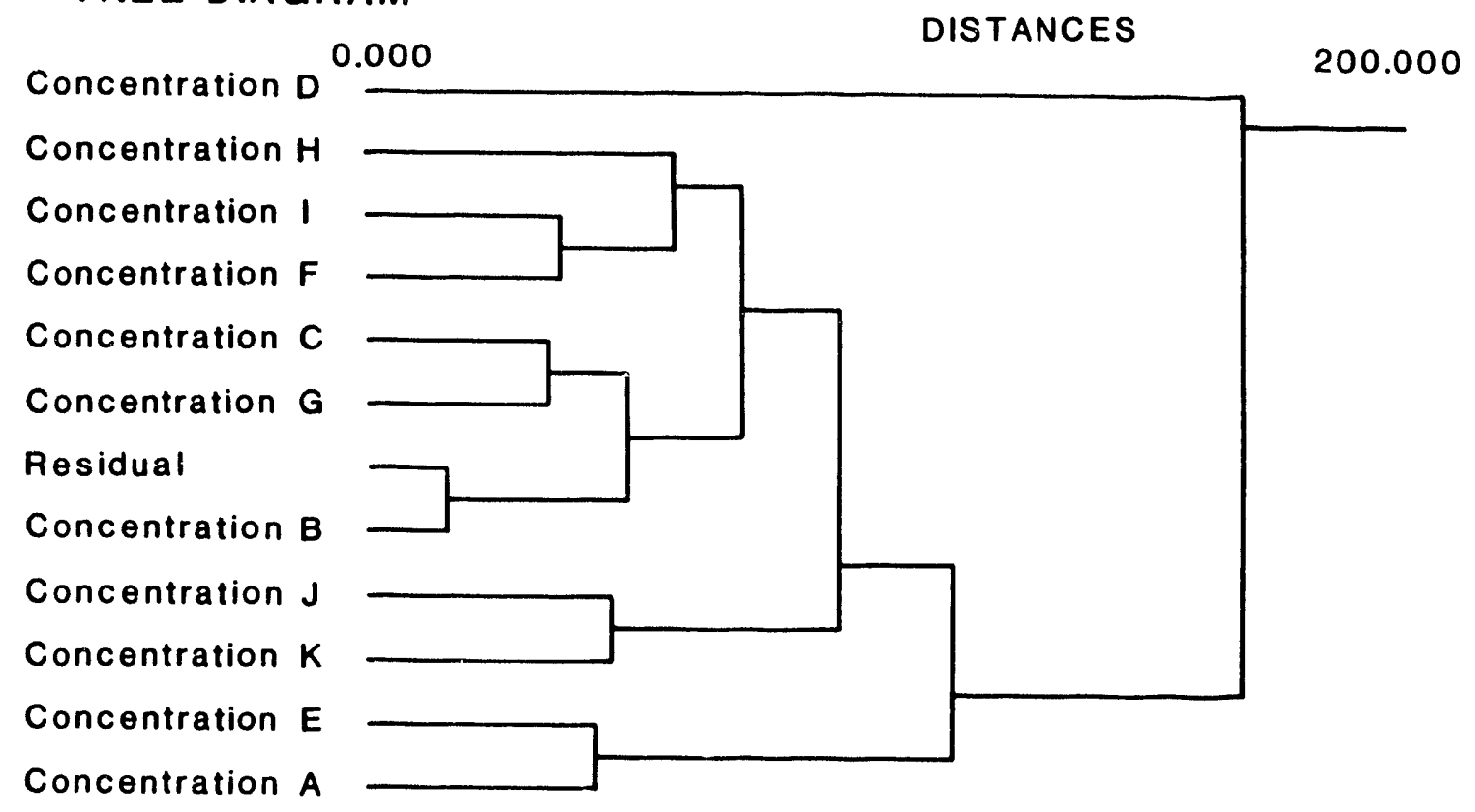

Figure 4-8. Tree diagram of the distances between the defined debitage concentrations based on proportions of debitage types for the U19au drill pad area. Pahute Mesa. Nevada. 

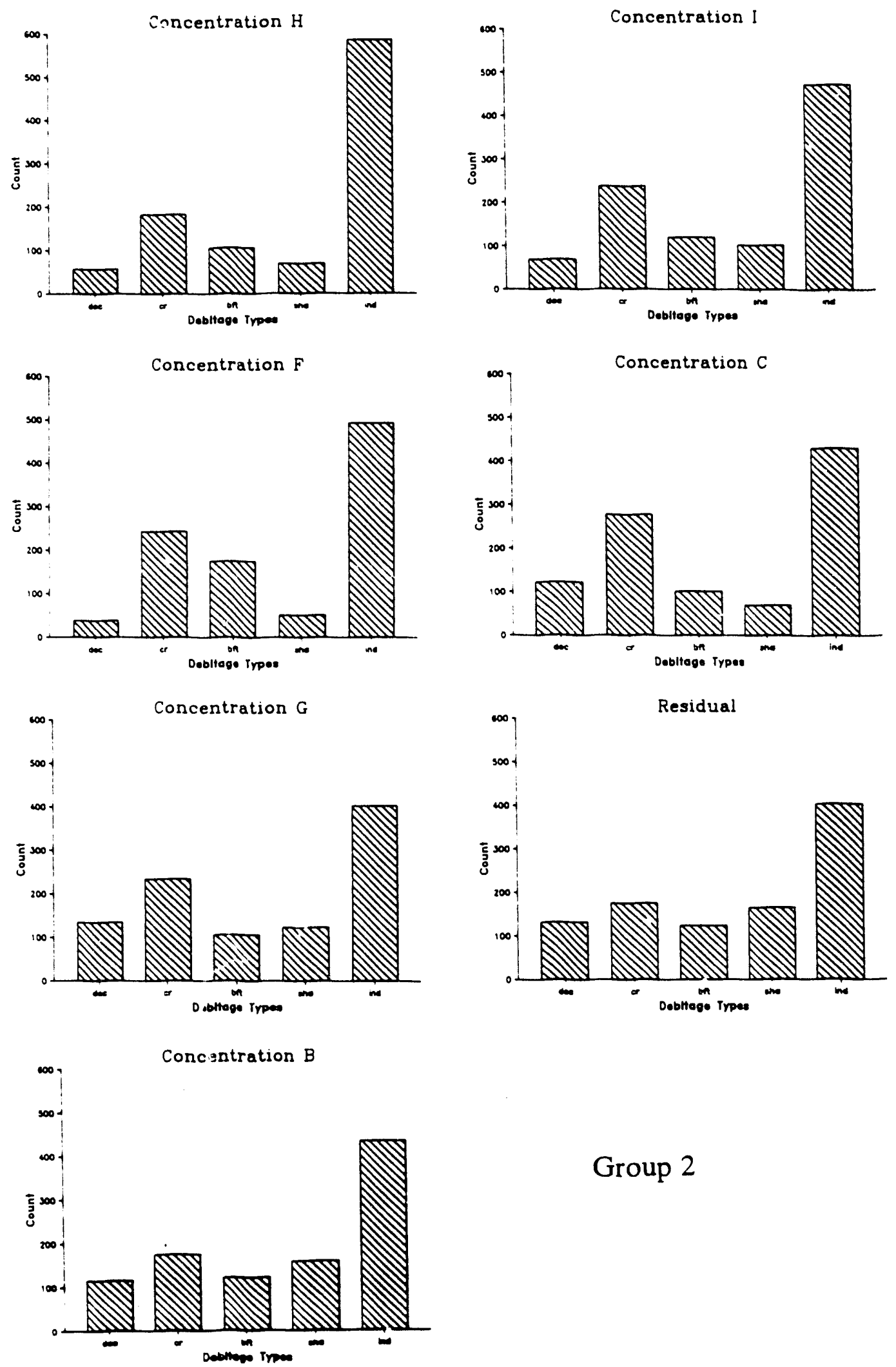

Group 2

Figure 4-9. Histograms of the proportions of debitage types for the defined concentrations of debitage at the drill pad area of U19au, Pahute Mesa, Nevada. 

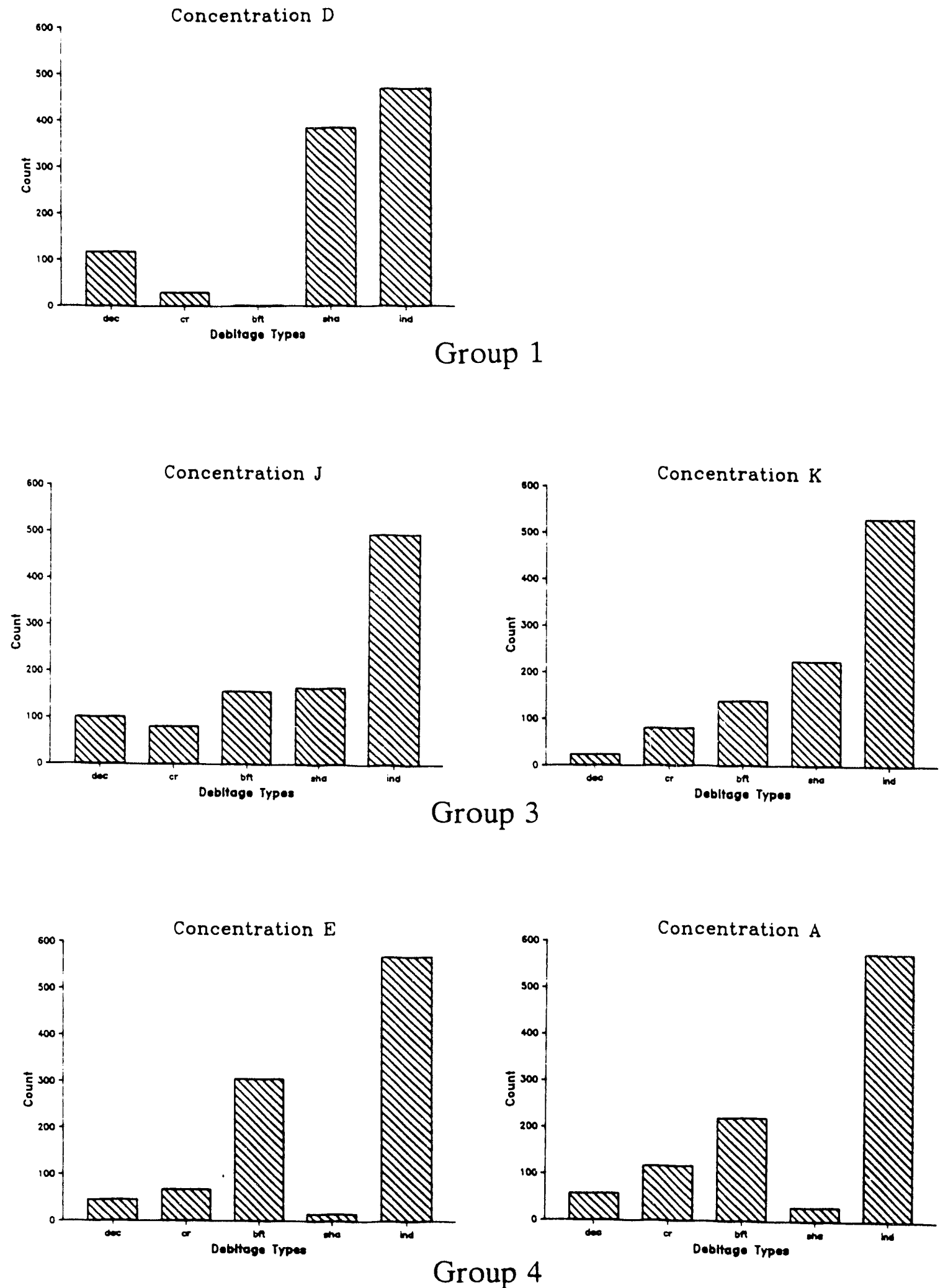

Figure 4-9. (continued) Histograms of the proportions of debitage types for the defined concentrations of debitage at the drill pad area of U19au, Pahute Mesa, Nevada. 
are away from the source of the materials. Concentrations $A$ and $E$ with high concentrations of biface thinning debitage appear more consistent with later reductions. The association with gentle open slope, as opposed to valley floor, may be fortuitous, or it may represent a preference for this environment for the activity. If so, the reasons for such a preference are unknown. It is comforting that concentrations $\mathrm{J}$ and $\mathrm{K}$ group together, as they are obviously campsites. However, they exhibit an odd assemblage of debitage, heavy in shatter and indeterminate debitage, moderate in biface thinning and core reduction debitage. Instinctively, one expects biface thinning, followed by core reduction, to be characteristic of these sites, following the notion that final lithic reduction would be conducted at the camps. But this expectation is typical of concentrations $A$ and $E$ and not the campsites. Both concentrations $\mathrm{J}$ and $\mathrm{K}$ have reasonable samples of debitage, so it is unlikely that this assemblage is an anomaly of a small sample. It appears that final lithic reduction is not a well-represented activity in these two camps.

\section{Bifaces}

Bifaces are routinely viewed as intermediate stages created during the manufacture of stone tools (Figures 4-10,4-11, 4-12, and 4-13). While undoubtedly used as tools themselves, they are interpreted here as unfinished tools. The production sequence for the manufacture of these tools is arbitrarily divided into five stages (see Chapter 5, Material Culture Analysis), as well as into intermediate forms between each of the first four main stages. Table 4-4 shows the number and types of bifaces recovered from each of the concentrations.

No bifaces were associated directly with the quarry area, concentration $D$, although early stage forms might be expected here. Concentration J contained only a few Stage III bifaces. Concentration $E$ contained an odd assortment of bifaces-three Stage I, one
Stage III, and one Stage IV. Concentration E had the highest proportion of biface thinning flakes, and this may represent a locus of final lithic reduction. The remainder of the concentrations appear to contain representative proportions of most types of bifaces, usually with the intermediate Stage II and III forms occurring in greater numbers than Stage I or IV forms.

\section{Groundstone Artifacts}

Excluding sites 26Ny4021 and 26Ny4040, 51 millingstones or fragments and 6 manos were recovered during the surface collection (Figure 4-14). Eleven additional millingstones or fragments and a mano were recovered from the surface of $26 \mathrm{Ny} 4021$ (concentration $\mathrm{J}$ ), and 3 millingstones were recovered from $26 \mathrm{Ny} 4040$ (concentration K). Millingstones and/or manos were recovered from all other concentrations except C, D, and E. Groundstone artifacts are most common in concentrations $A, G, I$, and $J$, and geographically they are located, for the most part, in the southern portion of the pad area near the central drainage.

\section{Pottery}

Pottery was recovered from five of the artifact concentrations of $26 \mathrm{Ny} 4015$ (A, B, C, E, and $G$ ), as well as from $26 \mathrm{Ny} 4021$ (concentration J) and $26 \mathrm{Ny} 4040$ (concentration K). Only one sherd was found in each of concentrations $C$ and $G$. The remaining sherds were recovered in three distinct areas in concentrations $A, B$, and $E$. In addition, a large scatter of pottery occurs outside the observed debitage concentrations around grid location $1470 \mathrm{~N}, 880 \mathrm{E}$. The pottery is discussed below.

\section{Projectile Points}

Recovered from surface collections at 26Ny4015 were 111 projectile points. Two more were recovered from $26 \mathrm{Ny} 4021$ (concentration J' and 8 from $26 \mathrm{Ny} 4040$ (concentration $K$ ) for $a$ total of 121 projectile points around the pad area. Table 4-5 shows the as- 


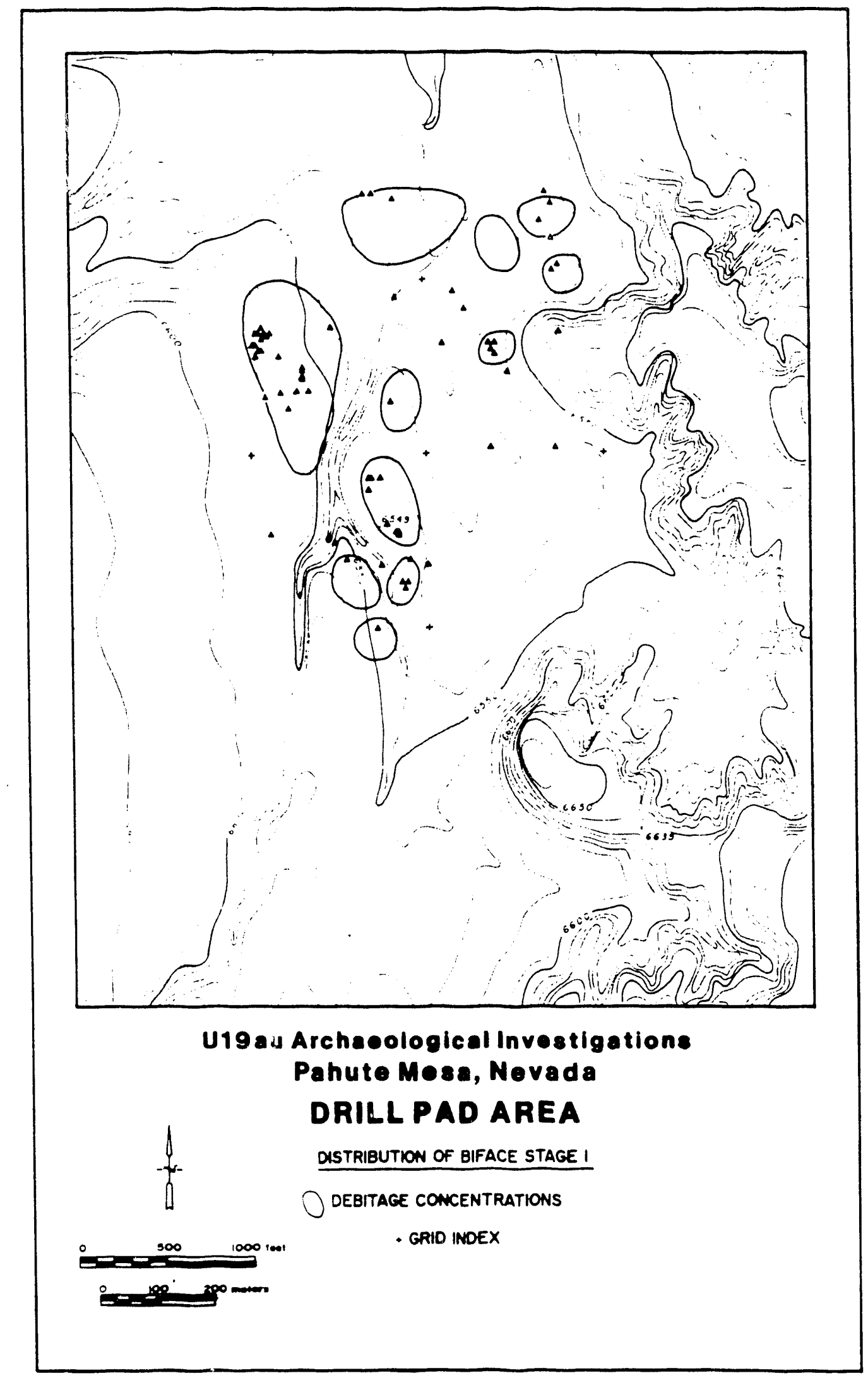

Figure 4-10. Distribution map of Stage I bifaces in the U19au drill pad area, Pahute Mesa, Nevada. 


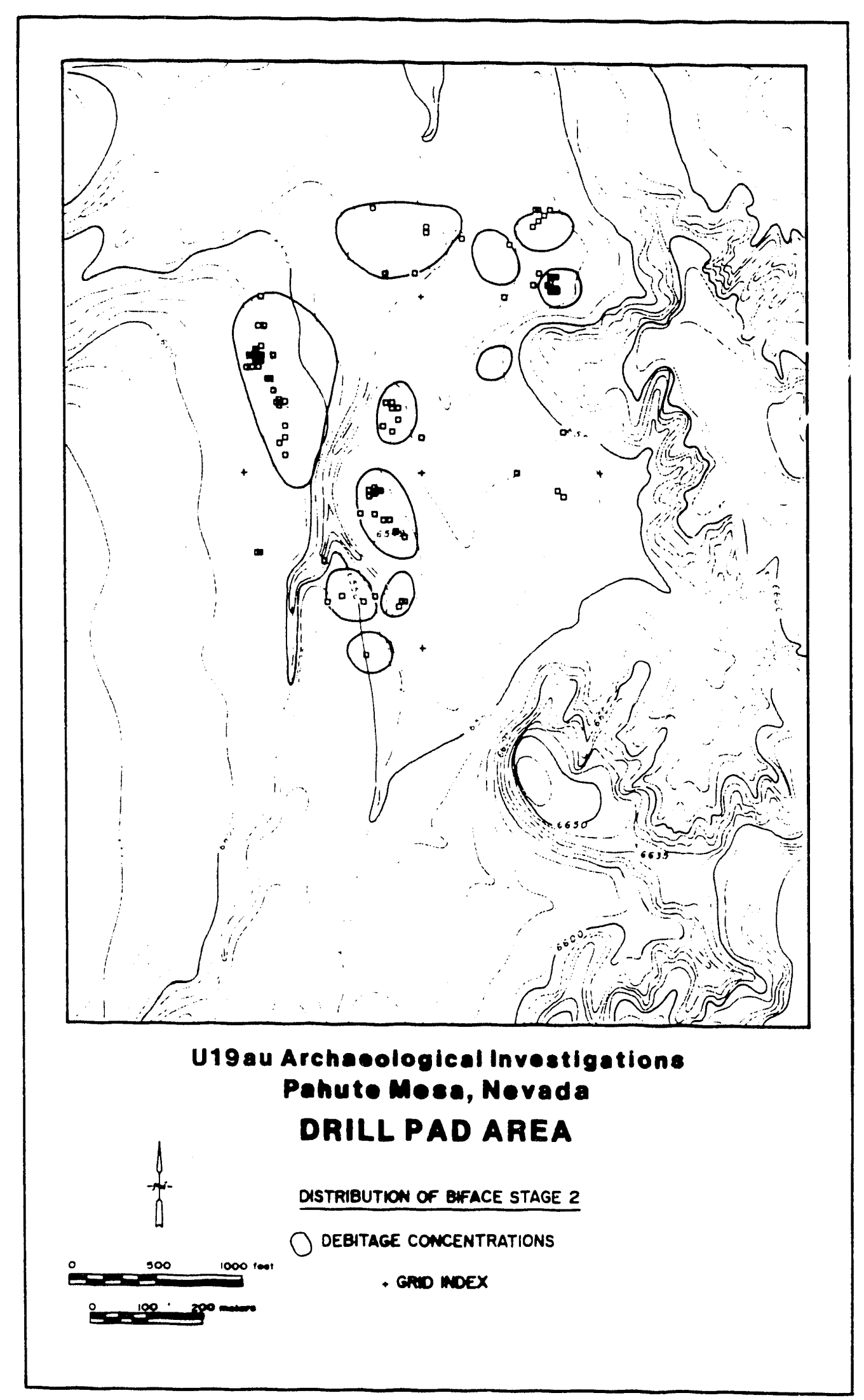

Figure 4-11. Distribution map of Stage II bifaces in the U19au drill pad area, Pahute Mesa, Nevada. 


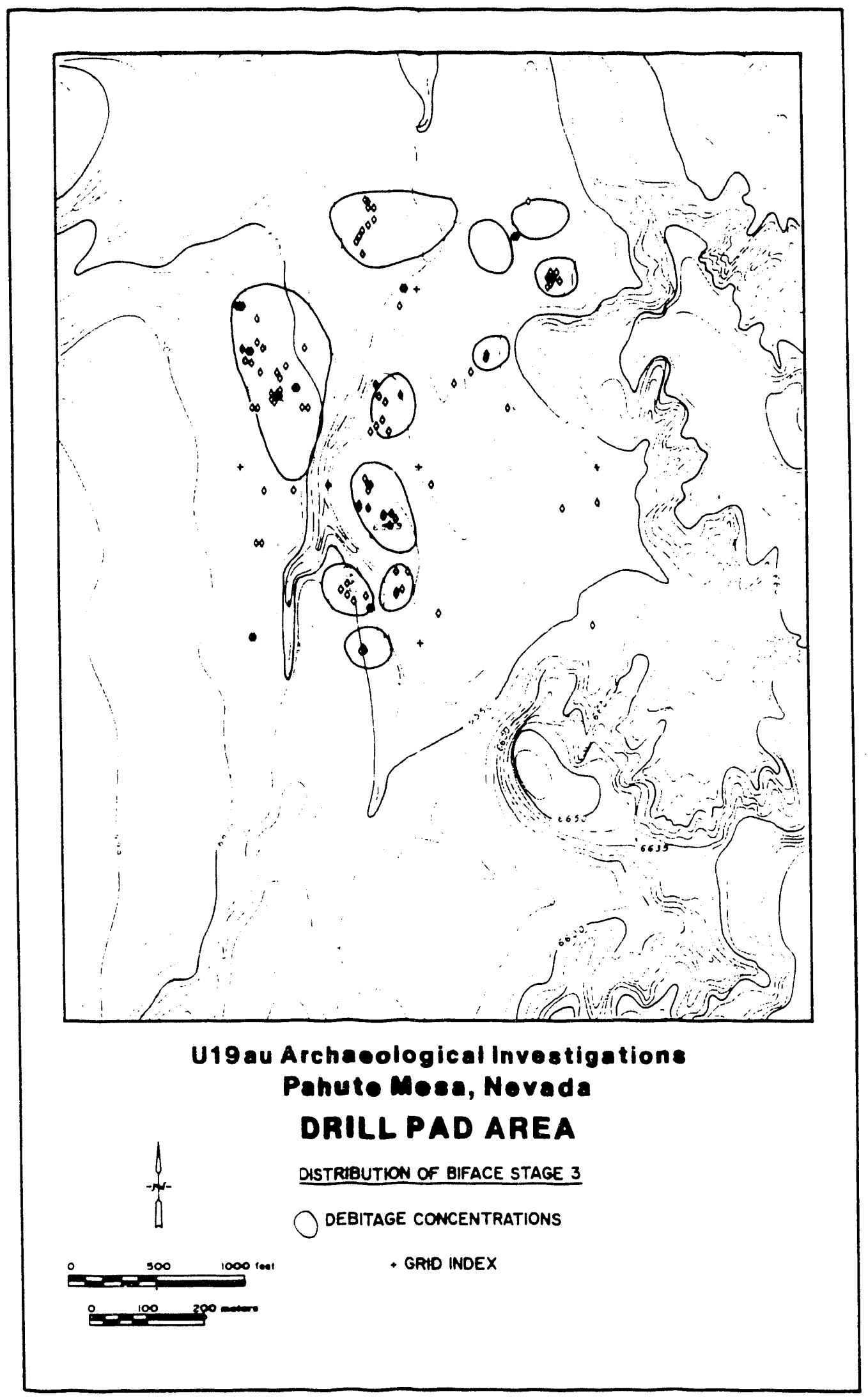

Figure 4-12. Distribution map of Stage III bifaces in the U19au drill pad area, Pahute Mesa, Nevada. 


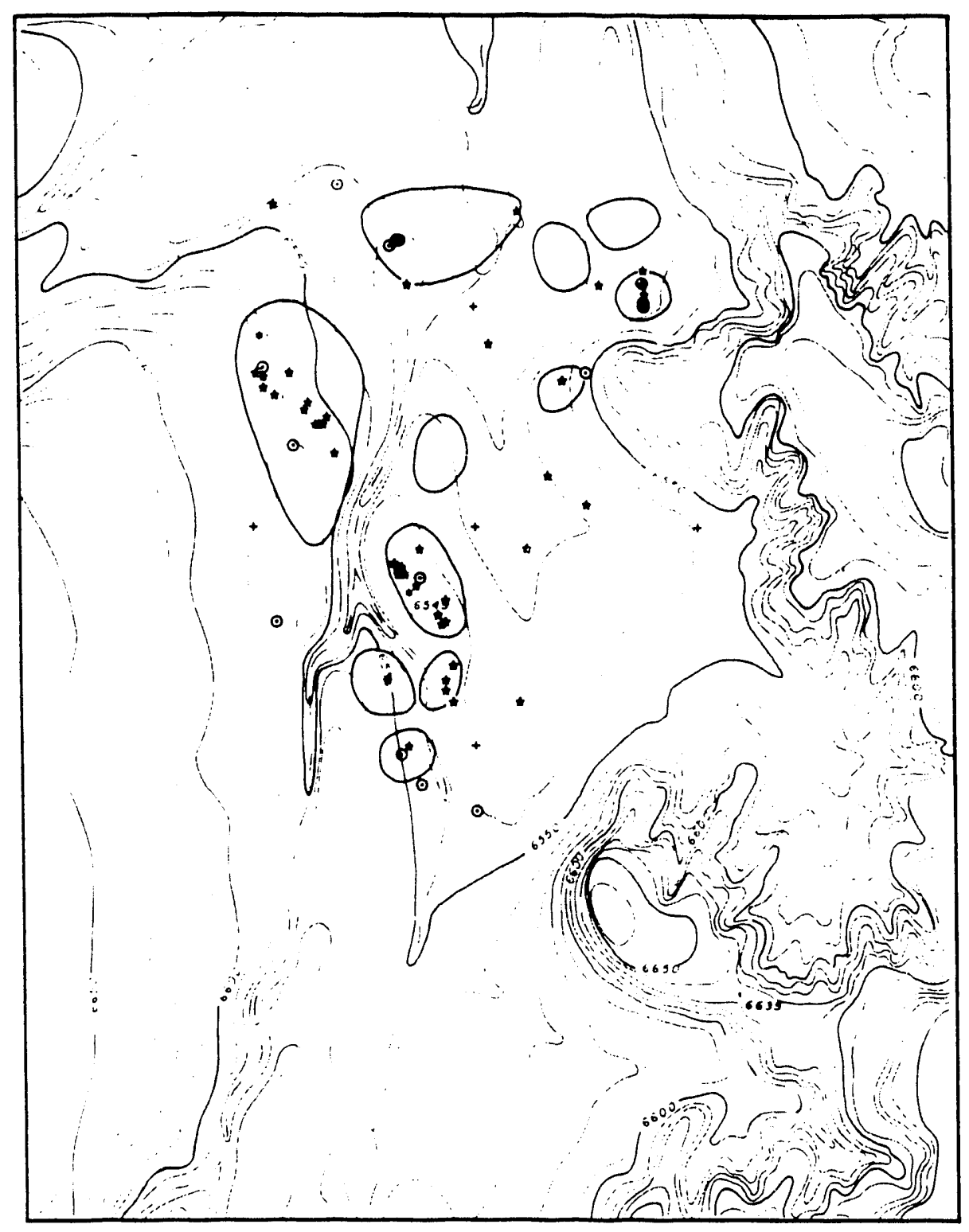

\section{U19au Archaeological Investigations \\ Pahute Mese, Nevada}

DRILL PAD AREA

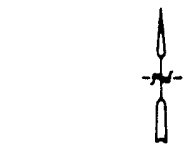

DISTRIBUTION OF BIFACES

- STAGE 4

- STAGE 5

O PERFERATOR /DRLLS

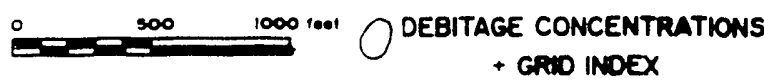

는

Figure 4-13. Distrịutiton man of dri!ls and Stage !V and V bifaces in the U19au dri!! pad area, Pahute Mesa, Nevada. 
Table 4-4. Nondebitage Surface Artifacts from Defined Concentrations at U19au, Pahute Mesa, Nevada.

\begin{tabular}{|c|c|c|c|c|c|c|c|c|c|c|c|c|}
\hline & \multirow[b]{2}{*}{ Manos } & \multirow[b]{2}{*}{$\begin{array}{l}\text { Milling- } \\
\text { stones }\end{array}$} & \multirow[b]{2}{*}{ Pottery } & \multirow[b]{2}{*}{$\begin{array}{c}\text { Uti } \\
\text { Flakes }\end{array}$} & \multirow[b]{2}{*}{ Mod } & \multirow[b]{2}{*}{ Cores } & \multirow[b]{2}{*}{51} & \multicolumn{3}{|c|}{ Bifaces } & \multirow[b]{2}{*}{$\begin{array}{l}\text { Perf/ } \\
\text { Drills }\end{array}$} & \multirow[b]{2}{*}{ Comments } \\
\hline & & & & & & & & II & III & IV & & \\
\hline Conc A & - & 8 & 12 & 28 & 9 & 1 & 20 & 30 & 25 & 13 & 2 & \\
\hline Conc B & - & 2 & 32 & - & - & 9 & 3 & 6 & 10 & 1 & 2 & $\begin{array}{l}\text { Hammerstone } \\
\text { incised }\end{array}$ \\
\hline Conc C & - & - & 1 & 3 & - & - & 2 & 6 & 1 & - & - & \\
\hline Cone D & - & - & - & - & - & 2 & - & - & - & - & - & \\
\hline Conc E & - & - & 18 & - & - & - & 3 & - & 1 & 1 & - & \\
\hline Conc F & - & 1 & - & 1 & 2 & - & 1 & 7 & 8 & - & - & \\
\hline Conc G & - & 9 & 1 & 4 & 2 & 4 & 5 & 12 & 9 & 10 & 1 & $\begin{array}{l}\text { Hammerstone } \\
\text { incised stone }\end{array}$ \\
\hline Conc $\mathrm{H}$ & - & 3 & - & - & - & 6 & 1 & 4 & 5 & 1 & - & Hammerstone \\
\hline Conc 1 & 1 & 12 & - & - & - & 2 & 3 & 3 & 4 & 4 & - & 2 Hammerstones \\
\hline Conc J & 1 & 11 & 67 & 2 & 1 & 4 & - & - & 2 & - & 2 & \\
\hline Conc $\mathrm{K}$ & - & 3 & 5 & 5 & 5 & 1 & - & 9 & 6 & 2 & 1 & Hammerstone \\
\hline Conc R & 3 & 16 & 253 & 13 & 8 & 19 & 15 & 10 & 24 & 9 & 3 & $\begin{array}{l}3 \text { Hammerstones } \\
2 \text { Choppers } \\
1 \text { incised stone }\end{array}$ \\
\hline
\end{tabular}

Table 4-5. Point Types with the Twelve Defined Concentrations.

\begin{tabular}{lllllllllll}
\hline & Pinto & \multicolumn{1}{c}{ LSN HumboldtGateclff } & Elko & Rsgte & DSN & Cottnwd & Ind & Total \\
\hline Conc A & 2 & 1 & 0 & 7 & 0 & 5 & 9 & 3 & 3 & 30 \\
Conc B & 0 & 0 & 0 & 1 & 2 & 2 & 0 & 0 & 0 & 5 \\
Conc C & 0 & 0 & 1 & 1 & 1 & 0 & 0 & 0 & 0 & 3 \\
Conc D & 0 & 0 & 0 & 0 & 0 & 0 & 0 & 0 & 0 & 0 \\
Conc E & 0 & 0 & 0 & 1 & 0 & 0 & 0 & 0 & 0 & 1 \\
Conc F & 0 & 0 & 0 & 0 & 2 & 0 & 0 & 0 & 0 & 2 \\
Conc G & 0 & 0 & 0 & 1 & 5 & 1 & 0 & 0 & 0 & 7 \\
Conc H & 0 & 0 & 0 & 0 & 5 & 0 & 0 & 0 & 1 & 6 \\
Conc I & 0 & 0 & 0 & 0 & 1 & 0 & 0 & 0 & 0 & 1 \\
Conc J & 0 & 0 & 0 & 0 & 1 & 0 & 0 & 1 & 0 & 2 \\
Conc K & 0 & 0 & 2 & 0 & 1 & 3 & 0 & 1 & 1 & 8 \\
Resid & 0 & 1 & 3 & 8 & 21 & 9 & 3 & 6 & 5 & 56 \\
Total & 2 & 2 & 6 & 19 & 39 & 20 & 12 & 11 & 10 & 121 \\
\hline
\end{tabular}




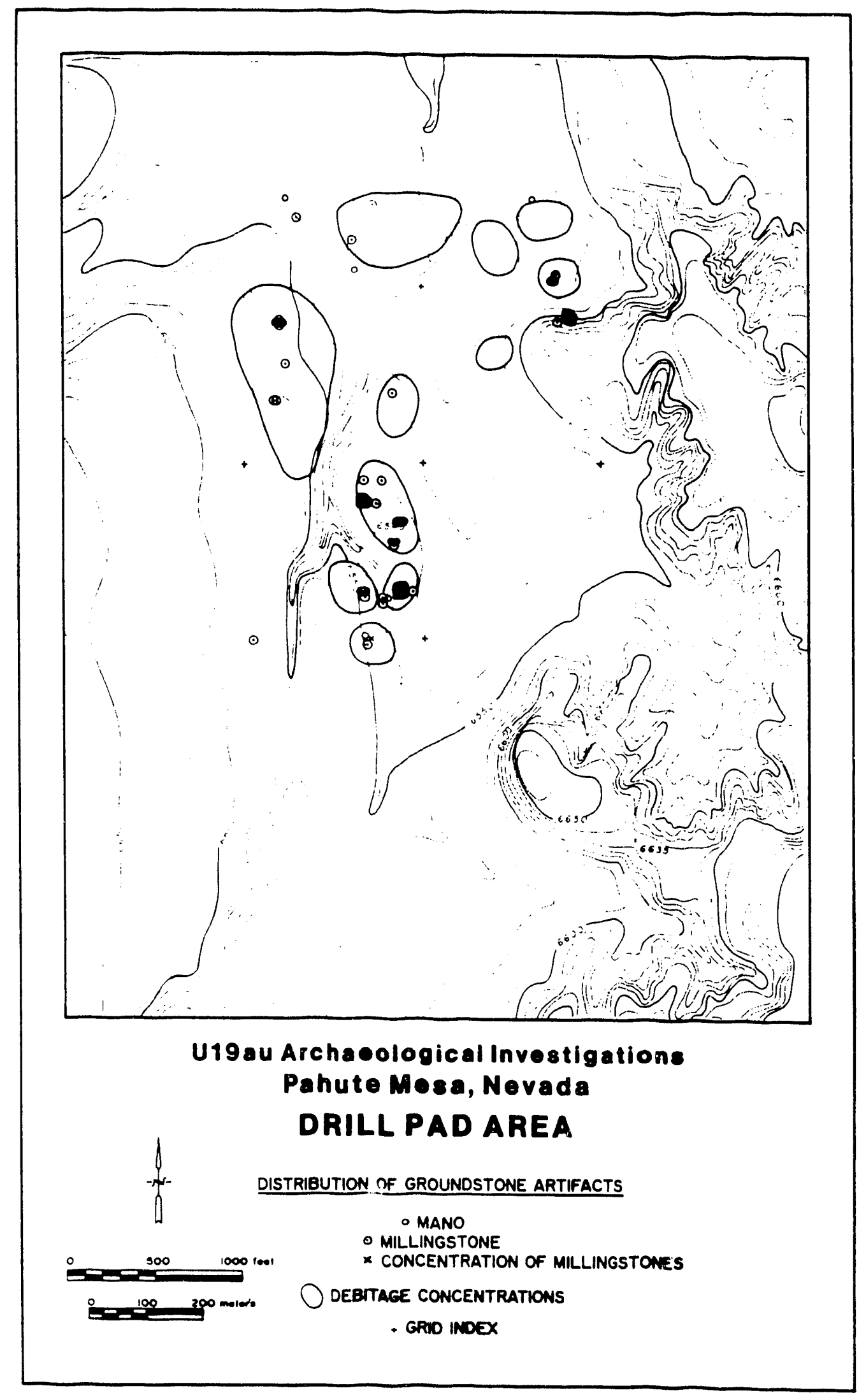

Figure 4-14. Distribution map of manos and millingstones in the U1Gau drill pad area, Pahute Mesa, Nevada. 
sociation of point types with the twelve defined concentrations. The largest number of projectile points (30) came from concentration A. This included a cache of 7 projectile points found under a juniper tree-5 Desert Side-notched (DSN) and 2 Cottonwoodand does not appear to be a modern pothunter cache. Some of the points are in relatively good shape and form a rather selective group of the projectile points available in the area. Of particular interest are both the Cottonwood and DSN types in this cache. These points were found on the periphery of the concentration containing substantial amounts of biface thinning debitage, but there was little debitage near them. An additional 4 DSN, 1 Cottonwood, 5 Rosegate, 7 Gatecliff, 2 Pinto, and 3 unidentifiable point fragments were found elsewhere in concentration $A$.

The 5 projectile points from concentration B fall into temporally tighter groups: 1 Gatecliff, 2 Elko, and 2 Rosegate. The 3 points from concentration $C$ fell into 3 types: a Humboldt, a Gatecliff, and an Elko. No points were found at the quarry (concentration $D$ ), and a single Gatecliff and an indeterminate were found at concentration $E$.

Elko point types were most common in the four concentrations found along the center of the valley, with 2 from concentration $F, 5$ from concentration $G, 6$ from concentration $H$, and 1 from concentration $I$. In addition, a Gatecliff and a Rosegate were found at concentration $\mathrm{G}$, and an indeterminate at concentration $\mathrm{H}$. Fifty-six projectile points were not associated with any of the observed artifact concentrations. In order of frequency of occurrence, they included 21 Elko, 9 Rosegate, 8 Gatecliff, 6 Cottonwood, 3 Desert Sidenotched, and 3 Humboldt. Five untypeable points were also recovered (see Figures 4-15-4-20).

Elko points were found throughout the open valley areas and Gateclifi-type points predominately along the gentle western slopes. Rosegate points were less common, but appear to be distributed similarly to Elko points. DSN and Cottonwood points appear in concentration $\mathrm{H}$ and near both of the structure sites, but generally not in the open valleys where Elko points are most often found.

\section{Cores}

Numerous cores were recovered during the surface collection, and their distribution is in large part limited to the debitage clusters. Most are found in the valley near the drainage and at the two structure sites, concentrations $J$ and $K$ (Figure 4-21).

\section{Modified Flakes}

Modified flakes, including scrapers and tools with reworked edges, are a type in a class of artifacts usually associated with maintenance or processing activities at temporary camps or more substantially inhabited sites and are less indicative of casual use. A substantial number of modified flakes were found during the surface collections, usually with the debitage clusters. The greatest density of modified flakes was found in concentration $K$, one of the structure sites, followed by $A$ and $B$ (Figure 4-22).

\section{Discussion}

Similarities of nondebitage artifacts in the 12 defined concentrations appear to be linked to geographic location. The western hillside. (concentration $A$ ) is not only relatively distinct in the types of debitage present, but also has a high prcportion of bifaces, lacks significant amounts of pottery and groundstone, and has Gatecliff and DSN projectile points as the most common types. The southern valley concentrations $(F, G, H, I)$ are distinct in having more core reduction debitage, a lower density of bifaces, considerably more millingstones, Elko projectile points as the most common type, and little pottery. Pottery is more common and millingstones less so in the northern vaiieys $(\bar{B}, \bar{C})$. Density of bifaces and predominance of Elko points are similar 

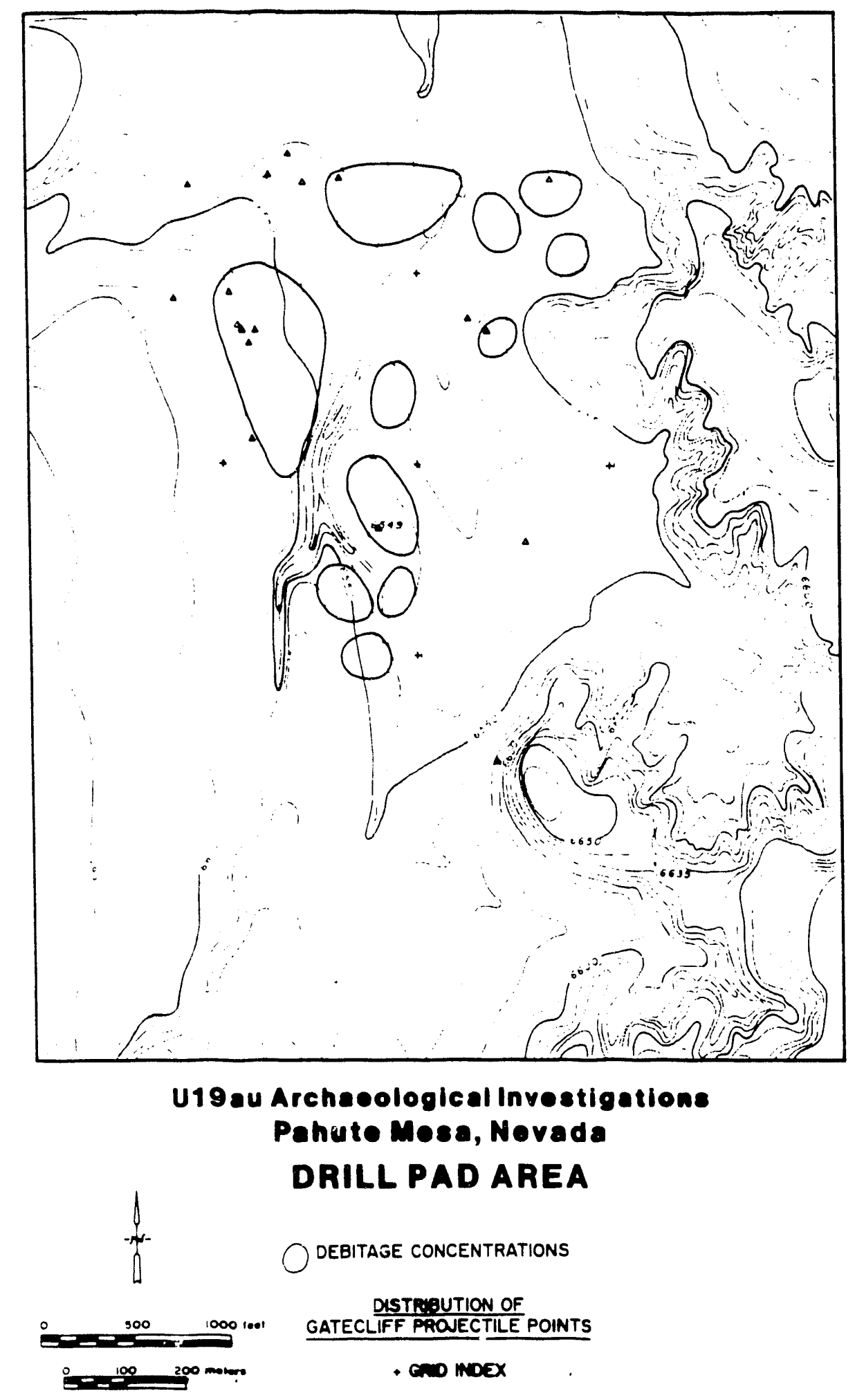

Figure 4-15. Distrituition mapo of Gatecilif and Gypsum projectiie points in the نi îau diiii pad area, Pahute Mesa, Nevada. 


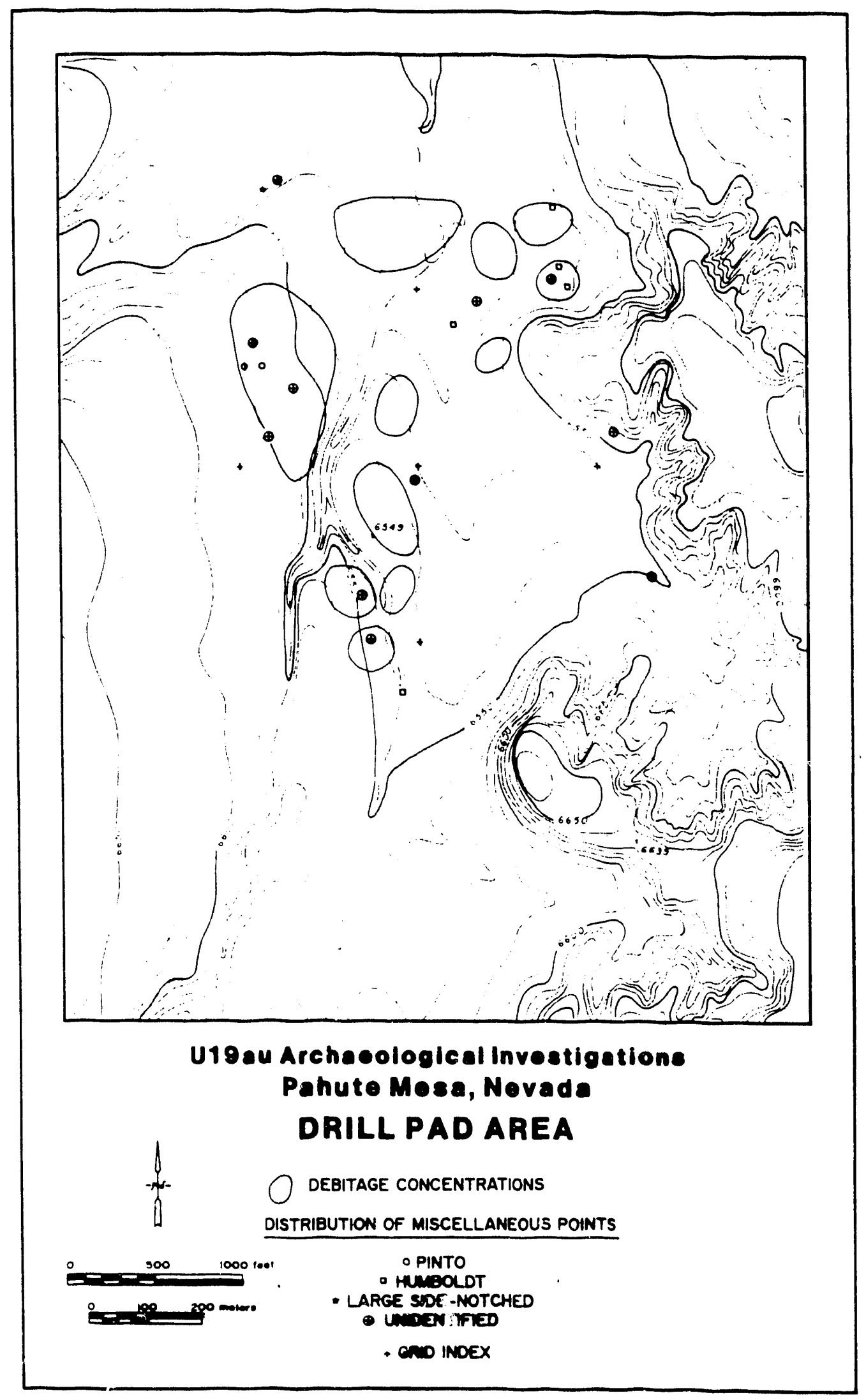

Figure 4-16. Distribution map of misceilaneous projectile points in the U19au drill pad area, Pahute Mesa, Nevada. 


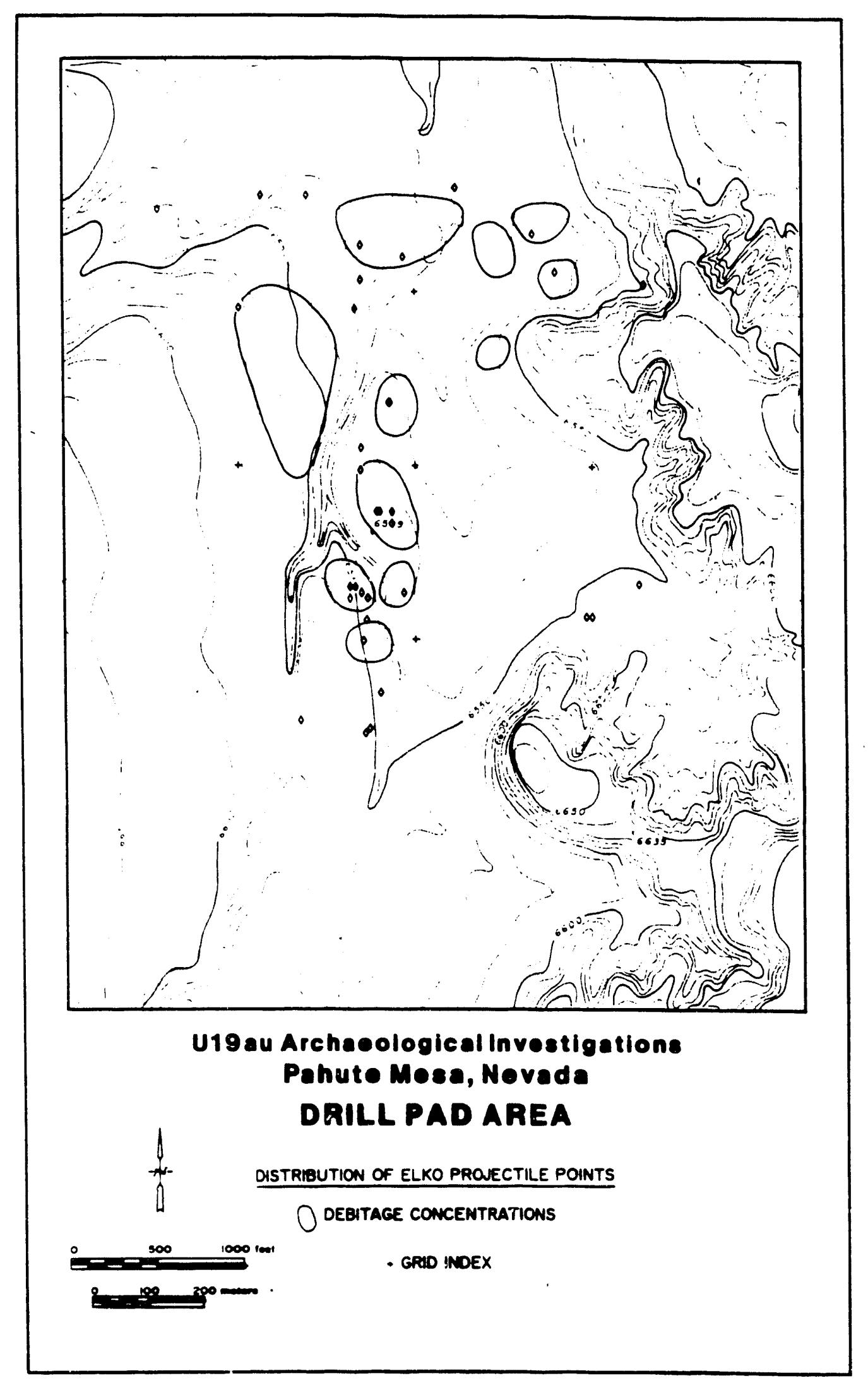

Figure 4-17. Distribution map of Elko projectile points in the U19au drill pad area, Pahute Mesa, Nievada. 


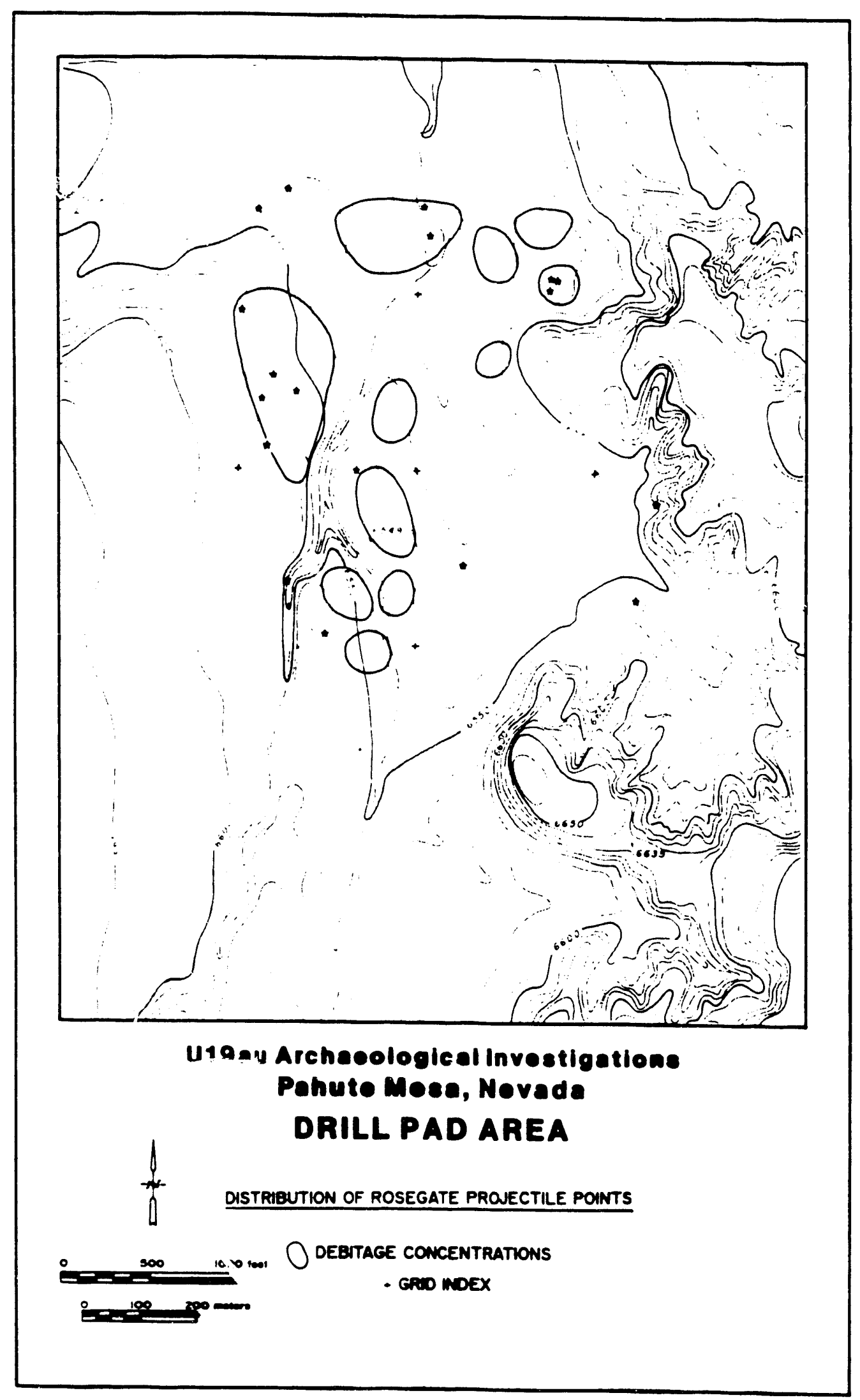

Figure 4-18. Distribution map of Rosegate projectile points in the U19au drill pad area, Fanute iviesa, Nevada. 


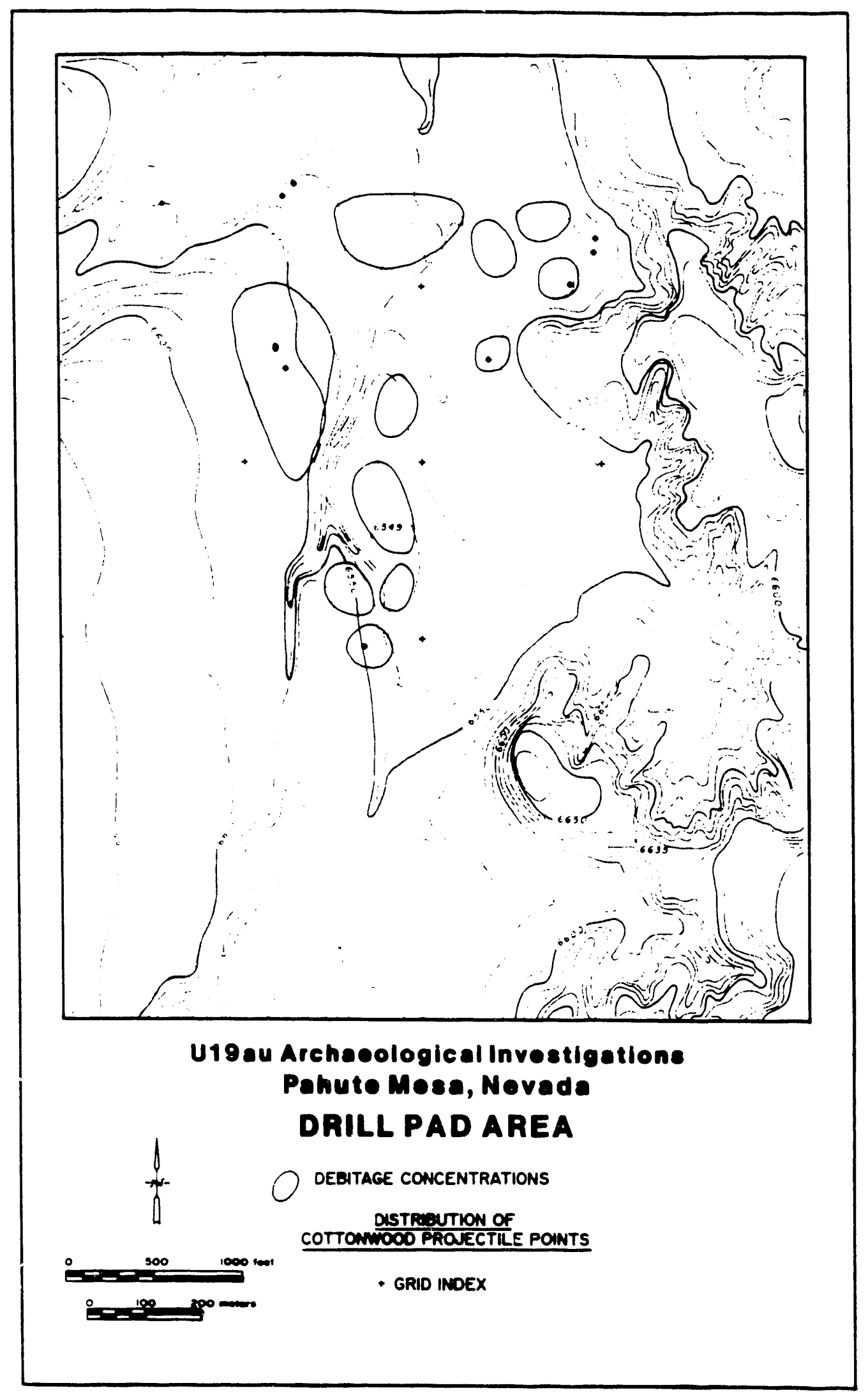

Figure 4-19. Distribution map of Cottonwood projectile points in the U19au drill pad area, Fanute ivesa, Nievada. 


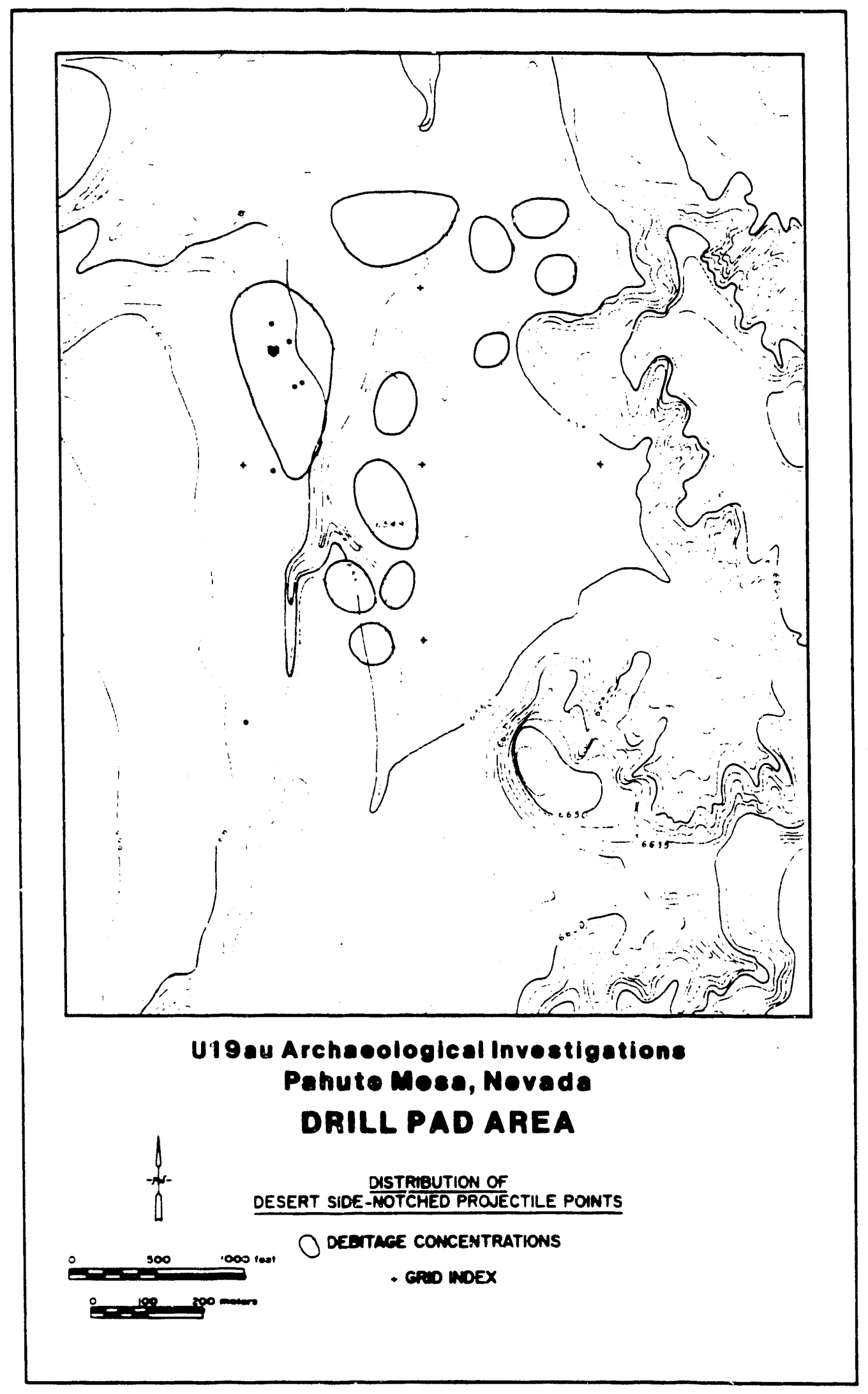

Figure 4-20. Distribution map of Desert Side-Notched projectile points in the U19au drill pad area, Fanute ímesa, Nivevada. 


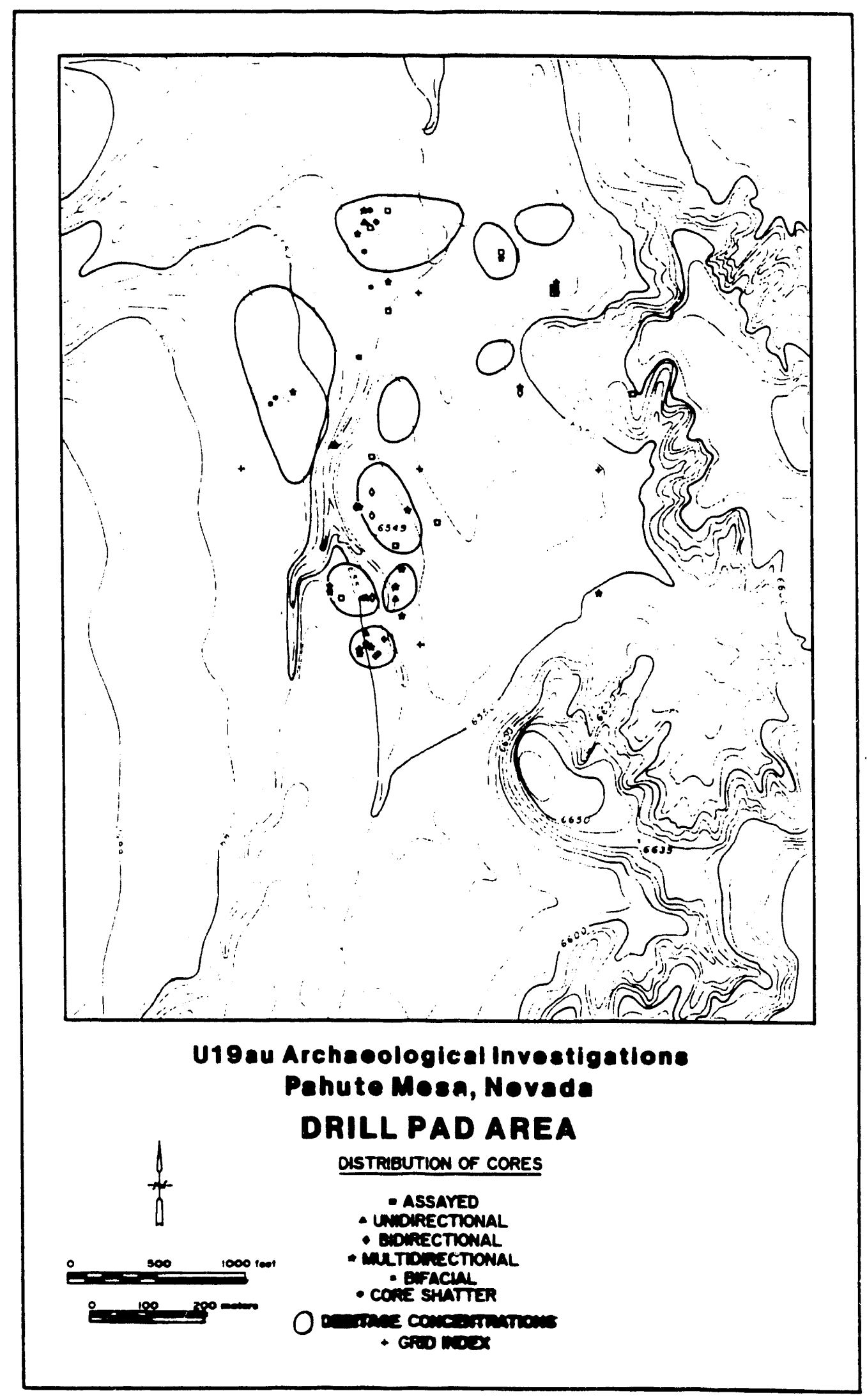

Figure 4-21. Distribution map of cores in the U19au drill pad area, Pahute Mesa, Nevada. 


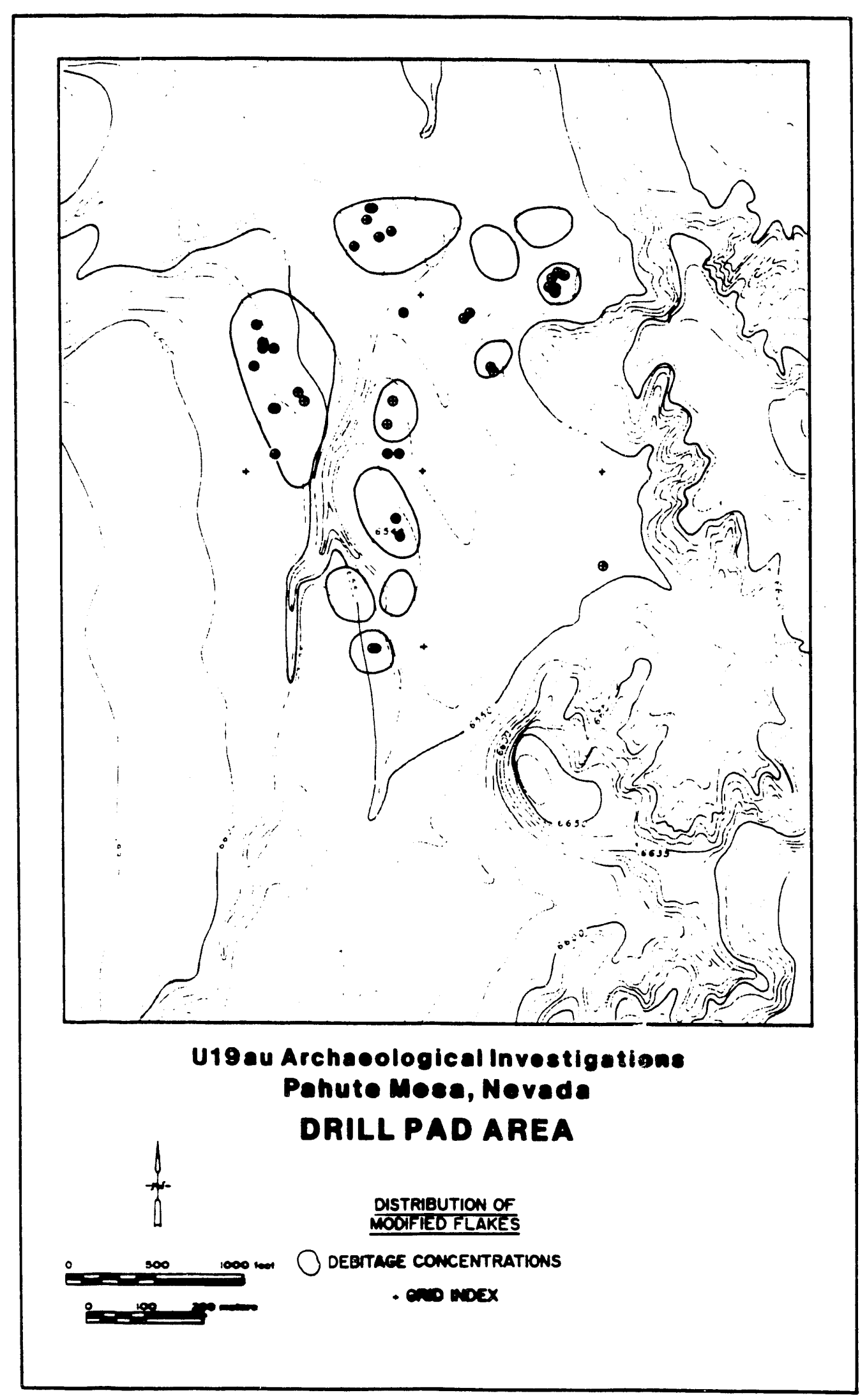

Figure 4-22. Distribution map of modified flakes in the U19au drill pad area. Pahute Mesa, Nevada. 
to the southern valley, as is the composition of the debitage.

If one assumes a general chronology based on a sequence of Gatecliff, Elko, Rosegate, and DSN/Cottonwood projectile point types, then the sequence for this area in the valley can be hypothesized. Initial intensive occupation would have occurred during Gatecliff times along the western slope of the valley in what is defined as concentration $A$. Given the high proportion of bifacial thinning debitage and numerous bifaces, intermediate lithic reduction was an important activity. With the transition to an Elko point type, a shift occurred to the lower regions near the valley drainages near concentrations $F, G, H$, and $I$, as well as at $B$ and $C$ at the northern end. The relative proportion of bifaces becomes smaller, and the debitage is dominated more by core reduction flakes, possibly indicating a more primary lithic reduction activity. Millingstones are much more prevalent, especially in the southern portion of the project area (concentrations $F, G, H, I$ ). Based on the similar distribution of Rosegate projectile points, this pattern apparently continued. Sites $26 \mathrm{Ny} 4021$ and $26 \mathrm{Ny} 4040$ appear to be late-period sites oriented on these earlier cultural remains. Pottery and DSN and Cottonwood projectile points are found near these sites, as well as at other relatively discrete locations, in close proximity to artifacts assumed to be from an earlier period.

When the drill pad was originally inspected, archazological sites were defined based on perceptions of artifact concentrations during the survey. Since numerous concentrations were observed at the time of the survey, the archaeologists realized that their grouping of sites may have been arbitrary. In comparing the sites as originally recorded with the location where artifacts were recovered during the surface collection, two inconsistencies are observed (Figure 4-23). First, some sites were located incorrectly. This is especially true of the original sites $26 \mathrm{Ny} 4032$.
26Ny4035, 26Ny4040, and 26Ny4036, and to a lesser extent of $26 \mathrm{Ny} 4021$. These inaccuracies are understandable: the map used for the original survey was a 7.5 minute quad and a square kilometer is a small area on which to record some $\mathbf{4 0}$ sites. These sites were later transferred to the larger scale map that appears as Figure 4-23.

Second, defining artifact concentrations is difficult in areas of low artifact density with few topographic boundaries. Original site 26Ny4017 contains three concentrations, 26Ny4021 contains two. In addition, original diffuse scatters $26 \mathrm{Ny} 4033,4032,4031$, and 4039 neither accurately reflect the extent of the debitage nor represent logical breaks in the cultural material.

Splitting extensive cultural remains into relatively small archaeological sites facilitates recording and administering sites. However, this arbitrarily superimposes a classification onto an area of diffuse surface cultural resources which may not accurately portray the true nature of the resources. Moreover, archaeologists conducting the survey do not necessarily have sufficient information to accurately determine boundaries and associations of widespread diffuse archaeological remains.

\section{Subsurface Scrapes at 26Ny4015}

Thirteen subsurface scrapes, numbered 1-9 and 12-15, were conducted in areas of concentrated surface artifacts at $26 \mathrm{Ny} 4015$. The goals of these scrapes were twofold: 1) to determine if visual collection methods bias sar.npling of debitage concentrations and 2) to det.ermine if the subsurface material is similar to the surface materials. The first goal can be accomplished by comparing the size of cultural materials recovered through visual inspection with those recovered by screening, the second by comparing the types of cultural materials recovered from the surface with material recovered from the immediate subsurface. These comparisons evaluate debitage recovered from the surface with that from the 


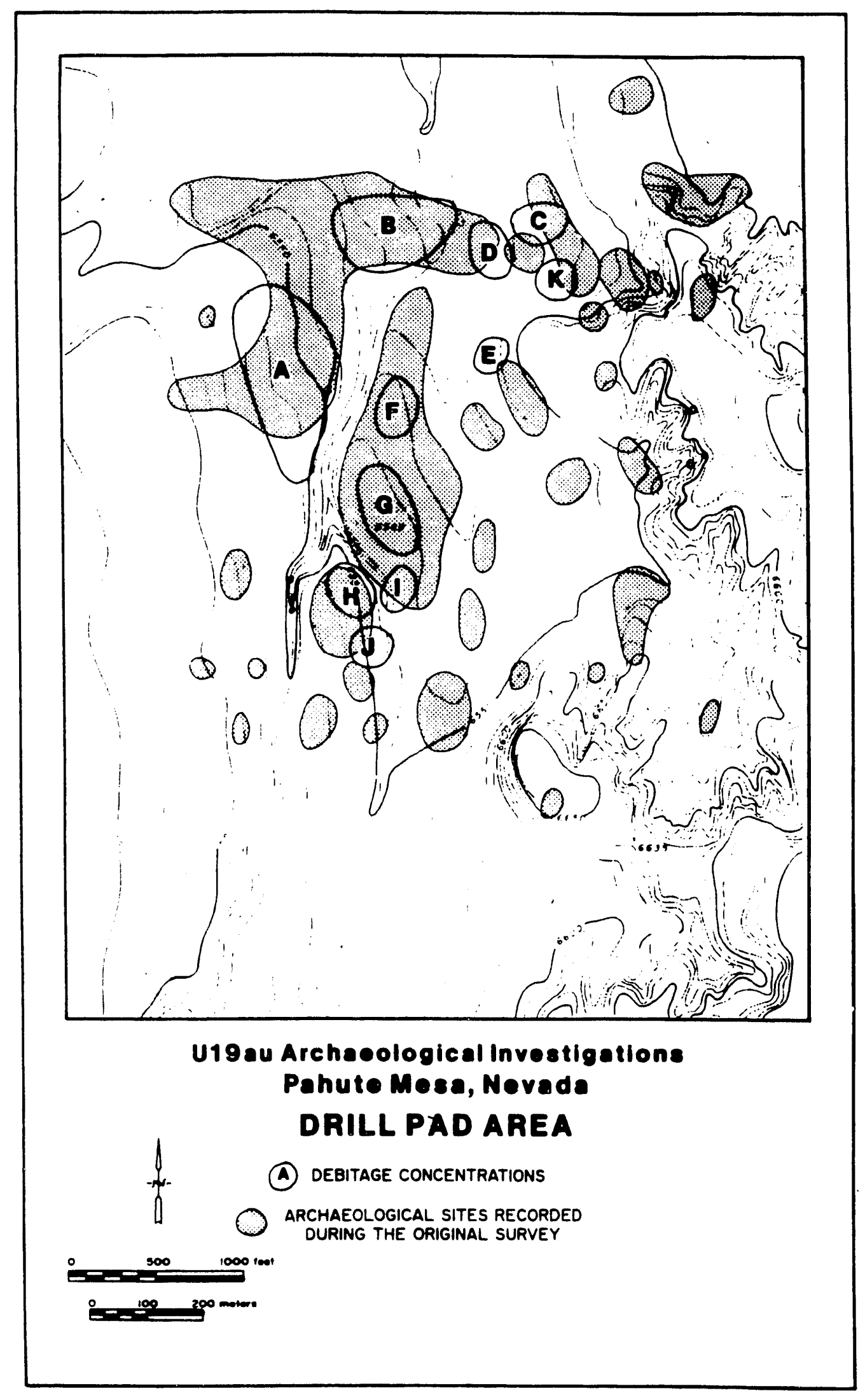

Figure 4-23. Map comparing the defined artifact concentrations with the locations of the archaeological sites as originally recorded in the U19au drill pad area, Pahute Mesa, Nevada. 
subsurface using chi-square tests to determine if both samples are derived from the same population.

\section{Scrape Descriptions}

Scrape 1 is a 3-by-3 m scrape located in a diffuse concentration of debitage at grid coordinates $920 \mathrm{~N}, 953 \mathrm{E}$. Artifacts found on the surface of this scrape included an obsidian utilized flake, an obsidian modified flake, and 20 pieces of debitage (Table 4-6). Subsurface materials included a single obsidian Stage III biface fragment and 36 fragments of debitage (Table 4-7).

Scrape 2 was located in a scatter of debitage and brownware pottery at grid coordinates $1179 \mathrm{~N}, 1116 \mathrm{E}$. Originally laid out as a 5-by-6 $m$ scrape, only a 4-by-6 $m$ area was collected and scraped because of a lack of material in the northernmost portion of the unit. A 2-by-3 m excavation unit, Unit 7, was delineated south and adjacent to the scrape at grid coordinates $1175 \mathrm{~N}, 1117 \mathrm{E}$, to test for the depth of cultural material. Like the adjacent scrape, the surface of this unit was collected. Then the first level of this unit was excavated to a depth comparable with the subsurface material from the scrape. Little cultural material was found in this first level, and further excavation in the unit was abandoned. Since the materiai collected from this unit is immediately adjaceitt to Scrape 2 and was collected in a similar manner, it was decided to include this material with Scrape 2 for analysis. Artifacts from the surface of Scrape 2 are 18 fragments of plain brownware pottery, a uniface, a core reduction flake, and a biface thinning flake, all of obsidian. Seventy-three pieces of plain brownware pottery were recovered from the subsurface along with a Desert Side-notched projectile point, single Stage I and Stage II/III bifaces, and a utilized flake, all of obsidian. Debitage numbered 16 flakes (Table 4-8).

Scrape 3 is a 2-by-2 $\mathrm{m}$ scrape conducted in a prehistoric quarry of chalcedony-like de- posits at grid coordinates $1375 \mathrm{~N}, 1130 \mathrm{E}$. Surface remains were limited to 417 fragments of debitage (Table 4-9). Subsurface cultural materials consisted of a chalcedony core and 276 debitage fragments (Table 4-10).

Scrape 4 is a 3-by-3 $\mathrm{m}$ scrape located at grid coordinates $1453 \mathrm{~N}, 920 \mathrm{E}$. This scrape was located in a concentration of chalcedony debitage with a Stage II obsidian biface and a Stage III chalcedony biface. Fifty-one fragments of debitage were recovered (Table 4-11).

Subsurface cultural material consisted of 35 debitage items (Table 4-12).

Scrape 5 is a 2-by- $3 \mathrm{~m}$ scrape located in a concentration of debitage, pottery, and groundstone at grid coordinates $867 \mathrm{~N}, 950 \mathrm{E}$. In addition to 2 manos and 2 plain brownware potsherds, single Stage I and Stage I/II bifaces, both of chalcedony, were recovered. Twenty-nine debitage fragments were recovered as well (Table 4-13).

Another 3 mano fragments were found in the subsurface materials, along with a chert Stage III biface and a chalcedony Stage I/II biface. Fifty-six fragments of debitage were recovered (Table 4-14).

Scrape 6 was located in a concentration of debitage and groundstone at grid coordinates $935 \mathrm{~N}, 900 \mathrm{E}$. This scrape was $5-\mathrm{by}-5 \mathrm{~m}$ in size. Artifacts recovered included 3 millingstone fragments, a chalcedony multidirectional core, and 5 bifaces--a chalcedony Stage II, 3 chalcedony Stage IVs, and a chert Stage IV. Recovered were 170 pieces of debitage (Table 4-15).

Subsurface material included an additional 5 millingstone fragments (2 from the same millingstone), a bidirectional chalcedony core, and 2 chalcedony bifaces (a Stage III and a Stage III/IV). Debitage totaled 272 fragments (Table 4-16)

Scrape 7 was a 5-by-5 m scrape located in a scatter of debitage and pottery at grid coordinates $1385 \mathrm{~N}, 890 \mathrm{E}$. A millingstone 
fragment and 29 plain brownware potsherds were recovered from the surface along with 70 pieces of debitage (Table 4-17).

Subsurface materials included another 6 plain brownware potsherds, an obsidian modified flake, and a chalcedony drill. Recovered from the subsurface were 121 fragments of debitage (Table 4-18).

Scrape 8 is a 4-by $-3 \mathrm{~m}$ scrape located at grid coordinates $781 \mathrm{~N}, 960 \mathrm{E}$. Artifacts recovered from this concentration included 6 millingstone fragments, a chert Stage III biface, an obsidian Stage IV biface, and 21 pieces of debitage (Table 4-19).

Subsurface materials from Scrape 8 consisted of 3 millingstone fragments, a chalcedony utilized flake, and 3 bifaces--a chalcedony Stage I, a chert Stage I, and a chert Stage III. Forty-two pieces of debitage were recovered from the subsurface (Table 4-20).

Scrape 9 is a 2-by-3 $\mathrm{m}$ scrape placed in a small artifact scatter at grid coordinates $864 \mathrm{~N}$, 726E. Three plain brownware potsherds, 2 chalcedony Stage II bifaces, and 6 pieces of debitage (an obsidian core reduction flake, 2 ubsidian biface thinning flakes, an obsidian indeterminate flake, and 2 chalcedony indeterminate flakes), were recovered from the surface. Eight plain brownware potsherds were recovered from the subsurface along with 12 pieces of debitage. Included in the debitage were 3 obsidian core reduction flakes, 2 obsidian indeterminate flakes, a chert decortication flake, 4 chert indeterminate flakes, a chalcedony decortication flake, and a piece of chalcedony shatter.

Scrape 12, the next one conducted at $26 \mathrm{Ny} 4015$, is located at grid coordinates $1110 \mathrm{~N}, 754 \mathrm{E}$. It was a 4-by-4 m scrape in a diffuse scatter of pottery and debitage. Artifacts recovered from the surface included 12 plain brownware potsherds, 2 millingstone fragments, a chalcedony drill, and a modified flake. Debitage included 5 core reduction flakes -1 of chert and the remainder chalcedony - and 4 indeterminate flakes -2 each of chert and chalcedony. Subsurface materials included 3 plain brownware potsherds, a chert core, a chalcedony modified flake, and a Stage I biface. Debitage consisted of 13 fragments, 2 chalcedony decortication flakes, 3 core reduction flakes - (1 each of obsidian, chert, and chalcedony), a chert biface thinning flake, $\sigma$ indeterminate flakes - (3 each of chert and chalcedony), and a chalcedony shatter fragment.

Scrape 13 was located in a small but dense chalcedony debitage concentration at grid coordinate $1122 \mathrm{~N}, 762 \mathrm{E}$. This 4-by $-4 \mathrm{~m}$ unit contained an obsidian Stage III biface, a chalcedony Stage 1 biface, and 191 fragments of debitage (Table 4-21).

Subsurface materials included another obsidian Stage III biface fragment and 115 pieces of debitage (Table 4-22).

Scrape 14, a 3-by-5 m scrape at grid coordinates $1133 \mathrm{~N}, 793 \mathrm{E}$ was a relatively diffuse scatter of artifacts with a high proportion of flaked stone tools. In addition to the 16 fragments of debitage recovered (Table 4-23), an obsidian projectile point fragment (untypeable), a chert Stage III biface, a chalcedony Stage I/II biface, and 2 utilized flakes -1 of chert and the other of chalcedony-were recovered.

Subsurface cultural material included a chalcedony Stage III biface and 6 pieces of debitage - an obsidian pressure flake, a chert biface thinning flake, a core reduction flake, an indeterminate flake, and two heat spalls all of chalcedony.

Finally, Scrape 15 was a 4-by-3 mi scrape at grid coordinates $1270 \mathrm{~N}, 702 \mathrm{E}$. This scrape was located in a sparse concentration of artifacts containing a chalcedony Elko series projectile point, 2 Stage III/IV bifaces - (1 obsidian, the other chalcedony) and 64 pieces of debitage (Table 4-24). 
Subsurface materials included a Stage III biface fragment of obsidian and 35 pieces of debitage (Table 4-25).

\section{Chi-square Tests}

Debitage with a sufficient number was recovered from 4 of the 13 scrapes, (scrapes 3 , 6,7 , and 13) to compute a chi-square comparison between surface and subsurface material. Two comparisons for each scrape were made, 1 for the size class of the debitage and 1 for the debitage counts. (Tables 4-26 and Table 4-27)

Debitage from the 4 scrapes was divided into 5 sizes by passing the debitage through nested screens of $2^{\prime \prime}, 1^{\prime \prime}, 1 / 2^{\prime \prime}$, and $1 / 4^{\prime \prime}$. Debitage that passed through all the screens was classified as less than 1/4". Debitage greater than 2" in size was so rare that it was

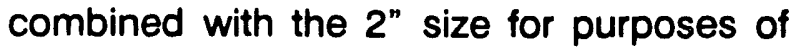
these chi-square comparisons. In two of the samples, the amount of $1-2^{n}$ debitage was small, so it was combined with the next smaller size class 1/2-1".

On this basis, all tests rejected the hypothesizes that the surface and subsurface samples were from the same population. The greatest discrepancy in the two sets of samples is the amount of less than 1/4-inch debitage recovered. Surface samples, where the debitage was recovered by visual inspection, had significantly more debitage of this size class than the subsurface materials recovered by screening through 1/4-inch screen. Presumably, a large proportion of less than 1/4-inch debitage is recovered during visual inspection but is lost through $1 / 4$-inch mesh screen. When the less than $1 / 4$ - inch size class is removed from consideration during the cr.i-square test, the results are noticeably different (Table 4-28).

The hypothesis that the surface and subsuriace size class material comes from the sarne population cannot be rejected in three of the four cases. In Scrape 3, 'ncated in the prehistoric quarry, the hypotheses is rejected; the subsurface was dominated by smaller size classes, the surface by larger classes.

A similar test was conducted for debitage types (Table 4-29) in the same four scrapes $(3,6,7$, and 13). The categories were composed of flake types and included decortication, core reduction, biface thinning, shatter, and indeterminate. Pressure flakes were not used because the counts were small for all concentrations. Not all concentrations had sufficient counts of each type to use all five categories for the comparison. If categories had to be combined to make the counts sufficient, they were combined in a meaningful way. For example, shatter category could be combined with decortication as both are most often the result of initial lithic reduction

Once again, the hypotheses that the surface and subsurface samples come from the same population cannot be rejected at 0.95 percent confidence level for the same three of the four scrapes compared. Scrape 3 fails because of an exceptionally low presence of core reduction flakes on the surface compared to the subsurface component. Additionally, the surface component has a substantially higher quantity of shatter compared to the subsurface. While explanations are speculative, the last aboriginal utilization of this quarry may have differed from previous ones: materials were no longer reduced at the quarry but taken elsewhere for later reduction, thus lowering the percentages of core reduction debitage.

\section{Discussion}

These tests appear to indicate that, by and large, the material just under the surface of the site is similar to that appearing on the surface.

Based on comparisons of the total counts of surface artifacts with those from subsurface scrapes with 20 or more artifacts on the surface (Table 4-30), subsurface investigations return between 56 and 200 percent of the artifacts found on the surface. Because of the different collection methods, this return is some- 
what size selective, with approximately 38 percent of the expected amount of debitage classified as less than 1/4-inch being recovered during the screening of subsurface material (Table 4-31).

In conclusion, it appears that visual inspection of surface materials at U19au pro- vides a representative sample of the cultural material in subsurface deposits. This sample ranges from about one third to two-thirds of the material recovered if used in conjunction with a subsurface scrape. In addition, intense visual inspection is likely to recover smaller material. 
Table 4-6. Debitage from the Surface of Scrape 1, 26Ny4015, Pahute Mesa.

\begin{tabular}{lccccccc}
\hline $\begin{array}{l}\text { Material } \\
\text { Type }\end{array}$ & $\begin{array}{c}\text { Decort- } \\
\text { ication }\end{array}$ & $\begin{array}{c}\text { Core } \\
\text { Reiluction }\end{array}$ & $\begin{array}{c}\text { Biface } \\
\text { Thinning }\end{array}$ & $\begin{array}{c}\text { Pres- } \\
\text { sure }\end{array}$ & $\begin{array}{c}\text { Shat- } \\
\text { ter }\end{array}$ & $\begin{array}{c}\text { Indeter- } \\
\text { minate }\end{array}$ & $\begin{array}{c}\text { Heat } \\
\text { Spall }\end{array}$ \\
\hline Obsidian & - & 1 & 1 & - & - & 3 & - \\
Chert & - & - & - & - & - & 2 & - \\
Chalcedony & 2 & 3 & - & - & 1 & 6 & 1 \\
\cline { 2 - 8 } & 2 & 4 & 1 & - & 1 & 11 & 1 \\
\hline
\end{tabular}

Table 4-7. Debitage from the Subsurface of Scrape 1, 26Ny4015, Pahute Mesa.

\begin{tabular}{lccccccc}
\hline $\begin{array}{l}\text { Material } \\
\text { Type }\end{array}$ & $\begin{array}{c}\text { Decort- } \\
\text { ication }\end{array}$ & $\begin{array}{c}\text { Core } \\
\text { Reduction }\end{array}$ & $\begin{array}{c}\text { Biface } \\
\text { Thinning }\end{array}$ & $\begin{array}{c}\text { Pres- } \\
\text { sure }\end{array}$ & $\begin{array}{c}\text { Shat- } \\
\text { ter }\end{array}$ & $\begin{array}{c}\text { Indeter- } \\
\text { minate }\end{array}$ & $\begin{array}{c}\text { Heat } \\
\text { Spall }\end{array}$ \\
\hline $\begin{array}{l}\text { Obsidian } \\
\text { Chert }\end{array}$ & 5 & 1 & 9 & - & 1 & 3 & - \\
Chalcedony & - & - & & - & - & - & 1 \\
Total & 2 & 3 & 1 & - & 7 & 3 & - \\
\cline { 2 - 8 } & 7 & 4 & 10 & - & 8 & 7 & - \\
\hline
\end{tabular}

Table 4-8. Debitage from the Subsurface of Scrape 2, 26Ny4015, Pahute Mesa.

\begin{tabular}{lccccccc}
\hline $\begin{array}{l}\text { Material } \\
\text { Type }\end{array}$ & $\begin{array}{c}\text { Decort- } \\
\text { ication }\end{array}$ & $\begin{array}{c}\text { Core } \\
\text { Reduction }\end{array}$ & $\begin{array}{c}\text { Biface } \\
\text { Thinning }\end{array}$ & $\begin{array}{c}\text { Pres- } \\
\text { sure }\end{array}$ & $\begin{array}{c}\text { Shat- } \\
\text { ter }\end{array}$ & $\begin{array}{c}\text { Indeter- } \\
\text { minate }\end{array}$ & $\begin{array}{c}\text { Heat } \\
\text { Spall }\end{array}$ \\
\hline Obsidian & 1 & - & 7 & - & 1 & 4 & - \\
Chalcedony & - & - & 2 & - & - & 1 & - \\
\cline { 2 - 9 } Total & 1 & - & 9 & - & 1 & 5 & - \\
\hline
\end{tabular}

Table 4-9. Debitage from the Surface of Scrape 3, 26Ny4015, Pahute Mesa.

\begin{tabular}{lccccccc}
\hline $\begin{array}{l}\text { Material } \\
\text { Type }\end{array}$ & $\begin{array}{c}\text { Decort- } \\
\text { ication }\end{array}$ & $\begin{array}{c}\text { Core } \\
\text { Reduction }\end{array}$ & $\begin{array}{c}\text { Biface } \\
\text { Thinning }\end{array}$ & $\begin{array}{c}\text { Pres- } \\
\text { sure }\end{array}$ & $\begin{array}{c}\text { Shat- } \\
\text { ter }\end{array}$ & $\begin{array}{c}\text { Indeter- } \\
\text { minate }\end{array}$ & $\begin{array}{r}\text { Heat } \\
\text { Spall }\end{array}$ \\
\hline Chert & 21 & 3 & - & - & 16 & 75 & - \\
Chalcedony & 27 & 3 & - & - & 166 & 106 & - \\
Total & 48 & 6 & - & - & 182 & 181 & - \\
\hline
\end{tabular}

Table 4-10. Debitage from the Su'sisurface of Scrape 3, 26Ny4015, Pahute Mesa.

\begin{tabular}{lccccccc}
\hline $\begin{array}{l}\text { Material } \\
\text { Type }\end{array}$ & $\begin{array}{c}\text { Decort- } \\
\text { ication }\end{array}$ & $\begin{array}{c}\text { Core } \\
\text { Reduction }\end{array}$ & $\begin{array}{c}\text { Biface } \\
\text { Thinning }\end{array}$ & $\begin{array}{c}\text { Pres- } \\
\text { sure }\end{array}$ & $\begin{array}{c}\text { Shat- } \\
\text { ter }\end{array}$ & $\begin{array}{c}\text { Indeter- } \\
\text { minate }\end{array}$ & $\begin{array}{c}\text { Heiat } \\
\text { Spitl }\end{array}$ \\
\hline Chert & 6 & 22 & - & - & 8 & 56 & - \\
C. alcedony & 26 & 16 & - & - & 83 & 59 & - \\
Total & 32 & 38 & - & - & 91 & 115 & - \\
\hline
\end{tabular}


Table 4-11. Debitage from the Surface of Scrape 4, 26Ny4015, Pahute Mesa.

\begin{tabular}{lccccccc}
\hline $\begin{array}{l}\text { Material } \\
\text { Type }\end{array}$ & $\begin{array}{c}\text { Decort- } \\
\text { ication }\end{array}$ & $\begin{array}{c}\text { Core } \\
\text { Reduction }\end{array}$ & $\begin{array}{c}\text { Biface } \\
\text { Thinning }\end{array}$ & $\begin{array}{c}\text { Pres- } \\
\text { sure }\end{array}$ & $\begin{array}{c}\text { Shat- } \\
\text { ter }\end{array}$ & $\begin{array}{c}\text { Indeter- } \\
\text { minate }\end{array}$ & $\begin{array}{c}\text { Heat } \\
\text { Spall }\end{array}$ \\
\hline Obsidian & - & - & 1 & - & - & 1 & - \\
Chert & 2 & - & 3 & - & 1 & 4 & - \\
Chalcedony & 3 & 6 & 10 & - & 1 & 19 & - \\
Total & 5 & 6 & 14 & - & 2 & 24 & - \\
\hline
\end{tabular}

Table 4-12. Debitage from the Subsurface of Scrape 4, 26Ny4015, Pahute Mesa.

\begin{tabular}{lccccccc}
\hline $\begin{array}{l}\text { Material } \\
\text { Type }\end{array}$ & $\begin{array}{c}\text { Decort- } \\
\text { ication }\end{array}$ & $\begin{array}{c}\text { Ccre } \\
\text { Reduction }\end{array}$ & $\begin{array}{c}\text { Biface } \\
\text { Thinning }\end{array}$ & $\begin{array}{c}\text { Pres- } \\
\text { sure }\end{array}$ & $\begin{array}{c}\text { Shat- } \\
\text { ter }\end{array}$ & $\begin{array}{c}\text { Indeter- } \\
\text { minate }\end{array}$ & $\begin{array}{c}\text { Heat } \\
\text { Spcil }\end{array}$ \\
\hline Obsidian & - & - & - & - & - & 1 & - \\
Chert & 1 & - & - & - & - & 6 & - \\
Chalcedony & 3 & 7 & 4 & - & - & 13 & - \\
Total & 4 & 7 & 4 & - & - & 20 & - \\
\hline
\end{tabular}

Table 4-13. Debitage from the Surface of Scrape 5, 26Ny4015, Pahute Mesa.

\begin{tabular}{lccccccc}
\hline $\begin{array}{l}\text { Materiai } \\
\text { Type }\end{array}$ & $\begin{array}{c}\text { Decort- } \\
\text { ication }\end{array}$ & $\begin{array}{c}\text { Core } \\
\text { Reduction }\end{array}$ & $\begin{array}{c}\text { Biface } \\
\text { Thinning }\end{array}$ & $\begin{array}{c}\text { Pres- } \\
\text { sure }\end{array}$ & $\begin{array}{c}\text { Shat- } \\
\text { ter }\end{array}$ & $\begin{array}{c}\text { Indeter- } \\
\text { minate }\end{array}$ & $\begin{array}{c}\text { Heat } \\
\text { Spall }\end{array}$ \\
\hline Chert & - & 5 & 1 & - & - & 13 & - \\
Chalcedony & - & 4 & - & - & - & 5 & - \\
\hline Total & - & 9 & 1 & - & - & 18 & - \\
\hline
\end{tabular}

Table 4-14. Debitage from the Subsurface of Scrape 5, 26Ny4015, Pahute Mesa.

\begin{tabular}{lccccccc}
\hline $\begin{array}{l}\text { Material } \\
\text { Type }\end{array}$ & $\begin{array}{c}\text { Decort- } \\
\text { ication }\end{array}$ & $\begin{array}{c}\text { Core } \\
\text { Reduction }\end{array}$ & $\begin{array}{c}\text { Biface } \\
\text { Thinning }\end{array}$ & $\begin{array}{c}\text { Pres- } \\
\text { sure }\end{array}$ & $\begin{array}{c}\text { Shat- } \\
\text { ter }\end{array}$ & $\begin{array}{c}\text { Indeter- } \\
\text { minate }\end{array}$ & $\begin{array}{c}\text { Heat } \\
\text { Spall }\end{array}$ \\
\hline Chert & 1 & 9 & 2 & - & 2 & 3 & - \\
Chalcedony & 7 & 10 & 8 & - & - & 14 & - \\
Total & 8 & 19 & 10 & - & 2 & 17 & - \\
\hline
\end{tabular}

Table 4-15. Debitage from the Surface of scrape 6, 26Ny4015, Pahute Mesa.

\begin{tabular}{lccccccc}
\hline $\begin{array}{l}\text { Material } \\
\text { Type }\end{array}$ & $\begin{array}{c}\text { Decort- } \\
\text { ication }\end{array}$ & $\begin{array}{c}\text { Core } \\
\text { Reduction }\end{array}$ & $\begin{array}{c}\text { Biface } \\
\text { Thinning }\end{array}$ & $\begin{array}{c}\text { Pres- } \\
\text { sure }\end{array}$ & $\begin{array}{c}\text { Shat- } \\
\text { ter }\end{array}$ & $\begin{array}{c}\text { Indeter- } \\
\text { minate }\end{array}$ & $\begin{array}{c}\text { Heat } \\
\text { Spall }\end{array}$ \\
\hline Chert & 9 & 23 & 3 & - & 25 & 40 & - \\
Chalcedony & 9 & 8 & - & - & 30 & 25 & - \\
Total & 18 & 31 & 3 & - & 53 & 65 & - \\
\hline
\end{tabular}


Table 4-16. Debitage from the Subsurface of Scrape 6, 26Ny4015, Pahute Mesa.

\begin{tabular}{lccccccc}
\hline $\begin{array}{l}\text { Material } \\
\text { Type }\end{array}$ & $\begin{array}{c}\text { Decort- } \\
\text { ication }\end{array}$ & $\begin{array}{c}\text { Core } \\
\text { Reduction }\end{array}$ & $\begin{array}{c}\text { Bifr.ce } \\
\text { Thinning }\end{array}$ & $\begin{array}{c}\text { Pres- } \\
\text { sure }\end{array}$ & $\begin{array}{c}\text { Shat- } \\
\text { ter }\end{array}$ & $\begin{array}{c}\text { Indeter- } \\
\text { minate }\end{array}$ & $\begin{array}{c}\text { Heat } \\
\text { Spall }\end{array}$ \\
\hline Obsidian & - & - & 4 & - & - & - & - \\
Chert & 4 & 20 & 3 & - & 8 & 38 & - \\
Chalcedony & 11 & 25 & - & - & 81 & 78 & - \\
Total & 19 & 45 & 7 & - & 39 & 116 & - \\
\hline
\end{tabular}

Table 4-17. Debitage from the Surface of Scrape 7, 26Ny4015, Pahute Mesa.

\begin{tabular}{lccccccc}
\hline $\begin{array}{l}\text { Material } \\
\text { Type }\end{array}$ & $\begin{array}{c}\text { Decort- } \\
\text { ication }\end{array}$ & $\begin{array}{c}\text { Core } \\
\text { Reduction }\end{array}$ & $\begin{array}{c}\text { Biface } \\
\text { Thinning }\end{array}$ & $\begin{array}{c}\text { Pres- } \\
\text { sure }\end{array}$ & $\begin{array}{c}\text { Shat- } \\
\text { ter }\end{array}$ & $\begin{array}{c}\text { Indeter- } \\
\text { minate }\end{array}$ & $\begin{array}{c}\text { Heat } \\
\text { Spall }\end{array}$ \\
\hline Obsidian & - & - & 9 & 1 & - & 7 & - \\
Chert & - & 1 & 3 & - & - & 2 & - \\
Chalcedony & 2 & 8 & 14 & - & 6 & 17 & - \\
\hline
\end{tabular}

Table 4-18. Debitage from the Subsurface of Scrape 7, 26Ny4015, Pahute Mesa.

\begin{tabular}{lccccccc}
\hline $\begin{array}{l}\text { Material } \\
\text { Type }\end{array}$ & $\begin{array}{c}\text { Decort- } \\
\text { ication }\end{array}$ & $\begin{array}{c}\text { Core } \\
\text { Reduction }\end{array}$ & $\begin{array}{c}\text { Biface } \\
\text { Thinning }\end{array}$ & $\begin{array}{c}\text { Pres- } \\
\text { sure }\end{array}$ & $\begin{array}{c}\text { Shat- } \\
\text { ter }\end{array}$ & $\begin{array}{c}\text { Indeter- } \\
\text { minate }\end{array}$ & $\begin{array}{c}\text { Heat } \\
\text { Spall }\end{array}$ \\
\hline Obsidian & - & - & 7 & - & - & 21 & - \\
Chert & - & 8 & 7 & - & - & 10 & - \\
Chalcedony & 2 & 4 & 22 & - & 5 & 35 & - \\
Total & 2 & 12 & 36 & - & 5 & 66 & - \\
\hline
\end{tabular}

Table 4-19. Debitage from the Surface of Scrape 8, 26Ny4015, Pahute Mesa.

\begin{tabular}{lccccccc}
\hline $\begin{array}{l}\text { Material } \\
\text { Type }\end{array}$ & $\begin{array}{c}\text { Decort- } \\
\text { ication }\end{array}$ & $\begin{array}{c}\text { Core } \\
\text { Reduction }\end{array}$ & $\begin{array}{c}\text { Biface } \\
\text { Thinning }\end{array}$ & $\begin{array}{c}\text { Pres- } \\
\text { sure }\end{array}$ & $\begin{array}{c}\text { Shat- } \\
\text { ter }\end{array}$ & $\begin{array}{c}\text { Indeter- } \\
\text { minate }\end{array}$ & $\begin{array}{c}\text { Heat } \\
\text { Spall }\end{array}$ \\
\hline Obsidian & - & - & 1 & 2 & - & 2 & - \\
Chert & 1 & 3 & 1 & - & - & 2 & - \\
Chalcedony & - & 1 & - & - & 5 & 3 & - \\
Total & $i$ & 4 & 2 & 2 & 5 & 7 & - \\
\hline
\end{tabular}


Table 4-20. Debitage from the Subsurface of Scrape 8, 26Ny4015, Pahute Mesa.

\begin{tabular}{lccccccc}
\hline $\begin{array}{l}\text { Material } \\
\text { Type }\end{array}$ & $\begin{array}{c}\text { Decort- } \\
\text { ication }\end{array}$ & $\begin{array}{c}\text { Core } \\
\text { Reduction }\end{array}$ & $\begin{array}{c}\text { Biface } \\
\text { Thinning }\end{array}$ & $\begin{array}{c}\text { Pres- } \\
\text { sure }\end{array}$ & $\begin{array}{c}\text { Shat- } \\
\text { ter }\end{array}$ & $\begin{array}{c}\text { Indeter- } \\
\text { minate }\end{array}$ & $\begin{array}{c}\text { Heat } \\
\text { Spall }\end{array}$ \\
\hline Obsidian & - & 1 & 2 & - & - & 8 & - \\
Chert & 2 & 3 & - & - & - & 4 & - \\
Chalcedony & 4 & 4 & - & - & 4 & 10 & - \\
Total & 6 & 8 & 2 & - & 4 & 22 & - \\
\hline
\end{tabular}

Table 4-21. Debitage from the Surface of Scrape 13, 26Ny4015, Pahute Mesa.

\begin{tabular}{|c|c|c|c|c|c|c|c|}
\hline $\begin{array}{l}\text { Material } \\
\text { Iype }\end{array}$ & $\begin{array}{c}\text { Decort- } \\
\text { ication }\end{array}$ & $\begin{array}{c}\text { Core } \\
\text { Reduction }\end{array}$ & $\begin{array}{l}\text { Biface } \\
\text { Thinning }\end{array}$ & $\begin{array}{c}\text { Pres- } \\
\text { sure }\end{array}$ & $\begin{array}{c}\text { Shat- } \\
\text { ter }\end{array}$ & $\begin{array}{l}\text { Indeter- } \\
\text { minate }\end{array}$ & $\begin{array}{l}\text { Heat } \\
\text { Spall }\end{array}$ \\
\hline Obsidian & - & - & 2 & - & - & 1 & - \\
\hline Chert & - & 2 & 8 & - & - & 9 & - \\
\hline Chalcedony & 5 & 9 & 49 & 14 & - & 92 & - \\
\hline Total & 5 & 11 & 59 & 14 & - & 102 & - \\
\hline
\end{tabular}

Table 4-22. Debitage from the Subsurface of Scrape 13, 26Ny4015, Pahute Mesa.

\begin{tabular}{lccccccc}
\hline $\begin{array}{l}\text { Material } \\
\text { Type }\end{array}$ & $\begin{array}{c}\text { Decont- } \\
\text { ication }\end{array}$ & $\begin{array}{c}\text { Core } \\
\text { Reduction }\end{array}$ & $\begin{array}{c}\text { Biface } \\
\text { Thinning }\end{array}$ & $\begin{array}{c}\text { Pres- } \\
\text { sure }\end{array}$ & $\begin{array}{c}\text { Shat- } \\
\text { ter }\end{array}$ & $\begin{array}{c}\text { indeter- } \\
\text { minate }\end{array}$ & $\begin{array}{c}\text { Heat } \\
\text { Spall }\end{array}$ \\
\hline Obsidian & - & - & 3 & - & - & 3 & - \\
Chert & - & 1 & 1 & - & - & 4 & - \\
Chalcedony & 4 & 11 & 24 & 3 & - & 61 & - \\
Total & 4 & 12 & 28 & 3 & - & 68 & - \\
\hline
\end{tabular}

Table 4-23. Debitage from the Surface of Scrape 14, 26Ny4015, Pahute Mesa.

\begin{tabular}{lccccccc}
\hline $\begin{array}{l}\text { Material } \\
\text { Type }\end{array}$ & $\begin{array}{c}\text { Decort- } \\
\text { ication }\end{array}$ & $\begin{array}{c}\text { Core } \\
\text { Reduction }\end{array}$ & $\begin{array}{c}\text { Biface } \\
\text { Thinning }\end{array}$ & $\begin{array}{c}\text { Pres- } \\
\text { sure }\end{array}$ & $\begin{array}{c}\text { Shat- } \\
\text { ter }\end{array}$ & $\begin{array}{c}\text { Indeter- } \\
\text { minate }\end{array}$ & $\begin{array}{c}\text { Heat } \\
\text { Spall }\end{array}$ \\
\hline Obsidian & - & - & - & 4 & - & - & - \\
Chert & 1 & 1 & - & - & - & 2 & 3 \\
Chalcedony & - & 1 & 1 & 1 & - & 2 & - \\
\hline Total & 1 & 2 & $i$ & 5 & - & 4 & 3 \\
\hline
\end{tabular}


Table 4-24. Debitage from the Surface of Scrape 15, 26Ny4015, Pahute Mesa.

\begin{tabular}{lccccccc}
\hline $\begin{array}{l}\text { Material } \\
\text { Type }\end{array}$ & $\begin{array}{c}\text { Decort- } \\
\text { ication }\end{array}$ & $\begin{array}{c}\text { Core } \\
\text { Reduction }\end{array}$ & $\begin{array}{c}\text { Biface } \\
\text { Thinning }\end{array}$ & $\begin{array}{c}\text { Pres- } \\
\text { sure }\end{array}$ & $\begin{array}{c}\text { Shat- } \\
\text { ter }\end{array}$ & $\begin{array}{c}\text { Indeter- } \\
\text { minate }\end{array}$ & $\begin{array}{c}\text { Heat } \\
\text { Spall }\end{array}$ \\
\hline Obsidian & - & - & 1 & - & - & 1 & - \\
Chert & - & - & 3 & - & - & 2 & 1 \\
Chalcedony & 5 & 3 & 14 & - & 2 & 31 & 1 \\
\cline { 2 - 8 } & 5 & 3 & 18 & - & 2 & 34 & 2 \\
\hline
\end{tabular}

Table 4-25. Debitage from the Subsurface of Scrape 15, 26Ny4015, Pahute Mesa.

\begin{tabular}{lccccccc}
\hline $\begin{array}{l}\text { Material } \\
\text { Type }\end{array}$ & $\begin{array}{c}\text { Decort- } \\
\text { ication }\end{array}$ & $\begin{array}{c}\text { Core } \\
\text { Reduction }\end{array}$ & $\begin{array}{c}\text { Biface } \\
\text { Thinning }\end{array}$ & $\begin{array}{c}\text { Pres- } \\
\text { sure }\end{array}$ & $\begin{array}{c}\text { Shat- } \\
\text { ter }\end{array}$ & $\begin{array}{c}\text { Indeter- } \\
\text { minate }\end{array}$ & $\begin{array}{c}\text { Heat } \\
\text { Spall }\end{array}$ \\
\hline Obsidian & - & - & 1 & - & - & - & - \\
Chert & - & 3 & - & - & - & 1 & - \\
Chalcedony & 2 & 3 & 8 & - & - & 17 & - \\
\cline { 2 - 7 } Total & 2 & 6 & 9 & - & - & 18 & - \\
\hline
\end{tabular}

Table 4-26. Row Counts of Size Classes of Debitage Used in Chi-square Analysis.

\begin{tabular}{lrrrrrrrr}
\hline & \multicolumn{2}{c}{ Scrape 3 } & \multicolumn{2}{c}{ Scrape 6 } & \multicolumn{3}{c}{ Scrape 7 } & \multicolumn{3}{c}{ Scrape 13 } \\
& Surface & Sub & Surface & Sub & Surface & Sub & Surface & Sub \\
\hline$x>2$ & 8 & --- & -- & --- & -- & -- & --- & -- \\
$1<x<2$ & 56 & 19 & 10 & 16 & 4 & 3 & 7 & 2 \\
$1 / 2<x<1$ & 151 & 92 & 53 & 80 & 14 & 27 & 26 & 15 \\
$1 / 4<x<1 / 2$ & 141 & 134 & 79 & 165 & 33 & 80 & 120 & 88 \\
$1 / 4<x$ & 61 & 31 & 28 & 19 & 17 & 11 & 44 & 10 \\
& & & & & & & & \\
\hline
\end{tabular}

Table 4-27. Results of Chi-square Tests for all Size Classes

\begin{tabular}{lccl}
\hline & Degrees of Freedom & Chi-Square & Results @ 0.95 \\
\hline Scrape 3 & 3 & 20.9 & Reject \\
Scrape 6 & 3 & 12.8 & Reject \\
Scrape 7 & 2 & 9.7 & Reject \\
Scrape 13 & 2 & 10.4 & Reject \\
\hline
\end{tabular}

Hypothesis:Surface and subsurface samples of size classes come from the same population. 
Table 4-28. Results of Chi-square Tests for all Size Classes Greater than 1/4-inch.

\begin{tabular}{lccl}
\hline & Degrees of Free & Chi-Square & Results @ 0.95 \\
\hline Scrape 3 & 2 & 19.1 & Reject \\
Scrape 6 & 2 & 2.2 & Cannot Reject \\
Scrape 7 & 1 & 1.0 & Cannot Reject \\
Scrape 13 & 1 & 0.2 & Cannot Reject \\
\hline
\end{tabular}

Hypothesis: Surface and subsurface samples of size classes come from the same population.

Table 4-29. Results of Chi-square Tests for Debitage Type.

\begin{tabular}{lccl}
\hline & Degrees of Freedom & Chi-Square & Results @ 0.95 \\
\hline Scrape 3 & 3 & 44.7 & Reject \\
Scrape 6 & 3 & 4.5 & Cannot Reject \\
Scrape 7 & 3 & 5.7 & Cannot Reject \\
Scrape 13 & 3 & 3.6 & Cannot Reject \\
\hline
\end{tabular}

Hypothesis: Surface and subsurface samples of size classes come from the same population.

Table 4-30. Comparison of Surface and Subsurface Debitage, Counts for Scrapes with more than 20 Artifacts on the Sur?:ace.

\begin{tabular}{lccc} 
Scrape & Surface & Subsurface & $\%$ \\
\hline 1 & 20 & 36 & 180 \\
3 & 417 & 276 & 66 \\
4 & 51 & 35 & 69 \\
5 & 29 & 56 & 193 \\
6 & 170 & 272 & 160 \\
7 & 70 & 121 & 173 \\
8 & 21 & 42 & 200 \\
13 & 115 & 60 \\
15 & 61 & 36 & 56 \\
\hline
\end{tabular}

Table 4-31. Comparison by Percentage of Less than 1/4-inch Debitage From Selected Surface Scrapes.

\begin{tabular}{lccc}
\hline Scrape & $\begin{array}{c}\text { \% Recovered } \\
\text { from Surface }\end{array}$ & $\begin{array}{c}\text { \% Recovered } \\
\text { from Subsurface }\end{array}$ & $\begin{array}{c}\text { Difference } \\
(\%)\end{array}$ \\
\hline 6 & 16.5 & 6.8 & 41 \\
7 & 25.0 & 9.1 & 36 \\
13 & 23.0 & 8.7 & 38 \\
\hline
\end{tabular}




\section{Data Recovery at Site 26Ny4021}

\section{Site Description}

Site 26Ny4021 (Figure 4-24) is a temporary campsite composed of three cleared circles, which are interpreted as habitation structures or shelters. These structures are grouped into three features, each composed of a single ring and all excavated as Unit 10. Feature 1 is a rock ring constructed of naturally occurring, moderately welded, tuff boulders exfoliat: 19 from shallow bedrock (Figure 4-25 and 4-26). The ring is doughnut shaped with an inside diameter of approximately $4 \mathrm{~m}$ and an outside diameter of about $7 \mathrm{~m}$. There appears to be a distinct break in the rock which composes the ring on the east side. The rocks that form the ring are rarely stacked more than two high; more often they are laid in a single course. One branch from a tree was found intertwined with the rocks along the south side of the ring, but its relationship to the feature is uncertain. One millingstone appeared to be used in the construction of the ring, but many more millingstone fragments were found both in the interior and around the ring. Darkened soil, most likely a hearth, was found in the northeast quadrant of the interior of the ring.

Shallow excavations conducted in and around the feature revealed three strata: the surface, stratum $A$; a gray sandy-silty "A" soil horizon, stratum $B$; and a reddish "B" horizon, stratum C. Stratum B was approximately 2 to $3 \mathrm{~cm}$ thick; the underlying $C$ stratum was excavated to a depth of about $3 \mathrm{~cm}$. These excavations revealed two additional stains of darkened soil in addition to the hearth. The first was located in the south half of the interior of the ring, the other to the immediate northeast and external to the ring. While the dark stains appear to be from charcoal, no concentration suggesting a hearth was found for these additional stains.

Artifacts viere found in all strata excavated at the site, and, given the shallowness of the excavations and the turbation process near the soil's surface, any stratification of artifacts is likely to be horizontal rather than vertical. Artifacts associated with this feature include 43 millingstone fragments, a hammerstone, 66 brownware potsherds, 2 cores, single Stage I and Stage IV bifaces, a white tuff Elko projectile point (found just outside the ring), and an opaque white glass bead. Charcoal from a hearth which contained the bead was extracted from a soil sample taken during the excavation and submitted for radiocarbon dating. The date returned was $470 \pm 50$ years B.P.

The debitage numbered 115 pieces -9 decortication flakes $(8 \%), 15$ core reduction flakes (13\%), 3 biface thinning flakes (3\%), 46 pieces of shatter $(40 \%), 35$ indeterminate flakes (30\%), and 7 heat spalls (6\%). Thirtyseven percent of this debitage was finegrained tuffs and chert, 63 percent were chalcedony or white welded tuff, and less than 1 percent was obsidian. Most of the debitage was concentrated in the center of the feature, around the hearth and eastward, extended to the exterior of the feature.

Feature 2 is composed of a single ring approximately the same size as Feature 1 ; Figure 4-27 and 4-28). This ring is also doughnut shaped with an exterior diameter of about $6 \mathrm{~m}$ and an interior diameter of about $4 \mathrm{~m}$. This ring is not as well defined as Feature 1, but it includes more branches intertwined with the rocks. These branches appear to be part of the structure.

The excavations at this site were quite shallow, revealing a thin layer of grayish soil similar to the vesicular A horizon (stratum B) of Feature 1 covering the bedrock. Like Feature 1, stratification at this site appears to be horizontal rather than vertical. Artifacts recovered during surface collection and excavations consisted of a millingstone, 2 utilized flakes, 2 multidirectional cores, a Stage II biface, 3 Stage iii biiaces, a óriii, and an obsidian Desert Side-notched projectile point. 


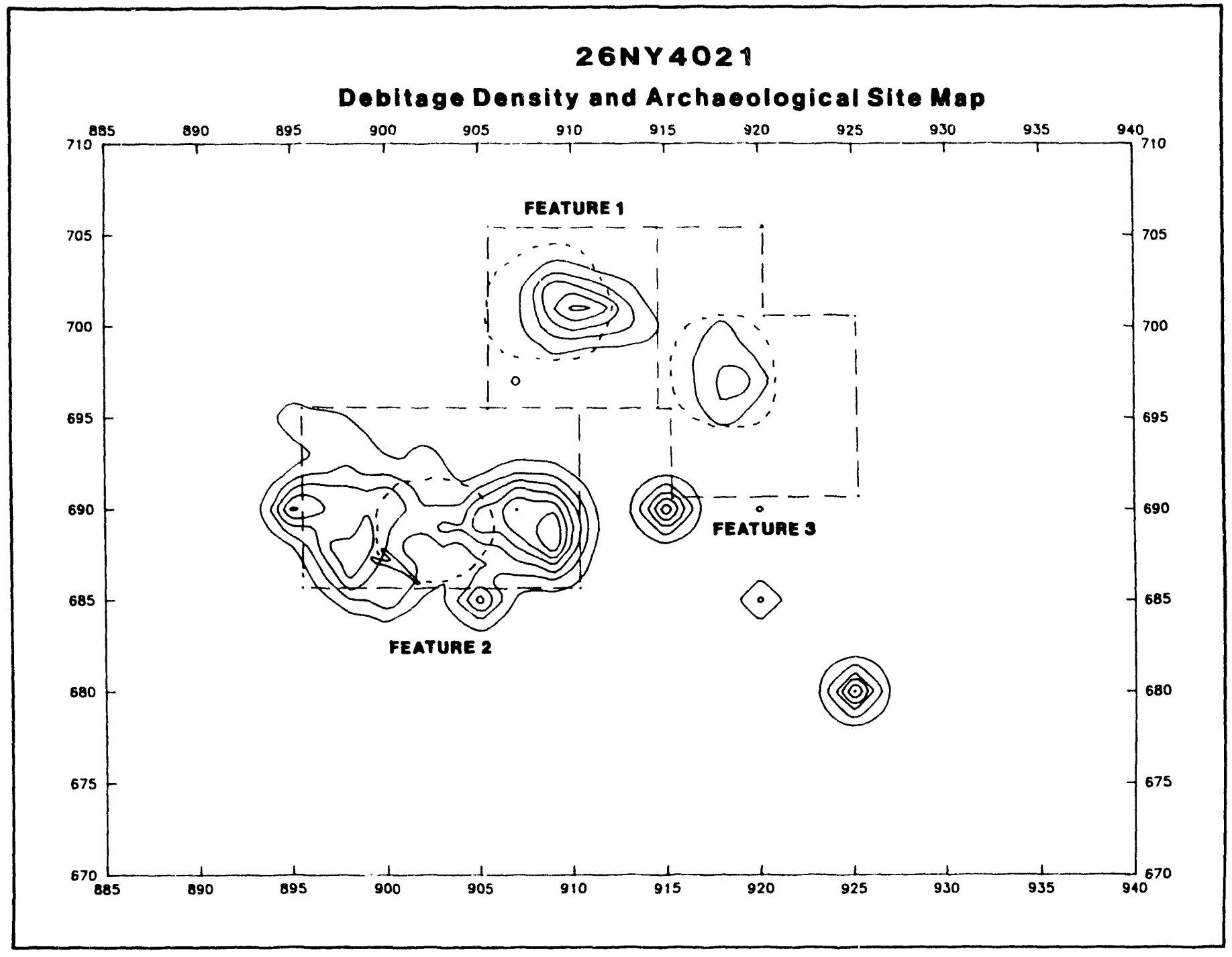

Figure 4-24. Archaeological site map after excavations at 26Ny4021, Pahute Mesa, Nevada. 


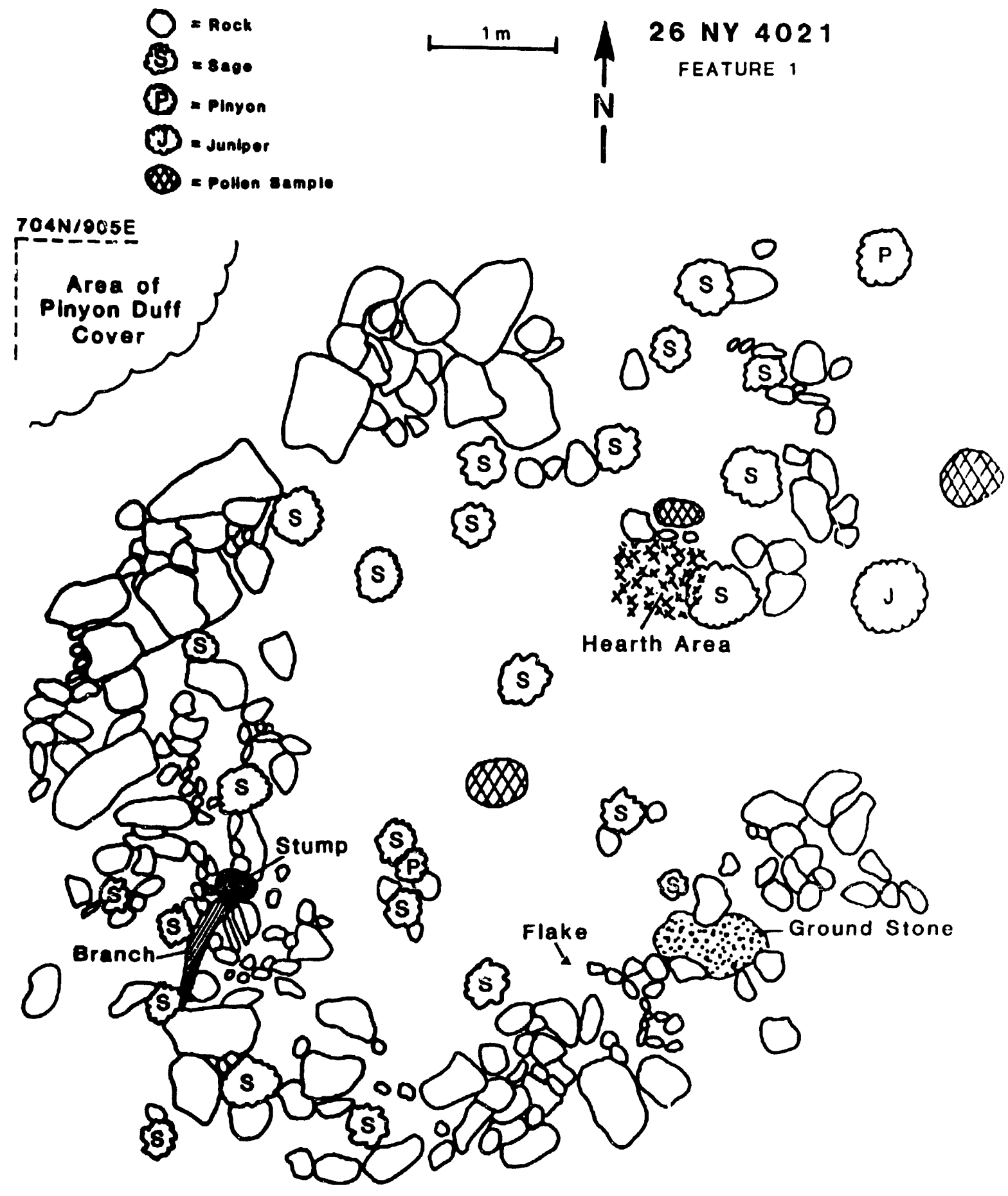

Figure 4-25. Drawing of Feature 1, as excavated, from site $26 \mathrm{Ny} 4021$. 


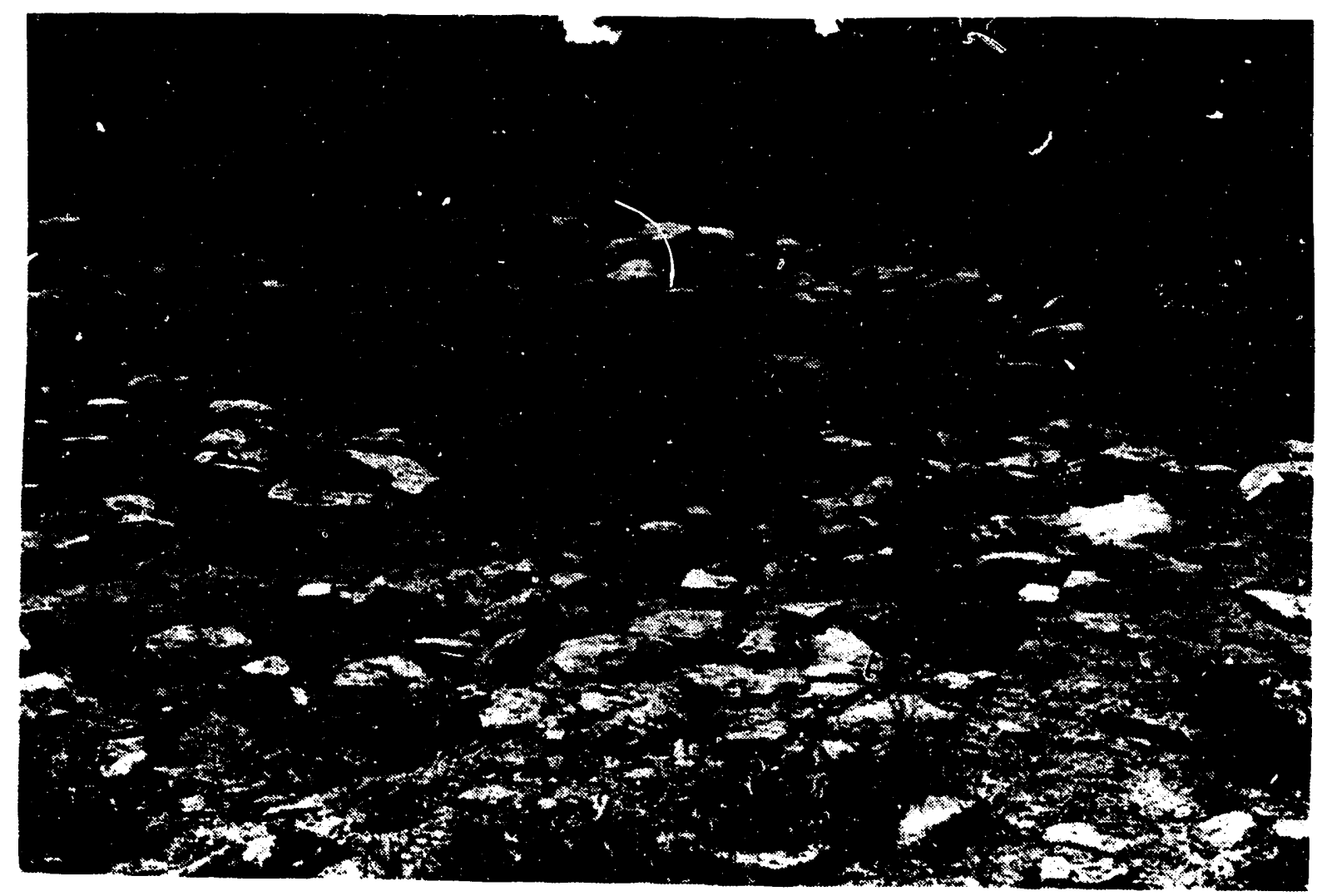

Figure 4-26. Photograph of Feature 1, as excavated, from site 26 Ny4021.

Collected were 267 pieces of debitage-14 decortication flakes (5\%), 24 core reduction flakes ( $9 \%), 50$ biface thinning flakes (19\%); 11 pressure flakes (4\%), 11 pieces of shatter (4\%), and 157 indeterminate flakes $(59 \%)$. Sixty-one percent of this debitage is obsidian, 2 percent chert and finegrained tuffs, and 37 percent white welded tuff (chalcedony). Debitage at this feature is found in two major concentrations, one to the east and one to the west of the ring. The composition of these concentrations is similar. dominated by biface thinning (usually broken) and indeterminate debitage. For the eastern concentration of debitage, the percentages of biface thinning and indeterminate debitage are 19 and 68 respectively; for the western, they are 19 and 54 . The western concentra- tion has 12 percent of core reduction debitage while the eastern concentration has only 3 percent.

Feature 3 appeared to be another rock ring when the site was originally recorded, but subsequent investigations cast doubt as to its exact nature (Figure 4-29 and 4-30). While it was similar in size to the rock rings, its structure was less definite. It contained no in situ features, such as hearths or cached millingstones, to help identify it as a structure. This feature is not typical of the rock rings identified as pinyon caches. These caches are usually smaller, have a well-defined ring structure, and are found on bedrock or shallow soil. Finally, the artifacts found at this feature are similar to those found at Feature 1, located ups- 


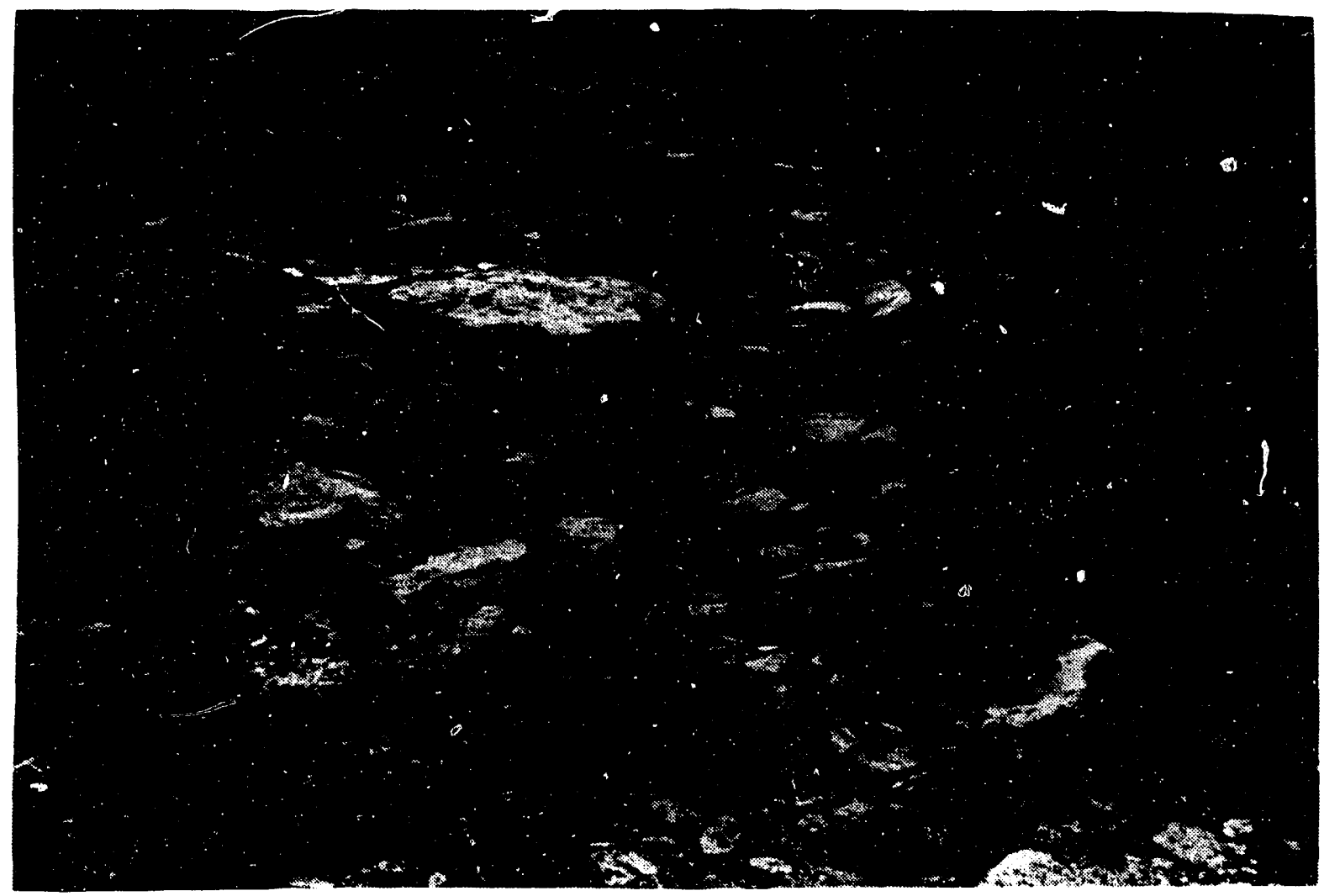

Figure 4-27. Photograph of Feature 2, as excavated, from site 26Ny4021.

lope and to the west, and could represent part of an activity area associated with or washed down from Feature 1. The outside diameter of Feature 3 is about $6 \mathrm{~m}$. The inside diameter is about $4 \mathrm{~m}$. Like the other rings, it is composed of naturally occurring weakly welded tuff. The doughnut shape evident at the other two rings is less apparent here.

Artifacts associated with this feature consist of a hammerstone, 59 plain brownware potsherds, a utilized flake, 2 modified flakes, a multidirectional core, and an obsidian Elko point. Of the 98 pieces of debitage recovered, 9 were decortication and 9 were core reduction ( $9 \%$ each), 3 were biface thinning flakes, $(3 \%), 2$ were pressure flakes $(2 \%), 32$ were pieces of shatter (33\%), 42 were indeterminate $(43 \%)$, and 1 appeared to be a heat spall (1\%). Of this debitage, 9 percent was obsidian, 11 percent cnert or fine-grained tuff, and 76 percent white welded tuff or chalcedony.
In addition to the rock rings, 4 other features were investigated at 26Ny4021. The first was a bedrock milling slick (Feature 4) composed of a single polished area on a large (2.5-by-4 $\mathrm{m}$ ) piece of exfoliating bedrock 23 $m$ southeast of the center of Feature 1. Features 7 and 8 were two unnatural appearing alignments of rocks. Rocks seemed to be piled around the base of two juniper trees. Excavations were conducted at both features, but no artifacts or additional features were found. These cairns, located next to each oth$\mathrm{er}$, are $38 \mathrm{~m}$ southwest of the center of Feature 1. Finally, a rock mound (Feature 9) was located $22 \mathrm{~m}$ south of Feature 1 . This mound is abcut a $1.5 \mathrm{~m}$ in diameter and $20 \mathrm{~cm}$ high.

Debitage not directly associated with any of the three rings was located to the south of these features in three diffuse concentrations. The total counts of debitage are low (Table 4-32), but the concentrations are distinct from 


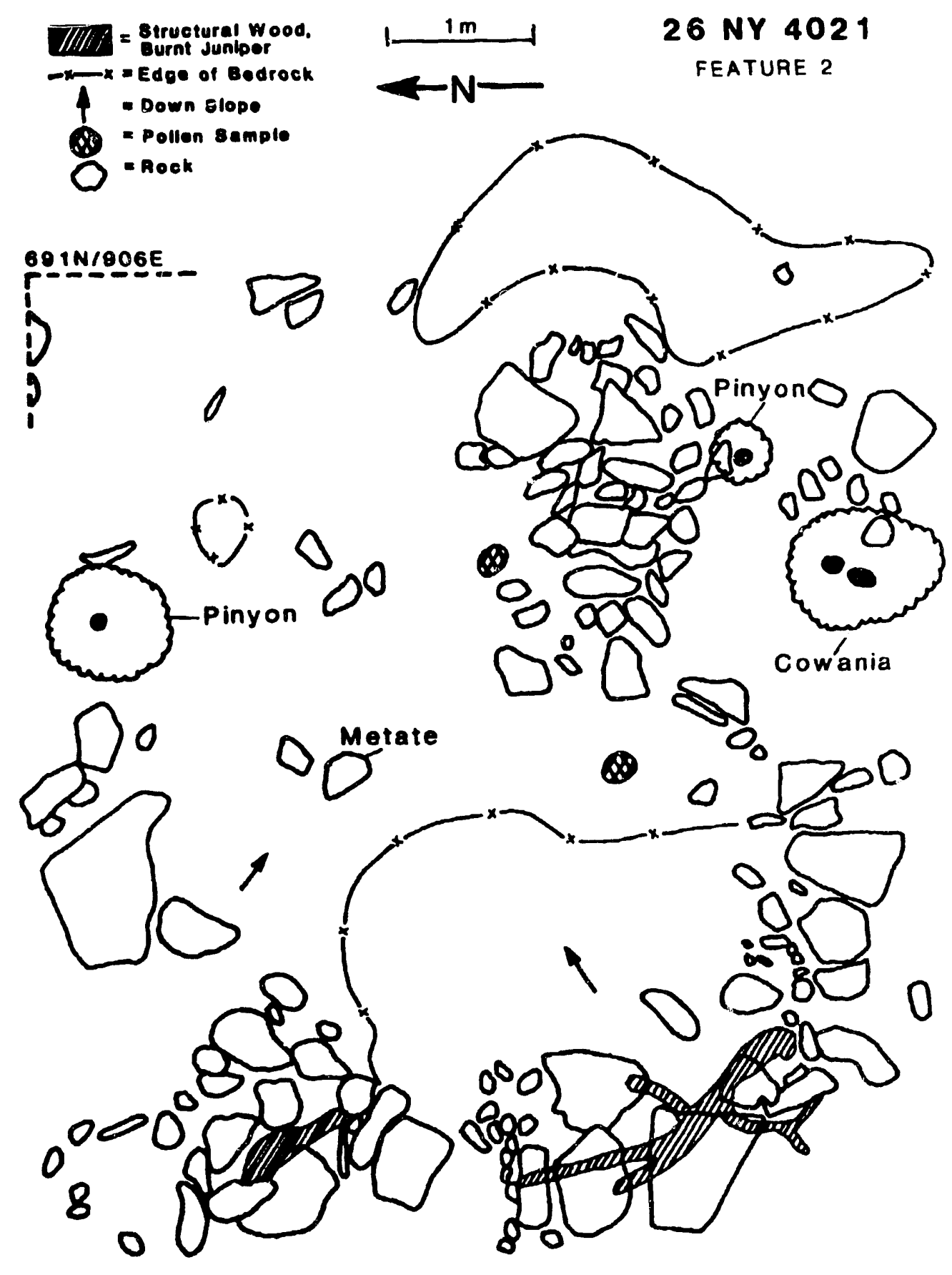

Figure 4-28. Drawing of Feature 2, as excavated, from site 26 Ny4021. 

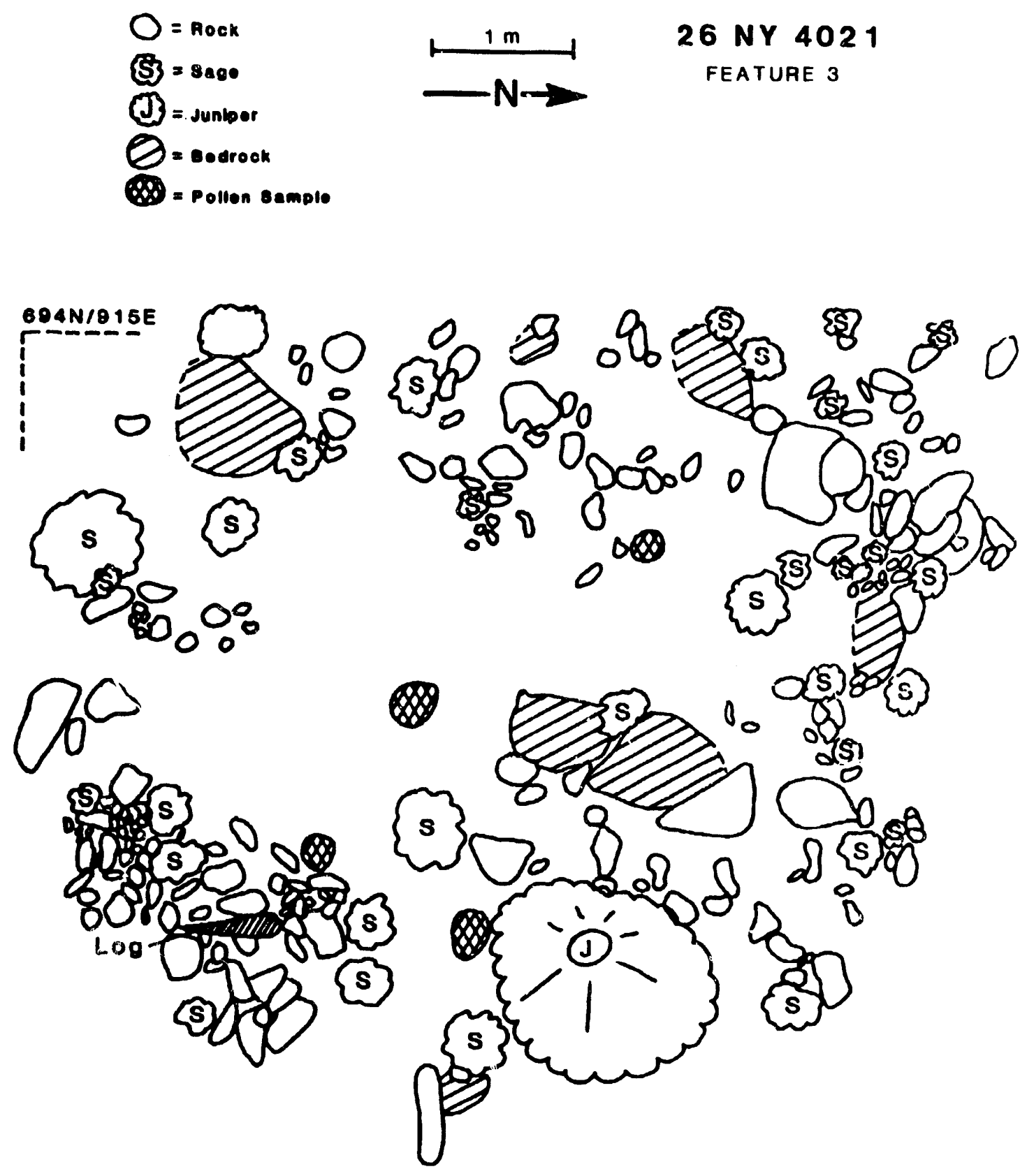

Figure 4-29. Drawing of Feature 3, as excavated, from site 26 Ny4021. 


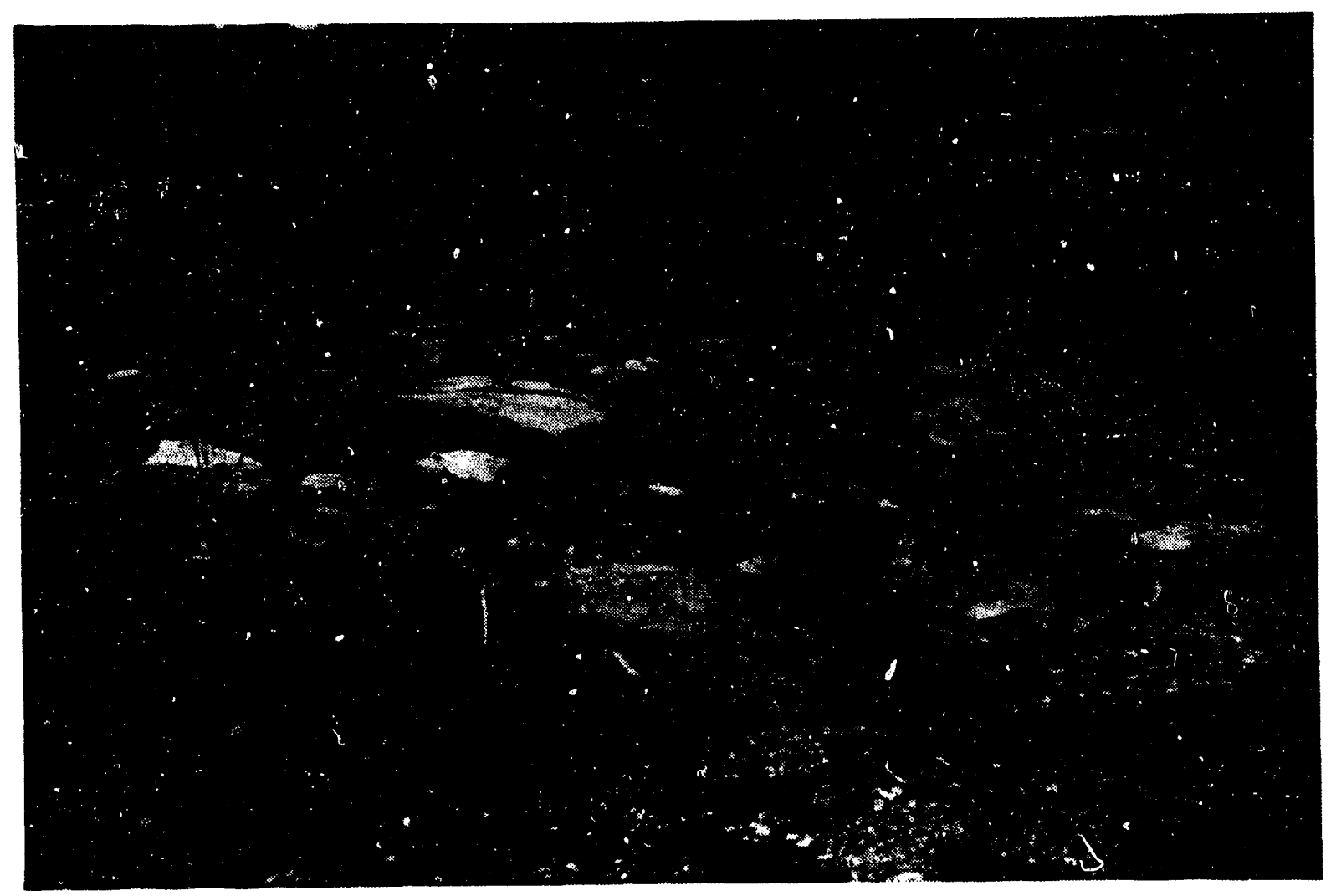

Figure 4-30. Photograph of Feature 3, as excavated, from site 26Ny4021.

each other in composition of both material and debitage types (Tables 4-32 and 4-33).

\section{Discussion}

Site 26Ny4021 appears to be a substantial campsite composed of two, perhaps three, habitation structures. There are numerous millingstones and potsherds and a relatively high proportion of artifacts to debitage. In addition to the brownware pottery, temporally diagnostic artifacts included single Elko and Desert Side-notched projectile points, a white glass bead, and a metal fragment. A radiocarbon date from a hearth in one of the structures dated to about 470 years ago, a date consistent with the Desert Side-notched point and the brownware pottery, somewhat early for the white glass bead found at the hearth, and inconsistent with the Elko point and the metal strip. The construction of the features at the brush structure sites, $26 \mathrm{Ny} 4023$ and $26 \mathrm{Ny} 4040$, are significantly dif- ferent from these ruck ring structures (discussed later) and, gauging from the numerous historic artifacts and the integrity of the structures, relatively late in time. The features at $26 \mathrm{Ny} 4023$ and $26 \mathrm{Ny} 4040$ are obviously late and differ in construction from the structures at 26 Ny4021. The rock ring structures are a somewhat earlier style which date perhaps some 300 to 400 years ago. Since one of the brush structure sites, 26Ny4023, is in close proximity to $26 \mathrm{Ny} 4021$, the metal strip may be connected with $26 \mathrm{Ny} 4023$ occupation, fortuitously discarded or lost at $26 \mathrm{Ny} 4021$. The Elko point may be an aboriginally curated artifact or a fortuitous association, or it may have been manufactured later in time and only appears to be an Elko type. The third alternative seems the least likely. The specimen exhibits the rather fine flaking patterns often observed in Elko-era points rather than the poorer detail of later point types. 
Table 4-32. Percentages of Debitage Types for Selected Concentrations at 26Ny4J21, U19au, Pahute Mesa, Nevada.

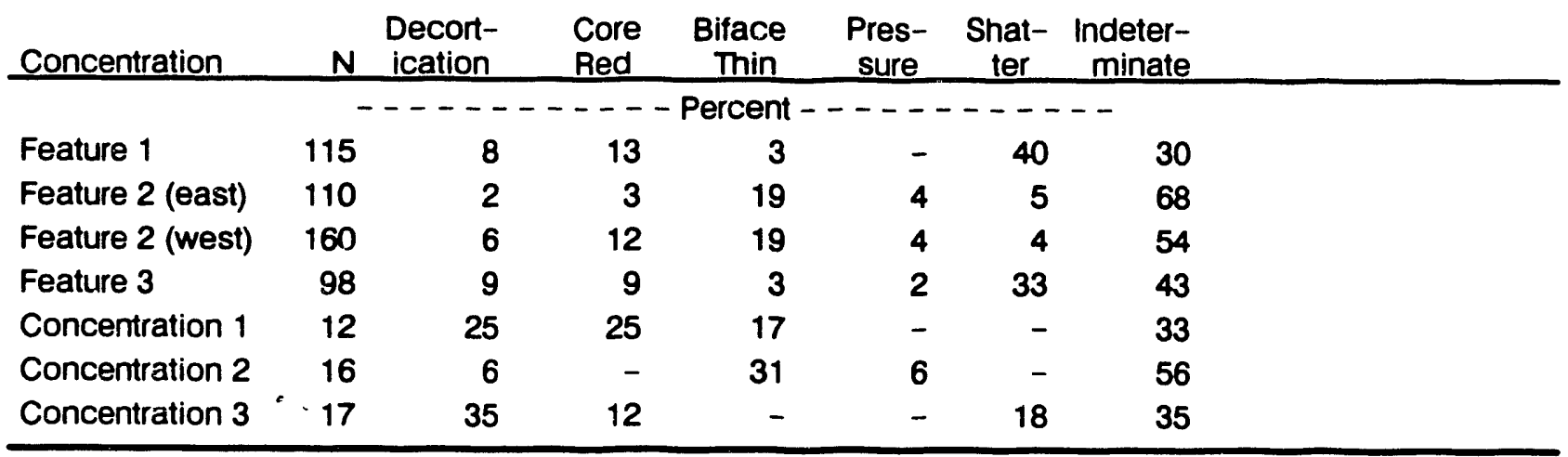

Table 4-33. Percentages of Material Types for Selected Debitage Concentrations at ?6Ny4021, Ui9au, Pahute Mesa, Nevada.

\begin{tabular}{lrrrr}
\hline & $N$ & Obsidian & Chert & Chalcedony \\
\hline Concentration & 115 & $<1$ & 37 & 63 \\
Feature 1 & 110 & 79 & $<1$ & 20 \\
Feature 2 (east) & 160 & 51 & 3 & 46 \\
Feature 2 (wesi) & 98 & 9 & 11 & 76 \\
Feature 3 & 12 & 58 & - & 42 \\
Concentration 1 & 16 & 94 & - & 6 \\
Concentration 2 & 17 & 6 & 35 & 59 \\
Concentration 3 & & & &
\end{tabular}

\section{Data Recovery at $26 \mathrm{Ny} 4040$}

\section{Site Description}

Temporary camp $26 \mathrm{Ny} 4040$ is the second of the two excavated sites in which structural remains were observed (Figure 4-31). This site is located at the base uf a slope along the south side of a small valley formed by one of the convolutions in the welded tuff rim rock of the eastern side of the primary valley. The site is situated iust within the tree line in the transition from sagebrush to pinyon-juniper. The site consists of three enhanced juniper tree structures enclosed in a larger scatter of artifacts including debitage, pottery, bifaces, projectile points, and millingstones. Excavations were limited to removing the duff and surface soil from all three of these structures. They re- vealed that, while all of the artifacts observed during the original reconnaissance were types common to prehistoric sites, historicperiod artifacts were associated with the structures as weil.

When discovered, the first structure, Feature 1 (Excavation Unit 4), was described as a living juniper tree with several branches underneath the canopy (Figures 4-32 and 4-33). These branches appeared to form a wall of brush built into the tree to act as a shelter. One of the branches was forked and appeared to be anchored in a pile of rocks: it probably served as the support for the fa: end of the wall. A well-used millingstone was observed just to the southwest of the feature, and some debitage was noted in the vicinity, 


\section{U 19 Au 26 NY 4040}
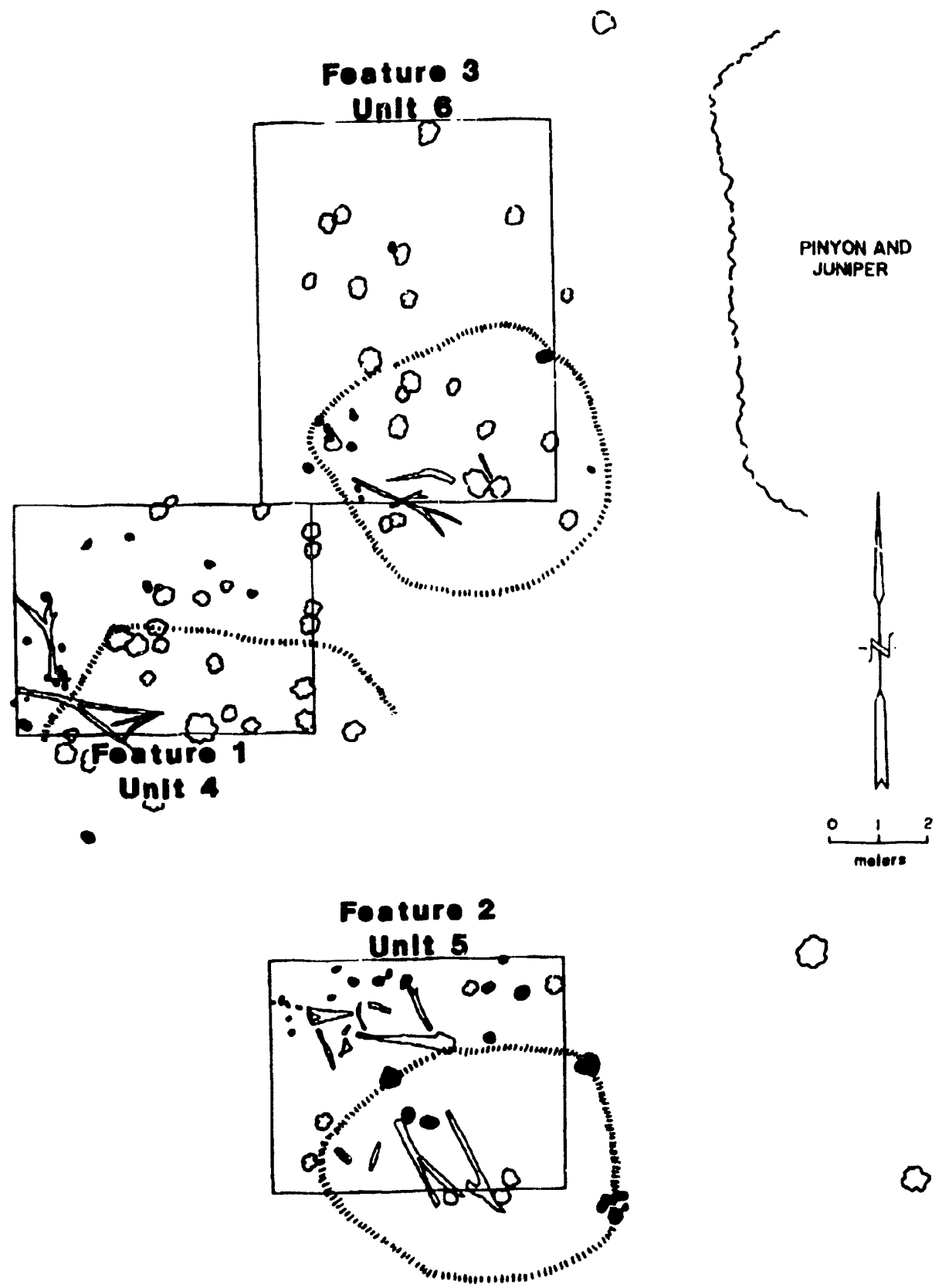

0

Figure 4-31. Archaeological site map after excavations for 26Ny4040, Pahute Mesa, Nevadz. 


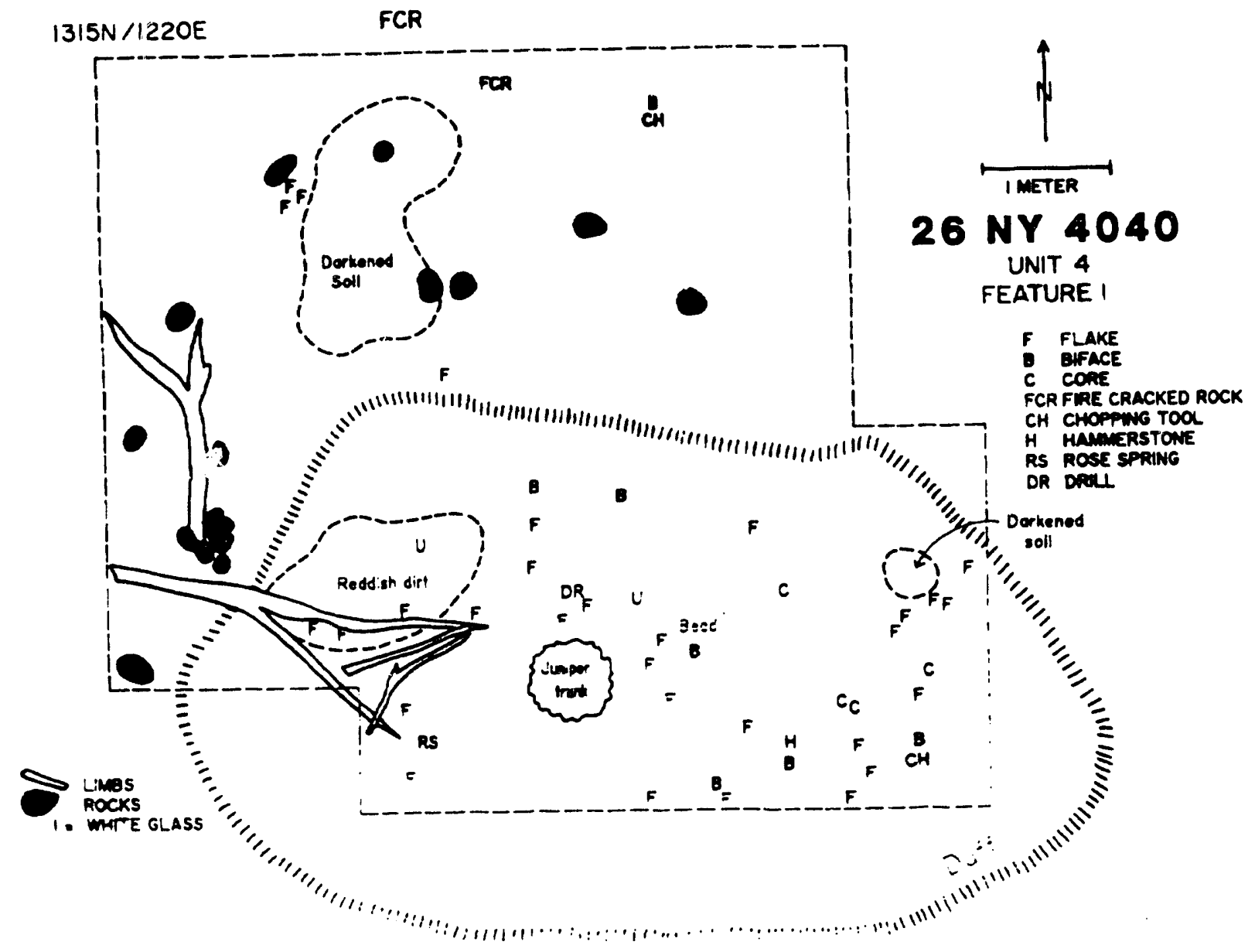

Figure 4-32. Drawing of Feature 1, as excavated, from site 26 Ny4040. 


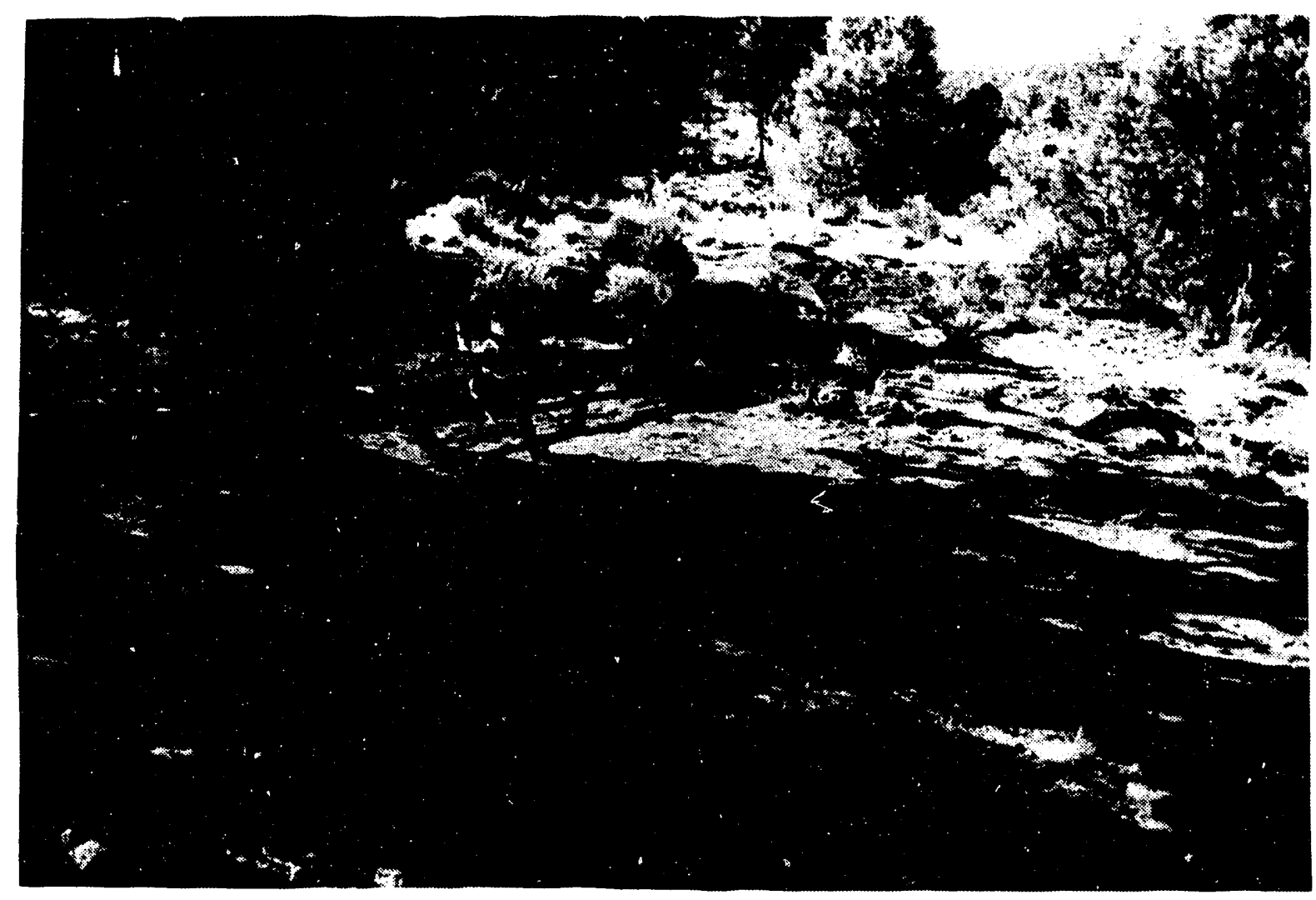

Figure 4-33. Photograph of Feature 1, as excavated, from site 26 Ny4040.

but the types and number of these artifacts did not differ significantly from the artifact scatter in the general site area.

Excavations at 26 Ny4040 involved removing and screening the duff accumulation from under the juniper and then removing and screening the first 3 to $5 \mathrm{~cm}$ of soil in the area of the feature. These excavations uncovered three areas of charcoal-darkened or oxidized soil, which probably represent hearths. The excavations also revealed a scatter of artifacts consisting predominately of debitage, but including a high proportion of stone tools, e.g., a hammerstone, several cores, a chopping tool, two unifacially worked flakes, and several bifaces. Additional artifacts found here included a Rose Spring Corner-notched projectile point, a drill tip, and a white glass bead (Figure 4-35).
Feature 2 (Excavation Unit 5) (Figures 4-34 and 4-37) was originally described as several living junipers with branches underneath for shelter enhancement. While not as obvious as the first shelter, one of the branches is forked and anchored by large stones. When originally recorded, only a single flake was observed here.

Using the same techniques as at the first shelter, the duff and first few centimeters of soil were removed. This revealed a hearth west of the feature as well as a concentration of fire-cracked rocks to the north. Artifacts found during the excavation included a pumice pipe, a drill fragment, a blue glass hexagonal trade bead, a square nail fashioned into an awl, and several cores (Figure 4-36).

The final feature (Feature 3, Excavation Unit 6) is composed of two living junipers 


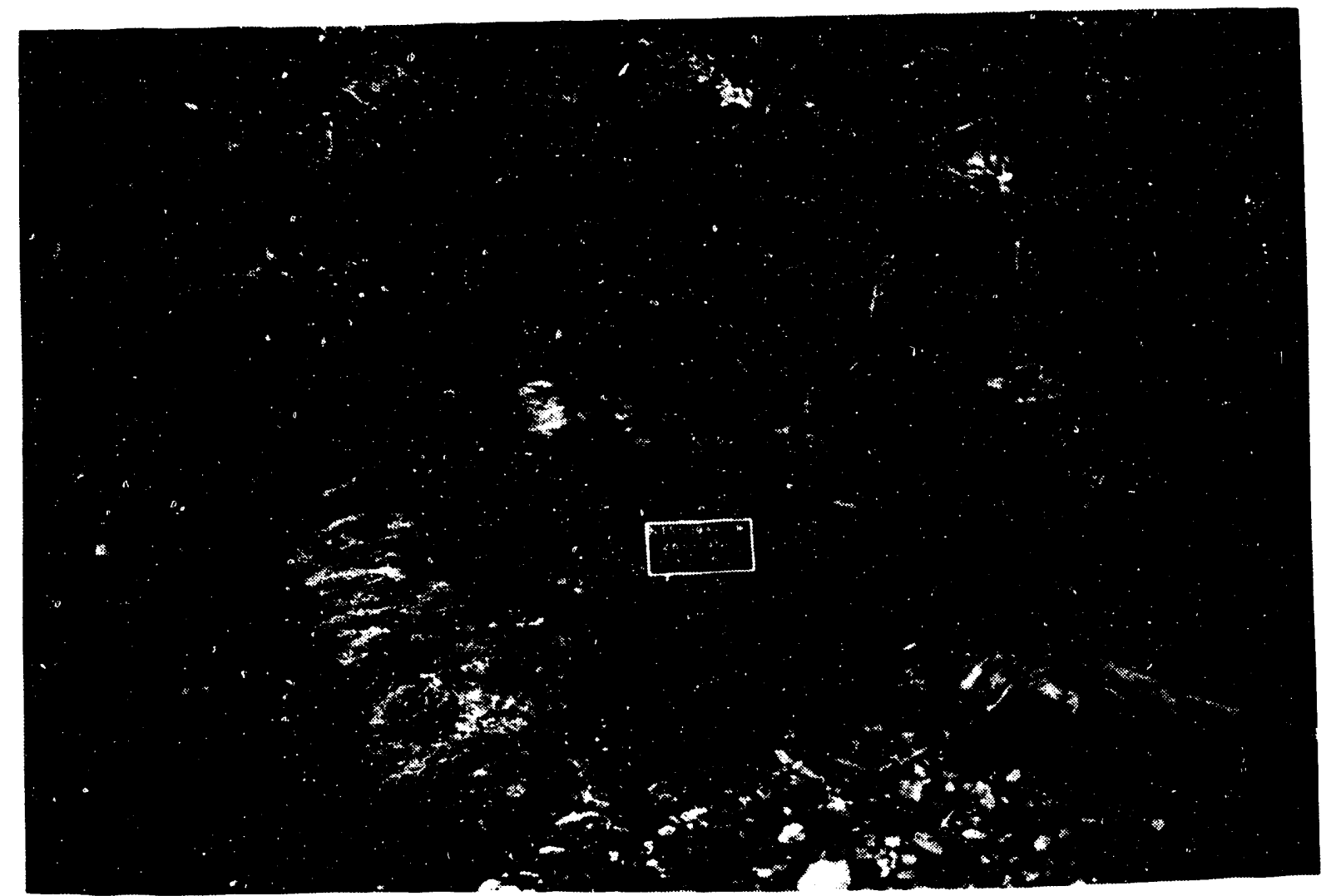

Figure 4-34. Photograph of Feature 2, as excavated, from site $26 \mathrm{Ny} 4040$.

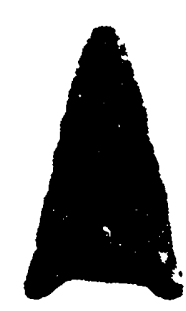

a

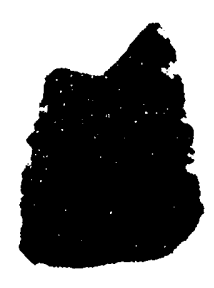

b

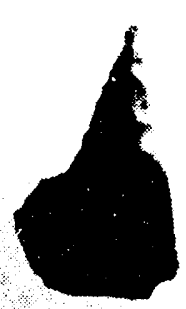

c
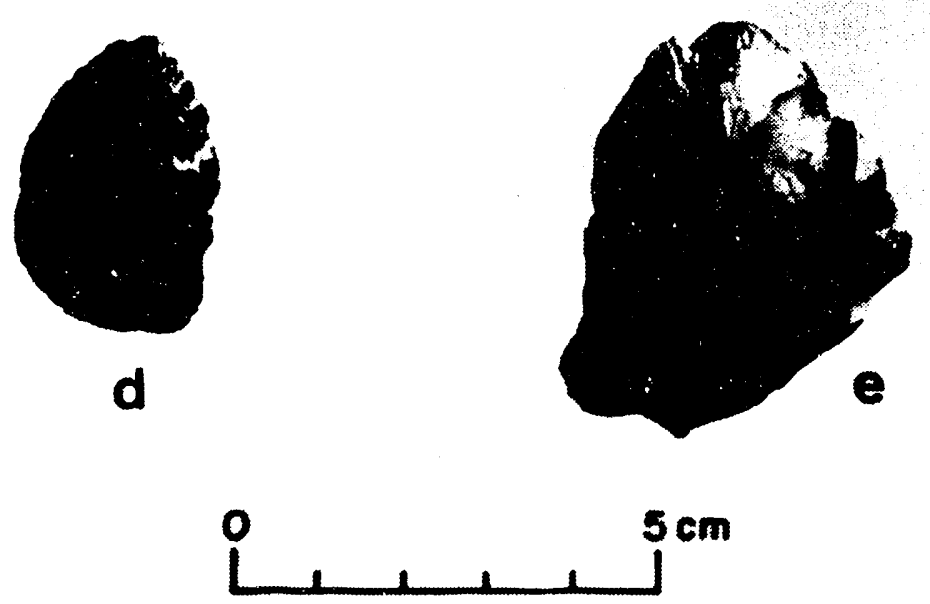

Figure 4-35. Photograph of artifacts trom Feature 1, site 26 Ny4040.

(see Appendix A for descriptions and reference numbers). 


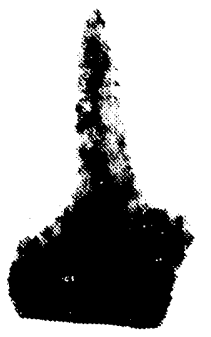

a

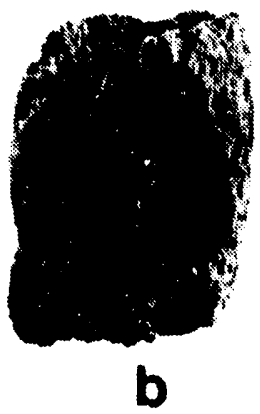

b

C

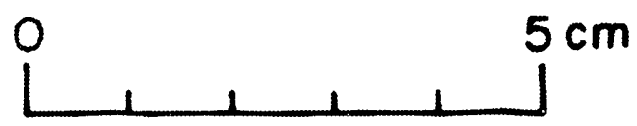

Figure 4-36. Photograph of artifacts from Feature 2, site 26 Ny4040. (see Appendix A for descriptions and reference numbers).

growing close together (Figures $4-3 \beta$ and 4-39). Evidence for enhancement consists of several branches underneath the canopy, including a forked branch. However, there is no rock pile anchor for this branch. A millingstone north of the shelter and a few flakes were the only artifacts observed.

Excavation revealed two hearths, firecracked rock, and a mano (Figures 4-40 and 4-41). Additional artifacts here included pottery, biface and core fragments, several unifacial tools, and three pendant fragments from two different rendants. Historic artifacts included three pieces of lead shot, two blue glass beads, a steel button, a white glass button, and a steel rivet of the type used in clothing.

Excavation Unit 8 (Figure 4-42) was dug in an area of darkened soil about $11 \mathrm{~m}$ southeast of Feature 2, at grid coordinates
1293.9N, 1238.5E. It was hoped that this soil darkening indicated a buried hearth or similar feature, but the excavations yielded only a diffuse scatter of small pieces of charcoal in the soil matrix and a few artifacts. Artifacts recovered from the surface of this unit included two decortication flakes, two indeterminate flakes, and three pieces of shatter, all of chalcedony. Five unidentifiable bone fragments, small and weathered, were also recovered. They came from a medium-sized mammal, and one of the fragments appeared burnt.

The first level, (Figure 4-43) Stratum B, between 2 and $4 \mathrm{~cm}$ thick, consisted of brown, sandy loam with a considerable amount of welded tuff gravels. Another three fragments of chalcedony indeterminate flakes were recovered. Underlying Stratum B is Stratum C, a layer of similar appearing soil which contains small, unconsolidated char- 


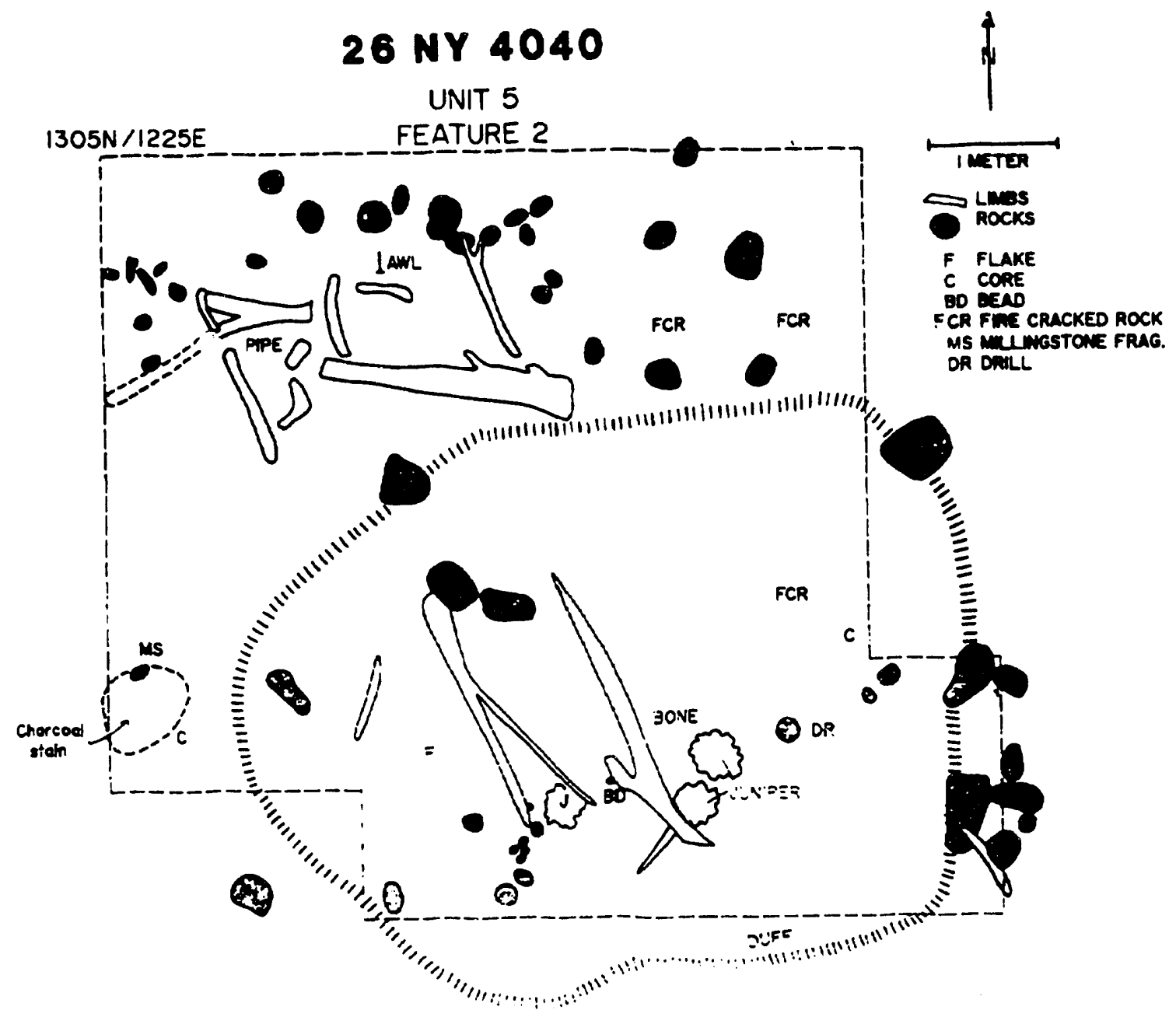

Figure 4-37. Drawing of Feature 2, as excavated, from site 26 Ny4040 (see Appendix A for descriptions and reference numbers). 


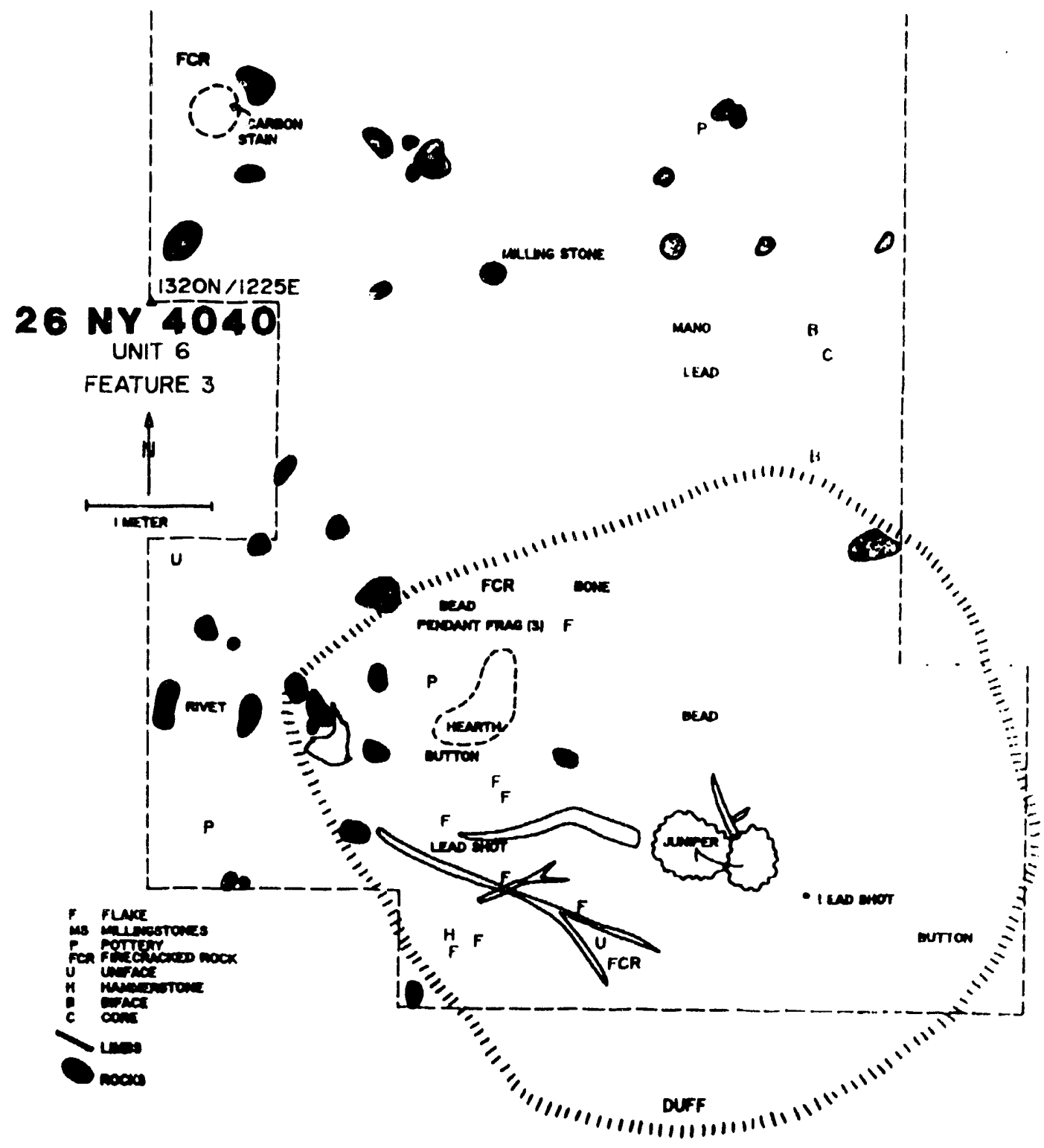

Figure 4-38. Drawing of Feature 3, as excavated, from site $26 \mathrm{Ny} 4040$. 


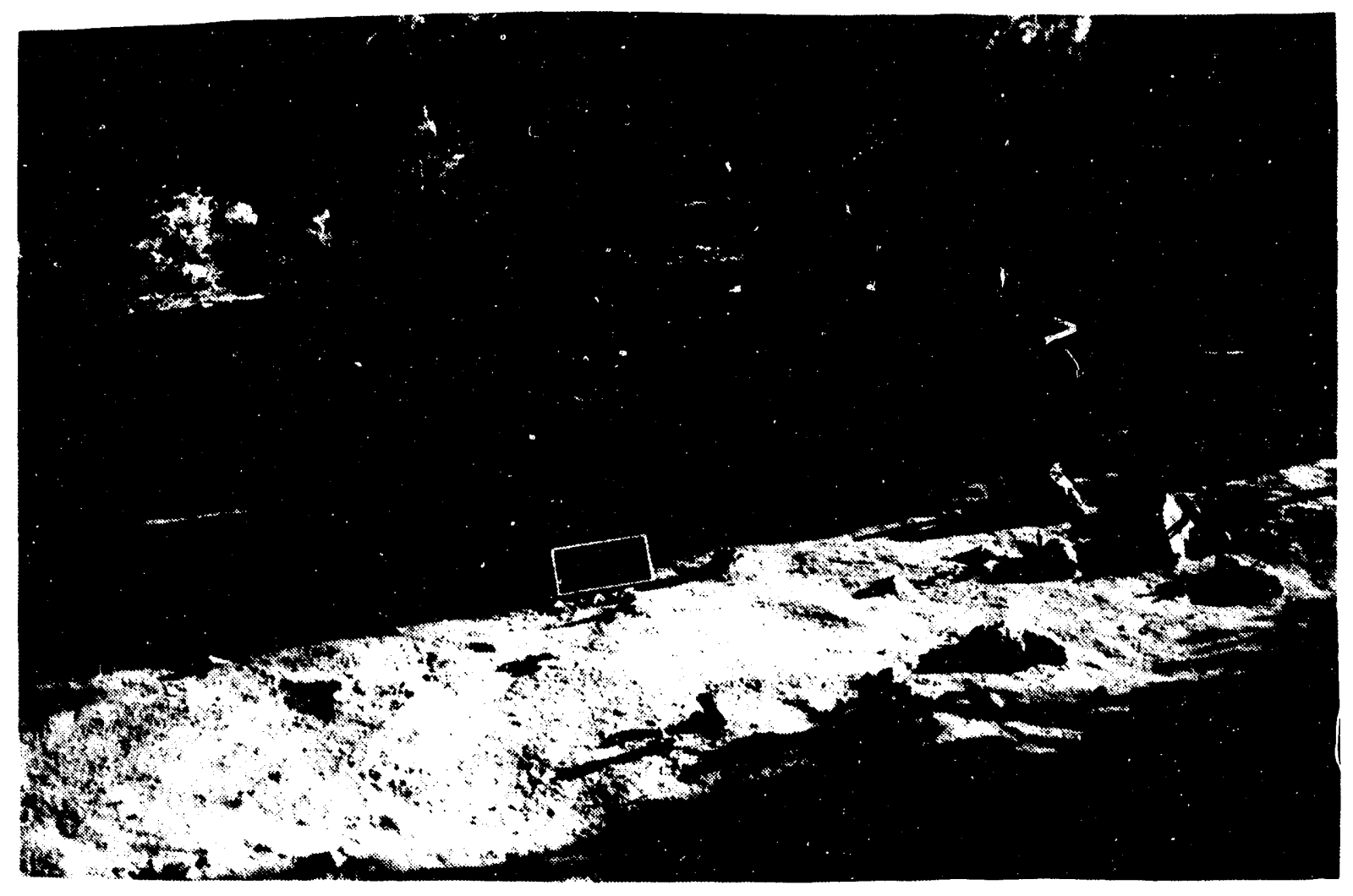

Figure 4-39. Photograph of Feature 3, as excavated, from site 26Ny4040.
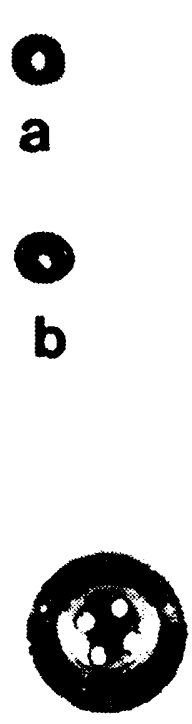

e

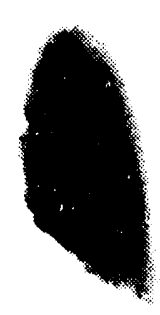

C

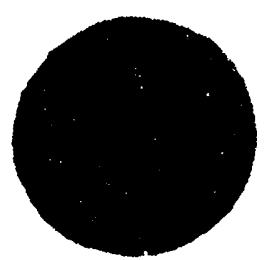

d

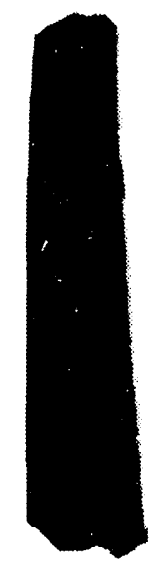

Figure 4-40. Photograph of artifacts from Feature 3, site 26Ny4040 (see Appendix A for descriptions and reference numbers). 

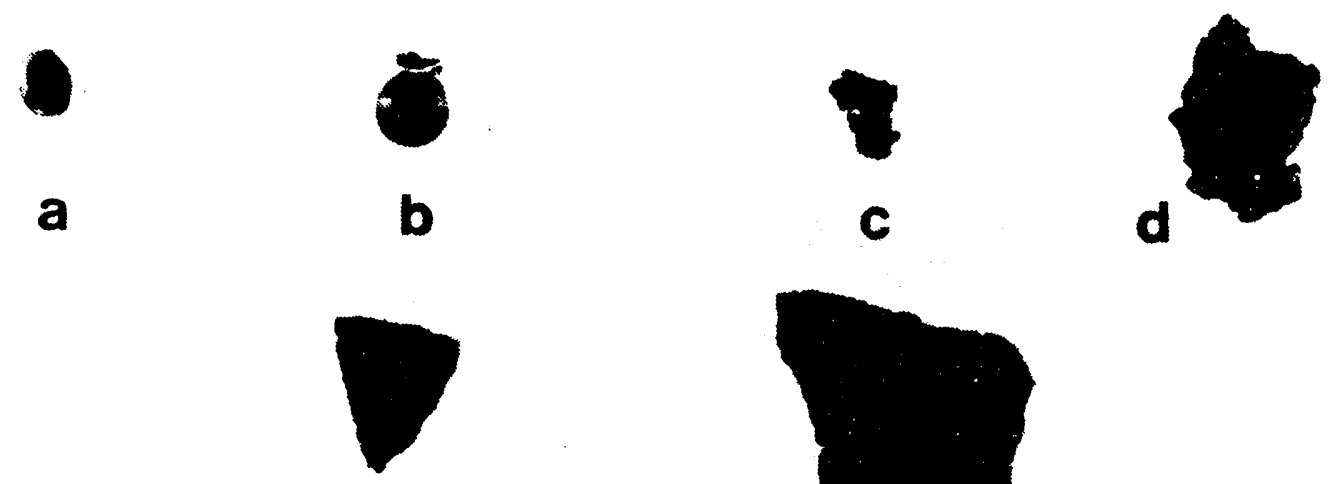

e
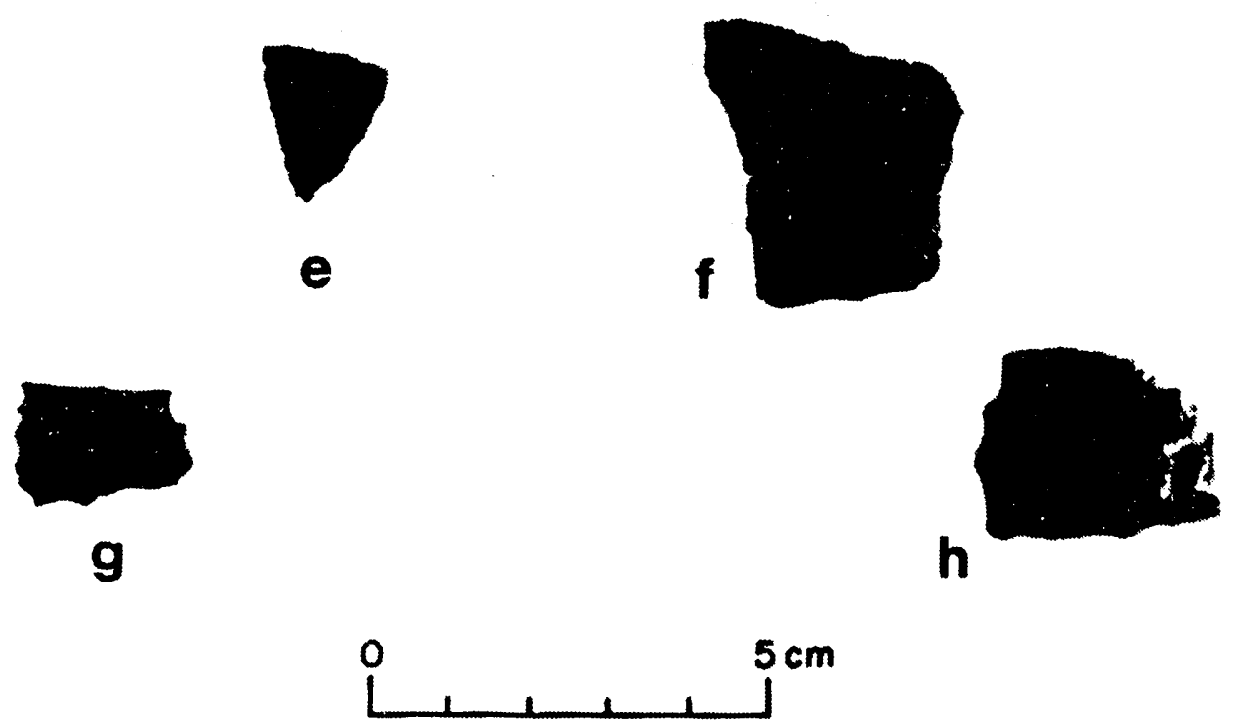

Figure 4-41. Photograph of artifacts from Feature 3, site 26Ny4040 (see Appendix A for descriptions and reference numbers).

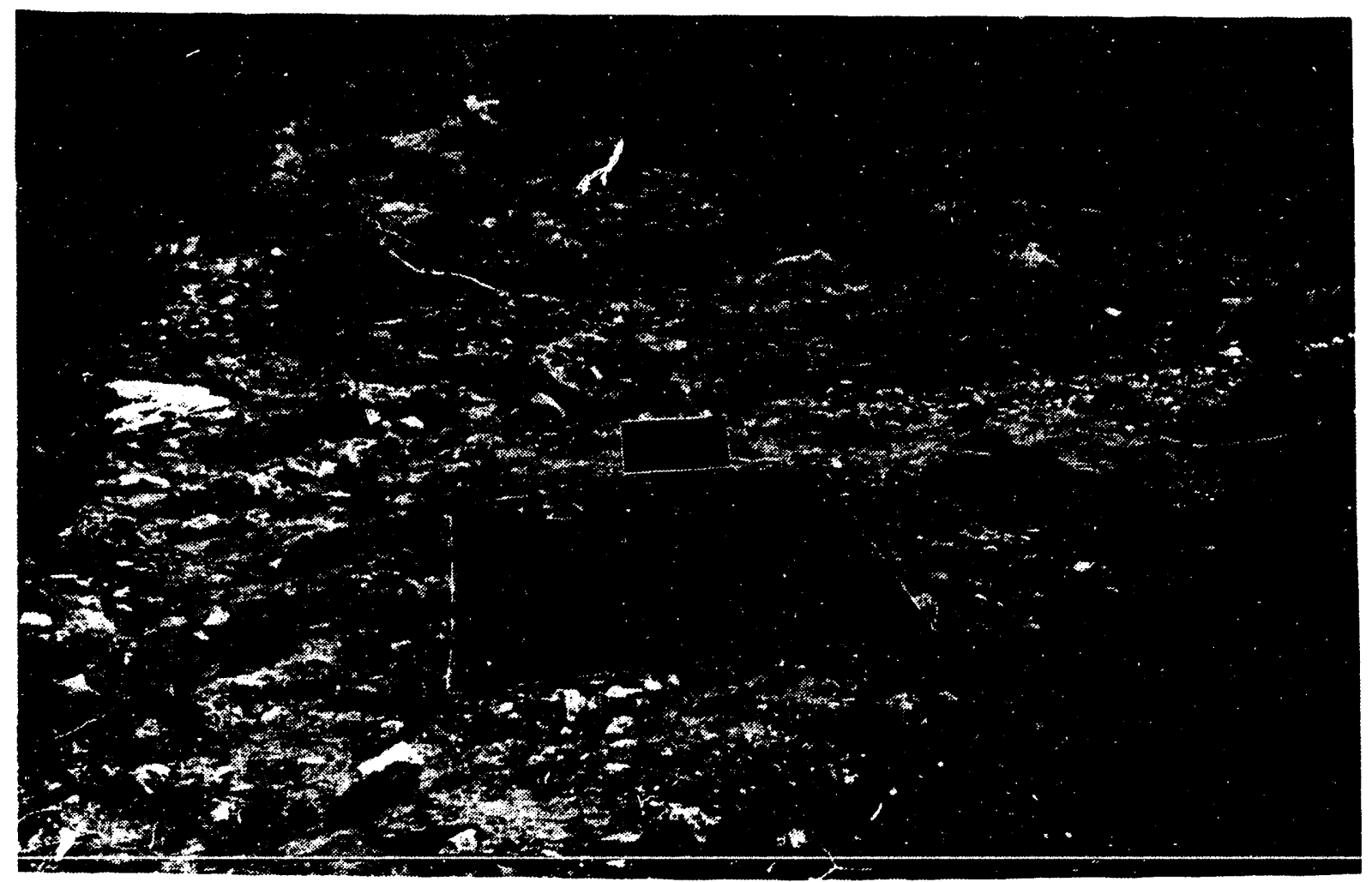

Figure 4-42. Photograph of Test Unit 8, site 26 Ny4040. 

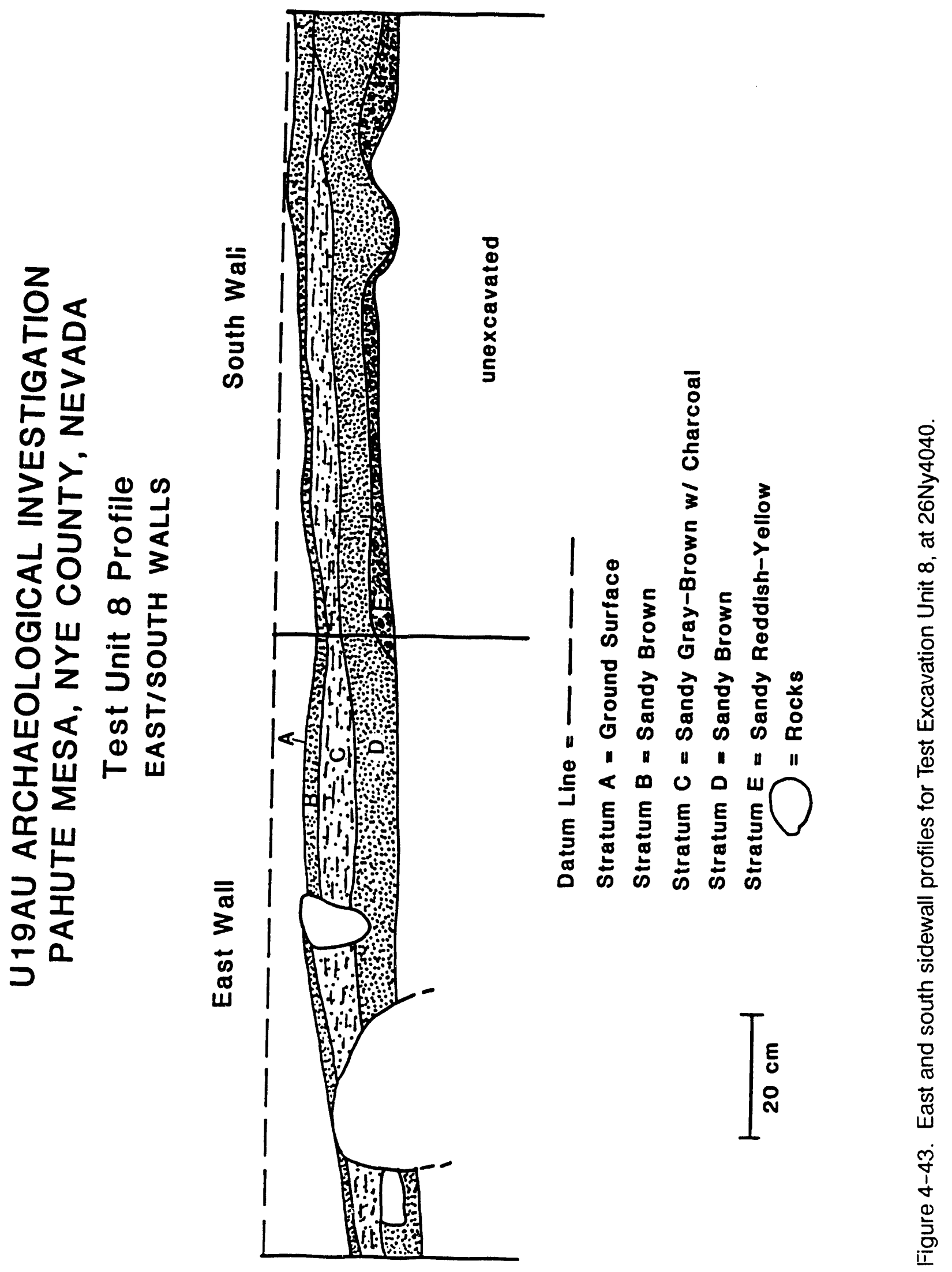
coal fragments that color the soil noticeably darker. This level was approximately $7 \mathrm{~cm}$ thick along the east wall and tapered to nothing in the west wall. Underlying Stratum $C$ is Stratum $D$, with a matrix similar to Stratum B, but with substantially fewer welded tuff gravels. This level was about $6 \mathrm{~cm}$ thick and culturally sterile. Stratum E underlies Stratum D and is composed of relatively hard, reddish, clayish soil with decomposing tuff bedrock inclusions. Excavated to a depth of 2 to $3 \mathrm{~cm}$ in the southern end of the unit, it too was culturally sterile.

Surrounding the structures is a scatter of lithic debitage which is most dense around structure 3 and structure 1 (Figure 4-44). Although the density is quite low in the rest of the site, it somewhat increases south of the features.

Additional nondebitage artifacts not definitely associated with any of the structures include several millingstones; numerous bifaces and unifaces; a drill midsection; brownware pottery; and a Cottonwood, four Rose Spring, an unfinished Elko, and two Humboldt projectile points (Figure 4-45). Historic artifacts include a white glass button and a tin strip with holes punched along one side. Such strips were added to the front lip of basketry seed beaters (Fowler and Dawson 1986:715, Figure 5e).

\section{Discussion}

Site 26 Ny4040 appears to be a late-period temporary camp with three enhanced brush shelters using of living juniper trees. The enhancements consist of branches in an upright position under the juniper canopy anchored with rock cairns and additional branches leaned against the uprights and the living tree. In and around these structures are millingstones, projectile points, other flaked stone tools, e.g., drills and bifaces, and numerous historic artifacts. Temporally diagnostic artifacts found at the site include brownware pottery and projectile points (a Cottonwood triangular, two Rosegate, a Humboldt, and a fragment of a possible Elkotype). The historic artifacts indicate that was used relatively late, less than 150 years ago. A sagebrush, removed from the living area of Feature 1 had 50 growth rings. While growth rings in sagebrush are related to wet events rather than to annual cycles, there is usually only one wet event per year in this area, and 50 probably represents a reasonable estimate of the plant's age. Since this plant was not at the site during occupation, occupation probably occurred more thian 50 years ago. With the exception of the fragment of the Elko point, this is not inconsistent with the artifact assemblage. 


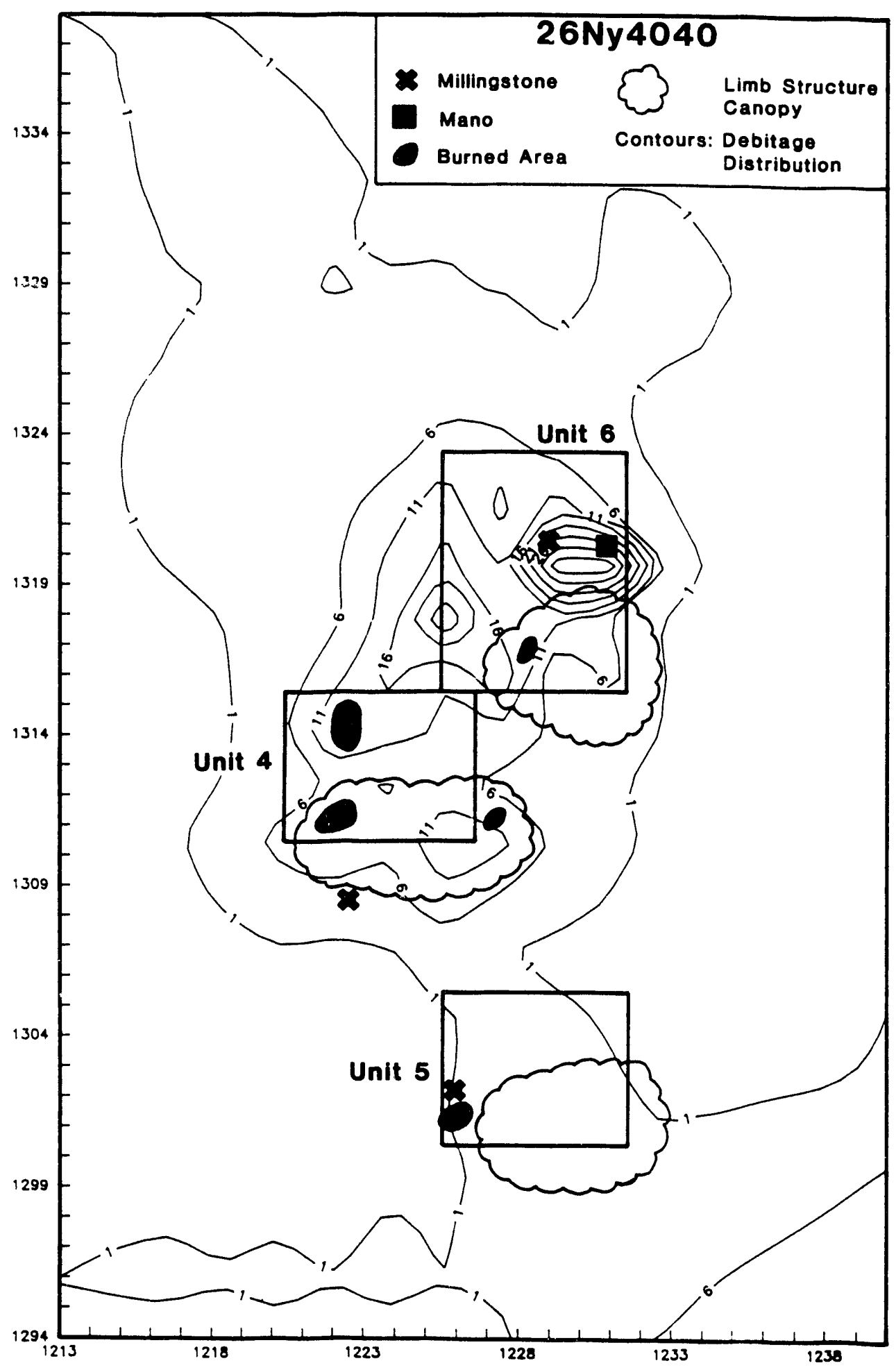

Figure 4-44. Debitage density map for site 26Ny4040, Pahute Mesa, Nevada. 

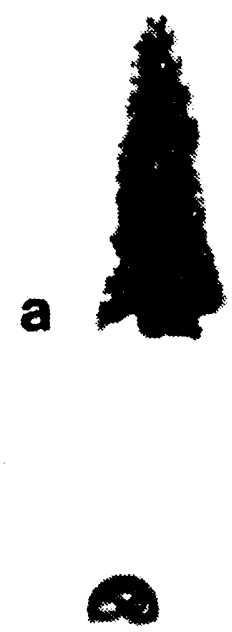

d

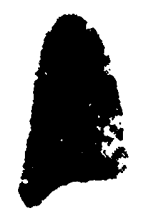

b
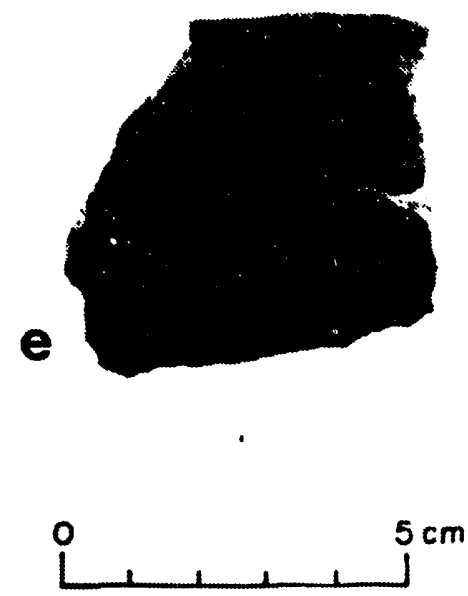

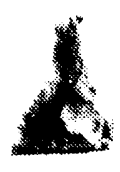

C

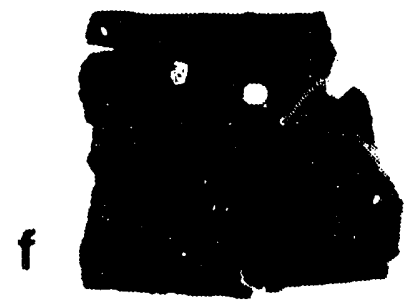

Figure 4-45. Photograph of miscellaneous artifacts from 26Ny4040, Pahute Mesa, Nevada (see Appendix A for descriptions and reference numbers). 


\section{MATERIAL CULTURE ANALYSIS}

\section{Cataloging}

The collected artifacts were removed to the CETO (now BECAMP) laboratory in Mercury, Nevada, where they were prepared for stripment to the Nevada Test Site archaeological laboratory facility at the Desert hesearch Institute, Reno, Nevada, for cataloging, preliminary analysis, and ultimately curation and storage. Initiwi, all artifacts were cleaned and prepared fo cataloguing and preliminary analysis. During this analysis, developed for the Nevada Test Site collections, various observable characteristics of the artifacts were encoded onto catuiog sheets, and this information was then input into a computer database management system.

All artifacts, other than debitage (unmodified flakes ano shatter), were assigned a unique artifact number consisting of a permanent site number, a reference number, and a sequential specimen number. Each permanent site number, assigned by the Nevada State Museum, consists of four characters indicating the state and county where the site is located and by a unique four-digit number for each site. The reference number denotes a unique location within that site - a unit of horizontal and/or vertical provenience--and corresponds to the field reference logs maintained by each field crew. Finally, a specimen number was assigned ior each unique artifact within a provenience unit. Debitage, on the other hand, was sorted by size, material type, and flake type anc' was assigned sequential specimen numbers in groups of similar flake types, sizes, and material characteristics.

\section{Material Types}

As part of the cataloging process, all lithic artifacts are identified by material types. There are many types of toolstone which occur on the Nevada Test Site, and many of these show a considerable variation in color and texture. For this report, toolstone has been combined into four primary types- coarse-grained tuff, chic.t, chalcedony, and obsidian. Coarse-f,iained tuffs include almost all of the native bedrock on the Test Site. It is brittle, usually reddish or brownish in color and, as the name implies, coarse-grained. Chert as used here means cryptocrystalline silicates which are opaque and not white in color. This material type is described as both chert and fine-grained welded tuff in other DRI publications on the Nevada Test Site. Chalcedony refers to the white, translucent to opaque, cryptocrystalline silicates which form in fissures and faults in the welded tuff bedrock. This material has also been referred to as white welded tuff and opalized chert in other DRI publications concerning the Test Site.

\section{Theoretical Orientations}

\section{Artifact Production Trajectories}

Figure 5-1 presents an idealized flow diagram for the stages of stone tool manufacture and use (Pippin and Hattori 1980:fig. 1) and provides the framework used for classifying artifacts from the U19au project. Several basic principles of stone tool manufacture and use are represented in this model. Any stage of artifact manufacture may represent a "finished tool." For example, primary flakes with unmodified working edges may be more efficient for certain tasks than those carefully prepared by retouching (Gould, Koster, and Sontz 1971:152, 156; Walker 1978). Concomitantly, worn working edges may have been resharpened or rejuvenated several times before the tool was discarded.

The second principle reflected in Figure $5-1$ is that artifacts may represent a variety of "unfinished" or "rejected" tools or by-products of tool manufacture (Holmes 1890:11-13). By isolating ancient techniques and methods represented in each stage of lithic tool production, researchers may accurately characterize ancient patterns of lithic tech: ology, as well as provide data pertinent to interpreting site function and significance 


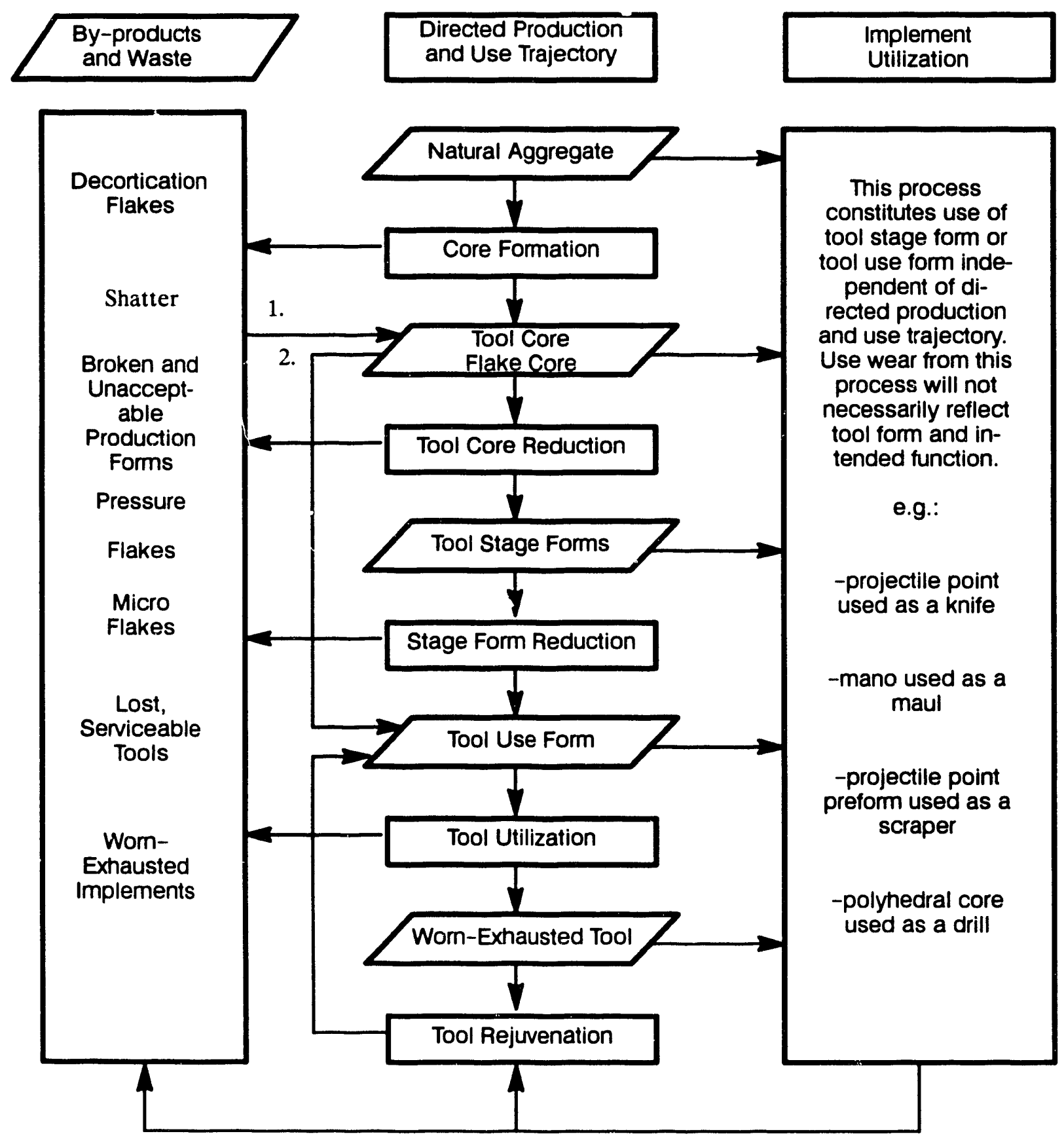

1. "Waste products" or "debitage" from most stages can reenter the directed trajectory as a tool core for other tool forms or modified versions of original tool forms.

2. Unmodified forms can be selected and enter a directed trajectory without modification.

Figure 5-1. Generalized flow diagram for chipped stone tool manufacture and use (from Pippin and Hattori 1980, fig. 1). 
(Bucy 1974; Collins 1975; Muto 1971a, 1971b; Sharrock 1966; Womack 1977). In addition, if differences in production techniques can be separated, possible technological, chronological, and/or functional information may be revealed and defined for a particular stage form. The strategies of tool manufacture and use also may vary according to several other factors. Among these are 1) the spatial locations of tool stone in relationship to the spatial locations of resources or tasks for which the tools were used, 2) the suitability of available toolstone for technological and task-specific functions, and 3) the overall strategy of seasonal human population movement and resource exploitation in the region (Chapman 1977:372-374).

\section{Functional Analyses}

The functional analysis of material culture from the project area was directed toward delineating artifact assemblages which might be associated with past resource procurement and processing systems. For example, artifact assemblages that resulted from hunting and/or butchering activities might be typified by artifacts discarded or lost during such procurement (Bettinger 1975:69-99). Here, it is important to heed Jelinek's (1976:31) warning that the discarded artifacts weie probably viewed as "trash" by the peoples responsible for their deposition. Artifact assemblages do not necessarily reflect complete "tool kits," but rather a restricted, and often biased, sample of only a segment of any particular activity.

\section{Debitage}

Residual flakes and shatter produced during the manufacture of lithic tools were the most abundant cultural remains recovered from U19au. Seven general flake types were identified in the field using the criteria presented in Table 5-1. When the analyst was not totally confident about classifying a particular flake, or when identifying characteristics were absent due to breakage, the flake was assigned to the indeterminate category.

Flakes with cortex on their dorsal surfaces are produced during initial preparation and shaping of cores. High frequencies of decortication flakes at a knapping locality signify the early stages of tool manufacture or the assaying of locally available toolstone.

Knapping of bifacial and other cores generally produces a varied quantity of residual lithic shatter. This shatter consists of blocky chunks of toolstone with poorly defined platforms, bulbs of applied force, and rings of

Table 5-1. Definitions of Flake Type Categories Used in the Analysis of Debitage from the U19au Drill Pad Area.

\begin{tabular}{ll}
\hline Flake Type & Definition \\
\hline $\begin{array}{l}\text { Decortication } \\
\text { Shatter }\end{array}$ & $\begin{array}{l}\text { Flakes which display more than } 25 \% \text { cortex on their dorsal surface, } \\
\text { All angular, blocky specimens which do not display identifiable platforms, bulbs of applied } \\
\text { force, and/or rings of force. }\end{array}$ \\
Core Reduction & $\begin{array}{l}\text { A relatively thick flake with a flat or contex-covered, but not multifaceted, platform. Previous } \\
\text { flake scars may occur along various orientations across the flake's dorsal surface. }\end{array}$ \\
Bifacial Thinning & $\begin{array}{l}\text { A thin, curved, expanding- or lanceolate-shaped flake with previous flake scars oriented at } \\
\text { various angles across its dorsal flake surface. This flake type should exhibit a bifacial or multi- } \\
\text { faceted platform, a truncated or diffuse bulb of applied force, and, usually, a lip formed directly } \\
\text { below the platform on the v'entral flake surface. } \\
\text { A relatively small, lanceolate- or expanding-shaped flake displaying an acuminate bulb, lon- } \\
\text { gitudinal curvature, and dorsal flake scars from the platform. These flakes may exhibit bifacial } \\
\text { edge remnants or flat platforms. } \\
\text { Debitage broken as the result of temperature change. } \\
\text { Heat Spall }\end{array}$ \\
Indeterminate & Any flake which, due to a lack of features, cannot confidently be identified. \\
\hline
\end{tabular}


force. This type of debitage is often produced by hard hammer blows during the initial stages of core shaping.

Following decortication, core reduction flakes may be removed from cores either to form tools or flake blanks or to shape the toolstone into a desired configuration. Bifacial thinning flakes at archaeological sites signify the production of bifacially flaked artifacts or flake blanks and tools produced from bifacial cores or stage forms.

Pressure flakes in the debitage assemblage signify the final shaping and/or resharpening of flaked stone tools. Debitage created by a change in temperature was placed in the heat spall category.

Finally, the indeterminate debitage category includes both whole or nearly complete flakes that could not be confidently assigned to one of the above categories, as well as flake fragments that did not retain enough characteristics to be confidently assigned to one of the other flake groups. Much indeterminate debitage appears to be broken biface thinning flakes.

All debitage recovered from the sites at U19au was classified according to this typolo- gy. Data recovery activities produced 15,546 pieces of debitage. Of these, 1,244 pieces were classified as decortication debitage, 2,071 as core reduction debitage, 1,986 as biface thinning debitage, 57 as pressure flakes, 2,683 as shatter, 7,449 as indeterminate debitage, and 56 as heat spalls. A discussion of the debitage and its spatial distribution is presented above in the description of data recovery activities at Site $26 \mathrm{Ny} 4015$.

\section{Cores}

Cores are pieces of lithic raw material exhibiting one or more flake scars. They may be used solely to produce flakes and/or may be part of a delayed strategy wherein they are subsequently reduced to a finished product.

Cores are classified as assayed, unidirectional, bidirectional, multidirectional, and bifacial (Table 5-2). The number of flake scars per platform and the relationship between platforms was monitored and metric attributes were recorded for maximum length, maximum width, thickness, and weight. Table 5-3 summarizes metric and morphological attributes.

Thirty-nine cores were identified in the collection. Assayed cores/cobbles dominate $(46 \%)$, followed by multidirectional cores

Table 5-2. Definitions of Core Types Used in the Analysis of Cores from the U19au Project Area.

\begin{tabular}{ll}
\hline Core Type Definition \\
\hline Assayed & $\begin{array}{l}\text { Characterized as having relatively few flake scars, a high percentage of cortex, and an irregular } \\
\text { shape. The presence of these characteristics implies that the toolstone was tested for its flak- } \\
\text { ing potential and subsequently discarded. } \\
\text { Characterized as having regular flake removals from one or more platforms, all in the same } \\
\text { direction. } \\
\text { Unidirectional }\end{array}$ \\
Bidirectional & $\begin{array}{l}\text { Characterized as having regular flake removals from at least two platforms, occurring in two } \\
\text { separate directions. }\end{array}$ \\
Multidirectional & $\begin{array}{l}\text { Characterized as having flake removals originating from a number of platforms, in several di- } \\
\text { rections. Multidirectional cores are the most common core type on the Nevada Test Site. }\end{array}$ \\
Bifacial & $\begin{array}{l}\text { Characterized as having regular flake removals along one or more bifacially edged platforms. } \\
\text { and overlapping and therefore often difficult to discern. } \\
\text { Includes any variation not described above. These cores may include exhausted cores which } \\
\text { exhibit characteristics indicating that they have been flaked to their existing capc }\end{array}$ \\
Other &
\end{tabular}




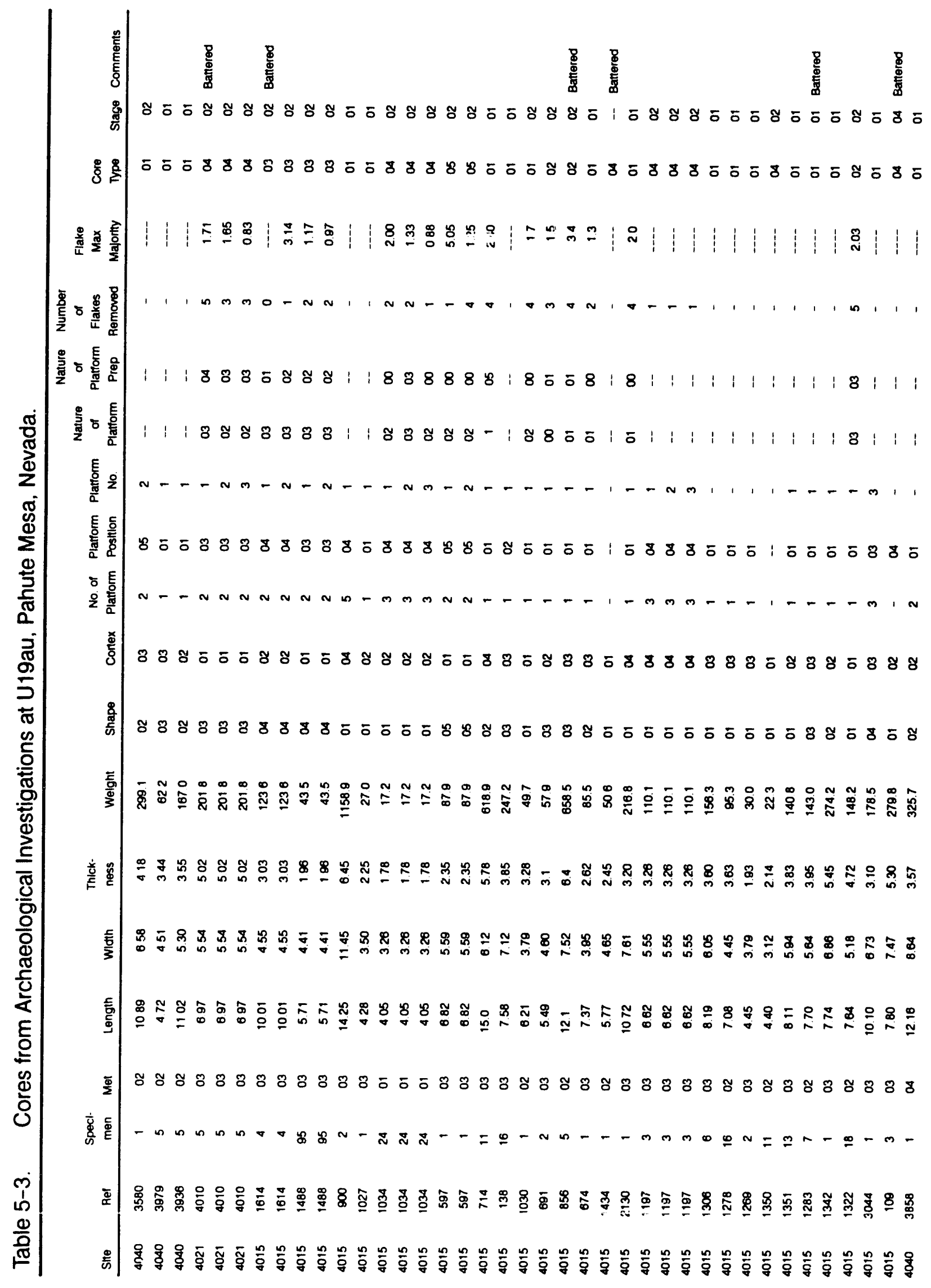


(30.7\%), bidirectional cores (10.2\%), unidirectional cores $(7.6 \%)$, and bifacial cores (5.1\%). Cuis samples for U19au are shown in Figure 5-2. The primary material type is chalcedony ( $64 \%)$, followed by chert (25.6\%), obsidian (7.6\%), and coarse welded tuff (2.5\%).

\section{Unifaces and Modified/Utilized Flakes}

Modified flakes include scrapers and tools with reworked edges. They are usually associated with maintenance and processing activities, such as hide and wood working, and are found at temporary camps or more substantial habitations.

Among the artifacts collected at U19au, there were 109 modified and utilized flake tools. A modified flake exhibits percussion or pressure flaking to shape or resharpen an edge. The modification may be bifacial or unifacial. Utilized flakes exhibit modification that is the by-product of use only, characterized by very small flake scars resulting from edge damage and often showing a slight dulling or rounding of the edge. Damage to flake edges can occur by natural actions such as tumbling and trampling, but such damage is usually random and irregular in comparison to the edge wear resulting from use (Figure 5-3, 5-4, and 5-5).

Seventy-two artifacts were identified as utilized flakes; 37 modified flakes were identified. The modified flakes were further analyzed by monitoring the number of edges, length of edges, and angle of each edge (Table 5-4). The most common toolstone used was chalcedony ( 21 items, $56.75 \%)$, followed by obsidian (13 items, $35.14 \%)$, and chert (3 items, $8.11 \%)$.

Twenty-six modified flakes (70.27\%) showed only unifacial modification; $11(20.97 \%)$ had bifacial modification. Two

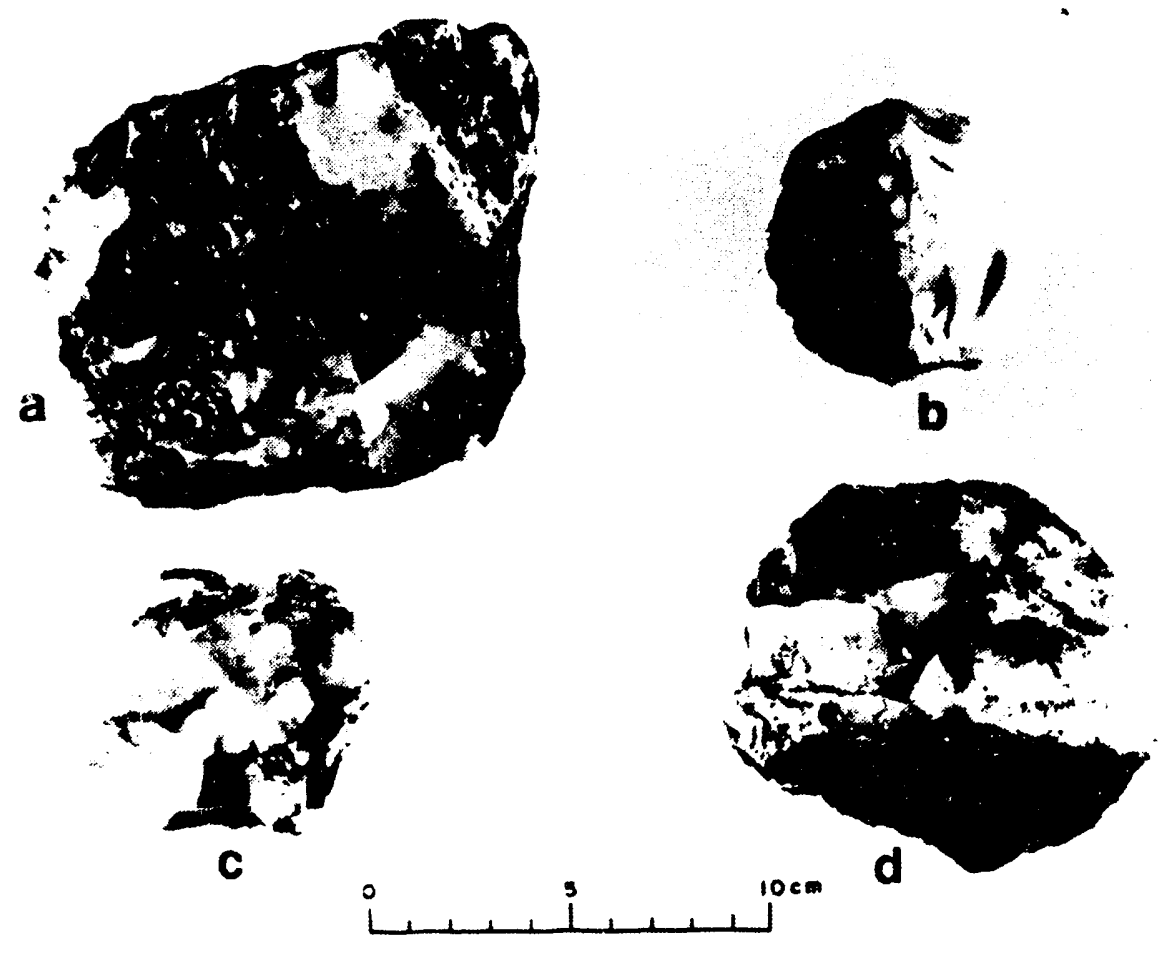

Figure 5-2. Photograph of cores from the U19au archaeological investigations, Panute Mesa, Nevada (see Appendix A for descriptions and reference numbers). 


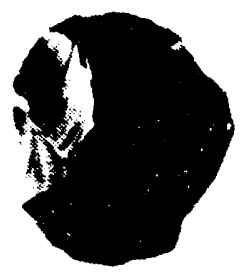

a

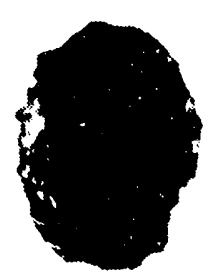

b

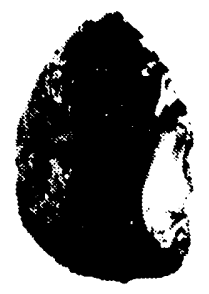

C

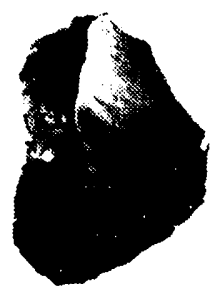

d

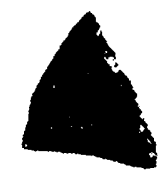

e

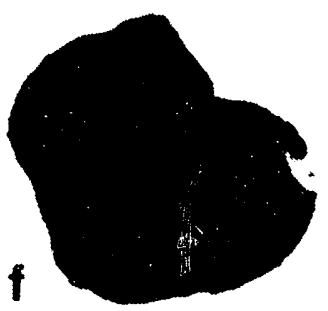

$5 \mathrm{~cm}$

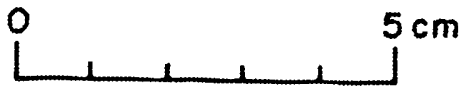

Figure 5-3. Photograph of modified flakes from the U19au archaeological investigations, Pahute Mesa, Nevada (see Appendix A for descriptions and reference numbers).

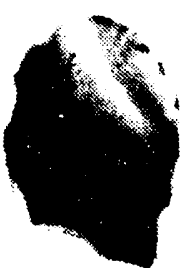

a

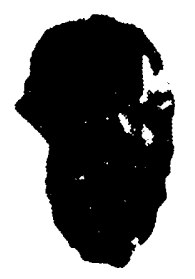

d

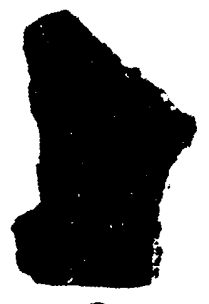

e

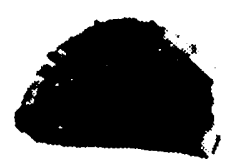

C

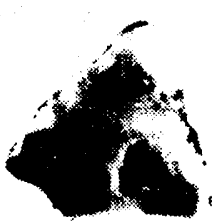

f

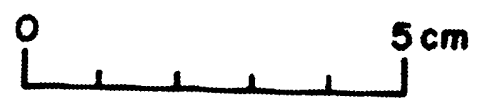

Figure 5-4. Photograph of modified flakes from the U19au archaeological investigations, Pahute Mesa, Nevada (see Appendix A for descriptions and reference numbers). 


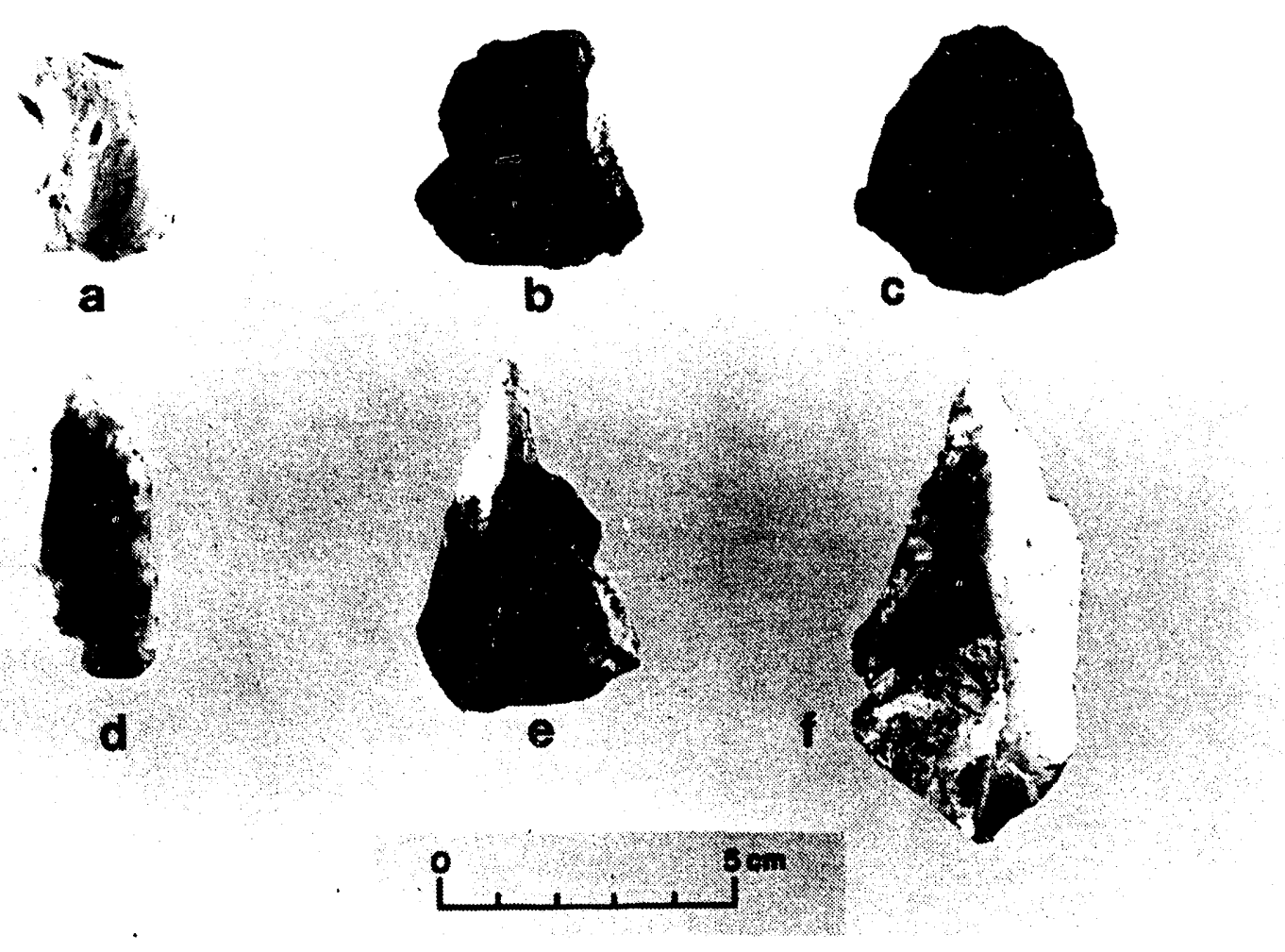

Figure 5-5. Photograph of utilized flakes from the U19au archaeological investigations, Pahute Mesa, Nevada (see Appendix A for descriptions and reference numbers).

artifacts were completely modified around their full circumference, forming ovate tools. Bothareofobsidian. One (26Ny4021-4445-1) shows bifacial modification and heavy use/ edge grinding; the other (26Ny4015-2131-29) has unifacial modification and use wear. Another distinctive artifact (26Ny4015-319-3) is a fragment of bifacially worked gold chert subsequently modified to form a tool with a steep, serrated, convex edge.

\section{Bifacial Stage Form Trajectories}

In the manufacture of bifacial tools, a piece of toolstone is reduced (flaked) until an acceptable tool is produced or the reduced specimen is discarded because of breakage or because the toolstone becomes unsuited for forming the desired tool. This manufacturing process is a contininuum of a series of reduction stages represented by each flake removal. The production sequence may termi- nate any time after the first flake is removed. Therefore, it is technologically meaningful to categorize bifacially thinned artifacts according to an idealized model of stage forms directed toward a desired end product. In this model, we conceptualize a sequence proceeding from platform establishment through edge regularization, thinning, shaping, and haft preparation. Of course, the artisan may bypass a reduction sequence and manufacture a stage form from a thin flake blank by merely sharpening a flake's edge and notching the base. Conversely, not all reduction sequences had thin, bifacially flaked, notched tools as the desired end product. Crude bifacially flaked edges of flake blanks from cobbles may have served as other tools, e.g., choppers, wedges, and denticulates. Therefore, ail stage iorms musi be considered as potentially finished tool forms that should be defined not by their technological stage of de- 


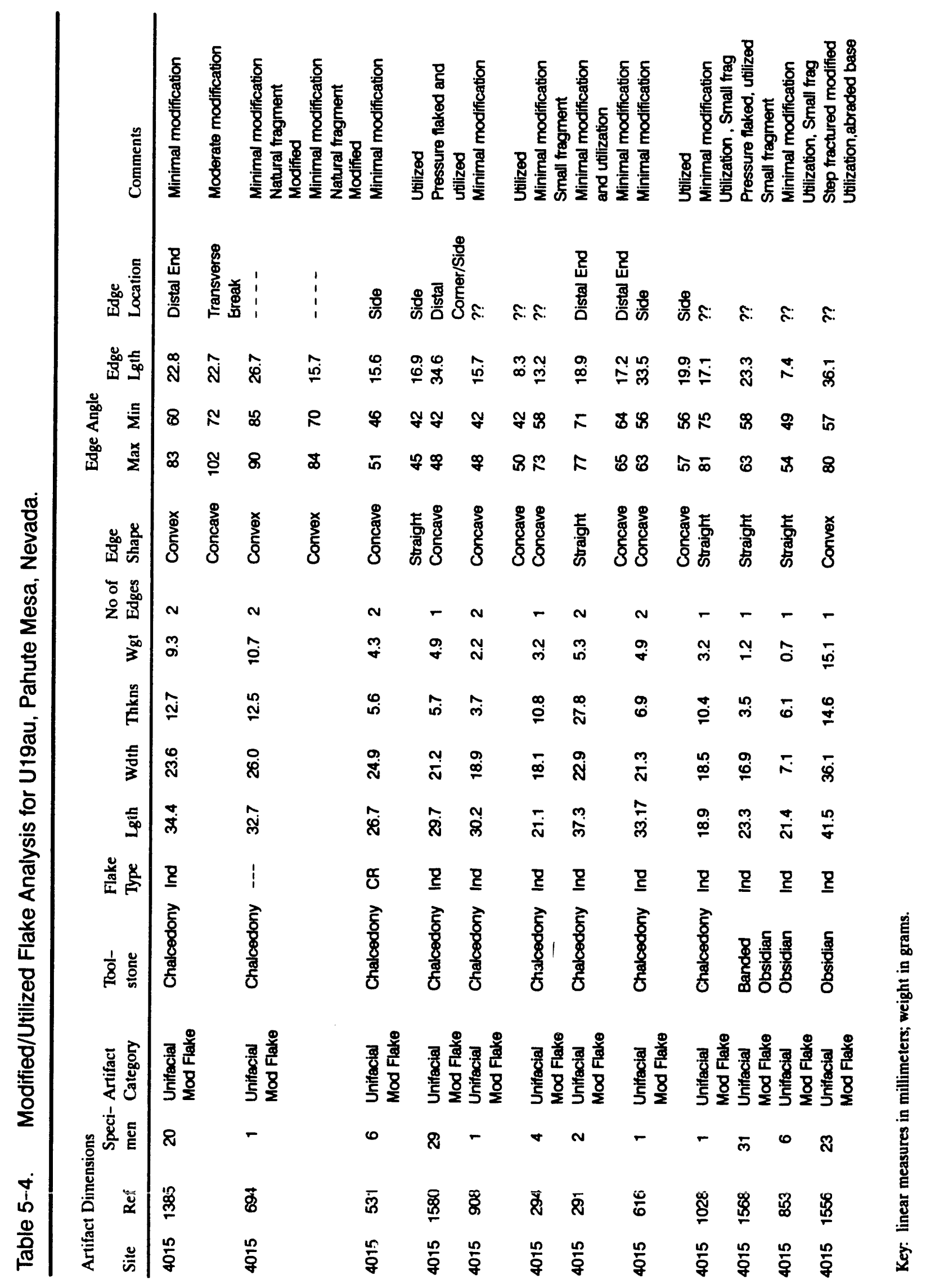




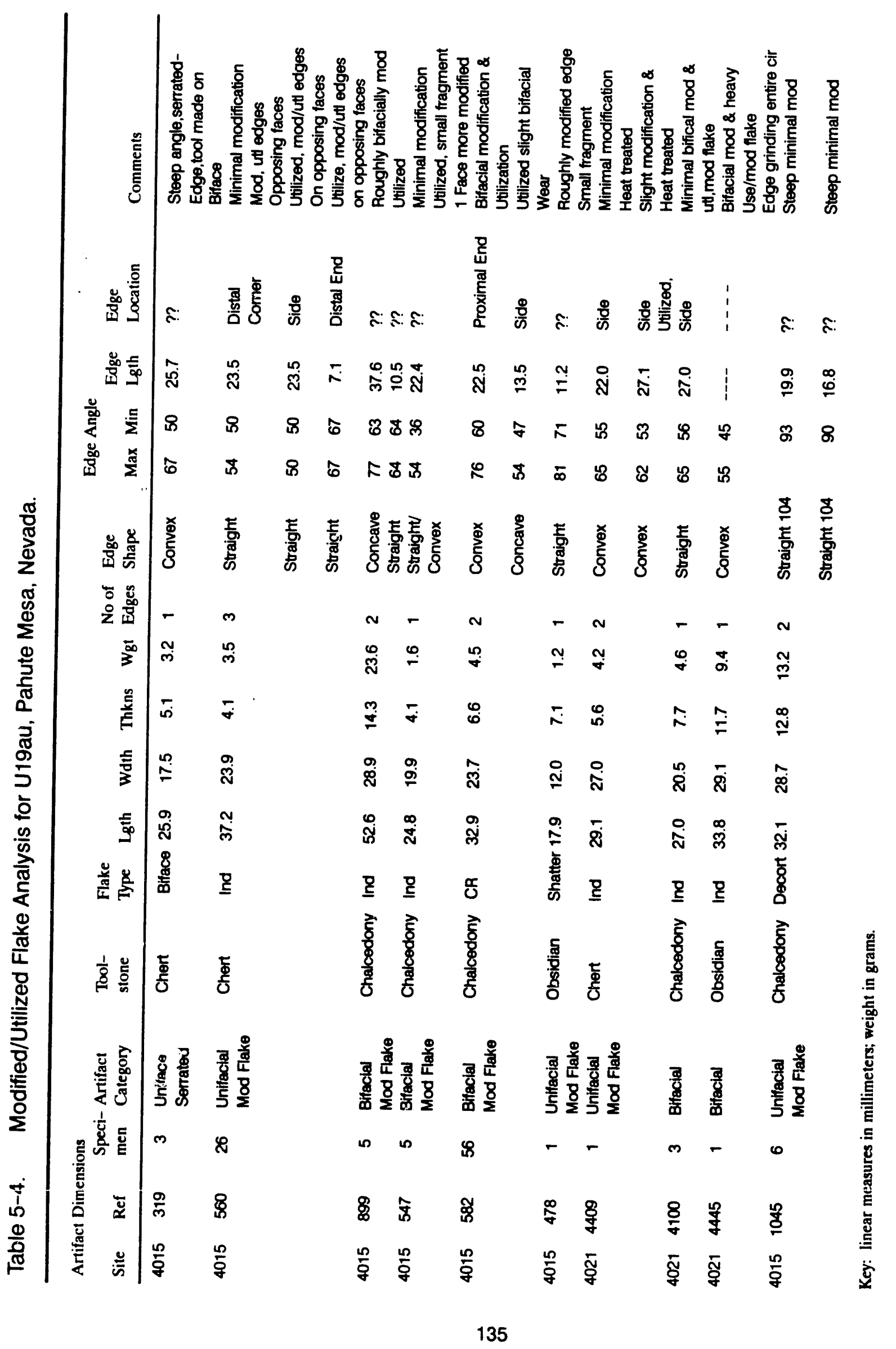




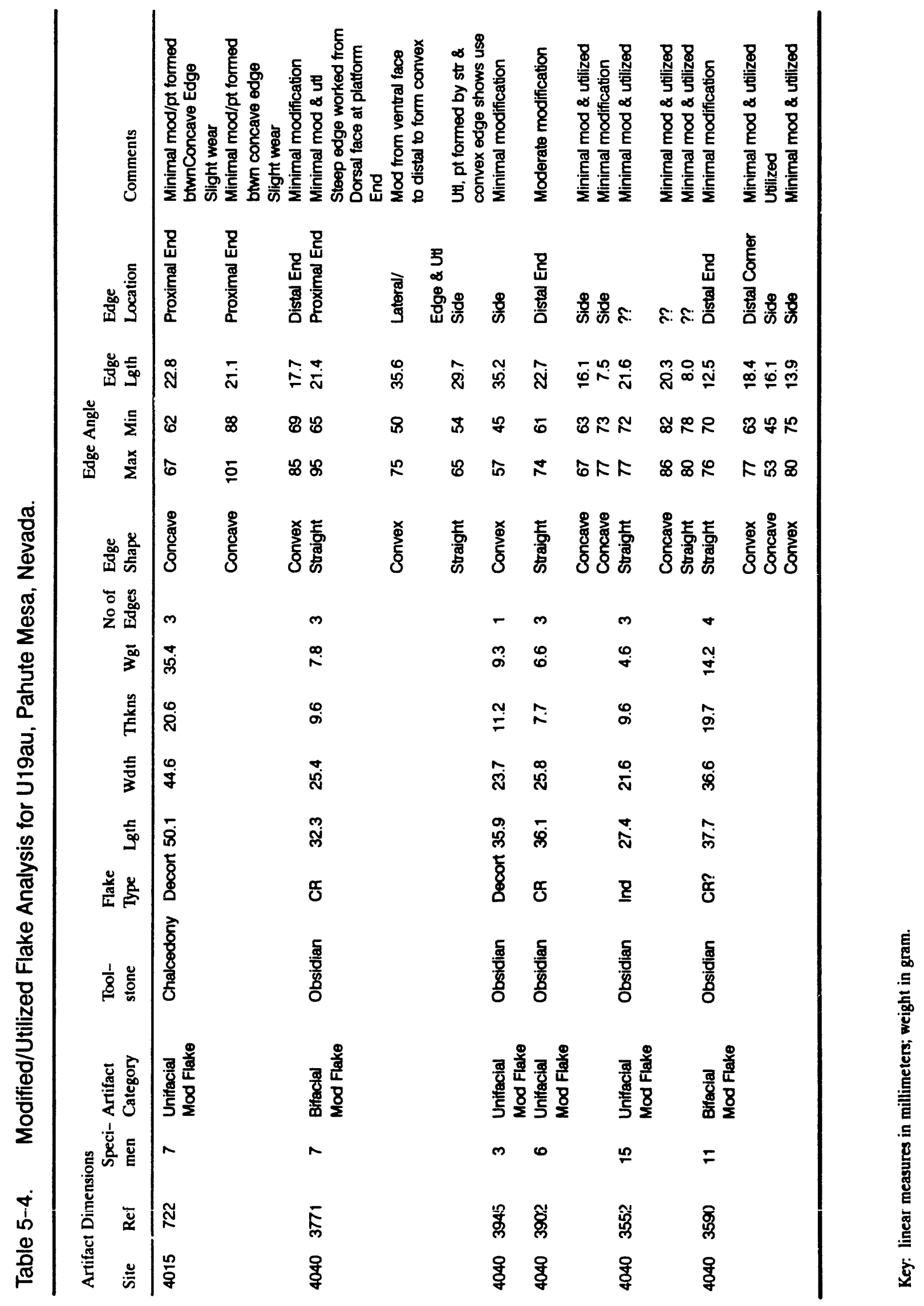


velopment, but by evidence of edge use (wear). Bifacial stage form morphology is summarized in Table 5-5.

Of the 347 bifaces recovered during the mitigation studies at U19au, 317 were identifiable to stage form (examples in Figure 5-6). Forty-three were classified as Stage I; another 25 as transitional between Stage I and II. Forty-four bifaces were considered Stage II; 49 were transitional between Stages II and III. There were 70 bifaces classified as Stage III, and 40 as transitional between Stages III and IV. Finally, 44 bifaces were classified as Stage IV and 2 as Stage $V$. The relatively equal numbers of the different stage forms found at U19au indicate a complete range of biface reduction. This was consistent with the different types of sites investigated (see the discussion of site $26 \mathrm{Ny} 4015$ above).

\section{Projectile Points}

Projectile points are artifacts designed for hafting and propulsion either by an arrow, at- latl dart, or spear. However, as with any tools, any particular projectile point might have been used for a variety of functions (e.g., cutting, scraping, or perforating).

Collected during the survey and mitigation of the affected areas of the U19au drill pad were 123 identifiable projectile points. Metric attributes of each artifact's weight, length, maximum width, thickness, maximum stem length, stem width at the juncture of the stem and shoulder, and maximum basal width were monitored. Metric values, recorded to the nearest $0.1 \mathrm{~mm}$ or $0.1 \mathrm{~g}$, are presented in Table 5-6. Locations of measurements on representative projectile point shapes are illustrated in Figure 5-7. Other recorded attributes are defined in Pippin and Hattori (1980, Figure 10).

Pinte Series - Because Pinto points have commonly been found with Lake Mojave or other Great Basin Stemmed Series projectile points on the shores of ancient pluvial lakes

Table 5-5. Production Sequence for Bifacially Flaked Stone Tools.

\begin{tabular}{|c|c|}
\hline Stage & Definition \\
\hline Stage I & $\begin{array}{l}\text { Thick, angular specimens with large, frequently irregular, flake removals that produce a variety of } \\
\text { shapes with uneven sections and edges. The primary goal is cortex removal, establishment of striking } \\
\text { platforms, and flake detachment. These bifaces can be madefrom a flake or natural nodule. Outline and } \\
\text { thickness are of secondary concern to knapper. The form can be relatively thick, very irregular in plan, } \\
\text { edges very sinuous and roughly centered viewing edge-on, angular in cross section with a sinuous mid- } \\
\text { line ridge, often exhibiting contex or original flake surface remnants, and flake scars frequently extending } \\
\text { across midline. }\end{array}$ \\
\hline Stage II & $\begin{array}{l}\text { The primary goals is to roughly thin and regularize edges through percussion flaking. Platforms are } \\
\text { maintained through strengthening and repositioning. The biface is thick with cross section less angular } \\
\text { and more rounded; midline ridge is prominent, moderately regular, and centered though sinuous; tip } \\
\text { and base are distinguishable. }\end{array}$ \\
\hline Stage III & $\begin{array}{l}\text { The primary goal is thinning of the bifaces cross section. Flakes are often removed in series, extending } \\
\text { across midline. Flake scars are broad and expanding and commonly removed with soft billets. Pressure } \\
\text { edge retouch may be located irregularly along edge in preparation for flake removals. The object form is } \\
\text { thin (approximately the thickness of the final desired tool); tip and base are well delineated though not } \\
\text { notched, edges are nearly straight viewed edge-on and are often centered. Lanceolate forms may ex- } \\
\text { hibit parallel, oblique flake removals at this stage. }\end{array}$ \\
\hline Stage IV & $\begin{array}{l}\text { The primary goal is the production of regular edges which are straight when viewed edge-on. Thick } \\
\text { arris remnants along edge are removed through pressure flaking. The tool form is complete except for } \\
\text { hafting element formation. This often constitutes a "preform" stage. }\end{array}$ \\
\hline Stage V & $\begin{array}{l}\text { The primary goal during this stage is the production of shoulder and haft elements. Even in outline and } \\
\text { regular in cross section. }\end{array}$ \\
\hline
\end{tabular}



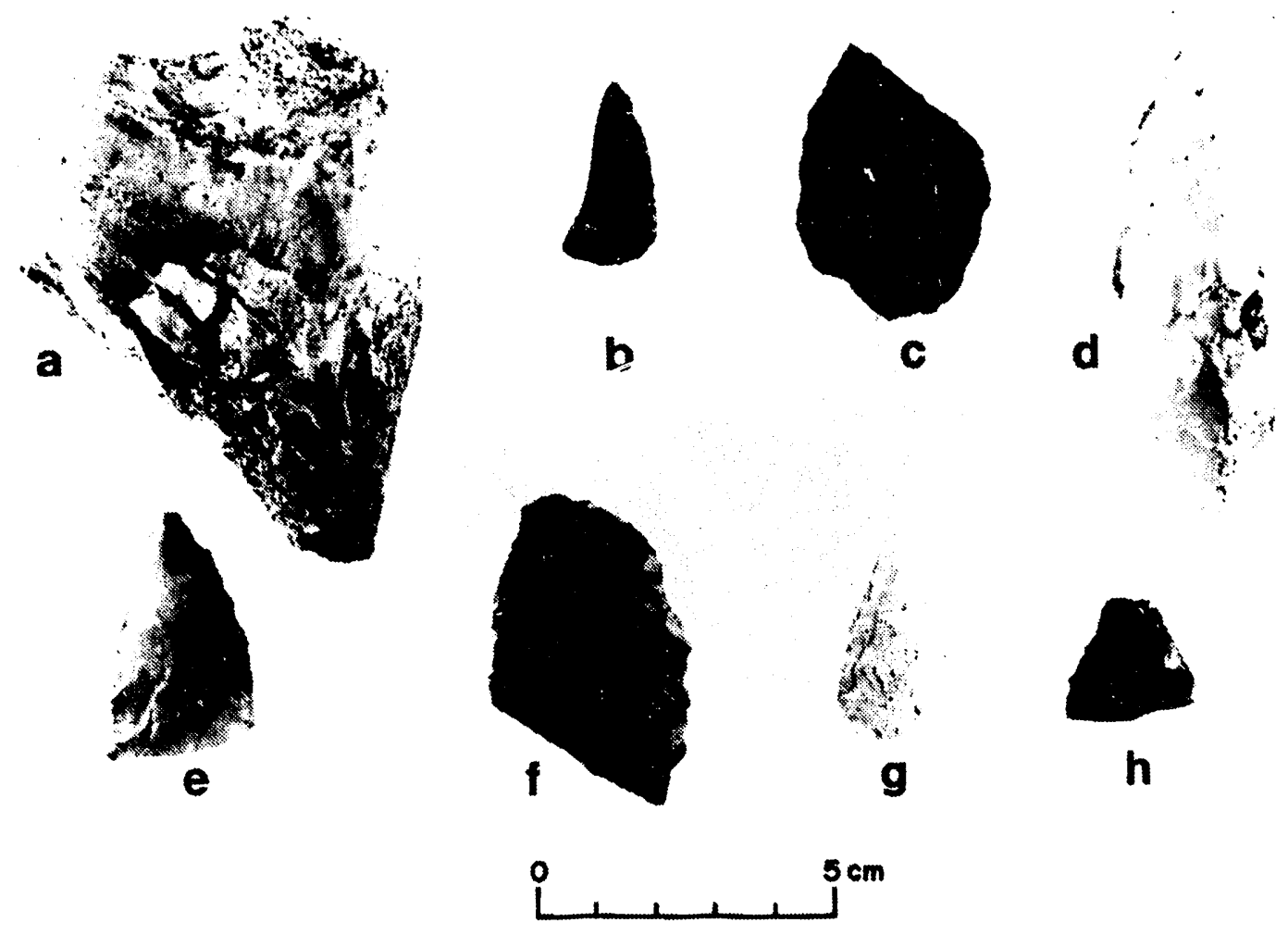

Figure 5-6. Photograph of bifaces from the U19au archaeological investigations, Pahute Mesa, Nevada (see Appendix A for descriptions and Reference numbers).

and rivers in the Mojave Desert, many prehistorians have assumed that they must be quite early in age and reflect a continuum from the Lake Mojave or San Dieguito period (Antevs 1952; Campbell and Campbell 1935; Susia 1964; Warren 1980). However, stemmedand indented-base atlatl dart points are found well outside the Mojave Desert (Hester 1973:26-28; Lister 1953). Other researchers (Bettinger and Taylor 1974; Hester 1973; Wallace and Wallace 1978) have pointed to dated occurrences of the "Pinto-like" points at Hidden Cave (Aikens 1970:56; Clewlow 1967; Pendleton 1985; Roust and Clewlow 1968), Kramer Cave (Hattori 1982), Gatecliff Shelter (Thomas 1981), and elsewhere (Dalley 1976:Table 5; Fowler, Madsen, and Hattori 1973; O'Connell 1971: Table 35) to argue that they date much later and that there might have been an occupational hiatus between the Lake Mohave and Pinto periods. Based on early radiocarbon dates $(7,800-6,600$ years B.P.) from Sudden Shelter and Hogup Cave, still others (Aikens 1970:56; Holmer 1978:66) have suggested that the Pinto style of projectile points may have originated in the eastern Great Basin and not in the Mojave Desert.

Much of this disagreement about Pinto points in the Great Basin appears to stem from confusion regarding the typology of these projectile points. Layton (1970), for example, felt that the Pinto or "Silent Snake Bifurcate Base" points he found in the northern Great Basin were typologically distinct from those illustrated by Campbell and Campbell (1935: Plate 13) from the Pinto Basin Site. In an attempt to remedy this situation, Thomas (1981:22-24, 33-36) has defined the Gatecliff Series, incorporating certain aspects of both the traditional Pinto Series and the Elko Contracting Stem style of projectile point. The 
Table 5-6. Analysis of Projectile Points from the U19au Drill Pad archaeological Investigations, Pahute Mesa, Nye County, Nevada.

\begin{tabular}{|c|c|c|c|c|c|c|c|c|c|c|}
\hline Site & Ref No & Type & Material & $\begin{array}{l}\text { Base } \\
\text { Width }\end{array}$ & $\begin{array}{l}\text { Stem } \\
\text { Width }\end{array}$ & $\begin{array}{l}\text { Stem } \\
\text { Lgth }\end{array}$ & Length & Width & $\begin{array}{l}\text { Thick- } \\
\text { ness }\end{array}$ & Weight \\
\hline 4015 & 1547 & Desert SN & Chalcedony & 1.12 & 0.64 & 0.72 & 2.22 & 1.15 & 0.33 & 0.5 \\
\hline 4015 & $1429-3$ & Desert SN & Chalcedony & $1.34^{\star}$ & 0.97 & 0.71 & 2.04 & $1.33^{\star}$ & 0.34 & 0.7 \\
\hline 4015 & $1605-13$ & Desent SN & Chert & 1.27 & 0.68 & 0.67 & 2.25 & 1.39 & 0.30 & 0.8 \\
\hline 4015 & 41 & Desert SN & Chert & 1.47 & 1.02 & 0.75 & $1.81 \star$ & 1.47 & 0.35 & 0.9 \\
\hline 4015 & 39 & Desert SN & Chert & $1.47^{\star}$ & 0.79 & 0.69 & $1.07 *$ & 1.54 & 0.29 & 0.4 \\
\hline 4015 & 40 & Desert SN & Chert & 1.55 & 0.95 & 0.90 & 1.88 & 1.60 & 0.34 & 0.8 \\
\hline 4026 & 1 & Desert SN & Obsidian & & & 1.05 & $1.80 \star$ & $1.01 *$ & 0.33 & 0.6 \\
\hline 4015 & 37 & Desert SN & Obsidian & & 0.62 & 0.57 & $1.73^{\star}$ & $1.33^{*}$ & 0.23 & 0.5 \\
\hline 4015 & 38 & Desert SN & Obsidian & 1.17 & 0.73 & 0.84 & 2.08 & 1.43 & 0.31 & 0.6 \\
\hline 4015 & $23-2$ & Desert SN & Obsidian & 1.33 & 0.79 & 0.91 & 2.58 & 1.36 & 0.27 & 0.6 \\
\hline 4048 & 1 & Desert SN & Obsidian & 1.35 & 0.67 & 0.82 & $2.18^{\star}$ & 1.35 & 0.30 & 0.7 \\
\hline 4015 & 1372 & Desert SN & Obsidian & 1.52 & 0.62 & 0.93 & 2.34 & 1.57 & 0.30 & 0.7 \\
\hline 4015 & $1526-17$ & Cottonwood & Obsidian & & & 0.32 & 1.89 & 0.96 & 0.25 & 0.4 \\
\hline 4015 & 14 & Cottonwood & Obsidian & & & 0.41 & 2.39 & 0.89 & 0.28 & 0.3 \\
\hline 4015 & 5 & Cottonwood & Obsidian & 0.93 & & & 1.98 & 1.11 & 0.33 & 0.5 \\
\hline 4015 & $494-4$ & Cottonwood & Obsidian & 1.14 & 1.14 & & 1.38 & 0.26 & 0.26 & 0.2 \\
\hline 4040 & $6-2$ & Cottonwood & Obsidian & 1.28 & 1.28 & & 1.98 & 1.33 & 0.43 & 1.0 \\
\hline 4021 & $4728-4$ & Cottonwood & Obsidian & 1.29 & 1.29 & & 1.02 & 1.29 & 0.29 & 0.4 \\
\hline 4049 & 4 & Cottonwood & Obsidian & 1.29 & 1.29 & & 2.43 & 1.33 & 0.32 & 0.8 \\
\hline 4015 & 46 & Cottonwood & Obsidian & 1.32 & & & 2.01 & 1.32 & 0.33 & 0.6 \\
\hline 4015 & 36 & Cottonwood & Obsidian & 1.34 & 1.34 & & $1.84^{\star}$ & 1.34 & 0.38 & 0.7 \\
\hline 4049 & 5 & Cottonwood & Obsidian & $1.40^{*}$ & $1.40^{*}$ & & $1.86^{\star}$ & 1.44 & 0.38 & 0.9 \\
\hline 4015 & 35 & Cottonwood & Obsidian & $1.54^{\star}$ & & & 3.11 & $1.54 *$ & 0.37 & 1.4 \\
\hline 3633 & $817-1$ & Rosegate & Chalcedony & & 0.75 & & $2.69 \star$ & $1.85^{\star}$ & 0.35 & 1.7 \\
\hline 4015 & $891-1$ & Rosegate & Chalcedony & & 0.85 & & $3.19 *$ & 2.44 & 0.37 & 2.8 \\
\hline 4015 & $1226-1$ & Rosegate & Chaicedony & & 0.87 & 0.55 & $2.82^{\star}$ & 1.79 & 0.37 & 1.6 \\
\hline 4015 & $1467-16$ & Rosegate & Chalcedony & 0.57 & 0.60 & 0.40 & $1.86^{\star}$ & 1.47 & 0.34 & 0.9 \\
\hline 4015 & $457-6$ & Rosegate & Chalcedony & 0.88 & 0.83 & 0.22 & $2.21 \star$ & 1.88 & 0.33 & 1.0 \\
\hline 4019 & 1 & Rosegate & Chalcedony & 1.00 & 0.90 & 0.15 & 1.31 & 1.95 & 0.32 & 0.8 \\
\hline 4015 & $468-1$ & Rosegate & Chalcedony & 1.08 & 0.80 & 0.53 & $2.70^{\star}$ & $1.83^{\star}$ & 0.45 & 2.1 \\
\hline 4015 & $1562-12$ & Rosegate & Chert & & & & 4.08 & 1.95 & 0.51 & 2.8 \\
\hline 4040 & $3967-3$ & Rosegate & Chert & & 0.70 & & $3.22 \star$ & 1.85 & 0.41 & 1.6 \\
\hline 4015 & 20 & Rosegate & Chert & 0.74 & 0.71 & 0.30 & $2.48^{\star}$ & 1.70 & 0.37 & 1.7 \\
\hline 4015 & $1347-5$ & Rosegate & Chert & 0.75 & 0.66 & 0.41 & $1.53^{\star}$ & $1.53^{\star}$ & 0.37 & 0.8 \\
\hline 4015 & $1480-1$ & Rosegate & Chert & 0.79 & 0.94 & 0.44 & $2.44^{\star}$ & $2.23^{\star}$ & 0.47 & 2.1 \\
\hline 4041 & 3 & Rosegate & Chert & 0.81 & 0.69 & 0.24 & $1.95^{\circ}$ & $1.90^{\star}$ & 0.34 & 1.2 \\
\hline 4040 & 2 & Rosegate & Chert & 0.87 & 0.67 & 0.37 & $1.74^{\star}$ & 1.72 & 0.31 & 1.0 \\
\hline 4040 & $3575-17$ & Rosegate & Chert & 0.91 & 0.88 & 0.15 & 4.99 & $2.02^{\star}$ & 0.40 & 3.3 \\
\hline 4054 & 1 & Rosegate & Chert & 0.94 & 0.79 & 0.36 & 1.98 & 1.79 & 0.34 & 1.1 \\
\hline 4015 & $1605-14$ & Rosegate & Chert & 1.01 & 0.72 & 0.47 & $1.08 *$ & 1.24 & 0.30 & 0.4 \\
\hline 4015 & $1592-20$ & Rosegate & Obsidian & 0.70 & 0.88 & 0.34 & 3.09 & 1.93 & 0.29 & 1.6 \\
\hline 4024 & 1 & Rosegate & Obsidian & 0.78 & 0.72 & 0.27 & 2.23 & 1.51 & 0.31 & 1.0 \\
\hline 4015 & 34 & Rosegate & Obsidian & 0.86 & 0.83 & 0.43 & $2.67^{\star}$ & $1.40^{\star}$ & 0.36 & 1.1 \\
\hline 4021 & 1 & Elko CN & Chalcedony & & & & 1.36 & 2.36 & 0.40 & 0.9 \\
\hline 4017 & 3 & Elko CN & Chalcedony & & & 2.07 & 3.00 & 2.10 & 0.55 & 2.6 \\
\hline 4015 & $1307-5$ & Elko CN & Chalcedony & 1.17 & 1.14 & 0.36 & $3.22 \star$ & 2.02 & 0.33 & 1.2 \\
\hline 4015 & $146-37$ & Elko CN & Chalcedony & 1.23 & 1.08 & 0.45 & $1.49 \star$ & 2.25 & 0.31 & 1.2 \\
\hline 4015 & 47 & Elko CN & Chalcedony & $1.43^{\star}$ & 1.04 & 0.70 & $3.19 \star$ & 2.22 & 0.47 & 3.1 \\
\hline 4015 & $1201-1$ & Elko CN & Chalcedony & $1.46^{\star}$ & 1.34 & $0.58 \star$ & $3.20 \star$ & $2.39 *$ & 0.49 & 3.2 \\
\hline 4021 & 2 & Elko CN & Chalcedony & 1.56 & 1.06 & 0.98 & 1.94 & 2.26 & 0.54 & 1.9 \\
\hline 4051 & 2 & Elko CN & Chalcedony & $1.67^{\star}$ & 1.18 & 0.53 & $3.89^{\star}$ & 2.03 & 0.43 & 3.4 \\
\hline 4015 & $1321-25$ & Elko CN & Chalcedony & 1.79 & 1.47 & 1.05 & 2.53 & 2.83 & 0.69 & 3.8 \\
\hline 4017 & 4 & Elko CN & Chert & & 1.27 & & 2.93 & 2.42 & 0.39 & 3.0 \\
\hline 4015 & $1262-4$ & Elko CN & Chert & 0.72 & 0.84 & 0.10 & $1.48^{\star}$ & $1.39^{\star}$ & 0.32 & 0.7 \\
\hline 4015 & $1036-8$ & Elko CN & Chert & $1.92^{\star}$ & 1.49 & 0.83 & 3.30 & $2.69 *$ & 0.47 & 3.8 \\
\hline
\end{tabular}


Table 5-6. (continued).

\begin{tabular}{|c|c|c|c|c|c|c|c|c|c|c|}
\hline Site & Ref No & Type & Material & $\begin{array}{l}\text { Base } \\
\text { Width }\end{array}$ & $\begin{array}{l}\text { Stem } \\
\text { Width }\end{array}$ & $\begin{array}{l}\text { Stem } \\
\text { Lgth }\end{array}$ & Length & Width & $\begin{array}{l}\text { Thick- } \\
\text { ness }\end{array}$ & Weight \\
\hline 4017 & 4 & Elko CN & Chert & & 1.27 & & 2.93 & 2.42 & 0.39 & 3.0 \\
\hline 4015 & $1262-4$ & Elko CN & Chert & 0.72 & 0.84 & 0.10 & $1.48^{\star}$ & $1.39 \star$ & 0.32 & 0.7 \\
\hline 4015 & $1036-8$ & Elko $\mathrm{CN}$ & Chert & $1.92 *$ & 1.49 & 0.83 & 3.30 & $2.69 *$ & 0.47 & 3.8 \\
\hline 4015 & $1324-9$ & Elko CN & Chert & $1.35^{*}$ & 1.16 & 0.62 & $1.91 *$ & $2.21 *$ & 0.42 & 1.4 \\
\hline 4015 & $561-1$ & Elko CN & Chert & 113 & 0.94 & 0.17 & 2.68 & 2.12 & 0.30 & 1.2 \\
\hline 4015 & $146-38$ & Elko CN & Chert & 1.13 & 1.05 & 0.47 & $1.32 *$ & $1.69 *$ & 0.27 & 0.7 \\
\hline 4040 & $3590-10$ & Elko CN & Chert & 1.15 & 0.93 & 0.41 & $2.63^{\star}$ & 1.92 & 0.37 & 2.0 \\
\hline 4015 & $7324-9$ & Elko CN & Chert & 1.35" & 1.16 & 0.62 & $1.91 *$ & $2.21 *$ & 0.42 & 1.4 \\
\hline 4015 & 29 & Elko CN & Chert & 1.84 & 1.52 & 0.91 & $2.81 *$ & 2.47 & 0.52 & 4.2 \\
\hline 3633 & $732-1$ & Elko CN & Obsidian & & 1.24 & & $2.15^{\star}$ & $2.46^{\star}$ & 0.40 & 1.9 \\
\hline 4024 & 3 & Elko CN & Obsidian & $0.63 *$ & 0.80 & 0.14 & 3.14 & $1.78^{\star}$ & 0.40 & 2.0 \\
\hline 4015 & $595-1$ & Elko $\mathrm{CN}$ & Obsidian & 0.80 & 0.81 & 0.40 & $1.94 *$ & 1.57 & 0.29 & 0.9 \\
\hline 4017 & 2 & Elko CN & Obsidian & 1.02 & 0.84 & 0.62 & 1.18 & 1.35 & 0.40 & 0.6 \\
\hline 4023 & 2 & Elko CN & Obsidian & $1.07^{*}$ & 0.85 & 0.53 & 2.40 & 1.89 & 0.47 & 2.1 \\
\hline 4015 & $125-4$ & Elko CN & Obsidian & & 1.21 & 0.76 & 3.53 & 2.41 & 0.47 & 4.2 \\
\hline 4048 & 5 & Elko CN & Obsidian & 1.79 & 1.15 & 1.14 & $2.19 *$ & 2.20 & 0.54 & 1.8 \\
\hline 4024 & 2 & Elko CN & Obsidian & 2.26 & 1.54 & 0.94 & 2.66 & 2.60 & 0.55 & 4.0 \\
\hline 4041 & 1 & Elko CN & Quartite & & 1.46 & 0.76 & $2.91 *$ & $2.34^{\star}$ & 0.60 & 4.6 \\
\hline 4015 & $969-4$ & Elko CN & Welded tuff & & 1.25 & & $5.22^{\star}$ & 1.98 & 0.56 & 4.8 \\
\hline 4022 & 1 & Elko Ear & Chalcedony & & 1.53 & & 2.90 & 3.06 & 0.45 & 4.0 \\
\hline 4015 & $1322-21$ & Elko Ear & Chalcodony & $1.57^{\star}$ & & 0.92 & $1.63^{*}$ & $1.83^{\star}$ & 0.42 & 1.0 \\
\hline 4015 & $1603-28$ & Elko Ear & Chalcodony & 1.83 & 1.59 & 0.63 & $3.68^{\star}$ & 2.54 & 0.47 & 4.1 \\
\hline 4015 & $1200-1$ & Elko Ear & Chatcedony & 1.94 & 1.48 & 0.72 & 4.17* & $2.34^{\star}$ & 0.51 & 5.0 \\
\hline 4015 & 1051 & Elko Ear & Chalcodony & 2.11 & 1.84 & 0.77 & $2.78^{\star}$ & 2.76 & 0.46 & 3.1 \\
\hline 4015 & 18 & Elko Ear & Chert & & & 0.67 & $2.55^{\star}$ & $2.45^{\star}$ & 0.45 & 2.3 \\
\hline 4015 & $1326-10$ & Elko Ear & Chert & $1.11^{*}$ & 1.07 & & $3.17^{\star}$ & 1.91 & 0.42 & 2.0 \\
\hline 4015 & $855-16$ & Elko Ear & Obsidian & $1.59^{*}$ & 1.19 & 0.72 & $2.38^{*}$ & 1.78 & 0.43 & 1.8 \\
\hline 4053 & 4 & Elko Ear & Obsidian & 1.61 & 1.15 & 0.74 & $2.08^{*}$ & 2.12 & 0.38 & 1.8 \\
\hline 4048 & 6 & Elko Ear & Obsidian & 2.24 & 2.13 & 1.05 & $3.11^{\star}$ & 2.61 & 0.50 & 4.5 \\
\hline 4015 & $641-7$ & Elko Ear & Obsidian & 2.32 & 2.12 & 0.93 & $2.64^{*}$ & $2.63^{\star}$ & 0.46 & 3.2 \\
\hline 4015 & $1024-9$ & Gatecliff & Chalcedony & & 1.30 & & 2.34 & 2.00 & 0.57 & 2.8 \\
\hline 4015 & 42 & Gateclitf & Chalcedony & 0.81 & 1.00 & 0.67 & $4.11^{\star}$ & 2.67 & 0.52 & 5.5 \\
\hline 4015 & 32 & Gatecliff & Chalcedony & 1.04 & 1.16 & 1.18 & $3.38^{*}$ & $2.26 *$ & 0.52 & 3.5 \\
\hline 4015 & $1556-21$ & Gatecliff & Chert & 0.59 & & 0.82 & 1.81 & 2.25 & 0.46 & 1.4 \\
\hline 4015 & 10 & Gateclitf & Chert & & & & 6.84 & 2.22 & 0.62 & 10.1 \\
\hline 4015 & $944-22$ & Gatecliff & Chert & $1.36^{*}$ & 1.23 & $0.72^{\star}$ & $4.13^{\star}$ & 2.33 & 0.56 & 5.6 \\
\hline 4015 & 49 & Gatecliff & Chent & 1.45 & 1.50 & 1.19 & 3.88 & 2.94 & 0.69 & 7.1 \\
\hline 4015 & 27 & Gatecliff & Obsidian & & 0.96 & 0.79 & 2.86 & 2.07 & 0.41 & 1.8 \\
\hline 4016 & 1 & Gatecliff & Obsidian & 0.72 & 1.06 & 0.78 & 2.74 & 2.64 & 0.46 & 3.2 \\
\hline 4015 & $287-1$ & Gateclitf & Obsidian & 0.74 & 0.70 & 0.39 & $0.56^{\star \prime}$ & $1.54^{*}$ & 0.28 & 1.0 \\
\hline 4015 & 43 & Gateclift & Obsidian & 0.91 & 1.30 & 0.86 & $2.79^{*}$ & 3.39 & 0.45 & 3.0 \\
\hline 4015 & $1592-21$ & Gateclitf & Obsidian & 0.97 & & 0.79 & $3.00 *$ & 2.42 & 0.47 & 3.0 \\
\hline 4015 & $366-5$ & Gateclitt & Obsidian & 1.02 & 1.28 & 0.71 & $2.66^{*}$ & 2.45 & 0.56 & 3.5 \\
\hline 4015 & $1128-1$ & Gateclitf & Obsidian & 1.47 & 1.45 & 0.56 & $2.25^{\star}$ & 2.82 & 0.53 & 2.8 \\
\hline 4015 & $309-1$ & Gypsum & Chert & & 0.97 & 0.59 & 3.60 & 2.27 & 0.56 & 5.0 \\
\hline 4038 & 1 & Gypsum & Obsidian & & & 0.50 & $4.05^{*}$ & $1.78^{*}$ & 0.50 & 3.1 \\
\hline 4015 & $1467-17$ & Gypsum & Obsidian & & 0.66 & 0.42 & $2.35^{\star}$ & 2.03 & 0.35 & 1.6 \\
\hline 4015 & $1580-36$ & Gypsum & Obsidian & & 1.08 & 0.80 & $1.94 *$ & 2.13 & 0.41 & 1.9 \\
\hline 4015 & $1548-12$ & Gypsum & Obsidian & & 1.25 & 0.80 & $2.43^{\star}$ & 2.90 & 0.56 & 2.6 \\
\hline 4015 & 12 & Gypsum & Obsidiar: & & 1.31 & 0.65 & 3.92 & 2.51 & 0.49 & 4.8 \\
\hline 4015 & 1536 & Large SN & Obsidian & 1.82 & 1.05 & 1.15 & 2.93 & 2.19 & 0.39 & 2.0 \\
\hline 4015 & 17 & Large SN & Obsidian & $1.84 *$ & 0.90 & 1.09 & 2.61 & $2.17^{\star}$ & 0.49 & 2.5 \\
\hline 4025 & 2 & Humboldt & Chalcedony & 1.44 & 144 & & $265^{\circ}$ & 186 & 068 & 39 \\
\hline 4015 & $265-1$ & Humbolot & Chatcedony & 1.66 & 1.66 & 0.75 & 4.18 & 2.57 & 0.72 & 7.3 \\
\hline 4048 & 4 & Humboldt & Obsidian & & & & $2.34^{*}$ & 2.20 & 0.40 & 2.3 \\
\hline 4015 & $957-7$ & Humboldt & Obsidian & 1.05 & 1.05 & 0.35 & $2.49^{*}$ & 1.10 & 0.52 & 1.3 \\
\hline
\end{tabular}


Table 5-6. (continued).

\begin{tabular}{|c|c|c|c|c|c|c|c|c|c|c|}
\hline Site & Ref No & Type & Material & $\begin{array}{l}\text { Base } \\
\text { Wiơth }\end{array}$ & $\begin{array}{l}\text { Stern } \\
\text { Width }\end{array}$ & $\begin{array}{l}\text { Stem } \\
\text { Lgth }\end{array}$ & Length & Width & $\begin{array}{l}\text { Thick- } \\
\text { ness }\end{array}$ & Weight \\
\hline 4040 & $6-1$ & Humboldt & Obsidian & 1.62 & 1.62 & & 3.08 & $2.17^{\star}$ & 0.58 & 4.5 \\
\hline 4040 & $3591-6$ & Humboldt & Obsidian & 1.64 & 1.64 & & 2.85 & 1.64 & 0.51 & 1.8 \\
\hline 4015 & $1574-2$ & Pinto & Obsidian & 1.31 & 1.66 & 1.09 & 3.07 & 2.01 & 0.70 & 3.8 \\
\hline 4015 & $1468-3$ & Unknown & Chert & & & & 1.71 & 1.74 & 0.36 & 1.1 \\
\hline 4015 & $1605-15$ & Unknown & Obsidian & & & & 1.32 & 2.26 & 0.26 & 0.8 \\
\hline 4017 & 1 & Unknown & Obsidian & & & & 1.35 & 1.86 & 0.56 & 1.2 \\
\hline 4015 & 26 & Unknown & Obsidian & & & & 1.50 & 1.48 & 0.53 & 1.0 \\
\hline 4041 & 7 & Unknown & Obsidian & & & & $1.60^{\star}$ & $2.11^{\star}$ & 0.66 & 1.8 \\
\hline 4015 & $1322-22$ & Unknown & Obsidian & & & & 1.63 & 1.35 & 0.51 & 1.1 \\
\hline 4015 & $1580-35$ & Unknown & Obsidian & & & & 1.92 & 2.05 & 0.44 & 1.8 \\
\hline 4015 & $303-4$ & Unknown & Obsidian & & & & 2.80 & 1.72 & 0.40 & 1.5 \\
\hline 4021 & 3 & Unknown & Obsidian & & & & 3.11 & 2.56 & 0.88 & 6.2 \\
\hline 4040 & $3575-16$ & Unknown & Obsidian & & & & 3.15 & 0.80 & 0.48 & 0.8 \\
\hline 4040 & 1 & Unknown & Obsidian & & 1.05 & & $2.22^{\star}$ & $2.12^{\star}$ & 0.39 & 2.0 \\
\hline 4054 & 2 & Unknown & Obsidian & & 1.08 & & 1.86 & 2.17 & 0.45 & 2.2 \\
\hline
\end{tabular}

PROJECTILE POINT SHAPE

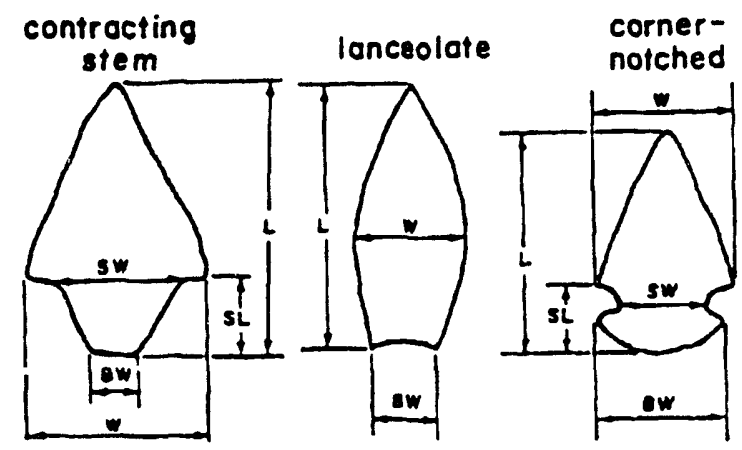

$$
\text { side- }
$$
notched

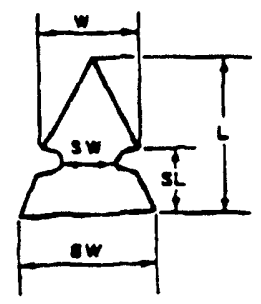

$$
\begin{aligned}
& \text { BW base widih } \\
& \text { SW stem width } \\
& S L \text { stem length } \\
& L \text { length } \\
& \text { W width }
\end{aligned}
$$

Figure 5-7. Location of metric attributes of projectile points summarized in projectile point analysis table. 


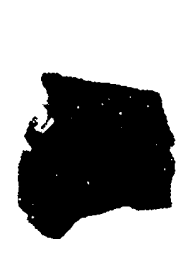

a

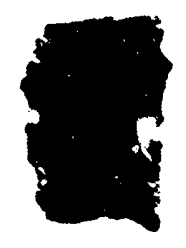

b

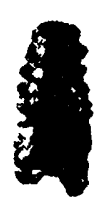

C

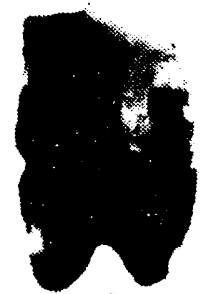

d

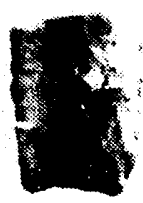

e

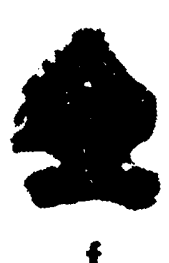

f

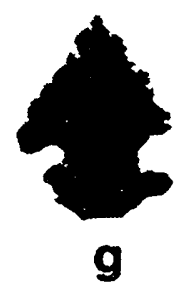

$\mathbf{g}$
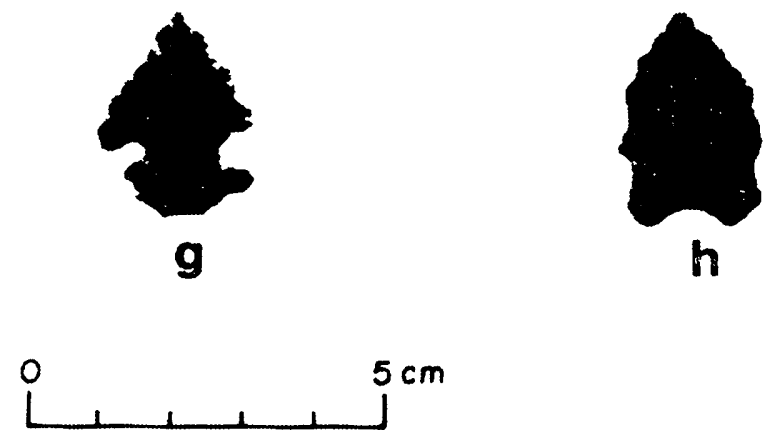

Figure 5-8. Photograph of Pinto, Humboldt and Large Side-Notched projectile points from the U19au archaeological investigations, Pahute Mesa, Nevada (see Appendix A for descriptions and reference numbers).

Gatecliff Series points are defined as "medium to large (greater than 1 gram in weight) contracting stem projectile points" with notch openings greater than $60^{\circ}$ (Thomas 1981:23). This series, then, is further subdivided into the Gatecliff Split-stem style, which is marked by the presence of a concave base, and the Gatecliff Contracting Stem style, which has a straight to convex base (Thomas 1981:23). On the basis of radiocarbon dates from Gatecliff Shelter, Thomas (1981:33-37) argues that both styles date between 5000 and 3200 radiocarbon years ago. Although he (Thomas 1981:33) apparently recognizes the existence of a "larger, cruder, (and) earlier" Pinto style of atlatl dart point as distinct from his Gatecliff Split-stem style,
Thomas does not provide a mechanism to separate the two types.

Only one complete obsidian projectile point from the collection at U19au has been assigned to the Pinto series (Figures 5-8h).

Humboldt Series - Six projectile points have been classified as belonging to the Humboldt Series (Heizer and Clewlow 1968:68). These points are lanceolate in overall shape and are typified by a lack of definable shoulders and concave bases (Figures 5-8 a-e). Four of the points are obsidian, the remainder chalcedony.

The age of Humboldt Series projectile points in the Great Basin is controversial. Hester (1973:24-26) postulates that these 
points date between 5,800 and 3,000 years B.P. However, Thomas (1981:17) feels that the Humboldt Series is a relatively poor time marker and points to evidence from Gatecliff Shelter indicating they date between 5,000 and 1,250 years B.P. In southern Nevada, radiocarbon dates from Coin Creek Dunes (Williams and Orlins 1963:12, Table 11, Plate 2a), Stuart Rockshelter (Shutler, Shutler, and Griffith 1960:7-8, 12, Plate 3), and the Barnett Site of Ash Meadows (Muto, Mehringer, and Warren 1976:170-172, figs. 3, 4) are associated with "Humboldt Concave Base A" and "Humboldt Indented Base" projectile points and date those styles between 5,200 and 3,800 years ago. We concur with Thomas (1981:17) that, at present, the Humboldt style of projectile point is a poor time marker.

Large Side-notched Series - Two (1.6\%) complete obsidian projectile points have beer assigned to the Large Side-notched series (Figure 5-8 $f, g$ ). One has a slightly concave base, and a lateral break near the tip has been repaired. The other retains original flake surface, and the base has only been partially finished. Large side-notched points, although not common, consistently occur throughout the Great Basin into the High Plains (Mason and Irwin 1960). These points have been variously termed Bitterroot Sidenotched (Swanson 1972:108-113), Northern Side-notched (Gruhn 1961:129-130), Madeline Dune Side-notched (Riddell 1960:18), Cold Springs Side-notched (Butler 1978:6-8), Elko Side-notched (Heizer, Baumhoff, and Clewlow 1968:6, Figure 1a-h), and Martis Side-notched (Elston et al. 1977:64).

Gatecliff and Gypsum Series - Thomas (1981:22-24, 33-36) introduced the Gatecliff Series to incorporate both the traditional Pinto Series and the Elko Contracting Stem style of projectile point. He defined Gatecliff Series points as "medium to large (greater than 1 gram in weight) contracting stem projectile points" with notch openings greater than $60^{\circ}$
(Thomas 1981:28). This series is further subdivided into the Gatecliff Split Stem style, marked by the presence of a concave base, and the Gatecliff Contracting Stem style, which has a straight to convex base. This second style has also been defined as Gypsum (Thomas 1981:23), and that is the name used here.

Fourteen (11.4\%) projectile points have been assigned to Gatecliff Split Stem (Figure 5-9 a-e). This type is characterized by a relatively straight stem with a basal notch. Basal morphology ranges from slightly expanding to slightly contracting with slight to relatively deep notches. Material type is dominated by obsidian (50\%), followed by chert $(28.5 \%)$ and shalcedony $(21.4 \%)$. One specimen retains the original flake surface. Another lacks a base and is tentatively assigned to this type.

Gypsum projectile points are typified by relatively square shoulders with a sharply contracting stem and a slightly convex to straight base (Figure 5-9 $f-j$ ). Six (4.9\%) specimens have been assigned to this category. Material type is dominated by obsidian (83.3\%), followed by chert (16.6\%).

Elke Series - Despite their common occurrence in Great Basin archaeological sites, there has been considerable controversy concerning the age of Elko Series projectile points (Heizer and Hester 1978:159-160; Thomas 1975). O'Connell (1967:132-135) has proposed that the Elko Corner-notched and Elko Eared dart point styles mark a period between about 3500 and 1,400 years ago. But Aikens $(1970: 45,46,51)$ has argued that because Elko-style dart points occurred throughout the strata of Hogup Cave $(7,000$ to 600 years B.P.), they are not time-sensitive artifacts. Thomas (1981:22) reports that 98 percent of the 274 Elko Series projectile points from Gatecliff Shelter were found in strata dated between 3,300 and about 1,250 years B.P. Elsewhere, Elko Series dart points have been found stratigraphically below Rose 
Spring Series arrowheads and above a radiocarbon date of 2,930 years B.P. at Wagon Jack Shelter (Heizer and Baumhoff 1961:130, Table 2; Hubbs, Bien, and Suess 1963:209-210); stratigraphically mixed with Gypsum-style projectile points at the Rose Spring Sites where they have been radiocarbon dated between 2,900 and 2,240 years B.P. (Clewlow, Heizer, and Berger 1970:Table 2; Lanning 1963:268, Table 3); stratigraphically above a radiocarbon date of 3,320 years B.P. at South Fork Shelter (Heizer, Baumhoff, and Clewlow 1968:25-26, Table 1); and scattered throughout the deposits of O'Malley Shelter, the Scott Site, Newberry Cave, and Civa II Rockshelter (Busby 1979:Table 3; Fowler, Madsen, and Hattori 1973: Tables 1, 4, 27; Grosscup 1960:16-17; Smith et al. 1957). From this data, it appears that the Elko Series projectile points found at
U19au date sometime between 3,500 and 1,300 years B.P.

The Elko Series, as originally defined by Heizer and Baumhoff (1962:128, Figures 3n$x, 4)$ and Heizer, Baumhoff, and Clewlow (1968:6-8, Figures 11-q, 2, 3a-k), includes a variety of corner-notched, "eared," sidenotched, and contracting stem projectile points that, due to their size (greater than 3 grams), are believed to have been hafted on atlatl darts. Thomas (1978:469-471) has examined the relationships between known (hafted) arrowheads and dart points and concludes that, in general, this assumption is probably valid.

Thirty-eight $(31.1 \%)$ projectile points have been assigned to the Elko Series (Figure 5-10). Included in this series are the Elko Eared and Elko Corner-notched varieties.

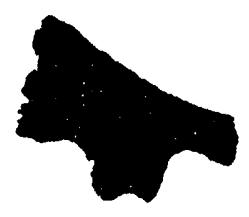

a

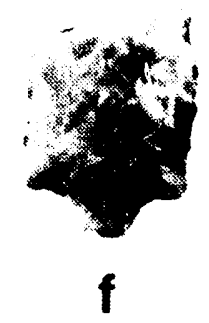

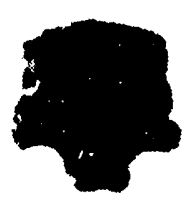

b

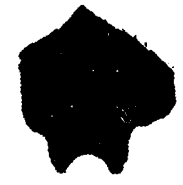

C
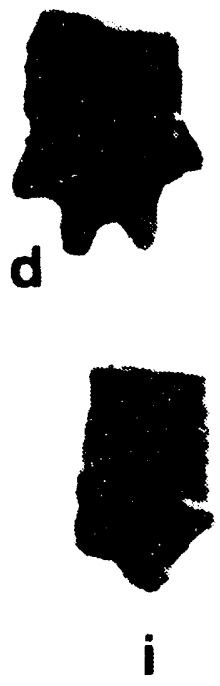
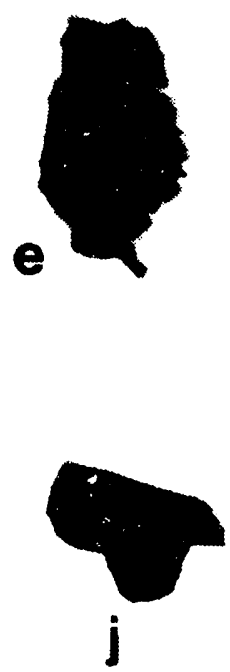

Figure 5-9. Photograph of Gatecliff and Gypsum projectile points from the U19au archaeological investigations, Pahute Mesa, Nevada. 
Following Thomas (1983:180), cornernotched projectile points with a basal width greater than $10 \mathrm{~mm}$ are assigned to the Elko Series. Eleven specimens have been assigned to the Elko Eared and 27 to the Elko Corner-notched varieties.

Among the Elko Eared specimens, basal concavity ranges from slightly concave to deeply notched. Material type is dominated by chalcedony $(45.4 \%)$, followed by obsidian (36.3\%) and chert (18.1\%).

Among the Elko Corner-notched specimens, basal morphology ranges from straight to convex. Material type is dominated by chert (33.3\%) and chalcedony (33.3 percent), followed by obsidian (25.9\%), welded tuff (3.7\%), and quartzite (3.7\%). One specimen appears to have been resharpened, and another has been reworked on a midsection break. Two projectile points are complete.

Rosegate Series - In the Great Basin literature, small corner-notched projectile points have traditionally been called Rose Spring Corner-notched and Eastgate Expanding Stem (Heizer and Baumhoff 1961:123-124, fig. 2; Lanning 1963:352, Plate 7c). Thomas $(1981: 19-20,30-32)$ has proposed that the term Rosegate Series be used for all small corner-notched points with basal widths less than or equal to $10 \mathrm{~mm}$ and with expanding stems. He suggests that both Rose Spring Corner-notched and Eastgate Expanding Stem styles merge in morphological features and represent a single temporal indicator.

Clewlow (1967:144) was the first to suggest that Rose Spring Corner- notched and Contracting Stem points could be used as

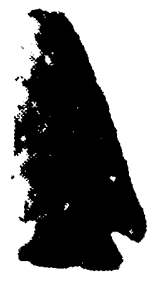

a

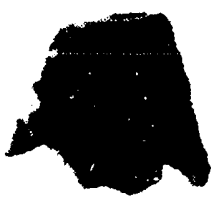

f

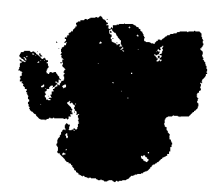

b

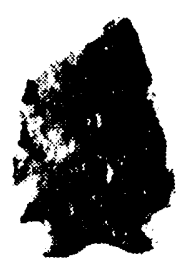

g

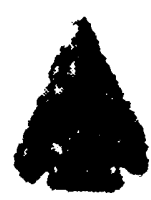

C

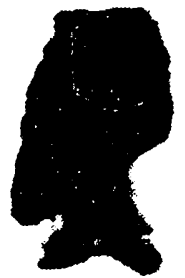

h

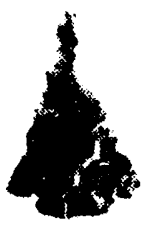

d

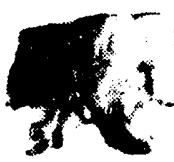

i

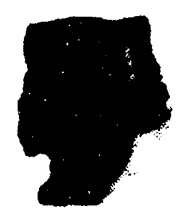

e

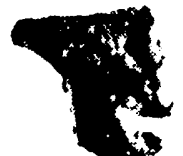

j

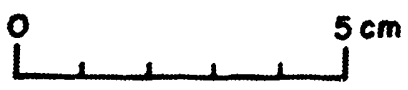

Figure 5-10. Photograph of Elko projectile points from the L'19a:」 archaeological investigations, Pahute Mesa, Nevada (see Appendix A for reference number). 
time markers in the western Great Basin, but his argument was based on stratigraphic superpositioning rather than on absolute dates. Heizer and Hester (1978:162, Table 6.4), Pippin et al. (1979:Table 9), and Thomas (1981:30-32) subsequently have summarized the radiocarbon evidence for the age of this point style and conclude that it dates between about 1,500 and 800 radiocarbon years ago.

Twenty (16.3\%) projectile points have been assigned to the Rosegate Series (Figure 5-11). Basal morphology ranges from straight to slightly convex with corner notches ranging from slightly to fairly deep. Material types are dominated by chert ( $50 \%)$, followed by chalcedony (35.0\%) and obsidian (15.0\%). One specimen is thermally altered.

Desert Side-notched Series - The Desert Side-notched style of projectile point as defined by Baumhoff (1957:10) and outlined by
Baumhoff and Byrne (1959) are small triangular arrow points typified by deep side notches and a slightly concave base, occasionally notched as well.

Twelve (9.8\%) small triangular projectile points have been classified as the Desert Side-notched series. These artifacts are typified by relatively deep side notches and bases that range from straight to concave (sometimes also notched) (Figure 5-12 a-e). Two projectile points retain the original flake surface. Five specimens are complete. Material types are dominated by obsidian (50\%), followed by chert (33.3\%) and chalcedony (16.6\%).

Cottonwood Series - Cottonwood projectile points are usually similar in size and shape to Desert Side-notched points except they lack the side notches. Eleven (9.0\%) obsidian triangular projectile points have been assigned to the Cottonwood Triangular series.
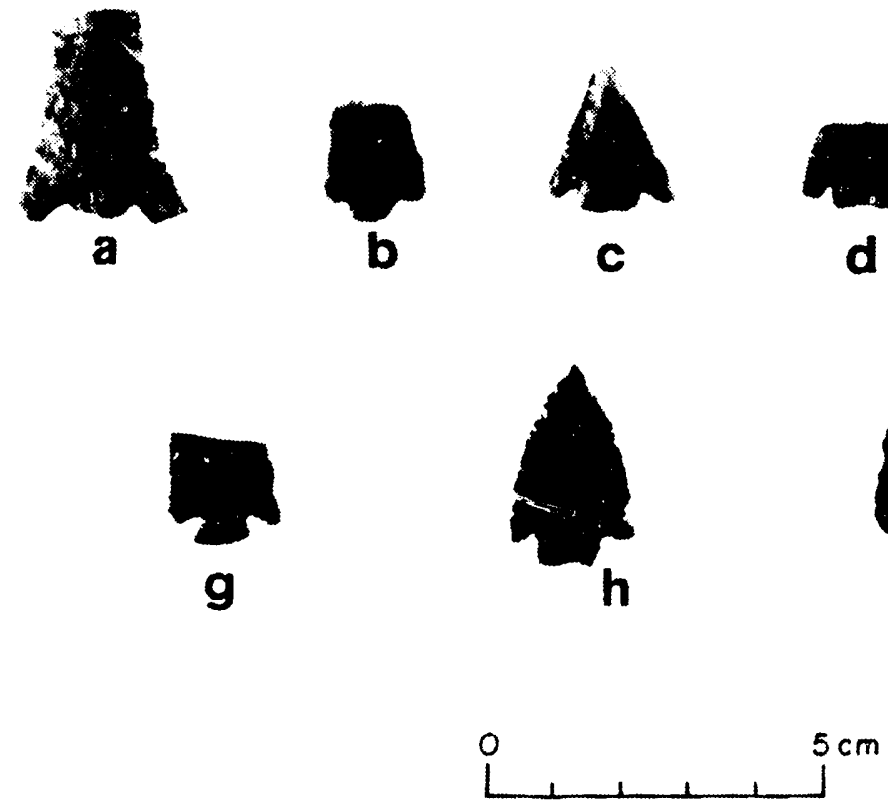
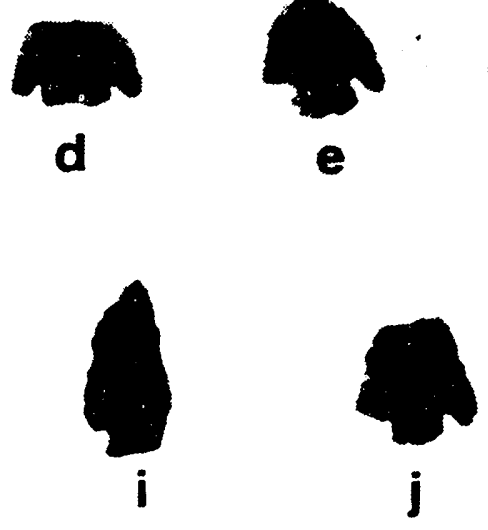

Figure 5-11. Photograph of Rosegate projectile points from the U19au archaeological investigations, Pahute Mesa, Nevada (see Appendix A for reference number). 
Basal morphology is variable, ranging from relatively straight to concave (Figure $5-12 f-j$ ). One specimen retains the original flake surface. Six projectile points are complete.

Drills and Penforaters - Eighteen drills or perforators were recovered from the project area (Table 5-7). Two specimens are fashioned from Elko Corner-notched projectile points; one may be fashioned from an indeterminate projectile point. Eleven specimens are modified flakes (Figure 5-13). Flake modification ranges from slight to predominant flake scar coverage. Material type is dominated by chalcedony (38.8\%), followed by chert (22.2\%) and obsidian ( $16.6 \%$ ).

Unidentified Projectile Points - Twelve $(9.8 \%)$ specimens are considered untypeable; two might fall within the Elko series. Eleven of these points are obsidian (91.6\%); one is chert (8.3\%).

\section{Groundstone Artifacts}

One hundred seventeen groundstone artifacts were recovered during the archaeological investigations. Twelve are manos or mano fragments (Figure 5-14 b-c); the remaining 105 are millingstones or millingstone fragments (Figure 5-15). All the millingstones were made from the locally available, moderately welded tuff and display considerable variation in the amount of use. Three of the mano fragments are a reddish quartzite and fit together. The remaining 9 manos or fragments are of moderately welded, locally available, welded tuff.

\section{Hammerstones}

Hammerstones (Figure 5-14 a) are defined as pieces of natural or modified lithic raw material that exhibit battering, presumably from striking another surface to modify it. Nineteen hammerstones have been identified in the U19au collections. These items are predominantly rounded pieces of lithic raw material that exhibit battering on ridges. Four $(21 \%)$ were fashioned from cores. A preponderance of these hammerstones exhibit mod- erate to heavy battering; only a few show minimal modification. Raw material for these artifacts is dominated by chalcedony $(63.1 \%)$, followed by chert (36.8\%).

\section{Miscellaneous Artifacts}

Miscellaneous artifacts include a pumice pipe (Figure 5-15d), a shaped pumice ball, and several pendant fragments, all from 26 Ny 4040 . The pipe, found at Feature 2, is tubular and biconically drilled. The overall shape tapers, and the outside diameter of the wider end is $23.9 \mathrm{~mm}$, the inside $16.7 \mathrm{~mm}$. The outside diameter of the narrower end is $22.9 \mathrm{~mm}$, with an inside diameter of $10.6 \mathrm{~min}$. The minimum diameter of the hole is $2.7 \mathrm{~mm}$. The shaped pumice ball (Figure 5-16c) was found at Feature 1. It has a maximum diameter of $39.2 \mathrm{~mm}$ and is made from rough pumice which does not clearly show striations from shaping.

The first pendant fragment (Figure 5-16a) is made from a soft talc-like white stone. It has been shaped, has rounded corners, and is well polished. There are no decorative incisings evident on the fragment. The fragment is $20.3 \mathrm{~mm}$ in length, $8.7 \mathrm{~mm}$ in width, and $2.5 \mathrm{~mm}$ in thickness. The other specimen is composed of two fragments (Figure 5-16b) of a greenish slate-like material fit together. Shaping stations are still quite evident, and the pendant tapers in width and thickness from one end to the other. The length is 38.8 $\mathrm{mm}$, the maximum width $8.5 \mathrm{~mm}$, and the maximum thickness $2.4 \mathrm{~mm}$. At the opposite end, the width is $6.1 \mathrm{~mm}$, and thickness is 1.3 $\mathrm{mm}$.

\section{Historic Artifacts}

The majority of historic artifacts collected were found during data recovery at the structure sites, 26Ny4021 and 26Ny4040. Several of the other archaeological sites recorded in the vicinity had historic artifacts in their assemblages, but since these sites were not in danger of being impacted, most of the artifacts were not collected. Three artifacts, all from different sites, are exceptions (Figure 


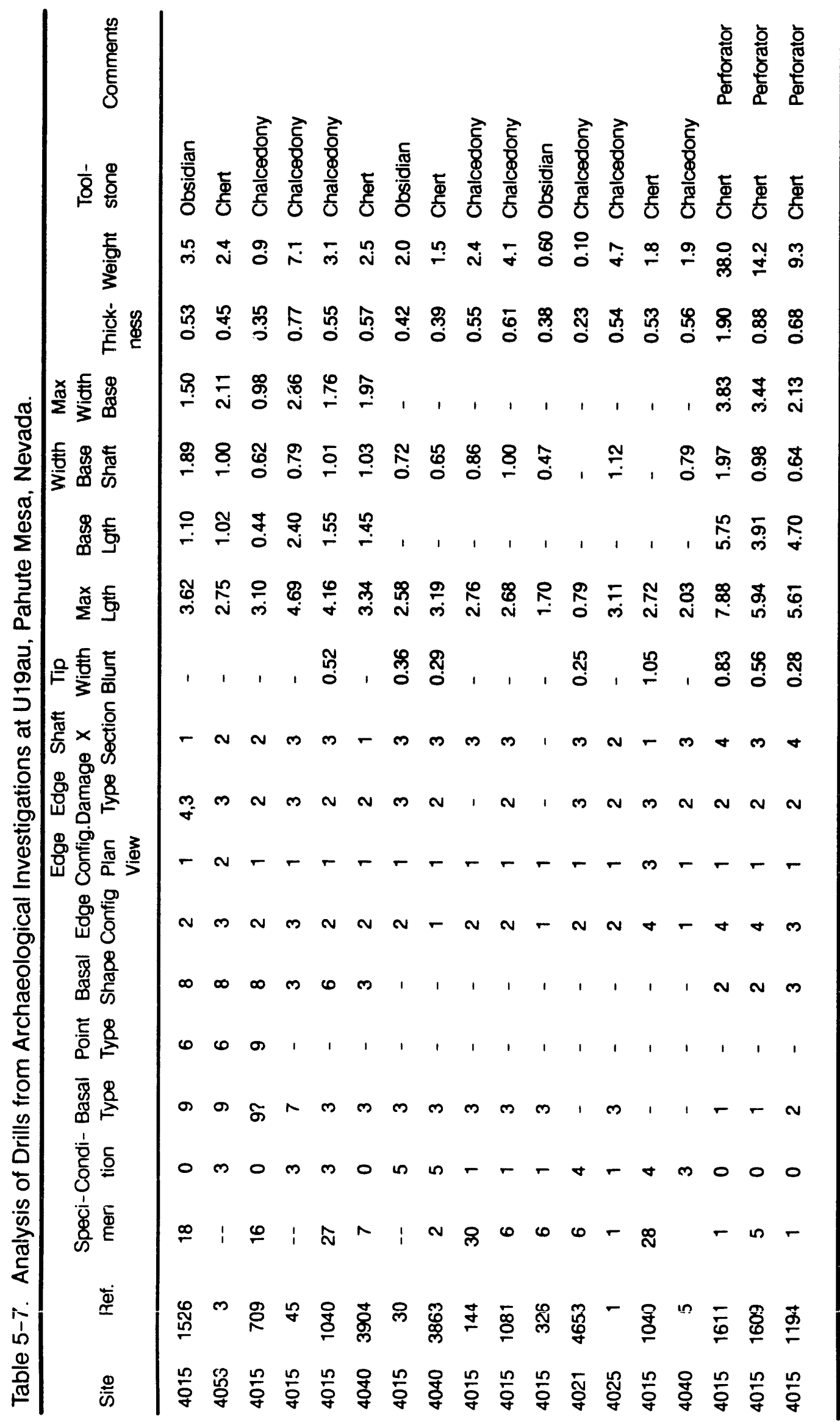




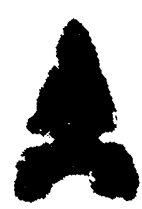

a

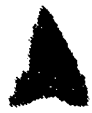

$\mathbf{f}$

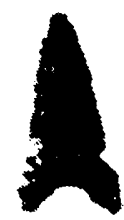

b

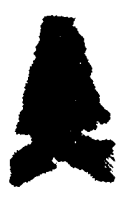

C

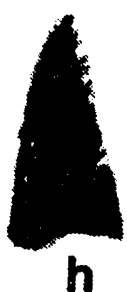

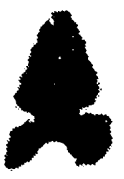

d

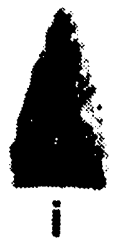

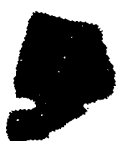

e

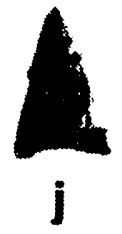

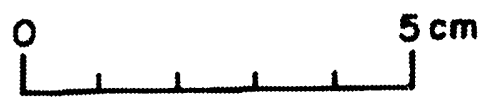

Figure 5-12. Photograph of Cottonwood and Desert Side-Notched projectile points from the U19au archaeological investigations, Pahute Mesa, Nevada (see Appendix A fo:

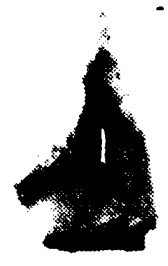

a

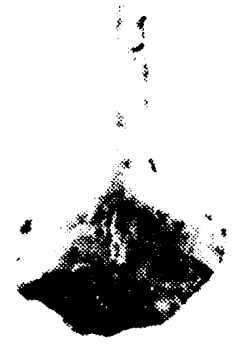

e

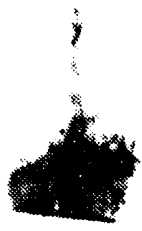

b

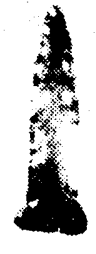

f
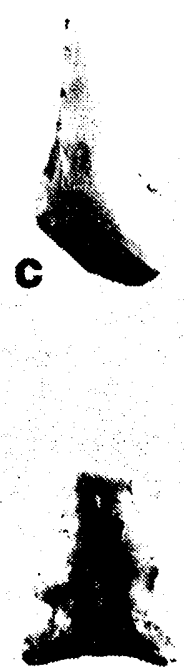

$\mathbf{g}$
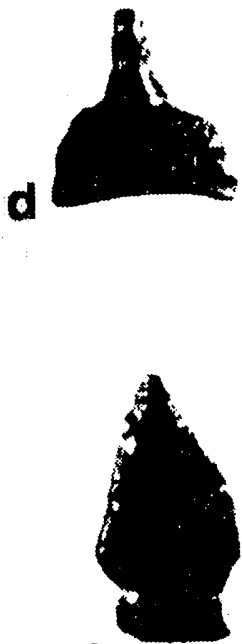

h

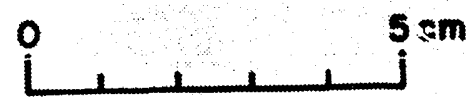

Figure 5-13. Photograph of drills from the U19au archaeological investigations, Pahute Mesa, Nevada (see Appendix A for descriptions and reference numbers). 


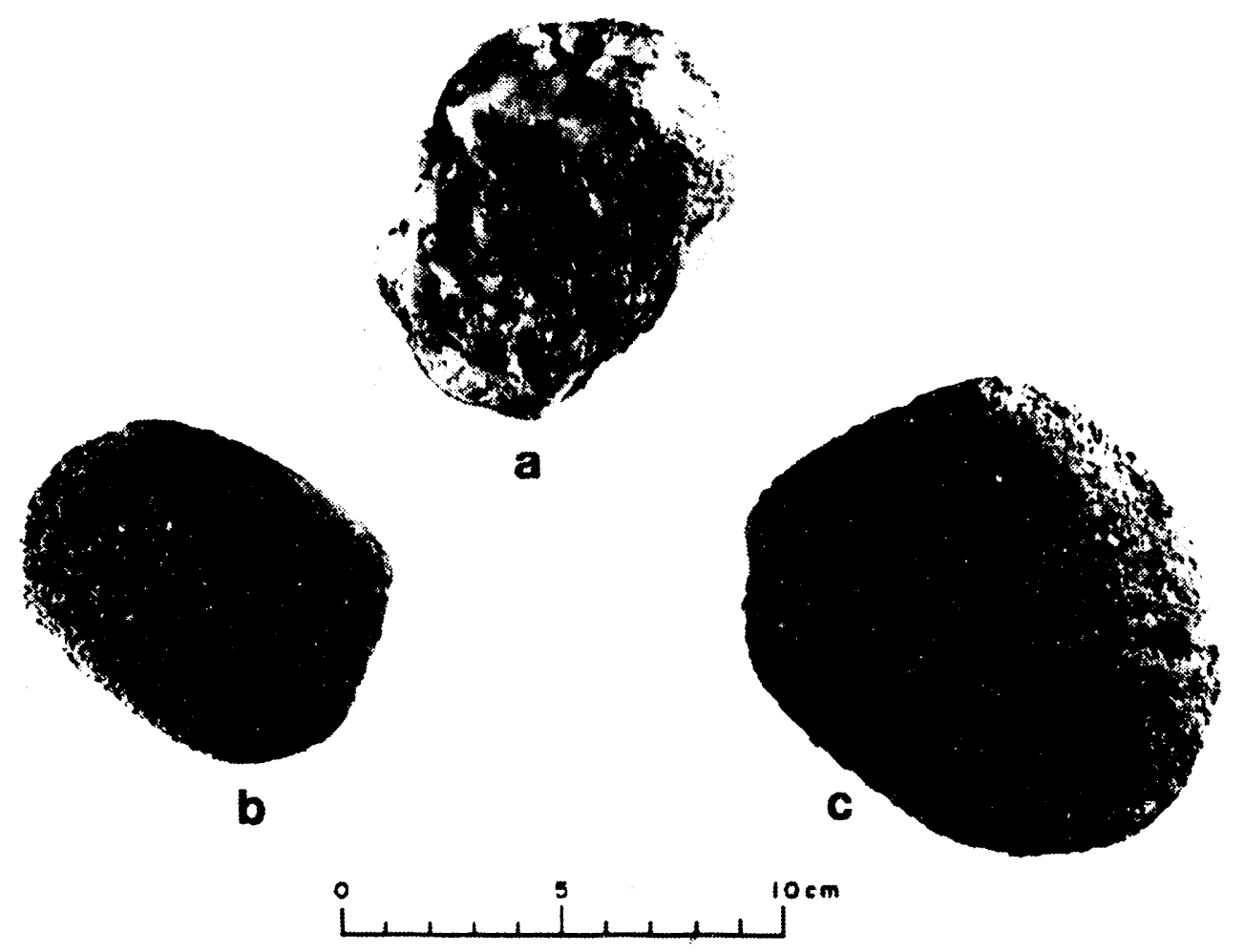

Figure 5-14. Photograph of a hammerstone and manos from the U19au archaeological investigations, Pahute Mesa, Nevada (see Appendix A for descriptions and reference numbers).

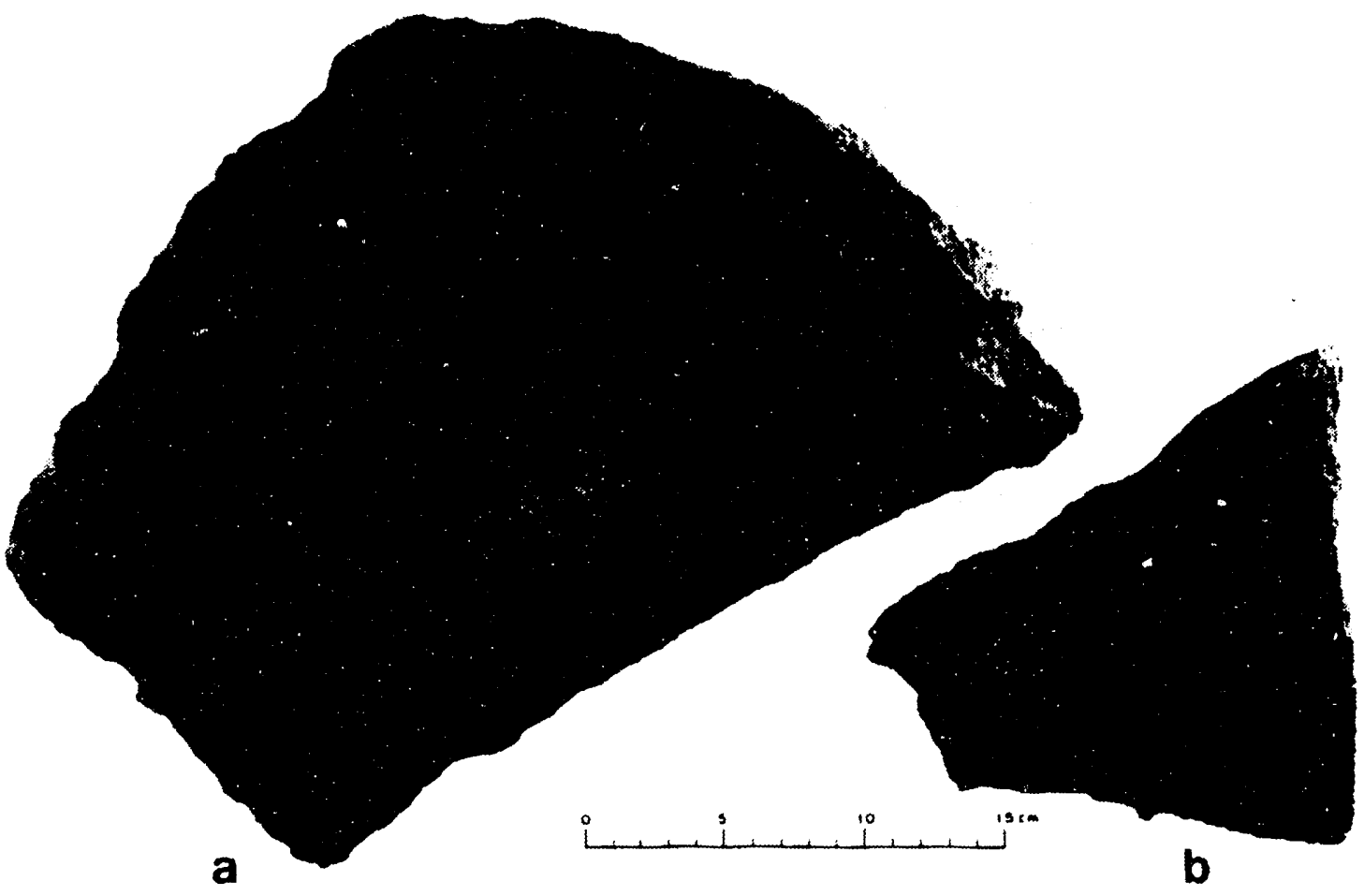

Figure 5-15. Photograph of millingstones from the U19au archaeological investigations, Pahute Mesa, Nevada (see Appendix A for descriptions and reference numbers). 


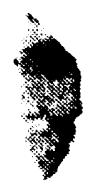

a b

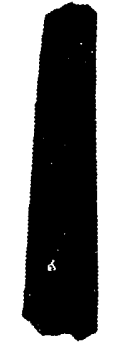

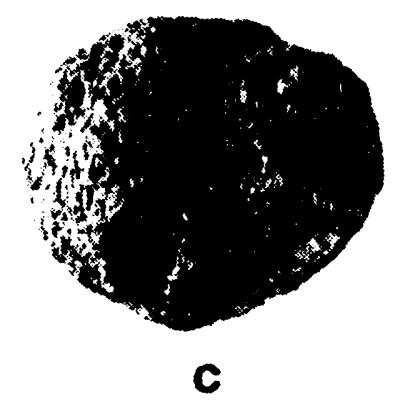
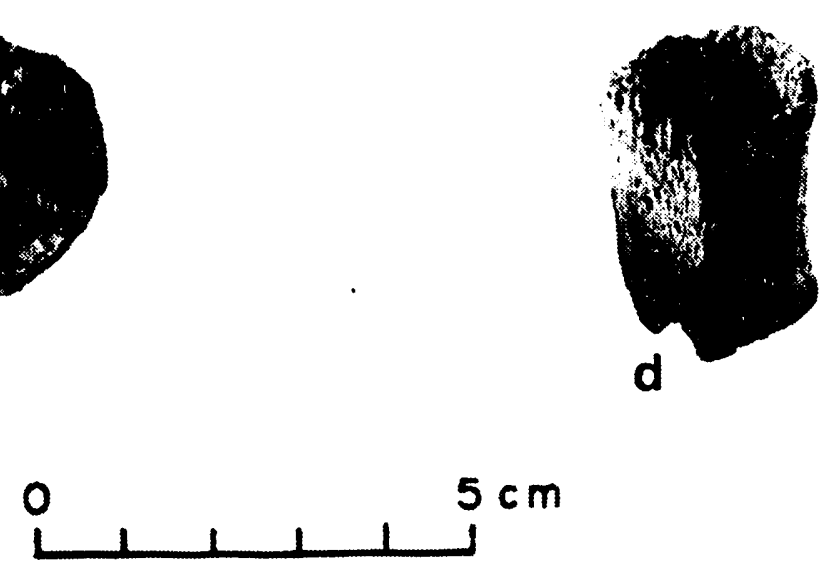

Figure 5-16. Photograph of miscellaneous prehistoric artifacts from the U19au archaeological investigations, Pahute Mesa, Nevada (see Appendix A for descriptions and reference numbers).

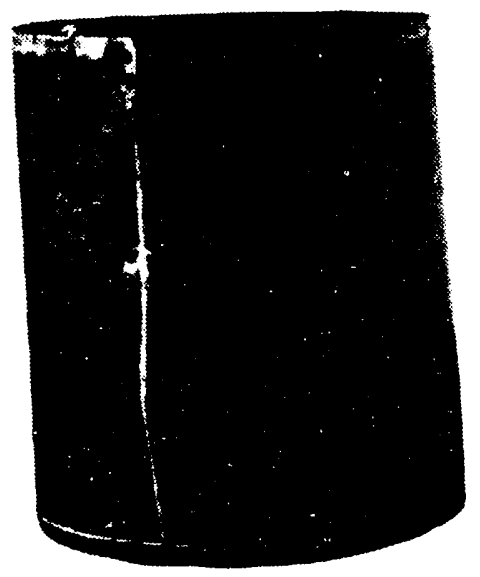

a
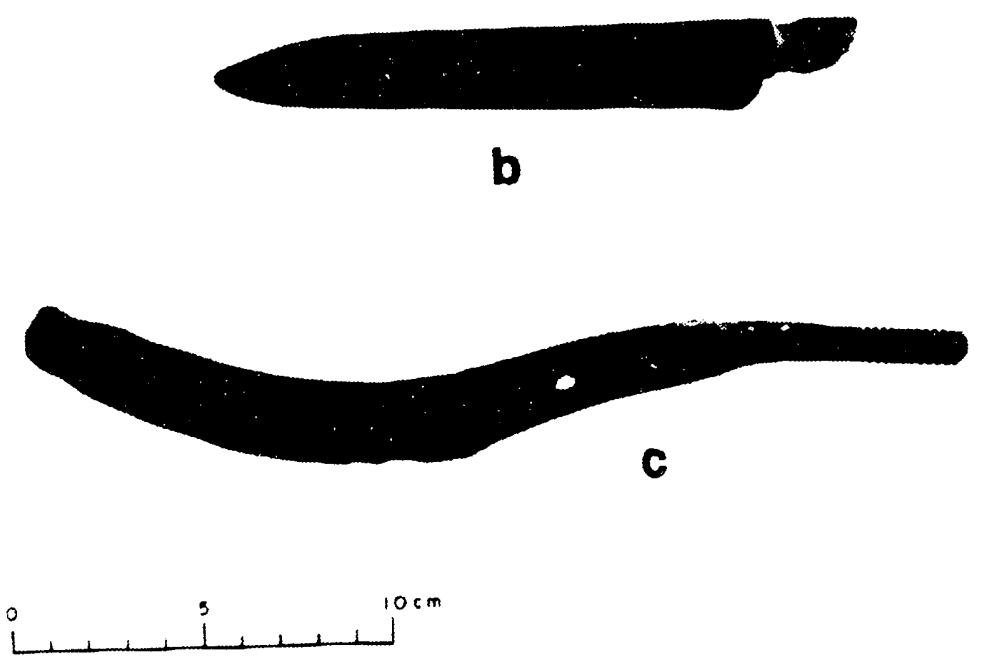

Figuie 5-17. Photograph of miscellaneous historic ariifacts irom the Uigau archaeoiogical investigations, Pahute Mesa, Nevada (see Appendix A for descriptions and reference numbers). 
$5-17)$. One is a steel knife blade recovered from the vicinity of Feature 2, a brush structure at $26 \mathrm{Ny} 4023$. This knife appears to be part of a "table setting" rather than a general-purpose knife and is missing its handle. It has been sharpened and bears the two-line inscription "JOSH KI \& SONS", "SHEFEIELD" (italics represent unclear or projected letters). The blade is $5.5 \mathrm{in}$. long, and the broken handle extends another inch; the width is 0.85 . in at a maximum, near the haft. The second artifact is a sickle blade of iron forged from square stock with a shank threaded for a screw-on handle. The $9.5 \mathrm{in}$. blade is recurved and has been sharpened on both sides. The flattened portion of the blade is 7 in. long and $0.9 \mathrm{in}$. wide. This artifact was an isolated find, 26Ny4047, cached in a small, wind-eroded opening in a welded tuff cliff. The final historic artifact, recovered from 26 Ny4053 is a soldered-seam can, with a diameter of $4 \mathrm{in}$. and length of $4.65 \mathrm{in}$. Because this can's lid was neatly removed, it was probably used as a container or cup.

Beads - Four of the five beads (Figure 5-18a-e) recovered during archaeological investigations were recovered from 26Ny4040. All are glass and all are different. Two are small, round, blue glass beads: one $3.1 \mathrm{~mm}$ in diameter by $2.2 \mathrm{~mm}$ in thickness with a hole $1.3 \mathrm{~mm}$ in diameter, the other 4.0 $\mathrm{mm}$ in diameter by $3.0 \mathrm{~mm}$ in thickness with a hole of $1.3 \mathrm{~mm}$. Both of these beads were found during excavations at Feature 3 . A larger, darker blue, hexagonal bead with an outer diameter of $4.4 \mathrm{~mm}$ by a thickness of $6.2 \mathrm{~mm}$ and a hole of $2.3 \mathrm{~mm}$ was found in association with Feature 2 of this site. A large, opaque white, round bead with a diameter of $5.5 \mathrm{~mm}$, a thickness of $4.5 \mathrm{~mm}$, and an opening of $1.5 \mathrm{~mm}$ was found near Feature 1. The only other bead was found at 26Ny4021, during the excavations near the heartr! in Feature 1. With a length of $5.7 \mathrm{~mm}$, a thickness of 3.9 $\mathrm{mm}$, and a diameter of $2.0 \mathrm{~mm}$, it was similar to the white opaque bead described above.
Buttons and Fasteners - Two buttons, a steel rivet (Figure 5-18 g, h, f), and a brass brad (Figure 5-19a) were recovered from 26Ny4040. Both the buttons were white glass, four-hole buttons. One was plain, and the others had a reddish brown painted pattern on the face. The plain button is $11.1 \mathrm{~mm}$ in diameter and $3.1 \mathrm{~mm}$ thick; the painted button is $11.5 \mathrm{~mm}$ in diameter and $4.4 \mathrm{~mm}$ thick. Additional clothing fasteners included a steel rivet-type button similar to those found on "button fly" blue jeans and an oval brass brad or stud, similar to those found on leather jackets. The dimensions of the rivet are $17.1 \mathrm{~mm}$ by $5.8 \mathrm{~mm}$. The length of the brad is $8.8 \mathrm{~mm}$, the width is $6.9 \mathrm{~mm}$; one of the two prongs which attached the brad is missing.

Miscellaneous Historic Artifacts - Miscellaneous artifacts include a cut steel nail fashioned into an awl (Figure 5-19 e) and several pieces of lead (Figure 5-19 b-d), probably portions of bullets or shot. The nail has been ground into a tapering round point with a length of $78.8 \mathrm{~mm}$, a maximum thickness of $8.0 \mathrm{~mm}$ and a point of about $1.0 \mathrm{~mm}$. The lead fragments include a lead ball about $9.4 \mathrm{~mm}$ in diameter and two irregular scraps of lead, one 26.4 by 17.6 by $9.8 \mathrm{~mm}$, the other 12.0 by 7.9 by $2.4 \mathrm{~mm}$.

\section{Analysis Of Pottery From U19au}

Cari L. Lockett

A total of 543 brownware and 3 greyware potsherds were collected from U19au during the survey, testing, and mitigation phases.

\section{Spatial Distribution}

The sherd collection from U19au is distributed into 27 spatially segregated localities consisting of from 1 to over 100 sherds. These concentrations or localities were determined by looking at clustering of grid locations of the individual sherds. Figure 5-20 shows the location of these concentrations in relation to the collection grid for the project.

The concentrations of individual sherds, using site, reference, and specimen numbers 
2

a

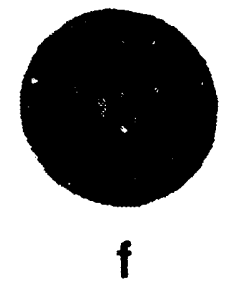

8

b

C

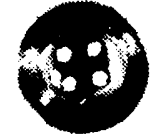

$\mathbf{g}$ $\infty$

d $\quad 0$

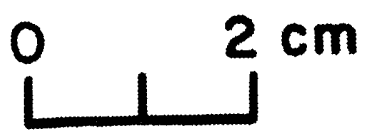

Figure 5-18. Photograph of buttons and beads from the U19au archaeological investigations, Pahute Mesa, Nevada (see Appendix A for descriptions and reference numbers).

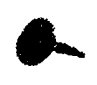

a

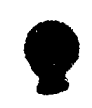

b

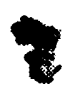

C

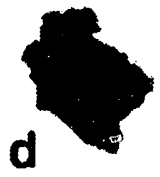

h

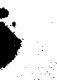


and grid locations, were checked against the artifact catalog and a computer printout of the project area. Sherds clustering in the same location were given a concentration number, examined for sherd consistency within that concentration, and compared to other concentrations in the project area. Features providing clues to vessel distinctions included surface finish (color, finishing technique, scraping technique, and decoration), temper, and sherd shape. Diagnostic features providing clues to vessel forms included rim variety, as well as basal and body shapes.

All were compared and determined relative to other known (reconstructed) vessel forms (Figure 5-21). Three types of conical vessels have been identifiec: Type $A$ has straight walls and rims and a rounded or squared base; Type $E$ is round shouldered, having an incurving rim of $1 \mathrm{~cm}$, straight walls and rims, and i rounded to squared base: Type $\mathrm{C}$ is rounder bodied, with more protruding shoulders and an incurving rim. Type B and $F$ are variations of wide-mouthed, globular vessels - Type B is narrow necked; Type $F$ is wide- mouthed with a more outflaring rim; both round and flat bases are represented. Types $D$ and $G$ are slight variations of a cup or scoop. Type $D$ being slightly deeper and steeper sided than Type $G$. Type $H$ is a classic bowl form.

Except for those complex locations in which several pots were represented, each location appears to be autonomous, having only one vessel or a single sherd from a single vessel. In total, 39 vessels are represented in the sherd collection from U19au (Table 5-8). A description of the diagnostic features of the sherds/vessels per each locality are described below. Selected reconstructed and interpreted vessels are presented in Figures 5-22 and 5-23.

\section{Sherd and Vessel Descriptions per Concentration}

Concentration \#1 - Concentration \#1 consists of 10 sherds, all fromi site $26 \mathrm{Ny} 4040$, a temporary camp composed of three brush structures and a hearth feature. Sherds were distributed throughout the area which was surface collected and subsurface scraped. The sherds were from four separate vessels:

Vessel \#1 is thick (6 mm) and appears to be conical. No rims are present. It has a rough-scraped interior and exterior, and the temper is coarse sand. Vessel size cannot be determined.

Vessel \#2 is cilso interpreted as conical. It is thick $(6.5 \mathrm{~mm})$ anc' has a straight rim. The interior is roughly sc aped. The exterior is semismooth with uncefined scrape marks, but it is not floated. The clay body is finegrained, and the temper is medium to fine.

Vessel \#3 (Figure 5-27 a), an unknown vessel form with a slightly incurving rim, is probably conical. The vessel is thick $(6.2$ $\mathrm{mm}$ ). The interior is horizontally scraped. The exterior is rough and may be impressed, cor-

Table 5-8. Pottery Vessels Identified in the U19au Project Area.

Project Name:

U19au/As
No.Nessel Types:

39 Vessels Or Vessel Fragments:

12 Type A/E/C Conical

(8 Possit: Conical)

1 Type H Bowl

3 Type D/G Cups

3 Unknown Globular

2 Unknown Greyware

10 Unknown Vessel Forms 
rugated, or tooled. Sherd size is small, and interpretation difficult. The temper is moderately coarse sand. Vessel size cannot be determined.

Vessel \#4 is an unknown vessel form with a rounded, incurving rim. The rim sherd curvature indicates a very round body, possibly a round bow'. The vessel is thick $(5.8 \mathrm{~mm})$. The interior is horizontally scraped over a floated surface, as if for decoration. The exterior is roughly scraped with small sand drags present. The exterior appears semifloated and slightly burnished. The temper is medium fine sand. Vessel size cannot be determined.

Cencentration \#2 - Concentration \#2 (Figure 5-24 and 5-22) consists of 69 sherds from a single vessel. This pot drop was collected from site $26 \mathrm{Ny} 4051$ during the initial survey of the project area. Since this area was not included in the surface collection, no additional sherds were collected. The vessel has been partially reconstructed and represents approximately one-third of a Type E conical vessel (Figure 5-21). The vessel has thin $(5 \mathrm{~mm})$, straight walls and a flat, slightly incurving (1 $\mathrm{cm}$ ) rim. The interior is roughly scraped with horizontal strokes. The exterior is semismooth and appears to have been floated. The exterior body is very red (from the clay and/or from firing). The temper is fine sand and very micaceous. Vessel size is $23 \mathrm{~cm}$ diameter at top and approximately $25 \mathrm{~cm}$ long. The basal features are unknown although one large reconstructed segment has the beginning of the basal construction similar to the vessel in Concentration \#4 (semisquared base).

Concentration \#3 - Concentration \#3 consists of five sherds from what appear to be two separate vessels. Four sherds are reconstructed and form a po: segment (Figure 5-23); the other sherd is singular. This concentration was collected from a portion of site 26 Ny 4049 during the initial survey. This area was not included in the surface collection; therefore, no additional sherds were col- lected. Site $26 \mathrm{Ny} 4049$ is a temporary camp/ lithic scatter with a brush structure. The site has four pottery Concentrations: $3,4,5$, and 8. Descriptions appear below.

Vessel \#1 represented in Concentration \#3 is thick $(7 \mathrm{rmm})$ and straight walled. The rim is rounded and slightly incurving $(1 \mathrm{~cm})$. The interior finish appears patted and then srnoothed with horizontal strokes. The exterior is semirough and appears to have a paddle and anvil (irregular) finish followed by vertical scraping. The clay body is very red. The temper is moderately coarse sand with unidentified white inclusions and mica. The vessel size is approximated at $21 \mathrm{~cm}$ in diameter. Length and basal features are unknown. The sherds appear to be from a conical vessel form.

The single sherd, vessel \#2, is thin ( $5 \mathrm{~mm})$, very red, and made of a very fine clay body. The temper is sand with quartz inclusions. The interior is scraped irregularly. The exterior has undefined scrape marks and possible floating. The vessel form cannot be determined.

Concentration\#4 - Concentration \#4 (Figure 5-25 and 5-23) consists of 18 sherds from a single Type $C$ conical vessel. This pot drop was collected from a portion of site $26 \mathrm{Ny} 4049$ described above during the initial survey of the pad. Since this area was not included in the surface collection, no additional sherds were collected. The vessel has been partially reconstructed and represents approximately one-third of a conical vessel. It is moderately thick $(6 \mathrm{~mm})$, is straight walled, and has a flattened and slightly incurving $(1 \mathrm{~cm})$ rim. The interior is patted and horizontally scraped. Coils are visible. The exterior is patted and irregularly to vertically scraped. The temper is medium coarse sand. Vessel size is estimated at $24 \mathrm{~cm}$ in diameter and $25 \mathrm{~cm}$ in height. The base is partiaily reconsirucieof. has a wide, semisquared (i.e., more flat than rounded or pointed) form, and is approximately $10 \mathrm{~cm}$ wide. 
Concentration\#5 - Concentration \#5 consists of a single sherd of unidentified greyware. The vessel size and form cannot be determined.

Concentration \#6 - Concentration \#6 consists of three sherds from a single vessel identified as a cup or scoop. This concentration was collected from a temporary camp/lithic scatter (26Ny4053) during the initial survey. This area was not included in the surface collection; therefore, no additional sherds were collected. The vessel has been partially reconstructed (Figure 5-26 and 5-23) and represents approximately one-fourth of a cup or scoop-type vessel, including rim sherds. The vessel is thin $(5 \mathrm{~mm})$ and similar in size and shape to the Concentration \#12 vessel (described below). Coils are visible. The rim is thin and straight. The interior has patted or pinched coils with irregular scraping. The exterior also has patted or pinched coils but no additional scraping. The temper is medium coarse sand with rounded to subangular quartz crystals. Vessel size can be reconstructed based on similarities with the vessel from Concentration \#12 and is estimated to measure $8 \mathrm{~cm}$ in diameter and $2.5 \mathrm{~cm}$ in depth.

Concentration\#7- Concentration \#7 (Figure 5-22) consists of one sherd. This sherd was collected from site 26 Ny4015 during a surface collection added after the original mitigation/surface collection phase. No previous collections were made. The sherd is from a vessel with an outflaring neck. The rim is not present, but the neck constriction is. The vessel is thick $(6 \mathrm{~mm})$. The interior is smooth and floated. The exterior is semismooth, floated, and semiburnished. The temper is coarse sand with round to subangular quartz. Vessel size can be reconstructed as having an opening with a $20 \mathrm{~cm}$ outside and $17.5 \mathrm{~cm}$ inside diameter. The other vessel characteristics are unknown. The vessel form is interpreted as being a jar with an outflaring rim.
Concentration\#8 - Concentration \#8 consists of one sherd. It was collected from a portion of site $26 \mathrm{Ny} 4049$ during the initial survey of the pad. Since this area was not included in the surface collection, no additional sherds were collected. The vessel is very thin ( $4 \mathrm{~mm}$ ) and straight walled. The sherd is an interior body sherd and shows no rim. The interior is roughly scraped with horizontal strokes. The exterior is also roughly scraped with sand drags present. The temper is coarse sand and contains large quartz/feldspar crystals. While vessel size cannot be reconstructed, characteristics indicate this sherd is from a conical pot.

Concentration \#9 - Concentration \#9 (Figure 5-22) consists of seven sherds from a single vessel. This concentration was collected from site $26 \mathrm{Ny} 4045$ during the initial survey of the pad and is an isolated pot drop locality. This area was not included in the surface collection; therefore, no additional sherds were collected. The vessel is thin (5 $\mathrm{mm}$ ) with a rounded and slightly incurving rim. The interior appears patted smooth followed by horizontal scraping. The exterior is pinched/patted coils followed by irregular scraping. Coils are visible. Irregular surface indicates possible paddle and anvil finishing, followed by scraping. The clay body is red/ brown although not as red as the vessel from Concentration \#3. The temper is medium coarse sand. Size of vessel is estimated at $23.5 \mathrm{~cm}$ diameter and 23-26 cm length. Basal features are unknown.

Concentration \#10 - Concentration \#10 (Figure 5-27 d-e and 5-22) consists of five sherds from a single vessel. This concentration was collected from site $26 \mathrm{Ny} 4041$, a temporary camp/lithic scatter, during the initial survey of the pad. Since this area was not included in the surface collection, no additional sherds were collected. The original site form indicates that sherds represent at least three vessels. Not all sherds were collected. Those that were appear to be from the same vessel. 
The vessel is thick $(7 \mathrm{~mm})$ with straight wails and a straight rim. The interior is horizontally and irregularly scraped over a floated surface, as if for decoration. The exterior is floated to form a smooth, shiny surface. The temper is coarse sand with rounded to subangular quartz. The vessel is decorated with fingernail indentations on the top of the rim and a unique, tooled design (as with a stick or reed rather than a fingernail) spiraling around the body. One rim sherd indicates that the design continues down the body at least $6 \mathrm{~cm}$ below the rim of the vessel. This decoration on a conical vessel is the first known example from the NTS collection. The vessel, of undetermined size, is interpreted as conical.

Concentration \#11 - Concentration \#11 (Figure 5-23) consists of 98 sherds from a single vessel. This pot drop was collected during the initial survey of the pad and is from site 26Ny4034, a lithic and pottery scatter. This area was included in the surface collection, and a subsurface scrape (\#2) was conducted in the area of the concentration. Approximately two-thirds of the sherds were recovered below the surface. The vessel has been partially reconstructed and represents approximately one-third of a conical vessel. It is thin $(6 \mathrm{~mm})$ and straight walled and has a flat to semirounded rim. The interior is roughly scraped with horizontal strokes. The exterior is also roughly scraped and has sand drags. The temper is coarse sand with visible quartz crystals. Breaks occur along coils. There is evidence of post-breakage burning on some of the sherds. The vessel size is approximately $26 \mathrm{~cm}$ in diameter. The length is unknown. A basal fragment indicates the vessel had a tapered, round bottom (Type A in Figure 5-21).

Cencentration \#12 - Concentration \#12 (Figure 5-26 c and 5-23) consists of a single, intact vessel classified as a cup or scoop. This vessel was collected from site $26 \mathrm{Ny} 4023$, a temporary camp/lithic scatter with four brush structures, during the initial survey of the pad.
This area was not included in the surface collection; therefore, no additional sherds or vessels were collected. The cup or scoop is ninetenths complete except for a small hole in the bottom at the thinnest part of the vessel. The cup has thin ( $5 \mathrm{~mm}$ ) walls and a tapered, narrow rim. The vessel appears to be modeled rather than coiled with a finger smoothed interior and a lightly scraped exterior. The temper is coarse sand with rounded quartz. The cup size is $8 \mathrm{~cm}$ in diameter and $2.5 \mathrm{~cm}$ deep.

Concentration \#13 - Concentration \#13 consists of three sherds from a single vessel. This concentration was collected during the initial survey of the fad from a portion of site 26Ny4022, a temporary camp/lithic scatter with an associated cleared area. The two spatially segregated pottery concentrations within site 26Ny4022 (\#13 and \#14) will be described separately. Since this area was not included in the surface collection, no additional sherds were collected. The sherds collected from Concentration \#13 are very fragmentary. They have a rough finish and are broken along the coil lines. The vessel is thin walled $(5 \mathrm{~mm})$. The interior is roughly scraped with horizontal strokes. The exterior has rough, vertical scrapes. The temper is coarse sand with large non-quartz(?) inclusions. The breakage pattern along coil lines and the surface finish suggest a conical form.

Concentration \#14 - Concentration \#14 consists of one sherd collected from a portion of site $26 \mathrm{Ny} 4022$, described above, during the initial survey of the pad. No additional sherds were collected as this area was not included in the surface collection. The vessel is thin walled $(5 \mathrm{~mm})$ and straight with no rim present. The interior is roughly scraped with deep horizontal strokes. The exterior is semismooth with less rough horizontal scrapes. The temper is coarse sand with large nonquartz(?) inclusions. Vessel size or shape cannot be determined although it is certain 
that this sherd is not related to the sherds in Concentration \#13.

Concentration \#15 - Concentration \#15 consists of 124 sherds from several vessels. This concentration was collected from site 26Ny4021, a temporary camp/lithic scatter with three rock ring features, during the initial survey and subsequent subsurface scrape of the area. Approximately one-half of the sherds were collected from the subsurface scrape. Analysis indicates that four individual vessels are represented.

Vessel \#1 (Figure 5-28 and 5-22) is a small, wide-mouthed bowl, a little more than three-fourths complete. The bowl is coiled with paddle and anvil and has a scraped finish. It is moderately thick (6 mm) and has a slightly incurving rim. The interior is scraped in semirough fashion with horizontal strokes. The temper is sand with unknown inclusions. The vessel is $12 \mathrm{~cm}$ in diameter and $8 \mathrm{~cm}$ deep with a rounded base.

Vessel \#2 (Figure 5-27b and 5-22) is a small, thick cup/scoop approximately threefourths complete. It has a thin $(5 \mathrm{~mm})$, straight, tapered rim and a thick base $(9 \mathrm{~mm})$ similar to the tapered/pointed bottom of a conical pot. The vessel interior is patted and lightly scraped. The exterior is smooth, but not scraped. The temper is undefined with large, rounded to subangular quartz crystals. The vessel is $7.5 \mathrm{~cm}$ in diameter and $4 \mathrm{~cm}$ deep.

Vessel \#3 (Figure 5-22) is moderately thick $(6 \mathrm{~mm})$ with straight walls and a rounded, slightly incurving rim. The interior is smooth and floated with horizontal scraping over the float. The exterior is vertically scraped and semiburnished. Both the interior and exterior appear to have been floated. The temper is coarse sand. The diameter can be reconsiructed as approximately $23 \mathrm{~cm}$ in diameter. The length is unknown. There are no basal fragments. The vessel is thought to be conical.
Vessel \#4 (Figure 5-22) is thick (6-7 mm) with straight walls and a straight rim. Both the interior and exterior are very roughly scraped and have sand drags present. The temper is coarse sand with quartz crystals. The vessel is interpreted to be conical.

Concentration \#16 - Concentration \#16 consists of 123 sherds representing several vessels. This concentration was collected from site 26Ny4015, a temporary camp/lithic scatter with several rock ring and clearedarea features, during the initial survey of the pad. This area was not included in the surface collection; therefore, no additional sherds were collected. Analysis of the sherd collection indicates six vessels are represented.

Vessel \#1 (Figure 5-23) is thin (5 mm) and straight walled and has a flat, lipped rim. There is very little curvature to the rim. Both the interior and exterior are smooth, over horizontal scraping, and have evidence of being floated and semiburnished. The exterior is smooth. No sand drags are present although the temper is coarse sand. The exterior on most sherds is deteriorating. The vessel form is unknown although the body sherds have a conical appearance.

Vessel \#2 (Figure 5-22) is thick (7 mm) and straight walled and has a straight rim. The exterior is rough scraped with sand drags. The interior is roughly icraped horizontally with slight sand drags. The temper is coarse sand. No basal fragments are present. Vessel size is undetermined. Body sherds and finishing technique indicate the vessel is a conical form.

Vessel \#3 is thick $(7 \mathrm{~mm})$ with a slightly incurving rim. The interior has a distinctive rough horizontal scrape. The exterior is floated and burnished. The clay body is very red, possibly the result of firing. The temper is fine grained and micaceous. There is burned residue on the interior which might be suitable for identification and/or dating. The vessel size cannot be determined. The slightly incurving rim and body sherds indicate a coni- 
cal form, although it appears wider and rounder than classic conical vessels.

Vessel \#4 (Figure 5-22) is thick (8 mm) and has an outflaring rim. Temper is coarse, unidentified sand. The interior of the sherds are deteriorating. The exterior is floated and semiburnished. Vessel size cannot be determined. The outflaring rim is indicative of a wide-mouthed bowl or jar.

Vessel \#5 consists of several thick $(8 \mathrm{~mm})$ lower body sherds from what appears to be a conical vessel. The interior is roughly scraped with horizontal strokes. The exterior has semismooth, vertical scrape marks. The temper is coarse sand. Vessel size cannot be determined. These sherds do not appear to be associated with other conical vessel sherds described above.

Vessel \#6 (Figure 5-27 b-c) consists of two sherds from a decorated vessel. Sherd 1 indicates that the vessel is thick $(7 \mathrm{~mm})$ and has a slightly lipped, rounded rim. Fingernail indentations occur $6 \mathrm{~mm}$ below the rim on the exterior. The second sherd is a lug/handle with fingernail indentations and is probably associa'ed with the other decorated sherd above. The lug has three rows of indentation along both lateral edges and along the midline. The vessel appears to be a bowl/jar form.

Vessel \#7 consists of three very small sherds with a straight wall and rounded to tapered rim. Vessel size and shape cannot be determined.

Concentration \#17 - Concentration \#17 consists of five sherds from a single vessel. This concentration was collected from site 26 Ny4015 during the surface collection. The vessel is thin $(6 \mathrm{~mm})$, and sherds are from the interior body of a bowl or jar. The interior has horizoniai scrapes over a smooth, rioated surface. The exterior is scraped with rough, horizontal strokes. The temper is fine-grained and unidentified. The clay body also appears finer than in other specimens. The vessel appears well fired. The constricted neck and outflaring rim indicate a bowl/jar form although vessel size cannot be determined.

Cencentration \#18 - Concentration \#18 (Figure-22) consists of one sherd collected from site $26 \mathrm{Ny} 4015$ during the surface collection. The vessel is thin $(5 \mathrm{~mm})$ and straight walled with a flat, slightly incurving $\operatorname{rim}(1 \mathrm{~cm})$. The interior appears floated with some sand drags visible through the horizontal scrapes. The exterior is semiroughly scraped in a haphazard, cross-hatch manner. There is a slight float on the exterior. The temper is medium coarse sand with quartz crystals. Although size cannot be determined, the sherd indicates a conical vessel.

Concentration \#19 - Concentration \#19 ( 5-27g! consists of one sherd. It was collected during the surface collection of site 26 Ny4015. The vessel is moderately thick (6 $\mathrm{mm}$ ) with a straight rim and is coiled with a possible paddle and anvil finish. Both the interior and exterior show evidence of horizontal scraping; both surfaces appear to have been floated and burnished. There are fingernail indentations along the top exterior of the rim. The straight rim on the body sherd indicates a conical form. Decoration on a conical pot is very unique. This is the second decorated conical vessel from the U19au collection.

Concentration \#20 - Concentration \#20 consists of two sherds from a single vessel. They were collected during the surface collection of site $26 \mathrm{Ny} 4015$. The vessel is moderately thick $(6 \mathrm{~mm})$. There are no rim sherds. The interior is horizontally scraped, the exterior vertically scraped. The temper is coarse sand with quartz and feldspar. The scraping characteristics indicate a conical vessel form.

Concentration \#21 - Concentration \#21 is a single sherd collected adjacent to Concentration \#1 (26Ny4040). It has been incorporated in that description above. 
Concentration \#22 - Concentration \#22 consizts of 35 sherds from what appears to be a single vessel. This concentration was collected from site $26 \mathrm{Ny} 4015$ during the surface collection. The vessel is straight walled and straight rimmed. The surface finish on both the interior and exterior is characterized by uneven scraping. One basal fragment is present. The nature of both the scraping and the rim variety indicates a conical vessel form.

Concentration \#23 - Concentration \#23 consists of 13 sherds from a single vessel. This concentration was collected from site 26 Ny4015 during the surface collection. The vessel is very thin $(4 \mathrm{~mm})$ and there are no rims. The clay body and finish are very red. The surface finish on both the interior and exterior is characterized by uneven scraping. The surfaces appear to have been floated and burnished. The temper is coarse sand with quartz and feldspar(?) inclusions. The nature of the scraping indicates a conical vessel form.

Concentration \#24 - Concentration \#24 consists of 15 sherds from a single vessel. This concentration was collected during the surface collection of $26 \mathrm{Ny} 4015$. The vessel is thin $(5 \mathrm{~mm})$, and there are no rim sherds. The interior and exterior finish is roughly scraped and indicates a conical vessel form. The temper is coarse sand. Vessel size cannot be determined.

Concentration \#25 - Concentration \#25 consists of two sherds from a single vessel identified as Moapa Greyware having olivine temper. This concentration was collected during the surface collection. The vessel is thick $(6 \mathrm{~mm})$ and of unknown form.

Concentration \#26 - Concentration \#26 consists of two sherds from two different vessels. This concentration was collected from site $26 \hat{N} y 4048$, a temporary camp/iithic scatter, during the initial survey of the project area. This area was not included in the surface collection; therefore, no additional sherds were collected. Sherd \#1, Vessel \#1 is thin $(6 \mathrm{~mm}$ ) and of unknown form. The temper is a mixed quartz sand with some olivine, possibly a Moapa Greyware. It appears unrelated to Concentration \#25. Sherd \#2, Vessel \#2 is a thin $(5 \mathrm{~mm}$ ) plain brownware. The interior is scraped horizontally; the exterior appears floated and burnished and is very shiny. The temper is coarse sand. The vessel form is unknown. These sherds appear unrelated to other sherds/vessels in the area.

Concentration \#27 - Concentration \#27 (Figure 5-27f and 5-23) consists of a single sherd. It was collected during the surface collection of site $26 \mathrm{Ny} 3633$, a lithic scatter along the access road. The vessel is thin $(6 \mathrm{~mm})$ and has a slightly incurving but straight rim. There is a punctate decoration, barely visible, $7 \mathrm{~mm}$ below the rim. The interior is smoothed and floated and overlain with a decorative scrape, perhaps with a brush or coarse sherd. The exterior is scraped vertically and smoothed but not floated. It appears slightly burnished. The temper is fine-grained and micaceous. The vessel size is approximately $23 \mathrm{~cm}$ in diameter; length is unknown. The curvature of the rim and body sherds indicates that the vessel could be either a bowl or conical form. .

\section{Conclusions}

To date, ten partial and full kilometer squares on Pahute Mesa have been collected using a standard 10-by-10 meter collection grid. These large-scale collections have added substantially to our understanding of the spatial distribution of sites and artifacts within the area. By comparing site and artifact composition and environmental information, we are beginning to discern patterns in human behavior and continue to increase our understanding of the spatial, cultural, and environmental relationships on Pahute Mesa during the last 3,500 years.

As noted in Pippin (1986), the environmental zones within the central area of Pahute Mesa are very consistent. They are character- 


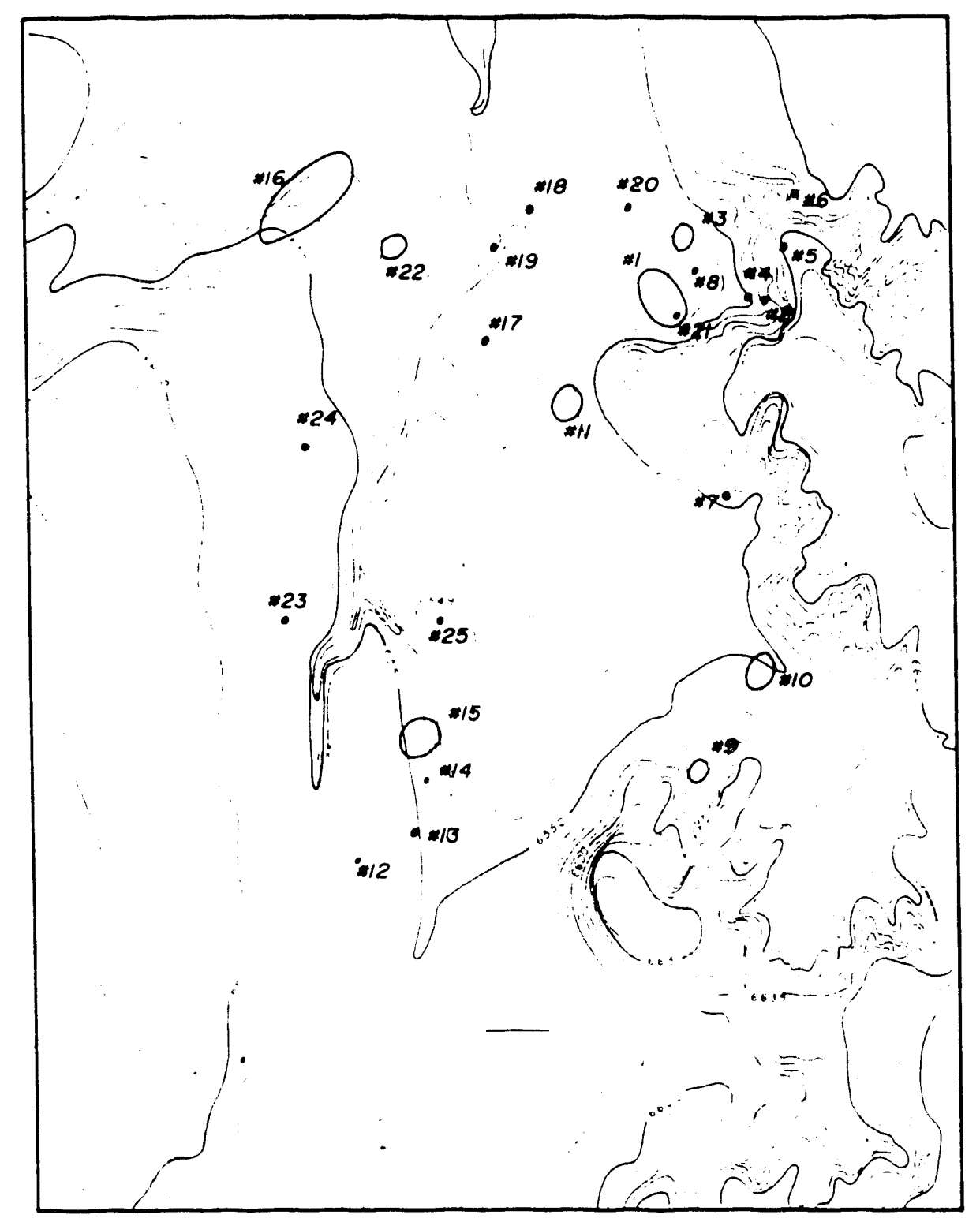

U19au Archeoological Investigations

Pahute Mesa, Nevada

DRILL PAD AREA

LOCATION OF POTTERY CONCENTRATIONS

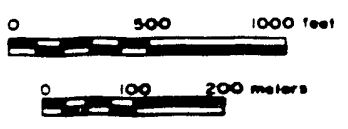

Figure 5-20. Locations of pottery concentrations at the U19au drill pad area, Pahute Mesa, Nevada. 


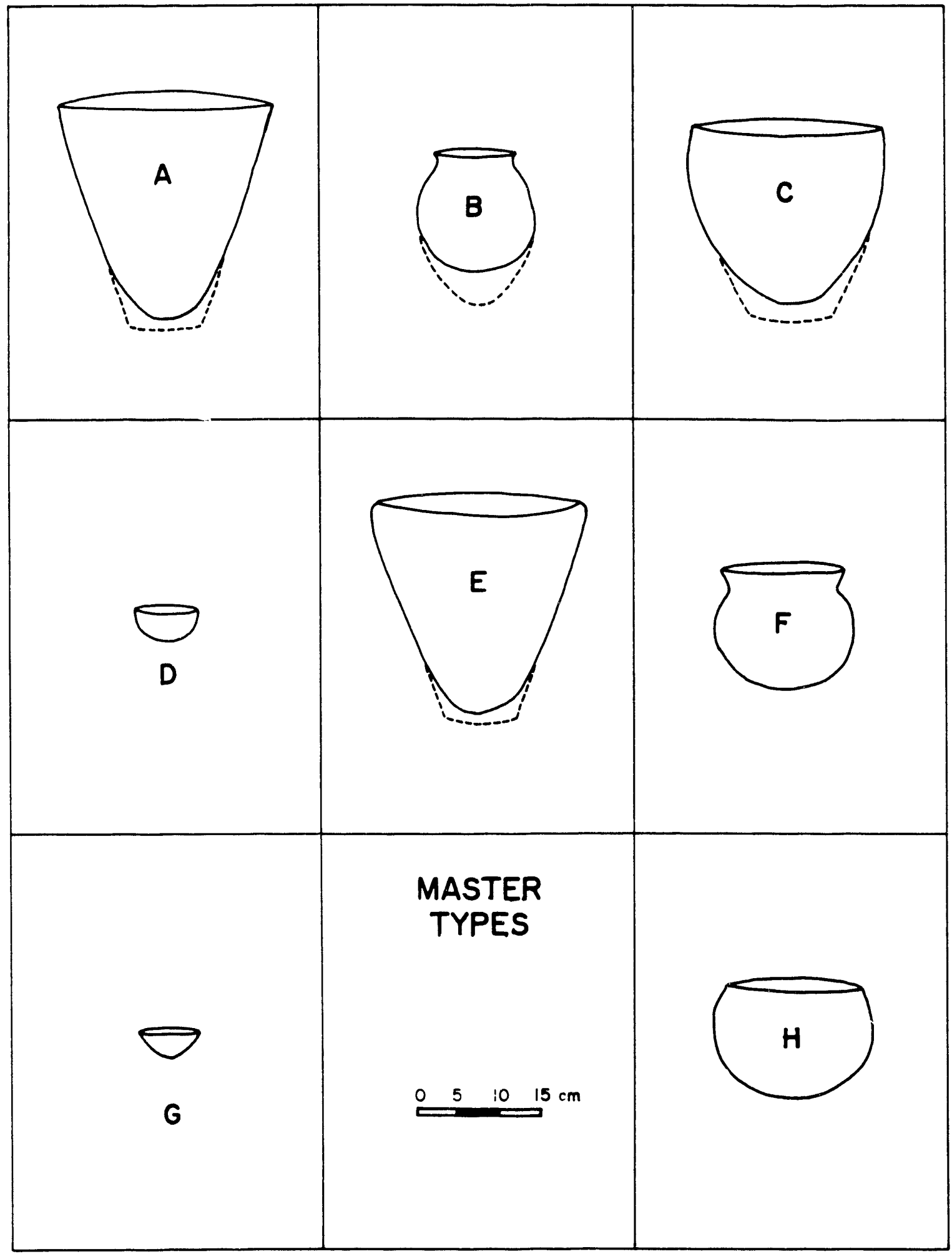

Figure 5-21. Generalized shapes of pots found in the Nevada Test Site area. 


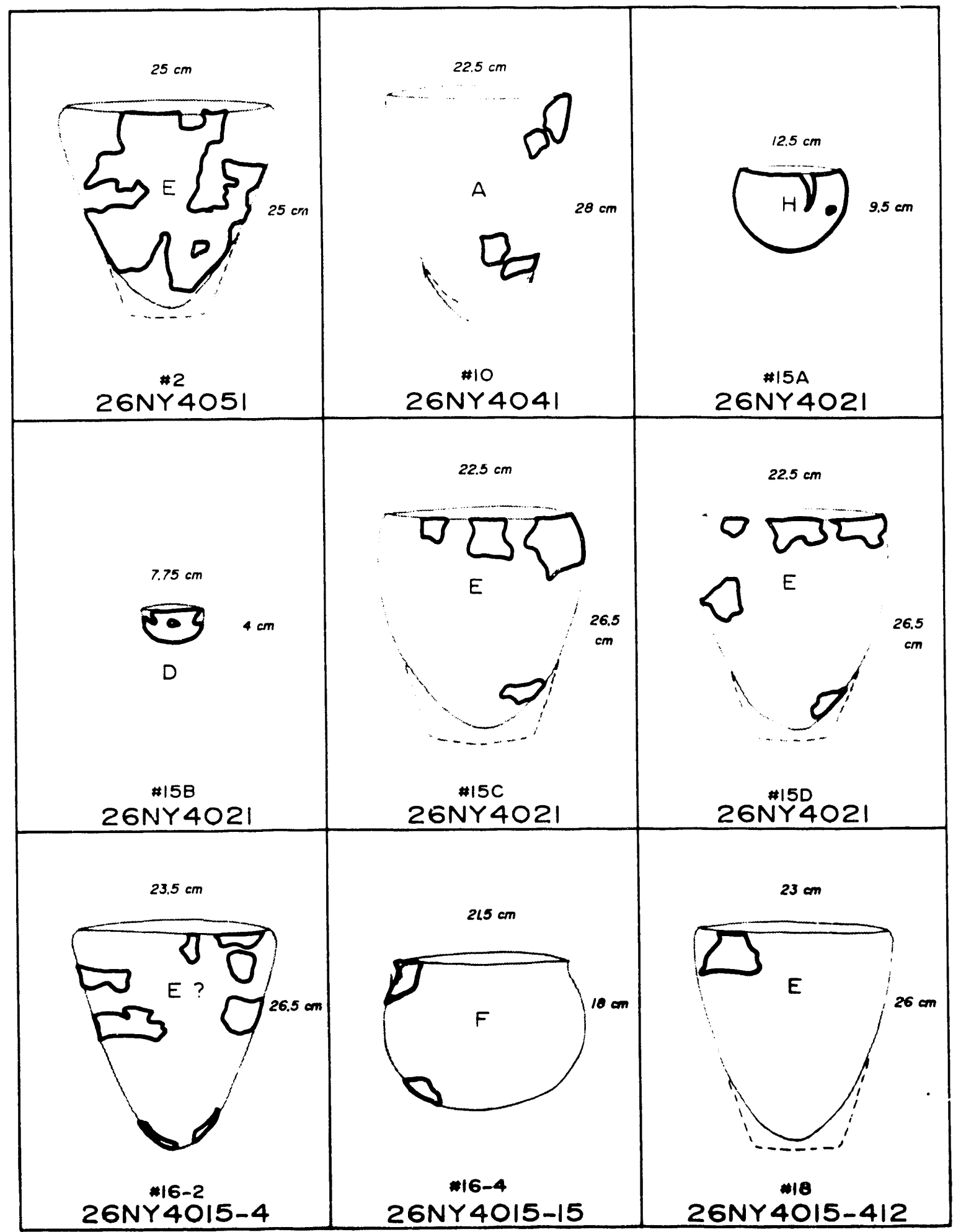

Figure 5-22. Partial reconstructions of pots from sites found in the vicinity of U19au, Pahute Mesa, ': veda. 


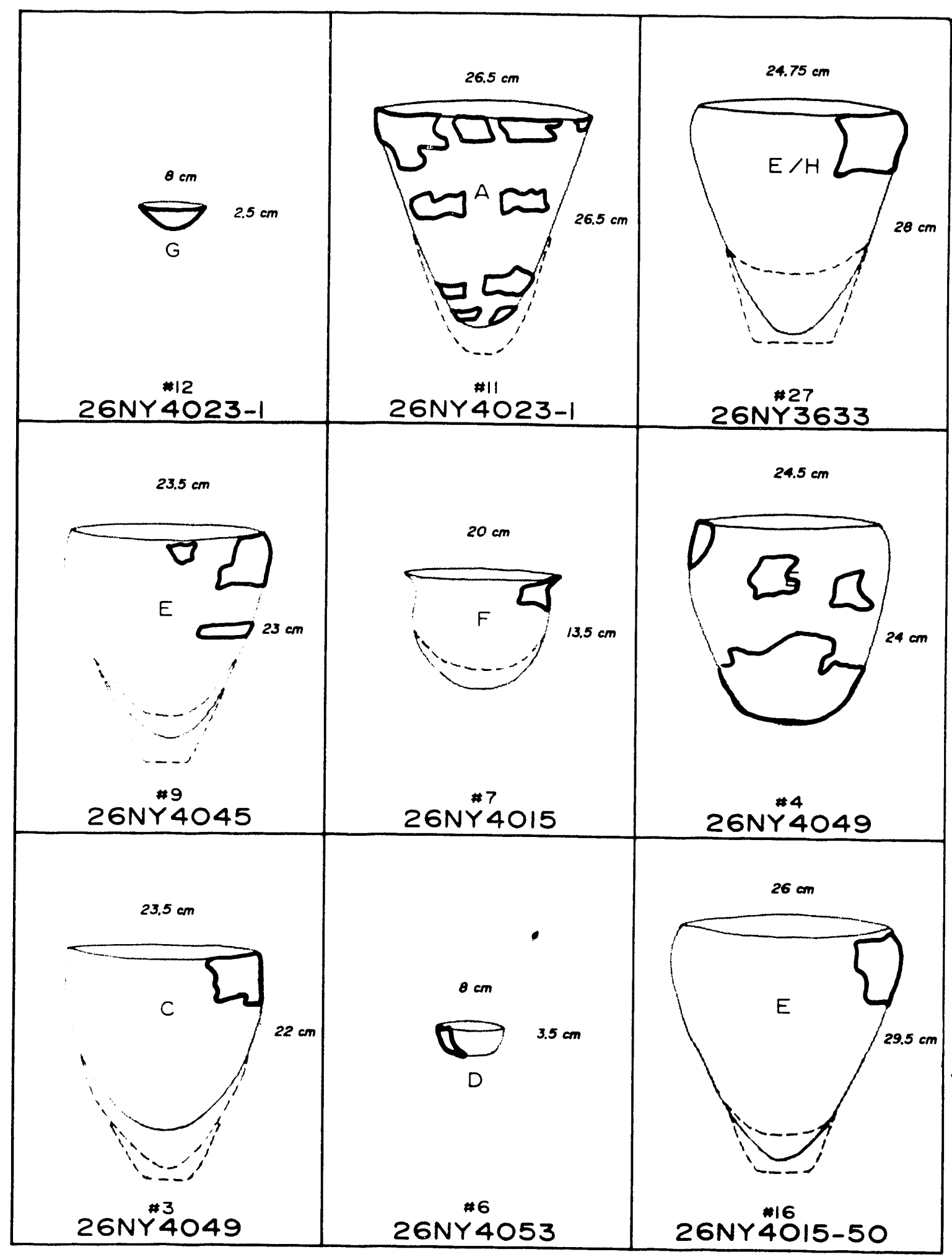

Figure 5-23. Partial reconstructions of pots from sites found in the vicinity of U19au, Pahute Mesa, Nevada. 


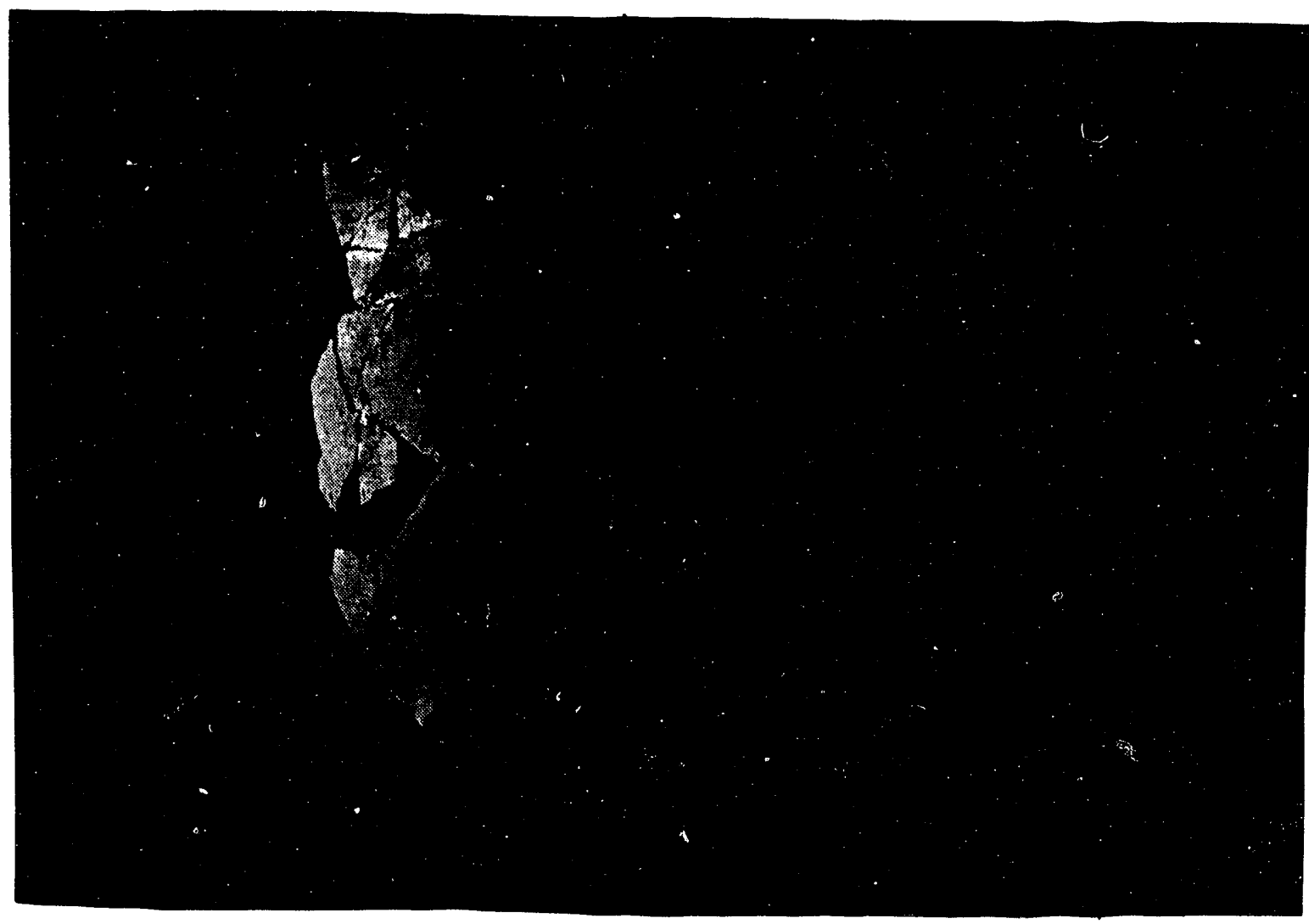

Figure 5-24. Photograph of partially reconstructed pot from pottery Concentration 2, Pahute Mesa, Nevada.

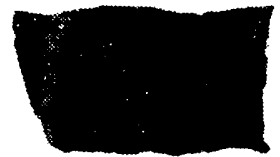

a

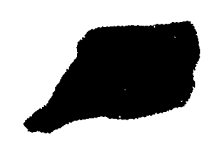

b
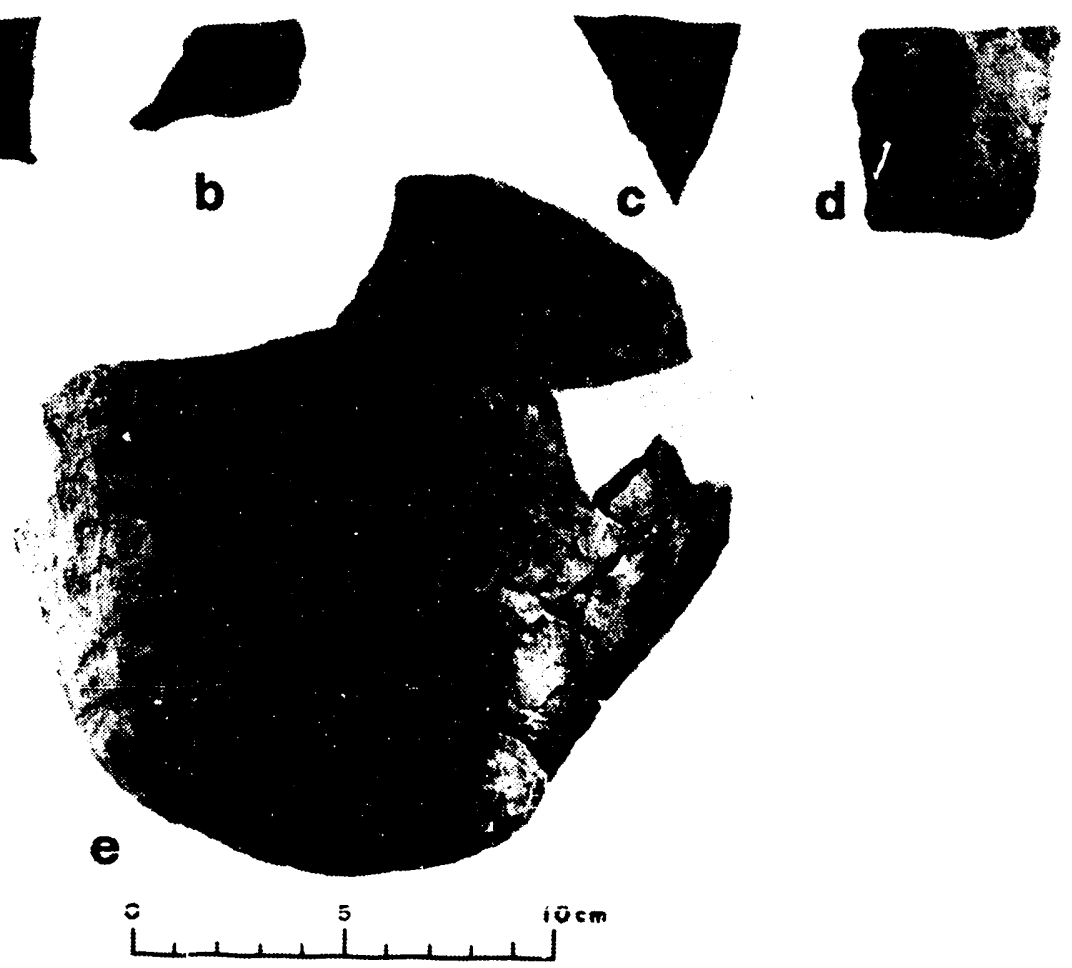

Figure 5-25. Photograph of a partially reconstructed pot and additional sherds from pcttery Concentration 4 from the U19au archae(logical investigations, Pahute Mesa, Nevada. 


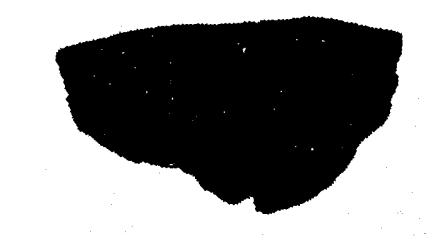

a

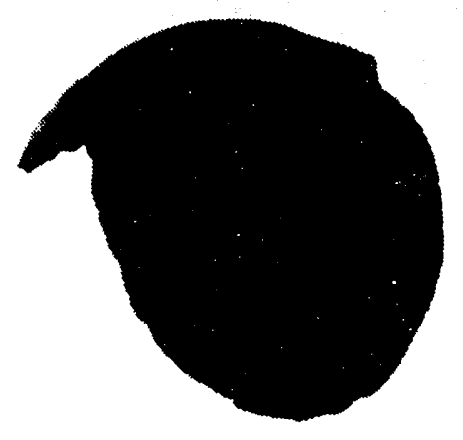

C

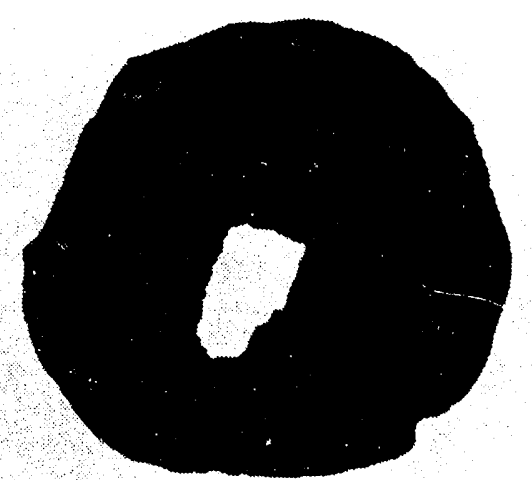

b

Figure 5-26. Photograph of pottery cups from U19au archaeological investigations, Pahute Mesa, Nevada.

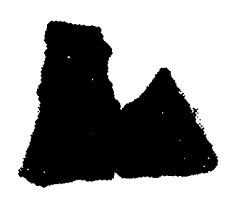

a

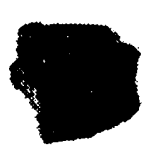

b

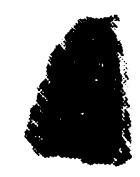

C

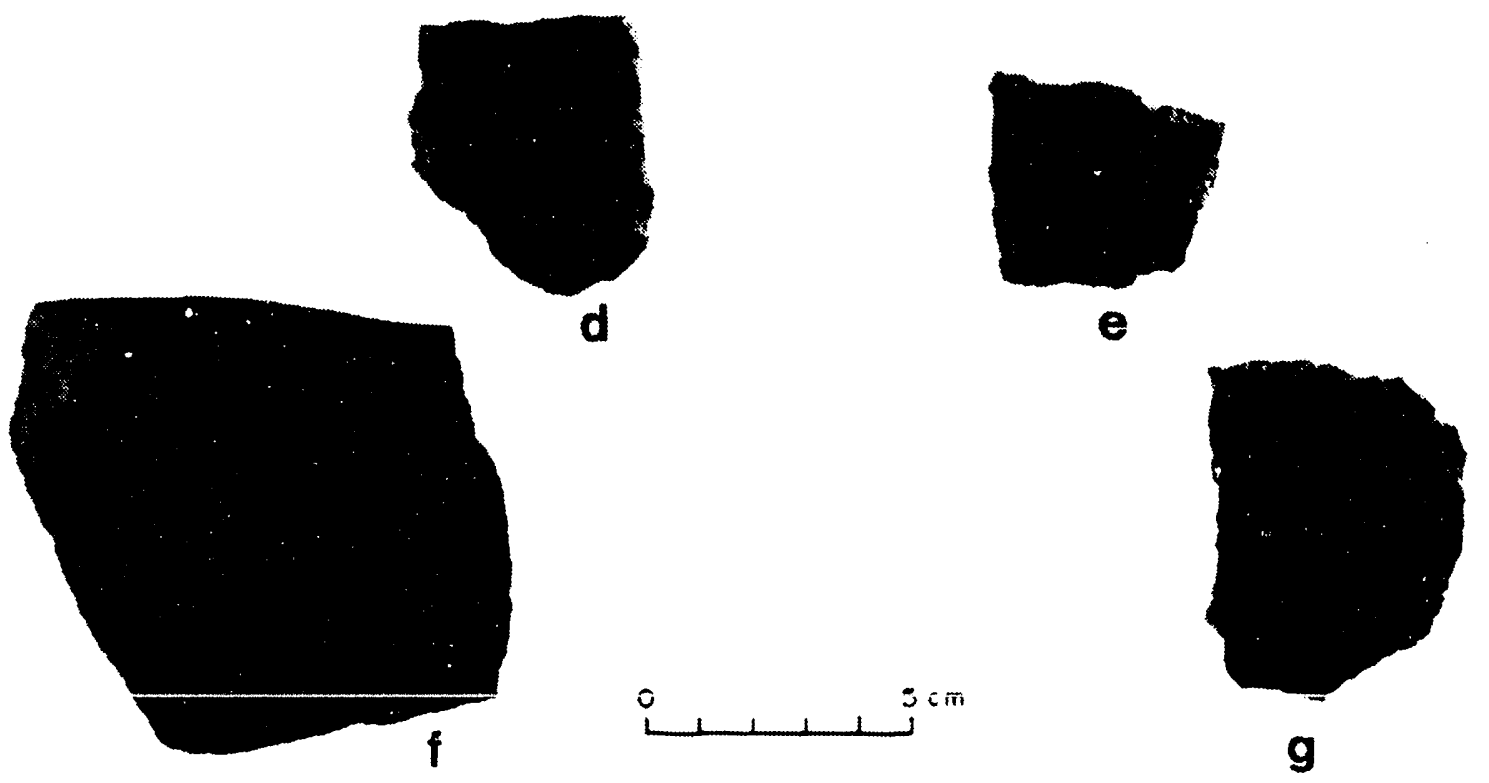

Figure 5-27. Photograph of decorated potsherds from the U19au archaeological investigations, Pahute Mesa, Nevada. 


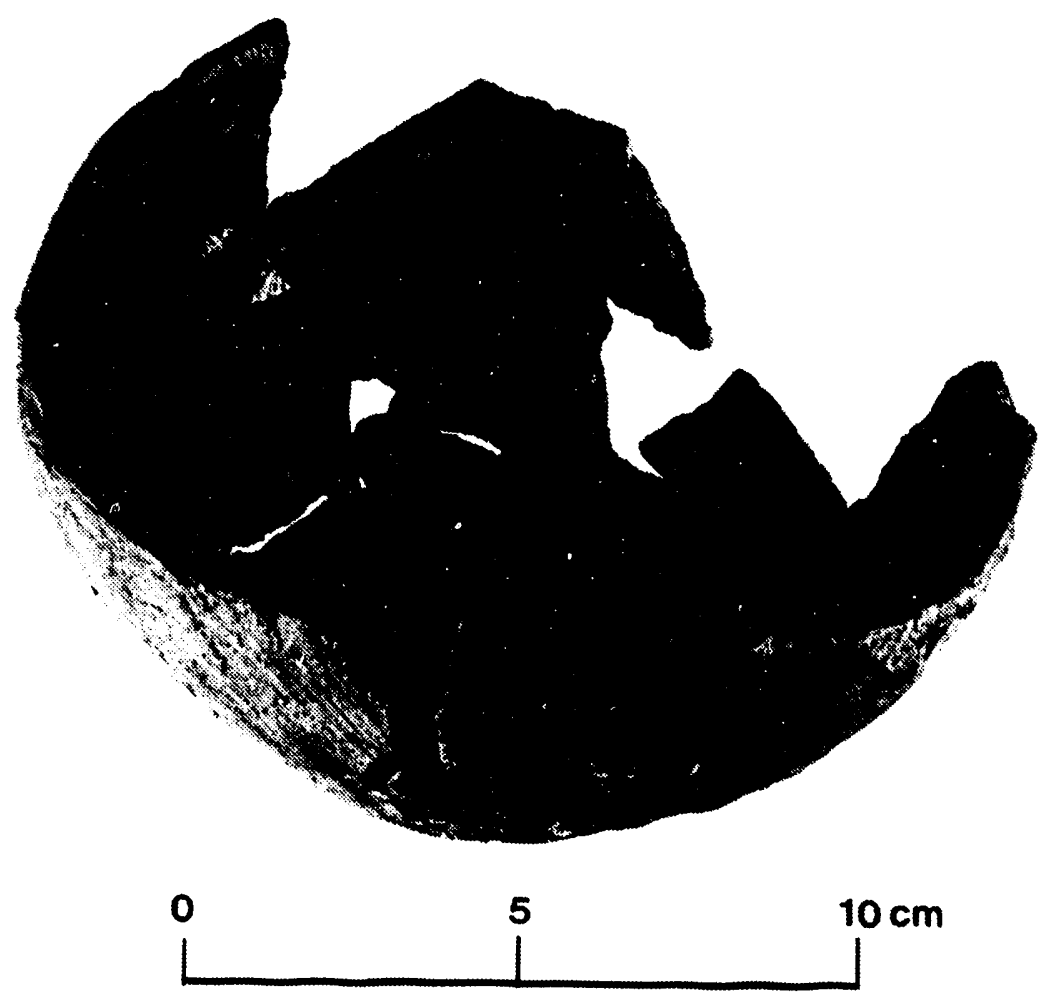

Figure 5-28. Photograph of reconstructed vessel 1 from pottery Concentration 15 (26Ny4021) from the U19au archaeological investigations, Pahute Mesa, Nevada.

ized by low ridges covered by thick pinyon and juniper, interspersed with narrow, sagecovered valleys. The environment changes to the west in NTS Area 20, where the elevation drops to form a sage/blackbrush covered, westward-sloping, dissected bench.

The site types recorded in these areas are also consistent within the environmental zones. In the central pinyon-juniper area of Pahute Mesa, temporary camps with rock rings, rock shelters, brush structures, and extensive lithic scatters are prevalent. Temporary camps, lithic scatters, and features occur less frequently to the west in the non-pinyon/ juniper area. To date, brush structures have not been found in this western area of Pahute Mesa. Yet, when we look at pottery distribution within this homogeneous site area, we see significant differences.

\section{Pottery and Feature Associations}

When comparing the differential distribution of pottery vessels relative to ethnohistoric features (brush structures, lean-tos, modern rock ring features) some interesting patterris are evident.

Table 5-9 below shows the distribution of pottery in association with ethnohistoric structures for areas of data recovery on Pahute Mesa. There are significant differences in the number of vessels represented per area. The majority of the project areas have only one or two vessels present. It is significant that U19au has 39 vessels represented relative to other areas. It is likely that one reason for this differential distribution of vessels is the presence of a large number of ethnohistoric structures in the project areas. U19au with 39 vessels also has eight brush structures. The ma- 
Table 5-9. Pottery Vessel Distribution and Ethnohistoric Feature Association for Selected Areas (Surveyed and Mitigated) on Pahute Mesa.

\begin{tabular}{lll}
\hline Project & No.Nessels Represented & Feature Assoc. \\
\hline U19an & 2 & None \\
U19aq & 3 & 1 Brush Structure \\
1 Rock ring & & None \\
U19af & 2 & None \\
U19ax & 1 & None \\
1.19ay & 5 & None \\
U19a0 & 5 & (adjacent to 19au) \\
(in progress) & & None \\
U20aw & 3 & None \\
(in progress) & & None \\
U20at & None & None \\
U20ax & 3 & 8 Brush Structures \\
U20az & 4 & \\
U19au/as & 39 & \\
$3+$ Rock ring features & & 1 Brush Structure \\
Surveys only: & & 3 Erush Structures \\
(both areas adjacent to U19au) & & \\
U19s & 7 & \\
U19k & 6 & \\
\hline
\end{tabular}

jority of these vessels are directly associated with the ethnohistoric structures. This association, while tentative, points to a late-period use arid perhaps to an increase in the use of pottery on Pahute Mesa.

\section{Analysis of Polien and Macrofossii Samples}

Martha L. Hemphill and Cheryl L. Nowak

\section{Introduction}

The U19au area is located in a shallow north-trending valley about four $\mathrm{km}$ north of the south rim of Pahute Mera at an elevation of about $6500 \mathrm{ft}$. This valley is $d$ : ained by a series or unnamed, ephemeral tributaries of South Silent Canyon. The major stream flows thivight a small. steep-wälled cinarinei formed by a fault in the welded tuff bedrock. approximately two meters below the floor of the valley The west side of the valley is formed by a relatively uniform gentle slope terminated by cliffs beyond the boundaries of ine project area. The maximum elevation in the project area is about $6620 \mathrm{ft}$. The eastern side of the valley is formed by convoluted and stepped welded tuff cliffs which form numerous small valleys and leve! benches, ultimately forming a level topped ridge at about $6600 \mathrm{ft}$ in elevation.

All three of the major vegetation communities found on Pahute Mesa are found at U19au: big sagebrush on the deeper alluvial soils of the valleys, Jlack sagebrush on the shallow soils to the edges of the valleys and on the bencnes, and pinyon-juniper on the ridges, benches and slopes.

Thirty-five samples from three sites

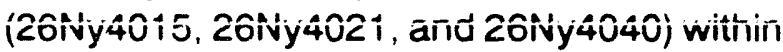
U19au were analyzed for significant differences in their pollen content. Thirty of these were sediment samples collected from features and as controls: five samples were 
derived from the surfaces of pottery sherds collected from two of the sites (Tables 5-10 and 5-11). Twenty-one sediment samples from features and one control sample underwent flotation to recover plant macrofossils for analysis. All macrofossil samples are from site $26 \mathrm{Ny} 4040$ and analysis results are presented in Appendix C.

Site 26 Ny4015 represents the ca. $750-$ by $-600 \mathrm{~m}$ area surface collected in the center of the drill pad. It includes all of the specific environmental components discussed above. The two remaining sites, 26 Ny 4021 and $26 \mathrm{Ny} 4040$, are more archaeologically complex areas within the surface collection area that warranted further study and were given individual site designations.

Site $26 \mathrm{Ny} 4021$ is a temporary campsite composed of at least two rock rings and associated features. The area is characterized by open pinyon-juniper woodland with a sagebrush understory. Temporary camp 26 Ny4040 is located at the base of a slope along the south side of a small valley formed by one of the convolution in the welded tuft rim rock of the eastern side of the primary valley. The site consists of the remains of at least three brush structures and an associated artifact and feature scatter situated just within the pinyon-juniper at the sagebrush margin.

\section{Methods}

\section{Pollen Analysis}

One tablespoon (13.8cc) of sediment was taken of each of the sediment pollen samples. For statistical purposes, 8 Lycopodium tracer spore tablets (Batch \#201.890; 11,329 349 spores per tablet $\times 8=90,632 \pm 2792$ per sample) were added to each sample. The pottery sherous were lightitiy cussied, and the remaining adhering matrix was washed into a $250 \mathrm{ml}$ beakers using $10 \% \mathrm{HCl}$. One Lycopodium tracer spore tablet $(11,329 \pm 349$ spores each) was added to each sample.
The 35 samples were treated with concentrated $\mathrm{HCl}$, screened through 100-mesh screens, treated with $\mathrm{HCl}$ again, transferred to $50 \mathrm{ml}$ test tubes, given one more concentrated $\mathrm{HCl}$ wash, and left overnight. The following day the samples were treated with fresh concentrated $\mathrm{HCl}$ and placed in a threeminute boiling water bath. Following two hot distilled water washes the samples were treated again with concentrated $\mathrm{HCl}$ and placed in a three-minute boiling water bath followed by two more hot distilled water rinses. The samples were then treated with $\mathrm{HF}$ and left to starid overnight. The samples were in a 30-minute boiling water bath after the HF was freshened. Following two hot distilled water washes, the samples were again treated with $\mathrm{HCl}$ followed by two further hot water washes. The samples were then transferred into $15 \mathrm{ml}$ glass test tubes. After a tenminute stand in $20 \%$ HNO3 and two hot water washes, the samples were treated with concentrated $\mathrm{HCl}$ and placed in a two-minute boiling water bath. Following two hot distilled water washes the samples were treated with Glacial Acetic acid followed by the acetolysis procedure (treatment with a solution of 9 parts acetic anhydride and 1 part $\mathrm{H} 2 \mathrm{SO} 4$ ). After another Glacial Acetic acid treatment and two further hot distilled water washes, the samples were treated with hot $5 \% \mathrm{KOH}$ and given hot distilled water washes until neutral. Staining with Safrinin aiter an initial drying alcohol treatment was followed by a second alcohol treatment. Additional drying with tert-butyl alcohol was followed by the addition of $2000 \mathrm{cs}$ silicone oil. The samples were then placed on a hot plate and the alcohol was allowed to evaporate.

The sampies were mounied on giass slides and at least 200 terrestrial pollen grains were counted on all thitty-five samples. Percentages were calculated from the raw counts divided by the total terrestrial pollen. Results 
Table 5-10. U19au Pollen Samples from Pottery Sherds.

\begin{tabular}{|c|c|c|}
\hline $\begin{array}{l}\text { Extraction } \\
\text { Run \# }\end{array}$ & Site & $\begin{array}{l}\text { Sample Description } \\
\#\end{array}$ \\
\hline 1 & 26 Ny4015 & $\begin{array}{l}\text { Sample is from Surface Scrape } \# 2 \text { - Level } 0 \text {, Stratum } A \text { and includes refer- } \\
\text { ence numbers } 477,478,479,479-3,480-2,481,482 \text {, and } 483 \text {. }\end{array}$ \\
\hline 2 & $26 \mathrm{Ny} 4015$ & $\begin{array}{l}\text { Sample is trom Surface Scrape } \# 2 \text { - Level 1, Stratum B and includes refer- } \\
\text { ence numbers } 484,485,486,487,488,489 \text { (all cleaned, some glued). }\end{array}$ \\
\hline 3 & 26 Ny4015 & $\begin{array}{l}\text { Sample is from Surface Scrape } \# 2 \text { - Level } 1 \text {, Stratum B and includes refer- } \\
\text { ence numbers } 490,491,493,494,495,497 \text {, and } 499 \text {. }\end{array}$ \\
\hline 4 & 26 Ny4015 & $\begin{array}{l}\text { Sample is from Surface Scrape\#2 - Level 1, Stratum B and includes refer- } \\
\text { ence numbers } 3500,3501,3502 \text {, and } 3503 \text {. }\end{array}$ \\
\hline 5 & $26 \mathrm{Ny} 4040$ & $\begin{array}{l}\text { Sample is from a brush structure, Level 2, Stratum C and includes refer- } \\
\text { ence number } 3755 \text {. }\end{array}$ \\
\hline
\end{tabular}

Table 5-11. U19au Pollen Samples from Sediments.

\begin{tabular}{|c|c|c|c|c|}
\hline $\begin{array}{l}\text { Extraction } \\
\text { Run \# }\end{array}$ & $\begin{array}{r}\text { Ref } \\
\#\end{array}$ & $\begin{array}{c}\text { Site } \\
\#\end{array}$ & $\begin{array}{l}\text { Feature } \\
\#\end{array}$ & Sample Description and Provenience \\
\hline 1 & 2135 & 26 Ny4015 & 13 & $\begin{array}{l}\text { From within rock ring/cache feature from on top of rock exposed by } \\
\text { removal of area " } \mathrm{B} \text { " flotation sample }\end{array}$ \\
\hline 2 & 2137 & $26 \mathrm{Ny} 4015$ & -- & $\begin{array}{l}\text { Control sample from surface of buried rock } 7 \mathrm{~m} \text { east (upslope) of } \\
\text { Feature } 13\end{array}$ \\
\hline 3 & 3687 & $26 \mathrm{Ny} 4040$ & -- & $\begin{array}{l}\text { Control taken } 20 \mathrm{~m} \text { upslope from brush structure features. } 0-15 \mathrm{~cm} \\
\text { depth }\end{array}$ \\
\hline 4 & 3579 & $26 N y 4040$ & 1 & From beneath metate \\
\hline 5 & $?$ & $?$ & $?$ & Surface $\# 1$, control \\
\hline 6 & $?$ & $?$ & $?$ & Surface $\# 2$, control \\
\hline 7 & 3920 & $26 N y 4040$ & 1 & Feature 1, Unit 4 flotation sample \\
\hline 8 & 3921 & $26 \mathrm{Ny} 4040$ & 1 & Feature 1, Unit 4 flotation sample \\
\hline 9 & 3922 & $26 \mathrm{Ny} 4040$ & 1 & Feature 1 Unit 4 flotation sample \\
\hline 10 & 3923 & $26 \mathrm{Ny} 4040$ & 1 & Feature 1, Unit 4 flotation sample \\
\hline 11 & 3924 & $26 N y 4040$ & 1 & Feature 1, Unit 4 flotation sample \\
\hline 12 & 3925 & $26 \mathrm{Ny} 4040$ & 1 & Feature 1, Unit 4 flotation sample \\
\hline 13 & 3926 & $26 N y 4040$ & 1 & Feature 1, Unit 4 flotation sample \\
\hline 14 & 3927 & $26 N y 4040$ & 1 & Feature 1, Unit 4 flotation sample \\
\hline 15 & 3928 & 26 Ny4040 & 1 & Feature 1, Unit 4 flotation sample \\
\hline 16 & 3929 & $26 N y 4040$ & 1 & Feature 1, Unit 4 flotation sample \\
\hline 17 & 3930 & 26 Ny4040 & 1 & Feature 1, Unit 4 flotation sample \\
\hline 18 & 3931 & $26 N y 4040$ & 1 & Feature 1, Unit 4 flotation sample \\
\hline 19 & 4975 & $26 N y 4021$ & -- & Unit 10 control sample from $10 \mathrm{~m}$ west of Feature 2 at $0-10 \mathrm{~cm}$ depth \\
\hline 20 & 4976 & $26 N y 4021$ & 5 & Unit 10 from under a mano lying below a metate in the NW area of the site \\
\hline 21 & 4977 & $26 N y 4021$ & 7 & Unit 10 from a rock ring lying among junipers in the SW corner of the site \\
\hline 22 & 4978 & 26 Ny4021 & 8 & $\begin{array}{l}\text { Unit } 10 \text { from a rock cache lying among junipers in the SW corner of the } \\
\text { site at } 0-10 \mathrm{~cm} \text { depth }\end{array}$ \\
\hline 23 & 4979 & $26 \mathrm{Ny} 4021$ & 2 & Unit 10 from a rock ring located in the SW area of the site \\
\hline 24 & $4400 \mathrm{a}$ & 26 Ny4021 & 3 & Unit 10 from the NW portion of a rock ring at $0-5 \mathrm{~cm}$ depth \\
\hline 25 & $4400 b$ & 26 Ny4021 & 3 & Unit 10 from the NW portion of a rock ring at $5-10 \mathrm{~cm}$ depth \\
\hline 26 & $4402 a$ & $26 N y 4021$ & 3 & Unit 10 from the $S W$ portion of a rock ring at $0-5 \mathrm{~cm}$ depth \\
\hline 27 & $4402 b$ & $26 N y 4021$ & 3 & Unit 10 from the SE portion of a rock ring at $5-10 \mathrm{~cm}$ depth \\
\hline 28 & 4151 & 26 Ny4021 & 1 & Unit 10 from next to 3 hearth in the NE part of a rock ring at $0-5 \mathrm{~cm}$ depth \\
\hline 29 & 4981 & $26 N y 4021$ & 9 & Unit 10 from the center of a rock cache at $0-10 \mathrm{~cm}$ depth \\
\hline 30 & 4982 & $26 \mathrm{Ny} 4015$ & 14 & Unit 10 from the east-central side of a possible hearth at $10 \mathrm{~cm}$ depth \\
\hline
\end{tabular}


of the pollen analyses from U19au is given in Tables 5-12, and 5-13.

\section{Macrofossil Analysis}

Sediment for flotation analysis was removed from the field collection container and poured into a large beaker to measure its volume. The soil and beaker were then placed into a laboratory drying oven for 24 hours at $105^{\circ} \mathrm{C}$. After dry sediment weights were recorded, the actual flotation process commenced.

To remove plant material from the soil sample, sediment was sprinkled into a large bucket of water. Contents were swirled around for a short period to separate soil and plant material. Plant remains were then skimmed from the water surface with a finemesh screen. The extracted contents were placed into a beaker and put into the laboratory drying oven for 24 hours at $105^{\circ} \mathrm{C}$.

After drying, the floated materials were weighed. The materials were then sorted through a stack of geologic sieves (\#5, 10, 18, 35 mesh) and put in containers by sieve size and labeled with field site designation - including site, reference and specimen number.

The contents of each container were sorted by plant type. Plants were identified using butanical reference books, a DRI seedleaf-twig reference collection; and DRI herbarium-mounted plants. Retrieved plant taxa were recorded by name, plant part, quantity, condition (i.e., fragmented or whole) and weight

Data were recorded onto a Botanical Samples Collection Log and were entered into a computer using a DBMS program. Processed (sorted and labeled samples) and unprocessed flotation sampies are piesentily being curated in the Paleo-r,otanical Laboratory at the Desert Ressarch, Institute, Reno, NV. Results of macrofossil analyses from U19au are presented in Appendix C.

\section{Results and Discussion}

\section{Pollen Analysis}

Differences in percentages of the main pollen types are evident (Figures 5-29 and 5-30), but to clarify the relationships between the samples a Pearcain's r correlation was run (Tables 5-13: 5-14). Some of the nonpottery pollen samples have a much lower correlation to the group formed by most of the other pollen samples.

Nonpottery pollen Samples 1 and 2 have a Pearson's $r$ that generally ranges between .44 and .77 (Table 5-14). However, when compared with each other, they have a Pearson's $r$ of about .87. Sample 2 was the control sample that was taken for sample 1 (Table 5-11). There is little significant difference between the two samples. The only suggestion of difference is in the proportion of Chenopodiineae pollen. This is greater in the rock ring/ cache feature and may reflect processing or storage of chenopod inflorescences within the feature. However, it may also reflect weedy plant succession after the site had been disturbed by aboriginal activity.

Nonpottery Sample 4 also shows a significant deviation from the trends of the other samples (Table 5-14). This sample obtained from beneath a metate is relatively much lower in Pinus (pine) and Juniperus (juniper) pollen and higher in weedy pollen, Asteroideae (aster-like plants) and Cichoroideae (chicory-like plants) (Tabl 5-12). This may reflect either seasonality or weedy species invasion after fire or site abandonment.

Nonpottery Sample 22 fits in least well with the other pollen samples with which it is being compared (Table 5-14). Examination of the pollen percentages for this sample clearly identitifies the cause (Tabie 5-12). Juniper poilen reaches its greatest values in this sample. In Table 5-11, it was noted that this sample was obtained from the surface of a rock cache feature lying beneath junipers. This sample 


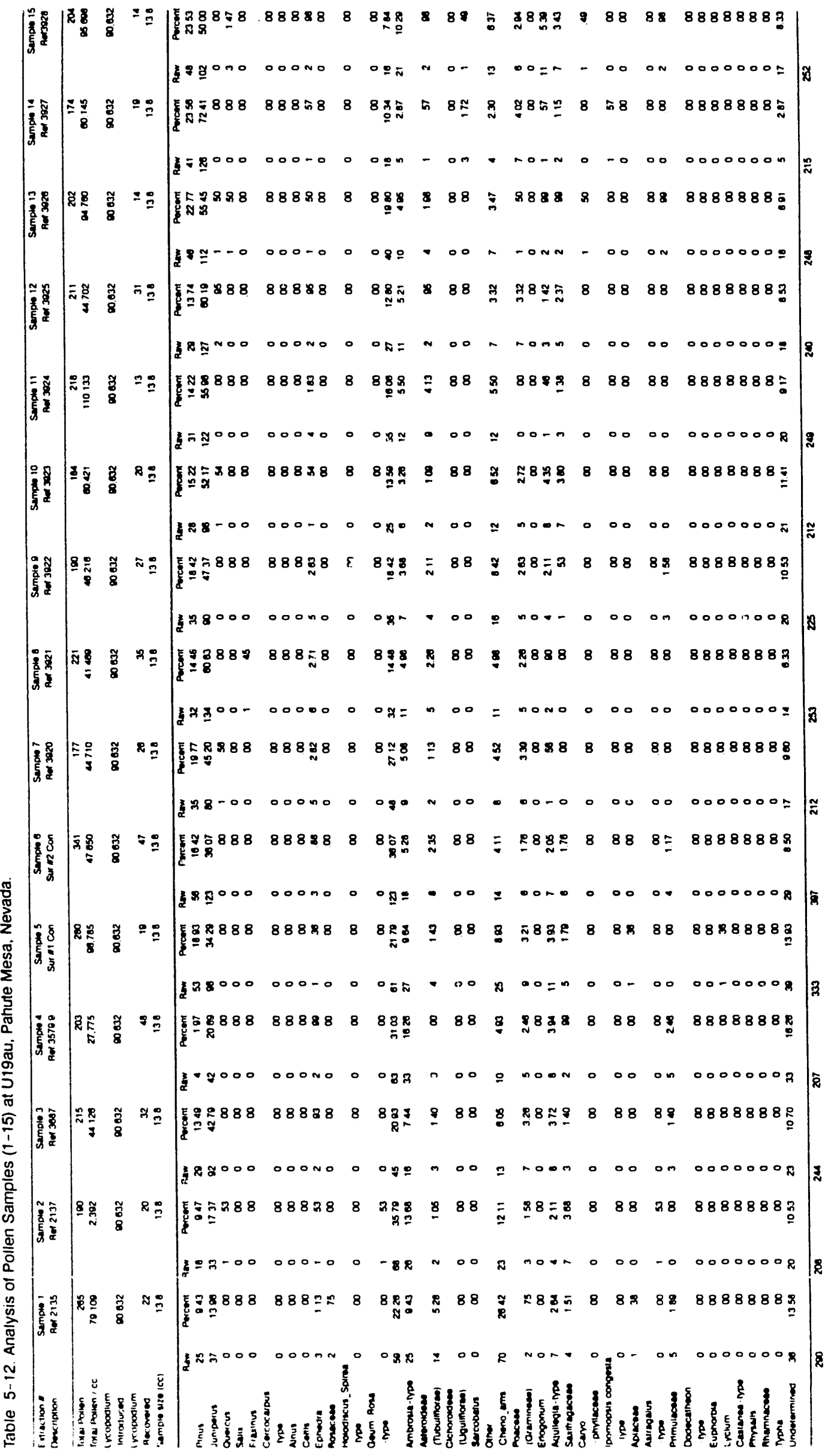




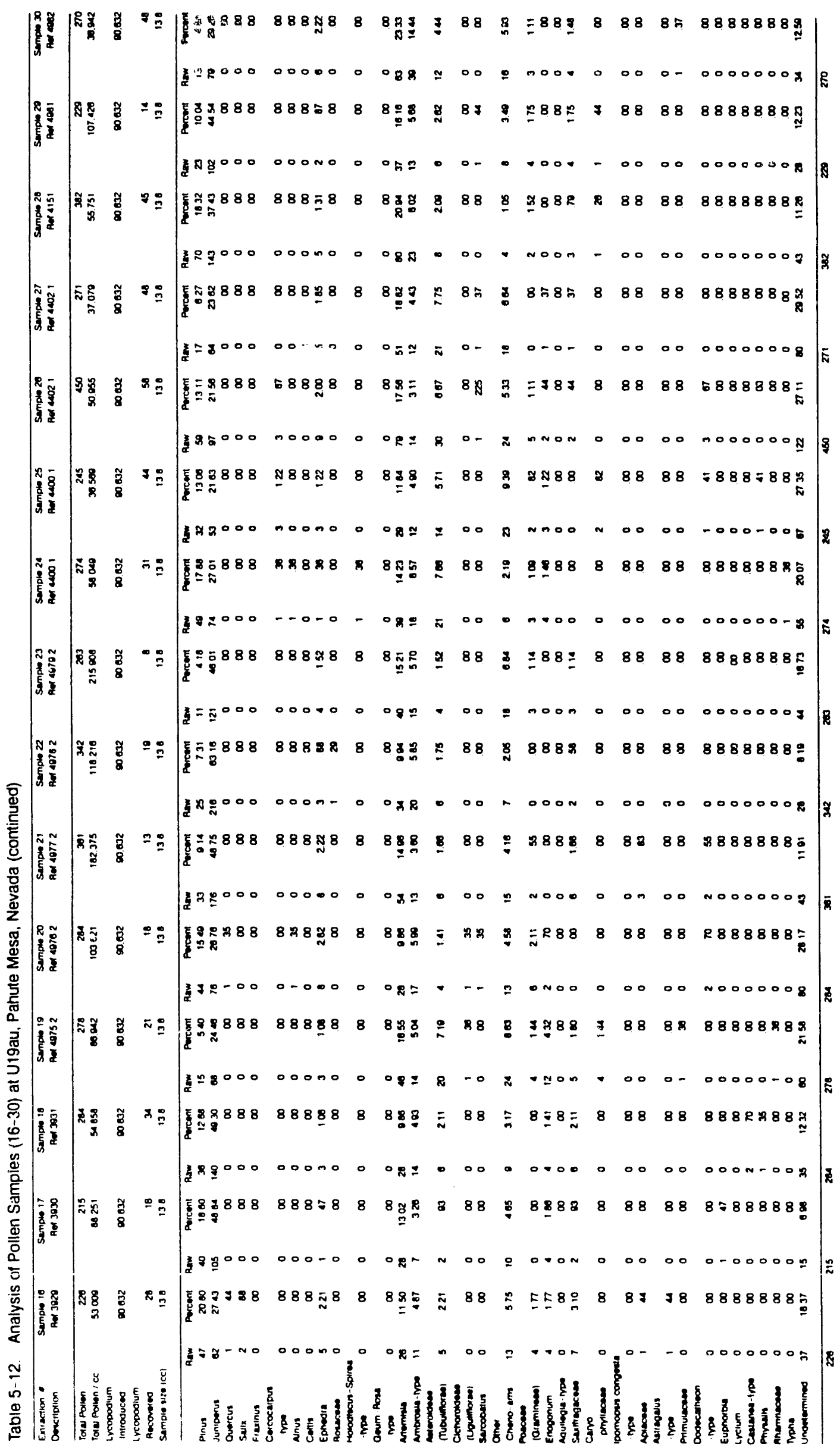


Table 5-13. Pollen Samples from Artifacts at U19au, Pahute Mesa, Nevada.

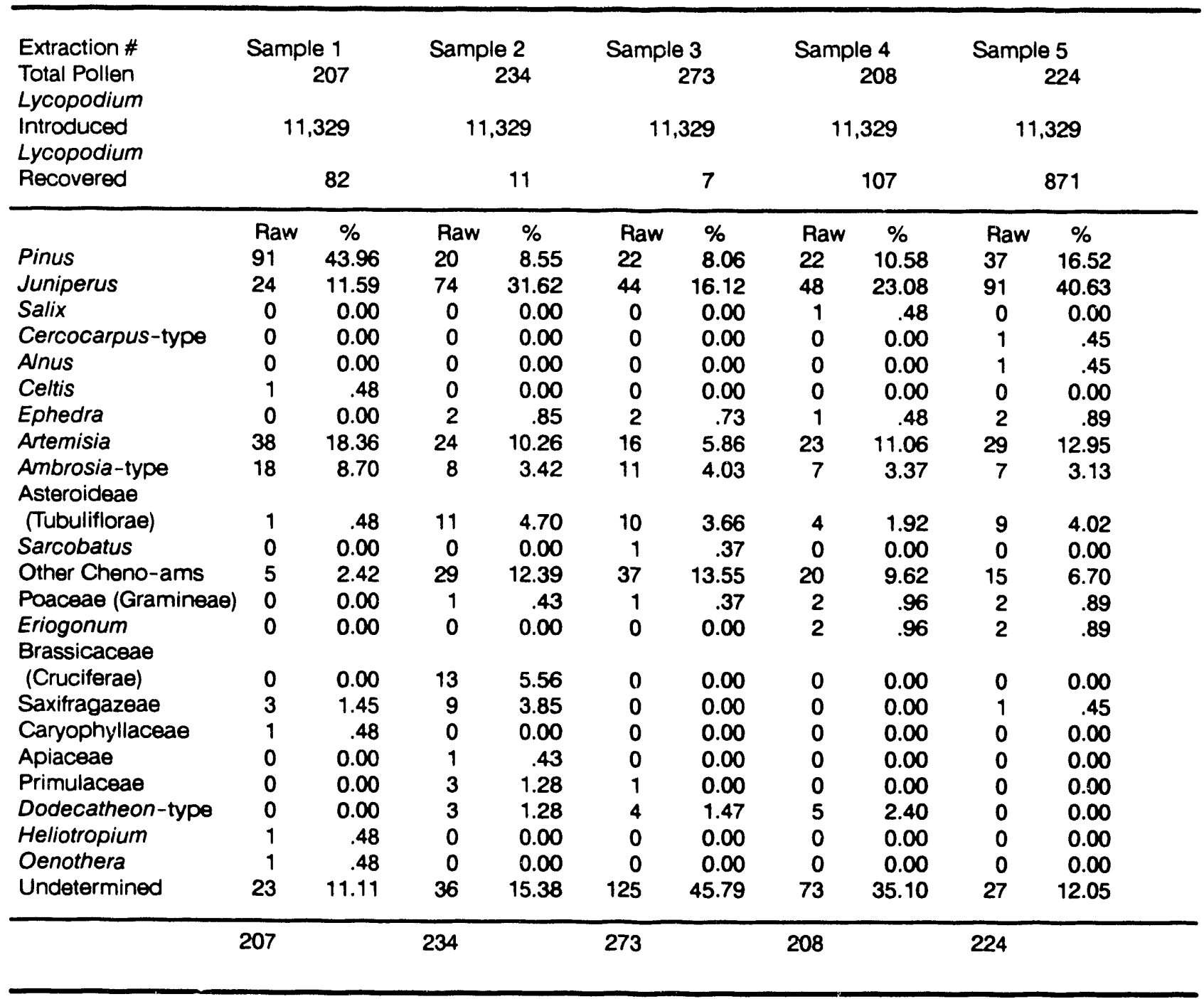

probably reflects the time of year that it was collected.

Nonpottery pollen Samples 7 through 18 taken from Feature 1, Unit 4 show no significant differences between them (Table 5-14). Some samples have much greater values of juniper than others, but that may again simply reflect the differences of season of collection (Table 5-12).

Pearson's r correlation run on pollen samples collected from pottery recovered from U19au (Table 5-15) indicates that whereas Samples $2-5$ are quite similar, Sample 1 is quite different. It deviates from the other four samples in much higher values of pine and $A$. temisia (sagebrush) pollen (Table 5-15). The only difference between these samples is that sample 1 was obtained from the surface and the other four samples were taken from beneath the surface (Table 5-10). Here we may be dealing with a real difference in pollen content due to a change in the local plant community. Because pine and sagebrush bloom at different times of the year, contamination during collection by pollinating plants probably may be ruled out. Instead, the difference between surface and subsurface pollen samples obtained from the pottery seems to indicate that pine and sagebrush have recently become more aburidant in this area. In addition, 


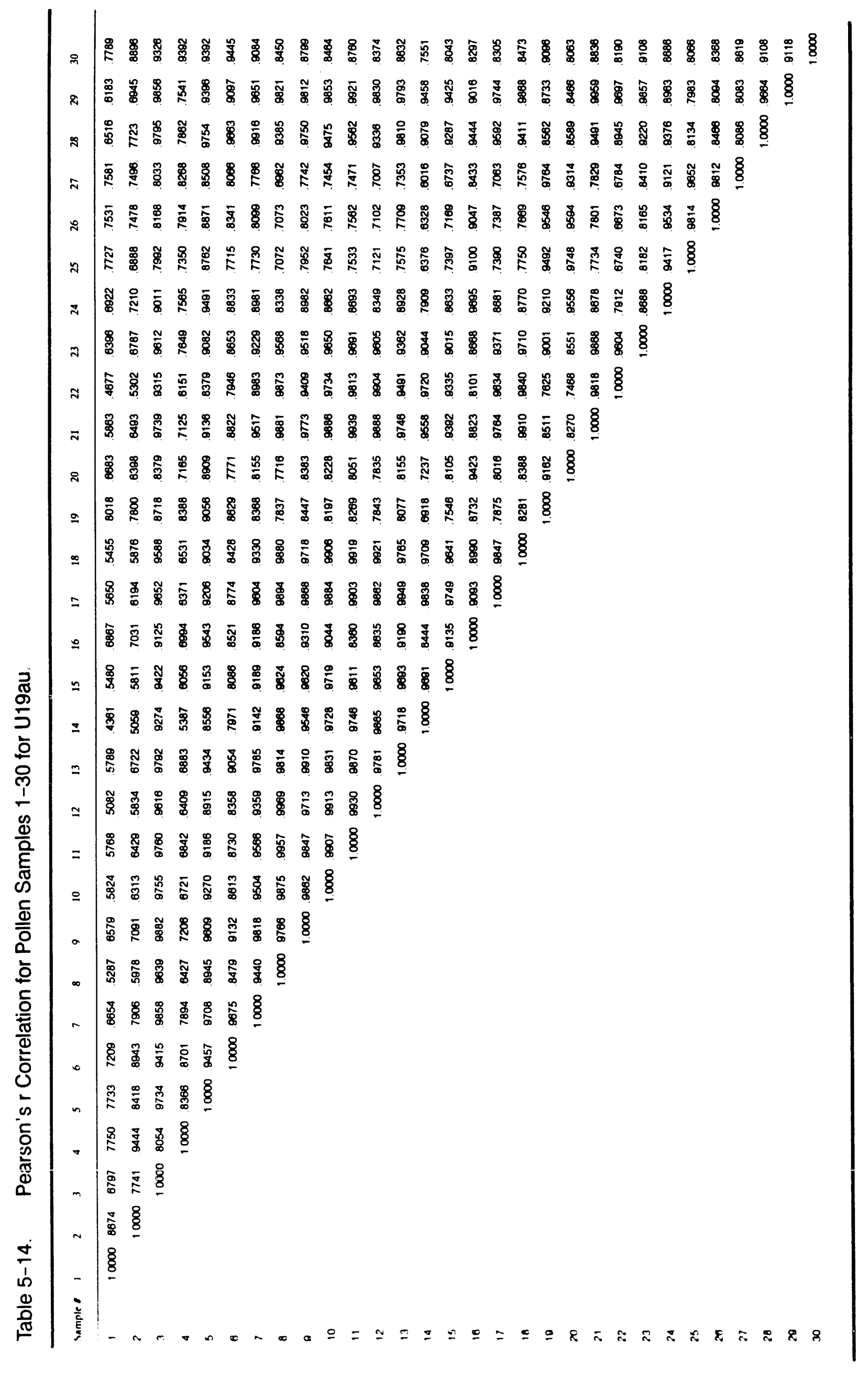




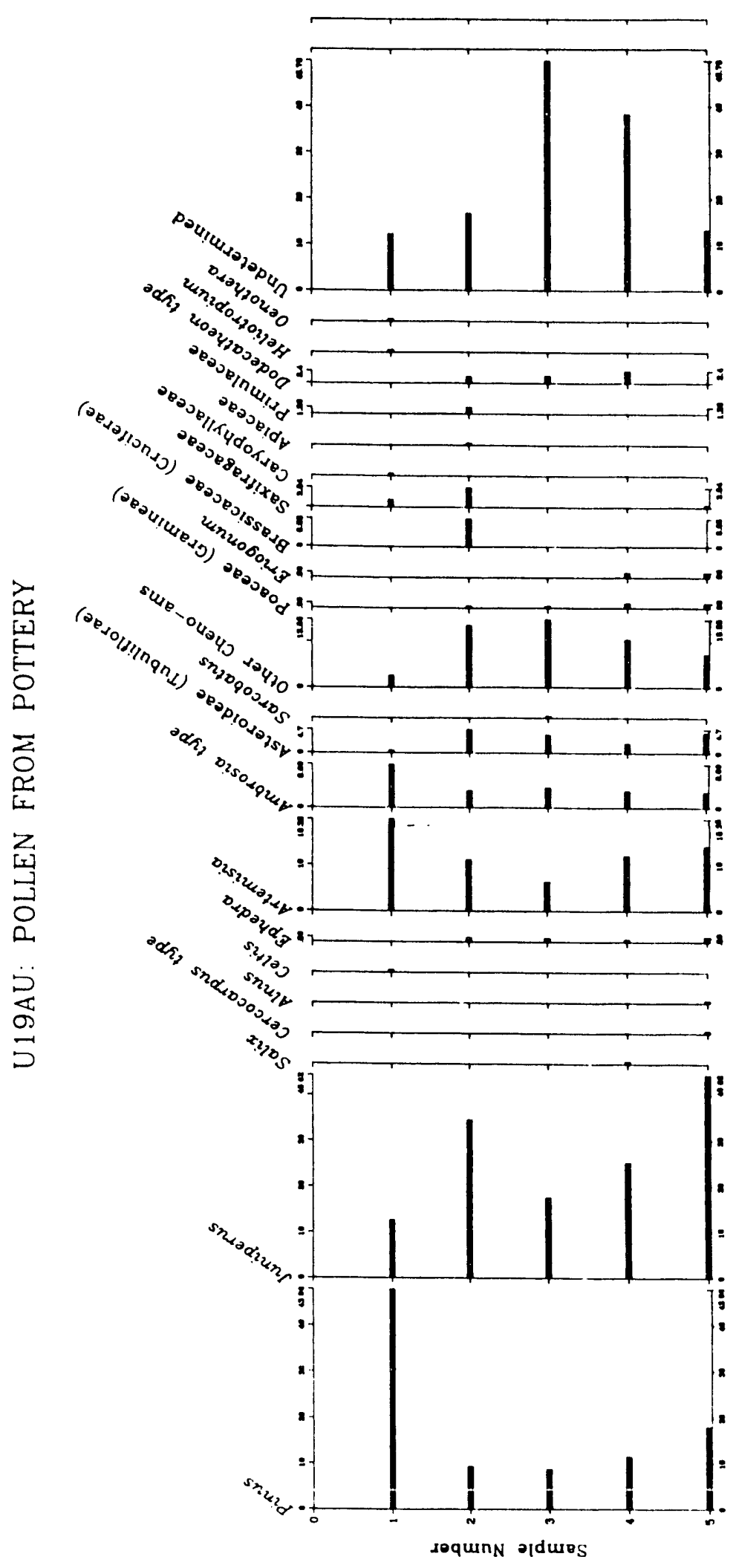

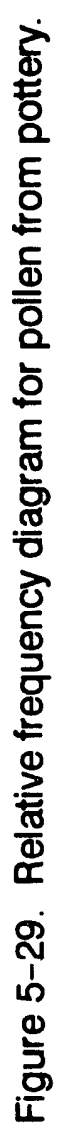




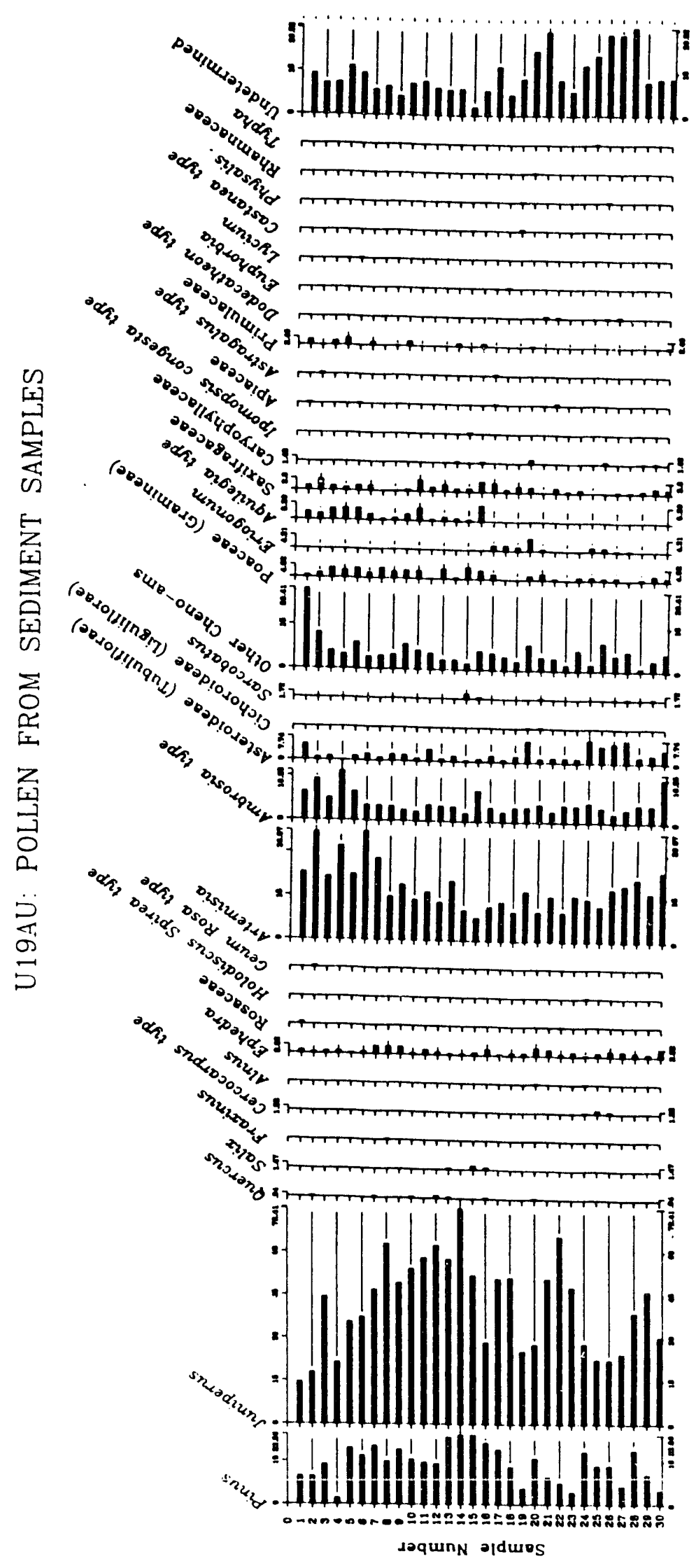

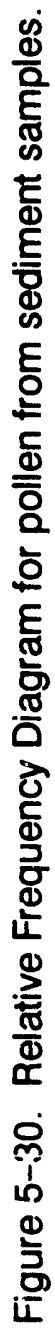


the similarity between the pollen samples removed from the subsurface pottery, whatever site it was from, suggests that the pollen removed from the pottery reflects the pollen contained in the soil matrix and not any pollen that may have been adhering to the surface of the pottery as the result of use.

\section{Macrofossil Analysis}

Plant taxa recovered through flotation came from three distinct feature types found at site $26 \mathrm{Ny} 4040$. The first was a group of five samples from charcoal stains, reference numbers $3761,3762,3777,3953$, and 3966. Retrieved plant parts were also examined from the brush structure, sample reference numbers 3920-3934. The third feature was a humic mat material found near the brush structure, sariple reference number 3973.
For statistical purposes, the charcoal stain information was combined and frequencies and abundances per sample were compared (Table 5-16). The same was done for the brush structure samples (Table 5-17). The humic mat sample was treated individually because it was the only one (Table 5-18). For a plant taxon to have any degree of significance, an examination of its presence, or percent of frequency, was considered. A high percent of plant macrofossils would need to be extracted from the feature as compared to the control sample to be considered significant. Secondly, the mean number per sample, or percent of abundance, was considered.

For the plant taxa from the charcoal stains that appeared in significant frequencies and

Table 5-15. Pearson's r Correlation for Pollen Samples from Artifacts at U19au.

\begin{tabular}{lrrrrr}
\hline Sample \# & 1 & 2 & 3 & 4 & 5 \\
\hline 1 & 1.000 & .515 & .420 & .548 & .717 \\
2 & & 1.000 & .709 & .850 & .948 \\
3 & & & 1.000 & .958 & .584 \\
4 & & & & 1.000 & .879 \\
5 & & & & 1.000 \\
\hline
\end{tabular}

Table 5-16. Significance of Plant Taxa Present in Charcoal Stains at 26Ny404C.

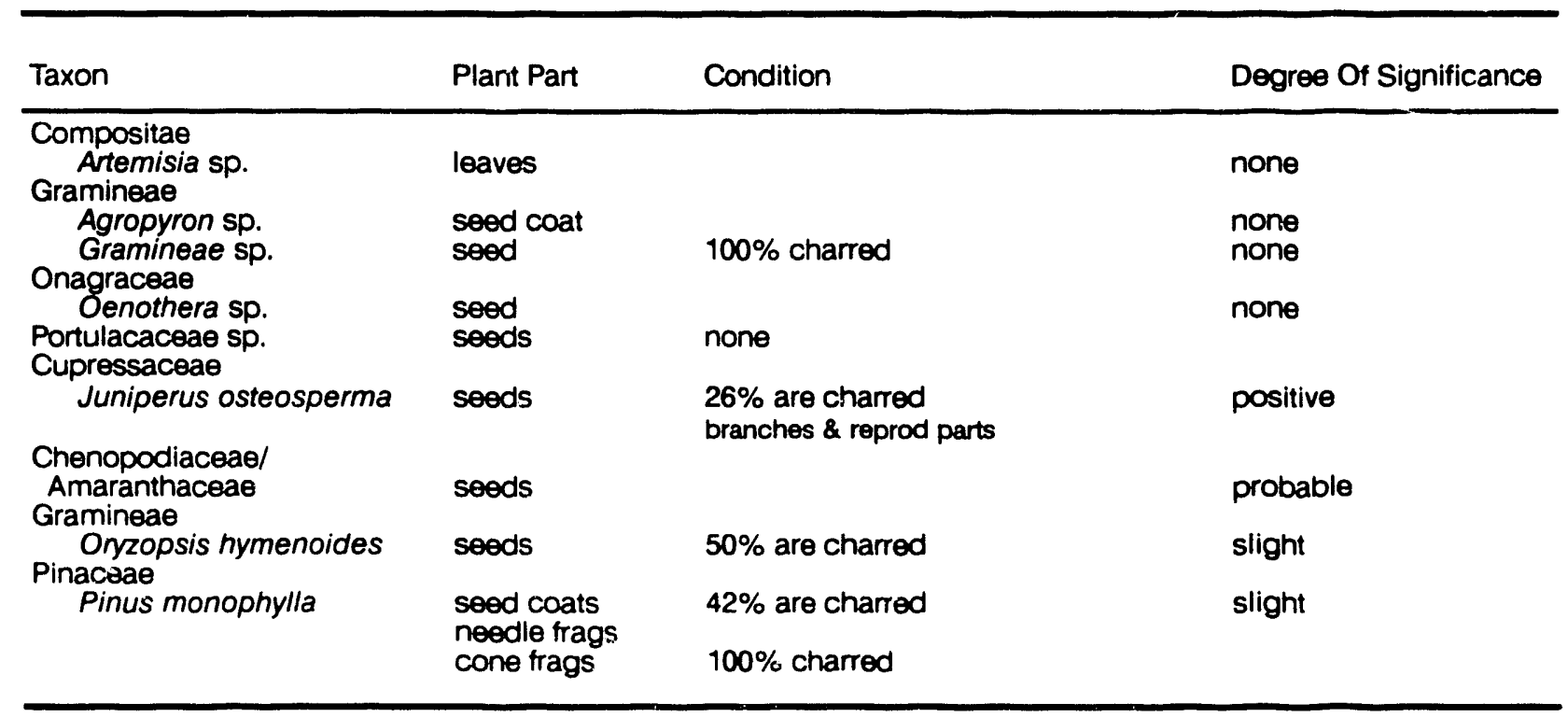


Table 5-17. Significance of Plant Taxa Present in the Brush Structure at 26 Ny4040.

\begin{tabular}{|c|c|c|}
\hline Taxon & Plant Part & Degree Of Significance \\
\hline $\begin{array}{l}\text { Composita } \\
\text { Tetradymia sp. } \\
\text { Chrysothamnus } \\
\text { Boraginaceae } \\
\text { Cryptantha scoparia } \\
\text { Euphobiaceae } \\
\text { Euphorbia parishii } \\
\text { Gramineae } \\
\text { Agropyron sp. } \\
\text { Stipa comata } \\
\text { Leguminosae } \\
\text { Astragalus sp. } \\
\text { Lamiaceae } \\
\text { Salvia dorrii } \\
\text { Loacaceae } \\
\text { Mentzelia albicaulis } \\
\text { Onagraceae } \\
\text { Oenothera sp. } \\
\text { Pinaceae } \\
\text { Pinus monophylla } \\
\text { Scrophulariaceae } \\
\text { Scrophularia sp. } \\
\text { Portulacaceae sp. } \\
\text { Cupressaceae } \\
\text { Juniperus osteosperma } \\
\\
\text { Compositae } \\
\text { Artemisia sp. } \\
\text { Chenopodiaceae/ } \\
\text { Amaranthaceae } \\
\text { Pinaceae } \\
\text { Pinus monophylla } \\
\text { Gramineae } \\
\text { Oryzopsis hymenoides }\end{array}$ & $\begin{array}{l}\text { seed } \\
\text { seed } \\
\text { seeds } \\
\text { fruit capsules } \\
\text { seeds \& seed coats } \\
\text { awn fragments none } \\
\text { seed } \\
\text { seed } \\
\text { seeds } \\
\text { seed } \\
\text { needle fragments none } \\
\text { seeds } \\
\text { seeds } \\
\text { seeds } \\
\text { immature seeds } \\
\text { branches \& reprod parts } \\
\text { leaves } \\
\text { seeds } \\
\text { seeds \& seed coats } \\
\text { seeds \& seed fragments }\end{array}$ & $\begin{array}{l}\text { none } \\
\text { none } \\
\text { none } \\
\text { none } \\
\text { none } \\
\text { none } \\
\text { none } \\
\text { none } \\
\text { none } \\
\text { none } \\
\text { none } \\
\text { positive }\end{array}$ \\
\hline
\end{tabular}

Table 5-18. Significance of Plant Taxa Present in the Humic Mat at 26 Ny4040.

\begin{tabular}{|c|c|c|}
\hline Taxon & Plant Part & Degree of Significance \\
\hline $\begin{array}{l}\text { Compositae } \\
\text { Avtemisia sp. } \\
\text { Lamiaceae } \\
\text { Salvia dorrii } \\
\text { Leguminosae sp. } \\
\text { Loacaceae } \\
\text { Mentzelia albicaulis } \\
\text { Portulacaceae sp. } \\
\text { Chenopodiaceae/ } \\
\text { Amaranthaceae } \\
\text { Cupressaceae } \\
\text { Juniperus osteosperma } \\
\text { Pinaceae } \\
\text { Pinus monophylla } \\
\text { Gramineae } \\
\text { Oryzopsis hymencides }\end{array}$ & $\begin{array}{l}\text { leaves } \\
\text { seed } \\
\text { seed } \\
\text { seeds } \\
\text { seeds } \\
\text { seeds } \\
\text { seed fragments probable } \\
\text { seed coat fragments } \\
\text { needle fragments } \\
\text { seeds }\end{array}$ & $\begin{array}{l}\text { none } \\
\text { none } \\
\text { none } \\
\text { none } \\
\text { none } \\
\text { probable } \\
\text { probable } \\
\text { slight }\end{array}$ \\
\hline
\end{tabular}


significant mean number per sample, some statements can be made. If the charcoal stains were caused by the activities of prehistoric peoples, then there appears to be a possible utilization of the following plant taxa:

1) Chenopodiineae;

2) Juniper osteosperma;

3) Oryzopsis hymenoides; and

4) Pinus monophylla.

As may be expected, many of the taxa from the charcoal-stain feature samples were charred. Clearly, the charcoal stains are associated with fire. Whether the plants were used to start the fire or were charred in the cooking process cannot be discerned from the flotation analysis.

Again the sample contents from the brush strusture feature were compared to the control sample from outside of the feature. Because the feature samples show some significant differences, a possible utilization of the following plant taxa may be considered:

1) Juniper osteosperma;;

2) Artemisia sp;

3) Chenopodiineae;

4) Oryzopsis hymenoides; and

5) Pinus monophylla

However, since the structural feature is associated with a juniper tree, a natural seed and plant part "rain" may have contributed to the juniper evidence that is present. Because the juniper macrofossils for this feature do not exhibit charring, a natural seed rain cannot be completely ruled out.

Because only one sample was obtained from the humic mat, it was difficult to compare feature and control samples. For this sample. the most significant plant taxa may be:

1) Chenopodiineae;

2) Juniperus osteosperma;

3) Pinus monophylla; and

4) Oryzopsis hymenoides
Overall results for the humic mat are consistent with the other features for this site. Like the brush structure, there is no charred material from the humic mat feature. Thus, utilization of these plants by prehistoric peoples cannot be confirmed without additional evidence.

\section{Conclusions}

Analyses of 35 pollen samples from U19au reveal few significant differences that cannot be accounted for through contamination from nearby pollinating plants. Only polIen Sample 1 collected from a pottery sherd may reflect a significant increase in the density of pine and sagebrush in the area. However, when compared to all other pollen samples this seems to be the exception rather than the rule. Even the differences found in the pollen from this sherd could be explained as overrepresentation of pine and sagebrush pollen due to the presence of nearby pinyon trees and sagebrush shrubs.

The plant taxa retrieved from soil flotation for $26 \mathrm{Ny} 4040$ are similar to what are currently found as modern vegeiátion assemblages for this geographic area. The main vegetation type is a pinyon-juniper community. The overstory consists of pinyon pine and Utah juniper with an understory of sagebrush, bitterbrush, buckwheats, bunchgrasses, and assorted mid-elevation forbs.

Analyses of 22 flotation samples from $26 \mathrm{Ny} 4040$ indicate that occurrence of seeds of juniper, chenopods, pinyon, and Indian rice-grass occur in archaeological contexts in greater abundance than in the control sample. This may iridicate prehistoric use of these seeds by native peoples. However, it may aiso simpiy refilect the vagaries of sampling. The charred seeds of juniper, chenopod, pinyon, and Indian rice-grass, may be our besi indication that these seeds were used by people. 


\section{CONCLUSIONS}

Archaeological investigations at U19au were guided by the 11 general research questions previously listed in this report. Many of these questions are regional in nature and cannot be addressed by investigations at a single location. Additionally, investigation may not provide information pertinent to a specific research question. Nevertheless, what follows is a review of information that was gained from archaeological investigations at U19au.

1. What are the relationships between Anasazi cultural remains on Pahute and Rainier mesas and those of the non-horticultural hunters and gatherers who traditionally utilized this environment?

DRI has proposed that relationships of Anasazi and hunter-gatherer groups may be determined by analyzing the spatial distribution of artifacts associated with the Anasazi groups. Artifact types which can definitely be associated with Anasazi groups are limited to certain pottery types, particularly graywares and painted pottery. Of the 546 sherds of pottery recovereci from the U19au area, only three of them are grayware and are likely to have originated in the Anasazi areas of southeast Nevada. Given the general lack of this type of materia!, the artifacts probably represent a traded item rather than Anasazi occupation. The evidence for Anasazi influence at U19au is minimal.

2. What is the relationship between past fluctuations in the environment of Pahute and Rainier mesas and prehistoric patterns of settlement and subsistence?

DRI and others are currently developing a regional history of environment at both Pahute Mesa and nearby Fortymile Canyon. Since these studies have not been completed, it is premature to address this issue. Based on the projectile points found, howev$\mathrm{er}$, the archaeological record here spans about 3,500 years.

3. What is the history and what are the pro- cesses of past residential mobility and demography on Pahute and Rainier mesas?

To address the history and evolution of hunter-gatherer adaptations and mobility on Pahute Mesa is difficult from the perspective of a single locality such as U19au since a regional database is required. DRI has reported on investigations at one other area on Pahute Mesa, drill site U19an (Henton and Pippin 1987). While the approximate times of utilization and the artifact types found are similar, the overall nature of the cultural remains are significantly different. Most of the area investigated at U19an involved an open pinyon-juniper covered bench with diffuse but widely distributed artifacts. Campsite and other artifact concentrations were difficult to identify and associate with specific funciions. At U19au, however, concentrations are easy to recognize, and functions for most are more easily discernible. In the later periods of aboriginal occupation, the U19au area was inhabited much more intensely than was the area around U19an.

The reasons for the more intensive use of the U19au area over U19an, especially in later periods of time, may relate primarily to its location on the mesa. U19an is in the interior of the mesa, somewhat far from historically recorded aboriginal campsites. U19au, on the other hand, located along the south end of the mesa in a valley, was likely a good route of travel from lower elevation sites on the Test Site and beyond to the Beatty area and Ash Meadows. U19au may also have been one of the logical stopping places on the annual excursion into the pinyon-juniper areas of Pahute Mesa while interior sites like U19an were only used periodically.

4. What are the sources of raw materials used in artifacts and features found at cultural resources on Pahute and Rainier mesas?

At this time, no investigations have been made into the sources of artifacts recnvered 
from the U19au area. Much of the material for flaked stone artifacts is locally occurring chalcedony, chert, or tuff and is likely to have come from the immediate vicinity. The nearest known source of obsidian to U19au occurs on Pahute Mesa near U19an, so this material is imported to a certain extent. Numerous obsidian sources occur elsewhere on Pahute Mesa and in the general vicinity, but the fingerprinting work necessary to identify these sources has yet to be completed. Until such time as the southern Nevada sources are adequately identified, sourcing of obsidian is not possible.

No systematic investigations for clay sources have been conducted on the Test Site, so sourcing of pottery is also not possible at this time.

5. What strategies of subsistence resource utilization are represented in the archaeological record of Pahute and Rainier mesas, how has this resource utilization affected settlement patterns, and how have these subsistence and settlement strategies or their relationship changed through time?

Like question 3 , this question requires a regional database to examine meaningful adaptations. Camping and maintenance activities are clearly represented at U19au and appear to be an important part of aboriginal subsistence patterns in this vicinity for the last 500 or so years. This camping probably supported pine nut gathering as that is the most conspicuous resource in the area. While here, aboriginals also exploited other resources, particularly locally occurring toolstone. Direct evidence for the exploitation of the local toolstone comes from an aboriginal quarry in close association with other site types and a substantial percentage of locally available toolstones in the artifact assemblages. Evidence for other exploitation is more inferential. The recovery of 123 projectile points representing the last 3,500 years of prehistory indicates that hunting was an important activity here. Manos and milling- stones indicate that plant resources other than pine nuts were also gathered and processed here. Analysis of plant macro-fossil samples from $26 \mathrm{Ny} 4040$, one of the campsites, indicates that aboriginally exploited plants may also include chenopods and Indian rice grass.

6. What is the history and magnitude of fluctuations in the environment of Pahute and Rainier mesas during the last 18,000 years?

Question 6 embodies the necessary environmental data to investigate Question 10. This information has yet to be developed in the detail necessary to provide the background for casual relationships between the cultural evolution and environment.

7. What behavioral information (e.g., methods of tool manufacture, changes in lithic technology, economy of resource use, and nature of associated activities) is represented by lithic debitage at lithic scatters on Pahute and Rainier mesas?

The analysis of artifact distributions from U19au has attempted to identify and define meaningful concentrations of artifacts recovered from the surface of the area investigated. This analysis is based on the assumption that the temporal and functional stratification at archaeological sites in this environment is primarily horizontal rather than vertical. Evidence supporting this assumption is inferential and is based on observations or common associations of temporally distinct artifacts, incongruous artifact assf mblages, lack of distinct boundaries for archaeological sites, and consistency of surface with subsurface assemblages (see Question No. 8 below).

Sorting cultural overlays is a difficult process at best, and here was limited to isolating artifact concentrations from each other and to comparing them. Using debitage types as an indicator of lithic tool manufacturing activity, 11 observed clusters of artifacts were compared. This comparison was free form; that is, no assumption of the outcome was made. 
Based on relative proportions of debitage types, the analysis identified four major group types for this vicinity. The first and easiest to explain is a concentration type associated with quarrying, dominated by shatter and decortication debitage. Next was a group composed of the debitage found around the two sites with observable structure features, sites $26 \mathrm{Ny} 4021$ and $26 \mathrm{Ny} 4040$. These concentrations have a two-to-one ratio of biface thinning to core reduction debitage, an obser. vation consistent with tool maintenance activities often inferred for campsites. The presence of significant amounts of shatter at these sites is more difficult to address, but it is this presence which discriminates this group from the next group.

The next group is composed of two concentrations - one very large, the other quite small-containing a high level of biface thinning debitage at least twice as great as core reduction debitage and a low percentage of shatter. In the case of the small concentration, this probably represents a single episode of bitace reduction, although the presence of different material types suggests several bifaces were reduced here. The large concentration is more difficult to interpret. Likely it represents an area where bifaces were reduced, but clearly not as a single event. This concentration occurs between two areas containing structures. One was not investigated, so its ultimate relationship with the significant cultural resources in the valley has yet to be determined.

The final group, composed of the six remaining clusters, is characterized by high core reduction debitage when compared to biface thinning debitage. The locations of clusters assigned to this group are distinct; they are all found in the open sagebrush valley. Whether these clusters represent earlier or just different activities is uncertain. However, diagnostic projectile points for these concentrations are typically Elko types, while Elko types are uncommon in the other clusters. Presumably, if this temporal association holds, stone tool manufacturing techniques, here associated with Elko times, are characterized by high relative percentages of core reduction debitage compared to other types. While it would be tempting to assume that later manufacturing is characterized by biface thinning debitage, this evidence is ambiguous. Clearly $26 \mathrm{Ny} 4021$ and $26 \mathrm{Ny} 4040$ are late, but the concentrailion associated with the highest relative percentage of biface thinning debitage contains a wide spread of diagnostic artifacts, including a substantial number of Gatecliff type points.

Another aspect of behavioral information which can be addressed is the size (e.g., number of structures) of archaeological sites having such features (Table 6-1). Six sites have recognizable structures. Site 26 Ny4015 contained two clusters, the smaller

Table 6-1. Number of Recognizable Structures Present at Archaeological Site at U19au.

\begin{tabular}{llc}
\hline & Site & Structures \\
\hline 4015 & Locus 1 & 4 \\
4015 & Features 7 and 8 & 2 \\
4021 & & 3 \\
4022 & & 4 \\
4023 & & 4 \\
4040 & & 3 \\
4049 & & 1 \\
\hline
\end{tabular}


about $30 \mathrm{~m}$ south of the larger. Within each cluster, the structures do not overlap and, therefore, may be contemporaneous. It appears that groups composed of three to four households occupied this area of Pahute Mesa and built structures in close proximity. Whether these clusters of structures represent a series of occupations or a single contemporaneous event is more difficult to answer. However, artifacts and dates associated with the two structure sites investigated indicate that they are not contemporaneous.

8. What are the processes and chronology of sediment deposition on Pahute and Rainier mesas, and how may natural geologic and biotic processes have affected the nature of the archaeological record there?

At U19au, 4 test pits were dug in geologically depositional environments, and 13 subsurface scrapes were conducted in varying deposits. Little cultural material was found at depth in any of the 4 test pits, indicating that the cultural material at these locations is probably a surface phenomena and that recent geologic deposition has little effect on the cultural resources observed on the surface. Of the 13 subsurface scrapes, 4 had artifact concentrations high enough to compare the surface and subsurface material. In 3 of the 4 cases, the proportions of artifacts based both on size and types could not be differentiated between surface and subsurface areas using chi-square tests. However, significant amounts of material are found just beneath the surface, ranging from 56 to 200 percent of the surface material. While uppermost levels of the surface in this area-unconsolidated sandy deposits - are quite active, this mechanical mixing generally is limited to within a few centimeters of the surface.

9. How are ethnohistoric sites on Pahute and Rainier mesas represented in the archaeological record, and how may this information be used in modeling more ancient settlements and activities?
At least five, and probably seven, ethnohistoric sites were observed at U19au. The five definite sites are 26Ny4021, 26Ny4023, 26Ny4040, 26Ny4047, and 26Ny4049. The two probable ethnohistoric sites consist of the northern area of $26 \mathrm{Ny} 4015$ and $26 \mathrm{Ny} 4022$. Of these seven sites, three (26Ny4021, 26Ny4022, and the northern portion of 26Ny4015) have structure clearings or rock rings. Three (26Ny4023, 26Ny4040, and 26Ny4049) have brush structures, and one is a cached historic artifact. One of the rock ring sites (26Ny4021) and a brush structure site were investigated during the data recovery phase of the project. Historic artifacts were recovered from both sites, but many more were found in the brush structure site than in the rock ring site. All historic artifacts at $26 \mathrm{Ny} 4040$ were discovered during exposures. One historic artifact was recovered from the surface of 26Ny4021, a tin strip apparently attached to a seed beater. Another artifact, a bead, was found in a hearth feature. While the association of the seed beater and 26Ny4021 may be fortuitous, the glass bead is not. A carbon date from the feature brackets the date to between 420 and 520 years B.P., somewhat early for the bead.

In spite of the glass bead at 26Ny4021, it appears that this site is older than either of the brush structure sites (26Ny4023 or 26Ny4040), and the rock ring sites appear generally older than the brush structure sites. This observation is based mostly on the numbers and types of historic artifacts present. At 26Ny4021, only a single artifact, a glass bead, can be definitely associated with the site, but the brush structure sites contain beads, buttons, lead shot, a knife, and miscellaneous tin strips. While the glass (white opaque) may have been acquired relatively early during historic contact, buttons, jean rivets, and the like appeared much later. If there is a shift from rock ring structures to brush windbreaks during historic times, its predominant manifestation in the archaeological record at U19au is 
an increase of historic items in the assemblage, undoubtedly representing to some extent a replacoment of prehistoric tools.

10. What are the spatial relationships of cultural remains on Pahute and Rainier mesas to each other and to available natural resources?

Although artifacts and cultural features are found throughout the project area, their distribution is not uniform. The most notable cultural features are rock rings or brush windbreaks. In this vicinity, both are interpreted as camping structures. These structures are observed in clusters of two to four features, implying group occupations of that many families. With the notable exception of $26 \mathrm{Ny} 4040$, they are located to the west of the valley and are distinct from each other. Because they are distinct, they may all represent a contemporaneous occupation, but the nature of the temporally diagnostic artifacts found at the sites indicated that they more likely represent recurring loci of activity in the valley spanning at least the last $\mathbf{5 0 0}$ or so years.

These camp sites overlie an artifact scatter containing temporally diagnostic artifacts which are considerably older, up to 3,500 years old. The relationships of these earlier scatters are more difficult to assess as they are less distinct. A relatively complete assemblage of projectile points from Gatecliff types to Desert Side-notched types indicates that use of this area has been relatively continuous if sporadic. The distribution of these point types is not uniform. However, it correlates somewhat to microtopographic features, so it appears that different areas of the valley were visited through time.

Analysis of pollen and plant macrofossil evidence indicates that particular plants, e.g., juniper, chenopods, pinyon, and Indian rice grass, are found in greater abundance in archaeological sites than in the control samples from the valley. This implies that these plant taxa were important economically to the aboriginals who camped here. Since all of these plants are common to the area, they probably represent locally exploited plant resources.

11. How old are the cultural remains in question?

With the exception of the radiocarbon date from the hearth at $26 \mathrm{Ny} 4021$, dating the cultural remains at U19au has been acconiplished by cross-referencing dates associated with temporally diagnostic artifacts, particularly projectile points. The majority of the 123 recovered projectile points were identifiable to type. These types are not randomly distributed over the U19au area; certain ones occur more frequently in some areas and less frequently in others. The most notable example is that of Elko and Gatecliff/ Gypsum points. Gatecliff and Gypsum points tend to be found in the northwest portion of the drill pad area on an open pinyon-juniper slope. Elko points, usually considered diagnostic of a comparable or younger age, are distributed along the valley bottoms in a sagebrush environment. Rosegate projectile points have a more uniform distribution with regards to environment, significantly overlap both Gatecliff/Gypsum and Elko distributions. While the terminal dates for Rosegate points are usually assigned to about 500 years B.P., three were found in association with 26 Ny4040, a site whose main temporal associations appear to be middle to late nineteenth century. Since these were surface finds, the association between the points and the historic artifacts is unclear and may represent either overlapping activities or secondary utilization. Oddly enough, Desert Side-notched projectile points have quite a limited distribution, similar to Gatecliff points. Again, this most likely reflects overlapping activities. Cottonwood points are found directly associated with the Desert Side-notched points and in small numbers around the two historic sites.

Based on the inference made from the projectile point types, prehistoric activities began about 3,500 years ago and continued to 
within the last 100 years. The current distribution of projectile points indicates that the location of these activities in the valley shift over time, occasionally overlapping previous activities.

\section{Management Recommendations}

The archaeological investigations at U19au involve two distinct areas - that of the original survey and that where data recovery activities were conducted. The survey area includes a one-square-kilometer area centered on the U19au drill hole as well as the access road. The data recovery area involves a significantly smaller area 600-by-750 meters plus the access road, totalling approximately 50 percent of the areal extent of the original survey.

The data recovery conducted in this smaller area appears sufficiently complete and suitable to mitigate adverse impacts to the cultural resources located within the area. But many, very significant archaeological sites and features lie in the area surveyed, beyond the limits of the data recovery efforts. Even though these archaeological sites were known to DOE, activities associated with the preparation of U19au as an event site went beyond the limits of the data recovery and adversely affected several of these significant sites. In one case, while placing remote sen- sors, a four-wheel-drive vehicle drove through two sites, narrowly missing the brush structures at $26 \mathrm{Ny} 4023$ and driving through a house ring at $26 \mathrm{Ny} 4022$. These resources were not protected because the DOE project field manager apparently perceived that, since the archaeologists were finished in the area, there were no longer any archaeological concerns. Moreover, the manager believed the area cleared for activities was the larger area of the survey, not the smaller area where data recovery actually took place. In the original data recovery plan (Pippin and Henton 1986), DRI proposed that the entire surveyed area be mitigated. DOE countered that adverse effects would be limited to the smaller area and authorized data recovery for that smaller area. While, by and large, most adverse effects were limited to the smaller area, not all were, and DOE did not take the appropriate steps to insure that those in the field knew of the limits of the cleared areas or the potential for adversely affecting known sites. It is our recommendation that DOE improve this kind of information exchange with those responsible for the fieldwork so that known archaeological sites and areas where archaeological reconnaissances have yet to be conducted are protected from adverse impacts from construction and support activities. 


\section{REFERENCES CITED}

Alkens, C.M.

1970 Hogup Cave. Anthropological Papers No. 93. University of Utah, Salt Lake City.

Antevs, $E$.

1952 Cenozoic Climates of the Great Basin. Geologische Rundschau 40:94-108.

Baker, R.G.

1983 Holocene Vegetational History of the Westem United States. In Late-Quaternary Environments of the United States, vol. 2, edited by H.E. Wright, Jr. University of Minnesota Press, Minneapolis.

Baumhoff, M.A.

1957 An Introduction to Yana Archaeology. University of Califomia Archaeological Survey Reports No. 40.

Baumhoff, M.A., and J.S. Byme

1959 Desert Side-notched Points as a Time Marker in Califomia. University of California Archaeological Survey Reports 48:32-65.

Beatley, J.C.

1976 Vascular Plants of the Nevada Test Site and Central-Southern Nevada: Ecologic and Geographic Distributions. U.S. Energy Research and Development Administration, Technical Information Center, Springtield.

Bergin, K., and R. Roske

1978 Literature Overview Conceming Cultural Resources of the Nellis Bombing and Gunnery Ranges, Nye, Lincoln and Clark Counties, Nevada. Unpublished report, archaeological Research Center, Museum of Natural History, University of Nevada, Las Vegas.

Bettinger, R.L.

1975 The Surface Archaeology of Owens Valley, Eastern Callfornia. Unpublished Ph.D. dissertation, Department of Anthropology, University of Califomia, Riverside.

Bettinger, R.L., and R.E. Taylor

1974 Suggested Revisions in Archaeological Sequences of the Great Basin and Interior Southem Califomia. In A Collection of Papers on Great Basin Archaeology, edited by R. Elston and L. Sabini, pp.1-26. Nevada Archaeological Survey Research Paper 5:1-26.

Binford, L.R.

1978 Dimensional Analysis of Behavior and Site Structure: Looking from an Eskimo Hunting Stand. American Antiquity 43(3):330-361.

Brakenridge, G.R.

1978 Evidence for a Cold, Dry Full-Glaclal Climate in the American Southwest. Quaternary Research 9:22-40.

Brinkmann, W.A.R.

1976 Surface Temperature Trend for the Northem Hemisphere--Updated. Quaternary Research 6(3):355-358.

Broecker, W.S., and P.C. Orr

1958 Radiocarbon Chronology of Lake Lahontan and Lake Bonneville. Geological Society of America Bulletin 69(8):1009-1032.

Bryan, A.L.

1979 Smith Creek Cave. In The Archaeology of Smith Creek Canyon, Eastern Nevada, edited by D.R. Tuohy and D.L. Rendall, pp. 162-253. Anthropological Papers No. 17. Nevada State Museum, Carson City.

Bucy, D.R.

1974 A Technological Analysis of a Basalt Quarry in Western Idaho. Tebiwa 16(2):1-45.

Busby, C.I.

1974 Pinyon Nut Gathering Equipment from the Vicinity of Gardnerville, Douglas County, Nevada. Contributions of the University of Califomia Archaeological Research Facility No. 21, Berkeley. 
1979 The Prehistory and Human Ecolcgy of Garden and Coal Valleys: A Contribution to the Prehistory of Southeastern Nevada. Cuntributions of the University of Califomia Archaeological Research Facility No. 39, Berkeley.

Butter, B.R.

1978 A Guide to Understanding Idaho Archaeology: The Upper Snake And Salmon River Country. 3rd ed. The Idaho Museum of Natural History, Pocatello.

Byers, F.M., Jr., and H. Bames

1976 Geological Map of the Paiute Ridge Quadrangle, Nye and Lincoln Counties, Nevada. U.S. Geological Survey, Washington, D.C.

Byers, F.M., Jr., W.J. Carr, P.P. Orkild, W.D. Quinlivan, and K.A. Sargent

1976 Volcanic Sultes and Related Cauldrons of Timber Mountain Oasis Valley Caldera Complex, Southern Nevada. Professional Paper No. 919. U.S. Geological Survey, Washington, D.C.

Campbell, E.W.C., and W.H. Campbell (editors)

1925 The Pinto Basin Site, An Ancient Aboriginal Camping Ground in the California Desert. Southwest Museum Papers No. 9.

Casjens, L.A.

1974 The Prehistoric Human Ecology of Southern Ruby Valley, Nevada. Ph.D. dissertation, Harvard University, Cambridge.

Chamberlin, R.V.

1911 The Ethno-Botany of the Gosiute Indians of Utah, vol. II, part 5. Memoirs of the American Anthropological Association, Kraus Reprint Corporation, New York.

Chapman, R.C.

1977 Analysis of the Lithic Assemblages. In Settlement and Subsistence along the Lower Chaco River: The CGP Survey, edited by C.A. Reher, pp. 371-452. The University of New Mexico Press, Albuquerque.

Clewlow, C.W. Jr.

1967 Time and Space Relations of Some Great Basin Projectile Point Types. University of Callfornia Archaeological Survey Reports 70:144-149.

Clewlow, C.W. Jr., R.F. Heizer, and R. Berger

1970 An Assessment of Radiocarbon Dates for the Rose Spring Site (CA- INY-372), Inyo County, Califomia. University of Callfornia Archaeological Research Facility 7:19-27, Berkeley.

Code of Federal Regulations (CFR)

1979 Protection of Historic and Cultural Properties, Amendments to Existing Regulations (36 CFR 800).

1987 National Register of Historic Places (36 CFR 60).

Collins, M.B.

1975 Lithic Technology as a Means of Processual Inference. In Lithic Technology: Making and Using Stone Tools, pp. 15-34, edited by E.H. Swanson. Mouton, The Hague.

Cressman, L.S.

1942 Archaeological Research in the Northern Great Basin. Carnegie Institute of Washington No.

Curtis, E.S. 538, Washington, D.C.

1926 The North American Indian, vol. 15. Nonwood, Massachusetts.

Dalley, G.F.

1976 Shallow Shelter and Assoriated Sites. Anthropological Papers No. 96. University of Utah, Salt Lake City.

Daubenmire, $\mathbf{R}$.

1966 Vegetation Identification of Typal Communities. Science 151:291-298.

Davis, E.L.

1962 Hunter-Gatherers of Mono Lake. The Masterkey 36(1):23-18.

1965 An Ethnography of the Kuzedika Paiute of Mono Lake, Mono County, California, pp 1-55. Anthropological Papers No. 75. University of Utah, Salt Lake City. 
1970 Archaeology of the North Easin of Panamint Valley, Inyo County, California. Anthropological Papers No. 15. Nevada State Museum, Carson City.

1969 Recent Discoveries of Fluted Points in California and Nevada, pp. 154-169. Anthropological Papers No. 14. Nevada State Museum, Carson City.

Davis, J.O.

1978 Quaternary Tephrochronology of the Lake Lahontan Area, Nevada and California. Nevada Archaeological Survey Research Paper No. 7

1983a Level of Leike Lahontan During Deposition of the Trego Hot Springs Tephra about 23,400 Years Ago. Quaternary Research 19(3):312-314.

1983b Sedimentary Facies and Paleoenvironment at Gatecliff Shelter. in The Archaeology of Monitor Valley 2, Gatecliff Shelter, edited by D.H. Thomas, pp. 64-87. Anthropological Papers No. 59(1). American Museum of Natural History, New York.

1985 Sediments and Geological Setting of Hidden Cave. in The Archaeology of Hidden Cave, edited by D.H. Thomas, pp. 80-103. Anthropological Papers No. 61(1). American Museum of Natural History, New York.

Dohrenwend, J.C.

1984 Nivation Landforms in the Western Great Basin and Their Paleoclimatic Significance. Quaternary Research 22:275-288.

Donnan, C.B.

1964 A Suggested Cultural Sequence for the Providence Mountains (Eastem Mojave Desert). Annual Reports of the University of California Archaeological Survey for 1963-1964:1-23, Berkeley.

Downs, J.F.

1966 The Two Worlds of the Washoe. Holt, Rinehart, and Winston, New York.

Dutcher, B.H.

1893 Pinon Gathering Among the Panamint Indian. American Anthropologist 6:377-380.

Egan, H.R.

1917 Ploneering the West, 1846 to 1878, edited by William M. Egan. Howard R. Egan Estate, Richmond, Utah.

Elston, R.G., J.O. Davis, A. Leventhal, and C. Covington

1977 The Archaeology of the Tahoe Reach of thie Truckee River. Report submitted to Tahoe-Truckee Sanitation Agency by the Nevada Archaeological Survey, University of Nevada, Reno.

Fenenga, $\mathbf{F}$.

1975 A Washoe Pine Nut Camp in Douglas County, Nevada. Journal of California Anthropology 2:205-13.

Forde, C.D.

1934 Habitat, Econoiny, and Society. Methuen, London.

Fowler, C.S., and L.E. Dawison

1986 Ethnographic Basketry. In Great Basin $n_{2}$ edited by W.L. d'Azevedo, pp. 173-182. Handbook of North American Indians, vol. 11, William G. Sturtevant, general editor. Smithsonian Institution, Washington, D.C.

Fowler, D.D., and C.S. Fowler

1971 Anthropology of the Numa: John Wesley Powell's Manuscripis on the Numic Peoples of Western North America 1868-1880. Contributions to Anthropology No. 14. Smithsonian Institution, Washington, D.C.

Fowler, D.D., and F.W. Sharrock

1973 Appendix A: Sunvey and Test Excavations. In Prehistory of Southeastern Nevada ${ }_{\alpha}$ by D.D. Fowler, D.B. Madsen, and E.M. Hattori. Desert Research Institute Publications in the Social Sciencos No. 6, Reno.

Fowler, D.D., D.B. Madsen, and E.M. Hattori

1973 Prehistory of Southeastern Nevada. Desert Research Institute Publications in the Social Sciences No. 6, Reno. 
Fremont, J.C.

1845 Report of the Exploring Expedition to the Rocky Mountains in the Year 1842 and to Oregon and Northern Calffornia in the Years 1843 and 1844. Gales and Seaton, Washington.

Gould, R.A., D.A. Koster, and A.H. Sontz

1971 The Lithic Assemblage of the Westem Desert Aborigines Australia. American Antiquity 36(2):149-169.

Grosscup, G.L.

1960 The Culture History of Lovelock Cave, Nevada. University of Calffornla Archaeological Survey Reports No. 52:1-71, Berkeley.

Gruhn, R.

1961 The Archaeology of Wilson Butte Cave, South-Central Idaho. Idaho State College Museum OcCasional Papers No. 6, Pocatello.

Harrington, M.R.

1933 Gypsum Cave. Southwest Museum Papers No. 8, Los Angeles.

Harris, A.H.

1977 Blotic Environments of the Paleolndian. In Paleolndian Lffeways, edited by E. Johnson, pp. 1-12. West Texas Museum Association, The Museum Joumal No. 17.

Harris, J.

1940 The White Knife Shoshone of Nevada. In Acculturation in Seven American Indian Tribes, edited by R. Linton, pp. 39-166. Appleton-Century, New York.

Hattori, E.M.

1982 The Archaeology of Falcon Hill, Winnemucca Lake, Washoe County, Nevada. Anthropological Papers No. 18. Nevada State Museum, Carson City.

Hauck, F.R., D.G. Weder, L. Drollinger, and A. McDonald

1979 A Cultural Resource Evaluation in Clark County, Nevada, Pt 1: Cultural Resource Overviow. Archaeological-Environmental Research Corporation Paper No. 7, Salt Lake Clty.

Haury, E.W.

1950 The Stratigraphy and Archaeology of Ventana Cave, Avizona. University of Arizona Press, Tucson.

Haynes, C.V.

1967 Quatemary Geology of the Tule Springs Area, Clark County, Nevada. In Plelistocene Studies in Southern Nevada, edited by H.M. Wormington and D. Ellis, pp. 15-104. Anthropological Papers 13(1). Nevada State Museum, Carson City.

Heizer, R.F., and M.A. Baumhoff

1961 The Archaeology of Two Sites at Eastgate, Churchill County, Nevada: Wagon Jack Sheiter. Anthropological Records 20(4). University of Califomia, Berkeley.

1962 Prehistoric Rock Art of Nevada and Eastern California. University of Califomia Press, Berkeley.

Heizer, R.F., M.A. Baumhoff, and C.W. Clewlow Jr.

1968 Archaeology of South Ford Shelter (NV-EP-11), Elko County, Nevada. University of California Archaeological Survey Reports 71:1-58, Berkeley.

Heizer, R.F., and R. Berger

1970 Radiocarbon Age of the Gypsum Cave Culture. Contributions of the University of Callfornia Archaeological Research Facility 7:13-16, Berkeley.

Heizer, R.F., and C.W. Clewlow Jr.

1968 Projectile Points from Site Nv-Ch-15, Churchill County, Nevada. Utiiversity of California Archaeological Survey Reports 71:59-101, Berkeley.

Heizer, R.F., and T.R. Hester

1978 Great Basin Projectile Points: Forms and Chronology. Ballena Press Publications in Archaeology, Technology, and History No. 10.

Henton, G.H.

1986 A Class III Cultural Resources Reconnaissance of Drill Hole U19as, Pahute Mesa, Nye County, Nevada. Desert Research Institute Cultural Resources Reconnaissance Short Report No. SR101783-1. 
Henton, G.H., and L.C. Pippin

1989 Archaeological Data Recovery at Drill Pad U19au, Nyo County, Nevada. Desert Research Institute Social Sciences Center Tectnical Report No. 55, (Review Draft).

1987 Archasological Data Recovery at Drill Pad U1San, Nye County, Nevada. Desert Research Instltute Social Sciences Center Technical Report No. 49.

Hobter, T.R.

1973 Chronological Ordering of Great Basin Prehistory. Contributions of the University of Calfornia Archaoological Research Facility 17:55-128, Berkeley.

Holmer, R.N.

1978 A Mathematical Typology for Archa/c Projectlie Points of the Eastem Great Basin. Ph.D. dissertation, University of Utah, Salt Lake City.

Holmes, W.H.

1800 A Quary Workshop of the Flaked-Sione Implement Makers in the District of Columbla. Amerlcan Anthropology 3(1):1-26.

Hoover, D.L., W.C. Swadley, and A.J. Gordon

1981 Correlation Characteristics of Surficial Deposits with a Description of Surficial Strattgraphy in

Hopkins, S.W.

the Nevada Test Stie Region. Open-File Report. U.S. Geologiral Sinvey, Washington, D.C.

1883 Lifo Among the Pailutes: Their Wrongs and Clalms, Cupple8, Upham, Boston.

Hubbs, C.L, G.S. Blen, and H.E. Suess

1963 La Jolla Natural Radiocarben Measurements III. Radfocarbon 5:254-272.

Hunt, A.P.

1960 Archeoology of the Death Valloy Salt Pan, Calfomla. University of Utah Anthropological Papers No. 47. Reprinted by Johnson Reprint Corporation, New York, 1971.

Huntington, E.

1914 The Climatc Factor as Illustrated in Avid North America. Publications No. 192. Camegie hstitution of Washington, Washington, D.C.

Jellnek, A.J.

1976 Fom, Function, and Style in Lithic Analysis, in Cuttural Change and Conthuihy. Essays in Honor of James Bennett Grifin, edited by C.E. Cleland, pp. 19-33. Academic Press, New York.

Jochim, M.A.

1981 Strategles for Sunvival, Cultural Behavior in an Ecological Context. Academic Press, New York.

Kelly, I.T.

1932 Ethnography of the Surprise Valley Palute. University of Calliornia Publications in American A. chaeology and Ethnology 31(3):67-210, Berkeley.

1964 Southern Palute Ethnography, Anthropological Papers No. 68, Gien Canyon Series No. 21. University of Utah, Salt Lake City.

Koenig, G. (editor)

1967 Valley of Salt, Memorles of Wine: A Joumal of Death Valloy 1849. The Friends of the Bancroin Library, Berkeley.

Kowta, $M$.

1969 The Sayles Complex A Late Millingstone Assemblage from Cajon Pass and the Ecologlcal Impifications of ths Scraper Planes. Publications in Anthropology No. 6. University of Callfornia, Berkeley.

Kroeber, A.E.

1939 Cutural and Natural Areas of Nattve North America. Publications in American Archaeology and Ethnology No. 38(1). University of Callfomia, Berkeley.

LaMarche, V.C., Jr.

1973 Holocene Climatic Variations Inferred trom Treeline Fluctuations in the White Mountains, Califomia. Quatomary Research 3(4):632-60.

1974 Paleoclimatic Inferences from Long Treo-Ring Records. Science 183(4129):1043-48.

Lanner, R.M.

1981 The Pinyon Pine - A Natural and Cultural History. University of Nevada Press, Reno. 
Lanning, E.P.

1963 Archaeology of the Rose Spring Site, INY-372. University of California Publications in American Archaoology and Ethnology 49(3):237-336.

Layton, T.N.

1970 High Rock Archaeology: An Interpretation of the Prehistory of the Northwestern Great Basin. Ph.D. dissertation, Department of Anthropology, Harvard University, Cambridge.

Loopold, E.B.

1967 Summary of Palynological Data from Searles Lake. In Guidebookfor Friends of the Pleistocene, Pacific Coast Section, pp. 52-66. U.S. Geological Survey, Menlo Park, Califomia.

1970 Late Wisconsin and Modern Pollen Rain at Searles Lake, California, pp. 11-12. Supplement to the Abstracts of the First Meeting of the American Quaternary Association.

Lingenfelter, R.E.

1986 Death Valley and the Amargosa: A Land of Illusion. University of Califomia Press, Berkeley.

Lister, R.H.

1953 The Stemmed, Indented Base Point, A Possible Horizon Marker. American Antiquity 18(3):265.

Little, E.L. Jr.

1938 Food Analysis of Pinon Nuts. Research Notes No. 48. U.S. Department of Agriculture, Forest Service, Souttwwestem Forest and Range Experiment Station.

Liverman, J.L.

1977 Final Environmental Impact Statement, Nevada Test Site, Nye County, Nevada. U.S. Energy Research and Development Administration, National Technical Information Service, Springfield.

Long, $M$.

1950 The Shadow of the Arrow. Caxton Printers.

Lowie, R.H.

1909 The Northern Shoshone. American Museum of Natural History Anthropological Papers 2(2):165-306. New York.

1924 Notes on Shoshonean Ethnography. American Museum of Natural History Anthropological Papers 20(3):185-314. New York.

1939 Ethnographic Notes on the Washo. University of California Publications in American Archaeology and Ethnology 36(5):301-352. Berkeley.

Lyneis, M.M.

1982a An Archaeological Element for the Nevada Historic Preservation Plan. Nivada Division of Historic Preservation and Archaeology, Carson City.

1982 Prehistory in the Southem Great Basin. In Man and Environment in the Great Basin, edited by D.B. Madsen and J.F. O'Connell. Society for American Archaeology Papers 2, Washington.

Martin, P.S., and P.J. Mehrirger, Jr.

1965 Pleistocene Pollen Analysis and Riogeography of the Southwest. In The Quaternary of the United States, edited by H.E. Wrignt, Jr. and D.G. Frey, pp. 433-451. Princeton University Press, Princeton.

Mason, R.J., and C. Inwin

1960 An Eden-Scottsbluff Burial in Northeastem Wisconsin. American Antiquity 26(1):43-57.

McGuire, K.R., and A.P. Garfinkel

1976 Tive Development of Pinyon Exploitation in Central Eastem Califomia. The Journal of Callfornia Anthropology 3(2):83-4.

Mclintosh, R.P.

1967 The Continuum Concept of Vegutation. Botanical Review 33:130-187.

Mehringer, P.J., Jr.

1967 Pollen Analysis of the Tule Springs Area, Nevada. In Pleistocene Studies in Southern Nevada, edited by H.M. Wormington and D. Ellis, pp. 130-200. Anthropological Papers No. 13. Nevada State Museum, Carsen City.

1977 Great Basin Late Quateniary Environments and Chronology. In Models and Great Basin Prehistory: A Symposium, edited by D. Fowler, pp. 113-167. Desert Research Institute rublications in the Social Sciences No. 12. Reno. 
Mehringer, P.J., Jr., and C.W. Ferguson

1969 Pluvial Occurrence of Bristlecone Pine (Pinus aristata) in a Mohave Desert Mountain Range. Journal of the Arizona Academy of Science 5(4):284-292.

Mehringer, P.J., Jr., and C.N. Warren

1976 Marsh, Dune, and Archaeological Chronology, Ash Meadoiss, Armagosa Desert, Nevada, pp. 120-150. Nevada Archaeological Survey Research Paper 6.

Minfin, M.D., and M.M. Wheat

1979 Pluvial Lakes and Estimated Pluvial Climates of Nevada. Bulletin No. 94. Nevada Bureau of Mines and Geology, Mackay School of Mines, University of Nevada, Reno.

Mitchell, J.M., Jr.

1961 Recent Secular Changes of Global Temperature. Annals of the Now York Academy of Sclences 95(3):235-50.

Morrison, R.B.

1964 Lake Lahontan: Geology of Southern Carson Desert, Nevada. Professional Papers 401. U.S. Geological Survey, Washington, D.C.

Muir, J.

1894 The Mountains of California. Century, New York.

Muto, G.R.

1971a A Technological Analysis of the Early Stages in the Manufacture of Lithic Artifacts. Master's the sis, Department of Anthropology Idaho State University.

1971b A State Analysis of Chipped Stone Implements. In Great Basin Anthropological Conference 1970, edited by C.M. Alkens. Anthropological Papers No. 1. University of Oregon, Eugene.

Muto, G.R., P.J. Mehringer, Jr., and C.N. Warren

1976 A Technological Analysis of Projectile Points from a Burial, Amargosa Desert, Nevada. Kiva 41(3-4):267-276.

Noble, D.C., R.D. Kushensky, E.J. McKay, and J.R. Ege

1968 Geologic Map of tive Dead Horse Flat Quadrangle, Nye County, Nevada. U.S. Geological Survay, Washington, D.C.

Norwood, R.H., C.S. Bull, and R. Quinn

1980 A Cultural Resource Overviow of the Eureka, Saline, Panamint and Danwin Region, East Central, Calfornia. Cultural Resources Publication in Anthropology-History. Bureau of Land Management, Califomia Desert Planning Staff, Riverside.

O'Connell, J.F.

1967 Elko Eared/Elko Comer-Notched Projectile Points as Time Markers in the Great Basin. Universjty of California Archaeological Sunvey Reports 71:129-140. Berkeley.

1971 The Archaeology and Cultural Ecology of Surprise Valley, Northeasi California. Unpublished Ph.D. clissertation, Department of Anthropology, University of Calfomia, Berkeley.

O'Connell, J.F., and R.D. Ambro

1968 A Preliminary Report on the Archaeology of the Rodriquez Site (CA- LAS-194), Lassen County, California. University of California Archaeological Survey Reports 73:45-194. Berkeley.

O'Farrell, T.P., and L.A. Emery

1976 Ecology of the Nevada Test Site: A Narrative Summary and Annotated Bibliography. U.S. Energy Research and Development Administration. National Technical Information Service, Springfield.

Ore, T.H., and C.N. Warren

1971 Late Pleistocene-Early Holocene Geomorphic History of Lake Mojave, California. Geological Soclety of America Bulletin_82:2553-2562.

Orkild, P.P., K.A. Sargent, and R.P. Snyder

1969 Geologic Map of Pahute Mesa, Nevada Test Site and Vicinity, Nye County, Nevada. Miscellaneous Geologic Investigations Map 1-567. U.S. Geological Survey, Washington, D.C. 
Pendieton, L.S.A.

1985 Material Culture: Artifacts of Stone. In Archaeologw of Hidden Cave, Nevada, edited by D.H. Thomas, pp. 183-218. Anthropological Papers of the American Museum of Natural History 61(1). Now Yorts.

Pendleton, L.S.A., and D.H. Thomas

1983 The Fort Sage Drfft Fence, Washoe County, Nevada. Anthropological Papers of the American Museum of Natural History No. 58(2). New York.

Pippin, L.C.

1979 Blghom Sheep and Great Basin Prehistory. In The Archaeology of Smith Creek Canyon, Eastern Nevada, edited by D.R. Tuohy and D.L. Rendall, Pp. 332-358. Anthropological Papers No. 17. Nevada State Museum, Carson Clty.

1986 An Oveniow of Cutura' Resources on Pahute and Rainier Mesus on the Nevada Test Sitc, Nyo County, Nevada. Desert hisearch Institute Social Sciences Center Technical Report No. 45. Desent Research It istitute Sonial Sciences Center, Reno.

Pippin, L.C., and E.M. Hattori

1980 An Analysis of Prehistoric Autfacts from Lassen National Forest, California. Desert Research Instltute Social Sciences Center Technical Report Series, No. 15. Reno.

Pippin, L.C., and G.H. Henton

1986 Data Recovery Plan for Negating Potential Adverse Effects on Cultural Resources at Drill Hole U18as, Pahute Mesa, Nevada Test Site, Nevada. Ms. On file at the Desert Research Institute Social Sciences Center, Reno. (Uune).

1988 Long Range Study Plan for Negating Potentlal Adverse Effects to Cultural Resources on Pahute and Rainier Mesas, Nevada Test Site, Nevada. Ms. Onfile at the Desert Research Institute Social Sciences Center. Reno. (October).

Pippin, L.C., and D.L. Zerga

1981 Cultural Resources Ovenview for the Nuclear Waste Storage Investijations, Nevada Test Site, Nye County, Nevada. Desert Research Institute Social Sciences Center Technical Report No. 30. Reno.

Pippin, L.C., J.O. Davis, E. Budy, and R. Elston

1979 Archaeological Investigations at the Pike's Point Site (4-Las- 537), Eagle Lake, Lassen County, Calfiornia. Desert Research Institute Social Sciences Center Technical Report No. 7. Reno.

Public Law (PL)

1966 National Historic Preservation Act of 1966. (PL 89-665, 15 Octobtr 1966).

1969 National Environmental Policy Act of 1969. (PL 91-190).

Rafferty, K.A.

1984 Cultural Resources Overview of the Las Vegas Valley. Contributions to the Study of Cultural Resources Technical Report No. 13. Bureau of Land Management, Reno.

Reitan, C.H.

1974 A Climatic Model of Solar Radiation and Temperature Change. Quaternary Research 4(1):25-38.

Reno, R.L.

1983 A Class III Cultural Resources Fieconnaissance of Drill Pad U19ao and an Access Road Linking this Dill Pad with the Pahute Mesa Road. Desert Research Institute Cultural Resources Reconnaissance Short Report Number SR060883-1.

Reno, R.L., and L.C. Pippin

1985 An Archaeological Reconnaissance of Yucca Flat, Nye County, Nevada. Desert Research Institute Social Sciences Center Technical Report 35.

Reno, R.L., G.H. Henton, L.C. Pippin, and C.L. Lockett

1989 Miscellaneous Data Recovery Studies at Yucca Mountain. Desert F esearch Institute Quatemary Sciences Center Technical Report No. 59. Reno. 
Riddell, F.A.

1960 The Archaeology of the Karlo Site (L-7), Califomia. University of California Archaesiogical Survey Reports ivis. 53(44):1-25.

Rogers, M.J.

1939 Early Lithic Industries of the Lower Basin of the Colorado River and Adjacent Desert Area. Archaeological Papers No. 3. San Diego Museum of Man. Repririted Ballena Press, Ramona, Califomia, 1973.

1958 San Dieguito Implements from the Terraces of the Rincon, Pantano and Rellito Drainage System. Kiva 24(1):1-23.

1966 Part II, The Ancient Hunters ... Who Were They? In Ancient Hunters of the Far West, edited by R.F. Pourade, pp. 21-108. Union-Tribune Publishing Company; San Diego.

Roosma, A.

1958 A Ulimatic Record from Searles Lake, Califomia. Science 128(3326):716.

Roust, N.L., and C.W. Clewlow Jr.

1968 Projectile Points from Hidden Cave (NV-Ch-16), Churchill County, Nevada. University of California Archaeological Survey Reports 71:103-115. Berkeley.

Sargent, K.A., and P.P. Orkild

1973 Geola. Map of the Wheelbarrow Peak - Rainier Mesa Area, Nye County, Nevada. U.S. Geological Survey, Washington, D.C.

Sharrock, F.W.

1966 Prehistoric Occupation Patterns in Southwest Wyoming and Cultural Relationships with the Great Basin and Plains Culture Areas, Anthropological Papers No. 77. University of Utah, Salt Lake City.

Shutler, R. Jr.

1961a. Lost City: Pueblo Grande de Nevada. Anthropological Papers of Nevada No. 5. Nevada State Museum, Carson City.

1961b Lost Clty, Pueblo Grande de Nevada. Masterkey 33(1):30-32.

1967 Cultural Chronology in Southem Nevada. In Pleistocene Studies in Southern Nevada, edited by H.M. Wormington and D. Ellis, pp. 304-308. Anthropological Papers No. 13. Nevada State Museum, Carson City.

Shutler, R. Jr., M.E. Shutler, and J.S. Griffith

1960 Stuart Rockshefter, A Stratified Site in Southern Nevada. Anthropological Papers No. 3. Nevada State Museum, Carson City.

Smith, G.A., W.C. Schuling, L. Martu, R.J. Sayles, and P. Jillson

1957 Newberry Cave, Calfornia. Scientific Series No. 1. San Bemardino County Museum.

Snyder, C.T., and W.B. Langbein

1962 The Pleistocene Lake In Spring Valley, Nevada, and its Climatic Implications. Journal of Geophysical Research 67(6):2385-94.

Spaulding, W.G.

1980 The Presettlement Vegetation of the Califomia Desert. Ms. on file, California Bureau of Land Management, Desert Planning Staff, Riverside.

1981 The Late Quaternary Vegetation of a Southern Nevada Mountain Range. Ph.D. dissertation, Department of Geosciences, the University of Arizona, Tucscin.

1983a Vegetation and Climates of the Last 45,000 Years in the Vicinity of the Nevada Test Site, SouthCentral Nevada. U.S. Geological Survey, Open-File Report 83-535.

1983b Late Wisconsin Macrofossil Records of Desent Vegetation in the American Southwest. Quaternary Research 19:256-264.

Spaulding, W.G., E.B. Leopold, and T.R. Van Devender

1983 Late Wisconsin Paleoecology of the American Southwest. In The Late Wisconsin of the United States: A Review Volume for the XI INQUA Congress, edited by S.C. Porter. University of Minnesota Press. 
Steward, J.H.

1933 Ethnography of the Owens Valley Paiute. University of California Publications in American Archaeology and Ethnology 33(5):423-38. Berkeley.

1938 Basin-Plateau Aborigjinal Soclopolitical Groups. Bureau of American Ethnology Bulletin No. 120. Simithscinian In, stitution, Washington, D.C.

1941 Culture Element Dir, tributions: XIV. Nevada Shoshone. University of California Anthropological Records 4(2):209-360.

1955 Theory of Culturd Change. University of Illinois Press, Urbana.

Stewart, O.C.

1941 Culture Element Distributions: XIV. Northem Paiute. University of Callfornia Anthropological Records 4(3):361-446. Berkeley.

Susia, M.L.

1964 Tule Springs Archaeological Surface Survey. Anthropological Papers No. 12. Nevada State Museum, Carson City.

Swanson, E.H., Jr.

1972 Birch Creek: Human Ecology in the Cool Deser of the Northern Rocky Mountains, 9,000 BC $A D$ 1850. Idaho State University Press, Pocate llo.

Thomas, D.H.

1969 Great Basin Hunting Patterns: A Quantitative M thod for Treating Faunal Remains. American Antiquity 34(4):392-401.

1972 Westem Shoshone Ecology: Settlement Pattems and Beyond. In Great Basin Cultural Ecology: A Symposium, edited by Don D. Fowler. Desert Research Institute Publications in the Social Sciences No. 8. Reno.

1973 An Empirica: Test for Steward's Model of Great Basin Settlement Patterns. American Antiquity 38(2):155-176.

1975 Nonsite Sampling in Archaeology: Up the Creek Without a Site? In Sampling in Archaeology, edited by J.W. Mueller, pp. 61-81. University of Arizona Press, Tucson.

1978 Arrowheads and AtlatI Darts: How the Stones get the Shaft. American Antiquity 43(3):461-472.

1981 How to Classify the Projectile Points from Monitor Valley, Nevada. Journal of Calfiornia and Great Basin Anthropology_3(1):7-43.

1983 The Archaeology of Monitor Valley 2, Gatecliff Shelter. Anthropological Papers 59(1). The American Museum of Natural History, New York.

Thomas, D.H., and E.H. McKee

1974 An Aboriginal Rock Alignment in the Tolyabe Range, Central Nevada. American Museum Novitiates No. 2534.

Tuohy, D.R.

1968 An Obsidian Ovate Biface from Pyramid Lake, Nevada. Nevada Archaeological Survey Reporter 2(2):12-15.

1969 Breakage, Burin Facets, and the Probable Technological Linkage Among Lake Mojave, Silver Lake, and other Varieties of Projectile Points in the Desert West. Anthropological Papers 14:132-152. Nevada State Musoum, Carson City.

1974 A Comparative Study of Late Paleoindian Manifestations in the Westem Great Basin. In A Co/lection of Papers on Great Basin Archaeology, edited by R. Elston and L. Sabini, pp 91-116. Nevada Archaeological Survey Research Paper No. 5. Reno.

U.S. Department of Energy

1983 Environmental Compliance Guide: Guidance Manual for Department of Energy Compllance with the National Historic Preservation Act. U.S. Department of Energy, Washington, D.C.

Van Devender, T.R.

1973 Late Pleistocene Plants and Animals of the Sonoran Desert: A Survey of Ancient Packrat Middens in Southwestern Arizona. Unpublished Ph.D. dissertation. University of Arizona, Tucson.

Van Devender, T.R., and W.G. Spaulding

1979 Development of Vegetation and Climate in the Southwestern United States. Science 204-701-710. 
Vayda, A.P., and R.A. Rappaport

1968 Ecology, Cultural and Non-Cultural. In Introduction to Cultural Anthropology, edited by J.A. Clifton, pp. 476-497. Houghton Mifflin, Boston.

Walker, P.L.

1978 Butchering and Stone Tool Function. American Antiquity 43(4):710- 715.

Wallace, W.J.

1962 Prehistoric Cultural Development in the Southern Californian Deserts. American Antiquity 28(2):172-180.

1977 A Half Century of Death Valley Archaeology. Journal of California Anthropology 4(2):249-258.

Wallace, W.J., and E.T. Wallace

1978 Ancient Peoples and Cultures of Death Valley National Monument. Acoma Books, Ramona, California.

Warren, C.N.

1967 The San Dieguito Cornplex: A Review and Hypothesis. American Antiquilty 32(2):168-185.

1980 The Archaeology and Archaeological Resources of the Amargosa-Mojave Basin Planning Units. In A Cultural Resources Overview for the Amargosa-Mojave Basin Planning Units, edited by C.N. Warren, M. Knack and E.T. Warren, pp. 2-134. Unpublished report submitted to the Bureau of Land Management Desert Planning Staff, Riverside, Califomia.

Warren, C.N., and R.H. Crabtree

1986 The Prehistory of the Southwestern Great Basin. In Great Basin, edited by W.L. D'Azevedo, pp. 183-193. Handbook of North American Indians, vol.11, William G. Sturtevant, general editor. Smithsonian Institution, Washington, D.C.

Warren, C.N., M. Knack, and E.T. Warren

1980 A Cultural Resource Overview for the Amargosa-Mojave Basin Planning Units. Unpublished Ms. submitted to the Bureau of Land Managerrient, Desert Planning Staff, Riverside.

Wells, P.V., and C.D. Jorgenson

1964 Pleistocene Wood Rat Middens and Climatic Change in Mojave Desert, A Record of Juniper Woodlands. Science 143(3611):1171-1174.

Wheat, M.M.

1967 Survival Arts of the Primitive Paiutes. University of Nevada Press, Reno.

Wheeler, S.M.

1973 The Archeology of Etna Cave, Lincoln County, Nevada, edited by D.D. Fowler. Reprint. Desert Research Institute Publications in the Social Sciences No. 7. Reno.

Whittaker, R.H.

1967 Gradient Analyses of Vegetation. Blological Review 42:207-264.

Williams, P.A., and R.I. Orlins

1963 The Corn Creek Dunes Site: A Dated Surface Site in Southern Nevada. Anthropological Papers No. 10. Nevada State Museum, Carson City.

Wissler, $\mathrm{C}$.

1926 The Relation of Nature to Man in Aboriginal American. Oxford University Press, New York.

Womack, B.R.

1977 An Archaeological Investigation and Technological Analysis of the Stockhoff Basalt Quarny, Northeastern Oregon. Unpublished Master's Thesis, Department of Anthropology, Washington State University, Pullman.

Worman, F.C.V.

1969 Archaeological Investigations at the U.S. Atomic Energy Commission's Nevada Test Site and Nuclear Rocket Development Station. University of Califomia, Los Alamos Scientific Laboratory Report LA4125. Los Alamos, New Mexico. 


\section{APPENDIX A}




\section{APPENDIX A: Descriptions And References For Artifacts}

Figure 4-35. Photograph of artifacts from Feature 1, site 26Ny4040.
a: Rosegate projectile point, 26Ny4040-3967-3
b: Stage IV biface, 26Ny4040-3940-9
c: Drill, 26Ny4040-3904-7
d: Uniface, 26Ny4040-3945-3
e: Stage III biface, 26Ny4040-3976-9

Figure 4-36. Photn graph of artifacts from Feature 2, site 26 Ny4040.

a: Urill, 26Ny4040-3863-2

b: Stone pipe, 26Ny4040-3841-1

c: AWI made from cut nail, 26Ny4040-3817-1

Figure 4-40. Photograph of artifacts from Feature 3, site 26 Ny4040.
a: Glass bead, 26Ny4040-3675-2
b: Glass bead, 26Ny4040-3683-2
c: Pendant fragment, 26Ny4040-3623-8
d: Pendant fragments, 26Ny4040-3744-5 and 26Ny4040-3745-9
e: Glass button, 2.6Ny4040-3752-2

Figure 4-41. Photograph of artifacts from Feature 3, site $26 \mathrm{Ny} 4040$.
a: Brad or stud, 26Ny4040-3754-1
b: Lead shot, 26Ny4040-3766-3
c: Lead fragment, 26Ny4040-3735-9
d: Lead fragment, 26Ny4040-3681-5
e: Potsherd, 26Ny4040-3745-10
f: Potsherd, 26Ny4040-3602-2
g: Stage III biface, 26Ny4040-3615-7
h: Uniface, 26Ny4040-3771-7
f: Metal button, 26Ny4040-3774-3

Figure 4-45. Photograph of miscellaneous artifacts from 26 Ny4040.
a: Rosegate projectile point, 26Ny4040-3575-17
b: Humboldt projectile point, 26Ny4040-3591-6
c: Drill fragment, 26Ny4040-5
d: Glas: button, 26Ny4040-3
e: Pottery, 26Ny4040-3986-1
f: Tin strip, 26Ny4040-3986-2

Figure 5-2. Photograph of cores from the U19au archeological investigations, Pahute Mesa, Nevada.
a: Assayed cobble, 26Ny4015-900-2
b: Multi-directional, 26Ny4021-4010-5
c: Multi-directionai/hammerstone, 26Ny4015-109-3
d: Chopper/pounder, 26Ny4015-1037-6

Figure 5-3. Photograph of modified flakes from the U19au archeological investigations, Pahute Mesa, Nevada.
a: 26Ny4021-4445-1
b: 26Ny4040-3902-5
c: $26 \mathrm{Ny} 4040-3945-3$
d: 26Ny4040-3902-6
e: 26Ny4015-1568-31
f: $26 \mathrm{Ny} 4040-3590-11$ 
Figure 5-4. Photograph of modified flakes from the U19au archeological investigations, Pahute Mesa, Nevada.
a: 26 Ny4015-582-56
b: 26Ny4015-1580-29
c: $26 \mathrm{Ny} 4015-319-3$
d: 26Ny4015-616-1
e: 26Ny4015-560-2b
t: 26Ny4040-3579-3

Figure 5-5. Photograph of utilized flakes from the U19au archeological investigations, Pahute ME sa, Nevada.
a: 26Ny4015-699-4
b: 26Ny4021-4216-4
c: 26Ny4015-1309-1
d: 26Ny4015-1194
e: 26Ny4015-1609-5
f: 26Ny4015-1611-1

Figure 5-6. Photograph of bifaces from the U19au archeological investigations, Pahute Mesa, Nevada.
a: Stage I, 26Ny4015-138-17
b: Stage II, 26Ny4015-313-27
c: Stage II, 26Ny4015-289-1
d: Stage II, 26Ny4015-1153
e: Stage III, 26Ny4015-299-1
f: Stage III, 26Ny4015-1344-5
g: Stage IV, 26Ny4015-226-2
h: Stage N, 26Ny4015-183-1

Figure 5-8. Photograph of Pinto, Humboldt and Large Side-Notched projectile points from the U19au archeological investigations, Pahute Mesa, Nevada.
a: Humboldt, 26Ny4048-4
b: Humboldt, 26Ny4040-6-1
c: Humboldt, 26Ny4015-957-7
d: Humboldt, 26Ny4015-265-1
e: Humboldt, 26Ny4025-2
f: Large Side-Notched, 26Ny4015-17
g: Large Side-Notched, 26Ny4015-1536
h: Pinto, 26Ny4015-1574-2

Figure 5-9. Photograph of Gatecliff and Gypsum projectile points from the U19au archeological investigations, Pahute Mesa, Nevada.
a: Gateclirf Split Stem, 26Ny4015-43
b: Gatecliff Split Stem, 26Ny4016-1
c: Gatecliff Split Stem, 26Ny4015-866-5
d: Gatecliff Split Stem, 26Ny4015-49
e: Gatecliff Split Stem, 26Ny4015-944-22
f: Gypsum, 26Ny4015-42
g: Gypsum, 26Ny4015-12
h: Gypsum, 26Ny4015-1967-17
i: Gypsum, 26Ny4015-309-1
j: Gypsum, 26Ny4015-1548-12 
Figure 5-10. Photograph of Elko projectile points from the U19au archeological investigations, Pahute Mesa, Nevada.
a: $26 \mathrm{Ny} 4051-2$
b: 26Ny4015-1321-25
c: 26Ny4015-561-1
d: 26 Ny4015-1307-5
e: 26Ny4041-1
f: 26Ny4022-1
g: 26Ny4015-1603-28
h: 26Ny4015-1200-1
i: 26Ny4015-1051
j: 26Ny4015-18

Figure 5-11. Photograph of Rosegate projectile points from the U19au archeological investigations, Pahute Mesa, Nevada.
a: 26Ny4015-891-1
b: 26Ny4015-1467-16
c: 26Ny4015-457-6
d: 26Ny4019-1
e: 26Ny4054-1
f: 26Ny4015-468-1
g: 26Ny4040-2
h: 26Ny4015-1592-20
i: 26Ny4015-34
j: 26Ny4041-3

Figure 5-12. Photograph of Cottonwood and Desert Side-Notched projectile points from the U19au archeological investigations, Pahute Mesa, Nevada.
a: Desert Side-Notched, 26Ny4015-1372
b: Desert Side-Notched, 26Ny4015-23-2
c: Desert Side-Notched, 26Ny4015-38
d: Desert Side-Notched, 26Ny4048-1
e: Desert Side-Notched, 26Ny4015-37
f: Cottonwood, 26Ny4015-494-4
g: Cottonwood, 26Ny4040-6-2
h: Cottonwood, 26Ny4015-35
i: Cottonwood, 26Ny4049-4
j: Cottonwood, 26Ny4015-46

Figure 5-13. Photograph of drills from the U19au archeological investigations, Pahute Mesa, Nevada.
a: 26Ny4040-3904-7
b: 26Ny4040-3868-2
c: 26Ny4015-1040-27
d: 26 Ny4015-30
e: 26Ny4015-45
f: 26Ny4015-709-16
g: 26Ny4053-3
h: 26Ny4015-1526-18

Figure 5-14. Photograph of a hammerstone and manos from the U19au archeological investigations, Panute Mesa, Nevada.
a: Hammerstone, 26Ny4015-1586-20
b: Mano, 26Ny4015-942-11
c: Bifacial mano, 26Ny4015-1316-2 
Figure 5-15. Photograph of millingstones from the U19au archeological investigations, Pahute Mesa, Nevada.

a: $26 \mathrm{Ny} 4015-1612-3$

b: 26Ny4021-4669-7

Figure 5-16. Photograph of miscellaneous prehistoric artifacts from the U19au archeological investigations, Pahute Mesa, Nevada.

a: Pendant fragment, 26Ny4040-3623-8

h: Pendant fragments, 26Ny4040-3744-5 and 26Ny4040-3745-9

c: Round rock, 26Ny4040-3936-6

d: Pipe, 26Ny4040-3841-1

Figure 5-17. Photograph of miscellaneous historic antifacts from the U19au archeological investigations, Pahute Mesa, Nevada.

a: Soldered seam can, $26 \mathrm{Ny} 4053-2$

b: Knife blade, 26Ny4023-3

c: Sickle blade, 26Ny4047-1

Figure 5-18. Photograph of buttons and beads from the U19au archeological investigations, Pahute Mesa, Nevada.

a: Glass bead, 26Ny4040-3675-2

b: Glass bead, 26Ny4040-3683-2

c: Glass bead, 26Ny4040-3861-1

d: Glass bead, 26Ny4040-3912-2

e: Glass bead, 26Ny4021-4173-2

f: Metal button, 26Ny4040-3774-3

g: Glass button, 26Ny4040-3752-2

h: Glass button, 26Ny4040-3

Figure 5-19. Photograph of historic artifacts from the U19au archeological investigations, Pahute Mesa, Nevada.

a: Brad or stud (from clothing?), 26Ny4040-37:j4-1

b: Lead shot, 26Ny4040-3766-3

c: Lead piece, 26Ny4040-3735-9

d: Lead shot, 26Ny4040-3681-5

e: Awl (made from cut nail), 26Ny4040-3817-1

f: Tin strip, 26Ny4040-3986-2

g: Tin strip, 26Ny4021-4146-2

Figure 5-24. Photograph of partially reconstructed pot from pottery concentration 2, Pahute Mesa, Nevada.

a: $26 \mathrm{Ny} 4051$

Figure 5-25. Photograph of a partially reconstructed pot and additional sherds from pottery concentration 4 from the U19au archeological investigations, Pahute Mesa, Nevada.

a-e: $26 \mathrm{Ny} 4049-7$

Figure 5-26. Photograph of pottery cups from the U19au archeological investigations, Pahute Mesa, Nevada.
a: $26 \mathrm{Ny} 4053-1$
b: 26Ny4023-1
c: 26 Ny4021 
APPENDIX A: Descriptions And References For Artifacts

Figure 5-27. Photograph of decorated pot sherds from the U19au archeological investigations, Panute Mesa, Nevada.

a: Impressed, 26Ny4040-3755

b: Incised rim, 26Ny4015-24-2

c: Incised lug, 26Ny4015-24-3

d: Incised rim, 26Ny4041-4

e: Punctate rim, 26Ny4041-6

f: Incised rim and body, 26Ny3633-2025-1

g: Incised rim and body, 26Ny4015-449-5

Figure 5-28. Photograph of reconstructed vessel 1 from pottery concentration 15 (26Ny4021) from the U19au archeological investigations, Pahute Mesa, Nevada.

a: Bowl, vessel 1 from concentration 15, 26 Ny4021 


\section{APPENDIX B}




\section{CORE ANALYSIS ATTRIBUTE CODES}

July 27, 1988

(Adopted from previous analysis for Yucca Mountain Survey and Mitigation Reports.)

ATTRIBUTES AND CODES DESCRIBING THE ARTIFACT AS A WHOLE

Site

Reference \#

Specimen\#

Material Type

01-Obsidian

02-Chert or Fine-Grained Tuff

03-Opalized Chert/Chalcedony

04-Coarse-Grained Tuif

05-Purple Brown Welded Tuff

Lengith

Width

Thickness

Weight

Shape describes the shape of each core.
01-Angular
02-Tabular
03-Rounded
04-Large Flake
05-Ovid/Discoidal
06-Bifacial

Contex describes the percentage of cortex remaining on the core.
00 None
$01 \quad 1-25 \%$
02 25-50\%
$03 \quad 50-75 \%$
$04 \quad 75-100 \%$

Number of Platforms counts the number of platforms on each core.

One

Two

Three

Four

etc.

Platform Position describes the platform's relationships to each other.

01-Uni-direction

02-Opposite (Bi-directional)

03-Perpendicular of Oblique (bi-directional)

04-Multi-directional

05-Bifacial

ATTRIBUTE CODES DESCRIBING EACH PLATFORM to be filled out per each platform.

Platform \#

Nature of Platform 
Appendix B: Uniface Analysis Attribute Codes

01-Cortex

02-Single Flake Removal

03-Faceted (multiple flake removals)

04-Faceted (bifacial or centered)

Nature of Platform. Preparation

D-None

01-Hinged Fractured Back

02-Hinged Fractured Down

03-Flaked Back

04-Flaked Down

05-Flaked Back and Down

Number of Flakes Removed from individual platform.

One

Two

Three

Four

etc.

Elake Lenoth measures the average flake length from a particular platform in $\mathrm{mm}$.

Maximum

Majority

Core Type classification into relative types based on above criteria.

01-Assayed 1-3

02-Uni-Directional

03-Bl-Directional [opposing direction]

04-Multi-directional

0.5-Bifacial

06-Split Cobble

09-Oblique

10-Large Flake

Stage measures whether the core is near exhausted.

01-Assayed

02-Mid Use

03-Exhausted

UNIFACE ANALYSIS ATTRIBUTE CODES

May 11, 1988

(Adopted from previous analysis for Lassen, Yucca Mountain Survey, and Yucca Mountain Mitigation reports.)

Sile

Beference \#

Specimen\#

Material Type (additive)

01-obsidian

02-white tuff

03-purple tutf

*-type 26 white tuff 


\section{Elake Type}

01-Primary Decortication

02-Secondary Decortication

03-Bifacial Tininning

04-Core Reduction (undifferentiated)

05-Indeterminate

Completeness of Artifact

01-Whole

02-1/3 artifact

03-1/2 artifact

04-2/3 artifact

05-Unknown

\section{Edae No.}

Sequentially number each segment of modified/utilized edge and record the following characteristics for uach edge segment.

\section{Lenoth of Edae}

Taken in millimeters.

Comoleteness of Edge

01-Complete

02-Intemupted (by breakage, by unmodified area, etc.)

Edge Location Measured relative to the bulb (proximal end) and flake termination (distal end)

01-Distal End

02-Proximal End

03-Right Side (relative to bulb/proximal end)

04-Left Side (relative to bulb/proximal end)

05-Proximal Comer

06-Distal Comer

Edoe Placement Measured relative to the dorsal (back) of flake or ventral (belly) of flake. In general, modification originates on the ventral surface towards the dorsal surface. Therefore, the modification is observed on the dorsal surface. Exceptions do occur.

01-Dorsal Surface

02-Ventral Suiface

Edge Shape Measured by calculating the ratio of the short axis $(X)$ divided by the long axis $M$.

01-Straight

02-Slightly Concave $\quad R<.10$

03-Concave $R=.10-.40$

04-Greatly Concave $R=.40-.80$

05-Notched $R=.80-.100$ 
06-Slightly Convex

07-Convex

08-Greatly Convex

09-Denticulate (irregular/undulated)

10-Chisel Like/Pointed/Spur

Maximum Angle Measured per each defined edge in 10 degree increments.

Minimum Angle Measured per each defined sdge in 10 degree increments.

Composite Angle

$01=10-30$ degrees $=$ Shallow

$02=\quad=$ Moderate to Shallow

$03=40-60$ degrees $=$ Moderate

$04=\quad=$ Steep to Moderate

$05=70-100$ degrees $=$ Steep

Wear Characteristics 1.2.3 Records observed wear in order of primary occurrence.

Do-None

01-Masked

02-Crushed/hinged/platform-like

03-Rounded

04-Polished

05-Stria

06-Microfeather

07-Undistinguishable

Edge Continuity Describes relationship of edges to each other.

01-Contiguous

02-Opposite Faces (Nentral/Dorsal)

03-Opposite Sides (Left/Right)

04-Discontinuous (breaks in modified/utilized edges) 


\section{DRILL ANALYSIS ATTRIBUTE CODES}

July 27, 1988

ATTRIBUTES AND CODES DESCRIBING THE ARTIFACT AS A WHOLE

Sile

Beference

Specimen

Condition describes which portion of a complete drill/perforator/graver the artifact represents.

0-Whole/Complete

1-Base Fragment

2-Whole Base

3-Base and partial midsection/shaft (missing $>1 / 3$ of proximal tip)

4-Base and whole shaft

5-Proximal Shatt Fragment

6-Proximal Shaft Whole

Overall Shape for whole or nearly whole specimens only.

1-Linear

2-Lanceolate

3-Ovate

4-Elliptic (diamond like)

5-Deltoid (triangular)

6-Falcate (curvad, tapering)

Weioht in grams for whole specimens only.

Contex estimates the percentage of cortex present on a specimen.

0 None

1 One surface, $0-10 \%$

2 One surface, $11-33 \%$

3 One surface, $>33 \%$

4 Two surfaces, $0-10 \%$

5 Two surfaci $3,11-33 \%$

6 Two surfaces, $>33 \%$

7 Three surfaces

Relationship of Shaft to Base

1-Shaft at proximal (bulb) end of flake

2-Shaft at lateral (side) of flake

3-Shaft at distal end of flake

4-Shaft at unknown relationship to flake

5-Shaft at proximal (butt) end of biface

6-Shaft at distal (point) end of biface 
7-Shar at unknown relationship to biface

8-Shaft at proximal (notched) end of point

9-Shaft at lateral edge of point

10-Shaft on modified ear/tang/haft of point

11-Shaft at distal end of point

12-Indeterminate relationship general

ATTRIBUTES AND CODES DESCRIBING THE BASAL PORTION OF DRILL/BURIN

Basal Type

1-Unmodified Flake

2-Unifacially Modified Flake

3-Bifacially Modified Flake

4-Biface Stage 1

5-Biface Stage 2

6-Biface Stage 3

7-Biface Stage 4

8-Biface Stage 5 (hafted)

9-Modified Point Base

7-Unidentifiable Fragment

For Modified Point Bases, list point type:

1-Clovis

2-GBS

3-Pinto

4-Humboldt

5-Gatecliff

6-Elko

7-Rosegate

8-DSN/Cottonwood 


\section{Basal Shape}

1-Rounded

2-Cuneate (acute wedge, angular)

3-Truncate (squared)

4-Oblique (irregular, uneven)

5-Cordate (heart shaped)

6-Lobate (general lobes)

7-Indeterminate Fragment

Break describes the nature of breaks on broken artifacts.

0-Unbroken

1-Broken in Twisting

2-Broken in Bending

3-Broken by Burin Blow

4-Unidentifiable Break type

Location of Break

0-Unbroken

1-Distal Base

2-Lateral Base

3-Proximal Base

Measurements: to be taken only on basal portion of artifact and only on complete aspects of specimens, ie. complete lengths, widths or thicknesses.

Lenoth in millimeters.

Width in millimeters.

Thickness in millimeters.

Lateral Edge Configuration as Seen Edge on

describes the sinuousness of the edge of basal portion as seen on edge.

0-Not Measurable

1-Straight or Less than $0.5 \mathrm{~mm}$ of variation

2-Slightly Sinuous or between 0.5 and $1.0 \mathrm{~mm}$ of variation

3-Sinuous or between 1.0 and $2.0 \mathrm{~mm}$ of variation

4-V.ry Sinuous or Greater than $2.0 \mathrm{~mm}$ of variation

5-Edge Perpendicular (not measurable)

\section{Lateral Edge Configuration as Seen in Plan}

describes the regularity of the basal edge as seen in plan.

0-Not Measurable

1-Regular or Less than $0.5 \mathrm{~mm}$ of variation

2-Slightly Irregular or between 0.5 and $1.0 \mathrm{~mm}$ of variation

3-Irregular or between 1.0 and $2.0 \mathrm{~mm}$ of variation

4-Very Irregular or Greater than $2.0 \mathrm{~mm}$ of variation 
Appendix B: Uniface Analysis Attribute Codes

Edge Damage describes the modification to the modified edges of the tool.

0-Not Measurable

1-Undamaged

2-Crushed Displaying Step Fracture

3-Crushed Displaying Small Flakes

4-Rounded Edges (as by drilling action)

5-Unmodified Cortex

ATTRIBUTES AND CODES DESCRIBING THE PROXIMAL SHAFT (POINT) END OF DRILL/PERFORATOR/ GRAVER

Lenoth measured from intersection of base and beginning to shaft to end of shaft.

Degree of Completeness

1-measurement complete

2-nearly complete

3-broken

Nature of Shaft

1-Unmodified Flake

2-Unifacially Modified Flake

3-Bifacially Modified Flake

4-True Biface 


\section{Shaft Shape}

1-Abrupt Acuminate (pointed)

2-Broad Acuminate

3-Narrow Acuminate

4-Broad Acute

5-Medium Acute

6-Narrow Acute

7-Linear (parallel sides)

8-Lanceolate

9-Ovate

10-Falcate (asymmetric, curved, generally tapering)

11-Indeterminate (tragment)

Location of Break(s) (encode for each break observed)

0-Unbroken

1-Proximal Shaft (at juncture of base)

2-Mid shaft

3-Distal Shaft

Brzak describes the nature of breaks along the shaft.

0-Unbroken

1-Broken in Twisting

2-Broken in Bending

3-Broken by Burin Blow

4-Unidentifiable Break type

Measurements: to be taken only on proximal/shaft portion and on complete aspects of specimens, ie. complete lengths, widths or thicknesses.

Length in millimeters.

Width in millimeters.

Thickness 1 in millimeters; measures the widest part of shaft.

Thickness 2 in millimeters; measures the narrowest part of shaft. 


\section{Lateral Edge Configuration as Seen Edge on}

describes the sinuousness of the edge of shaft portion as seen on edge.

0-Not Measurable

1-Straight or Less than $0.5 \mathrm{~mm}$ of variation

2-Slightly Sinuous or between 0.5 and $1.0 \mathrm{~mm}$ of variation

3-Sinuous or between 1.0 and $2.0 \mathrm{~mm}$ of variation

4-Very Sinuous o: Greater than $2.0 \mathrm{~mm}$ of variation

5-Edge Perpendicular (not measurable)

Lateral Edge Configuration as Seen in Plan

describes the regularity of the shaft edge as seen in plan.

0-Not Measurable

1-Regular or Less than $0.5 \mathrm{~mm}$ of variation

2-Slightly Irregular or between 0.5 and $1.0 \mathrm{~mm}$ of variation

3-Irregular or between 1.0 and $2.0 \mathrm{~mm}$ of variation

4-Very Irregular or Greater than $2.0 \mathrm{~mm}$ of variation

Edge Damage describes the modification to the modified edges of the tool.

0-Not Measurable

1-Undamaged

2-C.ushed Displaying Step Fracture

3-Crushed Displaying Small Flakes

4-Rounded Edges (as by drilling action)

5-Unmodified Cortex 


\section{APPENDIX C}




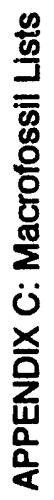

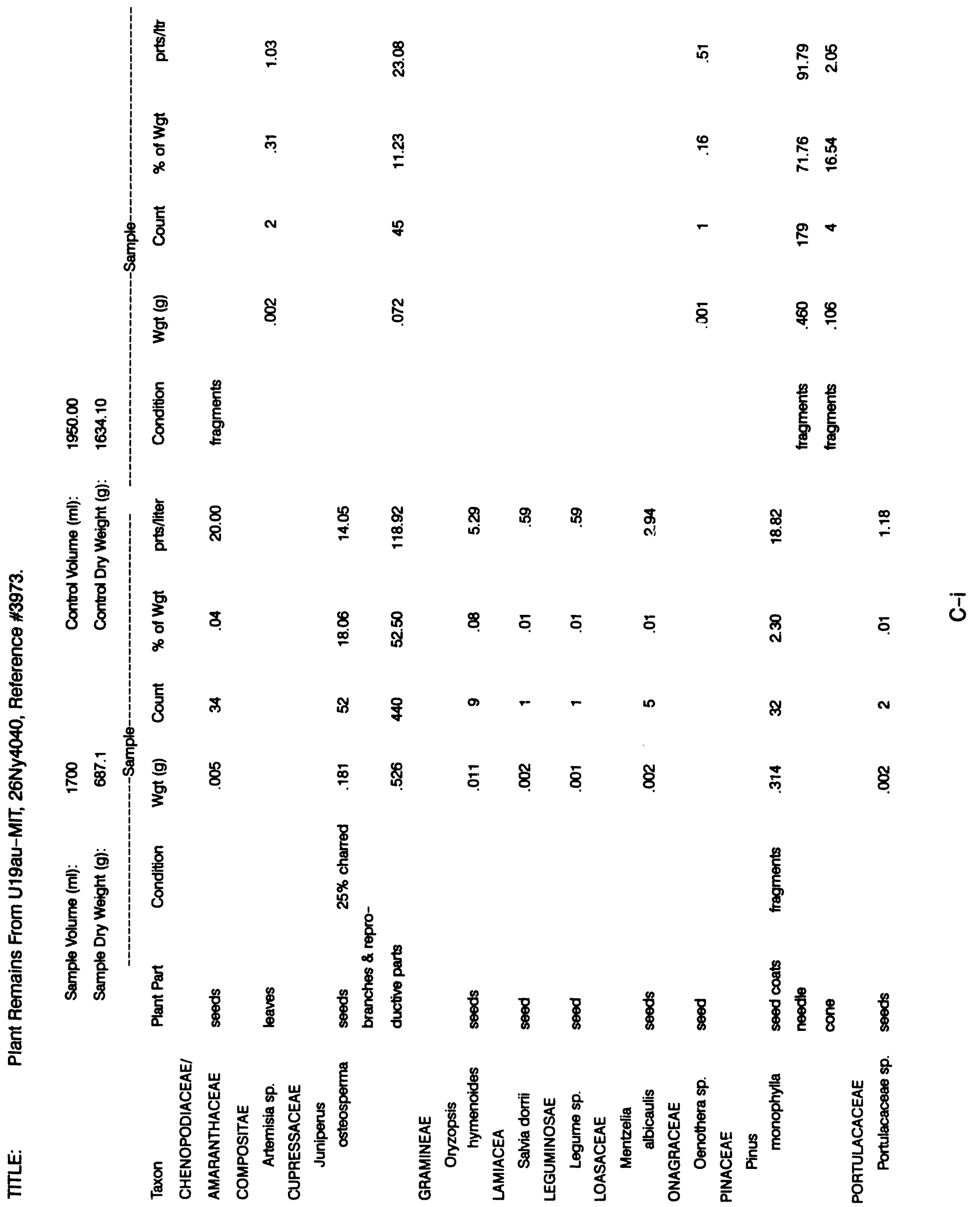




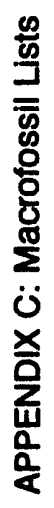

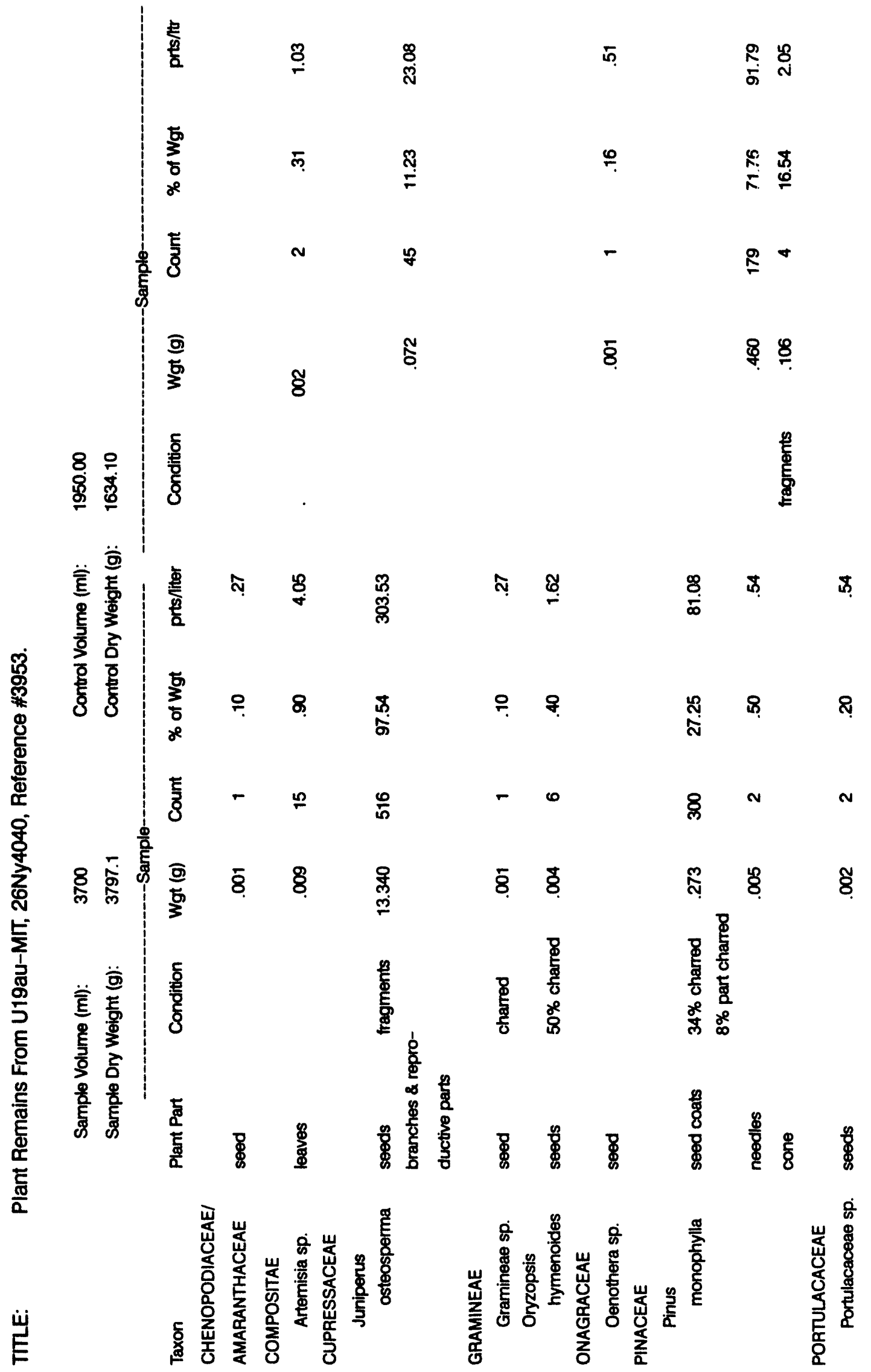




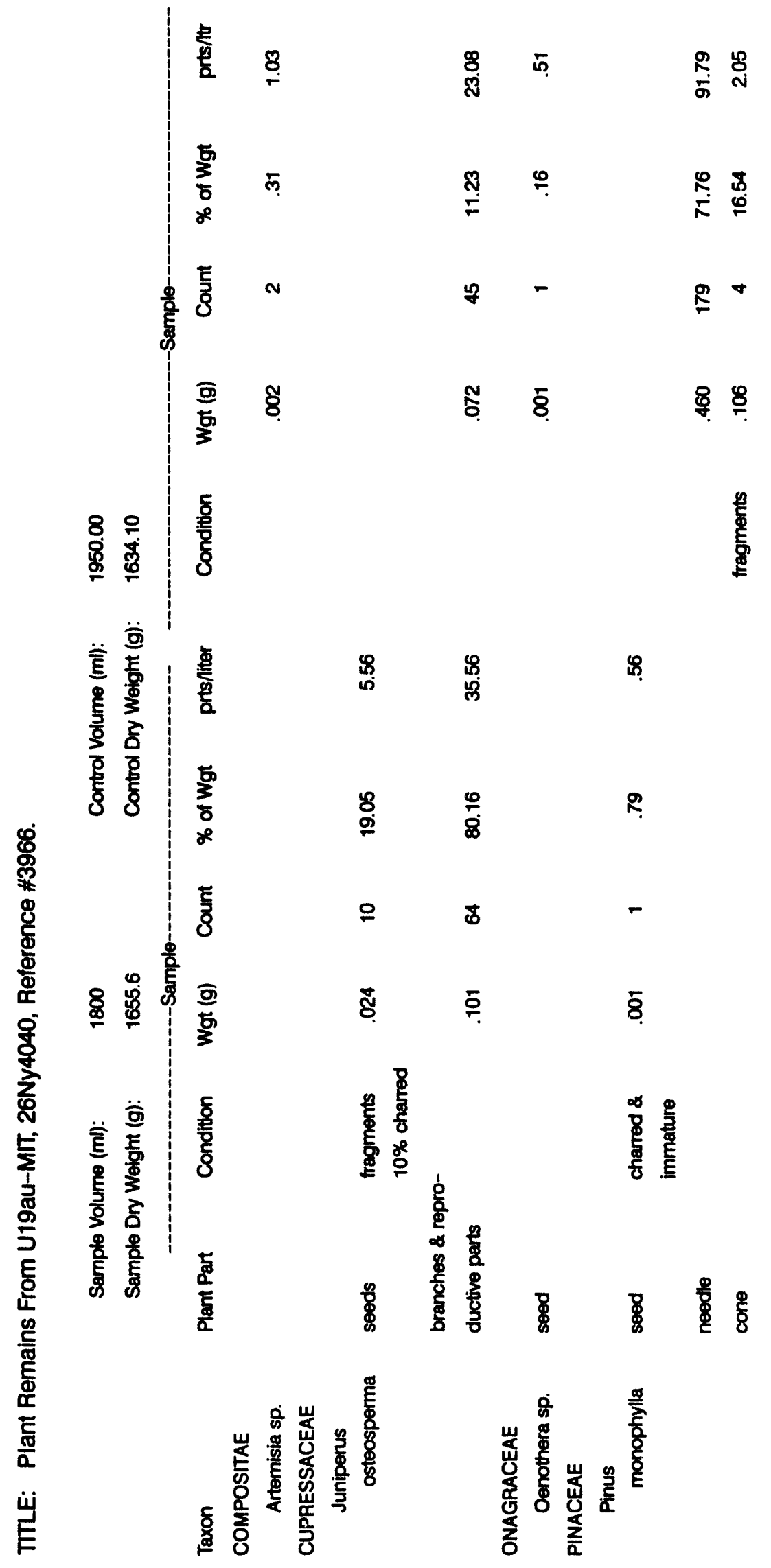

: 


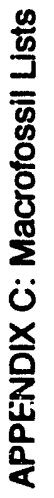

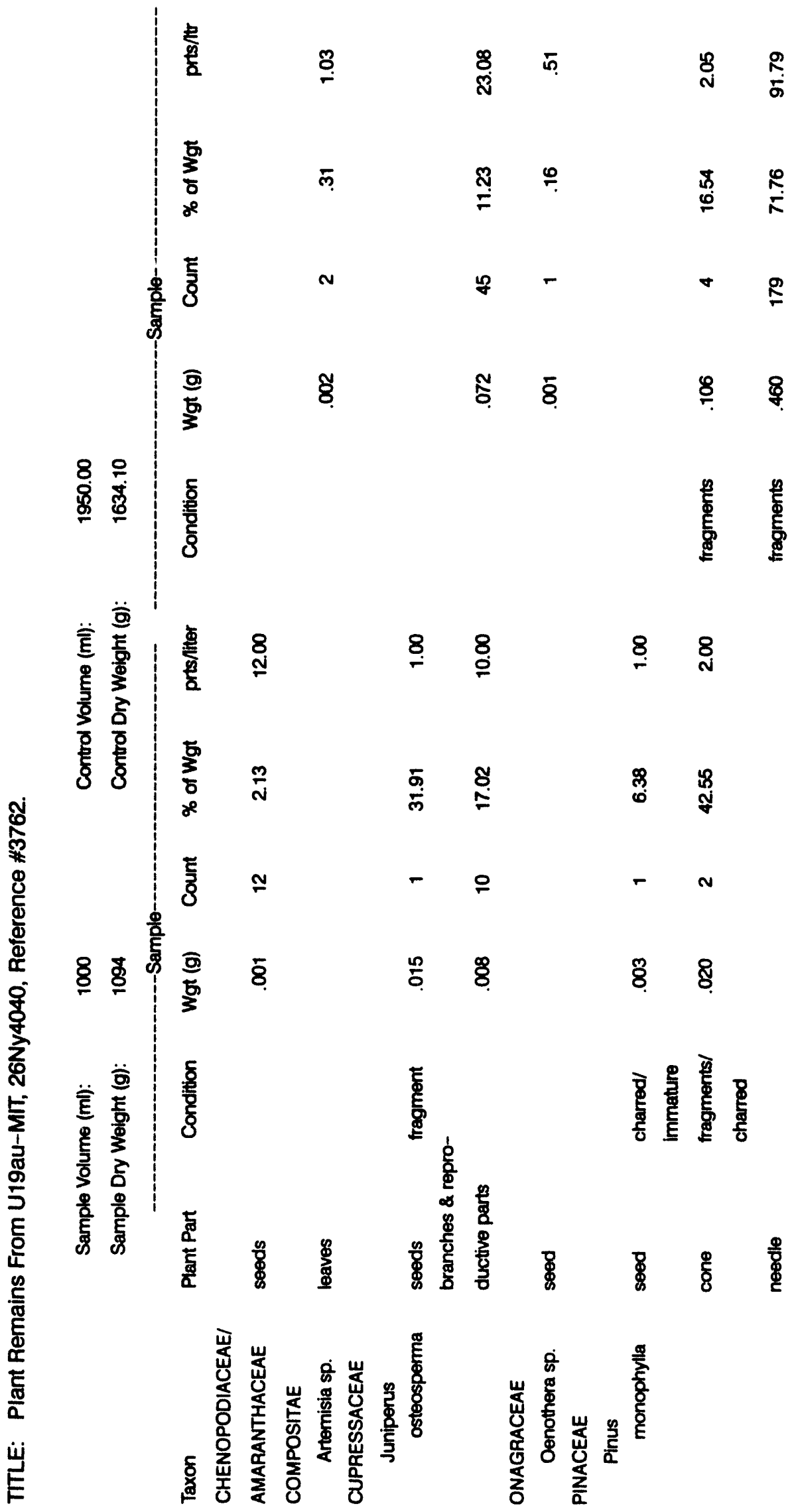




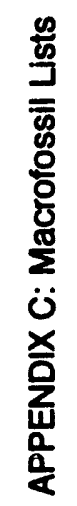

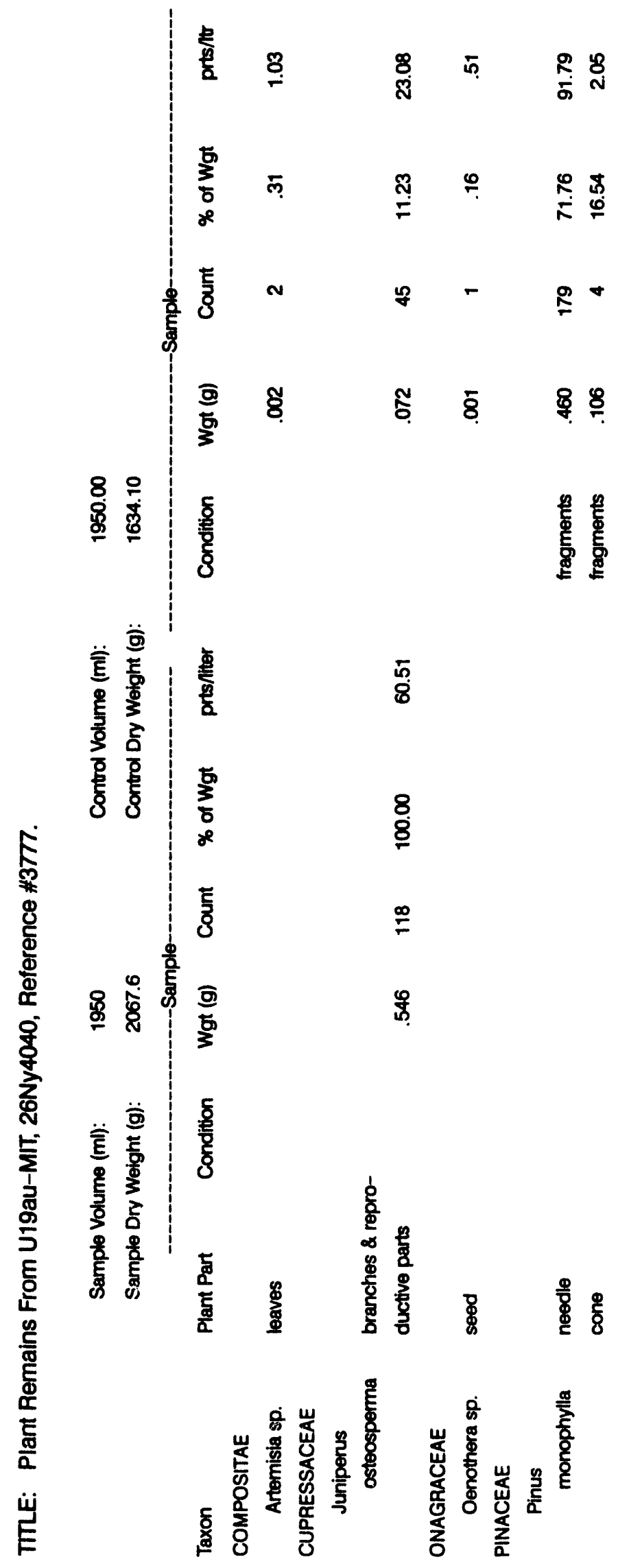




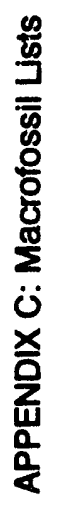

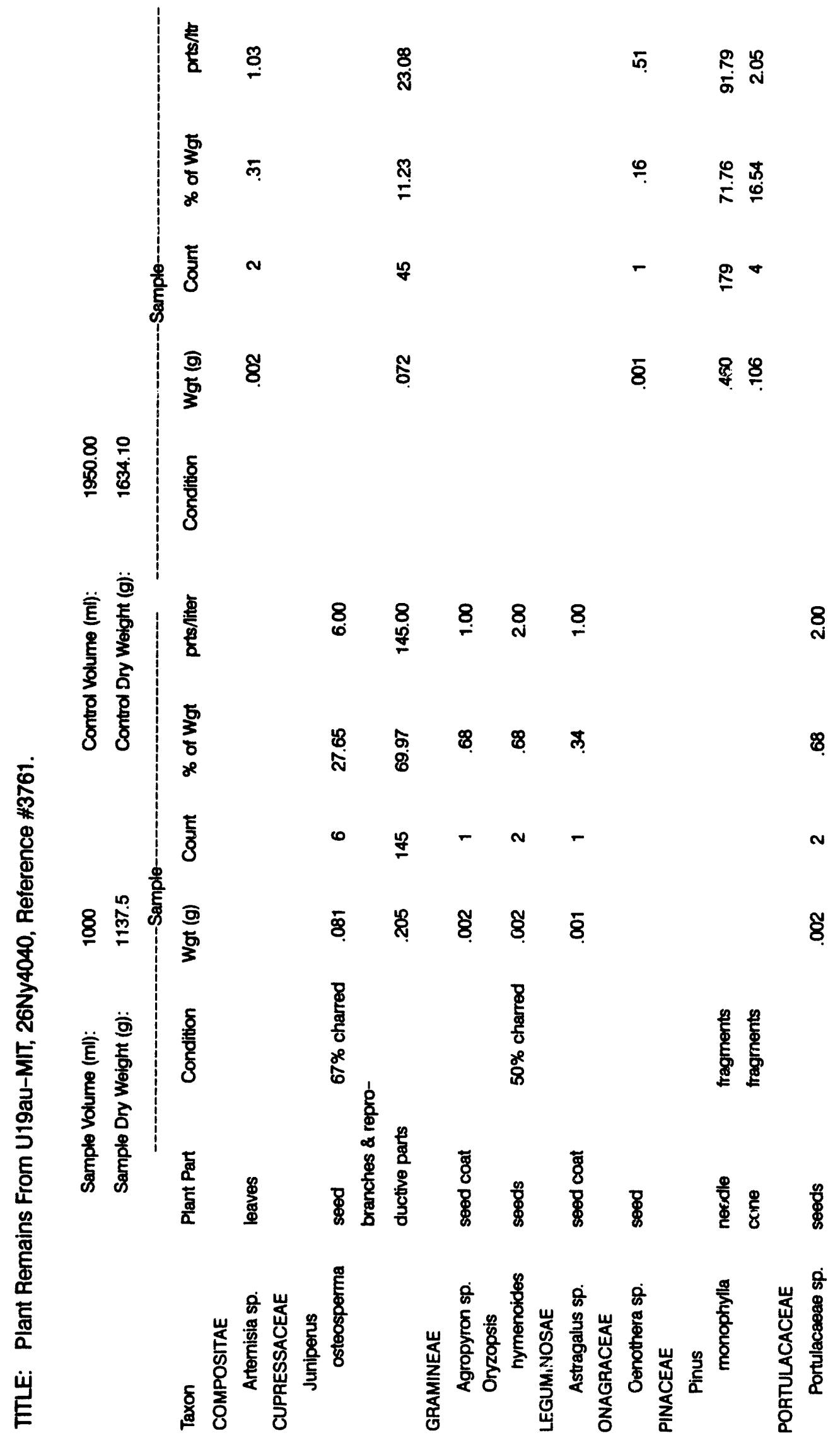




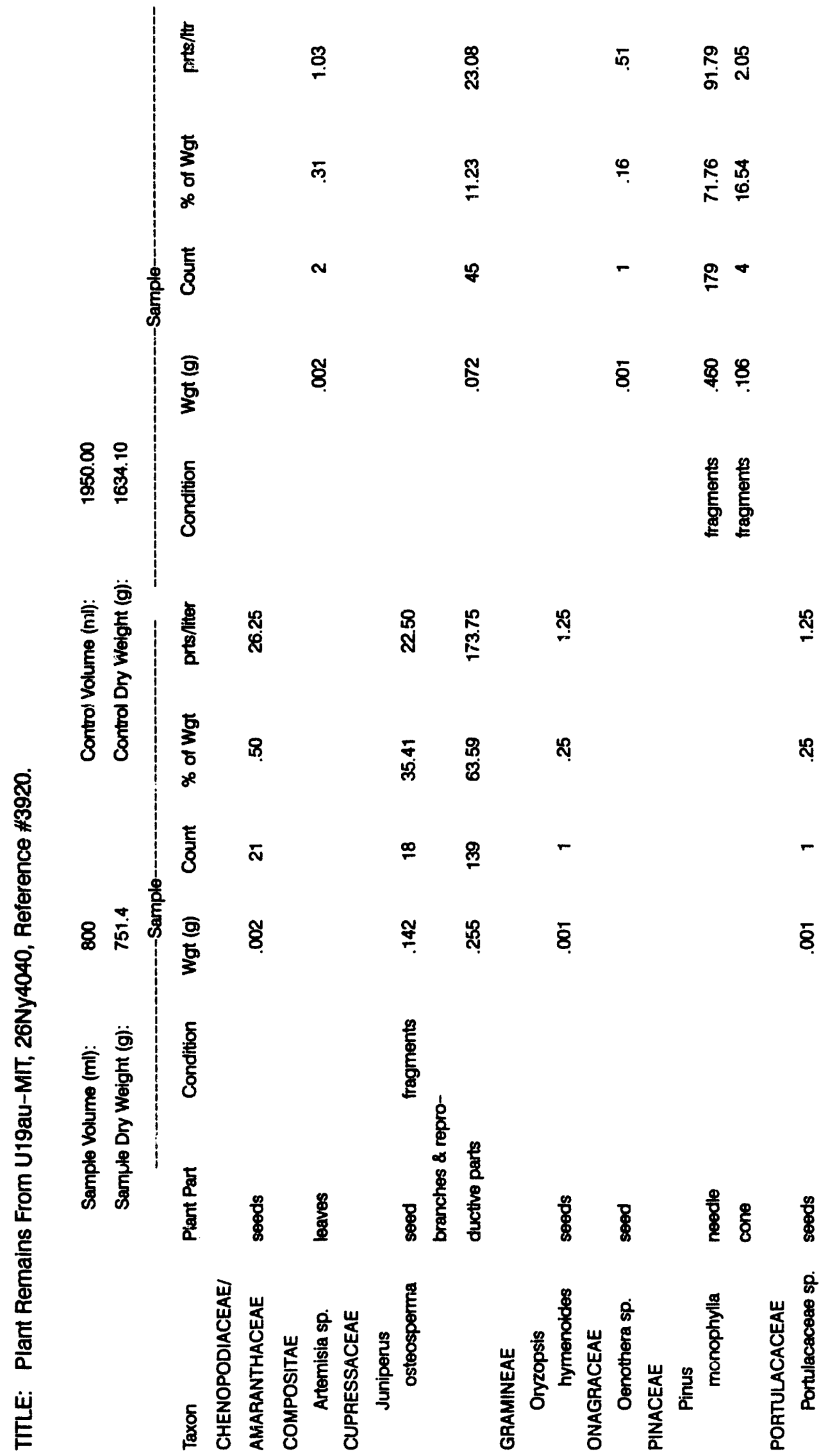




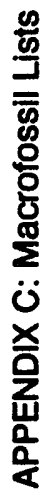

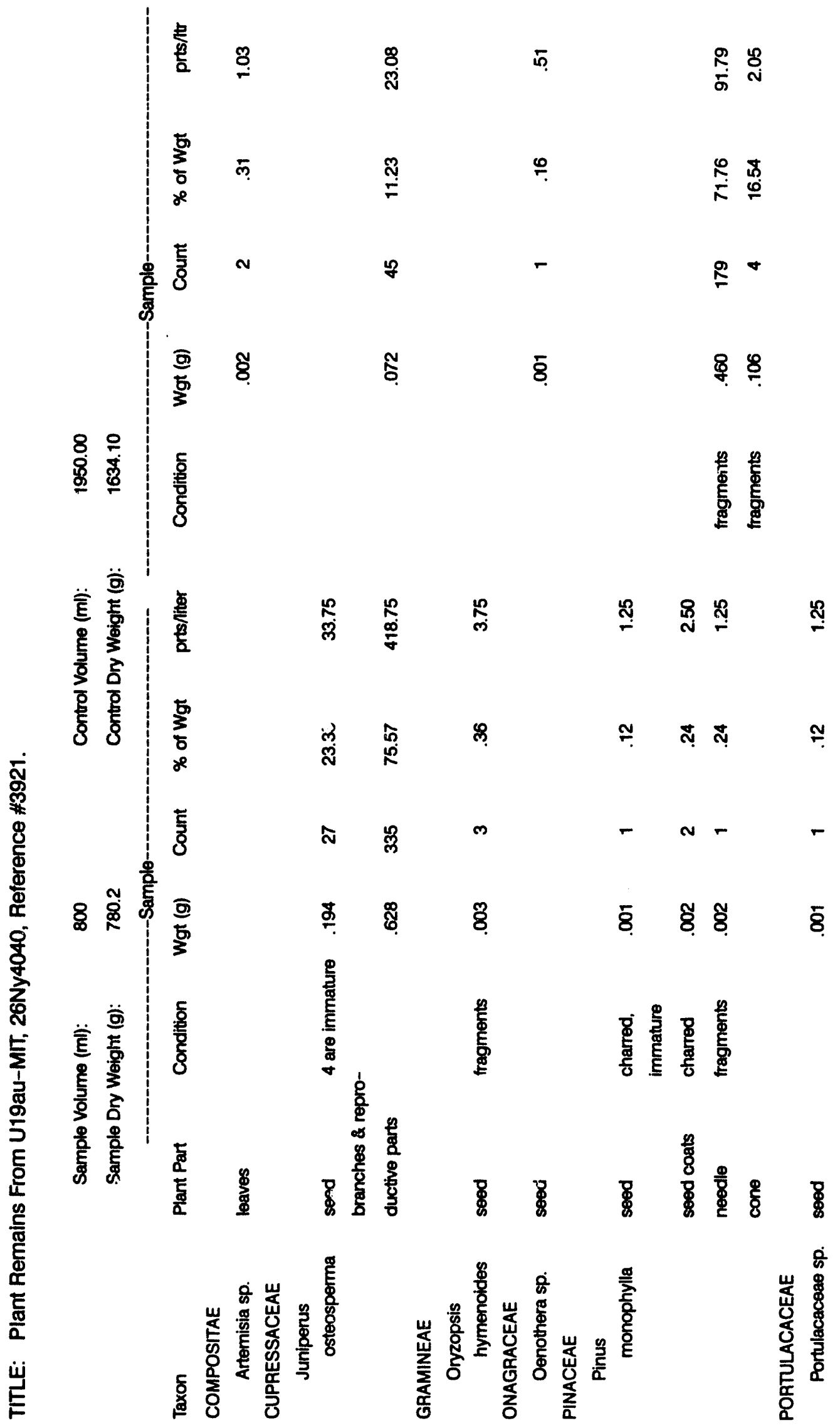




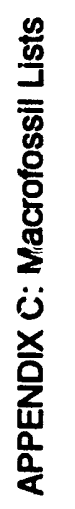

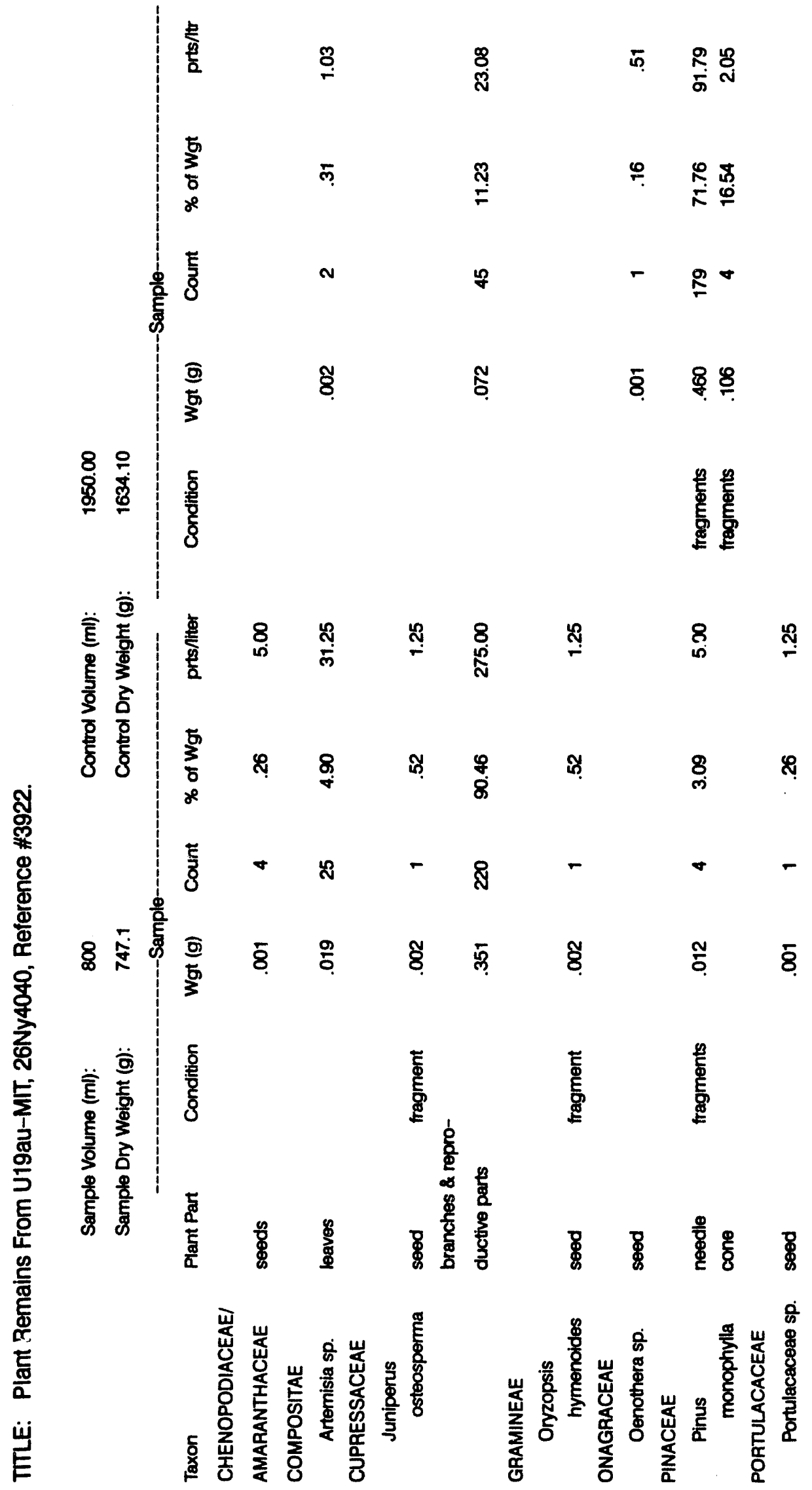




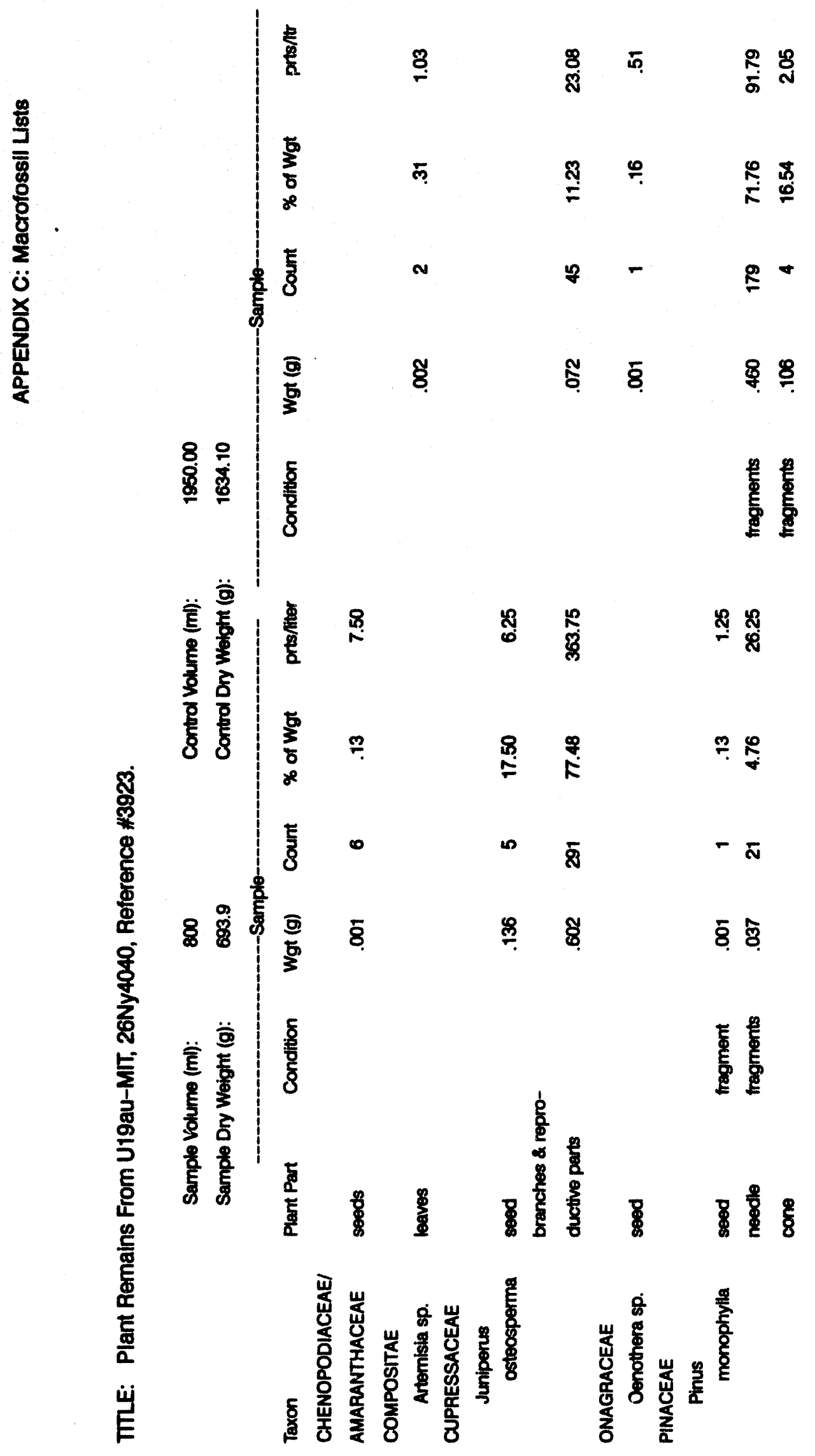




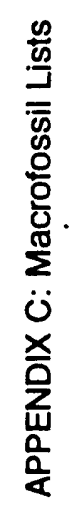

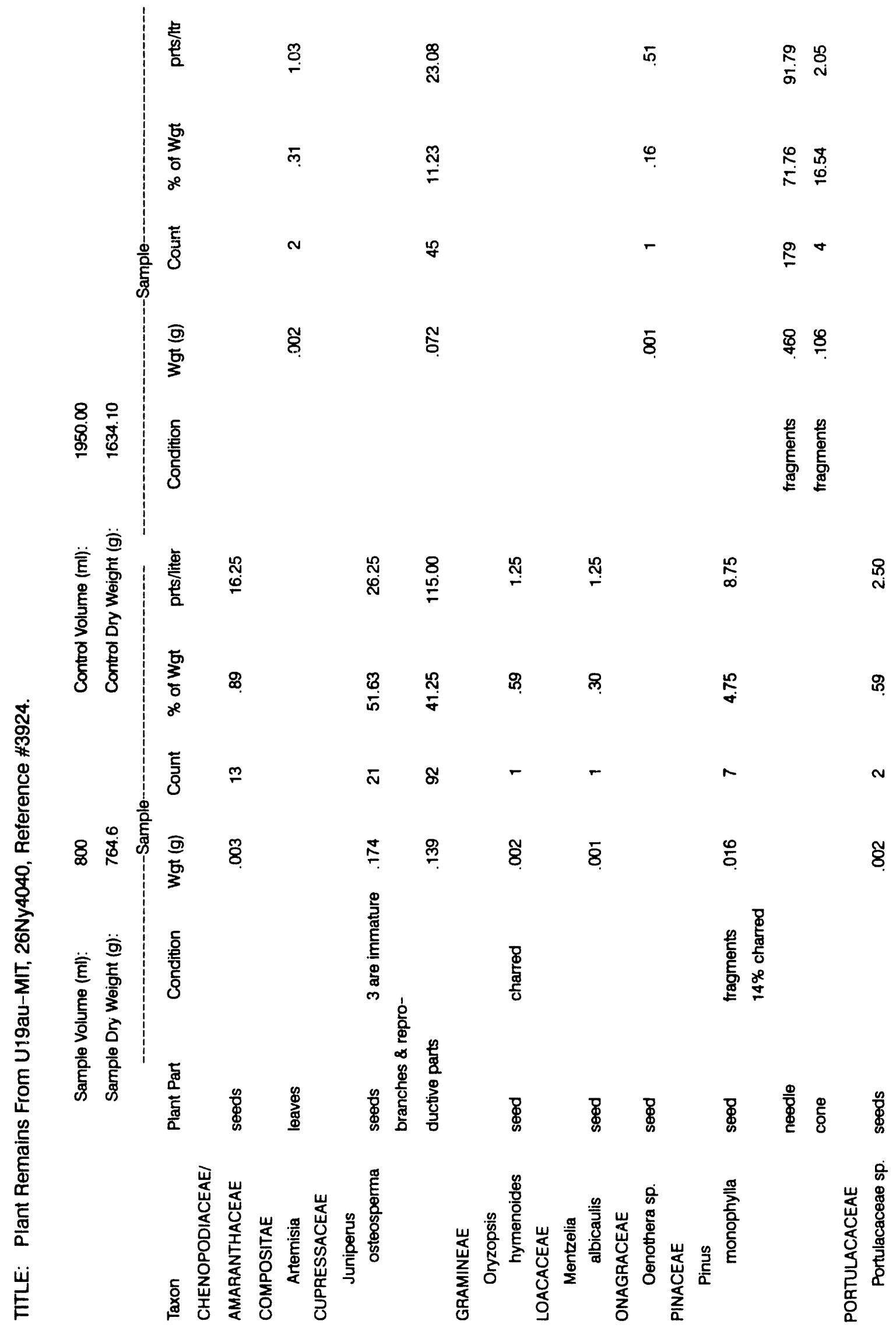




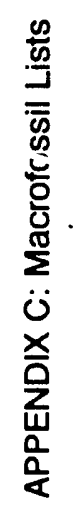

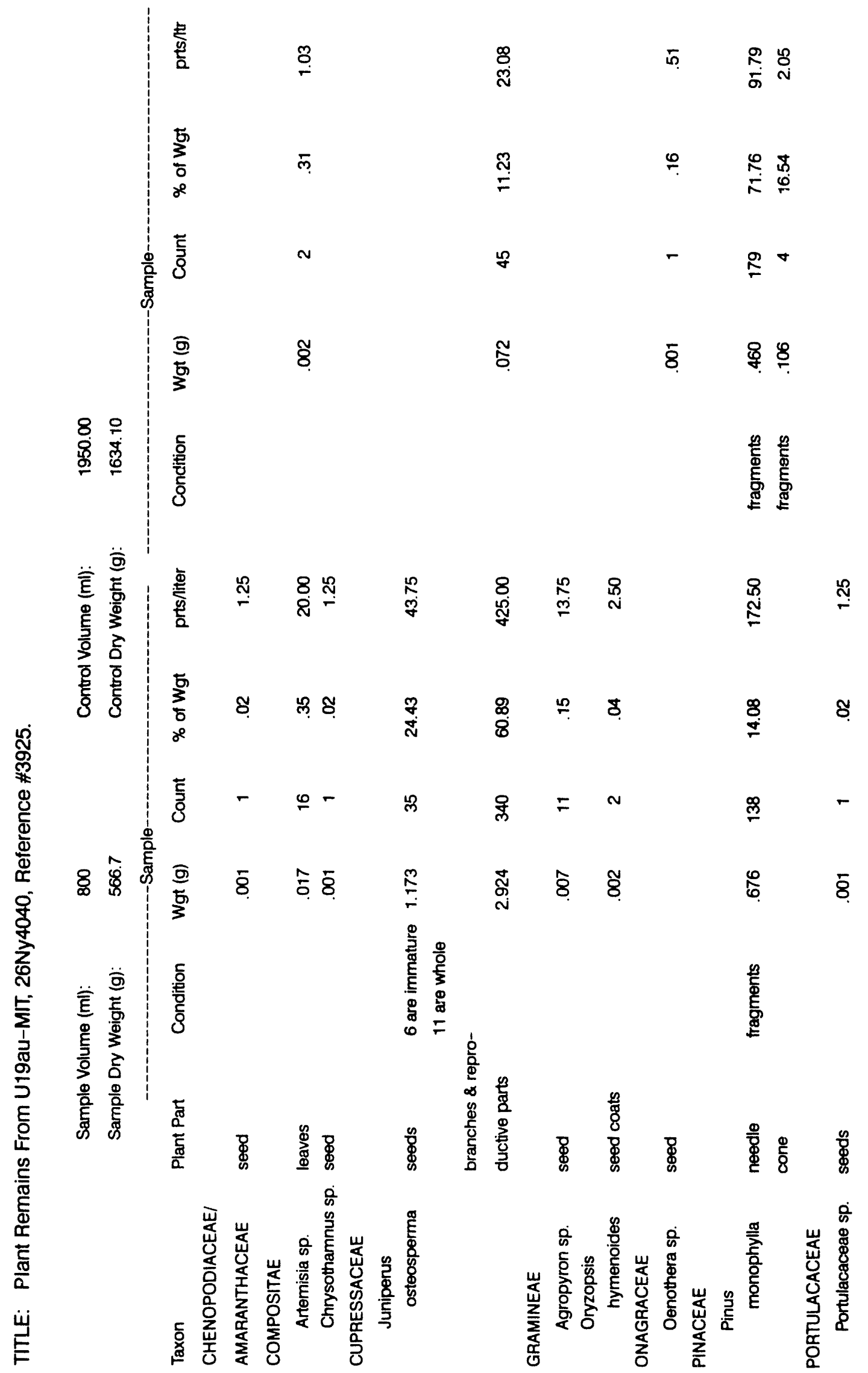




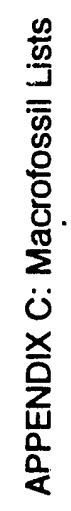

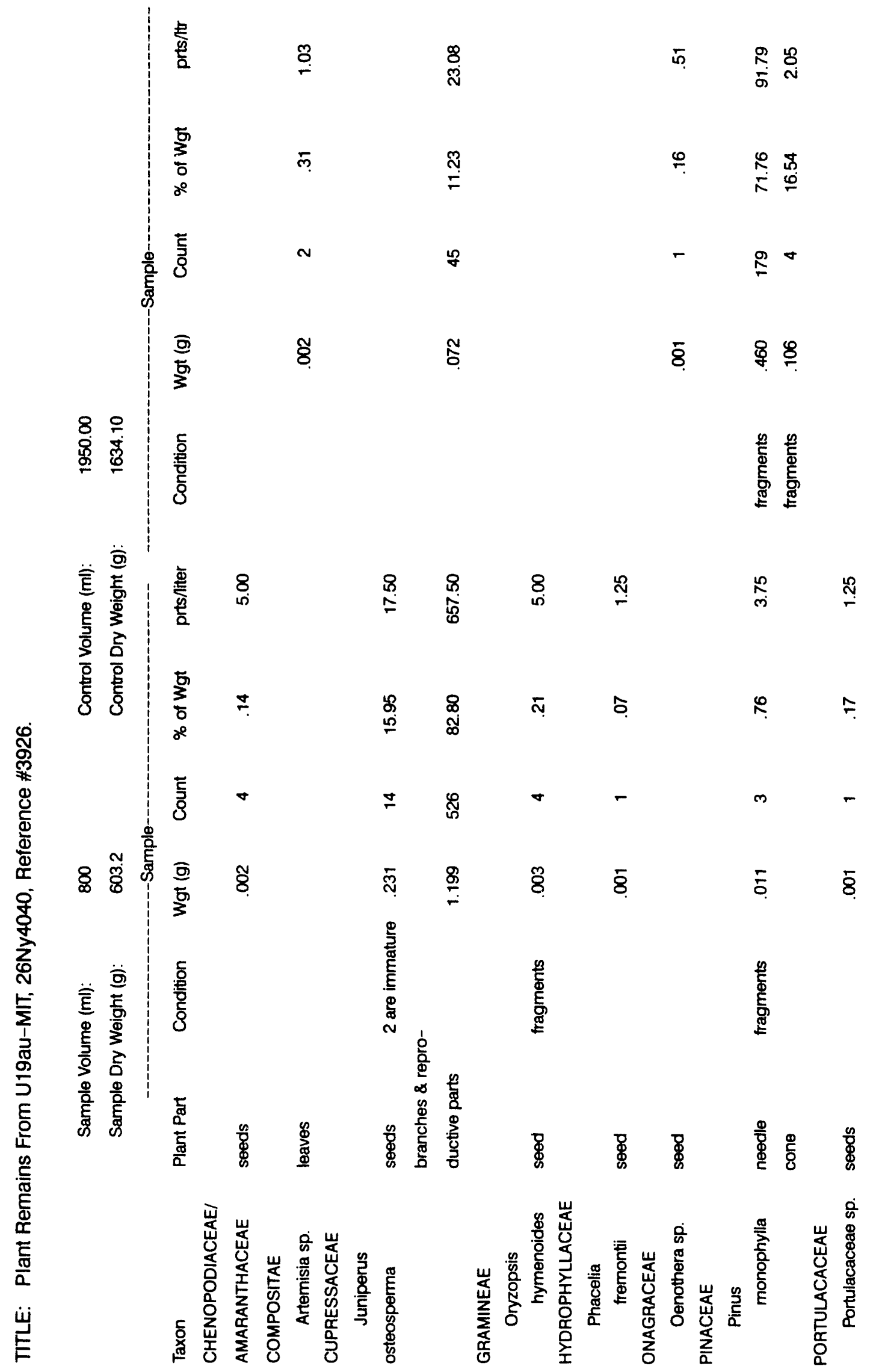




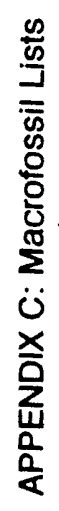

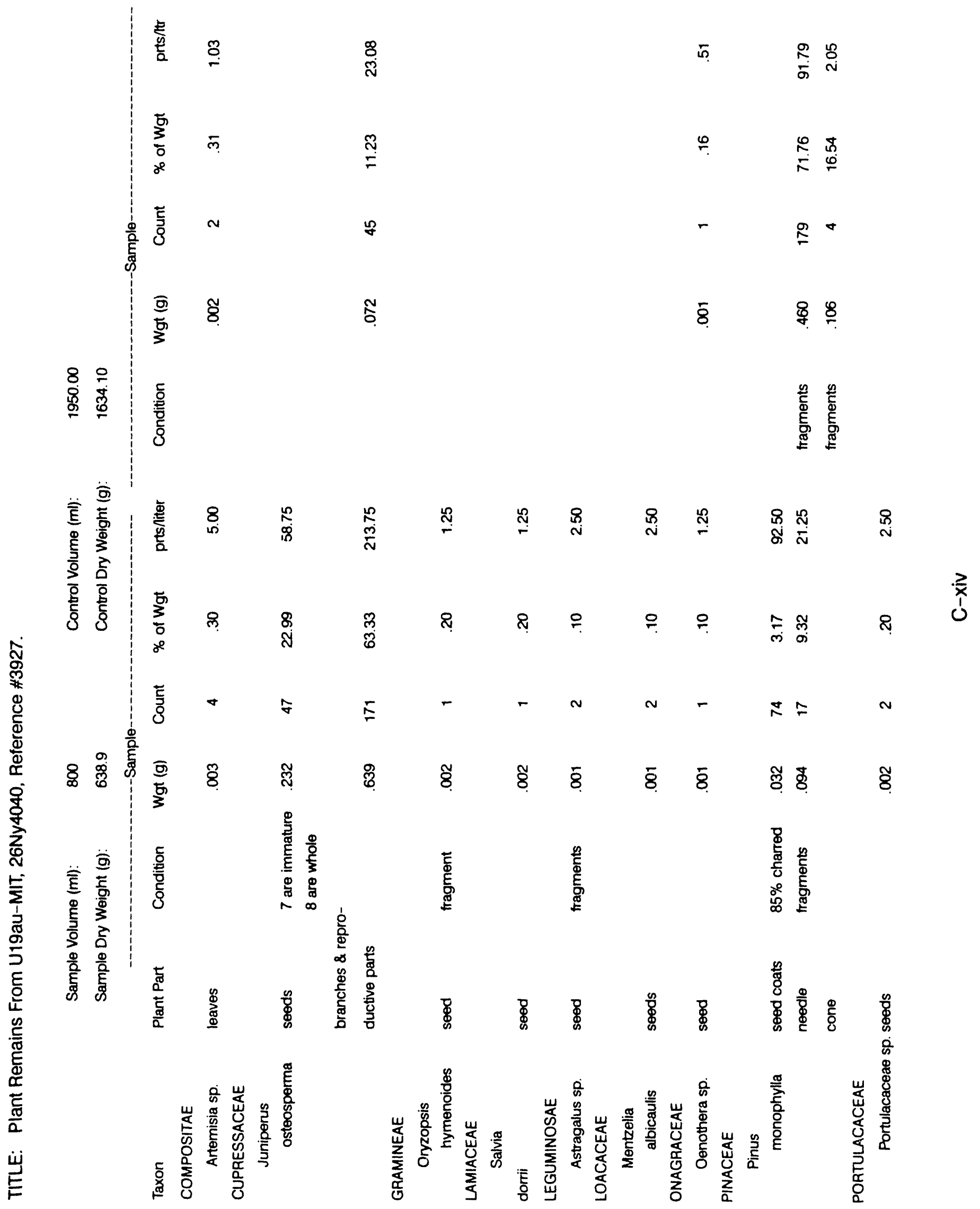




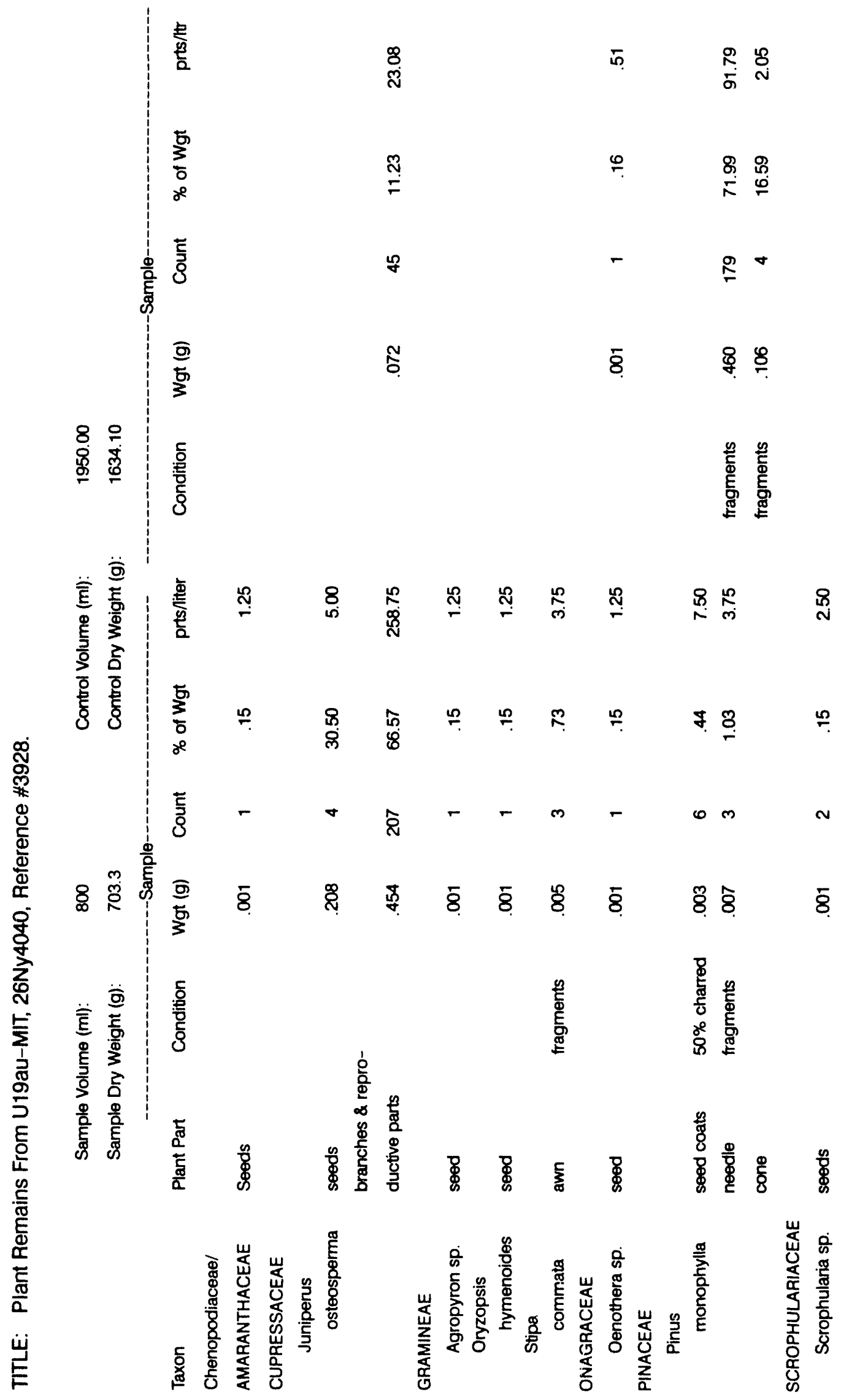




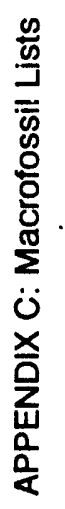

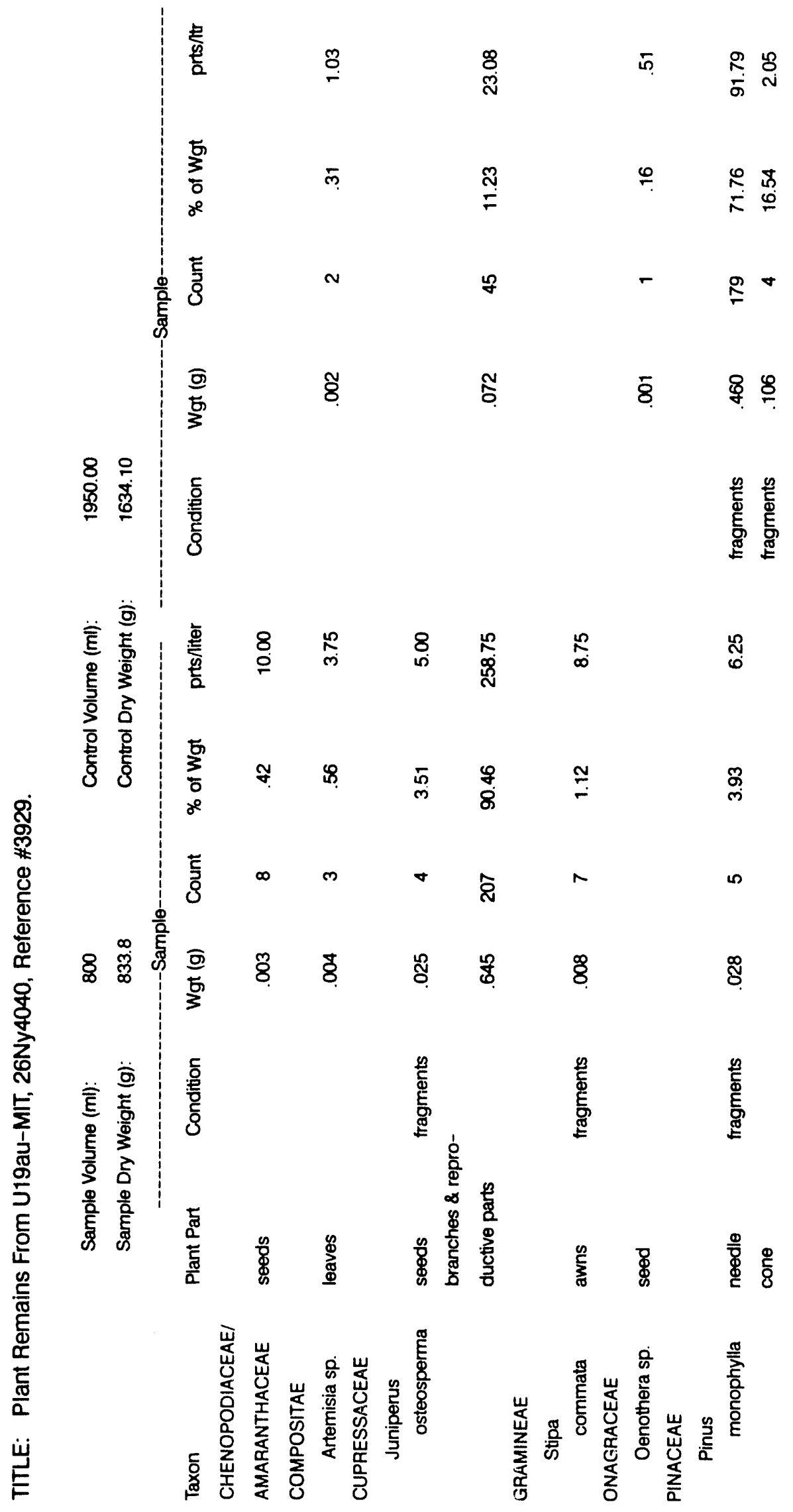

j 


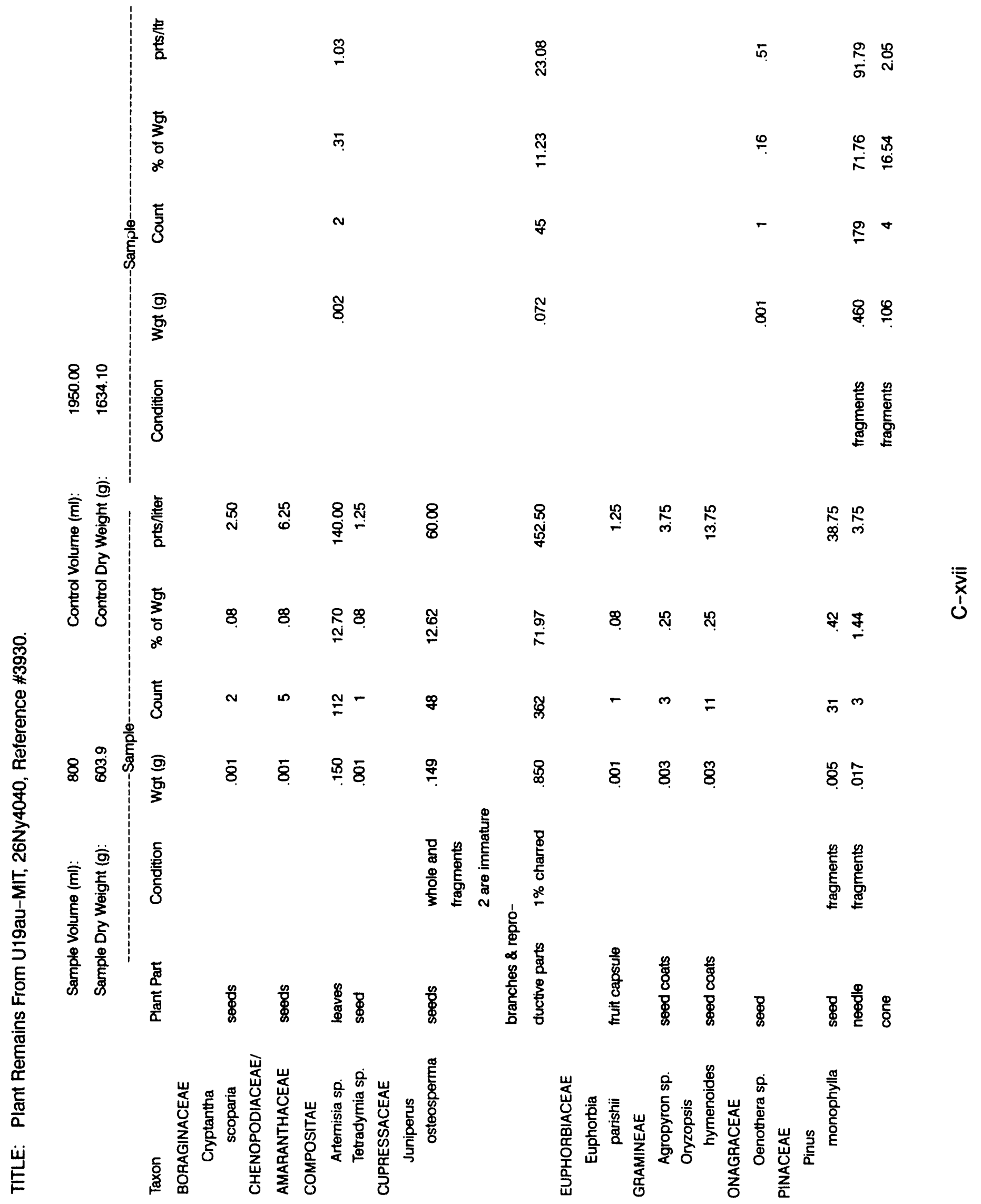




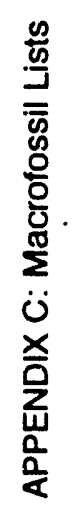

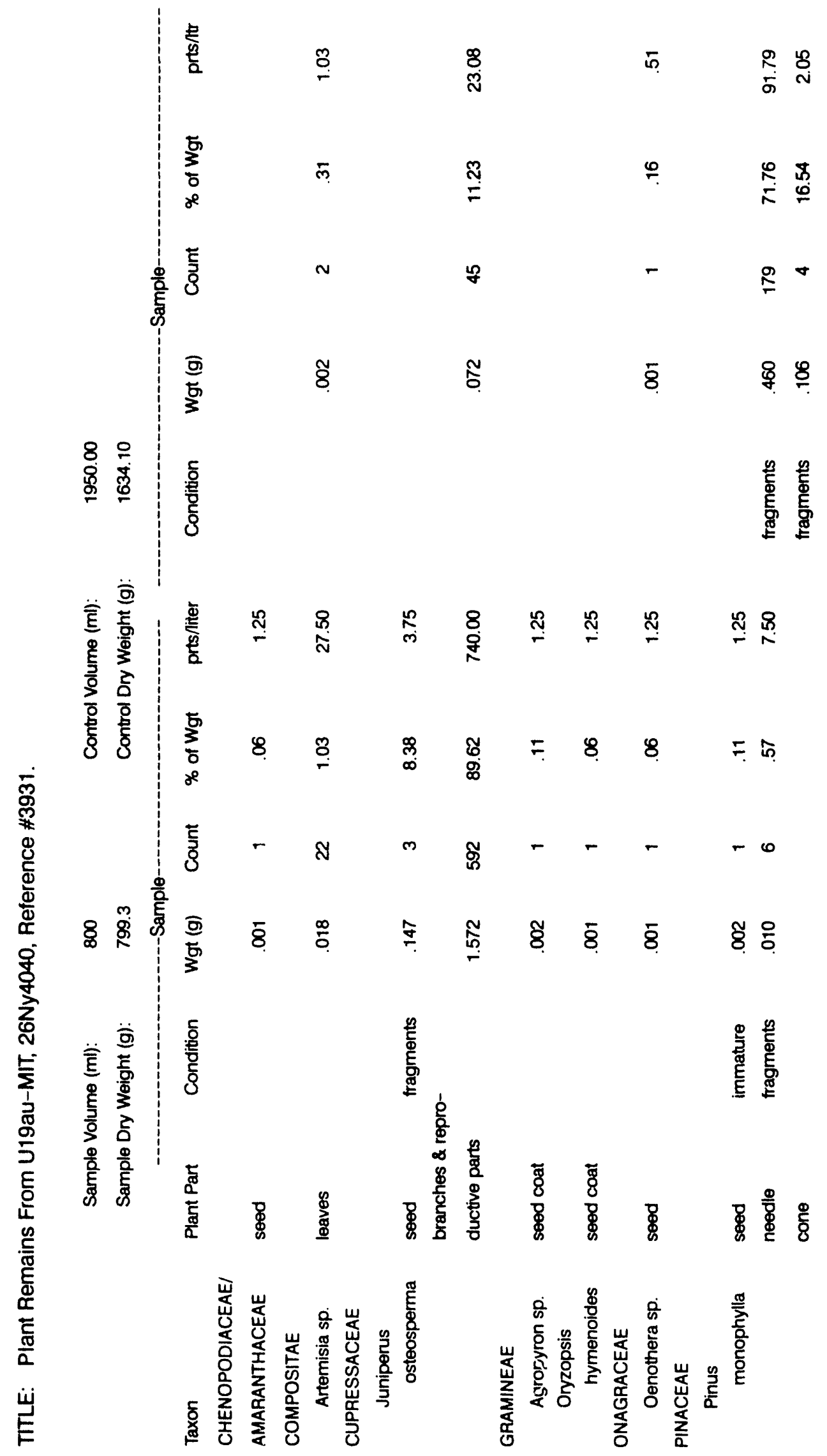

: 


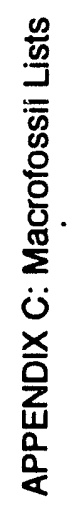

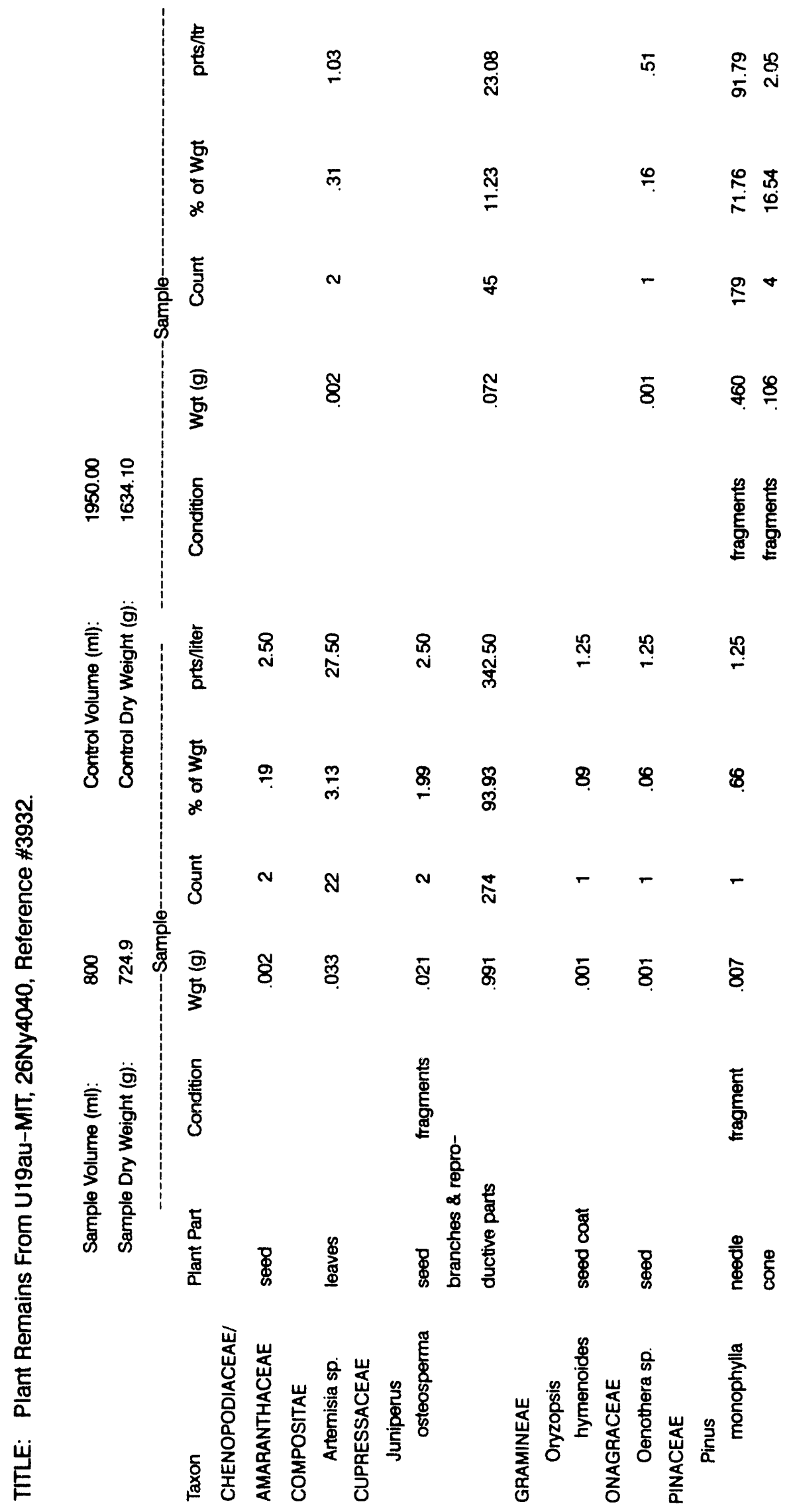




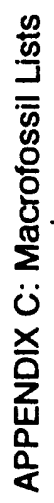

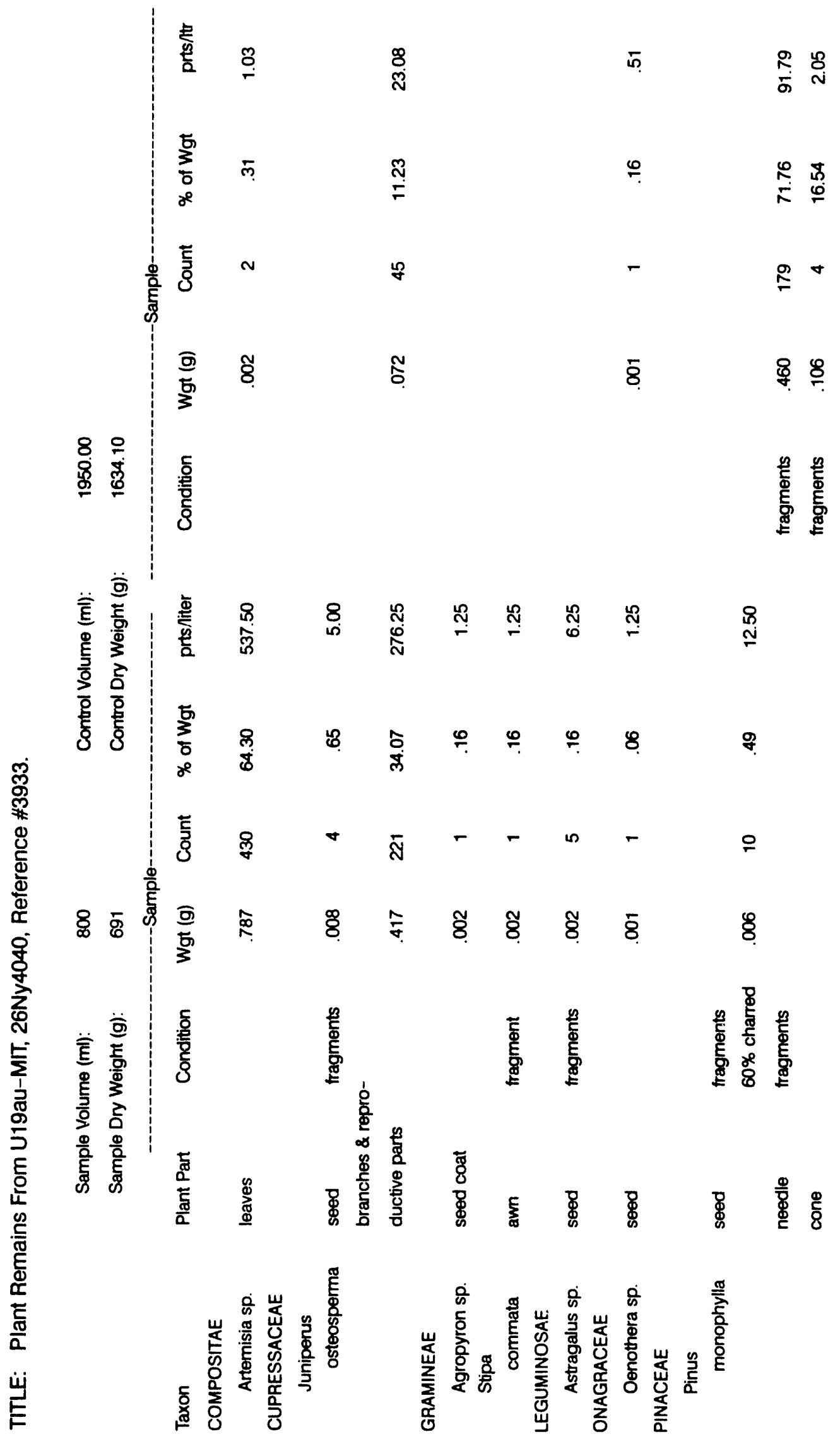




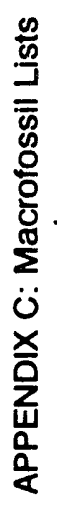

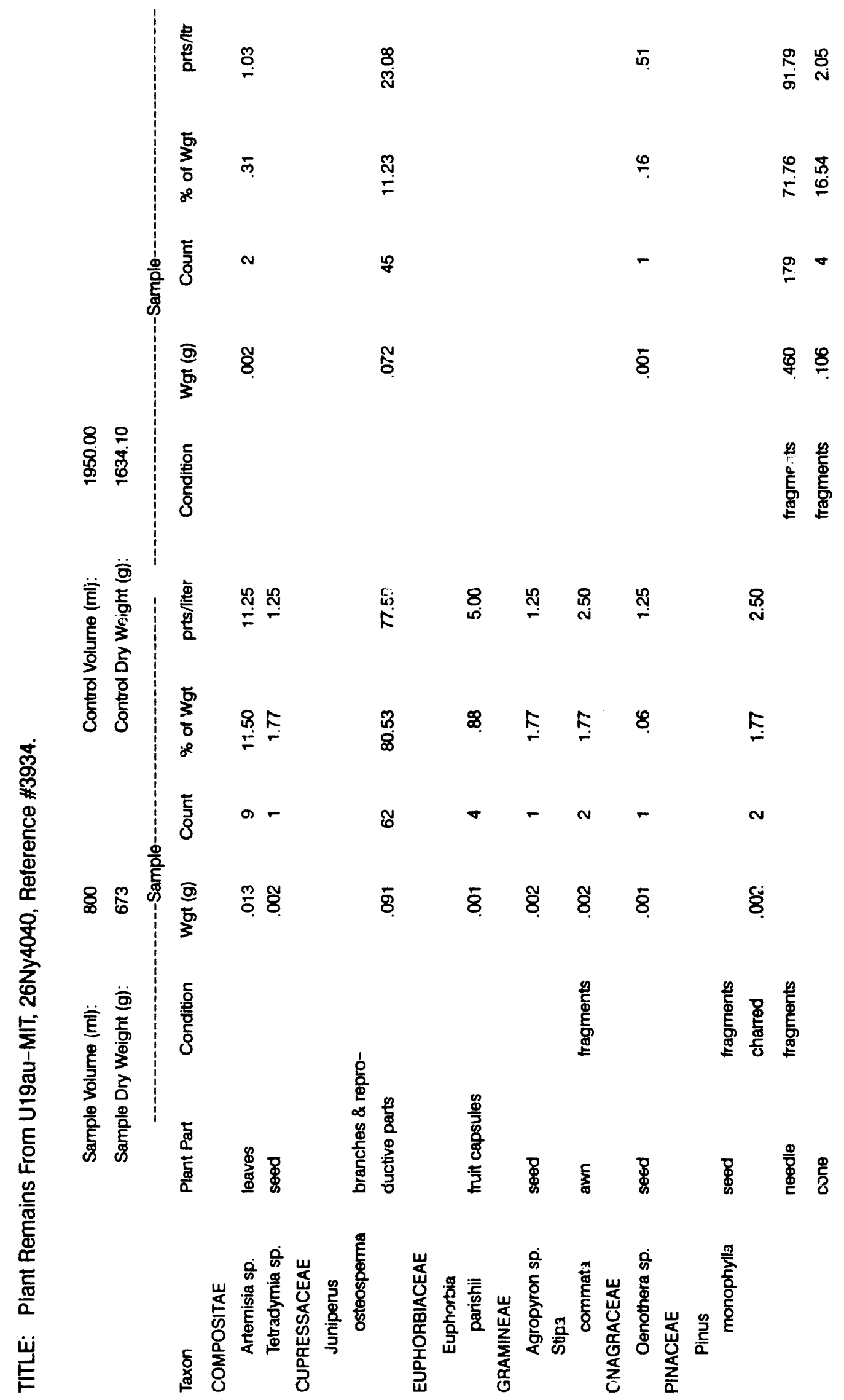



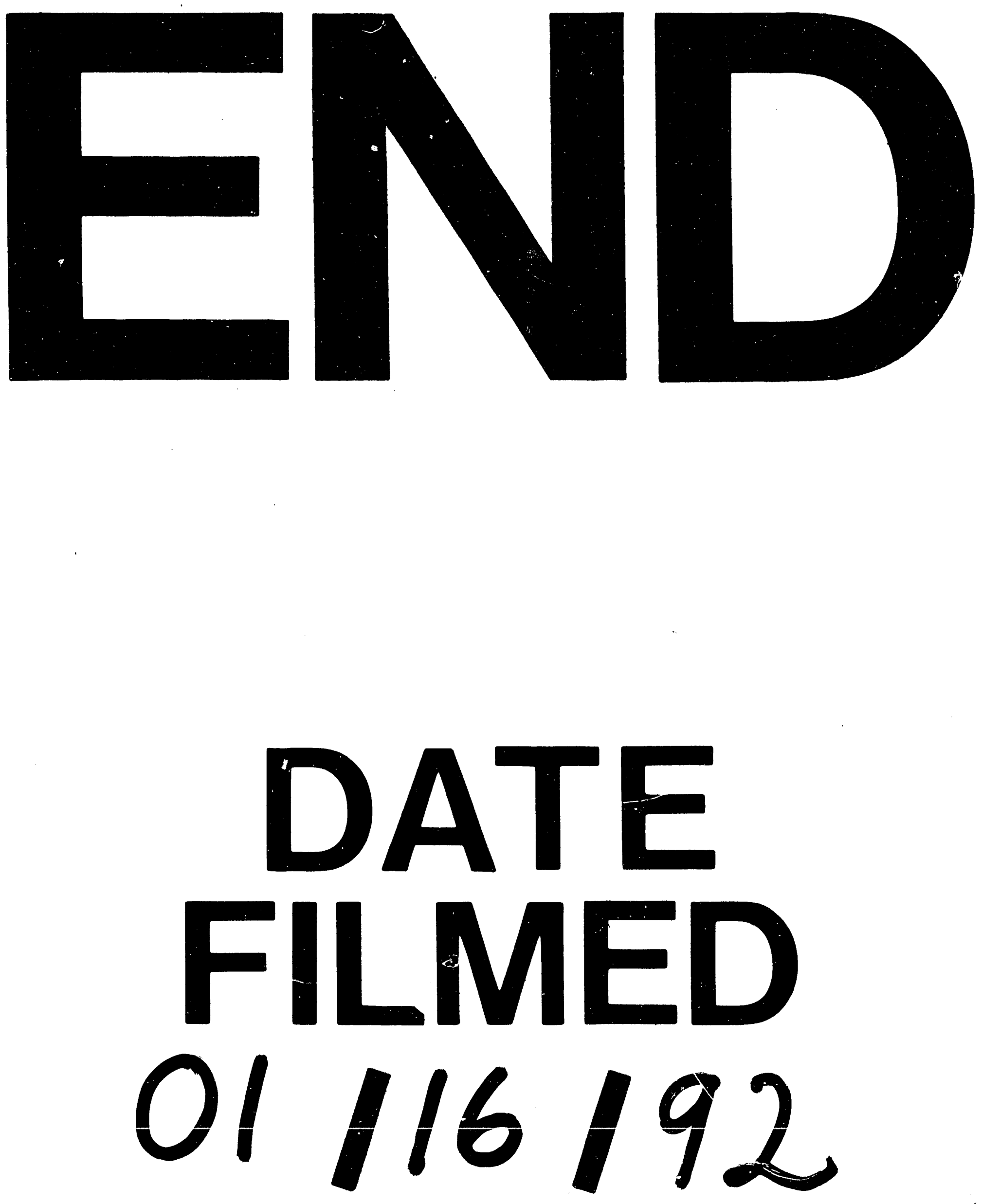

1 
